\title{
ASPECTOS FONÉTICOS, LEXICAIS E MORFOSSINTÁTICOS DA VARIANTE AÇORIANA CATARINENSE
}

\author{
vol.1
}

Dissertação apresentada ao curso de PósGraduação em Língua Portuguesa, Área de Concentração de Filologia e Língua Portuguesa, do Departamento de Letras Clássicas e Vernáculas da Universidade de São Paulo, como requisito parcial para a obtenção do título de Mestre.

Orientador: Prof. Dr. Mário Eduardo Viaro

São Paulo

2007 


\section{AGRADECIMENTOS}

Primeiramente, gostaria de agradecer ao meu orientador e amigo, professor Doutor Mário Eduardo Viaro. Obrigada por seus ensinamentos e conselhos, pela paciência, pelo incentivo, pela mão amiga e pela compreensão nas horas em que vacilei ou não me sentia capaz. Obrigada por me acompanhar todos esses anos, desde a disciplina Fonética e Fonologia do Português, e me incentivar a pesquisa e o espírito crítico.

Agradeço a todos os professores da Graduação e da Pós-Graduação, do curso de Língua Portuguesa, pelo conhecimento que possibilitou construir este trabalho. Aos professores que formaram minha Banca de Qualificação, Doutores Valéria Gil Conde e Manoel Mourivaldo de Almeida, pelas úteis observações feitas ao desenvolvimento da pesquisa.

Agradeço também à FAPESP (Fundação de Amparo à Pesquisa do Estado de São Paulo) pelas bolsas de Iniciação Científica e de Mestrado, que viabilizaram a concretização das pesquisas de campo e as viagens aos locais estudados.

Aos informantes e colaboradores diretos e indiretos agradeço pelos dados que servem de base para esta dissertação. Aos meus tios Paulo e Flávia, pela companhia nos trabalhos de campo na antiga região de Itapocorói.

Aos meus pais, pelo incentivo e suporte. À minha filha, por entender, mesmo tão pequena, que a mamãe precisava ficar horas seguidas em silêncio, transcrevendo fitas e analisando os dados obtidos. Aos amigos, por compreenderem meus longos períodos de ausência; e, às vezes, me lembrar que há outras coisas importantes na vida. Ao meu irmão de coração, Paulo Ribeiro, por todo o auxílio e amizade, de grande valia para a conclusão desta dissertação. 
Aos meus queridos pais:

Edvaldo e Lídia 


\section{SUMÁRIO}

RESUMO ... 4

ABSTRACT... 5

INTRODUÇÃO ... 6

\section{PARTE 1 - DADOS DA REGIÃO PESQUISADA}

1. A Colonização de base açoriana no litoral catarinense ... 9

2. Principais fatos históricos, tradições e costumes dos locais pesquisados ... 16

2.1 A antiga enseada de Itapocorói ... 16

2.2 São Francisco do Sul ... 22

2.3. As tradições e os costumes ... 27

2.3.1 Festas religiosas ... 27

2.3.2 As brincadeiras de criança ... 29

2.3.3 Pasquim ... 29

2.3.4 Farra do Boi ... 30

2.4. Principais mudanças históricas, políticas e sociais ... 31

\section{PARTE 2 - TRABALHO DE CAMPO}

1.1 A caracterização dos informantes ... 33

1.2 As entrevistas ... 37

1.2.1 O Paradoxo do Observador ... 37

1.2.1.1 O tópico conversacional ... 40

1.2.1.2 A argumentação na gravação de entrevistas sociolingüísticas ... 45

1.3 A gravação da fala espontânea ... 49

1.4 O Questionário Lingüístico ... 50

1.5 O Questionário Valorativo ... 54

\section{PARTE 3 - ANÁLISES LINGÜÍSTICAS}

1. Análise fonética ... 56

2. Análise lexical ... 75

1.1 O Questionário Lexical... 76

1.2 Análise dos dados... 98

3. Análise morfossintática ... 113

4. Análise comparativa do Questionário Valorativo ... 123

CONSIDERAÇÕES FINAIS ... 137

GLOSSÁRIO ... 148

REFERÊNCIAS BIBLIOGRÁFICAS ... 171

ANEXO 1 - Dados pessoais dos informantes ... 181

ANEXO 2 - Transcrições ... 191

ANEXO 3 - Pasquim ... 387 


\section{RESUMO}

Diz-se que há uma grande influência açoriana no litoral catarinense. Muitos trabalhos são realizados para estudar esse tema, porém, poucos analisam esse fato do ponto de vista lingüístico, principalmente em seus aspectos fonéticos e morfossintáticos. As poucas pesquisas realizadas estão voltadas para características muito gerais da fala catarinense ou se concentram na região de Florianópolis, atual capital do Estado. A escassez de material indica que pouco se conhece sobre a dita influência açoriana.

O presente trabalho propõe investigar a fala de duas das três regiões mais antigas de Santa Catarina, cuja base de colonização foi açoriana: a antiga região de Itapocorói (que atualmente compreende a área dos municípios de Penha, Balneário de Piçarras e uma pequena parte do sul de Barra Velha) e o povoado de Nossa Senhora das Graaças do Rio São Francisco (hoje São Francisco do Sul).

Para isto, foi preciso realizar duas pesquisas lingüísticas de campo, uma na região de Itapocorói e outra em São Francisco do Sul, com a finalidade de descrever as variantes atuais locais e verificar possíveis transformações fonéticas, lexicais e morfossintáticas em um grupo de sessenta informantes divididos em três faixas etárias distintas (trinta de cada localidade pesquisada). Foram utilizados dados colhidos em trabalho de campo por meio de: (a) locução espontânea; (b) aplicação de questionário lingüístico com 49 perguntas; (c) questionário valorativo com 6 perguntas.

As características apontadas serão aquelas que, de maneira geral, diferenciem a variante local de outras variantes do Português do Brasil. Acreditamos que, com isto, seja possível conhecer um pouco mais a variante açoriana catarinense e sua história. 


\section{ABSTRACT}

It is said that there is a great influence of Azores in the Santa Catarina coastline. Many works are carried out to study this subject, however, a few analysis this fact from the linguistics point of view mainly in their morphosyntactical and phonetics aspects. The few researches carried out are turned towards a lot of general characteristics of Santa Catarina speech or they centralize in Florianópolis region, present capital of the state. The lack of materials shows that not much is known about the related influence of Azores.

The present work suggests investigating the speech of the three more ancient regions of Santa Catarina, whose colonization basis was from Azores: the ancient region of Itapocorói (that nowadays includes the cities areas of Penha, Piçarras and a small part of the south of Barra Velha) and the village of Nossa Senhora das Graças of Rio São Francisco (nowadays São Francisco do Sul).

That is why, it was necessary to carry out two linguistics field searches, one in Itapocorói region and the other in São Franciso do Sul, with the purpose of describing the present local variant and the possible phonetics, lexical and morphosyntactical variants transformation in a group of sixty informers divided in three different age groups (thirty of each places researched). It was made use of data gathered work field through: a) spontaneous idiomatic expression; b) linguistic questionnaire application with 49 questions and c) valorables questionnaire with six questions.

The characteristics showed will be the ones that, in general differ the local variant and the other variants of Portuguese from Brazil. We believe that, with this, it will be possible to know a bit more the variant from Azores of Santa Catarina and its story. 


\section{INTRODUÇÃO}

O Sul do Brasil, entre outros locais do território nacional, recebeu uma quantidade significativa de imigrantes açorianos. Migração estimulada pela Coroa Portuguesa, como uma tentativa de colonizar as terras do sul do país e protegê-las dos invasores, principalmente dos espanhóis. Primeiramente, chegaram nos séculos XVII e XVIII, em um número que ultrapassou largamente o da exígua população. Depois, novas migrações ocorreram no século XVIII e XIX (MENESES, 1993: 50-1).

Os Açores são um conjunto de ilhas localizadas no Oceano Atlântico, a 1800 quilômetros de Lisboa: Santa Maria, São Miguel, Terceira, Graciosa, São Jorge, Pico, Faial, Flores e Corvo. Ponto estratégico no meio do oceano, colonizadas predominantemente por portugueses, porém, com presença francesa, inglesa, belga e holandesa (FARIAS, 2001: 356).

Os açorianos instalaram-se principalmente na faixa litorânea de Santa Catarina. Acreditase que a influência açoriana é muito presente até a atualidade, sendo base da cultura, costumes e tradições locais (FARIAS, 2001: 651). Muitos pesquisadores dedicam-se a esses estudos em Santa Catarina. Núcleos como o NEA (Núcleo de Estudos Açorianos), organizado pela UFSC (Universidade de Santa Catarina), são exemplos da importância da história desse povo para a região. Porém, poucos trabalhos analisam este fato do ponto de vista lingüístico, principalmente em seus aspectos fonéticos e morfossintáticos.

Como os Açores são um arquipélago, é inviável admitir que o falar de todas as ilhas seja uniforme. Se há muitos pontos em comum, há também diferenças. Por isso, é preciso frisar que a denominação "variante açoriana" designa, em realidade, o conjunto das variantes faladas no arquipélago, que, por sua vez, se formou por meio da influência dos povos que colonizaram as ilhas e as utilizaram como ponto de passagem entre as viagens marítimas. Considerar-se-á, em um primeiro momento, "variante açoriana catarinense" a fala do litoral catarinense colonizado pelos açorianos.

O presente trabalho investiga a fala da antiga região catarinense de Itapocorói, que compreende a área de três municípios: Penha, Balneário de Piçarras e uma pequena parte do sul de Barra Velha, e o município de São Francisco do Sul. Colonizados principalmente por portugueses vindos dos Açores, essas são duas das mais antigas áreas de colonização de Santa Catarina, remontando à segunda metade do século XVII. (FARIAS, 2000: 133) Portanto, têm grande 
importância para estudos de natureza histórica e sociolingüística de variantes da língua portuguesa no Brasil.

Sendo a região de Itapocorói uma das que mais recebeu açorianos, e a de São Francisco do Sul um dos portos mais antigos do Estado, entendemos que, se essa influência lingüística ainda está presente, esteja na fala de seus habitantes, em sua maioria, nos mais velhos, daqueles que vivem na zona rural, em praias mais isoladas ou que não tiveram acesso à educação formal.

A metodologia empregada consistiu na gravação da elocução espontânea e da aplicação de dois questionários (um lingüístico e outro valorativo) para sessenta informantes, distribuídos de forma igualitária entre as duas regiões pesquisadas. Trabalhamos com a questão do tempo aparente, sendo assim, esses informantes estão divididos entre três faixas etárias: A, B e C.

O tempo aparente, fornecido pelas diversas faixas etárias, pode nos fornecer dados capazes de não só retratar a fala da comunidade de maneira sincrônica, mas também diacrônica. Assim, temse uma maneira de conhecer quais traços lingüísticos estão se perdendo ou se fortalecendo ao longo do tempo.

O grupo $\mathbf{A}$ abrange os informantes de até vinte anos. $\mathrm{O}$ grupo $\mathbf{B}$ de vinte a cinqüenta $\mathrm{e}$ cinco anos. O grupo $\mathbf{C}$ os informantes com mais de cinqüenta e cinco anos - que acreditamos ser formado por aqueles que preservam os traços lingüísticos mais antigos. Após o levantamento e a análise dos dados, esses foram comparados entre si e com o material bibliográfico disponível.

São poucas as publicações lingüísticas que descrevam o falar das regiões catarinenses. As que o descrevem o fazem de forma mais abrangente, englobando todo o falar do Sul do país. Para exemplificar, podemos citar o ALERS (2002) - Atlas lingüístico-etnográfico da região Sul do Brasil, Borba Corrêa (2000), Campos Imaguire (1999) e Furlan (1989). Se há pesquisas específicas, trabalham na maior parte com a influência italiana ou alemã, como Bonatti (1974). Por isso, a maioria do material citado se refere a obras de Dialetologia, Sociolingüística ou Lingüística histórica em geral, ou, ainda, sobre aspectos puramente históricos e geográficos de Santa Catarina.

Porém, estudos desse tipo são extremamente importantes para o conhecimento das variantes do Português Brasileiro e suas relações com o Português Europeu e também para entender como uma variante pode reagir perante as mudanças trazidas pelo tempo, pelo contato com outras variantes ou até mesmo com outras línguas. ${ }^{1}$

\footnotetext{
${ }^{1}$ É pertinente lembrar que a região da antiga Itapocorói recebe muitos turistas estrangeiros, principalmente falantes de língua espanhola, predominando os argentinos e que a cidade de São Francisco do Sul é portuária, recebendo pessoas de várias partes do Brasil e do estrangeiro.
} 
Estudar a língua falada é um desafio já bem conhecido de vários projetos, como o $N U R C$ (Norma urbana culta), o PORCUFORT (Português culto de Fortaleza) ou o Projeto Vertentes (português rural da Bahia). A fala reflete o homem em um determinado tempo, uma vez que todo enunciado se compõe de duas dimensões básicas; que compreendem o momento em que é produzido e as variações sociolingüísticas a ele associado. Conhecendo-a melhor, podemos compreender aspectos da história do Português Brasileiro que são obscuros.

"Este é o 'vernáculo' - o estilo no qual o mínimo de atenção é dado no monitoramento da fala. Observar o vernáculo nos fornece a maior sistematização de dados para a análise de estruturas lingüísticas." ${ }^{2}$ (DOWNES, 1984: 85)

Se estudá-la não é fácil, sistematizá-la, então, parece ainda mais difícil. E o que seria da curiosidade humana, que impulsiona o conhecimento, se não houvesse desafios? A presente pesquisa busca fazer, por meio de dados colhidos em trabalho de campo, uma sistematização dos aspectos relevantes da variante em questão.

\footnotetext{
${ }^{2}$ Tradução da autora: "This is the 'vernacular' - the style in which the minimum attention is given to the monitoring of speech. Observation of the vernacular gives us the most systematic data for our analysis of linguistic structure."
} 


\section{PARTE 1 - DADOS DA REGIÃO PESQUISADA}

\section{A COLONIZAÇÃO DE BASE AÇORIANA NO LITORAL CATARINENSE}

Para que possamos falar da migração açoriana para o Brasil é necessário, primeiramente, conhecer alguns dados básicos sobre o arquipélago dos Açores. Localizado em um ponto estratégico em pleno Atlântico Norte, a 1800 quilômetros de Lisboa, foi um local de grande importância para as rotas marítimas desde a época das Grandes Navegações. Porto seguro, os Açores eram o local de partida e chegada de vários tipos de mercadorias, entre elas: escravos, especiarias, metais preciosos etc. (FARIAS, 2001: 356).

Descoberto por volta de 1432, os Açores foram povoados principalmente por portugueses vindos do continente. Ele é formado por nove ilhas: Santa Maria e São Miguel (orientais), Terceira, São Jorge, Graciosa, Faial e Pico (centrais), Flores e Corvo (ocidentais) (PIAZZA, 1983: 139). ${ }^{3}$

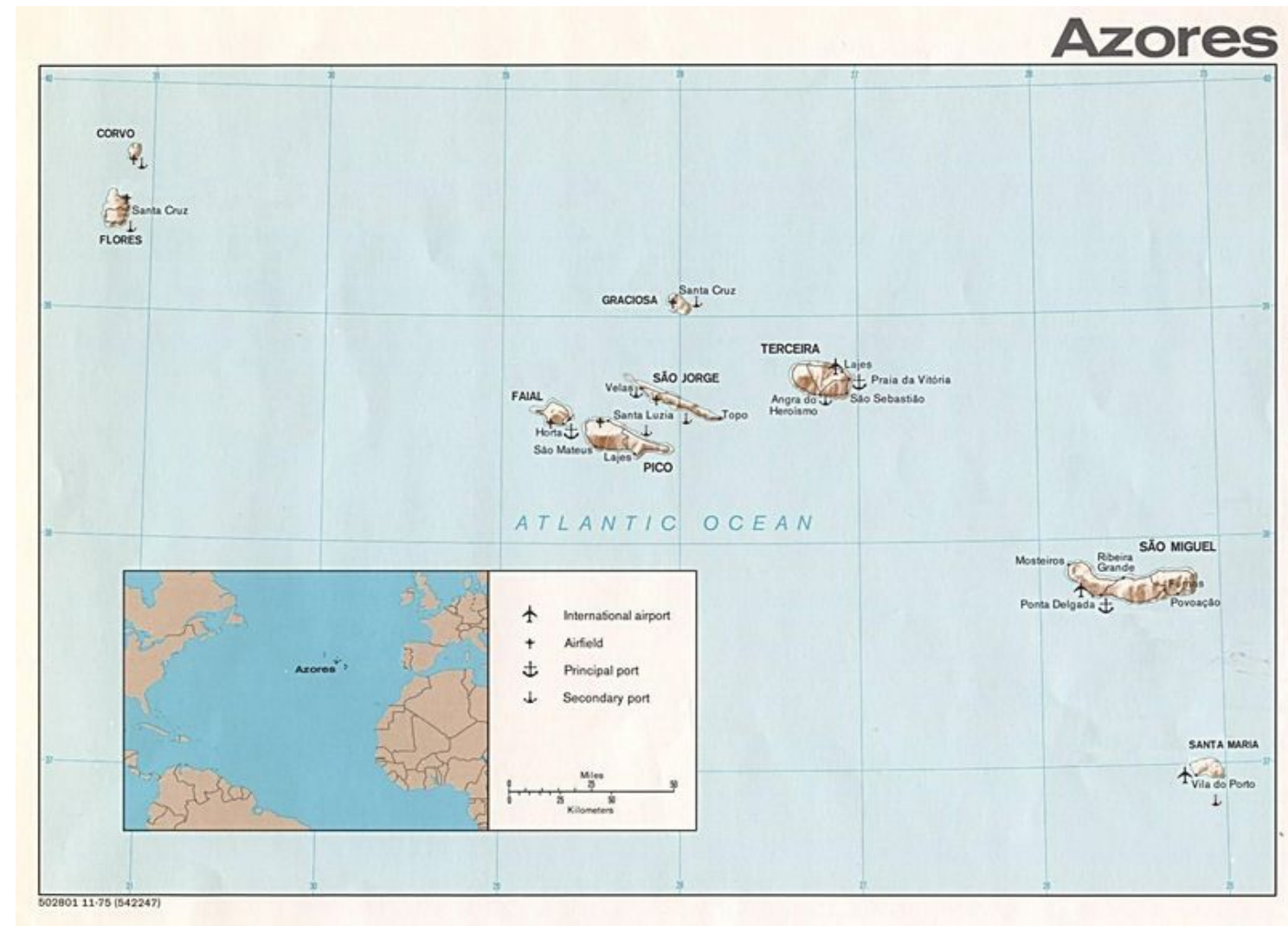

\footnotetext{
${ }^{3}$ MAPA: http://pt.wikipedia.org/wiki/imagens:AzoresC/Aorg
} 
As relações entre os Açores e o Brasil foram inicialmente devidas ao comércio marítimo. Desde o século XVI, o Brasil se transformou em um parceiro comercial dos Açores; porém, sob a tutela de Portugal. Esse fato desagradava aos açorianos e fomentou o contrabando (FARIAS, 2001: 356). A emigração açoriana para o Brasil começou no século XVII e estende-se até hoje.

"O processo da emigração açoriana para o Brasil desenvolveu-se em ciclos alternados que, começando no início do século XVII, estenderam-se até o século XX. Ainda que representando dois momentos distintos, os imigrantes açorianos dos séculos XVII - XVIII e os do século XIX - XX tiveram como motivação a busca de melhores condições de vida.[...] No período colonial (séc. XVII e XVIII) esta emigração foi disciplinada, promovida e financiada pela Coroa portuguesa, que buscava solucionar com estes deslocamentos populacionais maciços diversas questões ligadas à geopolítica lusitana para suas vastas áreas coloniais.” (FARIAS, 2001: 360)

O primeiro contingente de imigrantes açorianos, patrocinados pelo governo português, chegou ao Brasil em 1619, em terras maranhenses.

"As origens da ocupação e do povoamento europeu iniciaram em terras maranhenses [...]. Tal missão, como nos propomos relembrar, foi destinada inicialmente aos imigrantes açorianos e à igreja através dos jesuítas, senhores do "século esquecido" maranhense (XVII) e parte do XVIII, quando o interesse maior da metrópole na região parecia ser, naquele momento, garantir fronteiras e afastar as ameaças das nações rivais, principalmente a França, a Holanda e a Inglaterra. As condições históricas desse processo, aparentemente foram determinadas pela estratégia de ocupação da costa brasileira onde, no convexo, a faixa litorânea central teria prioridade, cabendo às periferias ou pontas a condição de expansão, o que justificaria tanto com as ocupações açorianas no norte no século XVII, quanto às do Extremo Sul no século XVIII (...).”(BARROSO, 2002: 17)

Até por volta da segunda metade do século XVIII, a exígua população que habitava o litoral catarinense era formada por vicentistas (portugueses oriundos da região de São Vicente, litoral do Estado de São Paulo) e grupos indígenas. Porém, já na segunda metade do século XVII, a enseada de Itapocorói era ponto de passagem e descanso para os viajantes que se deslocavam entre os povoados de Nossa Senhora das Graaças do Rio São Francisco, e de Nossa Senhora do Desterro, na Ilha de Santa Catarina (SILVA, s/d: 07). 


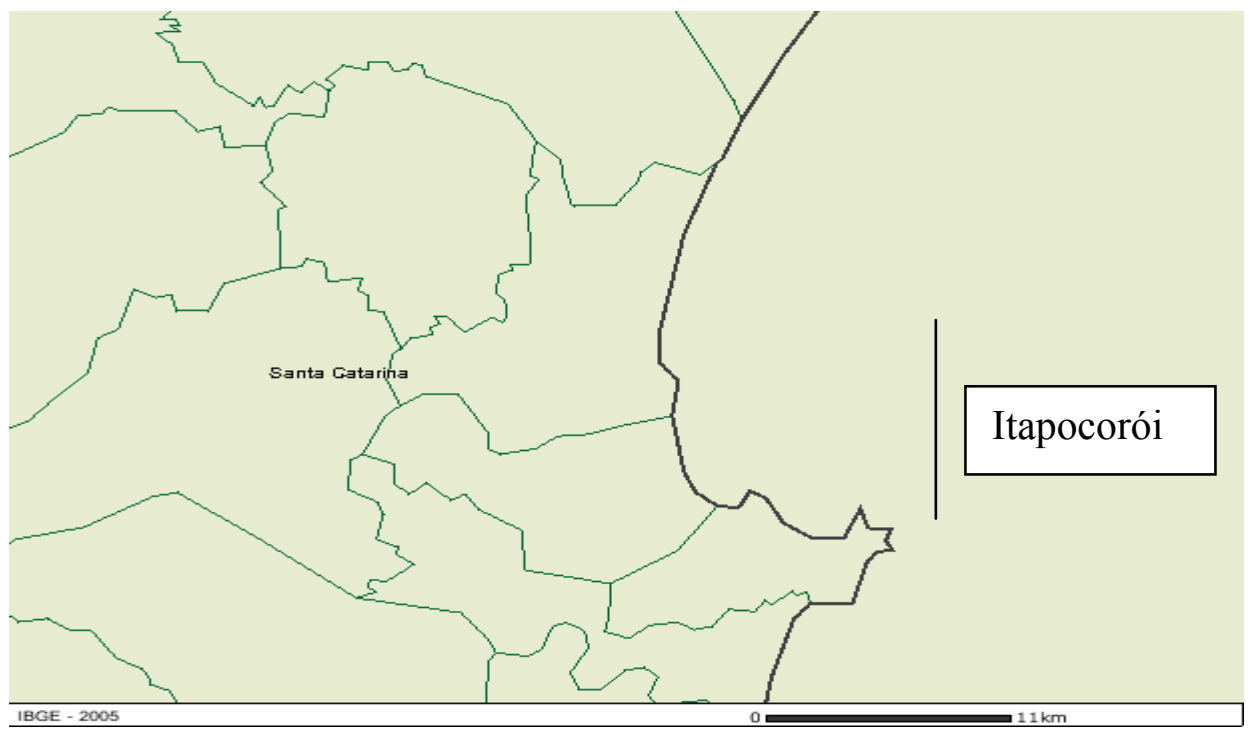

Área da antiga Armação de Itapocorói ${ }^{4}$

Esses locais são os três pontos mais antigos do Estado de Santa Catarina, possuindo em comum o fato de terem sido colonizados principalmente por açorianos (PIAZZA, 1983: 152). E também, por terem supostamente preservado até a atualidade muitas das características dessa cultura.

"Ao longo dos 250 anos da colonização açoriana foi se consolidando no litoral catarinense uma identidade única, cuja essência se fundamenta nos valores transplantados do arquipélago dos Açores. A estes valores foram somados os da cultura vicentista (paulistas que já haviam se fixado no litoral catarinense nos séculos XVII e XVIII), bem como das culturas indígenas, negra e de outras minorias. A esta cultura lusófona resultante, praticada ao longo do litoral catarinense pelos descendentes dos imigrantes açorianos (maioria da população regional) e por outras etnias aculturadas chamamos de CULTURA DE BASE AÇORIANA CATARINENSE."5 (PIAZZA, 1983: 652)

Desde a época do Descobrimento do Brasil, a Ilha de Santa Catarina foi visitada por navegadores e aventureiros. Predominavam os espanhóis. Porém, somente na segunda metade do século XVII iniciou-se o povoamento da Ilha (hoje Florianópolis) pelo vicentista Francisco Dias Velho, em 1673 (CABRAL, 1970: 34).

\footnotetext{
${ }^{4}$ MAPA: www.ibge.org.br

${ }^{5}$ Termos destacados pelo próprio autor.
} 
Devido à posição estratégica do sul do país e à constante ameaça de ocupação exercida pelos espanhóis, a Coroa Portuguesa nomeou, em 1738, o continente do sul e a Ilha de Santa Catarina como capitania subalterna ao Rio de Janeiro. Além disso, autorizou e estimulou, como muitas vantagens, a vinda de cerca de 6000 açorianos para a Ilha de Santa Catarina, que chegaram entre 1748 e 1756, número que ultrapassava largamente o de moradores (PIAZZA, 1983: 155) e (FARIAS, 1998: 242). ${ }^{6}$

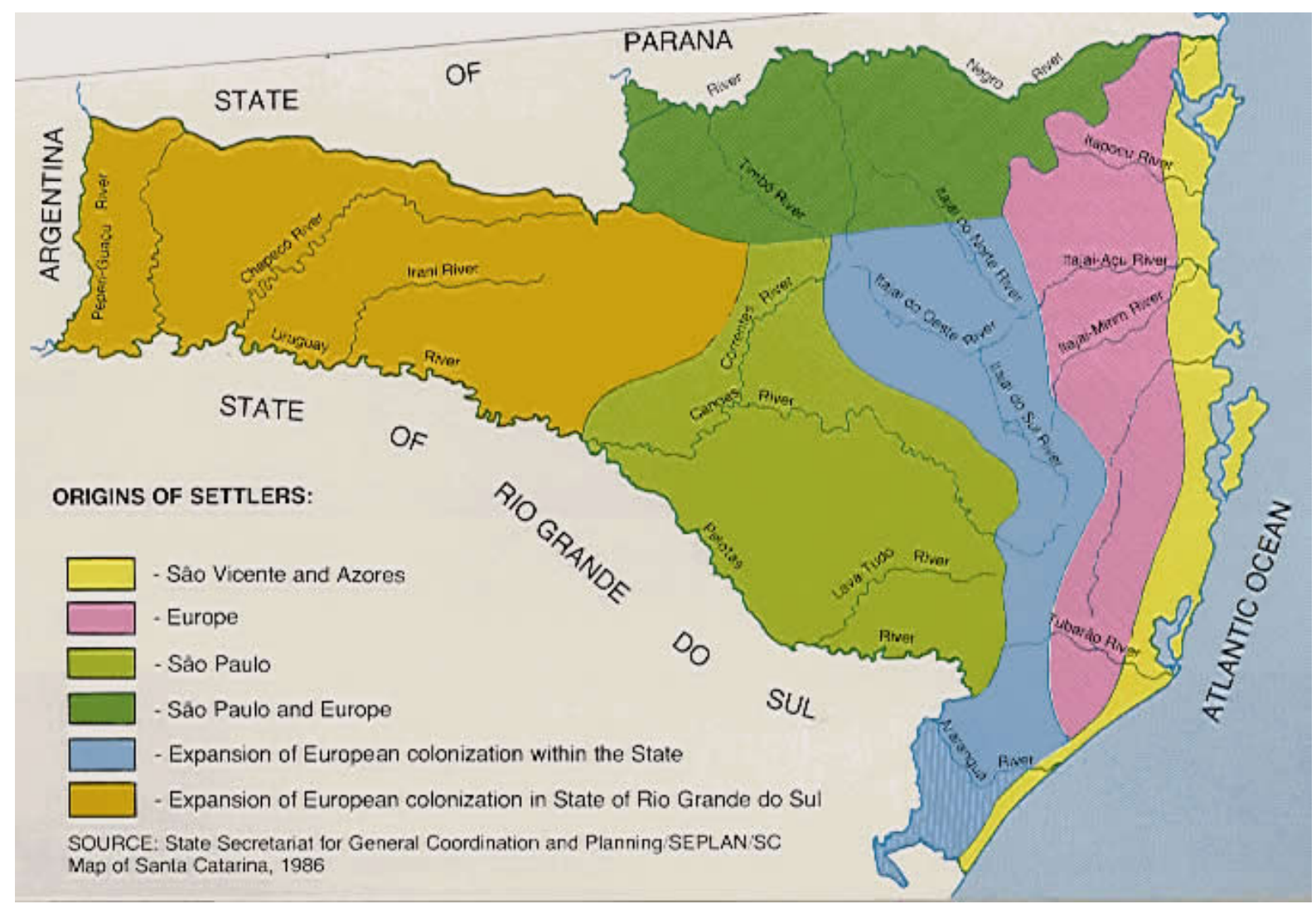

O número de açorianos que embarcou para o Brasil, assim com a ilha de origem e o local do desembarque podem ser encontrados, por exemplo, em PIAZZA (1983) e FARIAS (1998), (2001). Porém, o local exato em cada família se estabeleceu não está disponível.

A Ilha de Santa Catarina, juntamente com seu continente frontal, foi a primeira região sistematicamente povoada em Santa Catarina. Centro irradiador do fluxo de colonização do litoral catarinense nos séculos XVIII e XIX, sem desconsiderar o papel relevante das vilas de Laguna e São Francisco do Sul; pois na Ilha desembarcavam os açorianos enviados para o sul do Brasil, inclusive os destinados ao Rio Grande do Sul. Estes colonos criaram e

\footnotetext{
${ }^{6}$ MAPA: www.portalsbs.com.br/historia/demais/mapas/santacatarina_colonizacao.jpg
} 
desenvolveram comunidades na Ilha, fundando diversas freguesias, tais como a da Santíssima Trindade, a Lagoa da Conceição, a de Santo Antônio de Lisboa, a de São João do Rio Vermelho, a de Canasvieiras, e a do Ribeirão da Ilha (FARIAS, 1998: 243) ${ }^{7}$.

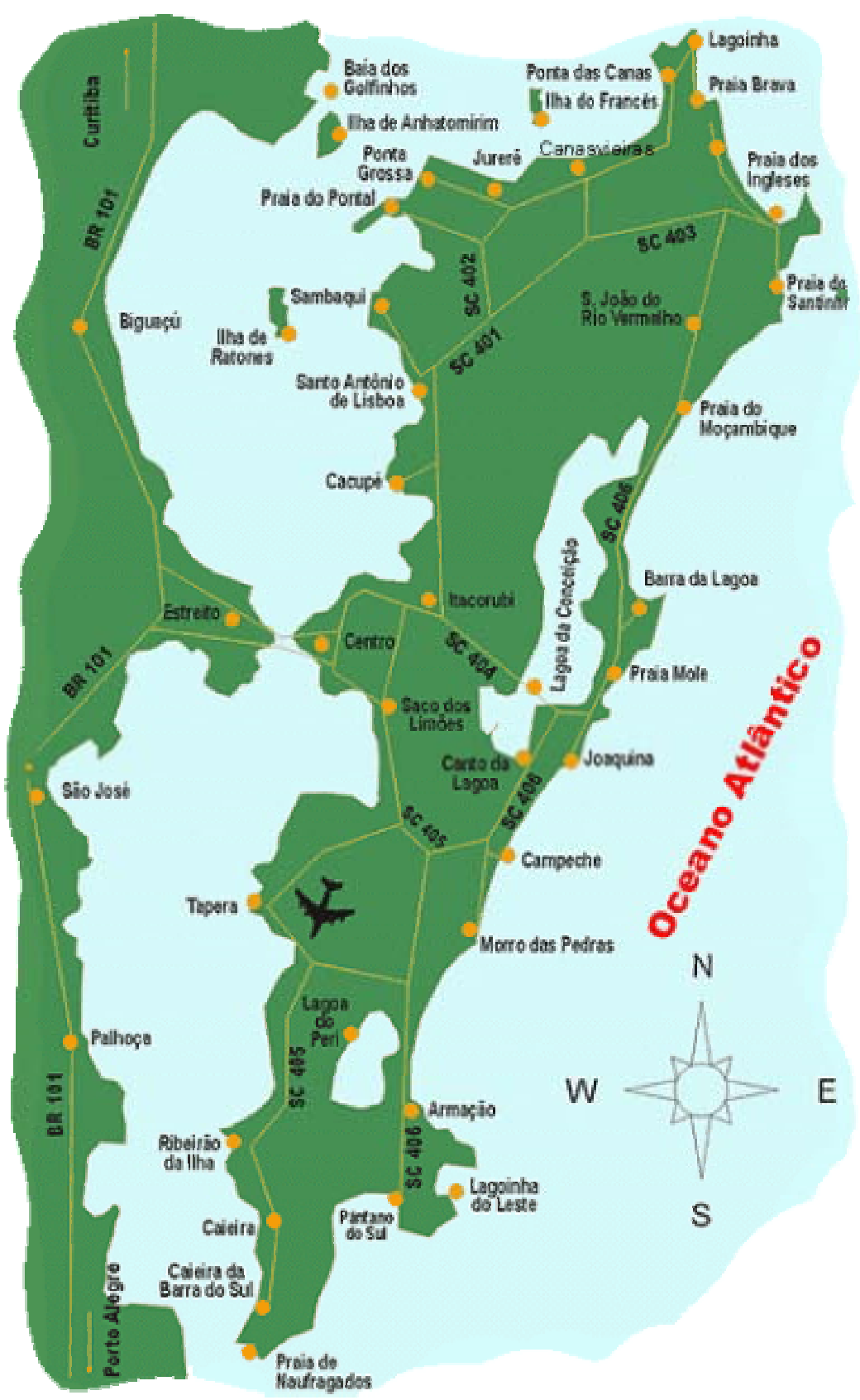

A transferência de estruturas familiares completas favoreceu o crescimento demográfico ao longo dos séculos XVIII e XIX, com um grande aumento populacional no século XX, entre os descendentes.

\footnotetext{
${ }^{7}$ MAPA: www.portaldailha.com.br/mapas
} 
Na segunda metade do século XVIII, o litoral catarinense recebeu outro contingente de portugueses vindos da região dos Açores. Estes, ao contrário dos alemães e italianos que se instalavam mais no interior do Estado, permaneceram na faixa litorânea, principalmente nas freguesias de Enseada de Brito e Lagoa da Conceição (FARIAS, 1998: 123)

Logo após a Independência do Brasil, um Decreto Imperial atribuiu a Desterro foros de cidade. Em 1894, Desterro passou a chamar-se Florianópolis (CABRAL, 1970: 35). Desde o começo do século XX, o desenvolvimento econômico e social de Florianópolis tem sido constante.

Desde 1823 capital de Santa Catarina, essa cidade é uma das maiores do Estado, com mais de trezentos mil habitantes. É ainda um pólo político, econômico e também cultural, já que abriga uma das maiores universidades do sul do país, a UFSC (Universidade Federal de Santa Catarina).

A hipótese mais corrente para a migração açoriana afirma que a motivação estaria no excesso populacional do Arquipélago açoriano; porém, essa hipótese cai por terra ao analisarmos as estruturas econômicas dos Açores. Carregando resquícios do sistema feudal, as terras do Arquipélago não podiam ser alienadas. Assim, além de causar vários entraves econômicos, a impossibilidade de comercialização das terras também estimulava o sonho da propriedade. E este era um dos itens prometidos pela Coroa Portuguesa àqueles que viessem para o Brasil. Além disso, os abalos sísmicos, aliados aos constantes períodos de escassez de alimento, estimularam a emigração (CARUSO, 1996: 61).

Agricultores e pecuaristas, os açorianos trouxeram na bagagem muitas técnicas que foram adaptadas às condições físicas, à fauna e à flora do litoral catarinense. Entre essas podemos citar os engenhos de farinha de trigo (que passaram a processar a mandioca produto base da alimentação indígena) e de cana, ainda hoje comuns na região.

“(...) o know-how dos açorianos estava adiante nas técnicas de moagem de cereais $\mathrm{e}$ processamento de outras matérias primas. Não lhes foi difícil assimilarem e aperfeiçoarem técnicas de redução da mandioca, transformação da cana-de-açúcar, do cultivo de tubérculos e algumas hortaliças, mais tarde de café sombreado, de aproveitamento de duras madeiras da biodiversidade florística das encostas e baixadas para nascentes indústrias de construção náutica, de confecção de carroças, estábulos (...)" (SANTOS, 2000: 76) 
Exímios pescadores em profundidade e com experiência na caça de baleias, devido às características físicas do Arquipélago, introduziram também técnicas de construção de barcos mais ágeis e fortes (lanchas baleeiras) e de redes para pesca (tresmalhas). Foram os açorianos os responsáveis pelas primeiras armações (local de caça e processamento dos produtos provenientes de baleias) no sul do país.

"As relações com o mar foram se ampliando, da técnica de coleta e de rudimentares armadilhas para a captura de crustáceos e peixes, graças aos meios de locomoção como canoas e as mais resistentes baleeiras, as redes de fibra de algodão, anzóis e arpões inicialmente importados. A caça de mamíferos aquáticos, baleias, que eram abundantes nestas latitudes, tornou-se o primeiro grande negócio relacionado aos recursos marinhos, acionado por empresa que apenas utilizou o estoque açoriano e afro-brasileiro como mão-de-obra.” (SANTOS, 2000: 77) 


\section{PRINCIPAIS FATOS HISTÓRICOS, TRADIÇÕES E COSTUMES DOS LOCAIS PESQUISADOS}

\subsection{A ANTIGA ENSEADA DE ITAPOCORÓI}

Situada na bacia hidrográfica do Vale do Rio Itajaí, no litoral norte do Estado de Santa Catarina, a antiga região da enseada de Itapocorói compreende hoje a área de três municípios: Penha, Balneário de Piçarras e uma pequena parte do sul de Barra Velha:

"Levando em conta que as águas de Itapocorói são as mesmas que banham Piçarras, e que a enseada no seu todo forma um baía que tem a outra margem em Itajuba e Barra Velha, podemos dizer que toda a região era um só lugar. À medida que as comunidades iam crescendo, como forma de identificação, foram se qualificando de acordo conforme alguns marcos naturais. Por exemplo, Itajuba é pela cor amarela e branca das pedras do costão que se destacam entre as demais de cor escura. (...) Penha = pedra, penhasco, topônimo de muitos lugares, inclusive em homenagem à virgem Maria, escolhida como padroeira da freguesia. (...) Piçarras, pela qualidade do solo, uma mistura de areia e argila chamada piçarro, muito própria para fazer trabalhos de cerâmica." (BERSI DE SOUZA, 2000: 26)

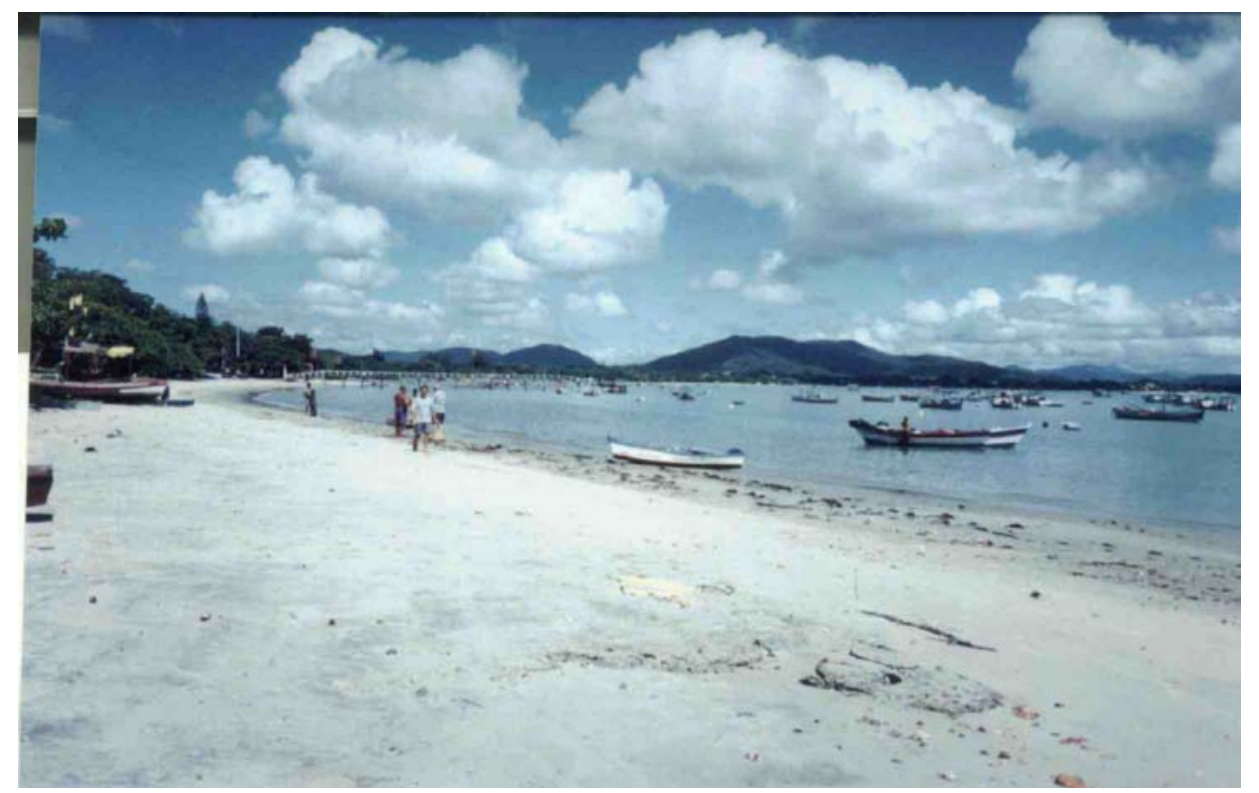

Praia de Itapocorói - Penha. (foto do arquivo da pesquisadora, janeiro de 2003) 
Apesar de a maioria das fontes pesquisadas se referir à região como Itapocorói, muitos dos moradores, principalmente os mais antigos, a denominam Itapocoroí ${ }^{8}$. Aparecem grafadas também, em textos históricos, as formas Itapocoroy, Itapocoróy e Itapocoróia. Como não há consenso, foi adotada neste trabalho a forma Itapocorói.

Quanto à etimologia de Itapocorói, há poucos indícios que a esclareçam. Para August de Saint' Hilaire:

“(...) escrevo Itapocoróia, porque assim que esse nome é pronunciado no lugar. Em outros autores encontram-se "Itapocoróia, Itapocoróya, Itapocorói e Itapocoroy". O nome parece derivar do guarani "Itapocorá", (parecido com um muro de pedra)." (SAINT-HILAIRE, 1936: 160)

A enseada de Itapocorói está entre as três localidades mais antigas do litoral catarinense, juntamente com a Ilha de Nossa Senhora do Desterro (hoje Florianópolis) e com a região de Nossa Senhora das Graaças do rio São Francisco (hoje São Francisco do Sul).

A primeira informação sobre a presença européia na região, registrada pela história, na Enseada data de 1715, quando Manoel Gonçalves de Aguiar, um sargento-mor português, desembarcou nas praias de Itapocorói e seguiu a pé até Nossa Senhora das Graaças do Rio São Francisco (FARIAS, 2000: 133).

A antiga região de Itapocorói era passagem obrigatória para aqueles que se deslocavam pelo litoral catarinense. Desde a metade do século XVII, quando foram fundadas as cidades conhecidas hoje como São Francisco do Sul e Florianópolis, a região de Itapocorói funcionava como passagem entre elas. As viagens por terra eram extremamente penosas, pois o rio Itajaí-Açu era um obstáculo natural. O mais comum era deslocar-se de barco de Desterro até Itapocorói, depois, prosseguia-se até São Francisco de barco ou por terra, e vice-versa (SILVA, s/d: 07).

Até por volta da segunda metade do século XVIII, a exígua população que habitava os pontos do litoral catarinense acima citados era formada por vicentistas (portugueses oriundos da região de São Vicente, litoral do atual Estado de São Paulo) e grupos indígenas.

Com a invasão espanhola na Ilha de Santa Catarina, em 1777, cerca de 100 açorianos mudaram-se para a enseada de Itapocorói, especificamente onde hoje é a praia de mesmo nome, na cidade de Penha. Devido às boas condições físicas do local, uma proteção natural contra os ventos

\footnotetext{
${ }^{8}$ Tal pronúncia é notada pela pesquisadora em conversas informais com moradores mais antigos da região.
} 
sul e norte, foram instaladas armações lá. Assim, surgiu o arraial de Itapocorói (SOUZA \& SERPA FILHO, 1995: 22).

"Entre 1748 e 1756 vieram para o litoral catarinense mais de 5 mil açorianos, especialmente para a Ilha de Santa Catarina, hoje Florianópolis. Foi nessa época que, fugindo do ataque de piratas e espanhóis que cerca de 100 açorianos saíram de Armação de Piedade e fundaram Armação de Itapocorói, no atual município de Penha, juntamente com padres jesuítas."

\section{$[\ldots]$}

"Na época, entre outras utilidades do óleo do mamífero, a principal era a iluminação pública, queimando nas lamparinas. A região de Itapocorói, em Armação, era considerado o maior celeiro de baleias de Santa Catarina." 10

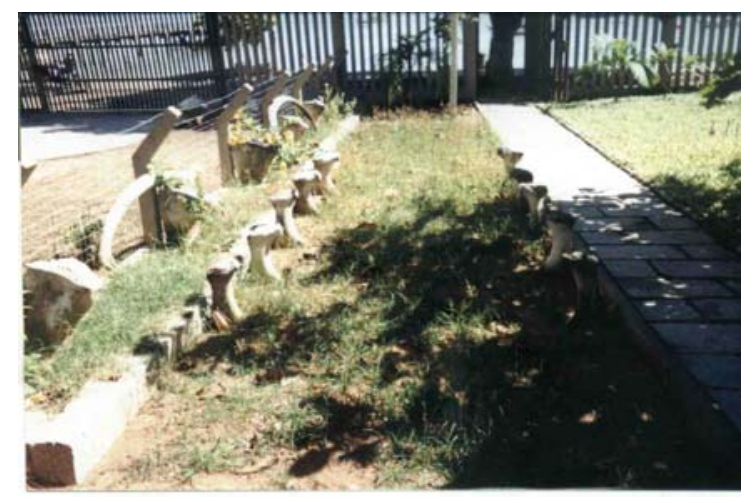

Entrada do Museu Porto Amado, feita com ossos de baleia - Penha.

(foto do arquivo da pesquisadora, janeiro de 2003)

É preciso lembrar que a região já possuía um número razoável de habitantes para a época; pois, em 1759 a Cúria Metropolitana do Rio de Janeiro autorizou a construção da capela de São João Batista no local. Esta, feita com óleo e ossos de baleia em sua estrutura, ainda permanece em sua forma original (SOUZA \& SERPA FILHO, 1995: 21).

Igreja de São João Batista - Penha

(foto do arquivo da pesquisadora,

\footnotetext{
${ }^{9}$ JORNAL DE SANTA CATARINA, Colonização açoriana.

${ }^{10}$ JORNAL DE SANTA CATARINA, Colonização açoriana.
}

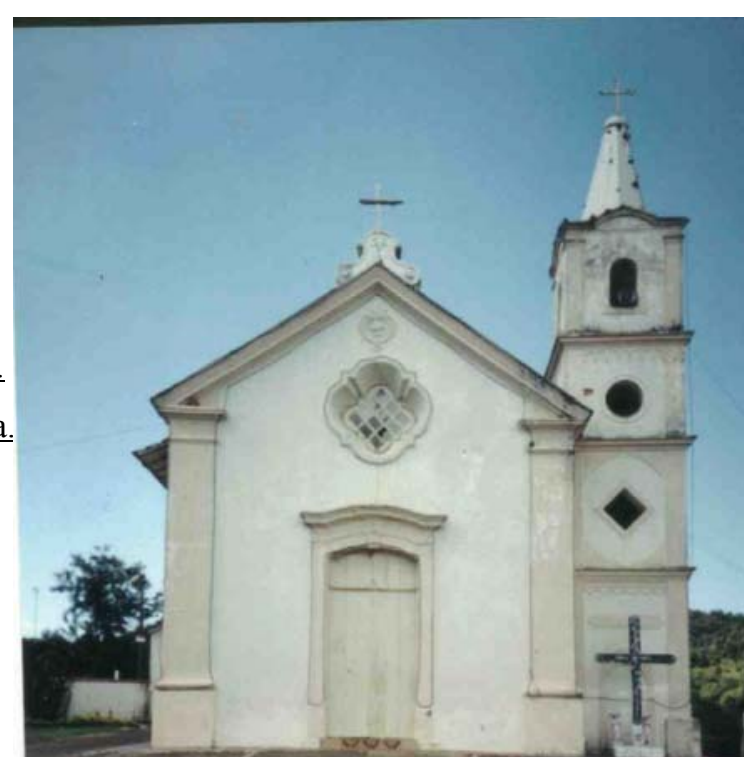


janeiro de 2003)

Passando a ser conhecida como Armação de Itapocorói, a região conheceu um longo período de prosperidade. O beneficiamento dos produtos da baleia, principalmente o óleo, trouxe riquezas para um local que chegava, em uma temporada de três meses, a caçar 100 baleias (SOUZA \& SERPA FILHO, 1995: 22).

Nos séculos XVIII e XIX outros açorianos foram se instalando na região.

"Destaca-se no período como equipamento de maior expressão a Armação Baleeira de Itapocorói, fundada na segunda metade do século XVIII. No final do Século XVIII tem início o processo de expansão dos descendentes de açorianos em direção à região ao norte da Ilha de Santa Catarina. As comunidades de Bombinhas, Itapema, Balneário de Camboriú, Itajaí, Navegantes, Piçarras, Penha, Barra Velha e outras em torno foram ocupadas por estes povoadores resultantes da migração no próprio litoral catarinense."11

No começo do século XIX, quando a administração das armações de Itapocorói passou totalmente para as mãos de particulares e com a redução do número de cetáceos, a produção começou a entrar em um período de decadência, que, por extensão, atingiu todo o local.

"Fiz uma descrição detalhada da Armação de Itapocoróia, tal como era em 1820, e mostrei também como foi grande a diminuição havida na pesca entre 1777 e 1819. Já então era fácil prever que aquele estabelecimento e todos os seus congêneres não conseguiriam manter-se por muito tempo. Parece que eles duraram vários anos após a minha viagem, mas atualmente restam apenas alguns vestígios da Armação de Itapocoróia." (SAINT-HILAIRE, 1936: 163)

\footnotetext{
${ }^{11}$ JORNAL DE SANTA CATARINA, Colonização açoriana. Suplemento especial, novembro de 1997, p.1.
} 
Com o fim das armações, cerca da metade da população mudou-se para outras regiões. A mão-de-obra que ficou deslocou-se para outras formas de subsistência: a agropecuária e a pesca. $\mathrm{O}$ desenvolvimento de outras atividades de subsistência originou o arraial da Penha (a seis quilômetros do local das armações).

Foi no século XIX que as comunidades de Penha, Balneário de Piçarras e Itajuba (parte sul do atual município de Barra Velha) começaram a ganhar seus contornos. Em 1820 foi fundado o povoado de Sacramento (Itajaí) que passou, algum tempo depois, em 1859, a ser a sede Jurídica de, entre outras terras, a Armação de Itapocorói (HISTÓRIA DE SC, 1970: 48).

Em 1834 o arraial de Penha foi elevado à condição de Distrito Policial de São Francisco do Sul. Em 23 de março de 1839 foi fundada a Freguesia de Nossa Senhora da Penha do Itapocorói. Os primeiros dados populacionais da Penha ${ }^{12}$ são de 1840 , quando um levantamento realizado indicava o número de 1640 habitantes (FARIAS, 2000: 134).

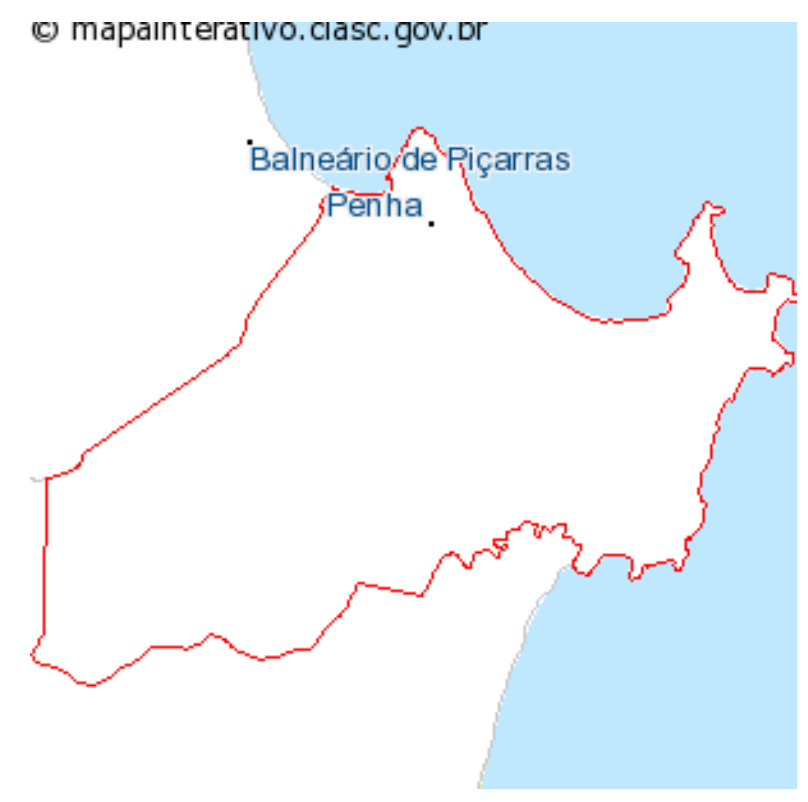

Em 1958 a Freguesia de Nossa Senhora da Penha tornou-se o município de Penha, data em que se iniciaram os movimentos de emancipação do Balneário de Piçarras ${ }^{13}$, que se tornou município em 1963. ${ }^{14}$

\footnotetext{
${ }^{12}$ MAPA: www.mapainterativo.ciasc.gov.br

${ }^{13}$ MAPA: www.mapainterativo.ciasc.gov.br

${ }^{14}$ http:// Wikipedia.org.wiki/Piçarras
} 


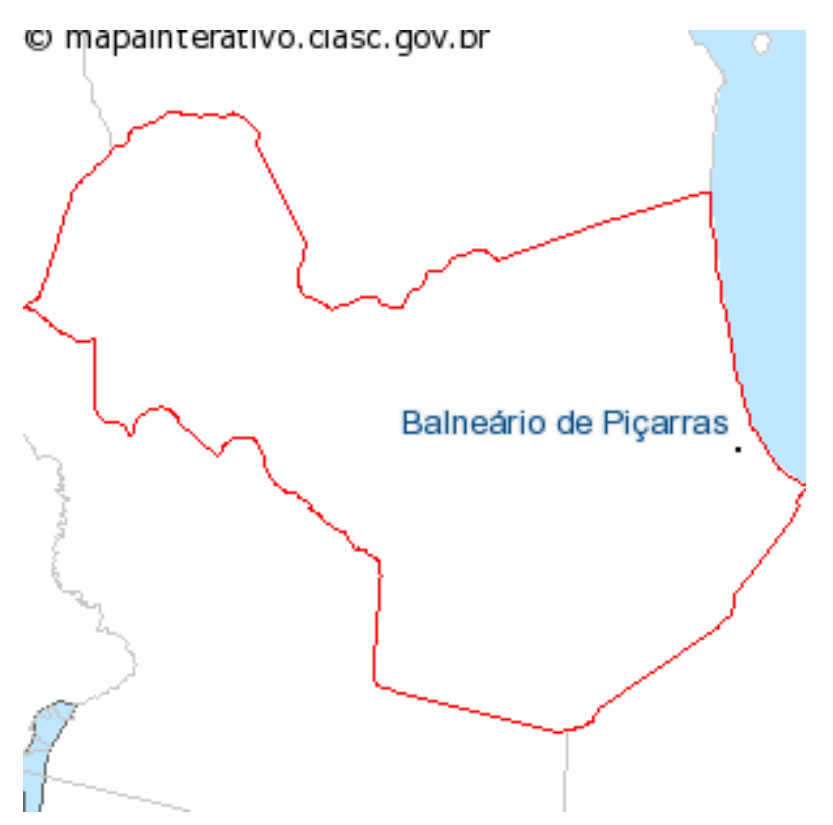

Já nessa época, Itajuba interagia muito mais com Barra Velha ${ }^{15}$, principalmente porque os pescadores da localidade estavam filiados à colônia de pescadores que pertence a Barra Velha, apesar de Itajuba estar mais próxima do Balneário de Piçarras.

"Penha ao longo dos seus mais de mais de 250 anos de história, teve um crescimento lento, fruto em parte, de ser um pólo irradiador de população. Os primeiros dados populacionais são de 1840, quando tinha 1.064 habitantes. No ano de 1866, sua população cresceu muito pouco, passando a 1.873 pessoas. No século atual, em 1920 tinha 4.830 habitantes, em 1970 passou a 7.502, atingindo no censo de 1996 um total de 15.490 habitantes. No entanto, como em outros municípios balneários, no período de janeiro a março esta população ultrapassa a 50.000 habitantes flutuantes."16

\footnotetext{
15 "Foi no final do século XVIII, que teve início o processo de migração dos descendentes de açorianos em direção à região do litoral norte de Santa Catarina. O Município de Barra Velha também recebeu estes povoadores, que tinham com principal ocupação a pesca da baleia. Os aspectos históricos do município tiveram início no século passado. Sua colonização se deve a uma gleba de terra doada pelo imperador Dom Pedro I ao português Joaquim Alves da Silva. Natural dos Açores, dedicou sua vida à pesca da baleia.” JORNAL DE SANTA CATARINA, Colonização açoriana. Suplemento especial, novembro de 1997, p.8.
}

${ }^{16}$ JORNAL DE SANTA CATARINA, Colonização açoriana. Suplemento especial, novembro de 1997, p.4. 
Hoje, Penha tem 20.063 habitantes e Piçarras tem 12.438. (censo de 2004) ${ }^{17}$. A principal fonte de renda é o turismo, que cresceu muito nos últimos dez anos após a inauguração do Beto Carrero World.

Ocupando uma área de 14 milhões de $\mathrm{m}^{2}$ o Beto Carrero World é o maior parque temático da América Latina e o quinto maior do mundo. Inaugurado no município de Penha em 28 de dezembro de 1991, atrai para esta cidade um enorme número de turistas vindos de todas as partes do Brasil e do Exterior. Além disso, também gera cerca de mil empregos diretos e seis mil indiretos. As cidades vizinhas também se beneficiam. É em Piçarras, para exemplificar, que está instalado o hotel oficial do parque ${ }^{18}$.

\subsection{SÃO FRANCISCO DO SUL}

A ilha de São Francisco está localizada no litoral norte do Estado de Santa Catarina, no qual se encontra a cidade histórica de São Francisco do Sul. Na parte continental, integrado ao município, encontra-se o Distrito do Saí.

“O município de São Francisco do Sul está localizado na microrregião de base cultural luso-açoriana do litoral norte de Santa Catarina: baía da Babitonga/rio Itapocu/Parati/baía de Itapocorói, a $215 \mathrm{~km}$ de Florianópolis, distante $35 \mathrm{~km}$ da BR 101”. (FARIAS, 2000: 117)

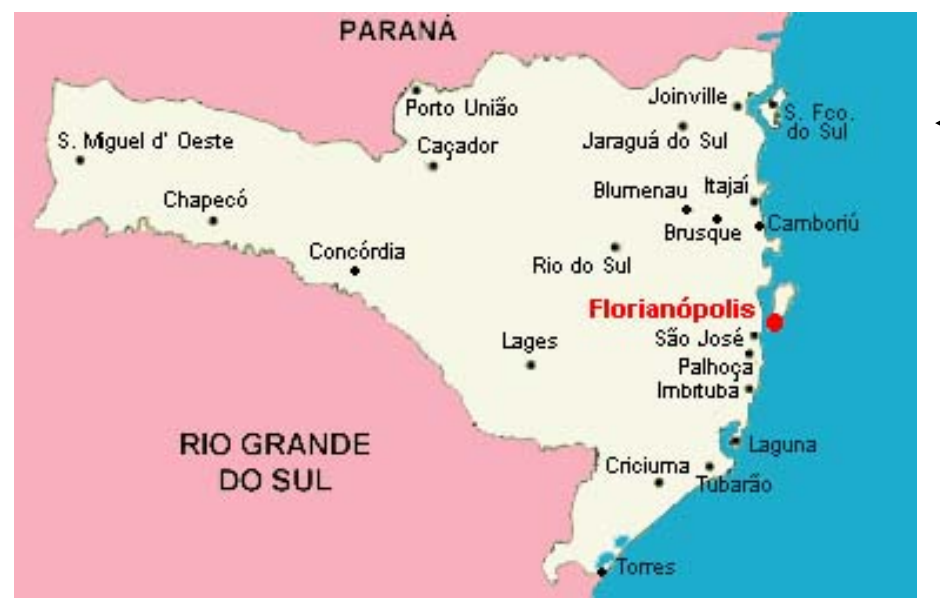

\footnotetext{
${ }^{17}$ http:// Wikipedia.org.wiki/Piçarras e http:// Wikipedia.org.wiki/Penha.

${ }^{18}$ SECRETARIA MUNICIPAL DE TURISMO, INDÚSTRIA E COMÉRCIO DE PENHA. Resumo Informativo, 2002.
} 


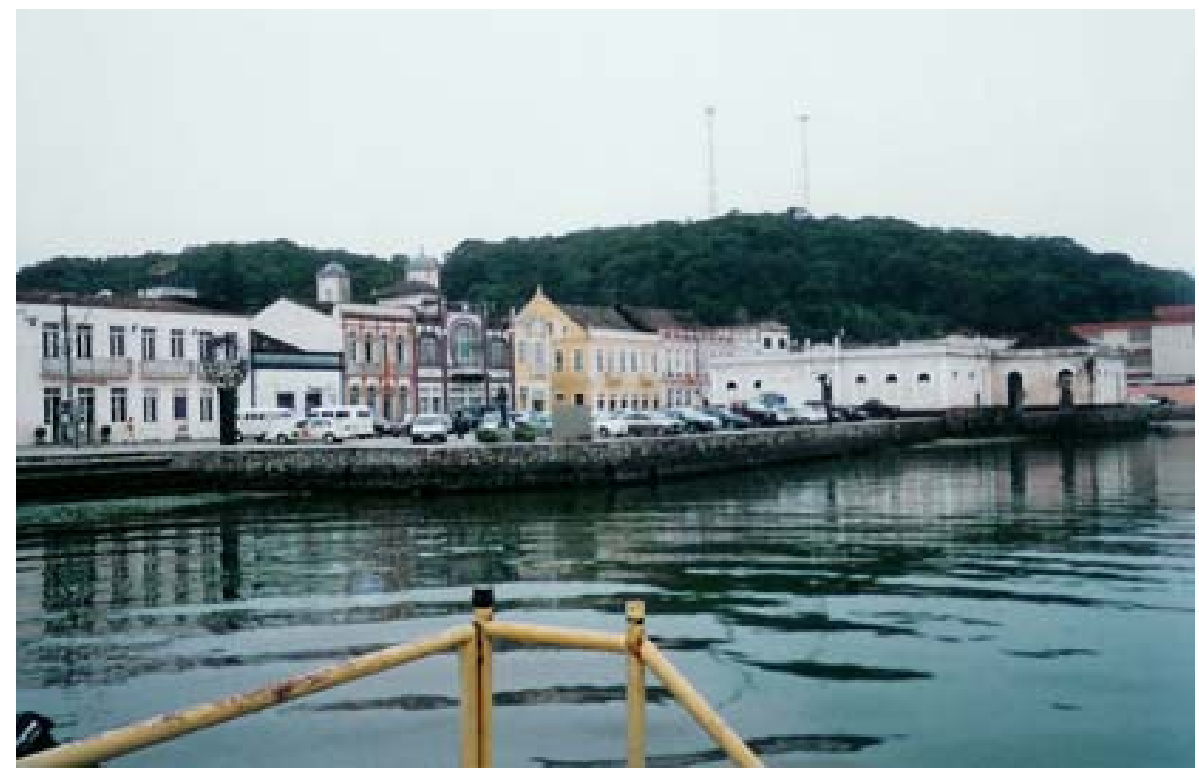

Baía da

Babitonga -

Centro Histórico

de São Francisco

do Sul.

(foto do arquivo

da pesquisadora,

julho de 2004)

O navegador espanhol Juan Dias de Sólis, ao passar pelo litoral sul do Brasil, em 1515, denominou a região em questão, em homenagem ao dia de São Francisco Xavier, de São Francisco. ${ }^{19}$

Já o nome Nossa Senhora das Graaças do Rio São Francisco originou-se do culto à Nossa Senhora da Graça, que na região de São Francisco é muito antigo. Conta-se que começou por meio do pagamento de uma promessa feita pelos ocupantes de um navio espanhol que enfrentava mau tempo em alto mar, em 1553. Os tripulantes, em sérias dificuldades, fizeram uma promessa à Nossa Senhora da Graça: se escapassem, construiriam uma capela na primeira terra firme que aportassem. A promessa foi cumprida e esta Santa passou a ser a padroeira da cidade ${ }^{20}$.

A denominação de São Francisco do Sul foi promulgada pelo decreto 238 de 18 de dezembro de 1938 (FARIAS, 2000: 118).

\footnotetext{
${ }^{19}$ Ilha encantada de São Francisco do Sul - Santa Catarina -Brasil, guia Cultural, 2000/2001.

${ }^{20}$ SECRETARIA MUNICIPAL DE TURISMO DE SÃO FRANCISCO DO SUL. Resumo informativo, 1996.
} 


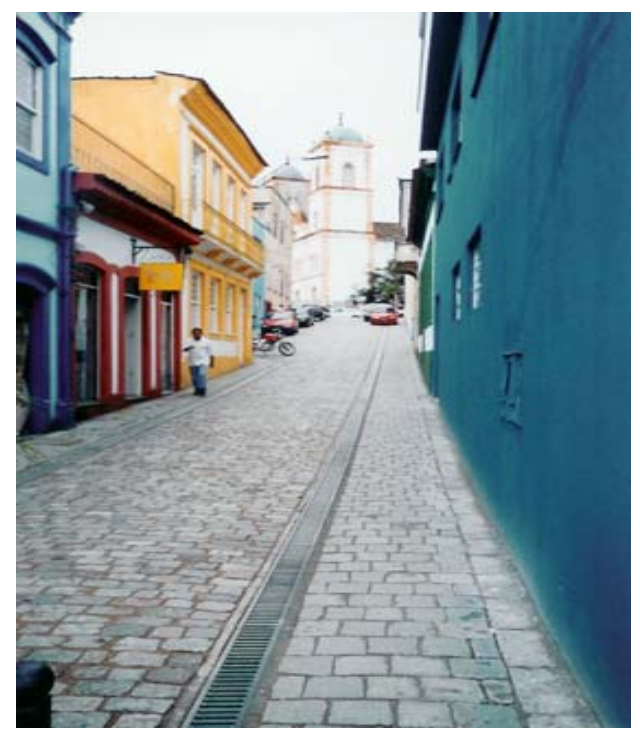

\author{
Vista parcial da Igreja Matriz \\ Nossa Senhora da Graça, construída em \\ 1699.
}

(foto do arquivo da pesquisadora, julho de 2004)

Primeiramente chegaram os franceses. A ilha de São Francisco foi o porto no qual encontrou abrigo a Expedição de Binot Paulmier de Gonneville, no ano de 1504, quatro anos somente após a data oficial do Descobrimento do Brasil ${ }^{21}$.

Essa expedição, financiada por comerciantes da Normandia (França), partiu do porto de Honfleur em 24 de julho de 1503, em busca das "Belas riquezas das Índias". A Nau "L' Espoir", desceu o Atlântico ao largo da África e perdeu a rota, aportando, em janeiro de 1504 em "terras desconhecidas", que, sabe-se hoje, era o litoral de Santa Catarina ${ }^{22}$.

O efetivo povoamento da região de São Francisco do Sul, iniciou-se em 1658, com Manoel Lourenço de Andrade, vicentista, que trouxe consigo, além de sua família, grande número de escravos, gados, instrumentos agrícolas e ferramentas para exploração de minas (CARUSO \& CARUSO, 2000: 80).

Na Carta Régia de 18/12/1656, com o nome de Nossa Senhora das Graaças do Rio São Francisco, a região foi promovida a freguesia. A povoação foi elevada à categoria de Vila em 1660. Em 1665 São Francisco do Sul foi elevada a Paróquia. Inicialmente, a Vila de São Francisco pertencia à Ouvidoria de Paranaguá (FARIAS, 2000: 119).

Após a criação da Ouvidoria de Santa Catarina, em 1729, iniciou-se um impasse que persistiu até 1831, quando São Francisco passou à Jurisdição de Santa Catarina. A elevação à categoria de cidade ocorreu em 15 de abril de 1847 (ALEXANDRE, 1972: 70).

\footnotetext{
${ }^{21}$ A NOTÍCIA (SC), E tudo começou há 500 anos. AN especial, 05/01/04, p.1.

${ }^{22}$ A NOTÍCIA (SC), E tudo começou há 500 anos. AN especial, 05/01/04, p.4.
} 
Com a construção da rede ferroviária, em 1905, a região teve um forte impulso de desenvolvimento. A importância dos trens para a economia de São Francisco se mantém até hoje, já que neles os produtos do município são transportados até o porto. Uma parte considerável da renda do município é proveniente da movimentação portuária. Atualmente, é o quinto porto do Brasil em movimentação de containers ${ }^{23}$.

O tombamento do centro histórico da cidade garantiu a preservação dos prédios e da arquitetura proveniente da colonização açoriana.

Cidade que valoriza sua memória, destacam-se: o Mercado Público Municipal (com mais de 100 anos), o Museu Histórico de São Francisco do Sul. O Museu do Mar e as ruínas do Leprosário. Em 23 de março de 1958 tornou-se município (ALEXANDRE, 1972: 71). Hoje, a população de São Francisco do Sul é de cerca de 40.000 mil habitantes ${ }^{24}$.
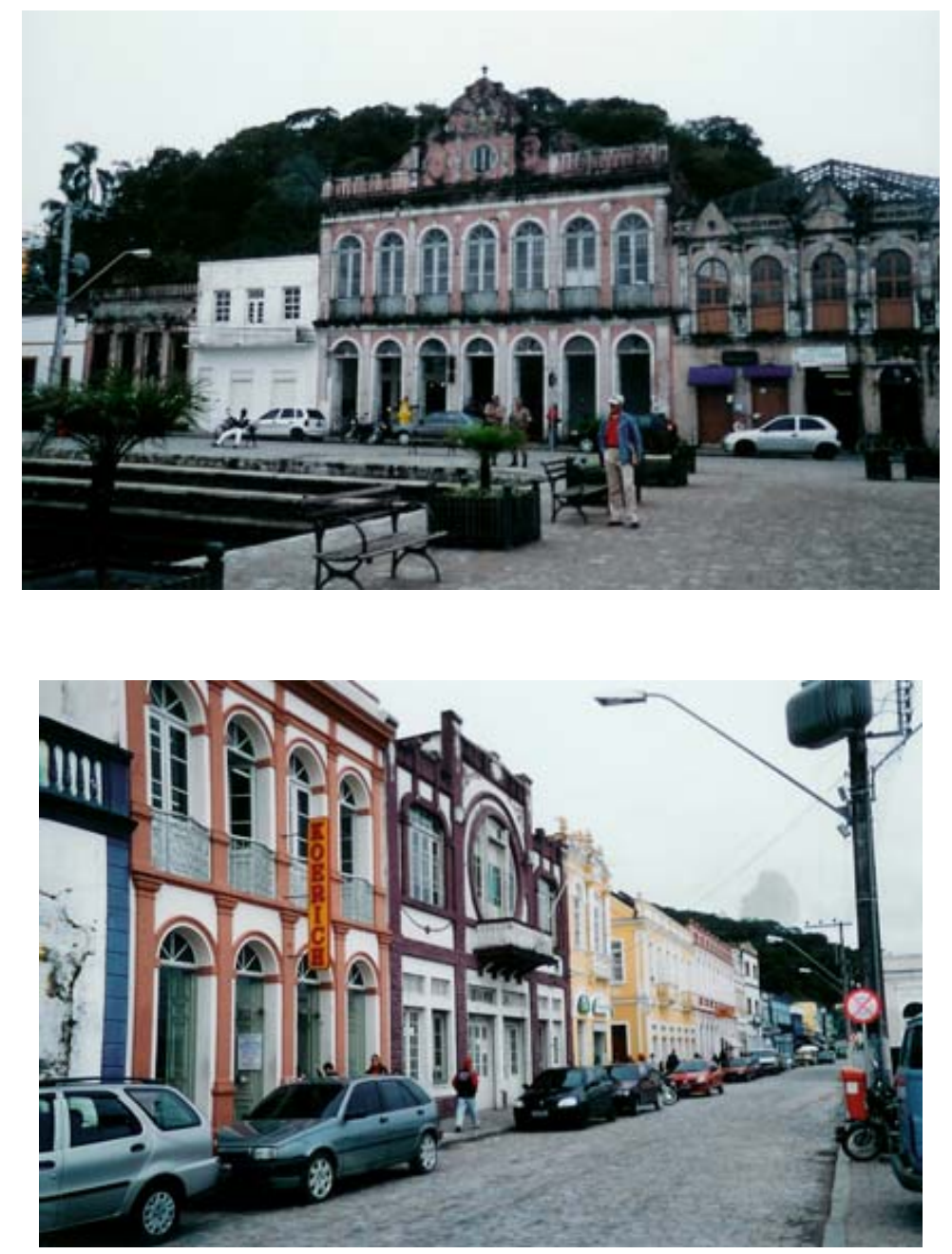

\footnotetext{
${ }^{23}$ SECRETARIA MUNICIPAL DE TURISMO DE SÃO FRANCISCO DO SUL. Resumo informativo, 1996.

${ }^{24}$ http:// Wikipedia.org.wiki/São_Francisco_do_Sul
} 
Vistas parciais do Centro Histórico de São Francisco do Sul.

(foto do arquivo da pesquisadora, julho de 2004)

Foram nos séculos XVIII e XIX que a região recebeu um grande número de açorianos. Estimulados pelas promessas realizadas pela coroa portuguesa, São Francisco do Sul foi um dos destinos possíveis para as pessoas provenientes dos Açores (FARIAS, 2000: 116 e 120).

"É importante registrar-se que a partir desses oito núcleos originais ${ }^{25}$ verificou-se a expansão da população de origem açoriana pelo território catarinense, num processo lento e seguro, que só se completou ao longo do século XX, após contribuírem na criação de dezenas de comunidades, muitas delas municípios, no litoral catarinense." (FARIAS, 2000: 116)

Em janeiro de 1842, chegaram ao Saí, atual Vila da Glória, um grupo formado por 100 franceses organizado pelo médico Benoit Jules Mure, fundador do Instituto Homeopático de Paris e do Instituto homeopático do Rio de Janeiro ${ }^{26}$.

"Esses franceses vieram para fundar um falanstério, tipo de sociedade baseada nas idéias de Fourier, francês nascido em Besançon no ano de 1772. Falanstério é uma organização comunitária baseada na igualdade, fraternidade e amor entre as pessoas, em que tudo o que se produz é dividido igualmente." (Andréa de Oliveira, 2004: 39)

A intenção dos franceses era fabricar uma série de produtos a vapor, porém, não havia saída para a produção. Buscou-se a agricultura como alternativa. Porém, essa não foi uma boa opção, pois eles não se adaptaram ao trabalho no campo. Com a chegada de outro grupo de franceses a comunidade se desentendeu e se desfez, sendo que apenas poucas famílias continuaram na região.

\subsection{AS TRADIÇÕES E OS COSTUMES}

\footnotetext{
25 “Lagoa da Conceição (1750), Enseada de Brito (1750), São Miguel (1752), Santo Antônio de Lisboa (1750), São José (1750), Vila Nova (1752), Desterro (1748-56) e Laguna (1748-56)”. (FARIAS, 2000: 115)

${ }^{26}$ INSTITUTO BRASILEIRO DE GEOGRAFIA E ESTATÍSTICA, São Francisco, SC, 1941.
} 
Em todo o litoral catarinense é possível encontrar reflexos dos costumes e das tradições ditas açorianas, em menor e maior grau dependendo da localidade: na religiosidade, nas festas, nas brincadeiras de criança, na alimentação, na pesca, entre outros.

"Fica assim registrada a face humana do 'estruturador do Brasil meridional', no episódio mais significativo de toda a imensa epopéia em que se constituiu a história dos Caminhos do Mar de Santa Catarina. Foram os açorianos que trouxeram as cores com que até hoje se diferencia o litoral catarinense, profundamente marcado por sua cultura e por suas tradições." ${ }^{27}$

Em seguida, falar-se-á um pouco sobre as consideradas principais tradições de base açoriana encontradas no litoral catarinense; sobretudo, na antiga região da Armação de Itapocorói e em São Francisco do Sul.

\subsubsection{Festas religiosas}

Católicos, os açorianos deixaram marcas de sua religiosidade em todo o litoral catarinense. De forma geral, ainda encontramos na atualidade três festas de cunho religioso de origem açoriana: Festa do Espírito Santo, Cantorias do Divino e a Pássio. Especificamente na região da Penha, Barra Velha e São Francisco do Sul preservam-se a Festa do Espírito Santo e as Cantorias do Divino em grupos restritos de moradores. Em Piçarras essas manifestações culturais já não são encontradas (FARIAS, 2001: 655).

Alguns historiadores alegam que as tradições acima citadas não são de origem açoriana, mas junção de costumes lusitanos e açorianos, como Luís Felipe Falcão, do Departamento de Estudos Geohistóricos da Udesc (Universidade do Estado de Santa Catarina):

"É um tanto difícil avaliar com precisão o significado da chamada "cultura açoriana" entre a população residente na faixa litorânea do estado de Santa Catarina, incluindo aí a região de Florianópolis. De imediato, pode-se afirmar que este assunto traz consigo várias dificuldades, como por exemplo distinguir hábitos e costumes já praticados anteriormente pelos vicentistas (como o uso da farinha de mandioca ou a construção de canoas) daqueles que teriam sido introduzidos pelos açorianos, ou como estimar e conceituar

\footnotetext{
${ }^{27}$ CAMINHOS DE SANTA CATARINA, Açorianos seguem a partir de 1747. 12/03/00, p.10.
} 
uma especificidade açoriana no contexto da cultura portuguesa (Uma outra cultura? Uma cultura regional?). ${ }^{28}$

Seja como for, em Florianópolis, por exemplo, a Irmandade do Divino Espírito Santo celebra a festa do Divino há cerca de 230 anos ${ }^{29}$ (data da vinda dos primeiros açorianos para o litoral catarinense).

É importante frisar também, que festas como as folias do Divino e do Boi de Mamão (outra festa típica do litoral catarinense cujas origens também são creditadas aos açorianos), trazem em si muitos elementos pagãos. Estes foram incorporados aos cultos religiosos para atrair o gentio na época da colonização.

A religião é um dos quesitos perguntados aos informantes desse trabalho ${ }^{30}$. Verificando as respostas, podemos confirmar o que muitos moradores apontam em conversas informais: nas últimas décadas, cresce cada vez mais o número de evangélicos.

Em relação aos trinta informantes de Itapocorói, 17 são católicos (57\%), 11 são evangélicos $(36,5 \%)$ e 02 consideram-se céticos (6,5\%). Apesar de o número de católicos ainda ser superior a $50 \%$ dos informantes, vemos que o número de evangélicos não é pequeno. Entre os mais velhos, o número de evangélicos rivaliza-se com o número de católicos: $50 \%$ cada. Em São Francisco do Sul temos 24 católicos (80\%), 5 evangélicos (17\%) e 1 cético (3\%). Na faixa $\mathbf{C}$ todos os informantes são católicos.

\subsubsection{As brincadeiras de criança}

Foi possível perceber, através dos informantes, que muitas das brincadeiras populares da infância de avós e pais não fazem mais parte do cotidiano das crianças.

A questão 16 do questionário lingüístico teve como objetivo verificar se os informantes conheciam o bodoque (objeto distinto do estilingue, que se usa para atirar pedras e é parecido com um arco). Entre os vinte informantes da faixa $\mathbf{A}$ - até vinte anos - só dois o conheciam, ambos de Itapocorói. O resultado indica que esse objeto, de certa forma, não faz mais parte da realidade (o que inclui a realidade lingüística) da faixa $\mathbf{A}^{31}$.

\footnotetext{
${ }^{28}$ DIÁRIO CATARINENSE, De uma ilha a outra. Especial Açores - Santa Catarina, 05/03/96, p.11

${ }^{29}$ DIÁRIO CATARINENSE, Uma tradição de dois séculos: festa do divino. 25/05/96, p.29.

${ }^{30}$ Anexo 1.

${ }^{31}$ Parte 3. Capítulo 2.
} 
Mas, segundo FARIAS (1998), ainda permanecem algumas denominações de brincadeiras ditas como de base cultural açoriana como a pandorga ${ }^{32}$ (pipa), a peca (bolinha de gude) e a funda (estilingue). Tanto a peca como a funda foram objetos de pergunta no questionário lingüístico nas questões 39 e 40, respectivamente. Em ambas, todos os informantes (com exceção de um informante da faixa $\mathbf{A}$ na questão 15) conheciam o objeto e afirmaram já ter brincado com ele alguma vez.

Portanto, apesar do número de informantes ser muito pequeno, se comparados ao número de habitantes, essa amostragem é capaz de refletir o atual conhecimento de mundo dessas comunidades e suas realidades lingüísticas.

\subsubsection{O Pasquim}

O pasquim é tido como uma das tradições açorianas que se mantém viva no município de Penha.

"O pasquim foi e ainda é um dos meios de comunicação apócrifos (sem autor confesso) que proporciona às comunidades uma forma de comunicação escrita espontânea. Surgiam os manuscritos repentinamente, por baixo de portas ou fixados em locais públicos, sempre que um assunto (fofoca) envolvesse alguém da comunidade. Os boatos e as gozações se espalhavam rapidamente, sem que se identificasse a fonte dos mesmos, para desespero dos envolvidos." (FARIAS, 1998: 331)

O último pasquim que veio à tona no município, em 2001, conta a história de "um morto que não morreu", isto é, o caso extremamente polêmico de um habitante que sumiu e depois reapareceu. O fato ocorreu em 2001 e envolveu muitos moradores da cidade. O pasquim, por ser um texto escrito que carrega muitos traços de oralidade, é um bom retrato da variante em estudo, principalmente no que se refere ao léxico ${ }^{33}$. Saiu em partes por quase dois meses, de autoria desconhecida e foi deixado nos pontos de grande circulação de pessoas (prefeitura, igrejas, praças, hospitais, comércios). Um dos informantes da Antiga região de Itapocorói (5CI) também recita, de cor, dois pasquins em sua fala espontânea.

\subsubsection{A farra do boi}

\footnotetext{
${ }^{32}$ Termo encontrado em FARIAS (1998). Não apareceu nenhuma vez nos corpora, apenas a forma pipa.

${ }^{33} \mathrm{O}$ pasquim em questão está em íntegra no ANEXO 3.
} 
Típica nos Açores no século XVIII, espécie de tourada improvisada praticada por todas as classes sociais, a brincadeira envolvendo "touro bravo" era realizada em datas comemorativas como o Natal, Páscoa e em dias de Santo. O boi destinado para o abate, se arisco, era solto para que fizesse a diversão dos presentes. Apesar da proibição da Igreja, até hoje podemos encontrar esse tipo de manifestação popular na ilha Terceira do Arquipélago ${ }^{34}$.

Por mais de 230 anos, a brincadeira de "boi-de-campo" ou "boi-na-vara", popularmente conhecida como "farra do boi" para o restante do país, foi realizada em inúmeros lugares de Santa Catarina. As brincadeiras ocorrem principalmente no litoral de influência açoriana, como, por exemplo, a cidade de Penha. Nas últimas décadas, grupos de moradores e de defesa dos animais pressionam os farristas para que a brincadeira seja extinta ${ }^{35}$.

Mais do que a segurança do animal, o que está em questão é, em realidade, o choque cultural entre os locais e a população recém-chegada de outras regiões. Principalmente a partir da década de 70, o litoral catarinense está sofrendo uma rápida urbanização por causa da construção da BR 101, da UFSC (Universidade Federal de Santa Catarina), da vinda de inúmeras empresas nacionais e estrangeiras, da construção do parque Beto Carrero World.

Adventos como os citados trouxeram para a região muitas pessoas de outras partes do país. O que para os moradores locais é visto como tradição, para os que são provenientes de outros lugares acaba sendo apenas violência.

\subsection{PRINCIPAIS MUDANÇAS HISTÓRICAS, POLÍTICAS E SOCIAIS}

Nas últimas décadas, há um crescente aumento por parte de estudiosos, órgãos públicos e moradores em entender e preservar a suposta cultura açoriana. Entre as muitas iniciativas, podemos citar: o núcleo de estudos açorianos da UFSC (Universidade Federal de Santa Catarina), a AÇOR (festa da cultura açoriana de Santa Catarina, promovida anualmente) e os inúmeros grupos de foliões do Divino, de Reis e do Boi de mamão.

“A Universidade Federal de Santa Catarina, através do Núcleo de Estudos açorianos, à frente deste processo de retomada cultural, tem conseguido mobilizar o litoral catarinense em torno de seus valores. $\mathrm{O}$

\footnotetext{
${ }^{34}$ DIÁRIO CATARINENSE, Tradição é ameaçada pela polêmica. 03/04/94, p.32.

${ }^{35}$ DIÁRIO CATARINENSE, Tradição é ameaçada pela polêmica. 03/04/94, p.31.
} 
orgulho, reprimido pela simplicidade do povo, revelou-se altivo, ao sentir ameaçados os valores culturais "do saber ser e saber fazer de base açoriana”." Vilson Francisco de Farias ${ }^{36}$

Foi em 1948, no $1^{\circ}$ Congresso de História Catarinense, que começaram a aparecer trabalhos mais aprofundados, mostrando a influência açoriana no folclore de Santa Catarina. Nessa época, o resgate e o reconhecimento das raízes açorianas intentava mostrar que a "perigosa" influência alemã era "incipiente" no estado. Em realidade, devido aos conflitos gerados pela II Guerra Mundial, parecia haver em Santa Catarina, (o estado que mais recebeu imigrantes alemães) uma vontade de rechaçar quaisquer indícios da cultura alemã presente ${ }^{37}$. É preciso frisar que há cidades de colonização basicamente alemã em Santa Catarina, principalmente no interior do Estado, como Blumenau, São Bento do Sul e Schroeder.

Também já havia certa rivalidade no que se refere às raízes da colonização: o litoral (colonizado, em sua maioria, por açorianos) pouco industrializado e o interior (colonizado, em sua maioria, por alemães e italianos) industrializado e mais rico.

Outro motivo que impulsionou os estudos açorianos foi a consciência da crescente perda motivada pelo semi-isolamento a que essas comunidades litorâneas foram expostas a partir da década de 60, com exceção das áreas portuárias de Itajaí e São Francisco do Sul, que receberam sempre um grande fluxo de pessoas.

“A situação de semi-isolamento, em que viveram as comunidades de base cultural açoriana até o início da década de 60 do século atual, favoreceu a permanência dos valores culturais trazidos dos Açores, ainda hoje, em grande parte intactos. Pressionada nos últimos 30 anos, por hábitos culturais introduzidos pelos turistas (gaúchos, paulistas, platinos) e pela mídia, esta população desorganizou-se culturalmente, criando-se perigoso vazio cultural, notadamente no campo das manifestações folclóricas. Vilson Francisco de Farias $^{38}$

\footnotetext{
${ }^{36}$ A NOTÍCIA (SC), Açorianos em SC. 15/09/94, p.2.

37 "O objetivo de resgatar o papel do açoriano em Santa Catarina escondia várias intenções subjacentes, como confessou o professor Manuel de Paiva Boléo, da Faculdade de Letras da Universidade de Coimbra, presente no $1^{\circ}$ Congresso: "Esse resgate constitui uma necessidade no Estado de Santa Catarina, onde a cultura luso-brasileira perigosamente enfrentou a cultura alemã " E prossegue: "A finalidade suprema dessa busca, embora não expressa, era a de demonstrar para os outros Estados da União, a brasilidade de Santa Catarina."” DIÁRIO CATARINENSE, $\underline{\mathrm{A}}$ cultura açoriana é realmente dominante na Ilha? Especial Açores, Ponto de Vista, 05/03/96, p.10.

${ }^{38}$ A NOTÍ́CIA (SC), Açorianos em SC. 15/09/94, p.2
} 
Assim como visto acima em relação à farra do boi, a industrialização, a televisão e o contato com outras culturas expuseram essas comunidades a outros hábitos e costumes. A explosão demográfica, causada pela vinda de pessoas de outros locais, em muitas comunidades de crescimento lento, como a maioria do litoral, também foi outro contribuinte. Para exemplificar, podemos usar a folia de Reis: enquanto um participante mais velho a contempla com fé, por ser uma das formas de manifestar sua religiosidade e da comunidade, um jovem já a contempla, apenas com curiosidade, com estranheza, pois para ele se perdeu o significado original da festa: o religioso. Se antes a Folia era espontaneamente organizada e envolvia toda a comunidade, hoje ocorre por incentivo do Estado, por meio das escolas (com exceção de grupos folclóricos que procuram manter as raízes locais).

Portanto, estamos diante de um momento histórico marcado por mudanças no modo de ver e sentir o mundo. Na região da Armação de Itapocorói, essas transformações se aceleraram ainda mais com a instalação do parque Beto Carrero World. E, todo esse processo também pode ser sentido através da variante lingüística usada pela comunidade em questão, como veremos nas Análises Lingüísticas. 


\section{PARTE 2 - TRABALHO DE CAMPO}

\subsection{A CARACTERIZAÇÃO DOS INFORMANTES}

Para que fosse possível fazer qualquer comparação entre as duas localidades pesquisadas, a região de Itapocorói e São Francisco do Sul, a metodologia para a coleta de dados foi a mesma. Após uma conversa inicial entre a pesquisadora e o informante, era gravada a fala espontânea, posteriormente, eram aplicadas as perguntas dos questionários. As fichas de identificação dos informantes eram preenchidas no final da entrevista. Há uma equivalência entre o número de informantes gravados. Os questionários aplicados também foram os mesmos.

Os sessenta informantes, trinta de cada localidade ${ }^{39}$, foram selecionados de acordo com as seguintes parâmetros: faixa etária, local de nascimento e o fato de nunca se afastarem dos locais da pesquisa por muito tempo. Dados como nome completo e endereço, foram coletados, mas serão omitidos no anexo.

Os informantes, de acordo com a faixa etária, foram divididos em três grupos: A, B e C. O grupo A com os informantes de até vinte anos. O grupo $\mathbf{B}$ de vinte a cinqüenta e cinco anos. O grupo C com os informantes com mais de cinqüenta e cinco anos. ${ }^{40}$

Os informantes são identificados através de suas iniciais. A faixa etária a qual pertencem vem assinalada por meio das siglas A, B e C, respeitando, respectivamente, a divisão dada anteriormente. Os informantes foram numerados pela idade, em ordem crescente. Para que não haja mistura entre os dados colhidos em São Francisco do Sul e Itapocorói, usaremos para os informantes de Itapocorói a maiúscula I após a sigla que assinala a faixa etária.

\footnotetext{
39 A escolha de trinta informantes por localidade pautou-se: na quantidade de critérios e parâmetros utilizados na pesquisa e na grande variação lingüística existente na região (fato que motivou a pesquisa em questão). Geralmente, os trabalhos na área de Dialetologia apresentam um número reduzido de informantes. Porém, neste ponto aproximamos, guardadas as devidas proporções, nosso trabalho ao do Projeto Vertentes, que trabalha com um número maior de informantes: 12 por localidade - em que o número de habitantes é bem menor ao das regiões aqui estudadas. "Pela lei dos grandes números, sabe-se que, até certo ponto, a probabilidade de que os resultados sejam fidedignos é diretamente proporcional ao tamanho da amostra." (OLIVEIRA e SILVA, 2003: 119)

${ }^{40}$ Que acreditamos ser formado por aqueles que preservam os traços lingüísticos mais antigos, anteriores à divulgação de meios de comunicação como rádio e televisão nas regiões consideradas.
} 
Deu-se prioridade aos falantes que nasceram nas regiões pesquisadas, cujos pais também nasceram. Dos trinta informantes de Itapocorói, quatro não se encaixam nesse quesito. Três deles, 6AI, 3BI e 5BI, embora tenham nascido em outras localidades (Joinville e Itajaí) foram ainda na infância para a região. O informante 3CI mora há mais de trinta anos na localidade, mas viveu muito tempo em Florianópolis. Como Florianópolis é, juntamente com a enseada de Itapocorói, uma das três regiões mais antigas de Santa Catarina de colonização açoriana, o informante foi considerado.

Dos trinta informantes de São Francisco do Sul, seis não se encaixam nesse quesito. $\mathrm{O}$ informante 1C nasceu em Barra Velha e os informantes 5C e 7C em Penha (ambos pertencem a antiga enseada de Itapocorói). Os informantes 2A, 1B e 4C, embora tenham nascido em outras localidades (Tubarão e Joinville), foram ainda na infância para a região, além de possuir ao menos um dos pais oriundos de São Francisco do Sul.

A maioria dos falantes nunca saiu das áreas em questão; exceto para curtas viagens às cidades vizinhas. Os informantes 2BI, 8BI, 10BI, 1CI e 10CI moraram em outras localidades por um período inferior a dois anos. Os informantes 8AI, 10AI e 7BI moraram alguns anos em São Francisco do Sul. Como a antiga região de Nossa Senhora das Graaças do Rio São Francisco (São Francisco do Sul) é uma das três regiões mais antigas do Estado, também de colonização açoriana, os informantes foram considerados.

Grande parte dos informantes de São Francisco do Sul nunca saiu da região; exceto para curtas viagens às cidades vizinhas. Os informantes 5B, 7B, 8B, 9B, 5C e 8C moraram em outras localidades por um período inferior a um ano.

Os informantes da antiga região de Itapocorói

\begin{tabular}{|l|l|l|l|}
\hline INFORMANTES & INICIAIS & IDADE & Data da entrevista \\
\hline 1 AI & L.F.Q. & 08 & 23.07 .2002 \\
\hline 2 AI & P.G.P. & 11 & 23.07 .2002 \\
\hline $3 A I$ & G.A.C.S. & 11 & 25.07 .2002 \\
\hline $4 A I$ & J.B. & 12 & 22.07 .2002 \\
\hline $5 A I$ & R.H.C. & 13 & 18.07 .2002 \\
\hline 6 AI & K.S. & 14 & 22.07 .2002 \\
\hline 7 AI & B.H.S. & 14 & 18.07 .2002 \\
\hline 8AI & H.G.R. & 14 & 20.07 .2002 \\
\hline
\end{tabular}




\begin{tabular}{|c|c|c|c|}
\hline 9AI & C.R.M. & 16 & 22.07 .2002 \\
\hline 10AI & P.N.R. & 16 & 20.07 .2002 \\
\hline 1BI & F.M.A. & 21 & 17.07 .2002 \\
\hline 2BI & A.P. & 23 & 23.07 .2002 \\
\hline 3BI & L.L.S. & 23 & 18.07 .2002 \\
\hline 4BI & L.A.S. & 40 & 20.07 .2002 \\
\hline 5BI & H.S. & 42 & 19.07 .2002 \\
\hline 6BI & J.P.M. & 42 & 18.07 .2002 \\
\hline 7BI & L.A.R. & 42 & 18.07 .2002 \\
\hline 8BI & E.S.G. & 43 & 21.07 .2002 \\
\hline 9BI & M.A.I. & 44 & 21.07 .2002 \\
\hline 10BI & M.G. & 52 & 21.07 .2002 \\
\hline 1CI & C.F.A. & 68 & 21.07 .2002 \\
\hline $2 \mathrm{CI}$ & J.J.A. & 71 & 25.07 .2002 \\
\hline 3CI & G.A.F. & 72 & 25.07 .2002 \\
\hline 4CI & M.A.C. & 78 & 21.07 .2002 \\
\hline 5CI & J.A.A. & 78 & 21.07 .2002 \\
\hline 6CI & G.P.A. & 80 & 27.07 .2002 \\
\hline 7CI & E.M.S. & 81 & 21.07 .2002 \\
\hline 8CI & T.M.A. & 81 & 26.07 .2002 \\
\hline 9CI & A.L.P. & 82 & 19.07 .2002 \\
\hline 10CI & J.A.A. & 83 & 2107.2002 \\
\hline
\end{tabular}

Os informantes de São Francisco do Sul

\begin{tabular}{|l|l|l|l|}
\hline INFORMANTES & INICIAIS & IDADE & Data da entrevista \\
\hline 1A & B.L.M.C. & 08 & 19.07 .2004 \\
\hline $2 A$ & T.S.M. & 10 & 19.07 .2004 \\
\hline 3A & D.A.F. & 11 & 21.07 .2004 \\
\hline 4A & T.A.M. & 11 & 19.07 .2004 \\
\hline 5A & B.P. & 13 & 16.07 .2004 \\
\hline 6A & F.S.G & 13 & 16.07 .2004 \\
\hline
\end{tabular}




\begin{tabular}{|c|c|c|c|}
\hline $7 \mathrm{~A}$ & B.M.S. & 14 & 16.07. 2004 \\
\hline $\mathbf{8 A}$ & D.P.F. & 16 & 21.07 .2004 \\
\hline 9A & F.C.M. & 17 & 16.07. 2004 \\
\hline 10A & G.S.O. & 20 & 16.07 .2004 \\
\hline 1B & M.S. & 30 & 17. 07. 2004 \\
\hline 2B & M.F.C. & 33 & 17.07. 2004 \\
\hline 3B & A.A.P. & 35 & 20.07. 2004 \\
\hline 4B & M.B.C. & 36 & 16.07. 2004 \\
\hline $5 B$ & P.F.J. & 38 & 19.07. 2004 \\
\hline 6B & E.L.G. & 46 & 17. 07. 2004 \\
\hline 7B & J.O.M. & 49 & 18.07. 2004 \\
\hline 8B & C.F.P. & 52 & 18. 07. 2004 \\
\hline 9B & J.T. & 54 & 18. 07. 2004 \\
\hline 10B & J.J.A. & 55 & 18. 07. 2004 \\
\hline $1 \mathrm{C}$ & J.F.B. & 60 & 21.07 .2004 \\
\hline $2 \mathrm{C}$ & O.P. & 62 & \begin{tabular}{|l|}
16.07 .2004 \\
\end{tabular} \\
\hline $3 \mathrm{C}$ & F.D.O. & 66 & 21.07 .2004 \\
\hline $4 C$ & A.B. & 68 & 21. 07. 2004 \\
\hline $5 C$ & A.F. & 71 & 20.07. 2004 \\
\hline $6 C$ & E.P.O. & 73 & 19.07. 2004 \\
\hline $7 \mathrm{C}$ & A.J.J.F. & 79 & 16. 07. 2004 \\
\hline $8 \mathrm{C}$ & C.O.M & 80 & 20.07. 2004 \\
\hline $9 \mathrm{C}$ & E.O. & 82 & 19.07. 2004 \\
\hline $10 \mathrm{C}$ & A.C. & 86 & 20.07 .2004 \\
\hline
\end{tabular}




\subsection{AS ENTREVISTAS}

$\mathrm{Na}$ maioria das entrevistas havia mais pessoas presentes do que apenas a pesquisadora e o informante, principalmente familiares. Porém, na maioria dos casos, o silêncio do ambiente da gravação foi absoluto. Em três entrevistas (3CI, 6CI e 8CI) houve a interferência de um intermediário, tio da pesquisadora, o que não chegou a atrapalhar.

Quanto às interferências externas, em 1AI, 2AI e 2BI temos, ao fundo, barulho de carros e motos, pois os locais das gravações eram muito próximos da rua. Em 3CI o maior problema é o som do abrir e fechar da porta da sala pelos netos do informante, o que inutilizou os primeiros sete minutos gravados. Em São Francisco do Sul os maiores problemas encontrados foram os ruídos contínuos produzidos pela chuva (típicas da época do ano) ou pelas ondas do mar (nas gravações realizadas nas colônias de pescadores) ${ }^{41}$.

Em uma das gravações - 7BI - temos a presença de uma terceira pessoa que dialoga com o informante, pois estes permitiram a gravação de uma conversa entre eles. Um dos relatos foi perdido: 9BI ficou completamente inaudível. Na segunda viagem feita pela pesquisadora o informante foi novamente procurado, mas estava viajando.

\subsubsection{O Paradoxo do Observador}

O primeiro passo no trabalho de campo é coletar o objeto de estudo, ou seja, gravar uma quantidade significativa de material lingüístico para análise. Esse material poderia ser fruto de conversas entre informantes, sem a intervenção do pesquisador?

"Uma primeira alternativa seria a de procurar fazer o papel do pesquisador-observador: o pesquisador que não participa diretamente da situação de comunicação. Dessa maneira não será prejudicada a naturalidade da situação! Os antropólogos - lingüistas ou não - muito têm se servido desse método de coleta de dados. O sociolingüista, porém, sentirá a necessidade de controlar tópicos de conversa e de eliciar realizações da variável lingüística em que esteja interessado. $O$ pesquisador da área da sociolingüística precisa, portanto, participar diretamente da interação.” (TARALLO, 2004: 20)

\footnotetext{
${ }^{41}$ As gravações realizadas em São Francisco do Sul foram feitas com gravador digital obtido com o auxílio da FAPESP.
} 
Portanto, a presença do pesquisador no momento da coleta de material lingüístico é inevitável. $\mathrm{Na}$ terminologia da Sociolingüística, este fato é denominado de o Paradoxo do Observador, termo utilizado primeiramente por Labov (1972).

No caso da coleta de dados em trabalho de campo, o pesquisador deve estar integrado com o modo de vida daquela comunidade. Conhecer a história, os hábitos, os costumes são condições prévias para estabelecer um canal de contato satisfatório entre o pesquisador e os informantes.

"Para produzir e sustentar uma conversação, duas pessoas devem partilhar um mínimo de conhecimentos comuns. Entre eles estão a aptidão lingüística, o envolvimento cultural e o domínio de situações sociais." (MARCUSCHI, 1986: 16)

Em relação ao Paradoxo do Observador, Labov (1972), um dos primeiros a refletir sobre o assunto no âmbito da Sociolingüística, nos mostra que a presença de um "estranho" dentro de uma comunidade isolada é uma situação atípica. Para que sua presença seja suavizada e a interação seja possível, o pesquisador deve ter cuidado redobrado na hora de abordar os informantes em potencial.

"O contato inicial deverá ser feito, ou com líderes comunitários, ou com missionários que trabalhem com a comunidade, ou com membros mais jovens e mais escolarizados da comunidade. $\mathrm{O}$ acesso a esses indivíduos é facilitado em função do seu grau de informação e de contato com o mundo exterior à comunidade, o que possibilita a apresentação da justificativa para a presença dos pesquisadores na comunidade (deve-se ter em conta que para a maioria dos membros da comunidade, e em particular para os melhores informantes, o trabalho de um sociolingüista é algo que está totalmente fora de seu universo e mesmo das suas possibilidades cognitivas)." ${ }^{42}$

Nesse contato inicial, o pesquisador deve buscar aproximar-se ao máximo de seus interlocutores. Para eles, o pesquisador pode até mesmo revelar os objetivos reais de seu trabalho de campo: coletar amostras de fala espontânea para posterior análise. Aos informantes em potencial, essa informação não pode ser revelada, pois, impossibilitaria obter dados lingüísticos fidedignos ${ }^{43}$.

\footnotetext{
${ }^{42}$ www.vertentes.ufba.br/paradoxo

${ }^{43}$ Omitir que a língua é o objeto de estudo usualmente é a regra metodológica, porém, há divergências. " $L a$ conversación grabada como técnica para obtener muestras de habla espontánea también ha sido blanco de críticas. [...] En verdad, en nuestro trabajo de campo hemos sentido a veces esta sensación de incomodidad, por lo que hemos establecido un nuevo procedimiento: declaramos abiertamente que el objetivo del estudio es el habla casual,
} 
Superada a primeira fase de contato com a comunidade, a tarefa que se segue é selecionar os informantes ideais para o trabalho que se pretende desenvolver. Na antiga região de Itapocorói, como a localidade já era bem conhecida pela pesquisadora, por questões familiares, a busca e o contato com os informantes não foi uma tarefa difícil. Muitos já eram conhecidos. Necessitou-se, porém, da ajuda de intermediários para encontrar alguns informantes que mais se encaixassem no perfil procurado. Todas as gravações foram realizadas entre os dias 17 e 27 de julho de 2002 .

As gravações foram realizadas entre os dias 16 e 21 de julho de 2004, na cidade de São Francisco do Sul. Foi difícil encontrar os informantes cujas características se encaixassem no perfil procurado: falantes nascidos e criados na localidade, cujos pais também se enquadrassem em tal perfil. A ajuda de intermediários foi de grande valia para encontrar os informantes.

São Francisco do Sul é uma cidade cujo desenvolvimento econômico e industrial tem sido exponencial, principalmente nas duas últimas décadas. Possui um dos maiores portos de Santa Catarina (uma das principais fontes de renda da cidade), uma estação da Petrobrás e grandes indústrias que estão a cada dia ampliando o quadro de funcionários. Por isso, muitos de seus moradores não são nascidos na região.

Acredita-se que as causas acima sejam as responsáveis pelas dificuldades em conseguir os informantes que mais se aproximassem do ideal estabelecido. Na principal região de São Francisco do Sul, a mais urbanizada - o Centro Histórico - foram poucos os informantes que se encaixaram no perfil procurado. A maioria dos informantes foram provenientes de bairros mais afastados e de comunidades de pescadores.

\subsubsection{O tópico conversacional}

O tópico é uma atividade construída cooperativamente, isto é, há uma correspondência pelo menos parcial - de objetivos entre os interlocutores. Muitas vezes, o sentido de "tópico discursivo", está associado a "sobre o que se fala". Para ampliar essa visão sobre o tópico, pensemos em estudá-lo dentro de um conceito maior: o da topicalidade.

espontánea, de la vida diaria y concertamos de antemano una reunión con cada persona seleccionada, en su hogar y a una hora que élella considere la mejor para conversar con tranquilidad por más de una hora." (SILVA-CORVALÁN, 1989: 27) 
"A topicalidade, pois, define as várias formas como os interlocutores se entrosam na organização, como desenvolvem e estruturam os tópicos; como processam a seleção tópica; como introduzem, mantêm, juntam, abandonam tópicos; como interagem enfim, para manter a unidade de conversação" (PRETI, 1999: 78)

Labov (1972) demonstrou que, para as pesquisas de campo, o supertópico mais produtivo é a narrativa de experiências pessoais. Ao narrar as experiências pelas quais ele passou na vida, o informante se aproxima mais do vernáculo. Dessa maneira, quanto mais envolvente e importante for para ele a narrativa, melhor será a entrevista. Um tópico, que segundo esse autor, é muito produtivo, é o que envolve o tema "perigo de vida".

De certa forma, a possibilidade de tópicos são inúmeras. Também não existe um mau tópico. Em verdade, o que é necessário é adaptar-se a realidade cultural do informante e saber selecionar o(s) tópico(s) de acordo com a situação. Em primeiro lugar, o pesquisador deve buscar conhecer profundamente a comunidade. Além disso, estar atento, no curso da interação, a produtividade do tópico em desenvolvimento.

Para os pesquisadores que trabalham com o tempo aparente, é possível trabalhar com grupos de tópicos mais apropriados para cada faixa etária. Mas, mesmo dentro de uma faixa etária, um tópico pode ser produtivo com alguns informantes e improdutivo com outros.

Os informantes desconheciam o fato de que o objeto de estudo era a variante em que se expressavam. Isso foi necessário para que não houvesse uma intimidação do falante. Para a faixa $\mathbf{A}$ era dito que o estudo se detinha no comportamento dos jovens. Para as faixas B e C, de uma forma geral, que era um estudo da história e dos costumes da região.

Um dos maiores problemas apresentados foi o ajuste do(s) tópico(s) mais interessantes ao informante no começo das gravações. Isso ocorreu principalmente com a faixa A. Os mais jovens, principalmente as crianças, mostraram-se muito mais concisos em suas respostas. Dificilmente, ampliam o tópico em questão, como é possível observar nos trechos abaixo, fato que não ocorreu nas faixas $\mathbf{B}$ e $\mathbf{C}$. :

\section{$5 A I-(L 2)$}

L1 - R.... eu queria que você contasse pra mim... onde você estuda... que matérias você estuda... L2 - eu estudo... na escola Rubem João de Souza... minha matéria... TOda[ $\left.\int\right]$ ? 
estuda?

L L1 - mas quais você

L2 - e[ $\left.\int\right]$ tudo... portuguê[j $\left.\int\right] . .$. geografia história... matemática... educação física... várias...

L1 - e::... o que você gosta de fazer... nos finais de semana?

L2 - gosto de con / conversar com os meus amigo[ $[$ ]... sair... coisas assim...

L1 - sair pra onde?

L2 - eu vou pra... capoeira... eu vou pra... lá pra pracinha...( )

$2 A-(L 2)$

L1 - T.... como que é morar aqui na... na Enseada?... perto da praia?.. é bom?... você gosta?... não gosta...

L2 - AH... eu gosto... é legal aqui...

L1 - gosta?... vai bastante na praia...

L2 - não muito

L1 - mais gosta?

L2 - gosto

L1 - sabe nadar?

L2 - sei

L1 - bastante?... e na escola... como que é a sua escola?... ( )

L2 - AH... ela é grande... tem... sei que ela é grande mais ( )...

L1 - ela tem cantina?... biblioteca?...

L2 - tem... tem

Como a intenção era ter um uma locução bem espontânea, os tópicos foram muito variados e tiveram que ser adequados à faixa etária dos falantes, como dito anteriormente. Na faixa A predominaram assuntos relacionados com desenhos infantis, filmes, brincadeiras, festas locais e a escola. A narração da história de filmes, principalmente de terror e aventura, foi um dos tópicos mais agradáveis a esse grupo.

Foi possível perceber, por meio dos informantes, que muitas das brincadeiras populares da infância de avós e pais não fazem mais parte do cotidiano das crianças. Como muitas crianças brasileiras, a televisão é o grande passatempo. O manejo de bodoques nas caçadas de passarinho, as marionetes e as petecas são praticamente desconhecidas pela juventude.

$\mathrm{Na}$ faixa $\mathbf{B}$ os tópicos foram muito variados, desde viagens com amigos, até relatos de vida (infância, adolescência, trabalho, casamento e experiências adquiridas ao longo dos anos). A faixa C é composta, em sua maioria, por relatos de vida e de histórias da localidade. Muitos dos falantes se emocionaram ao contar suas vidas e experiências. Alguns mesmos chegaram a chorar. 
No supertópico "histórias da localidade", alguns tópicos foram recorrentes, principalmente na faixa C: a produção agrícola e pesqueira - sendo que a caça às baleias foi extremamente produtiva para a coleta de dados na antiga região de Itapocorói.

Apesar da caça as baleias não fazer parte da realidade da comunidade a mais de um século, esse fato ainda se mantém bem vivo, na memória, como anteriormente dito, dos informantes da faixa $\mathbf{C}$ :

\section{CI - (L2)}

(...)

L2 - portuguê[ $\left.\int\right]$ também tinha... eles fizer[u] ali na Armação... aquele[ $\left.\int\right]$ tanque... ainda tinha por ali naquelas casa... de botar o azeite da baleia... o figo da baleia... e aquele[ $\left[\int\right]$ tanque de óleo... tudo guardado ali...

L1 - era aqui né?...

L2 - era aqui na Armação... aqui... em frente à igreja... por ali... pra lá...

L1 - eles pegavam as baleia...

L2 - hoje em dia se quiser ver uma baleia não tem... né? ( )

L1 - a senhora chegou a ver alguma... chegou a ver?...

L2 - vi... ( )

L1 - aqui mesmo?... a senhora viu

L L2 - é... foi ali... ficava boiada... foi ali...

L1 - faz tempo que a senhora não vê então...

L2 - ah é... depoi[ $\left.\int\right]$ que eu fiquei grande eu não vi mais...

7C - (L2)

(...)

L1 - o senhor sabe de alguma história... conhece famílias portuguesas aqui...

L2 - não... eu não faço nem idéia... eu não sei se tem aqui... aqui eu sei qu[e] tinha a pesca de baleia né?... pescavam baleia lá na Ilha... tinha tanque de derreter... eles vinham destripar... eles vinham cortar baleia aqui na praia... isso aí a gente sabe... tem que saber também... descendent[e] $\mathrm{d}[\mathrm{e}]$ portugu[e]s... meu avô era portugu[e]s...

Foi também comum nas faixas B e C os contrastes entre "o novo e o antigo", principalmente em relação à violência, o comportamento dos jovens e a estrutura das cidades.

\section{CI - (L2)}

(...)

L1 - como era vida aqui do senhor... quando o senhor chegou... como que era a cidade...( ) 


\section{LL2-quando}

cheguei aqui... quando cheguei aqui... não tinha ninguém... não tinha nada... era só lá na praia... uma[S] casa bem rala... ( ) tinha um salão de baile... do[S] Figueiredo né?... tinha só a família Figueiredo... né?... família:... Figueiredo e o[S] Pinto... família Pinto e a família Figueiredo que e[ $\left.\int\right]$ istia aqui em Piçarra... né?... isso aí era tudo deles... aí veio gente de fora... gente de fora... e ele $\left[\int\right]$ for $[\tilde{u}]$ vendendo terreno... hoje tá uma cidade... Piça[r]a já passou pra município né?...

$10 \mathrm{C}-(\mathbf{L} 2)$

$(\ldots)$

L2 - isso aí é uma região que não tinha nada... nós não tínhamos nem estrada pra chegar aqui... é... a e[S]trada que nós tínhamos aqui era uma estrada de chão batido... que vinha de São Francisco até a Enseada... mas isso era muito difícil né?... transporte passar aqui era difícil... ficou muitos anos assim ... aí depois de mil (novecento) e cinqüenta e quatro... depois que foi aberto de Ubatuba até a Enseada... fica na ponta né?... vai... foi aberta só a:: a mata e ficou... assim... chão de... chão ficou muito tempo... aí depois mais tarde é que a prefeitura começou a... a por um material... uma casca de casqueira... na época podia né?... então começou a tirar umas casca de casqueira... na época podia se mexer em casqueira né?... então começou a tirar uma casca de casqueira... a gente ia (desbastando) ... e:.... aí começou... estamos aí... está melhor... ficou até... es/essa estrada assim péssima até mil novecentos e:.... setenta e $\left[\int\right]$ inco... quando a Petrobrás entrou aqui... setenta e $\left[\int\right]$ inco pra cá... porque a Petrobrás asfa[ \ulcorner] tou daí... ( ) de Joinville até São Franci $\left[\int\right]$ co...

Quando se perguntava a opinião dos informantes de Itapocorói em relação ao parque Beto Carrero World, muitos demonstraram um certo receio em responder. Ficou claro que a presença do parque suscita algumas polêmicas. Entre elas, o grande número de estranhos que passaram a morar nas imediações do parque e a construção de uma estrada que ligaria o parque diretamente à BR 101 (uma das principais rodovias de acesso a Santa Catarina) que passa por um dos bairros mais calmos e rurais da Penha: Santa Lídia.

\section{CI - (L2)}

\section{$(\ldots)$}

L1 - e a senhora acha que o fato... de vir o Beto Carrero pra cá... a senhora acha que isso melhorou ou trouxe problemas com... porque traz turistas... pessoas de fora... o que a senhora pensa?...

L2 - pode ser... que o Beto Carrero tenha trazido problema[S]... pras outras comunidades... eu acho que na nossa comunidade não ( )... nada não...

L1 - bom e:: tem muito turista pra cá?... nas férias?... 


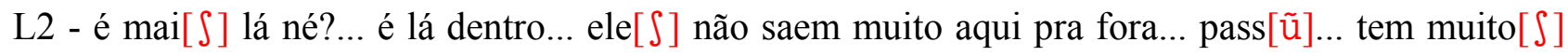
carros né?... ma[S] tá indo pra praia né?... pro Beto Carrero... melhorou né?... melhorou pro município...

As festas típicas da região, outro tópico muito produtivo, apareceu em todas as faixas etárias. Entre elas podemos citar o Terno de Reis, o Boi de Mamão, a Festa do Divino etc.

\section{C (L2) e 9C (L3)}

\section{(...)}

L1 - e a senhora... é... quando a senhora era mais nova... o senhor também seu E.... tinha a:.... é festa de Terno de Reis?... Boi de Mamão?... essas coisas?... então o senhor vai me contar do Terno de Reis... e a senhora me conta do Boi de Mamão... como que era... um Terno de Reis?

L2 - era um... eram duas pessoa três pessoa... até quatro... então... saiam cantando na porta... as pessoas cantavam... depois o pessoal... aquele da da casa... abria a porta... eles entravam... falavam e:.... cantavam... sentavam-se... conversava um pouco ali com o dono da casa... conversav[ũ]... aí o dono da casa dava... oferta pra eles né?... dava oferta pra eles... aí eles cantav[ũ]... outra vez de vo[ $[$ ta ali também ali... [ $\varnothing]$ gradecido a oferta que eles dão... depois sai[ũ] e i[ũ] já cantar em outra casa...

L1 - e o Boi de Mamão?...

L3 - no Boi de Mamão... tem vários bicho né?... tinha a bernúncia... tinha o sapo... tinha o corvo... tinha de tudo

$$
\text { L L2 - cavalo }
$$

L3 - tinha o cavalo marinho né?... então né... cada:.... cada de cada pra cada bicho tinha um verso... eles cantava aquele verso... mas era muito divertido... muito... lá na Laranjeira faziam muito... tinha um $\mathrm{ta}[\ulcorner]$ de Benedito que ele que... ele formava aquilo né?... tinha de cor... não sei como é aqueles verso tudo... mas era muito bonito... a gente que é criança gostava de ver... quando chegav[ũ]... "ah vem ver filho vem"... "vem mãe vem"... a mãe chamava os filho... "vem ver... olhe"... olha o cavalo... oh o boi... o Boi de Mamão... a bernúncia... oh o ganso... a tinha um ganso desse tamanho assim $((\operatorname{risos})) \ldots$ aí vinha assim... e a gente ia montar nele assim... e montav[u]... a não... quer dizer que não era ganso né?... era era um... uma coisa...

\subsubsection{A argumentação na gravação de entrevistas sociolingüísticas}

Segundo Aquino (1997: 145):

“A argumentação pode ser entendida como função característica da língua que reestrutura as três funções primárias de Bühler (1934): exprimir quem sou; descrever o mundo; agir sobre o mundo. Apontada como um recurso utilizado em qualquer tipo de discurso, passível de observação pelo interlocutor, 
corresponde a todos os expedientes utilizados numa situação discursiva que arrasta o ouvinte a acreditar numa idéia, numa ação.”

No caso da pesquisa de campo, a argumentação faz parte integrante do trabalho do pesquisador. Desde o primeiro contato com a comunidade, as estratégias argumentativas são imprescindíveis não só para ser aceito no grupo, mas também para conseguir informantes.

Como convencer um informante em potencial a ceder uma parte de seu tempo para uma entrevista? Ou o termo "persuadir" seria mais adequado neste contexto?

"Para quem se preocupa com o resultado, persuadir é mais do que convencer, pois a convicção não passa da primeira fase que leva a ação. Para Rousseau, de nada adianta convencer uma criança "se não se sabe persuadi-la". / Em contrapartida, para quem está preocupado com o caráter racional da adesão, convencer é mais que persuadir. (...) Propomo-nos chamar persuasiva a uma argumentação que pretende valer só para um auditório particular e chamar convincente àquela que deveria obter a adesão de todo ser racional" (PERELMAN \& OLBRECHTS-TYTECA, 1996: 30-1)

Com os contatos iniciais, quando buscamos aqueles que nos podem introduzir na comunidade, devemos argumentar e demonstrar a utilidade do trabalho proposto. Através da razão, expondo uma série de argumentos favoráveis à pesquisa, conseguimos convencê-los a auxiliar-nos na busca do informante em potencial.

Em relação ao informante ideal, do qual escondemos o verdadeiro objetivo da entrevista (gravar sua fala em situação espontânea), mais do que convencê-lo, é preciso persuadi-lo a participar. Com as crianças, principalmente, os apelos que pertencem mais ao campo do emocional que da razão são muito mais eficazes para angariar colaboração.

Infelizmente, essa primeira parte do trabalho de pesquisa de campo não aparece documentada. Muitas vezes, estamos perante um informante em potencial e não conseguimos sua colaboração, por mais argumentos que sejam colocados. Falha na argumentação? Podemos dizer que sim, se consideramos seu objetivo:

“O objetivo de toda a argumentação, como dissemos, é provocar ou aumentar a adesão dos espíritos às teses que se apresentam a seu assentimento: uma argumentação eficaz é a que consegue aumentar essa intensidade de adesão, de forma que desencadeie nos ouvintes a ação pretendida (ação positiva ou abstenção) ou, pelo menos, crie neles uma disposição para a ação, que se manifestará no momento oportuno." (PERELMAN \& OLBRECHTS-TYTECA, 1996: 50) 
As gravações realizadas para obter amostras de fala espontânea de uma localidade são um tipo muito específico de entrevista. Em primeiro plano está em estudo a fala em si, por isso, o conteúdo tem uma posição secundária. Como vimos em relação ao tópico discursivo, a importância de desenvolver um ou outro tópico está vinculada à obtenção de trechos mais favoráveis para a análise.

"A entrevista deve ter uma duração média de 40 a 60 minutos, durante os quais o entrevistador deve buscar extrair do informante o máximo de fala espontânea. Nesse sentido, o entrevistador deve trabalhar de modo que a interação seja a mais descontraída possível. O clima de conversa informal deve predominar sobre o clima de entrevista." ${ }^{44}$

Quanto maior for a descontração do informante e menor a intervenção do pesquisador, melhor a qualidade dos dados obtidos ${ }^{45}$. Entretanto, não é facilmente que atingimos esse tipo de situação. Mas, para que isso seja possível, podemos recorrer a uma série de estratégias argumentativas.

Desde a postura do entrevistador, até a forma como ele olha para o informante são significativas para a interação. Os elementos prosódicos também devem ser utilizados de forma estratégica: a entonação e o ritmo da fala devem mostrar calma e interesse na narrativa do informante.

O pesquisador deve conhecer a fala local: isso inclui estar familiarizado com o léxico e com as expressões mais utilizadas. Aproximar a sua variante da variante em questão também é uma boa estratégia, desde que isso não aparente ser artificial. Se a variante utilizada pelo pesquisador for muito distinta da variante do informante, este pode prestar demasiada atenção na fala do pesquisador, sendo este um fator negativo de distração.

\footnotetext{
${ }^{44}$ www.vertentes.ufba.br/paradoxo

45 "Na maioria das vezes, não há necessidade de se esconder o gravador. Os sociolingüistas observam uma norma que diz respeito à ética perante o entrevistador e que impede que se esconda o fato de que o entrevistador será gravado. Podemos apresentar simplesmente a aparelhagem como necessária para todos os detalhes da conversa (isto reforçará a importância que o pesquisador dá a essa conversa). O fato de mostrar o gravador não significa que ele deva ser posto debaixo do nariz do falante, nem o microfone dentro da sua boca. Ambos podem ser postos discretamente fora do alcance do seu olhar para que ele fale e, tanto quanto possível, se esqueça desses objetos” (Oliveira e Silva, 2003: 118)
} 
Durante a entrevista, uma grande atenção deve estar voltada para as perguntas, que é uma das formas de controle do discurso:

"Dentre as formações lingüísticas passíveis de observação, destacam-se as perguntas como elementos que, de acordo com os objetivos conversacionais e com o contexto, permitem a organização do texto falado, especificamente o de entrevistas, delineando graus diferentes de interação”. (AQUINO, 1997: 90)

As perguntas diretas e as retóricas não devem ser usadas nas entrevistas. Na maioria dos casos elas resultam em respostas curtas e desinteressantes para o desenvolvimento do tópico. O pesquisador pode testar um tópico por meio de comentários, se o informante aceitá-lo, ele mesmo prosseguirá com a fala. No trecho abaixo, em negrito, vemos um exemplo de comentário que incita o informante a falar sobre o tópico anteriormente introduzido.

\section{A - (L2)}

\section{$(\ldots)$}

L1 - e um outro filme de ação... que tenha assistido... que tenha gostado...

L2 - ( ) Sessenta Segundos...

L1 - aí... conta pra mim... ((risos))... eu já vi... é que eu adorei... então você vai contar pra mim lembrar...

L2 - ahn... era um:... era um cara né?... tinha um irmão... daí eles roubav[ũ] carro pa vender... pra... po/... re[S] to do mundo assim.. daí... o irmão se meteu numa encrenca assim... que era dá cinqüenta carros em uma semana... só que daí o irmão não cumpriu... daí eles iam matar o irmão... só que o cara... co / como o mocinho da história...

O silêncio também é uma estratégia argumentativa bastante utilizada. Porém, sua utilização no começo da entrevista pode desnortear o informante. Muitas vezes, para "quebrar o gelo" dos primeiros minutos, o entrevistador pode narrar, de forma sucinta, um fato interessante ao informante. Com o decorrer da conversa, o entrevistador deve-se manter o máximo em silêncio predominando em sua fala turnos que indicam que ele está "acompanhando" as palavras do locutor. Vejamos outros usos para o silêncio:

“(...)freqüentemente, a evocação de um tema é seguida de uma resposta rápida e uma pausa em que o informante reflete mais sobre o tema proposto. Nesses momentos, o entrevistador deve manter-se em silêncio também. O informante se sente compelido a preencher o silêncio e não raro retira da sua reflexão uma ótima 
narrativa. De modo contrário, uma seqüência rápida de sugestões de temas, seguidas de respostas rápidas, conduz ao rápido esgotamento dos temas produtivos e ao fracasso da entrevista." ${ }^{46}$

$10 \mathrm{C}-(\mathbf{L} 2)$

(...)

L1 - e me contaram uma história que o senhor matou uma cobra grande pra fazer banha...

L2 - AH... eu matei uma cobra que deu três metro e vinte que / de comprimento... Jaracuçu... ((silêncio)) tinha sessenta e quatro ovo grande do tamanho de ovo grande... do tamanho de ovo de galinha... tinha duzent[o] e quarenta e três pequeno... e mais de dois disco assim comprido com

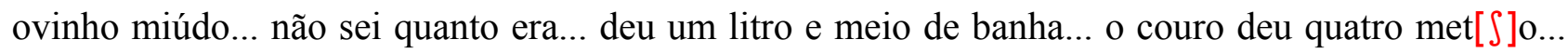
abriu trinta e sete centímetro o couro de largura... deu quat $[\varnothing]$ o metro de comprimento o couro... roubar[ũ]...

Atacar a imagem do informante, entrar em desacordo com o ato enunciativo, refutar, desprezar o relato, retificar ou utiliza a ironia são estratégias argumentativas que devem ser a todo custo evitadas, pois, podem instalar o conflito na conversação, invalidando a entrevista (AQUINO, 1997).

\subsection{A GRAVAÇÃO DA FALA ESPONTÂNEA}

As gravações na antiga região de Itapocorói foram feitas em microcassetes. Foram gravadas mais de trinta horas entre elocução espontânea e a aplicação dos questionários. Todavia, em muitos trechos a gravação se tornou de difícil audibilidade. Em São Francisco do Sul, a fala dos informantes, além de ser coletada em microcassetes, foi também coletada em um gravador digital, modelo Power Pack DVR 2B50, adquirido com a verba fornecida pela FAPESP, totalizando também mais de trinta horas de material gravado ${ }^{47}$. Não foi possível aplicar os questionários em dois informantes: 6CI e 8CI. Em ambos os casos o motivo foi o mesmo: a pouca audição dos informantes inviabilizava a aplicação.

Foram transcritos entre dez e quinze minutos da fala espontânea de cada informante ${ }^{48}$. Estes trechos foram selecionados de acordo com os seguintes critérios: ausência de ruídos ou

\footnotetext{
${ }^{46}$ www.vertentes.ufba.br

47 As gravações cuja audibilidade estavam reduzidas foram passadas para o computador e analisadas pelo programa Cool Edit 96 (Syntrillium Software Corporation).

${ }^{48}$ Os critérios para a transcrição e as transcrições estão em íntegra no ANEXO 2.
} 
interferências, desenvolvimento tópico contínuo e espontaneidade do informante. Todos os dados transcritos, de ambas localidades, foram analisados e confrontados, para que fosse possível verificar o atual estado das variantes locais, as mudanças que vêm sofrendo nas últimas gerações e a presença dos ditos traços da fala açoriana catarinense.

Como este é um trabalho de Lingüística Histórica, que estuda a influência açoriana no português das localidades escolhidas, fez-se uma análise quantitativa e qualitativa dos corpora. Porém, tanto pelo objeto de estudo quanto pela metodologia empregada, este trabalho também se aproxima da Dialetologia e da Sociolingüística.

A aplicação e análise do questionário lingüístico, principalmente na parte que se refere à verificação lexical, assim como no glossário, aproximam-se dos estudos dialetológicos. A opção por trabalhar com o tempo aparente é um recurso empregado pelos estudos sociolingüísticos ${ }^{49}$.

Quando necessário os dados foram apresentados por meio da freqüência relativa (\%), porém, não se utilizou o programa VARBRUL - recurso técnico utilizado pela Sociolingüística Variacionista - para a quantificação das freqüências de ocorrências dos dados.

\subsection{O QUESTIONÁRIO LINGÜÍSTICO}

Baseado no $\underline{\mathrm{ALiB}}$ (Atlas Lingüístico do Brasil) de 2001, o questionário lingüístico aplicado foi feito pela pesquisadora. As questões foram formuladas para documentar o que ela já havia observado em outras viagens à região de Itapocorói, já que sua mãe e os avós maternos são de Penha. As respostas esperadas são provenientes dessa vivência anterior.

O questionário lingüístico é composto de quarenta e nove questões. As vinte e cinco primeiras averiguam questões fonéticas e fonológicas; as vinte e quatro últimas, as questões semânticas e lexicais. Dentro dessas, estão presentes questões sobre: fenômenos atmosféricos (1 e 2), atividades pesqueiras (3 e 4), animais (5, 6 e 7), corpo humano (8 e 9), objetos (10, 11, 12 e 13), jogos (14 e 15), religião (16), vida urbana (17), comportamento social (18, 19, 20 e 21) e outras (22, 23 e 24$)$.

Quase todos os informantes, embora tenham sido avisados que as perguntas eram simples, de certa forma ficaram assustados com elas, principalmente os das faixas B e C. Muitos, após a

\footnotetext{
${ }^{49}$ Resumidamente, o tempo aparente é um recurso utilizado pela sociolingüística para solucionar uma questão metodológica. É por meio desta que é possível estudar a mudança lingüística em curso. (LUCCHESI, 2004: 166)
} 
aplicação dos questionários, me perguntaram acerca da finalidade dessas perguntas. A maioria das questões foram respondidas sem nenhum problema.

\section{Questionário fonético-fonológico}

1 - Fonema / r / no início de palavra. \#\$_v

O gato gosta de caçar o ... $\underline{\text { RATO }}$

2 - Fonema / r / em posição intervocálica. v\$_v

e quem gosta de caçar o gato é o... CACHORRO

3 - Arquifonema / R / em final de palavra. v_\$\#

Se o dia está muito quente, se diz que faz muito... CALOR

4 - Fonema / r / após consoante. c_v

Qual o nome do objeto em que se põe a comida, depois de pronta, pra gente comer?

PRATO ou TRAAESSA

5 - Arquifonema / R / em final de sílaba seguido por consoante. v_\$c

As pessoas entram em uma casa pela... PORTA

6 - Arquifonema / S / em final de sílaba seguido por consoante. v_\$c Quando alguém faz aniversário, os pais ou amigos costumam fazer uma...FE $\underline{T} T A$

7 - Arquifonema / S / em final de palavra. v_\$\#

Quem nasce em Portugal é...PORTUGUÊS

8 - Arquifonema / S / em final de palavra. v_\$\#

Depois do número um, segue-se o número...DOI $\underline{S}$

9 - Arquifonema / O / em posição pretônica.

Os meninos gostam de brincar com carrinhos, as meninas gostam de brincar com...B $\underline{B}$ NECAS

10 - Arquifonema / O / em final de palavra. c_\$\#

A galinha bota...OV므

11 - Arquifonema / E / em posição pretônica.

Em que estação do ano faz mais calor?

VERÃO

12 - Fonema / e / seguido de travamento nasal. c_N\$

Toda à noite, antes de dormir, é preciso escovar os...DENTES

13 - Arquifonema / E / em final de palavra. c_\$\#

Quem reza a missa na Igreja Católica é o...PADRE 
14 - Alofonia de / 1 / posvocálico em final de sílaba. v_\$

Um homem com mais de dois metros de altura é muito...ALTO

15 - Alofonia de / 1 / posvocálico em final de palavra. v_\$\#

Durante o dia brilha no céu o...SOL

16 - Rotacismo de / 1/. c_v

A margarida é uma...FLLOR

17 - Alofonia da / $\Lambda$ / lateral palatal. v\$_v

(...) aquela pessoa que trabalha no circo, usa um nariz vermelho e faz todos rirem?

PALHAÇO

18 - Alofonia de / v / fricativa lábio-dental sonora. \$_v

$\mathrm{O}$ que se usa para varrer a casa?

VASSOURA

19 - Alofonia de / v / fricativa lábio-dental sonora. \$_v

De qual animal retiramos o leite para beber?

VACA

20 - Alofonia de / n / nasal palatal. v\$_v

Quando se está muito sujo, para se limpar, é preciso tomar um...BANHO

21 - Alofonia de / t / oclusiva alveolar surda. \$_ [i]

A irmã de sua mãe é sua...TIA

22 - Alofonia de / t / oclusiva alveolar surda. [j] __v

Depois do número sete, segue-se o número...OITIO

23 - Alofonia de / d / oclusiva alveolar sonora. \$_ [i]

As estrelas só brilham de noite, o sol só brilha de...DIA

24 - Alofonia de / d / oclusiva alveolar sonora. \$_ [i]

O limão é azedo, a pimenta é...ARDIDA

25 - Alofonia de / a / em início de palavra seguido por sílaba iniciada em nasal. \#\$_ [+nasal]

O natal é comemorado no fim do...ANO

\section{Questionário Semântico-lexical}

1 -Resposta esperada: AGUACEIRO, PÉ D’ÁGUA, CHUVÃO 
$(\ldots)^{50}$ uma chuva muito forte?

2 -Resposta esperada: PÉ DE VENTO, VENTANIA

(...) um vento muito forte?

3 -Resposta esperada: BAMBU, BUMBU, CANIÇO

Você sabe o nome da planta que se usa para fazer vara de pescar?

4 -Resposta esperada: BATEIRA, CANOA, BARQUINHO

(...) aquele barco pequeno usado para pescar?

5 -Resposta esperada: ANGOLISTA, TRAFACO, GALINHA D'ANGOLA

(...) aquele tipo de ave que grita: "tô fraco, tô fraco".

6 -Resposta esperada: VAREJEIRA

(...) a mosca meio azulada, que põe bicheira nos animais?

7 -Resposta esperada: GERVÃO, BICHO PINTO, TATURANA, LAGARTA

(...) o bicho que é pequeno, "peludo", que come as folhas das plantas e quando encostamos nele queimamos a pele?

\section{8 -Resposta esperada: ROXA, MAGOADA}

Quando se machuca uma parte do corpo, e a carne ali fica com uma mancha, dizemos que a carne ficou...

\section{9 -Resposta esperada: CARECA, QUECA}

A pessoa que não tem cabelo é....

10 -Resposta esperada: POMBOCA, LAMPIÃO, LAMPARINA

(...) o objeto pequeno, de ferro, em que se punha querosene para iluminar a casa quando não havia energia elétrica?

\section{1 -Resposta esperada: LANTERNA, FACHILETE}

e (...) o objeto, que vai pilha, usado a noite para iluminar o caminho?

\section{2 -Resposta esperada: BARBANTE}

(...) a linha que fica no rolo e serve para amarrar as coisas?

\section{3 -Resposta esperada: RABECA}

(...) um tipo de violino feito em casa?

\section{4 -Resposta esperada: PECA, PILICA, BOLINHA DE GUDE}

(...) aquela bolinha de vidro, pequena, usada para brincar?

\section{5 -Resposta esperada: FUNDA, ESTILINGUE}

\footnotetext{
${ }^{50}$ A indicação (...) é utilizada para substituir, na escrita, o início da pergunta: “ - como se chama”.
} 
(...) o objeto pequeno que se usa para atirar pedrinhas, principalmente para acertar passarinhos?

\section{6 -Resposta esperada: BODOQUE}

e (...) um outro objeto que se usa para atirar pedras, só que grande, parecido com um arco?

17 -Resposta esperada: SINALEIRO, SEMÁFORO, SINAL

(...) o lugar em que as crianças costumam vender bala e água para as pessoas que estão de carro?

\section{8 -Resposta esperada: INIMIGO, COLUDO}

Se Deus está no céu, quem está no inferno é o...

\section{9 -Resposta esperada: PROSA, FELIZ}

Quando uma pessoa ganha um presente, ela fica toda...

20 -Resposta esperada: AVE DE PENA, BICHO DE CABELO, LEVADA

Quando uma criança é muito arteira, ela é...

21 -Resposta esperada: MEDONHO, HORRÍVEL

Quando alguém é muito feio, ele é...

\section{2 -Resposta esperada: TANSO}

Quando alguém é pouco inteligente, vive fazendo coisa errada, ele é um...

\section{3 -Resposta esperada: CÓCORAS, COCA}

Quando uma pessoa está abaixada, dizemos que ela está de..

24 -Resposta esperada: VERONISTA, TURISTA

(...) a pessoa que vem passar as férias aqui?

\subsection{O QUESTIONÁRIO VALORATIVO}

O questionário valorativo também foi montado pela pesquisadora. O principal objetivo de sua aplicação foi conhecer como cada informante se posiciona em relação aos informantes de outras faixas etárias. Além disso, se ele reconhece diferenças entre a fala da região com as comunidades vizinhas.

\section{Resposta esperada: APAIXONADO(a)}

a) Quando se fica muito triste, dizemos que ficamos...

b) O que você entende por ficar apaixonado?

c) Você conhece outro significado para esta palavra?

d) Já ouviu alguém falar assim? Paixão como tristeza? 
a) Você acha que os mais velhos falam de forma diferente? Pergunta para as faixas A e B.

b) Você acha que os mais novos falam de forma diferente? Pergunta para as faixas $\mathbf{B}$ e $\mathbf{C}$.

3

a) Você lembra de alguma(s) palavra(s) que os mais velhos usavam e hoje não se usam mais? Pergunta para as faixas A e B.

b) Você lembra de alguma(s) palavra(s) que os jovens usam e antigamente não se usavam? Pergunta para as faixas B e C.

\section{4}

a) O que você pensa da forma que os mais velhos falam? Pergunta para as faixas A e B.

b) O quê você pensa da forma que os mais jovens falam? Pergunta para as faixas $\mathbf{B}$ e $\mathbf{C}$.

\section{5}

a) As pessoas que moram em outras cidades de Santa Catarina falam de forma igual ou diferente daqui?

b) O que você acha disso?

c) Lembra de algum exemplo?

\section{6}

a) Você acha que um catarinense fala de forma igual ou diferente de um paranaense?

b) Lembra de um exemplo?

c) Você acha que um catarinense fala de forma igual ou diferente de um gaúcho?

d) Lembra de um exemplo? 


\section{PARTE 3 - ANÁLISES LINGÜÍSTICAS}

\section{ANÁLISE FONÉTICA}

Encontram-se nas línguas realizações sonoras que são determinadas não somente por oposições fonológicas, mas também por fatos gramaticais, além de outros parâmetros, como os fatores sociolingüísticos, estilísticos, pragmáticos etc:

"Ao descrever alguns contextos, há a necessidade de se levar em conta, em alguns casos, não simplesmente os sons precedentes e subseqüentes, mas o fato do contexto estar ou não ligado a limites externos de palavras (também chamados de juntura intervocabular), ou pertencer a determinada categoria lexical ou sintática (por exemplo, verbo no infinitivo, nome etc). Isto mostra que alguns processos fonológicos só podem ser devidamente explicitados, quando se levam em considerações fatos de natureza gramatical, sobretudo morfológica." (CAGLIARI, 1997: 62)

Quantos aos fatores sociolingüísticos, é preciso fazer algumas considerações sobre o corpus utilizado para a realização desse trabalho. Primeiramente, é impraticável realizar a análise de uma língua esperando englobar todas as diferenças encontradas dentro de um sistema lingüístico, isto é, abranger as maneiras diversas de utilização da língua pelos falantes.

Delimitar o corpus é o primeiro passo para se estudar uma língua. Um corpus extremamente abrangente e com delimitações pouco claras pode tornar a análise impossível, pois o número de contradições apresentadas pode superar o número de regras encontradas. Mesmo dentro de uma língua podemos identificar grupos com características peculiares, por isso, conhecer a realidade do grupo em questão é primordial para a obtenção de um corpus coeso.

Por causa da variação lingüística, o trabalho de análise deve ser feito com muito cuidado. Se não nos atentarmos para a questão da variação, a interpretação e os resultados obtidos podem perder grande parte do seu valor.

Sabemos que uma língua é um conjunto de subsistemas lingüísticos. Estudar cada sistema individualmente para depois compará-los pode ser muito mais interessante para o conhecimento da realidade lingüística do português do Brasil.

Isto não significa que não podemos conhecer uma representação geral da língua através da análise da fala de um informante. Como falante de uma língua, ele não é um ser isolado do sistema, 
portanto, por meio de sua fala, muitos traços da língua em questão podem ser conhecidos. Porém, quando estendemos a análise para vários informantes, dados mais fidedignos podem ser levantados.

Sendo assim, a homogeneidade do sistema é dependente de fatores históricos, geográficos e sociais. Nos corpora em questão, o fator histórico preponderante é a suposta colonização açoriana. Por isso, a análise fonética partiu dos traços considerados como típicos da variante açoriana catarinense, segundo FURLAN (1989). Outro fator predominante dentro dessa pesquisa é o trabalho com o tempo aparente.

Para analisar os dados fonéticos levantados na pesquisa de campo, utilizar-se-ão como parâmetro de comparação, entre a variante catarinense em questão e a variante açoriana, os dados encontrados principalmente em FURLAN (1989).

Para o autor, sete são os traços fundamentais da variante açoriana catarinense:

“(...) 1. pronúncia álveo-palatal de / s / travante; 2. absorção de iode por / s / palatalizado; 3. pronúncia velar/uvular do fonema / r /; 4. resíduos de apoio paragógico a oxítonos em - / w, r, s / 5. africação ou palatalização de / t / entre iode e vogal recuada átona; 6. ênfase da tônica e rapidez de ritmo; 7. elevação entonacional da parte final das assertivas enfáticas.” (FURLAN, 1989: 101)

Apresentar-se-á o resultado da análise comparativa entre as assertivas de FURLAN (1989) e os dados colhidos na pesquisa de campo, tanto aqueles provenientes da fala espontânea, quanto aqueles obtidos por meio da primeira parte do questionário lingüístico (fonético-fonológica) ${ }^{51}$, com exceção dos pontos 6 e 7, pois não fazem parte da proposta do trabalho realizado. Além disso, mostrar-se-á um retrato das principais características fonéticas da antiga região de Itapocorói e São Francisco do Sul.

\section{CARACTERÍSTICAS FONÉTICAS}

\section{VOGAIS PRETÔNICAS:}

\footnotetext{
${ }^{51}$ Quando necessário, citar-se-á o informante que utilizou uma forma diversa da esperada no questionário fonéticolexical, esta será dada em nota de pé de página.
} 
Normalmente o padrão açoriano catarinense para as vogais pretônicas é o mesmo da forma paulista e não foge do padrão brasileiro. Assim, menino se diz [mi'ninu] e bonita [bu'nita], uma vez que foram introduzidas dessa forma e não são, do ponto de vista diacrônico, alçamentos posteriores (cf. 5C [sigu'ro].

Nas localidades pesquisadas, tanto na fala espontânea quanto no questionário lingüístico (questões 9 e 11), o arquifonema / E / e / O / em posição pretônica foram muitas vezes realizados, respectivamente, como [e] e [o], segundo TEYSSIER, tais realizações são típicas do Centro-Sul

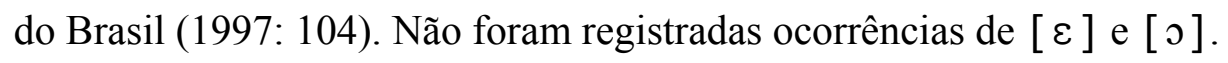

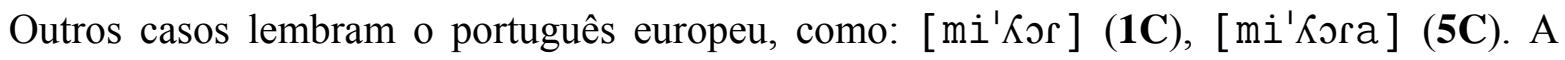
realização [mi'Kora ] (5C) também ocorre no português falado no Ceará (ARAGÃO, 2000: 177). Uma síncope semelhante ao do português europeu ocorre duas vezes com a palavra ['psoa] em 9B e em [kro'zena ] "querosene", em 9CI; esta foi encontrada no dicionário de ALEXANDRE (1994) como "crosena", o que pode indica que esta forma pode ser comum em Santa Catarina (s. v. crosena). A forma 6BI [ e'greza ] é um arcaísmo, segundo AMARAL (1920).

Alguns alçamentos lembram as variantes centro-setentrionais do português brasileiro: 10BI [prusi'sẽw], 6CI [bu'kadu], 5C [mu'Kadu], 2C [bati'ria] e 10C [u'fẽdi]. Curiosa é também 1C [demo'li] “demolir"e 6CI [su'zina ].

No entanto, ocorrem aí várias formas que devem ser registradas e analisadas, todas dissimilações: 7AI [zio'loziku], 5CI [vi'nenu ], 5CI [be'bẽti].

A oscilação entre [vero'nista] (1BI, 7B, 6CI) e [vere'nista] (8BI) ${ }^{52}$ se deve, provavelmente, por causas analógicas. Também a situação de pretônica do ditongo /aw/ faz que ele se torne [o] em [oto'ridadi] (3C).

As aféreses registradas são: [ero'porto] (1AI), ['kaba] (5AI), [le'fẽuti ] (6AI), [kosta'mẽtu ] (7AI), [trave'sa ] (2CI) [vẽ'sarẽw] “avançaram” (5CI), [ga'ha ]

\footnotetext{
${ }^{52}$ Ambas as formas aparecem na questão 24 do questionário lingüístico, parte semântica. Ver: análise lexical.
} 
"agarrar" (5CI), ['topi ] “autópsia” (5CI), [ lẽbi'ka] (5CI), [mũ'disa] (5CI), [ba'tuba ] "Ubatuba" (7B, 10B, 1C), [ta'zuba ] "Itajuba" (9CI), ['greza ] "igreja" (9CI), ['zudẽw ] "ajudam" (2A), [sis'ti] "assistir" (9B), [he'karda] "arrecada" (9B), [bẽ do'nadu] (9B), [nawfa'betu ] (9B), [pozẽ'tadu] (3C), [gwẽ'trmus] (5C), [pare'sia] “aparecia” (7C), [grade'sidu ] (9C). Uma síncope interessante é [elu'iw ] “evoluiu” (7C).

Nasalização do [i] inicial ocorre com [ĩzis'tia] (2CI), [ĩ'gwaw] (4A), [í'vita ] "evita" (10B), [ĩ'zisti] "existe" (5C). Nazalizações neste mesmo contexto, quando o [i ] vem isolado no início da palavra, também são encontradas no português do Nordeste (MARROQUIM, 1945: 56) e no dialeto caipira (AMARAL, 1920: 56).

Próteses aparecem em menor freqüência: [avu'a ] (1AI, 7AI), [ade'pojs ] (10BI, 9B, 6C), [apovu'adu ] (10BI), [ahese'be ] (4CI), [a'lĩpa (5CI), [ĩkõvi'dadu ] "convidado" (5CI), [alevẽ'tej] (9CI), [a'lẽbru] (9B), [ahe'scbi] (3C), [aka'va ] “cavar” (6C), [alevẽ 'to] (9C).

\section{VOGAIS TÔNICAS}

As vogais tônicas são bastante estáveis, não havendo grande modificação no seu uso. Monotongação de $[e j]>[e]$ antes de $[r],\left[\int\right],[3]$, bem como de $[a j]>[a]$ antes de $\left[\int\right]$, [3] são antigas e verificadas também no sul de Portugal. A monotongação [ow ] > [o] é comum em todas as variantes do português. Algumas realizações de [ow] se verificam, porém, em 3AI e $1 B I$.

Uma vogal aberta [a] no lugar de [ $\mathfrak{e}$ ] se encontra em ['anu ] (3CI), caso único em todos os corpora. Essa ocorrência também não aparece no questionário lingüístico (questão 25).

\footnotetext{
${ }^{53}$ É registrada como “lambicar” em ALEXANDRE (1994).
} 
O informante 10CI diz ['idju] para "índio". O informante 7C diz [kes'tẽ ] para “questão".

\section{VOGAIS PÓS-TÔNICAS:}

O fenômeno da transformação das proparoxítonas em paroxítonas, que remonta ao latim vulgar também é freqüente na variante em estudo: 4AI [ipo'potu], 5CI ['topi ] "autópsia", 5CI [mũ'disa ] "imundície”, 6CI ['sabu] "sábado", 7CI ['figu] "fígado", 8CI ['kroka ] “cócoras", 5CI ['koka] "cócoras", 5C ['hoja] "royalty", 9C [he'lẽpu] "relâmpago". O mesmo ocorre com 1C quando diz patrimônio história, em vez de patrimônio histórico.

\section{/E/}

Supomos que a pronúncia original seja *[e].

$\mathrm{Na}$ fala espontânea e no questionário lingüístico (questão 13), a vogal /E/ pós-tônica se realiza normalmente como [i ]. É possível imaginar que * [ ] $>$ [i ] já em fase bastante antiga ou que o sulismo [e] seja inovação recente na região. Em Itapocorói, apenas ocorre na fala espontânea das faixas mais antigas: 5CI, 6CI, 9CI, todos com mais de 70 anos, a realizam de forma assistemática. Nas faixas mais jovens, ocorre apenas com 5A e 5AI, ambos com 13 anos, em 2BI e 3BI, ambos com 23. Em São Francisco do Sul, ocorre também na fala espontânea na faixa intermediária: 5B, 8B, 9B, 10B e na mais velha: 2C, 5C, 6C, 7C, 9C. Também 10C apresenta indícios da pronúncia de [e] em ['mile]. Uma realização curiosa ocorre com 2C [kõ'formo] "conforme".

$/ \mathrm{O} /$

Supomos que a pronúncia original seja *[o].

No questionário lingüístico (questão 10), a vogal / O / em posição pós-tônica é realizada como $[u]$. Na fala espontânea ocorre, algumas vezes, a realização de [o] em todas as faixas 
etárias. Em Itapocorói, [ o ] é audível mesmo nos mais novos: 1AI, 3AI, 5AI, 10AI, 1BI, 2BI, 3BI, 10BI, 2CI, 5CI, 6CI. Em São Francisco do Sul, esta realização é mais rara, mas aparece em 5A, 5B, 8B, 9B, 10B, 2C, 5C, 6C.

A transformação $*[o]>[\mathrm{u}]$, ao que tudo indica, é mais recente, mas ocorreu há mais tempo em São Francisco do que em Itapocorói.

\section{CONSOANTES EM POSIÇÃO DE ATAQUE.}

Normalmente esta posição é extremamente estável, não gerando grandes complicações. Há, porém alguns fenômenos importantes:

(a) A realização do / $\mathrm{r} /$ em posição de ataque

Normalmente, o / $\mathrm{r} /$ se realiza [h], mas nos mais idosos, costuma ocorrer a vibrante (múltipla) [ r ]: 1CI, 6CI, 8CI, 9CI, 10CI, 3C, 6C, 9C. A vibrante múltipla é a tendência geral do falar cuiabano (ALMEIDA, 2000: 175). Como tepe ocorre com os informantes 5CI [ka'Soru], ['moru ] "morro", [ I'teru ] "enterro", [ İte'ra ] "enterrar” e 7CI ['karu ] "carro", [ka'rinu ]. Segundo VIARO (2005: 232), a neutralização de [ $\ulcorner$ ] [ [ ] além de ocorrer em Santa Catarina, também ocorre no crioulo falado na Guiné-Bissau, em Cabo Verde e Damão (Índia).

No questionário lingüístico (questão 1), em São Francisco do Sul, 27 informantes realizaram o fonema / r / como [ $\mathrm{h}$ ] no início de palavra (90\%). Os outros 3 informantes o apresentaram como $[r]$ : 1C, 6C e 10C. Já nas locuções espontâneas, 1C e 10C não apresentaram essa realização, utilizando sempre [ $\mathrm{h}$ ] no início de palavra. Porém, 9C, que não apresentou a realização de $[r]$ no questionário, utiliza as duas formas em questão na sua fala. O informante 6C utiliza [ r ] em quase $100 \%$ dos casos.

No questionário lingüístico, na antiga região de Itapocorói, independentemente da faixa etária, todos realizaram o fonema / $\mathrm{r} /$ como $[\mathrm{h}$ ] no início de palavra. Fato que não se repetiu nas locuções espontâneas. 
No questionário lingüístico (questão 2), dos 28 informantes de Itapocorói, 22 (79\%) utilizaram [h ], 2CI, 7CI, 9CI o tepe e 5BI [ r ]. É importante notar que o tepe só é encontrado na faixa C. Dos $26^{54}$ informantes de São Francisco do Sul, 21 (70\%) utilizaram o [h], 1A, 4A, 9C o [r] e 6C $[r]$.

A pronúncia velar/uvular do fonema / $\mathrm{r} /$ em começo de palavra é mais um dos quesitos básicos da fala açoriana catarinense (FURLAN, 1989: 126). Para CORRÊA (2000), a área da variante açórico-madeirense-luso-vicentista é a que sofre menos influência gauchesca, sendo o fonema / $\mathrm{r}$ / um dos traços que a separam:

"Se fôssemos delimitar um espaço geolingüístico catarinense onde não há influência gauchesca, esta área com certeza seria no máximo do norte de Imbituba a São Francisco. Nesta rota, abrangendo as cidades próximas ao oeste, na região da Grande Florianópolis, Tijucas, Vale do Itajaí e Região Norte, região delimitada fonéticamente (sic) pelo falar do / S / chiado e do / R / vibrante, fricativo, velar." (CORREAA, 2000: 35)

Analisando os dados obtidos pelas gravações, é possível observar uma sensível mudança: se na época do levantamento de FURLAN, cerca de 20 anos atrás, essa ocorrência era comum, hoje ela está restrita aos falantes da faixa $\mathbf{C}$ nas regiões pesquisadas. Isso indica que a pronúncia velar/uvular do fonema / r / tende a desaparecer com o tempo. Provavelmente, será substituída por [h], que prevaleceu na maioria das ocorrências. Acreditamos que não seja por influência da variante falada pelos gaúchos, pois, de acordo com o ALERS (2002: 149 -v.2) a pronúncia uvular / velar do fonema / r / em começo de palavra é a mais freqüente no Rio Grande do Sul.

(b) A realização do / s / na posição de ataque

O sistema de quatro fricativas pode deixar alguns resquícios na realização [ $\left.\int\right]$ em posição

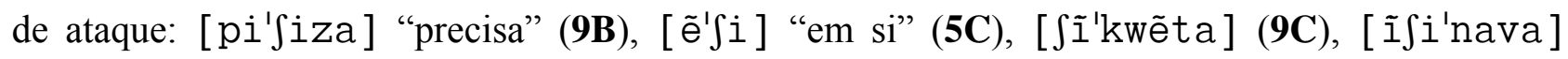

\footnotetext{
${ }^{54}$ O informante 5A apresentou como resposta: “ cão", 8B "urso". 4B, 9B e 4C não responderam a questão.
} 


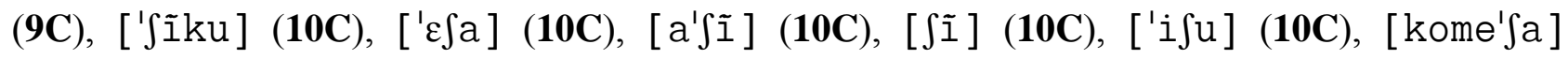

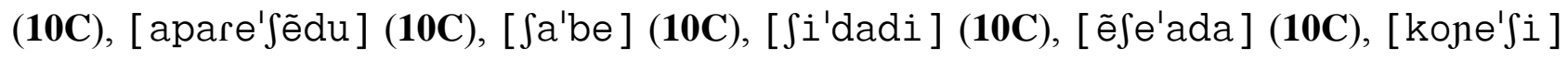

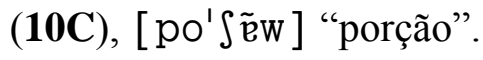

Curiosas são as formas [ i $\int_{i}$ 'tia $^{\prime}$ "existia" (9CI) e [i'fisti] "existe" (5C), paralela à

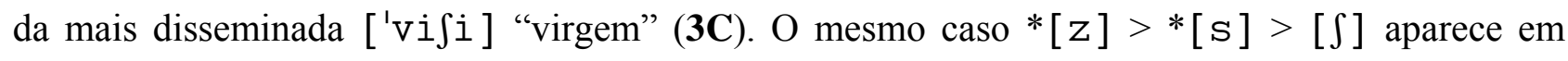
[koho'Sivus] (5C) e em [pre'Sẽti] (10C).

(c) Realização de / $\mathrm{t} /$ na posição de ataque

O litoral catarinense normalmente pronuncia $[\mathrm{ti}]^{55}$ e não [t $\left.\int \mathrm{i}\right]$, mas a africada aparece nas gerações mais novas, considerando os corpora de fala espontânea e os dados do questionário lingüístico. Na fala espontânea, esta ocorre sobretudo em São Francisco do Sul (1A, 2A, 4A, 5A, 9A, 4B, 9B, 10B).

Para os casos de alofonia de / $t$ / antes de [i] no questionário lingüístico (questão 21), constata-se o uso de [t] está presente em 25 dos 28 informantes (89\%) de Itapocorói. Em São Francisco do Sul, o uso de [t] está em 24 de $29^{56}$ informantes (83\%). Utilizaram [t $\int$ os informantes 10AI, 3BI, 4CI, 2A, 6A, 7A, 8A e 6B. A palavra [arteze'nadu ] sofreu sonorização analógica (9C).

Nas locuções espontâneas, encontramos ainda a africada motivada por metátese: estão ausentes nos informantes da faixa A, ocorre uma única vez na faixa $\mathbf{B}$ (em seu informante mais velho-10BI) em final de palavras: [ 'mũjt $\left.\int \mho\right]$ e [bu 'nit $\int u$ ]; e nos seguintes informantes da

\footnotetext{
${ }^{55}$ ALERS (2002: 101-6-v.2), cartas 28 e 29.

${ }^{56}$ Outra resposta: "prima" (10B).
} 
faixa C, também em final de palavras: 2CI, 5CI, 7CI, 10CI [ 'mũjt $\int v$ ] 6CI [ 'ot $\int v$ ], 4CI e 7CI ['mutsu], ['mũjtsv], 9C ['mutu] e 10CI ['kwatsu], ['mũjtsv], ['met $\int u$ ] “metro" e [ 'matsu]. Já no questionário lingüístico (questão 22), os únicos informantes que utilizaram [ $\mathrm{t} \int$ ] foram 9CI e 10B.

Em 4CI e 7CI encontramos duas realizações diferentes para a mesma palavra, "muito": ['mutsu] e ['mũjtsv]. O mesmo ocorre em 10CI com o numeral quatro: ['kwat $v$ ], [ 'kwat $\left.\int u\right]$ e ['kwatrv]. A metátese / jt / > [t $\left.\int\right]$ ou [jt $\int$ é bastante antiga e também

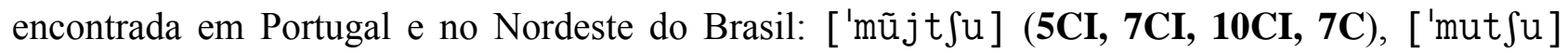
(10BI, 4CI, 7CI), [ 'ojt $\int u$ ] (5CI). Outra solução é [ 'mutu ] (9CI).

Para FURLAN (1989), a oclusiva alveolar desvozeada [ $t$ ], no açoriano catarinense, sofre um "processo de assimilação progressiva parcial consonantal: $t>t \int>t j$ ". Sendo assim, podemos encontrar sua africatização ou sua palatalização:

"No açoriano-catarinense, o fenômeno limita-se à oclusiva surda / t /, quando vem precedida de vogal tônica $+/ \mathrm{j} /$ e seguida de vogal recuada, não havendo sido registrados casos para a sonora / d /; manifesta-se, às vezes num mesmo falante, as duas fases do mesmo fenômeno de assimilação parcial, a saber: palato-alveolarização do / t /, do que resulta uma africação, cuja distensão palatal é pouco tensa; ex.: oito ['ojtšu], gaita ['gajtša], peito ['pejtšu]; palatalização do / t /; ex.: ['ojtju], ['gajtja], ['pejtju]. [...] Não sofre, pois, nem africação nem palatalização o / $\mathrm{t}$ / de palavras como leite, pente, pátio, tipitim, tio, ótimo, dia, diário, bate, pede, que seriam africadas no falar carioca, nem poitar, deitar." ${ }^{257}$ (FURLAN, 1989: 1356)

O uso da africada [t $\left.\int\right]$, no contexto anterior, está restrito aos informantes mais velhos. Isso indica uma mudança: o [t $\int$ ] perdeu quase que totalmente o espaço para o [t]. Esse fato

\footnotetext{
${ }^{57}$ Grifos do autor.
} 
acaba descaracterizando um dos sete quesitos considerados por Furlan como base do falar açoriano catarinense $\mathrm{s}^{58}$.

(d) Realização de /d/ na posição de ataque

A pronúncia catarinense normalmente pronuncia $\left[d_{i}\right]^{59}$ e não $\left[d_{3} i\right]$, mas a africada aparece nas gerações mais novas, sobretudo em São Francisco do Sul (1A, 5A, 9A, 5C). Curiosa é a forma ['3ia] para “dia” na expressão hoje (em) dia (9B).

Em relação ao uso de [d3], seu uso só foi registrado no questionário lingüístico (questões 23 e 24) nos informantes 10AI, 2BI, 3BI e 9A. Em outros contextos, [d3] não ocorre em metáteses. ${ }^{60} \mathrm{~A}$ inexistência da africatização de / d / é uma das teses de FURLAN (1989) que limita esse fenômeno ao / $t$ / na variante açoriana catarinense.

(e) A oposição / b / : / / na posição de ataque

A neutralização, comum nos dialetos do norte de Portugal, não ocorre, exceto em palavras muito comuns em outras áreas do português brasileiro ${ }^{61}$, como brabo (2BI) e braba (4A), encontradas na fala espontânea. Ocorreu também em bassoura (4A - no questionário lingüístico, questões 18 e 19).

(f) A queda do / I / da segunda posição do ataque por meio de * [. I ]

\footnotetext{
${ }^{58}$ Para FURLAN (1989: 135), o fenômeno da africatização e palatalização do / $\mathrm{t} /$ é próprio da variante açoriana catarinense. Ele não deve ser confundido com a africada palatal / t $\int$, proveniente do latim, que ocorre no dialeto caipira ou em Cuiabá; nem ser confundido com a africatização que ocorre no Rio de Janeiro, em que são africados / $\mathrm{t}$ / e / d / seguidos de / i / e / j / (tratados na questão 21, já comentada).

${ }^{59}$ ALERS (2002: $\left.107-\mathrm{v} .2\right)$, carta 30.

${ }^{60}$ Como ocorre no Nordeste: $\underline{\text { ódio }}$ ['ojdzu ], rádio ['hajdzu].

${ }^{61}$ Encontradas em AMARAL (1920) e MARROQUIM (1945).
} 
Ocorrem em ['dẽtu] (2CI, 5CI) [pusi's̃̃w] (5CI), ['koka] "cócoras" (5CI), [pisi'zava] (9B), [pi'Siza] "precisa" (9B), ['bagi] "bagre” (2C), ['safa] "safra” (2C). Algumas soluções de *[I] são [S] ou Ø: ['ot $\left.\int u\right]^{62}$ "outro" (6CI) ao lado de ['otu] "outro" (9CI, 9B, 2C, 6C), ['kwat Ju ] (10CI) ao lado de ['kwatu ] (10CI, 2C). Interessante é o plural ['otuf] de 10C. O informante 6C imitando "fala de escravo" realiza [so'bow] para "sobrou" e [pi'lẽw ] para "pirão".

De acordo com VIARO (2005: 233-4), a simplificação do cluster [ $\mathrm{c}$ ] > [ t ] pode ser encontrada em várias partes e aparece em transcrições de Barra Longa-MG; Nossa Senhora do Livramento-MT; em Taubaté-SP e no Nordeste. Outros clusters que sofreram simplificação na fala espontânea e coloquial são $[\mathrm{pr}]>[\mathrm{p}]$ e o $*[\mathrm{mb}]>[\mathrm{m}]$, este último representado nos corpora por [ ta'mẽ ], aparece também em VASCONCELOS (1928).

No questionário lingüístico (questão 4) o tepe foi utilizado por todos os informantes nas palavras esperadas ['pratu] e [tra'vesa].

(g) $\mathrm{O}$ rotacismo do / $1 /$ na segunda posição do ataque

$\mathrm{Na}$ fala espontânea em [prẽétava] (7CI), [is'prika] (4A), [ĩ'grejs ] (4A), [bisi'kreta] (4A) e em ['fro] (7C - no questionário lingüístico, questão 16).

(h) A realização do $/ \Lambda /$ :

Não é comum a realização como [ $j$ ], mas ela ocorre na fala espontânea em 2C: ['teja ], ['paja], [traba'ja] 3C ['fiju] e 10BI [pa'jasu] "palhaço", esta última no questionário lingüístico, questão 17. Formas recorrentes também em AMARAL (1920), MARROQUIM (1945) e ALMEIDA (2000), o que demonstra que tal ocorrência é encontrada em várias partes do Brasil.

\footnotetext{
${ }^{62}$ Encontrado em ALMEIDA (2000: 175). "Formas reprimidas na infância, como ['otu], aparecem na "fala rápida do PB (de qualquer região) e são a forma-base em outras variedades." (VIARO, 2005: 245)
} 


\section{CONSOANTES EM POSIÇÃO DE CODA}

/S/

Supomos que a pronúncia original seja $*\left[\int\right]$ ou $\varnothing$.

A consoante / S / em coda silábica é normalmente realizada como [S], mas há vários casos do [ [ ] típico da fala açoriana catarinense ${ }^{63}$. Em Itapocorói, essa realização é documentada em todas as faixas etárias: 2AI, 3AI, 4AI, 5AI, 6AI, 9AI, só voltando a aparecer nos informantes acima de 40 anos: 6BI, 10BI, 1CI, 2CI, 3CI, 4CI, 5CI, 6CI, 7CI, 8CI, 9CI, 10CI. Em São Francisco do Sul, a realização [ $\int$ ] é mais rara na faixa mais jovem, ocorrendo apenas muito esparsamente em

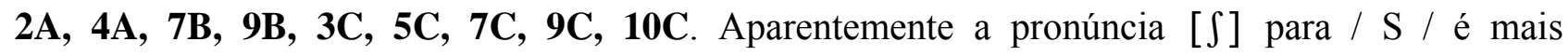
estigmatizada e policiada, uma vez que tende a sumir na faixa intermediária. Em São Francisco do Sul, a transformação dos $*\left[\int\right]>[S]$ parece ter ocorrido há mais tempo do que em Itapocorói.

Como em outras variantes brasileiras, a queda do / S / final ocorre, por razões morfossintáticas, com muita freqüência nos plurais dos adjetivos e substantivos, bem como na primeira pessoa do plural dos verbos, mas isso não é regra: 8CI, com 81 anos, diz ['kroka] ao

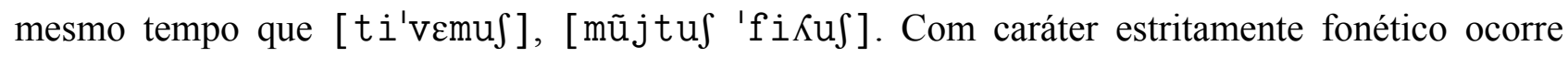
com mais freqüência com a conjunção/ advérbio [maj] (1CI, 4CI, 6CI, 9CI, 10CI) ou [ma ] (7CI, 2A, 2C, 9B) e com o pronome ['n॰j ] (5CI, 6CI, 10CI), mais rara com outras palavras: 7AI ['menu ], 5CI ['ajdi ] (“aids”), 8CI [kus'ku], [luj ], 9B [de'poj ], 1C ['onibu ].

A queda muitas vezes deixa a vogal temática da palavra: *['vezis] > ['vezi]: essa forma é comuníssima na expressão às vezes [az'vezi], que ocorre com mais velhos em Itapocorói e em todas as faixas etárias de São Francisco do Sul (8BI, 2CI, 9CI, 3A, 5A, 6A, 1B, 6B, 7B, 9B, 10B, 1C, 2C, 4C, 5C). Também ['vezi ] com numerais em 10A [duaz 'vezi ], 5B ['sĩku 'vezi], 10C ['mũjtaz 'vezi] ou sozinho em 2C ['tẽ 'vezi]. Há outros casos

\footnotetext{
${ }^{63}$ A mesma variação é encontrada na baixada cuiabana (ALMEIDA, 2000: 167).
} 
parecidos nas faixas mais antigas: 2CI [ha'pazi], 7CI [portu'gezi], 10A [portu'gezi], 9CI ['mezi], 10CI [mu'Keri], 9B ['mezi]. Obviamente também ocorre, embora menos comumente, a forma [az 'vejs ], como em 2B, 9B.

Essa queda é posterior à ditongação das vogal tônica precedente: *[lus ] $>*[\operatorname{lujs}]>$ [ $\left.\mathrm{luj}_{\mathrm{j}}\right]$. Aparentemente, essa forma ocorria paralelamente ao [ $\left.\int\right]$, que muitas vezes não ditonga a

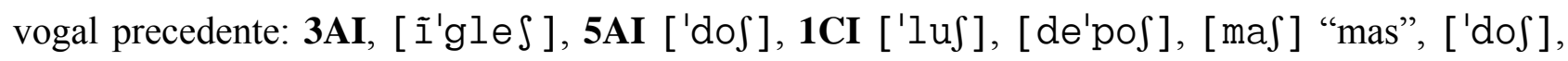

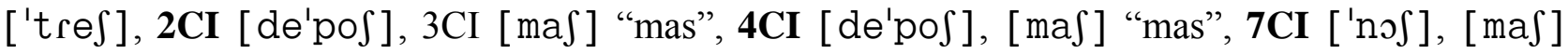

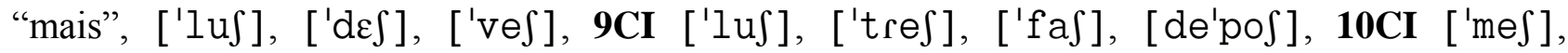

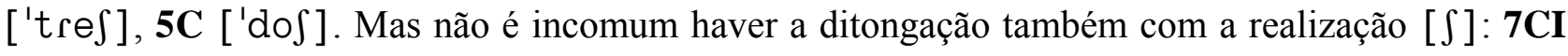

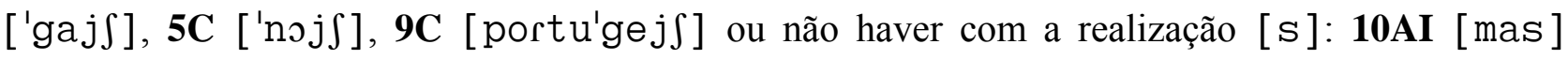
(“mais"), 2C [de'pos ], ['dos ], ['tres ].

A forma dous e *depôs devem ser tomadas como ponto de partida para entender essas realizações e não um apagamento do iode, pois ocorre em outras regiões no Brasil, como no Pará [de'puf], ['duf] e na baixada cuiabana (ALMEIDA, 2000: 177).

"Monotongações do tipo oi > o são interpretações errôneas do processo: o crioulo de Cabo Verde tem ['dodu] por doido, ['noti] por noite, mas trata-se obviamente de formas monotongadas de ou : doudo, noute." (VIARO, 2005: 223)

No entanto, não deixam de ser interessante as formas epentéticas muito antigas, usadas por 2CI ['fazi], 9CI ['dewzi], 10CI ['sejzi], 2C ['fazi].

Na realização do / S / em final de sílaba seguido por consoante, no questionário lingüístico (questão 6), a [s] apresentou-se em 19 dos 28 informantes (68\%) da antiga região de Itapocorói. Em São Francisco do Sul, em 24 dos 30 informantes (80\%). A outra forma encontrada é [ $\int$ ]. Em Itapocorói foi realizada por 7 informantes (25\%) - 3AI, 5AI, 6AI, 6BI, 9BI, 10BI e 2CI. Em São Francisco essa realização é reduzida a 3 informantes (10\%) - 1C, 5C e 10C. 
Trazida pelos primeiros açorianos, para FURLAN (1989), a pronúncia alveopalatal do / S / implosivo é um dos traços que mais caracteriza o falar açoriano catarinense, pois é amplamente difundida e abrange a maioria dos falantes do litoral de Santa Catarina (1989: 104).

Em relação ao arquifonema / S / em final de palavra, no questionário lingüístico foram aplicadas duas perguntas para verificar como ele poderia ocorrer (questões 7 e 8). Somando os dois resultados, encontramos, em Itapocorói, o uso de [ $\int$ ] em 10 informantes: 3AI, 6AI, 2BI, 3BI, 6BI, 8BI, 2CI, 4CI, 7CI e 10CI, o que totaliza 36\% das respostas. Já em São Francisco essa realização só foi produzida por um único informante, 10C, o que representa cerca de 3\% das respostas.

Assinala FURLAN (1989) que, de forma geral, no Brasil há um iode entre o / S / final dos oxítonos e a vogal que o precede. Ao contrário da maioria, afirma que a variante açoriana catarinense não introduz um iode nesse contexto, e, muitas vezes, não o realiza mesmo quando ela está presente. É esse fato que diferencia a variante em questão, por exemplo, da variante carioca, mesmo sabendo que ambas utilizam, na maioria dos casos, a fricativa alveopalatal desvozeada [ $\int$ ]. (1989: 114)

Especificamente na região de Itapocorói, vemos que o uso de [ $\int$ ] está bem presente, mas sua realização não implica a presença ou a ausência de iode. Em São Francisco do Sul, apesar do uso de [ $\int$ ] ser mais restrito, a afirmação em relação ao iode é a mesma.

Supomos que as pronúncias originais sejam *[l] ou [ [ ].

A consoante /L/ em coda silábica é normalmente realizada como [w], realização de todos os informantes na questão 14 do questionário lingüístico, mas as faixas mais antigas, como em outras regiões do Brasil, ou realizam-na de maneira velarizada na fala espontânea, isto é, como [ł] ou a rotacizam em [ $\ulcorner$ ] ou ainda fazem uma epêntese quando em final de palavra.

“Na pronúncia mais comum o [ł] velar, que é, em Portugal, a realização de todos os $I$ em final de sílaba, vocaliza-se em [w]. Escreve-se animal, Brasil, amável, sol, e pronuncia-se [animaw], [braziw], [amavew], [sow]. A distinção entre mal (advérbio) e mau (adjetivo) 
desaparece. Somente o extremo sul do país mantém regularmente a antiga distinção.” (TEYSSIER, 1997: 103)

Pronunciam-na como [ł]: 7CI ['mał], 9CI [ka'zał], 10CI ['mił], 5C ['mił], 6C ['mał], 10C [materi'ał] ['mił]. Praticam rotacismo, 6AI [polisi'ar ], 2CI [a'sartu ], 5CI ['vorta], [sor'ta], 7CI [ar'ta], ['vorta], 9CI ['kurtu], ['sarga], 10CI [ar'ta], ['tar], ['arku], ['porva], 6B [alu'ger], 9B [ĩbor'sa], 10B [vor'tava], ['karma ], [dis'karsu], [ar'gũ ], 1C [ar'gũ ], 2C [sor'dadu], 3C [ar'gũ ], 4C [ar'gũ ], 5C [ar'tura ], 6C ['tar ], [sor'tarũ ], [vor'to], 9C ['vorta ], ['vortũ ], 10C [ĩduftri'ar ], [karku'ladu ], [mar'dadi], [ar'gẽj], [ar'gũ ], [asfar'to], ['karmu ], [pesu'ar ]. Em sílabas átonas finais também ocorre a queda: 1CI ['məvi ], 7CI [awto'məvi ], 9CI ['məvi], 10CI ['arku], 1C [di'fisi], 2C [di'fisi], 5C [z̃'krivi]. A epêntese ocorre apenas em 2CI ['fazi], 9CI ['dewzi], 10CI ['sejzi], 2C ['fazi], 7C [kwar'tele], 10C [peska'doru], ['mile] e 9C ['sole] (realização encontrada no questionário lingüístico, questão 15).

Para FURLAN (1989), a presença de resíduos de apoio paragógico a oxítonos terminados em - / L /, / R /, / S / é mais um dos traços que diferenciam a variante açoriana catarinense. Relacionando à assertiva acima com os dados obtidos, é possível notar que esse é um processo que está tornando-se raro também: só está presente em algumas ocorrências na faixa $\mathbf{C}$, o que indica que tal uso irá desaparecer das localidades pesquisadas.

CUESTA \& LUZ (1971: 54) assinalam que o apoio paragógico é recorrente em quase toda a península Ibérica. Além disso, registram que há ocorrências do apoio paragógico em Alagoas, Sergipe e Goiás (1971: 135). ALMEIDA (2000: 177) também registra seu uso na baixada cuiabana.

Em final de sílaba átona, a pronúncia original remonta a *Ø. 
A forma ['omi ${ }^{64}$ é generalizada (5AI, 9AI, 1BI, 5BI, 8BI, 6CI, 8CI, 1C) e remonta ao português antigo, embora o incomum. Curiosa é, porém, a forma usada por 5C ['omi $\left.\int\right]$. O mesmo se pode dizer de ['õti] (6C).

“As postônicas nasais não ocorrem nos falares não-europeus, exceto por relexicalização. Essa desnasalização já ocorrera em época muito antiga no próprio português europeu: home por homem, onte por ontem. Formas assim não são exclusivas do português do Brasil, pois são as bases de todas as variantes africanas e asiáticas: no Sri Lanka: hómi, órdi, nuvè, virze; em Damão: hom, ont, ord, viaz, varj (de *varje e não de várzea); no crioulo malaio-portugês.” VIARO (2005: 226)

Também a terceira pessoa do plural é freqüentemente pronunciada sem a nasalidade característica da última vogal: 4BI [eliz'fazi]. Outras palavras que perdem a nasalidade final: [i'mazi ] (6AI, 10CI), [vi'azi ] (6CI), [pa'sazi ] (9CI), ['najlu ] "nylon"(8B), ['nuvi ] (9B). AMARAL (1920: 50), registra que a queda da nasalização neste mesmo contexto, é comum no dialeto caipira. Os ditongos nasais em posição átona final são freqüentemente desnasalados e monotongados: [bẽsa] "bênção" (8BI, 10B), ['ligu] "ligam" (7CI), ['goftu ] "gostam" (3C).

A desnasalação de sótão se torna, curiosamente, ['soti] em 1CI.

$/ \mathrm{R} /$

Supomos que as pronúncias originais sejam *[r] ou Ø.

$\mathrm{O} / \mathrm{R}$ / em posição de coda é, normalmente, pronunciado [ $\mathrm{r}]$, mas uma variante $[\mathrm{x}]$, provavelmente de origem vicentina, ocorre de maneira assistemática em muitos falantes das classes mais jovens, sobretudo de Itapocorói (3AI, 4AI, 6AI, 7AI, 9AI, 10AI, 1BI, 7BI, 8BI, 10BI, 5A). Um curioso [〕] também se ouve em São Francisco do Sul: 4A [ka'dernu ] 6B [mar], 9B [bar],

\footnotetext{
${ }^{64}$ Encontrada em AMARAL (1920), VASCONCELOS (1928), MARROQUIM (1945), ALMEIDA (2000).

${ }^{65}$ Para AMARAL (1920: 50), esta palavra toma esta forma por influência do artigo feminino.
} 
10B ['parti ], ['porta], [ĩteri'or]. O questionário lingüístico (questão 5) segue o mesmo padrão, com o uso da variante [x ] por 3AI, 6AI, 1N1, 2BI, 4A.

Os $r$ do infinitivo, como na maioria das variantes do português brasileiro, não são realizados. Segundo VIARO (2005: 233): "Apócope antiga é sem dúvida do -r do infinitivo, encontrada até mesmo no romeno e forma-base para todas as variantes não-européias, a despeito da grafia que raramente a ignora." No entanto, é comum que outras palavras monossílabas e oxítonas, em todas as faixas etárias, não realizem o /R/ final: [mu' $\kappa \varepsilon$ ] (1BI, 2BI, 7BI, 1CI, 2CI, 7CI, 8CI, 8CI, 9CI, 10CI, 2A, 3A, 4A, 8A, 9A, 10A, 9B, 1C, 3C, 6C), [me'

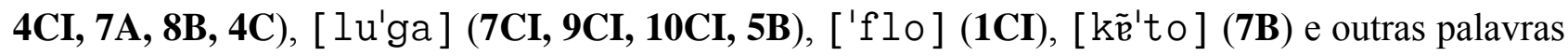
com o sufixo -dor: [trabaKa'do] (6CI), [dow'to] (6CI), [peska'do] (2B, 8B, 9B, 5C),

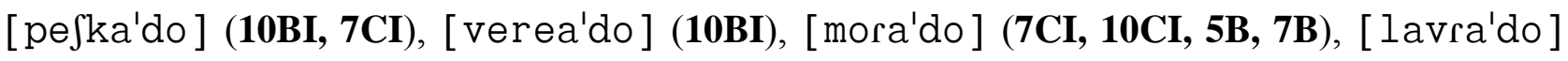
(7CI), [ lava'do ] (8CI), [3oga'do ] (3C), [heboka'do ] (9B). A palavra "altar" ocorre às vezes como [ar'ta ] (7CI, 10CI).

Como em outras variantes brasileiras, o / R / cai também nas sílabas finais átonas: 9B ['kẽsi ] “câncer”. Na situação de coda de sílaba não-final, raramente ocorre a queda: 9B [po'ke ] "porque", 5CI [be'bẽeti] "barbante".

No questionário lingüístico (questão 3), [ r] foi a realização predominante. Aparece a variante $[\mathrm{x}]$ em $\mathbf{6 A}$, assim como em sua fala espontânea.

\section{OUTROS FENÔMENOS FONÉTICOS:}

Metátese e síncope

Metátese do [r] em 8CI ['kroka], 9CI [pregũ'to], 1C [persi'zava]. Um caso

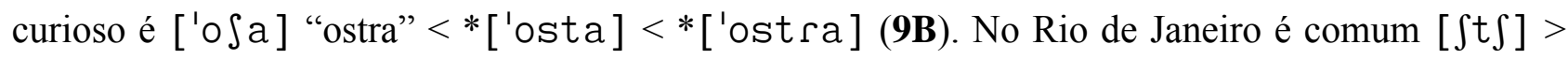
$\left[\int\right]$. 
Muitas dessas formas ditas sincopadas são na verdade arcaísmos: o [j] só é entendido como supostamente sincopado em [ba'lea] (1B, 10B) se partimos de baleia, mas a forma mais antiga é balea < balẽa < lat. balcenam. Outro caso que aponta para um arcaísmo é o de [kõdi'sõs] "condições" (9B). O mesmo se pode dizer de *area < lat. arenam presente em areão (2C). Outro caso de arcaísmo é [agarde'sia] de 10C.

Uma forma geral em todo português brasileiro é [po'brema ] (5B).

Um caso curioso de síncope: 10B [kũprime'nava ]

Epêntese:

Alguns casos notáveis: arrecarda (8BI) “arrecada” (também recarda em 9B), triatro (2CI), injerção (5CI).

Haplologia:

Único caso digno de observação: banalzinho (1CI) "bananalzinho".

Assimilação:

Apenas um exemplo merece ser notado: catatumba (5CI).

Os temas das perguntas 12 e 20 do questionário lingüístico não foram analisadas nos corpora, por isso, só citaremos as respostas, pois a seqüência / eN / é sempre realizada como [ẽ ] e não como [ ẽj ] e na alofonia de / $\mathrm{n} /$ todos realizaram como [n] e não como [ j ] . 


\section{ANÁLISE LEXICAL}

Lidar com a variação lexical é fato recorrente para aqueles que trabalham com dados de língua obtidos principalmente com questionários lingüísticos. O fato de uma pergunta ter muitas respostas distintas não significa que essas palavras possuam identidade semântica ou até mesmo uma equivalência semântica entre si, como vemos na análise dos dados.

Não é também a característica de ser permutável em um mesmo contexto que as caracterizam como sinônimos. Mesmo que não seja fácil de demonstrar, a variação lexical implica também uma variação de sentido. Muitas vezes, essas sutilezas se escondem atrás do questionário semântico-lexical, pois não nos podemos esquecer de que esta não é uma situação espontânea de locução. O contexto da aplicação de questionários lingüísticos é restrito, assim como as próprias perguntas realizadas, sendo assim, em uma situação real de uso, podem surgir especificidades ou variações semânticas mais sensíveis:

"O sentido é uma decorrência do contexto: o sentido de um gramema depende de seu contexto imediato, o lexema ao qual o gramema se prende, assim como o sentido das palavras depende do contexto frásico no qual elas se inserem, e o sentido das frases depende do contexto mais amplo do texto que as enclausura." (LOPES, 2001: 256)

Os casos mais peculiares referentes ao léxico de todo os corpora estão presentes no Glossário. Porém, algumas considerações, quando pertinentes ${ }^{66}$, são apresentadas neste capítulo. Primeiramente, apresentar-se-ão as ocorrências obtidas no questionário lingüístico. Após isso, será feita a análise conjunta dos dados relevantes. Mesmo estando em um mesmo capítulo, sempre assinalamos a procedência: se obtidos nos Questionários ${ }^{67}$ ou se do corpora de fala espontânea ${ }^{68}$. Para facilitar o manuseio dos dados, eles são apresentados em ordem alfabética. Além disso, o alfabeto fonético só será usado quando houver necessidade ${ }^{69}$.

Todas as palavras foram primeiramente procuradas no Aurélio século XXI: o dicionário da língua portuguesa (1999) e no Houaiss eletrônico (2001). Algumas, sentidas como típicas do Sul do país, foram procuradas nos dicionários específicos da região: ALEXANDRE (1994), CORRÊA

\footnotetext{
${ }^{66}$ Geralmente arcaísmos e palavras consideradas típicas da região.

${ }^{67}$ Neste capítulo, quando mencionarmos o questionário lingüístico, entenda-se como a parte semântico-lexical.

${ }^{68}$ Os exemplos que se apresentam em um contexto, isto é, em frases, são retirados da fala espontânea.

${ }^{69}$ Vide critérios de transcrição (Anexo 2).
} 
(2000), FISCHER (1999), JAMUNDÁ (1974), MORAES (1935), NUNES \& NUNES (1992), OLIVEIRA (2002) ou no ALERS (2002).

Entre outras obras e dicionários, consultamos também: ALMEIDA (2000), ALVES (1965), AMARAL (1920), BIVAR (1948), CARVALHO (1983), IMAGUIRE (1999), IRMEN \& KOLLERT (1935), MACHADO (1952-59), MANSUR GUÉRIOS (1979), MARROQUIM (1945), MICHAELIS (1998), SILVA (1949-59), SIMÕES (1984), SOUTO MAIOR (1985), TAUNAY (1914), TORRINHA (1939), VASCONCELLOS (1928) e VILLAR (1989).

\subsection{O QUESTIONÁRIO LEXICAL}

Alguns informantes deram mais de uma resposta para uma mesma pergunta, por isso, eles podem ser citados, em uma única questão, mais de uma vez.

\section{1 - Resposta esperada ${ }^{70}$ : AGUACEIRO, PÉ D’ÁGUA, CHUVÃO}

(...) uma chuva muito forte? ${ }^{71}$

Aguaceira (10A), aguaceiro (2C, 7C), aguaceiro forte (3CI), carga d’água (4CI), chuva forte (2CI, 9CI), chuvarada (9A, 4B, 10B), enchente (8BI, 7CI), granizo $(8 \mathrm{~B}, \mathbf{1 0 C})$, grossa (3CI), pé d'água ou tromba d'água (5B), rebojo (9AI), tempestade (6AI, 8AI, 10AI, 2BI, 4BI, 5BI, 10BI, 5CI, 10CI, 7A, 3B, 6B, 9B, 3C, 5C, 6C, 9C), temporal (3AI, 7AI, 6BI, 7BI, 1A, 5A, 6A, 1B, 2B, 7B, 1C, 8C), trovão (5C), trovoada (1AI , 2AI , 5AI, 1BI, 3BI, 6C), trovoada grande (9BI). Não responderam: 4AI, 2A, 3A, 4A, 8A, 4C.

\section{Número de ocorrências:}

Faixa AI Faixa BI Faixa CI Faixa A Faixa B Faixa C

\footnotetext{
${ }^{70}$ Para entender o que seja a resposta esperada, ver o capítulo Trabalho de Campo (1.4 - O questionário lingüístico, p.50).

${ }^{71}$ As formas granizo e trovoada são encontradas também em Florianópolis (IMAGUIRE, 1999: 407).
} 


\begin{tabular}{lllllll}
\hline aguaceira & 1 & 0 & 0 & 0 & 0 & 0 \\
aguaceiro & 0 & 0 & 0 & 0 & 0 & 2 \\
aguaceiro forte & 0 & 0 & 1 & 0 & 0 & 0 \\
carga d'água & 0 & 0 & 1 & 0 & 0 & 0 \\
chuva forte & 0 & 0 & 2 & 0 & 0 & 0 \\
chuvarada & 0 & 0 & 0 & 1 & 2 & 0 \\
enchente & 0 & 2 & 1 & 0 & 0 & 0 \\
granizo & 0 & 0 & 0 & 0 & 2 & 1 \\
grossa & 0 & 0 & 1 & 0 & 0 & 0 \\
pé d'água & 0 & 0 & 0 & 0 & 1 & 0 \\
rebojo & 1 & 0 & 0 & 0 & 0 & 0 \\
tempestade & 3 & 4 & 2 & 1 & 3 & 4 \\
temporal & 2 & 2 & 0 & 3 & 3 & 2 \\
tromba d'água & 0 & 1 & 0 & 0 & 0 & 0 \\
trovão & 0 & 0 & 0 & 0 & 0 & 1 \\
trovoada & 3 & 2 & 0 & 0 & 0 & 1 \\
trovoada grande & 0 & 1 & 0 & 0 & 0 & 0 \\
não responderam & 1 & 0 & 0 & 1 & 0 & 1 \\
\hline
\end{tabular}

2 - Resposta esperada: PÉ DE VENTO, VENTANIA

(...) um vento muito forte? ${ }^{72}$

Ciclone (7C), rajada (10B), rebojo (9AI, 8BI, 2CI, 10A), tempestade (10BI, 5A, 9B, 9C), temporal (6B), tornado (2BI), trovoada (4CI), tufão (3CI, 7CI, 10CI, 2B, 5C, 6C), vendaval (2AI, 6AI, 7AI, 1BI, 6BI, 7BI, 5CI, 1B, 3B, 7B, 8B, 3C, 10C), ventania: (1AI, 3AI, 4AI, 10AI, 3BI, 4BI, 5BI, 1CI, 4A, 6A, 7A, 9A, 4B, 5B, 1C, 2C, 8C), ventania grande (9BI), vento forte (9CI). Não responderam: 5AI, 8AI, 1A, 2A, 3A, 8A, 4C.

Número de ocorrências ${ }^{73}$ :

\footnotetext{
${ }^{72}$ As formas temporada, tempestade, chuva de trovoada, vendaval e vento forte são encontradas também em Florianópolis (IMAGUIRE, 1999: 407).

73 Os lexemas tempestade, temporal, trovoada e rebojo, considerados como equivalentes semânticos de "uma chuva muito forte", também apareceram como resposta para esta questão (2). Assim, podemos perceber que, apesar das duas
} 


\begin{tabular}{lccccccc}
\hline & Faixa AI & Faixa BI & Faixa CI & Faixa A & \multicolumn{2}{c}{ Faixa B } & Faixa C \\
\hline ciclone & 0 & 0 & 0 & 0 & 0 & 1 \\
rajada & 0 & 0 & 0 & 0 & 1 & 0 \\
rebojo & 1 & 1 & 1 & 1 & 0 & 0 \\
tempestade & 1 & 0 & 0 & 1 & 1 & 1 \\
temporal & 1 & 0 & 0 & 0 & 0 & 0 \\
tornado & 0 & 0 & 1 & 0 & 0 & 0 \\
trovoada & 0 & 0 & 1 & 0 & 0 & 0 \\
tufão & 0 & 0 & 3 & 0 & 1 & 2 \\
vendaval & 3 & 3 & 1 & 0 & 4 & 2 \\
ventania & 4 & 3 & 1 & 4 & 2 & 3 \\
ventania grande & 1 & 0 & 0 & 0 & 0 & 0 \\
vento forte & 0 & 1 & 0 & 0 & 0 & 0 \\
não responderam & 2 & 0 & 0 & 4 & 0 & 1 \\
\hline
\end{tabular}

3 - Resposta esperada: BAMBU, BUMBU, CANIÇO

Você sabe o nome da planta que se usa para fazer vara de pescar?

Bambu (1AI, 2AI, 3AI, 4AI, 5AI, 6AI, 8AI, 1BI, 2BI, 3BI, 4BI, 5BI, 7BI, 8BI, 10BI, 2CI, 4CI, 5CI, 6CI, 7CI, 8CI, 9CI, 10CI, 3A, 5A, 6A, 7A, 8A, 9A, 10A, 1B, 2B, 3B, 5B, 6B, 7B, 8B, 10B, 1C, 4C, 5C, 9C), bambule (7C), bumbu (1CI), caniço (6BI, 9B, 3C, 6C, 9C), mambu (2C). Não responderam: 7AI, 9AI, 10AI, 9BI, 3CI, 1A, 2A, 4A, 4B, 8C.

Número de ocorrências:

\begin{tabular}{lccccccr}
\hline & Faixa AI & Faixa BI & Faixa CI & Faixa A & Faixa B & Faixa C \\
\hline bambu & 7 & 8 & 8 & 7 & 8 & 4 \\
bambule & 0 & 0 & 0 & 0 & 0 & 1 \\
\hline
\end{tabular}

perguntas estarem dirigidas para fenômenos atmosféricos diferentes, alguns lexemas repetem-se nas questões, mostrando-nos, então, que os campos de significação das palavras não são tão nítidos e distintos como podem parecer em um primeiro momento. Eles se interpenetram e se mesclam gerando nuanças de sentido. De acordo com ULLMANN: “(...) a definição referencial de significado não deve levar-nos a uma visão atomística da linguagem, na qual cada palavra fosse considerada como uma unidade isolada e fechada em si própria. Além da relação muito especial e sui generis que une o nome ao sentido, as palavras estão também associadas a outras palavras, com as quais têm qualquer coisa em comum, no som, no sentido, ou em ambos ao mesmo tempo.” (ULLMANN, 1964: 130) 


\begin{tabular}{lllllll}
\hline bumbu & 0 & 0 & 1 & 0 & 0 & 0 \\
caniço & 0 & 1 & 0 & 0 & 0 & 0 \\
mambu & 0 & 0 & 0 & 0 & 0 & 1 \\
não responderam & 3 & 1 & 1 & 3 & 1 & 1 \\
\hline
\end{tabular}

4 - Resposta esperada: BATEIRA, CANOA, BARQUINHO

(...) aquele barco pequeno usado para pescar?

Baleeira $^{74}$ (4BI, 1CI, 4CI), barquinho (2C), bote (4AI, 7AI, 8AI, 1BI, 4CI, 9CI, 10CI, 2C, 3C, 5C), bateira $^{75}$ (6AI, 2BI, 3BI, 10BI, 2CI, 9CI, 5A, 6A, 9A, 10A, 1B, 2B, 3B, 5B, 6B, 7B, 9B, 10B, 1C, 7C, 8C), caico (8B), canoa (1AI, 2AI, 3AI, 5AI, 8AI, 5BI, 6BI, 7BI, 3CI, 4CI, 5CI, 10CI, 2A, 4A, 7A, 9A, 10A, 4B, 5B, 1C, 2C, 8C), embarcação (8A), lancha (8BI, 2CI, 7CI, 3A, 1C). Não responderam: 10AI, 9BI, $1 \mathrm{~A}$.

Número de ocorrências:

\begin{tabular}{lccccccc}
\hline & Faixa AI & Faixa BI & Faixa CI & Faixa A & Faixa B & Faixa C \\
\hline baleeira & 0 & 1 & 2 & 0 & 0 & 0 \\
barquinho & 0 & 0 & 0 & 0 & 0 & 1 \\
bote & 3 & 1 & 3 & 0 & 0 & 3 \\
bateira & 1 & 3 & 2 & 4 & 8 & 3 \\
caíco & 0 & 0 & 0 & 0 & 1 & 0 \\
canoa & 5 & 3 & 4 & 5 & 2 & 3 \\
embarcação & 1 & 0 & 0 & 0 & 0 & 0 \\
lancha & 0 & 1 & 2 & 1 & 0 & 1 \\
não responderam & 1 & 1 & 0 & 1 & 0 & 0 \\
\hline
\end{tabular}

\footnotetext{
${ }^{74}$ [bale 'era] ou [bali 'era].

${ }^{75}$ [ba 'tera] ou [ba' tejra].
} 
5 - Resposta esperada: ANGOLISTA, TRAFACO, GALINHA D’ANGOLA

(...) aquele tipo de ave que grita: "tô fraco, tô fraco".

Angola (10BI, 8B, 9B), angolista ${ }^{76}$ (3AI, 4BI, 5BI, 6BI, 7BI, 8BI, 1CI, 2CI, 3CI, 4CI, 5CI, 7CI, 10CI, 6B, 7B, 1C, 2C, 3C, 4C, 6C, 7C, 9C), galinha d'angola (3AI, 2CI, 3B, 5B, 1C, 8C, 10C), grandeúva (6BI), tãofraco (5C), trafaco (4BI). Não responderam: 1AI, 2AI, 4AI, 5AI, 6AI, 7AI, 8AI, 9AI, 10AI, 1BI, 2BI, 9CI, 1A, 2A, 3A, 4A, 5A, 6A, 7A, 8A, 9A, 10A, 1B, 2B, 4B, 8B, 9B, 10B.

Número de ocorrências:

\begin{tabular}{|c|c|c|c|c|c|c|c|}
\hline & Faixa AI & Faixa BI & Faixa CI & Faixa A & Faixa B & Faixa $\mathrm{C}$ & \\
\hline angola & & 0 & 1 & 0 & 0 & 2 & 0 \\
\hline angolista & & 1 & 5 & 7 & 0 & 2 & 7 \\
\hline galinha d'angola & & 1 & 0 & 1 & 0 & 2 & 3 \\
\hline grandeúva & & 0 & 1 & 0 & 0 & 0 & 0 \\
\hline tãofraco & & 0 & 0 & 0 & 0 & 1 & 0 \\
\hline trafaco & & 0 & 1 & 0 & 0 & 0 & 0 \\
\hline não responderam & & 9 & 2 & 1 & 10 & 6 & 0 \\
\hline
\end{tabular}

6 - Resposta esperada: VAREJEIRA

(...) a mosca meio azulada, que põe bicheira nos animais?

Butuca (9BI), bareja (3AI, 5AI, 6AI, 7AI, 8AI, 10AI, 1BI, 2BI, 3BI, 7BI, 8BI, 3CI, 5CI, 1CI, 2CI, 4CI, 7CI, 9CI), barejeira (9AI, 6BI), mosca de bicheira (10C), vareja (5BI, 9A, 2B, 7B, 8B,), varejeira (4BI, 10BI, 7CI, 10CI, 10A, 1B, 3B, 5B, 6B, 8B, 9B, 10B, 1C, 2C, 3C, 4C, 5C, 6C, 7C, 8C), mosca azulada (10A, 8C) vareja (depois retificam como bareja) (10AI, 7BI, 8BI, 3CI, 5CI). Não responderam: 1AI, 2AI, 4AI, 6CI, 8CI, 1A, 2A, 3A, 4A, 5A, 6A, 7A, 8A, 4B.

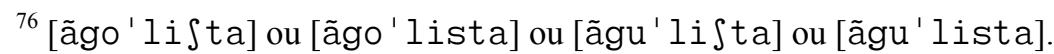


Número de ocorrências:

\begin{tabular}{lccccccc}
\hline & Faixa AI & Faixa BI & Faixa CI & Faixa A & Faixa B & Faixa C \\
\hline butuca & 0 & 1 & 0 & 0 & 0 & 0 \\
bareja & 6 & 5 & 7 & 0 & 0 & 0 \\
barejeira & 1 & 1 & 0 & 0 & 0 & 0 \\
mosca de bicheira & 0 & 0 & 0 & 0 & 0 & 1 \\
vareja & 0 & 1 & 0 & 1 & 3 & 0 \\
varejeira & 0 & 2 & 2 & 1 & 7 & 8 \\
mosca azulada & 0 & 0 & 0 & 1 & 0 & 1 \\
não responderam & 3 & 0 & 2 & 8 & 1 & 0 \\
\hline
\end{tabular}

\section{7 - Resposta esperada: GERVÃO, BICHO PINTO, TATURANA, LAGARTA}

(...) o bicho que é pequeno, "peludo", que come as folhas das plantas e quando encostamos nele queimamos a pele? ${ }^{77}$

Bicha (2BI), bicha cabeluda (1AI, 2AI, 5AI, 10BI), bicha foguinha (3A), bicha rata (1B, 2B, 8B, 1C), bicho pinto (1CI, 2CI), bira (4C), formiga (8BI, 7CI, 9A), gervão (7BI, 4CI), imbira (5BI, 6A, 7A, 8A, 4B, 5B, 7B, 1C, 2C, 6C, 8C, 9C, 10C), lagarta (6AI, 3BI, 6BI, 9CI, 10A, 7C), lagartixa (9BI), lagartixinha (10B), largata (4AI, 7AI, 8AI, 3CI), larva (5BI), larva peluda (1C), lucrécia (5CI), mandaruvá (6B), marandová (3C), minhoca (10AI), queima-queima (1A), tarturana (4BI, 5C). Não responderam: 3AI, 1BI, 2A, 4A, 5A, 3B, 9B.

\footnotetext{
${ }^{77}$ Respostas como formiga, lagartixa (inha) ou minhoca demonstram, provavelmente, que o informante não entendeu ou desconhecia o objeto da pergunta. Não podem ser consideradas equivalentes semânticos de tarturana, pois, designam bichos completamente diferentes. Após responder ao questionário lingüístico, questionei sobre essas respostas e os informantes confirmaram minhas suposições.
} 
Número de ocorrências:

\begin{tabular}{lcccccc}
\hline & Faixa AI & Faixa BI & Faixa CI & Faixa A & Faixa B & Faixa C \\
\hline bicha & 0 & 1 & 0 & 0 & 0 & 0 \\
bicha cabeluda & 3 & 1 & 0 & 0 & 0 & 0 \\
bicha foguinha & 0 & 0 & 0 & 1 & 0 & 0 \\
bicha rata & 0 & 0 & 0 & 0 & 3 & 1 \\
bicho pinto & 0 & 0 & 2 & 0 & 0 & 0 \\
bira & 0 & 0 & 0 & 0 & 0 & 1 \\
formiga & 0 & 1 & 1 & 1 & 0 & 0 \\
gervão & 0 & 1 & 1 & 0 & 0 & 0 \\
imbira & 0 & 1 & 0 & 3 & 3 & 6 \\
lagarta & 1 & 2 & 1 & 1 & 0 & 1 \\
lagartixa & 0 & 1 & 0 & 0 & 1 & 0 \\
largata & 3 & 0 & 1 & 0 & 0 & 0 \\
larva & 0 & 1 & 0 & 0 & 0 & 0 \\
larva peluda & 0 & 0 & 0 & 0 & 0 & 1 \\
lucrécia & 0 & 0 & 1 & 0 & 0 & 0 \\
mandaruvá & 0 & 0 & 0 & 0 & 1 & 0 \\
marandová & 0 & 0 & 0 & 0 & 0 & 1 \\
minhoca & 1 & 0 & 0 & 0 & 0 & 0 \\
queima-queima & 0 & 0 & 0 & 1 & 0 & 0 \\
tarturana & 0 & 1 & 0 & 0 & 0 & 1 \\
não responderam & 1 & 1 & 0 & 3 & 2 & 1 \\
\hline & & & & & & 0
\end{tabular}

8 - Resposta esperada: ROXA, MAGOADA

Quando se machuca uma parte do corpo, e a carne ali fica com uma mancha, dizemos que a carne ficou $^{78} \ldots$

Carne viva (2B), casquinha (2A), cicatriz (10B), esmagada (7CI), estragada (1CI), exposta (8C), ferida (3BI, 3CI, 9CI, 10CI), hematoma (5C), machucada (3AI, 6AI, 3BI, 2CI, 3CI, 9CI, 10CI, 4A, 5A, 6A, 7A, 10A, 7B, 6C), magoada (9AI, 1BI, 6B, 8B, 3C), manchada (5AI, 8AI, 9BI, 1B, 1C, 10C), marcada (9B), podre (7AI, 9BI), preta (4BI), queimada (2BI, 8BI, 9A), ralada (3A, 8C),

\footnotetext{
${ }^{78}$ Esta foi uma das questões que obteve o maior número de variações nas respostas. Todas essas formas, relacionadas com contusões, possuem significados distintos: queimar-se é muito diferente, por exemplo, de ralar-se ou ter o local ferido estragado ou podre.
} 
roxa (1AI, 2AI, 10AI, 4BI, 5BI, 6BI, 7BI, 9BI, 10BI, 10A, 3B, 5B, 2C, 4C, 7C). Não responderam: 4AI, 1A, 8A, 4B, 9C.

Número de ocorrências:

\begin{tabular}{lcccccc}
\hline & Faixa AI & Faixa BI & Faixa CI & Faixa A & Faixa B & Faixa C \\
\hline carne viva & 0 & 0 & 0 & 0 & 1 & 0 \\
casquinha & 0 & 0 & 0 & 1 & 0 & 0 \\
cicatriz & 0 & 0 & 0 & 0 & 1 & 0 \\
esmagada & 0 & 0 & 1 & 0 & 0 & 0 \\
estragada & 0 & 0 & 1 & 0 & 0 & 0 \\
exposta & 0 & 0 & 0 & 0 & 0 & 1 \\
ferida & 0 & 1 & 3 & 0 & 0 & 0 \\
hematoma & 0 & 0 & 0 & 0 & 0 & 1 \\
machucada & 2 & 1 & 4 & 5 & 1 & 1 \\
magoada & 1 & 1 & 0 & 0 & 1 & 2 \\
manchada & 2 & 1 & 0 & 0 & 1 & 2 \\
marcada & 0 & 0 & 0 & 0 & 1 & 0 \\
podre & 1 & 1 & 0 & 0 & 0 & 0 \\
preta & 0 & 1 & 0 & 0 & 0 & 0 \\
queimada & 0 & 2 & 0 & 1 & 0 & 0 \\
ralada & 0 & 0 & 0 & 1 & 0 & 1 \\
roxa & 3 & 6 & 0 & 1 & 0 & 1 \\
não responderam & 1 & 0 & 0 & 2 & 1 & 1 \\
\hline
\end{tabular}

9 - Resposta esperada: CARECA, QUECA

A pessoa que não tem cabelo é....

Lisa (6B), pelado (9BI, 4C), careca: demais informantes.

Número de ocorrências:

\begin{tabular}{lccccccr}
\hline & Faixa AI & Faixa BI & Faixa CI & Faixa A & Faixa B & \multicolumn{2}{c}{ Faixa C } \\
\hline careca & 10 & 9 & 8 & 10 & 9 & 10 \\
lisa & 0 & 0 & 0 & 0 & 1 & 0 \\
pelado & 0 & 1 & 0 & 0 & 0 & 1 \\
\hline
\end{tabular}

10 - Resposta esperada: POMBOCA, LAMPIÃO, LAMPARINA 
(...) o objeto pequeno, de ferro, em que se punha querosene para iluminar a casa quando não havia energia elétrica?

Candeia (4CI, 5CI, 7CI, 10CI, 1C), lamparina (8AI, 7BI, 2CI, 3CI, 9CI, 4C, 6C, 7C, 9C), lampião (1AI, 2AI, 4AI, 5AI, 6AI, 9AI, 10AI, 5BI, 9BI, 10BI, 1CI, 4A, 7A, 8A, 9A, 10A, 1B, 3B, 5B, 6B, 7B, 8B, 9B, 10B, 2C, 3C, 5C, 7C, 8C, 9C, 10C), lanterna (3A), liquinho (a) (2BI, 6A, 4B), pomboca (3BI, 4BI, 8BI), tocha (6BI). Não responderam: 3AI, 7AI, 1BI, 1A, 2A, 5A, $2 B$.

Número de ocorrências:

\begin{tabular}{lccccccc}
\hline & Faixa AI & Faixa BI & Faixa CI & Faixa A & Faixa B & Faixa C \\
\hline candeia & 0 & 0 & 4 & 0 & 0 & 1 \\
lamparina & 1 & 1 & 3 & 0 & 0 & 4 \\
lampião & 7 & 3 & 1 & 5 & 8 & 7 \\
lanterna & 0 & 0 & 0 & 1 & 0 & 0 \\
liquinho(a) & 0 & 1 & 0 & 1 & 1 & 0 \\
pomboca & 0 & 3 & 0 & 0 & 0 & 0 \\
tocha & 0 & 1 & 0 & 0 & 0 & 0 \\
não responderam: & 2 & 1 & 0 & 3 & 1 & 0 \\
\hline
\end{tabular}

11 - Resposta esperada: LANTERNA, FACHILETE

e (...) o objeto, que vai pilha, usado a noite para iluminar o caminho?

Fachelaite (6C), fechelaite (7C), fachilete (7CI, 2CI, 3CI, 5CI, 7CI, 9CI, 9C), fachoelétrico (4CI), lanterna (1AI, 2AI, 3AI, 4AI, 5AI, 6AI, 7AI, 8AI, 9AI, 10AI, 2BI, 3BI, 4BI, 5BI, 6BI, 7BI, 8BI, 9BI, 10BI, 1CI, 3CI, 6CI, 8CI, 10CI, 1A, 2A, 3A, 4A, 5A, 6A, 7A, 8A, 9A, 10A, 1B, 3B, 5B, 6B, 7B, 8B, 10B, 1C, 2C, 3C, 4C, 5C, 8C, 9C), luz (9B), tachilaite (10C). 
Número de ocorrências:

\begin{tabular}{lcccccc}
\hline & Faixa AI & Faixa BI & Faixa CI & Faixa A & Faixa B & Faixa C \\
\hline fachelaite & 0 & 0 & 0 & 0 & 0 & 1 \\
fechelaite & 0 & 0 & 0 & 0 & 0 & 1 \\
fachilete & 0 & 0 & 6 & 0 & 0 & 1 \\
fachoelétrico & 0 & 0 & 1 & 0 & 0 & 0 \\
lanterna & 10 & 9 & 5 & 10 & 7 & 7 \\
luz & 0 & 0 & 0 & 0 & 1 & 0 \\
tachilaite & 0 & 0 & 0 & 0 & 0 & 1 \\
\hline
\end{tabular}

12 - Resposta esperada: BARBANTE

(...) a linha que fica no rolo e serve para amarrar as coisas? ${ }^{79}$

Algodão (9BI), barbante (9AI, 3BI, 4BI, 6BI, 9A, 5B, 1C, 6C, 8C), carretel (2BI, 8BI, 7CI, 2B, 4B, 9C), corda (8BI, 10BI, 4CI, 3B, 1C, 2C), cordão (2C, 4C), cordel (10CI), de pesca (5C), filé (9CI), fio (3AI, 2CI, 3CI, 1A, 8A, 1B, 10C), linha (1C), naylon (3A, 7C), novelo (5AI, 1CI, 10CI), retrós (1BI, 6B), rolo (10B). Não responderam: 1AI, 2AI, 3AI, 5AI, 6AI, 7AI, 9AI, 7BI, 2A, 4A, 5A, 6A, 7A, 10A, 7B, 8B, 9B, 3C.

\footnotetext{
${ }^{79}$ Esta questão apresentou grande dificuldade para os informantes. Muitos mostraram dúvidas quanto ao objeto a que a pergunta se referia. Depois, consultando os dicionários, entendemos que a confusão não é apenas dos informantes. No dicionário de sinônimos utilizado para esta pesquisa (FERNANDEZ, 2002), encontramos, para exemplificar: “Barbante: corda, cordel”, “Corda: amarra, barbante, baraço, cabo, serga, calabre, linha, soga, cordão” e “Fio: linha, cordel" (grifos nossos). Vemos que os lexemas barbante, corda, cordel e linha aparecem indistintamente nas entradas das palavras barbante, corda e fio. Se barbante é dado como sinônimo de corda e cordel, por que não é sinônimo de linha e fio, já que estes também são apresentados assim em outras entradas?
} 
Número de ocorrências:

\begin{tabular}{|c|c|c|c|c|c|c|c|}
\hline & Faixa AI & Faixa BI & Faixa CI & Faixa A & Faixa B & Faixa $\mathrm{C}$ & \\
\hline algodão & & 0 & 1 & 0 & 0 & 0 & 0 \\
\hline barbante & & 1 & 3 & 0 & 1 & 1 & 3 \\
\hline carretel & & 0 & 2 & 1 & 0 & 2 & 1 \\
\hline corda & & 0 & 2 & 1 & 0 & 1 & 2 \\
\hline cordão & & 0 & 0 & 0 & 0 & 0 & 2 \\
\hline cordel & & 0 & 0 & 1 & 0 & 0 & 0 \\
\hline de pesca & & 0 & 0 & 0 & 0 & 0 & 1 \\
\hline filé & & 0 & 0 & 1 & 0 & 0 & 0 \\
\hline fio & & 1 & 0 & 2 & 2 & 1 & 1 \\
\hline linha & & 0 & 0 & 0 & 0 & 0 & 1 \\
\hline naylon & & 0 & 0 & 0 & 1 & 0 & 1 \\
\hline novelo & & 1 & 0 & 2 & 0 & 0 & 0 \\
\hline retrós & & 0 & 1 & 0 & 0 & 1 & 0 \\
\hline rolo & & 0 & 0 & 0 & 0 & 1 & 0 \\
\hline não responderam & & 7 & 1 & 0 & 6 & 3 & 1 \\
\hline
\end{tabular}

13 - Resposta esperada: RABECA

(...) um tipo de violino feito em casa?

Bandolim (9B), cavaquinho (10BI, 1C), machete (9CI, 10B), rabeca 5CI, 10CI, 3B, 5B, 8B, 2C, 6C, 7C, 8C), rebeca (4BI, 6BI, 2CI, 5B, 7B, 5C, 9C), viola (8BI, 7CI, 4B, 10C), violão (9AI, 7BI, 1CI, 8A, 9A, 10A, 6B, 3C), violino (1B, 6B, 1C), violino caseiro (3A), violoncelo (3BI, 5BI). Não responderam: 1AI, 2AI, 3AI, 4AI, 5AI, 6AI, 7AI, 8AI, 10AI, 1BI, 2BI, 8BI, 9BI, 3CI, 4CI, 6CI, 8CI, 1A, 2A, 4A, 5A, 6A, 7A, 2B, 4C. 
Número de ocorrências:

\begin{tabular}{lcccccc}
\hline & Faixa AI & Faixa BI & Faixa CI & Faixa A & Faixa B & Faixa C \\
\hline bandolim & 0 & 0 & 0 & 0 & 1 & 0 \\
cavaquinho & 0 & 1 & 0 & 0 & 0 & 1 \\
machete & 0 & 0 & 1 & 0 & 1 & 0 \\
rabeca & 0 & 0 & 2 & 0 & 3 & 4 \\
rebeca & 0 & 2 & 1 & 0 & 2 & 2 \\
viola & 0 & 1 & 1 & 0 & 1 & 1 \\
violão & 1 & 1 & 1 & 3 & 1 & 1 \\
violino & 0 & 0 & 0 & 0 & 2 & 1 \\
violino caseiro & 0 & 0 & 0 & 1 & 0 & 0 \\
violoncelo & 0 & 0 & 2 & 0 & 0 & 0 \\
não responderam & 9 & 4 & 4 & 6 & 1 & 1 \\
\hline
\end{tabular}

14 - Resposta esperada: PECA, PILICA, BOLINHA DE GUDE

(...) aquela bolinha de vidro, pequena, usada para brincar? ${ }^{80}$

Bola de vidro (9CI), bola / bolinha de gude (8AI, 5BI, 7BI, 10BI, 1A, 4A, 5A, 7A, 4B, 5B, 6B, 8B, 2C, 5C, 6C), peca $^{81} /$ pequinha (1AI, 2AI, 3AI, 4AI, 6AI, 7AI, 9AI, 10AI, 1BI, 2BI, 3BI, 6BI, 8BI, 9BI, 1CI, 2CI, 3CI, 5CI, 6CI, 7CI, 8CI, 10CI, 3A, 9A, 10A, 1B, 2B, 3B, 4B, 6B, 7B, 10B, 1C, 2C, 4C, 6C, 7C, 8C, 9C, 10C), peca de vidro (4CI), pingue-pongue ${ }^{82}$ (9B), pilica (5AI, 4BI). Não responderam: 2A, 6A, 8A, 3C.

\footnotetext{
${ }^{80}$ Nenhuma das variações lingüísticas utilizadas pelos informantes, para designar bolinha de gude, foi encontrada no AURÉLIO (1999).

${ }^{81}$ ['peka].

${ }^{82}$ A forma pingue-pongue, apresentada em tom de dúvida por um informante, não parece apresentar relação semântica com o objeto da pergunta.
} 
Número de ocorrências:

\begin{tabular}{lccccccr}
\hline & Faixa AI & Faixa BI & Faixa CI & Faixa A & Faixa B & \multicolumn{2}{c}{ Faixa C } \\
\hline bola de vidro & 0 & 0 & 1 & 0 & 0 & 0 \\
bola / bolinha de gude & 1 & 3 & 0 & 4 & 4 & 3 \\
peca / pequinha & 8 & 6 & 8 & 3 & 7 & 8 \\
peca de vidro & 0 & 0 & 1 & 0 & 0 & 0 \\
pingue-pongue & 0 & 0 & 0 & 0 & 1 & 0 \\
pilica & 1 & 1 & 0 & 0 & 0 & 0 \\
não responderam & 0 & 0 & 0 & 3 & 0 & 1 \\
\hline
\end{tabular}

15 - Resposta esperada: FUNDA, ESTILINGUE

(...) o objeto pequeno que se usa para atirar pedrinhas, principalmente para acertar passarinhos?

Cetla $^{83}(5 B I)$, cetra $^{84}(2 \mathrm{~A}, 5 \mathrm{~A}, 6 \mathrm{~A}, 7 \mathrm{~A}, 8 \mathrm{~A}, 9 \mathrm{~A}, 10 \mathrm{~A}, 1 \mathrm{~B}, 2 \mathrm{~B}, 3 \mathrm{~B}, 4 \mathrm{~B}, 5 \mathrm{~B}, 6 \mathrm{~B}, 7 \mathrm{~B}, \mathbf{8 B}, 9 \mathrm{~B}, 10 \mathrm{~B}, 1 \mathrm{C}$, 2C, 3C, 4C, 6C, 7C, 8C, 9C, 10C), estilete ${ }^{85}$ (10CI), estilingue (2BI, 3CI, 1A, 2B), funda (1AI, 2AI, 3AI, 4AI, 5AI, 6AI, 7AI, 8AI, 10AI, 1BI, 3BI, 4BI, 5BI, 6BI, 7BI, 8BI, 9BI, 10BI, 1CI, 2CI, 3CI, 4CI, 5CI, 6CI, 7CI, 8CI, 9CI, 10CI, 2C), tilica (7BI), pelota (5C), xilóida (4BI, 6B, 2C), xilóide (5BI, 8B, 7C). Não responderam: 9AI, 3A, 4A.

\footnotetext{
${ }^{83}$ ['setla].

${ }^{84}$ ['setra].

${ }^{85}$ A forma estilete, apresentada por apenas um informante, parece não possuir relação de equivalência semântica com o objeto em questão. Talvez, o informante tenha se confundido com a palavra estilingue.
} 
Número de ocorrências:

\begin{tabular}{lccccccr}
\hline & Faixa AI & Faixa BI & Faixa CI & Faixa A & Faixa B & Faixa C \\
\hline cetla & 0 & 1 & 0 & 0 & 0 & 0 \\
cetra & 0 & 0 & 0 & 7 & 10 & 9 \\
estilete & 0 & 0 & 1 & 0 & 0 & 0 \\
estilingue & 0 & 1 & 1 & 1 & 1 & 0 \\
funda & 9 & 9 & 10 & 0 & 0 & 1 \\
tilica & 0 & 1 & 0 & 0 & 0 & 0 \\
pelota & 0 & 0 & 0 & 0 & 0 & 1 \\
xilóide & 0 & 1 & 0 & 0 & 1 & 1 \\
xilóida & 0 & 1 & 0 & 0 & 1 & 1 \\
não responderam & 1 & 0 & 0 & 2 & 0 & 0 \\
\hline
\end{tabular}

16 - Resposta esperada: BODOQUE

e (...) um outro objeto que se usa para atirar pedras, só que grande, parecido com um arco?

Apá (3C), arco e flecha (5A, 6A), bidoque ${ }^{86}$ (9CI), bodoque ${ }^{87}$ (7AI, 4BI, 5BI, 7BI, 8BI, 1CI, 2CI, 4CI, 5CI, 7CI, 10CI, 5B, 8B, 1C, 2C, 4C, 5C, 6C, 7C, 9C), budogue ${ }^{88}$ (3AI), catapulta ${ }^{89}$ (1B, 8C), cetra (9B), flecha (2BI, 6BI, 10BI, 2A, 3A, 4A, 3B, 6B), frecha (7A, 10B). Não responderam: 1AI, 2AI, 4AI, 5AI, 6AI, 8AI, 9AI, 10AI, 1BI, 3BI, 9BI, 3CI, 6CI, 8CI, 1A, 8A, 9A, 10A, 2B, 4B, 7B, 10C.

\footnotetext{
${ }^{86}$ [bi 'doki].

87 [bo 'doki].

${ }^{88}$ [bu' dogi].

${ }^{89}$ A catapulta é um engenho de guerra utilizado para atirar pedras ou objetos similares de grande porte. Fora o fato de atirar pedras, ela não mantêm nenhuma relação com o objeto da pergunta, por isso, é muito difícil considerá-la como um equivalente semântico de bodoque.
} 
Número de ocorrências:

\begin{tabular}{lccccccc}
\hline & Faixa AI & Faixa BI & Faixa CI & Faixa A & Faixa B & Faixa C \\
\hline apá & 0 & 0 & 0 & 0 & 0 & 1 \\
arco e flecha & 0 & 0 & 0 & 0 & 2 & 0 \\
bidoque & 0 & 0 & 1 & 0 & 0 & 0 \\
bodoque & 1 & 4 & 6 & 0 & 2 & 7 \\
budogue & 1 & 0 & 0 & 0 & 0 & 0 \\
catapulta & 0 & 0 & 0 & 0 & 1 & 1 \\
cetra & 0 & 0 & 0 & 0 & 1 & 0 \\
flecha & 0 & 3 & 0 & 3 & 2 & 1 \\
frecha & 0 & 0 & 0 & 1 & 1 & 0 \\
não responderam & 8 & 3 & 3 & 4 & 3 & 1 \\
\hline
\end{tabular}

\section{7 - Resposta esperada: SINALEIRO, SEMÁFORO, SINAL}

(...) o lugar em que as crianças costumam vender bala e água para as pessoas que estão de carro? ${ }^{90}$

Asfalto (1BI, 5A, 6A, 3B), cruzamento de semáforo (5C), escola (8B), estacionamento (9B), estrada (8BI, 9BI, 9C, 10C), farol (10CI), feiras (4CI), parque (7C), rua (2C, 4C, 6C), semáfaro (8AI, 9AI, 2BI, 3CI, 4B), sinaleira (4BI, 6BI, 7BI, 10BI, 5CI, 8A, 10A, 2B), sinaleiro (5AI, 6AI, 7AI, 7BI, 9A, 5B), trailler (6B), trânsito (3A). Não responderam 1AI, 2AI, 3AI, 4AI, 10AI, 3BI, 5BI, 1CI, 2CI, 6CI, 7CI, 8CI, 9CI, 1A, 2A, 4A, 7A, 1B, 7B, 10B, 1C, 3C, 8C.

Número de ocorrências:

\begin{tabular}{lccccccr}
\hline & Faixa AI & Faixa BI & Faixa CI & Faixa A & Faixa B & \multicolumn{2}{c}{ Faixa C } \\
\hline asfalto & 0 & 1 & 0 & 2 & 1 & 0 \\
cruzamento de semáforo & 0 & 0 & 0 & 0 & 0 & 1 \\
\hline
\end{tabular}

\footnotetext{
90 Essa foi a pergunta que mais apresentou dificuldade para os informantes responderem. Muitos davam a resposta com dúvida. Alguns informantes falaram que não conheciam esse lugar. Analisando os motivos para tal dificuldade, foi levantado que nas cidades pesquisadas há pouquíssimos semáforos. Em Penha, por exemplo, há somente dois. Além disso, não há crianças vendendo mercadorias junto a eles. Por esses motivos, encontramos respostas tão heterogêneas.
} 


\begin{tabular}{|c|c|c|c|c|c|c|}
\hline escola & 0 & 0 & 0 & 0 & 1 & 0 \\
\hline estacionamento & 0 & 0 & 0 & 0 & 1 & 0 \\
\hline estrada & 0 & 2 & 0 & 0 & 0 & 2 \\
\hline farol & 0 & 0 & 1 & 0 & 0 & 0 \\
\hline feiras & 0 & 0 & 1 & 0 & 0 & 0 \\
\hline parque & 0 & 0 & 0 & 0 & 0 & 1 \\
\hline rua & 0 & 0 & 0 & 0 & 0 & 3 \\
\hline semáforo & 2 & 1 & 1 & 0 & 1 & 0 \\
\hline sinaleira & 0 & 4 & 1 & 2 & 1 & 0 \\
\hline sinaleiro & 3 & 1 & 0 & 1 & 1 & 0 \\
\hline trailler & 0 & 0 & 0 & 1 & 0 & 0 \\
\hline trânsito & 0 & 0 & 0 & 1 & 0 & 0 \\
\hline não responderam & 5 & 2 & 6 & 4 & 3 & 3 \\
\hline
\end{tabular}

18 - Resposta esperada: INIMIGO, COLUDO

Se Deus está no céu, quem está no inferno é o ${ }^{91} \ldots$

Bicho (1CI), capeta (1AI, 2AI, 5AI, 7AI, 8BI, 10A, 1B), demo (5CI), demônio (3CI, 1A, 2C, 4C, 7C), diabo (3AI, 4AI, 6AI, 8AI, 9AI, 10AI, 1BI, 2BI, 3BI, 4BI, 6BI, 7BI, 9BI, 10BI, 2CI, 4CI, 6CI, 7CI, 8CI, 9CI, 10CI, 2A, 3A, 4A, 5A, 6A, 7A, 8A, 9A, 2B, 3B, 4B, 5B, 7B, 8B, 10B, 1C, 3C, 5C, 6C, 8C, 9C), homem (6B, 10C), inimigo (9B), pererenga (5BI), satanás (5BI).

\section{Número de ocorrências:}

\begin{tabular}{lccccccc}
\hline & Faixa AI & Faixa BI & Faixa CI & Faixa A & Faixa B & Faixa C \\
\hline bicho & 0 & 0 & 1 & 0 & 0 & 0 \\
capeta & 4 & 1 & 0 & 1 & 1 & 0 \\
demo & 0 & 0 & 1 & 0 & 0 & 0 \\
demônio & 0 & 0 & 1 & 1 & 0 & 3 \\
\hline
\end{tabular}

91 Tratando de um tabu lingüístico, a questão 18 foi uma das poucas questões que obteve $100 \%$ de respostas. Na aplicação do questionário sentimos a surpresa de muitos dos informantes com esta pergunta. Um informante, da faixa A, chegou mesmo a perguntar se realmente ele poderia responder à pergunta.

“O tabu é de importância vital para o lingüista porque impõe uma proibição não só sobre certas pessoas, animais e coisas, mas também sobre os seus nomes. Na maioria dos casos, embora não em todos, a palavra tabu será abandonada e introduzir-se-á um substituto inofensivo, um eufemismo, para preencher a fenda. Isto acarretará muitas vezes um ajustamento do significado do substituto, e, deste modo, o tabu é uma causa importante de mudanças semânticas." (ULLMANN, 1964: 426). 


\begin{tabular}{lllllll}
\hline diabo & 6 & 8 & 7 & 8 & 7 & 6 \\
homem & 0 & 0 & 0 & 0 & 1 & 1 \\
inimigo & 1 & 0 & 0 & 0 & 1 & 0 \\
pererenga & 0 & 1 & 0 & 0 & 0 & 0 \\
satanás & 0 & 1 & 0 & 0 & 0 & 0 \\
\hline
\end{tabular}

19 - Resposta esperada: PROSA, FELIZ

Quando uma pessoa ganha um presente, ela fica toda...

Alegre (6AI, 6A, 9A, 5B, 7B, 10B, 9C, 10C), cheio de alegria (7CI), contente (3AI, 10AI, 8BI, 1CI, 3CI, 4CI, 5CI, 9CI, 10CI, 7A, 2B, 3B, 6B, 9B, 1C, 2C, 3C, 4C, 5C, 6C, 7C, 10C), feliz (2AI, 4AI, 5AI, 7AI, 8AI, 9AI, 1BI, 2BI, 3BI, 4BI, 5BI, 6BI, 7BI, 9BI, 10BI, 2CI, 6CI, 7CI, 8CI, 1A, 2A, 3A, 4A, 5A, 7A, 8A, 10A, 1B, 4B, 8B, 8C), prosa (9C). Não respondeu: 1AI.

Número de ocorrências:

\begin{tabular}{lccccccr}
\hline & Faixa AI & Faixa BI & Faixa CI & Faixa A & Faixa B & Faixa C \\
\hline alegre & 1 & 0 & 0 & 2 & 3 & 2 \\
cheio de alegria & 0 & 0 & 1 & 0 & 0 & 0 \\
contente & 2 & 1 & 6 & 1 & 4 & 8 \\
feliz & 6 & 9 & 4 & 8 & 3 & 1 \\
prosa & 0 & 0 & 0 & 0 & 0 & 1 \\
não respondeu & 1 & 0 & 0 & 0 & 0 & 0 \\
\hline
\end{tabular}

20 - Resposta esperada: AVE DE PENA, BICHO DE CABELO, LEVADA

Quando uma criança é muito arteira, ela é...

Abelhuda (7BI), arteira (4AI, 10CI, 3B, 4C), atentada (9AI, 2A), bagunceiro(a) (3AI, 3BI, 7A, 4B, 10B), chata (7AI), imperativa (7BI), levada (6AI, 8AI, 1BI, 4BI, 8BI, 9BI, 10BI, 1CI, 2CI, 5CI, 6CI, 7CI, 8CI, 5A, 1B, 2B, 6B, 5C, 6C, 8C), malvada (10A, 8B), peralta (5BI, 5B), perarta (10C), perversa (2BI, 6BI), rebelde (10AI, 5B, 7B, 9B 1C, 7C), ruim (3A), sapeca (5AI, 5BI, 2C), saúde (9C), travessa (3CI, 3C), triste (1A). Não responderam: 1AI, 2AI, 9CI, 4A, 6A, 8A, 9A.

Número de ocorrências:

\begin{tabular}{lccccccr}
\hline & Faixa AI & Faixa BI & Faixa CI & Faixa A & Faixa B & Faixa C \\
\hline abelhuda & 0 & 1 & 0 & 0 & 0 & 0 \\
\hline
\end{tabular}




\begin{tabular}{|c|c|c|c|c|c|c|}
\hline arteira & 1 & 0 & 1 & 0 & 1 & 1 \\
\hline atentada & 1 & 0 & 0 & 1 & 0 & 0 \\
\hline bagunceiro(a) & 1 & 1 & 0 & 1 & 2 & 0 \\
\hline chata & 1 & 0 & 0 & 0 & 0 & 0 \\
\hline imperativa & 0 & 1 & 0 & 0 & 0 & 0 \\
\hline levada & 2 & 5 & 6 & 1 & 3 & 3 \\
\hline malvada & 0 & 0 & 0 & 1 & 1 & 0 \\
\hline peralta & 0 & 1 & 0 & 0 & 1 & 0 \\
\hline perarta & 0 & 0 & 1 & 0 & 0 & 0 \\
\hline perversa & 0 & 2 & 0 & 0 & 0 & 0 \\
\hline rebelde & 1 & 0 & 0 & 0 & 3 & 2 \\
\hline ruim & 0 & 0 & 0 & 1 & 0 & 0 \\
\hline sapeca & 1 & 1 & 0 & 0 & 0 & 1 \\
\hline saúde & 0 & 0 & 0 & 0 & 0 & 1 \\
\hline travessa & 0 & 0 & 1 & 0 & 0 & 1 \\
\hline triste & 1 & 0 & 0 & 0 & 0 & 1 \\
\hline Não responderam & 2 & 0 & 1 & 4 & 0 & 0 \\
\hline
\end{tabular}

21 - Resposta esperada: MEDONHO, HORRÍVEL

Quando alguém é muito feio, ele é...

Coisa feia (7CI, 2A), coitado (8C), corisco (8BI), esquisito (10BI, 10CI, 1CI, 2CI, 5CI,), feio (2AI, 1A, 8B, 10B, 10C), feioso (6BI, 7A, 4B, 5B, 2C), horrível (6AI, 8AI, 9AI, 10AI, 5BI, 3CI, 4CI, 4A, 8A, 1B, 3B, 5B, 6B, 7B, 1C, 3C, 5C, 7C, 9C), horroroso (1BI, 2BI, 3A, 2B, 9B, 6C), medonho (7AI, 3BI, 4BI, 4C, 8C), muito feio (9BI), ridículo: 5A, 9A, 10A. Não responderam: 1AI, 3AI, 4AI, 5AI, 7BI, 9CI, 6A.

Número de ocorrências:

\begin{tabular}{lccccccc}
\hline & Faixa AI & Faixa BI & Faixa CI & Faixa A & Faixa B & Faixa C \\
\hline coisa feia & 0 & 0 & 1 & 1 & 0 & 0 \\
coitado & 0 & 0 & 1 & 0 & 0 & 0 \\
corisco & 0 & 1 & 0 & 0 & 0 & 0 \\
esquisito & 0 & 1 & 1 & 0 & 0 & 3 \\
feio & 1 & 0 & 0 & 1 & 2 & 1 \\
feioso & 0 & 1 & 0 & 1 & 2 & 1 \\
horrível & 4 & 1 & 2 & 2 & 5 & 5 \\
horroroso & 0 & 2 & 0 & 1 & 2 & 1 \\
\hline
\end{tabular}




\begin{tabular}{lllllll}
\hline medonho & 1 & 2 & 0 & 0 & 0 & 2 \\
muito feio & 0 & 1 & 0 & 0 & 0 & 0 \\
ridículo & 0 & 0 & 0 & 3 & 0 & 0 \\
não responderam & 4 & 1 & 1 & 1 & 0 & 0 \\
\hline
\end{tabular}

22 - Resposta esperada: TANSO.

Quando alguém é pouco inteligente, vive fazendo coisa errada, ele é um...

Analfabeto (4CI, 7B, 9B, 4C, 5C), besta (10C), bobo (4AI, 6BI, 7CI, 9CI), burro (1AI, 3AI, 6AI, 9AI, 1BI, 2BI, 3BI, 5BI, 7BI, 9BI, 10BI, 2CI, 3CI, 6CI, 8CI, 10CI, 3A, 4A, 5A, 6A, 7A, 8A, 9A, 1B, 2B, 3B, 4B, 5B, 6B, 8B, 10B, 1C, 2C, 3C, 6C, 7C, 8C), cabeçudo (2AI), chato (5AI), distraído (4B), esquisito (1CI), feio (9C), idiota (5CI), inútil (8AI), malandro (7AI), porco (10AI), safado (4BI), simpre (5CI), tanso ${ }^{92}$ (8BI). Não responderam: 1A, 2A e 10A.

\footnotetext{
${ }^{92}$ A forma esperada, tanso, dada por muitos dicionários regionais do Sul do país como uma realização típica, só foi citada por um informante.
} 
Número de ocorrências:

\begin{tabular}{lcccccc}
\hline & Faixa AI & Faixa BI & Faixa CI & Faixa A & Faixa B & Faixa C \\
\hline analfabeto & 0 & 0 & 1 & 0 & 2 & 1 \\
besta & 0 & 0 & 0 & 0 & 0 & 1 \\
bobo & 1 & 1 & 1 & 0 & 0 & 1 \\
burro & 4 & 7 & 5 & 7 & 8 & 6 \\
cabeçudo & 1 & 0 & 0 & 0 & 0 & 0 \\
chato & 1 & 0 & 0 & 0 & 0 & 0 \\
distraído & 0 & 0 & 0 & 0 & 1 & 0 \\
esquisito & 0 & 0 & 1 & 0 & 0 & 0 \\
feio & 0 & 0 & 0 & 0 & 0 & 1 \\
idiota & 0 & 0 & 1 & 0 & 0 & 0 \\
inútil & 1 & 0 & 0 & 0 & 0 & 0 \\
malandro & 1 & 0 & 0 & 0 & 0 & 0 \\
porco & 1 & 0 & 0 & 0 & 0 & 0 \\
safado & 0 & 1 & 0 & 0 & 0 & 0 \\
simpre & 0 & 0 & 1 & 0 & 0 & 0 \\
tanso & 0 & 1 & 0 & 0 & 0 & 0 \\
Não responderam & 3 & 0 & 0 & 0 & 0 & 0 \\
\hline
\end{tabular}

23 - Resposta esperada: CÓCORAS, COCA

Quando uma pessoa está abaixada, dizemos que ela está de ${ }^{93}$..

Agachada (3CI, 10C), arcado: (1C), coca (4C), cócora (4BI, 7BI), cócoras (8AI, 9AI, 10AI, 2BI, 3BI, 5BI, 3B, 8C), coroca (5CI, 4C), croca (4A, 2B, 5B, 6B, 8B, 9B, 10B, 2C, 6C, 7C, 9C), croque (1BI, 9A, 10A, 7B, 5C), deitada (1A), de bunda pra cima (9CI), de joelho (2AI), de pé (3A), de quatro (5A, 7A), joelhos (8A, 1B) quatro pé (7CI), sentado(a) (4A, 3C), trabalhando (4CI). Não responderam: 1AI, 3AI, 4AI, 5AI, 6AI, 7AI, 6BI, 8BI, 9BI, 10BI, 1CI, 2CI, 6CI, 8CI, 10CI, 2A, 6A, 4B.

\section{Número de ocorrências:}

\footnotetext{
93 cócoras só perdeu em uso para sua forma reduzida croca. Outras variantes desse mesmo lexema são: coca, coroca, cócora, e croque. As outras palavras utilizadas não guardam qualquer relação de equivalência semântica com a pergunta realizada aos informantes. De forma geral, demonstram posições corporais diversas.
} 


\begin{tabular}{lcccccc}
\hline & Faixa AI & Faixa BI & Faixa CI & Faixa A & Faixa B & Faixa C \\
\hline agachada & 0 & 0 & 1 & 0 & 0 & 1 \\
arcado & 0 & 0 & 0 & 0 & 0 & 1 \\
coca & 0 & 0 & 0 & 0 & 0 & 1 \\
cócora & 0 & 2 & 0 & 0 & 0 & 0 \\
cócoras & 3 & 3 & 0 & 0 & 1 & 1 \\
coroca & 0 & 0 & 1 & 0 & 0 & 1 \\
croca & 0 & 0 & 0 & 1 & 6 & 4 \\
croque & 0 & 1 & 0 & 1 & 1 & 1 \\
deitada & 1 & 0 & 0 & 0 & 0 & 0 \\
de bunda pra cima & 0 & 0 & 1 & 0 & 0 & 0 \\
de joelho & 1 & 0 & 0 & 0 & 0 & 0 \\
de pé & 0 & 0 & 0 & 1 & 0 & 0 \\
de quatro & 0 & 0 & 0 & 2 & 0 & 0 \\
joelhos & 0 & 0 & 0 & 1 & 1 & 0 \\
quatro pé & 0 & 0 & 1 & 0 & 0 & 0 \\
sentado(a) & 0 & 0 & 0 & 1 & 0 & 1 \\
trabalhando & 0 & 0 & 1 & 0 & 0 & 0 \\
não responderam & 6 & 4 & 5 & 2 & 1 & 0 \\
\hline
\end{tabular}

24 - Resposta esperada: VERONISTA, TURISTA

(...) a pessoa que vem passar as férias aqui?

Estudante (7CI), passear (4C), turista (4AI, 6AI, 10AI, 1BI, 3BI, 7CI, 3A, 1B, 2B, 3B, 4B, 5B, 6B, 9B, 10B, 1C, 2C, 5C, 6C, 8C, 9C), veraneio ou está veraneando (10C), veranista (2AI, 6AI, 9AI, 1BI, 3BI, 8BI, 9CI, 5A, 6A, 7A, 8A, 9A, 10A, 7B, 2C, 3C, 7C), veronista (3AI, 7AI, 4BI, 6BI, 7BI, 4CI), visita (10CI, 1A), visitante (5AI, 5BI, 5CI, 4A). Não responderam: 1AI, 9BI, 1CI, 7CI, 2A, 8B. 
Número de ocorrências:

\begin{tabular}{lcccccr}
\hline & Faixa AI & Faixa BI & Faixa CI & Faixa A & Faixa B & \multicolumn{2}{c}{ Faixa C } \\
\hline estudante & 0 & 0 & 1 & 0 & 0 & 0 \\
passear & 0 & 0 & 0 & 0 & 0 & 1 \\
turista & 3 & 2 & 1 & 1 & 8 & 6 \\
veraneio/ está veraneando & 0 & 0 & 0 & 0 & 0 & 1 \\
veranista & 3 & 3 & 1 & 6 & 1 & 3 \\
veronista & 2 & 3 & 1 & 0 & 0 & 0 \\
visita & 0 & 0 & 1 & 1 & 0 & 0 \\
visitante & 1 & 1 & 1 & 1 & 0 & 0 \\
não responderam & 1 & 1 & 2 & 1 & 1 & 0 \\
\hline
\end{tabular}

\subsection{ANÁLISE DOS DADOS ${ }^{94}$}

agardecer: AMARAL (1920: 33), em seu estudo sobre o dialeto caipira, aponta essa forma como algo antigo na língua. 10C: o pessoar agardeciam né? (v. s. aguardecê). MEGALE (1998: 22) cita esta forma com um arcaísmo encontrado na área estudada pelo Grupo de Trabalho Filologia Bandeirante $^{95}$. MARROQUIM (1945: 147), em seu estudo sobre a fala de Alagoas e Penambuco, também a cita como um arcaísmo. Forma presente também em Maia, Portugal, (VASCONCELLOS 1928).

aguaceiro (a): no questionário lingüístico, questão 1, aparecem as formas aguaceiro e aguaceira. Na fala espontânea é encontrada em 5CI: aí veio um aguaceiro de chuva que choveu vinte minuto. Aguaceiro também aparece em FISCHER (1999), um dicionário de Porto-Alegrês, com o mesmo sentido. É interessante notar que as formas aguaceiro e aguaceira, em um primeiro momento, poderiam ser maneiras de se referir a um mesmo fenômeno, variando somente na questão do gênero. Porém, se aguaceiro é um equivalente semântico de tempestade, aguaceira é a "água ou saliva que se expele da boca por indisposição do estômago" (AURÉLIO, s. v.). Mas, para os informantes que utilizaram a forma aguaceira, parece não existir essa diferença na localidade.

\footnotetext{
${ }^{94}$ Exemplos da fala espontânea só serão dados quando necessário. Para ver em que informante(s) ocorrem o termo em questão e um exemplo de uso consulte o Glossário.

95 “Geograficamente a pesquisa cobre os territórios dos Estados de São Paulo, Minas Gerais, Goiás e Mato Grosso". (MEGALE, 1998: 13).
} 
alembrar: forma arcaica, realizada por 9B: me alembro que ele contava que vinha de carroça. AMARAL (1920), em seu estudo sobre o dialeto caipira, assinala que "esta prótese vem de muito longe na língua e ainda é popular”. Forma presente também em Maia e Celorico de Bastos, Portugal, VASCONCELLOS (1928).

alimpar: encontrado em Celorico de Bastos e Paços de Ferreira, Portugal, VASCONCELLOS (1928). 5CI: cura da AID... do câncer e também alimpa o pulmão.

almanzém: encontrado como almazém em Maia e Paços de Ferreira, Portugal, VASCONCELLOS (1928). 2CI: começaram a colocar almanzém né?

angola: uma das formas de se referir à galinha d'angola. Apareceu exclusivamente nas faixas $\mathbf{B}$ do questionário lingüístico. Foi encontrada em AMARAL (1920), em seu estudo sobre o dialeto caipira.

angolista: TAUNAY (1914) cita o uso como típico de certas regiões do Estado de São Paulo no começo do século XX. Hoje, essa também é a forma predominante nas áreas pesquisadas do litoral catarinense. Porém, como vimos na questão 6 do questionário lingüístico, seu uso é mais freqüente nos mais velhos e cai, progressivamente, quanto mais jovem é o informante. Na fala espontânea, ela apareceu no informante 3AI: $a$ angolista é a galinha d'angola. Encontrado em ALEXANDRE (1994), dicionário específico de Florianópolis. Encontrado também em OLIVEIRA (2002), dicionário que retrata o vocabulário gaúcho.

apá: uma das respostas dadas à pergunta 16 do questionário lingüístico, referindo-se ao objeto que a maioria dos informantes se referiu como bodoque. Apá é uma palavra de origem indígena, porém em nenhuma das acepções dicionarizadas encontramos relação com o objeto da questão: "1. Bot. $V$. espadeira; 2. Cesto, ger. pequeno, em forma de tigela usada clo coador ou p/ servir alimentos sólidos" (AURÉLIO, s. v.). Em CORRÊA (2000), em seu dicionário catarinense, encontramos como sinônimo de nádegas.

apaixonado: significando triste, chateado, apareceu tanto no questionário valorativo, questão 1 , como na fala espontânea de 5CI: o Deca da Leonida ficou muito apaixonado... neste enterro da 
cobra não foi inconvidado. Encontrado em ALEXANDRE (1994), dicionário específico de Florianópolis. É um arcaísmo presente na língua (MARROQUIM, 1945: 151).

areão: local com muita areia, só areia. Forma arcaica ${ }^{96}$. 2C: aqui era só um areão...

atentar: está presente no questionário lingüístico, questão 20 (como um adjetivo - atentada), em dois informantes da faixa A, e em 6C: é porque ele... de certo ficou perdido... atentando né?... e aí vinha atentar os outro. Essa acepção também é encontrada em AMARAL (1920), em seu estudo sobre o dialeto caipira.

balea: (baleia) forma arcaica. $^{97}$

baleeira: aparece no questionário lingüístico, questão 4, realizada por três informantes de Itapocorói, para denominar um barco pequeno usado para pescar. Sentido como um arcaísmo, o uso de baleeira como forma genérica de se referir a uma embarcação data de 1871, segundo CUNHA (1989). No Dicionário da Ilha de Santa Catarina, o lexema é encontrado como "Embarcação feita de inúmeras tábuas, utilizada inicialmente na pesca de baleias. Atualmente, já motorizadas, são usadas na pesca costeira. O mesmo que lancha” (ALEXANDRE, v. s. baleeira).

bambu: a forma predominante no questionário lingüístico, questão 3, foi bambu, que coincide com a forma dicionarizada. Indica qualquer espécie de gramínea do gênero Bambusa (AURÉLIO, s. v.). As outras formas, apresentadas somente pela faixa $\mathbf{C}$, bambule, bumbu e mambu, com exceção de caniço, provavelmente são variação dessa forma principal. A forma mambu é encontrada em CORRÊA (2000) e ALEXANDRE (1994).

bambule: ver bambu.

\section{bareja: ver varejeira.}

bateira: barco pequeno. Três informantes, pescadores, no questionário lingüístico, questão 4, fizeram questão de citar juntas as palavras bateira e canoa, e explicar a diferença entre elas.

\footnotetext{
${ }^{96}$ Ver: Parte 3, Análise Fonética (outros fenômenos fonéticos).

${ }^{97}$ Ver: Parte 3, Análise Fonética (outros fenômenos fonéticos).
} 
Segundo esses informantes, bateira é o barco pequeno feito de várias tábuas e canoa é um barco pequeno feito de um pau só. Aparece na fala espontânea também.

bernúncia: uma das personagens do Boi de Mamão. 6C: no Boi de Mamão... tem vários bicho né?... tinha a bernúncia. No ALERS (2002), aparece como uma das questões semântico-lexicais específicas para as regiões de Santa Catarina em que há influência portuguesa; porém, grafada como bernuca ou bernunca. Para FURLAN (1989) é uma palavra de origem açoriana.

bicha e bicha cabeluda: foram encontradas no AURÉLIO (1999) como maneiras de designar uma taturana. Questionário lingüístico, questão 7. As variantes bicha foguinha, bicha rata, bicho pinto e larva peluda não foram encontradas em nenhuma das obras e dicionários pesquisados.

bicha cabeluda: uma das denominações da taturana ALEXANDRE (1994). CORRÊA (2000) faz uso dessa forma ao definir gervão: "pode ter dois sentidos: para designar uma espécie de bicha cabeluda ou uma planta também conhecida por Ogerbão.”. Questionário Lingüístico, questão 7.

bicharia: forma encontrada em AMARAL (1920) para indicar o mesmo que bicharada. 10B: dançar as coisas... bicharia... cavalo-marinho... onça... tudo isso tinha.

bidoque: para o informante 9CI é uma forma de denominar bodoque, questão 16 do questionário lingüístico. Realização também encontrada em Florianópolis, só que para designar a funda (IMAGUIRE, 1999).

bira: ver imbira.

boca [o]: buraco feito no chão para jogar peca (CORRÊA, 2000). 3AI: peca é um monte de bolinha... tem que acertar na boca. Termo encontrado também em Florianópolis (IMAGUIRE, 1999) e (ALEXANDRE, 1994).

bodega: realização encontrada em Porto Alegre também, FISCHER (1999) a considera proveniente da Língua Espanhola. 5BI: chama o dono da bodega aí ninguém paga merda nenhuma. 
bodoque: no questionário da ALIB (2001: 34), bodoque é colocado como sinônimo de estilingue. $\mathrm{Na}$ região em estudo isso não confere com a realidade, pois bodoque e estilingue são objetos completamente diferentes (ALEXANDRE, 1994). Uma descrição do objeto em questão, que confere com o visto pela pesquisadora na casa do informante 5CI, é dada por AMARAL (1920): "arco, quase idêntico ao com que os índios atiram frechas, mas de pequenas proporções (cinco, seis, oito palmos), usado para arremessar pelotas de barro, à caça de passarinhos (...)”. Questionário lingüístico, questão 16.

bolinha de vidro: bolinha de gude. Realização também encontrada em Florianópolis (IMAGUIRE, 1999).

bumbu: ver bambu.

butuca: de origem tupi, a forma butuca foi encontrada dicionarizada como mutuca (AURÉLIO, s. v. mutuca).

caíco: "pequeno barco que é transportado nos barcos maiores para ajudar na pescaria." (ALEXANDRE, s. v.). questionário lingüístico, questão 4.

candeia: “(...) pequeno aparelho de iluminação, abastecido com óleo, proveniente do século XIII."(CUNHA, s. v. candeia). Questionário lingüístico, questão 10. Encontrado em ALEXANDRE (1994) e AMARAL (1920).

carrada: termo que apareceu na fala espontânea para indicar uma grande quantidade. A mesma acepção foi encontrada em ALEXANDRE (1994). 6CI: NETO BISNETO... tenho uma carrada.

carreira: forma utilizada, no pasquim do Morto Vivo ${ }^{\mathbf{9 8}}$, para indicar o ato de deslocar-se rapidamente. A mesma acepção está em AMARAL (1920).

\footnotetext{
${ }^{98}$ Ver: anexo 3.
} 
carreiro: denominação que a comunidade de pescadores da Ericeira, Portugal, utiliza para um caminho estreito, em ALVES (1965). Encontrado também em AMARAL (s. v. carrêro). 10BI: por um carreiro lá... eles contrabandeavam uísque.

casqueira: encontrado em ALEXANDRE (1994). Indica um conjunto de conchas e cascas de animais marinhos; o mesmo que sambaqui (s. v. casqueiro). 10C: a prefeitura começou a... a por um material... uma casca de casqueira... na época podia né?

cetra: foi encontrada no dicionário catarinense de CORRÊA (2000). No AURÉLIO (1999) é apontada como típica de Santa Catarina. AGUILERA (2000: 110) cita setra como termo recorrente nos questionários aplicados no Paraná. Forma predominante em São Francisco do Sul. Questionário lingüístico, questão 15.

corisco: foi encontrado em um dicionário de regionalismos típicos da Ilha de Florianópolis com duas acepções diferentes: "Relâmpago. Também pessoa malvada" (ALEXANDRE, s. v.). Apareceu no questionário lingüístico, questão 21, para designar uma pessoa muito feia ${ }^{99}$.

crosena: (querosene) foi encontrada em ALEXANDRE (1994). 9CI: não tinha luz naquele tempo... usava crosena né?...

demo: forma citada por um informante da faixa C de Itapocorói, no questionário lingüístico, questão 18. É apontada como típico arcaísmo, encontrado no século XIII (CUNHA, s. v.).

entonce: (então) para MARROQUIM (1945), em seu estudo sobre a fala de Alagoas e Pernambuco, tal ocorrência, presente nas regiões estudadas, é um arcaísmo na língua. 1C1: entonce pra nós não era um sacrifício era um prazer.

egreja: forma arcaica, segundo AMARAL (1920).

escalar: o particípio do verbo escalar (escalada) foi usado para indicar que o peixe foi limpo e salgado. Informante 6C: tainha escalada... feito cambira. $\mathrm{Na}$ comunidade de pescadores da Ericeira, Portugal, o mesmo verbo, dado como sinônimo de alinhar, é a ação de "abrir o peixe de

\footnotetext{
${ }^{99}$ Ouvido pela pesquisadora várias vezes na região de Itapocorói.
} 
alto a baixo, ao rés da espinha, tirando-lhe esta e a cabeça.” (ALVES, s. v. alinhar). Para ALEXANDRE (1994) é o “Ato de abrir, salgar e colocar o peixe para secar".

\section{estilingue: ver funda.}

fachelaite, fechelaite, tachilaite e fachilete: variantes citadas exclusivamente por informantes da faixa C, são, provavelmente, provenientes de uma mesma forma originária da língua inglesa ${ }^{100}$. A forma fachilete foi encontrada em BORBA CORRÊA (2000) como "Nome de uma espécie de lanterna usada para iluminar a pesca de fisga da tainha”. Como boa parte da renda das regiões estudadas sempre foi proveniente da pesca, é provável que seu uso tenha passado a designar todo o tipo de aparelho portátil usado para iluminar. Segundo ULLMANN (1964), as mudanças de sentido podem ser causadas por infinitas possibilidades. Utilizando a nomenclatura deste mesmo autor, o processo de generalização é muito produtivo dentro de uma comunidade lingüística. Cita que "um certo número de termos da caça e falcoaria, por exemplo, passaram à linguagem vulgar, alargando correspondentemente o seu significado." (1964: 416). Podemos perceber o mesmo fenômeno nas comunidades de pescadores em que a pergunta foi realizada.

\section{fachilete: ver fachilaite.}

fachoelétrico: este termo, usado para designar lanterna, pode pode ter duas origens: ser proveniente, por hipercorreção, de fachilete ou de facho, que, segundo AURÉLIO (1999), pode indicar "tudo o que emite luz, clarão: luzeiro, farol, lanterna etc.".

filé: "lavor de agulhas; do francês filet", segundo MACHADO (1952-59). Da mesma origem também é retrós: "é o fio ou fios de seda torcidos, ou de algodão mercerizado, para costura. Do francês retors, século $X V$ ”.(CUNHA, s. v.). questionário lingüístico, questão 12.

fornear: apareceu na fala espontânea como o ato de fazer a farinha. "Colocar a massa da farinha no forno. Fazer farinha. Linguagem figurada ao ato de fazer a farinha. "Fornear a farinha.",

\footnotetext{
${ }^{100}$ Mesmo na obra de BORGES (1960), que estuda a Influência anglo-americana no falar da ilha de S. Miguel (Açores), não encontramos nada que pudéssemos fazer uma aproximação.
} 
CORRÊA (2000). ALEXANDRE (1994) apresenta também um outro uso para o mesmo verbo: manter relações sexuais (s. v. forneá).

funda: aparece no questionário lingüístico, questão 15, e em 7CI: deixa eu brincar um pouco com a tua funda que tu brinca um pouco com meu carrinho. FISCHER (1999), em seu dicionário de Porto-Alegrês, faz o seguinte comentário: "Aquilo que no Brasil se chama bodoque (que também se usa aqui, mas menos) ou estilingue (que aqui nunca ouvi).” (FISCHER, s. v.). Segundo IMAGUIRE (1999: 485), funda é o termo mais usado em Florianópolis. Nos corpora estudado a forma estilingue aparece somente em quatro informantes, no questionário lingüístico. Note-se que funda é bem comum na antiga região de Itapocorói, mas não em São Francisco do Sul, em que predomina, para o mesmo objeto, o termo cetra ${ }^{\mathbf{1 0 1}}$. Também encontrada em CORRÊA (2000), ALEXANDRE (1994) como variante de estilingue (ambos dicionários específicos de Santa Catarina) e em IMAGUIRE (1999).

gervão: (taturana) segundo CORRÊA (2000): “pode ter dois sentidos: para designar uma espécie de bicha cabeluda ou uma planta também conhecida por Ogerbão.”, questionário lingüístico, questão 7. ALEXANDRE (1994) só nos apresenta a primeira acepção.

grandeúva: em todas as obras pesquisadas não foi encontrada a forma grandeúva, citada por apenas um informante, como um equivalente semântico para a galinha d'angola, questionário lingüístico, questão 6. Sua presença só está registrada como "árvore da família das Ulmáceas." (SILVA, s. v. grandeúva) ou “árvore do litoral catarinense." (CORRÊA, s. v. grandiúva).

imbira: a resposta mais freqüente no questionário lingüístico, questão 7, dada pelos informantes de São Francisco do Sul ${ }^{102}$. Segundo CUNHA (1989), além de indicar uma espécie de planta, é também a "forma paralela de fibra, filamento, estopa". Esta mesma acepção é encontrada em AMARAL (1920) e ALEXANDRE (s. v. embira). Daí, pela semelhança de formato, talvez seja a procedência do uso de imbira para designar uma taturana. Acreditamos que bira seja uma redução deste termo.

\footnotetext{
${ }^{101}$ Vide cetra, p. 88.

${ }^{102}$ Vide imbira, p. 81.
} 
iniço: tal designação para o satanás apareceu na fala do informante 5CI: e aquilo que era o iniço eu não entendi que era ele... né? Esta palavra não foi encontrada em nenhuma das obras pesquisadas. É possível que iniço se relacione com o significado de inço (algo que cresce e se alastra com facilidade, geralmente ervas daninhas), comum em Santa Catarina, (CORRÊA, s. v. inço) ou com o uso que se dá em Florianópolis, segundo ALEXANDRE (1994): “Coisa ou pessoa que não prestam." (s. v. inço/isso).

japona: (jaqueta) termo citado por um informante, no questionário valorativo, questão 3, como um termo que antigamente era usado e hoje não se usa mais. A mesma acepção foi encontrada em AMARAL (1920).

lambicar: processo que transforma a cana-de-açúcar em cachaça. Forma encontrada em ALEXANDRE (1994). 5CI: lambicar cachaça.

lestado ou lestás: segundo o informante, indica o vento do leste. 6B: vem de fora... lestado... e na época de lestás da muito... danifica muito. Encontrado em ALEXANDRE (1994) como "Ventos com chuvas vindos do mar, do leste, e que normalmente dura vários dias." (s. v. lestada).

liquinho(a): não foi encontrado em nenhuma das obras ou dicionários pesquisados. Questão 10 do questionário lingüístico.

lucrécia: usada como equivalente semântico de taturana, questionário lingüístico, questão 7. Só foi encontrada no AURÉLIO (1999) como nome de uma cidade.

machete e rabeca: usadas exclusivamente pelas faixas $\mathbf{B}$ e $\mathbf{C}$, as formas machete e rabeca (e a forma paralela rebeca) são perceptíveis arcaísmos. Machete: "s. do cast. Machete, relacionado com o s. machado. Séc. XVIII, na acepção de <viola pequena>: <es una sonata / De adife / de machete e castanholas >, Dinis da Cruz e Silva, Hissope, VII, p.99, ed. de 1911." (MACHADO, s. v. machete). No AURÉLIO (1999) a palavra rabeca foi assinalada como: "[ Do ár. Rabāb, pelo fr. ant. rebec ou pelo provenç. Ant. rebec] s.f. 1. Designação antiquada do violino [forma paralela: rebeca, var. arrabeca].". 


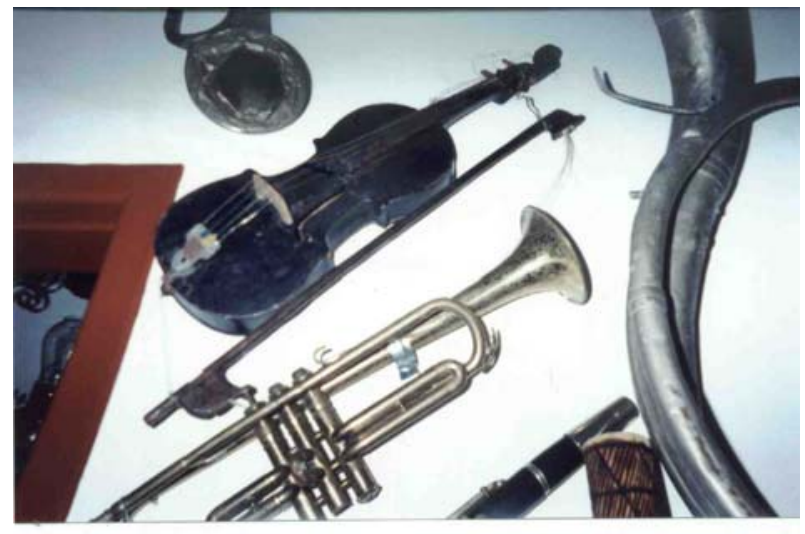

Machete

(foto do arquivo da pesquisadora, janeiro de 2003)

mambu: ver bambu.

mandaruvá e marandová: designações para taturana, questionário lingüístico, questão 7 . Marandová foi encontrada em TAUNAY (1914). Mandorová, segundo CORRÊA (2000), é forma encontrada em alguns lugares do Oeste catarinense (s. v. gervão). A forma mandorová também está presente em AMARAL (1920). Em ALEXANDRE (1994) apresenta-se a forma manduruvá. Encontrada no AURÉLIO (1999) e no HOUAISS (2001) como mandruvá.

mariscal: lugar em que se cultiva ou se encontra mariscos. Termo encontrado no pasquim do Morto Vivo ${ }^{103}$. Segundo CORRÊA (2000), é o nome dado a uma praia de Porto Belo.

molho: (conjunto de) na fala espontânea aparece para indicar buquê de orquídeas (1CI): ia $p a$ Blumenau... com dois molho de orquídea... ia vender em Blumenau pra ajudar a criar meus filho. Forma encontrada em ALEXANDRE (1994).

molhe: porto de pedra. 5C: poderia ter uma marina... aqui entrava no rio... fazia o molhe. Encontrado no HOUAISS (2001), significa cais, quebra mar.

nhanhá e nhonhô pronome de tratamento usado pelos escravos. 6C: “nhanhá... dá mais um... mais um pedacinho de camarão?" e "chama nhonhô pa ver se tá bão o buraco”. De origem africana, encontrados como yayá e yôyô, em MARROQUIM (1945: 167). Encontrados como nha e nho em AMARAL (1920).

\footnotetext{
${ }^{103}$ Ver: anexo 3.
} 
pa mor de eu: MARROQUIM (1945: 103) nos explica que a expressão por amor de sofreu modificações e pode se apresentar de diversas formas: pro mode ou mode ${ }^{\mathbf{1 0 4}}$ e pode significar por causa de ou para. 6CI: pa mor de eu ir pa casa dela. Também encontrado em VASCONCELLOS (1928).

peca [e]: "variante de bolinha de gude. Idiotismo encontrada em Joinville." (CORRÊA, s. v.). Porém, é a forma predominante no questionário lingüístico, questão 14 e também encontrada na fala espontânea.

pelado: citado por dois informantes no questionário lingüístico, questão 9, segundo TORRINHA (1939), é a "forma arcaica de se referir àqueles que não possuem cabelo".

pelota: segundo ALEXANDRE (1994), é o nome da "bola de argila seca ao sol ou no forno utilizada como munição para fundas e estilingues". Para o informante 5C é equivalente semântico da própria funda, questão 15 do questionário lingüístico. Em IMAGUIRE (1999) é citado por um informante como sinônimo de bolinha de gude.

pensão: aparece citado como um termo que hoje não se usa mais, questionário valorativo, questão 3, para indicar preocupação. Em CORRÊA (2000), ALEXANDRE (1994) e AMARAL (1920) aparece com a mesma acepção. (s. v. pensão).

pererenga: uma das formas de designar o satanás, questionário lingüístico, questão 18. Só foi encontrado no HOUAISS (2001) como “tipo de pequeno atabaque maranhense”.

pilica: aparenta ser uma variante de quilica, uma das formas como a bolinha de gude é conhecida em Santa Catarina, (CORRÊA, s. v. quilica). questionário lingüístico, questão 14.

pingola: um dos informantes, no questionário valorativo, questão 3, cita como expressão usada pelos antigos, que caiu em desuso: estar só na pingola, que significava estar bem no fim. Hoje, é uma das formas usadas para se referir ao órgão reprodutor masculino, como explicou a informante.

${ }^{104}[$ 'modi ] ou ['modi ]. 
pomboca: "Pode ter dois significados: vulva ou lamparina a querosene, que Silveira Junior afirma no Boletim da Comissão Catarinense de Folclore, ser idiotismo de Camboriú" (CORRÊA, s. v.). As duas acepções também aparecem em ALEXANDRE (1994). No questionário lingüístico, questão 10 , este termo aparece com a segunda acepção descrita acima ${ }^{105}$.

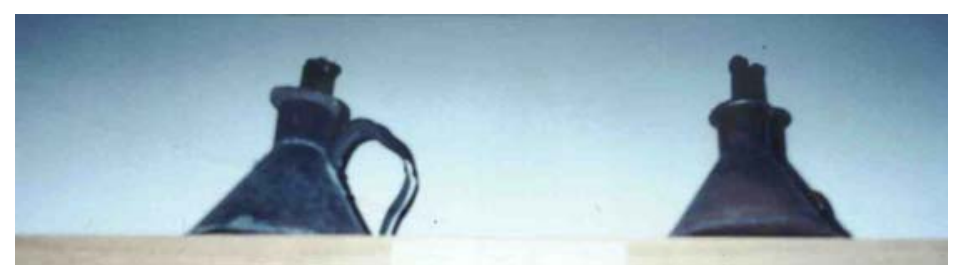

Pomboca (foto do arquivo da pesquisadora, janeiro de 2003)

porva: (pólvora) forma encontrada em AMARAL (1920). 10CI: lá tinha uma qualidade de.:... carrapato porva.... que enchia o braço e a perna da gente.

prantar: encontrado em VASCONCELLOS (1928), em Paços de Ferreira e Maia, Portugal. 7CI: de dia eu tinha que ir pra roça... prantava.

preguntar: forma apontada como um arcaísmo em AMARAL (1920). Realização também encontrada no Nordeste MARROQUIM, 1945: 66). 9CI: preguntou “o que é que tem essa?"

queima-queima: usada como equivalente semântico de taturana, questionário lingüístico, questão 7. Só foi encontrada no HOUAISS (2001) como lava-pés.

\section{rabeca: ver machete.}

rancho: casa, cobertura. 9B: eu por exemplo quero um rancho pra botar minhas coisa e não tenho. Encontrado em ALEXANDRE (1994). AMARAL (1920) aponta que este termo é geral no Brasil e cita um exemplo de uso no Rio Grande do Sul.

rebojo: foi encontrado como "percussão ou redemoinho provocado pela mudança de direção do vento, usado no litoral catarinense" (CORRÊA, s. v.). Grafado como rebojo / reboja em ALEXANDRE (1994). Citado pelos informantes no questionário lingüístico, questão 2, e por 2C:

\footnotetext{
${ }^{105}$ A pesquisadora também ouviu pomboca, em Penha, com o significado da primeira acepção dada.
} 
que tá o vento sul ai né?... esse rebojo que o pescador chama né?. Na questão 1, do questionário lingüístico, um informante da faixa A de Itapocorói o utiliza para nomear uma chuva forte. Curiosamente, no questionário valorativo, questão 3, um informante cita rebojo como sendo um termo que não se usa mais. Encontrado também em OLIVEIRA (2002), dicionário que retrata o vocabulário gaúcho, para designar um vento de sudoeste.

relampo: (relâmpago) encontrado em AMARAL (1920). 9C: o relampo caiu bem assim perto de nós na água.

renar: encontrado na fala espontânea como sinônimo de brigar, repreender. 2AI: ela rena daí. AMARAL (1920), em seu estudo sobre o dialeto caipira, também apresenta este vocábulo com uma acepção distinta: fazer travessuras (s. v. reinar). Em ALVES (1965), em seu estudo sobre a comunidade de pescadores de Ericeira, Portugal, sua significação é diferente das duas dadas anteriormente e indica brincar, jogar ou reinar. ALEXANDRE (1994) também apresenta outra acepção além de brincar: o nome do período de cio dos animais (s. v. reinar).

retrós: ver filé.

roseta: tipo de planta que nasce na praia, cheia de espinhos, CORRÊA (2000). 2C: aqui era só um... uma roseta... um rosetário... por aqui não tinha nada. Palavra encontrada somente em OLIVEIRA (2002), dicionário que retrata o vocabulário gaúcho, com a mesmo significado.

rosetário: lugar cheio de rosetas. $2 \mathrm{C}$ : aqui era só $u m$... uma roseta... um rosetário... por aqui não tinha nada. Foi encontrada a forma roseteiro, em OLIVEIRA (2002), dicionário que retrata o vocabulário gaúcho, para designar um campo de rosetas.

safa: (safra) forma utilizada por 2C: aqui nós tinha a safa da.... a safa do cação... a safa do bagre... a safa da corvina. ALVES (1965) nos apresenta a mesma forma como típica da comunidade de pescadores da Ericeira, Portugal. 
sinaleiro(a): apareceu no questionário lingüístico, questão 17, como a palavra mais recorrente para designar o semáforo: “O nome do sinal de trânsito, que em São Paulo é farol e no Brasil em geral é sinal." (FISCHER, s. v. sinaleira).

tãofraco / trafaco: aparentam ser equivalentes semânticos surgidos por onomatopéia dos sons que imite a galinha de Angola. Nenhuma das duas formas foi encontrada nas obras pesquisadas. Uma forma próxima encontrada foi tô fraco (ALEXANDRE, s. v. angolista).

tarrafa: rede de pesca. Encontrada em ALEXANDRE (1994). 8B: a linha da rede era tirada do tucum pra fazer o pipa... a tarrafa pra rede.

terral: aparece citado como um termo que hoje não se usa mais, questionário valorativo, questão 3, para indicar um vento norte. Em CORRÊA (2000) indica o vento que vai da terra para o mar (s. v. terralão). Em ALEXANDRE (1994) é o vento que de oeste para leste que vai da terra para o mar.

ti: redução de tio. 8B: não conhece o ti $J$. né?... forma encontrada também em Portugal. (CUESTA \& LUZ, 1971: 56)

tilica: aparenta ser uma variante de quilica, termo que originalmente refere-se à bolinha de gude (CORREAA, s. v. quilica) ou, uma variante de pelica, termo que faz referência à parte de trás da funda, feita geralmente de couro, em que se coloca as pedras para atirar (ALEXANDRE, s. v. pelica). Se considerarmos a segunda hipótese como correta, a forma tilica, assim como pelota, são exemplos de partes de um objeto utilizadas para representar o todo, já que para o informante ela é equivalente semântico de funda, questionário lingüístico, questão 15.

tipitim: palavra de origem tupi (MARROQUIM, 1945: 162 - tipiti). Em AMARAL (1920) aparece com o mesmo uso dado ao objeto em Itapocorói: cesto ou outro receptáculo em que se espreme a mandioca ralada." (s. v. tipití). 2CI: o tipitim é feito de mambu.

varejeira: "De varejo, de varejar <revistar>, pois esta mosca como que revista os lugares por onde anda."(MORAIS, s. v.). No questionário lingüístico, questão 6, a forma bareja, a mais conhecida pelos informantes de Itapocorói e que não aparece em São Francisco do Sul, é apontada 
como "um arcaísmo, presente, por exemplo, em $<$ tem mil barejas $>$ de Gil Vicente, Auto da India, na Copilaçam, fl. 196”.(MACHADO, s.v. varejeira). Em CORRÊA (2000), bareja é o nome dado para a larva da varejeira.

veranista ou veronista: forma freqüentemente utilizada pelos informantes na fala espontânea e que também apareceu em quantidade significativa no questionário lingüístico, questão 24 . 8BI: milhares e milhares de turistas... veranistas... isso foi bom pra cidade. Segundo AURÉLIO (1999), turista, em uma de suas acepções, é aquele que faz turismo: "viagem ou excursão, feita por prazer, a locais que desperta interesses" (AURÉLIO, s. v.). Já veranista, e sua variante veronista, são aqueles que passam o verão em algum lugar. Sendo assim, se nem todo o turista é um veranista, todo o veranista é um turista. Aparentemente esta diferença não é sabida pelos informantes. Note-se que a forma veronista não ocorre em São Francisco do Sul ${ }^{106}$.

xilóida ou xilóide: este termo aparece no questionário lingüístico, questão 15, exclusivamente em informantes das faixas B e C. No ALERS (2002), aparece como uma das questões semânticolexicais específicas para as regiões de Santa Catarina em que há influência alemã; porém, grafado como chilóide. Foi encontrada no dicionário de alemão de IRMEN \& KOLLERT (1995) como estilingue (v. s. Schleuder).

\footnotetext{
${ }^{106}$ Vide veronista, p. 96
} 


\section{ANÁLISE MORFOSSINTÁTICA}

Segundo FURLAN (1989: 88): “A morfo-sintaxe do falar açoriano-catarinense abrasileirou-se, pouco de original apresentando (...)”. As principais mudanças, em relação ao português europeu, são: a baixa concordância verbal e nominal, fatos comuns nos demais falares brasileiros também, de acordo com o autor.

Como uma característica ainda ligada ao português europeu, cita o uso do pronome pessoal tu, no tratamento familiar, acompanhado por verbo conjugado na $2^{\mathrm{a}}$ pessoa do singular.

"No AÇORIANO-CATARINENSE, o tuteamento é a forma típica e geral de tratamento entre familiares, amigos e colegas de profissão. Por você são tratados os interlocutores que não se acham incluídos nesse âmbito social; você guarda, pois, resíduos da conotação cerimoniosa de vossa mercê; o uso de você no trato familiar atesta que o falante não é de ascendência açoriana. [...] no açoriano catarinense a forma verbal que acompanha o tu é a $2^{\mathrm{a}}$ pessoa, sendo estranho o uso da $3^{\mathrm{a}}$. O tuteamento é a forma que se emprega em toda a área do açoriano-catarinense e que compreende todos os seus níveis sociolingüísticos, conquanto esteja entrando em uso o voceamento. (FURLAN, 1989: 151) 107 $^{109}$

A seguir serão apresentados os dados obtidos nas gravações pertinentes à morfossintaxe ${ }^{108}$. Devido ao tamanho dos corpora, optou-se por analisar apenas a questão relativa ao uso do pronome tu e da sua suposta concordância verbal ${ }^{109}$. Além disso, apresentar-se-ão os casos peculiares ${ }^{110}$ referentes tanto a Morfologia quanto a Sintaxe.

Os informantes 4AI, 7AI, 9AI, 2BI, 5BI, 8BI, 4CI, 5CI, 8CI, 8A e 9B utilizam o pronome reto tu, de segunda pessoa do singular, acompanhado por verbo conjugado na terceira pessoa do singular. Em 4BI o informante utiliza-se tanto de tu como de você. Além disso, 3BI, 4BI, 7BI, 2CI e 3CI ora utilizam o verbo conjugado na $2^{\mathrm{a}}$ pessoa, ora conjugado na $3^{\mathrm{a}}$.

\footnotetext{
${ }^{107}$ Grifos do autor.

108 Todos os dados aqui apresentados foram extraídos da fala espontânea, pois os questionários aplicados não abordaram este tipo de questão. Para facilitar a leitura, as transcrições fonéticas só serão utilizadas quando necessárias.

${ }^{109}$ Todas as ocorrências do pronome tu estão sublinhadas no anexo 2.

${ }^{110}$ Arcaísmos, construções e usos atípicos ou não-padrões da língua.
} 


\begin{tabular}{|l|l|l|}
\hline & verbo conjugado na $2^{\text {a }}$ pessoa & verbo conjugado na $3^{\mathrm{a}}$ pessoa \\
\hline 3BI & $\begin{array}{l}\text { tu fosse } \\
\text { tu } \text { viesse }^{112} \text { a pé ( ) }\end{array}$ & $\begin{array}{l}\text { Tu tava } \\
\text { tu ficou } \\
\text { tu não queria }\end{array}$ \\
\hline 4BI & tu não chegasse $^{I 13}$ a vê?? & Tu viu \\
\hline 7BI & não visse? $^{114}$ & $\begin{array}{l}\text { Tu viu } \\
\text { tu amassa }\end{array}$ \\
\hline 2CI & vencesse né? $^{115}$ & Tu vai \\
\hline 3CI & tu já tens $^{\text {Tu vai }}$ \\
\hline
\end{tabular}

No pasquim do Morto Vivo ${ }^{116}$, recolhido em Penha, aparecem cinco realizações que merecem ser comentadas. Três usos de tu acompanhado por verbo conjugado na terceira pessoa ( "tu não vai", "tu tá bebo", "tu vai”") ${ }^{117}$ e dois verbos conjugados na $2^{\text {a }}$ pessoa, porém, sem a presença do pronome ("Se estavas com problemas" e "Tens que ficar escondido") ${ }^{118}$.

Ocorrências de tu em Itapocorói ${ }^{119}$ :

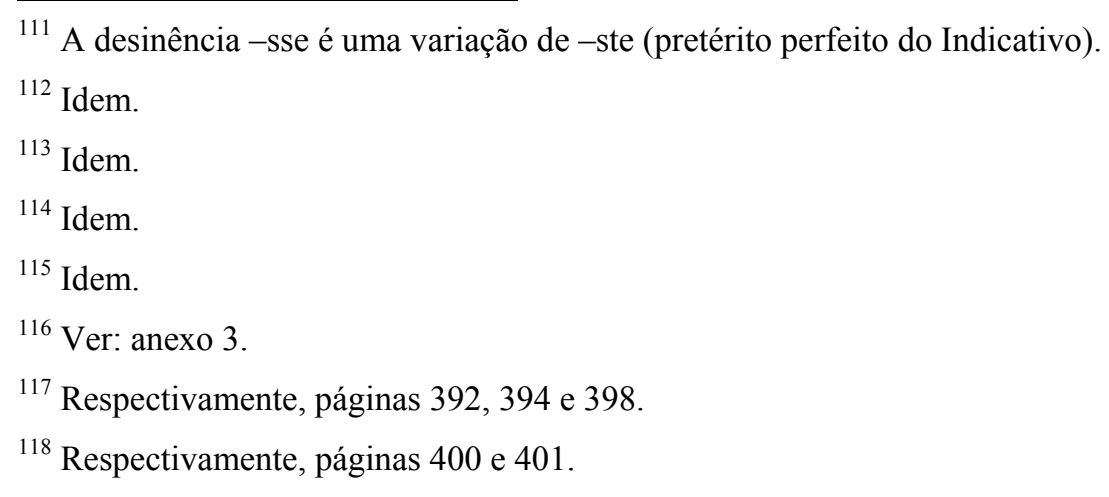

${ }^{119}$ 3BI, 4BI e 3CI foram computados duas vezes: por usar o tu acompanhado por verbos na $2^{\mathrm{a}}$ e na $3^{\mathrm{a}}$ pessoas. 7BI e 2CI só entram no gráfico em tu com verbo na $3^{\mathbf{a}}$ pessoa, pois o verbo conjugado na $2^{\mathrm{a}}$ pessoa não aparece acompanhado com o pronome tu. Os dados retirados do pasquim também não entraram no gráfico. 


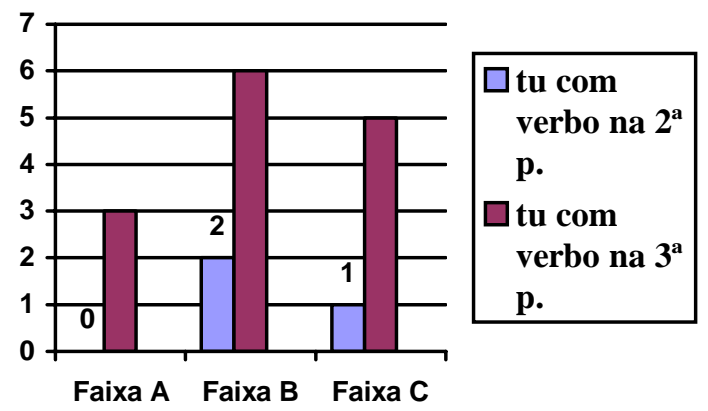

Em 8B e 6C o uso do pronome reto tu só aparece quando o informante reconstitui, na forma de discurso direto, a fala de outras pessoas, mesmo assim, o verbo está conjugado na $3^{\text {a }}$ pessoa. Já 10C utiliza o pronome reto tu uma única vez ("tu sabes”). Esta última realização, em que o pronome de segunda pessoa tu é acompanhado pelo verbo conjugado na segunda pessoa do singular, é um fato isolado em São Francisco do Sul.

Ocorrências de tu em São Francisco do Sul ${ }^{120}$ :

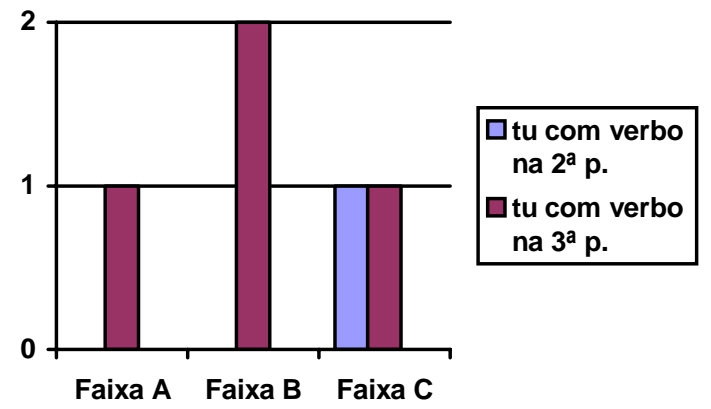

Assim, nota-se que houve uma mudança na relação entre o verbo e o pronome que o acompanha. O tratamento por tu é ainda é presente e está distribuído pelas três faixas etárias consideradas em Itapocorói, porém, o verbo que o acompanha é na maioria dos casos conjugado na terceira pessoa. Contrariamente, o uso do pronome reto tu apresentou baixíssima realização em São Francisco do Sul.

No ALERS (2002) há um quadro morfossintático que mostra a concordância verbal no trato de irmão com seu irmão.

\footnotetext{
${ }^{120} \mathbf{8 B}$ e 6C foram computados como informantes que utilizaram o tu acompanhado por verbo na $3^{\mathrm{a}}$ pessoa.
} 


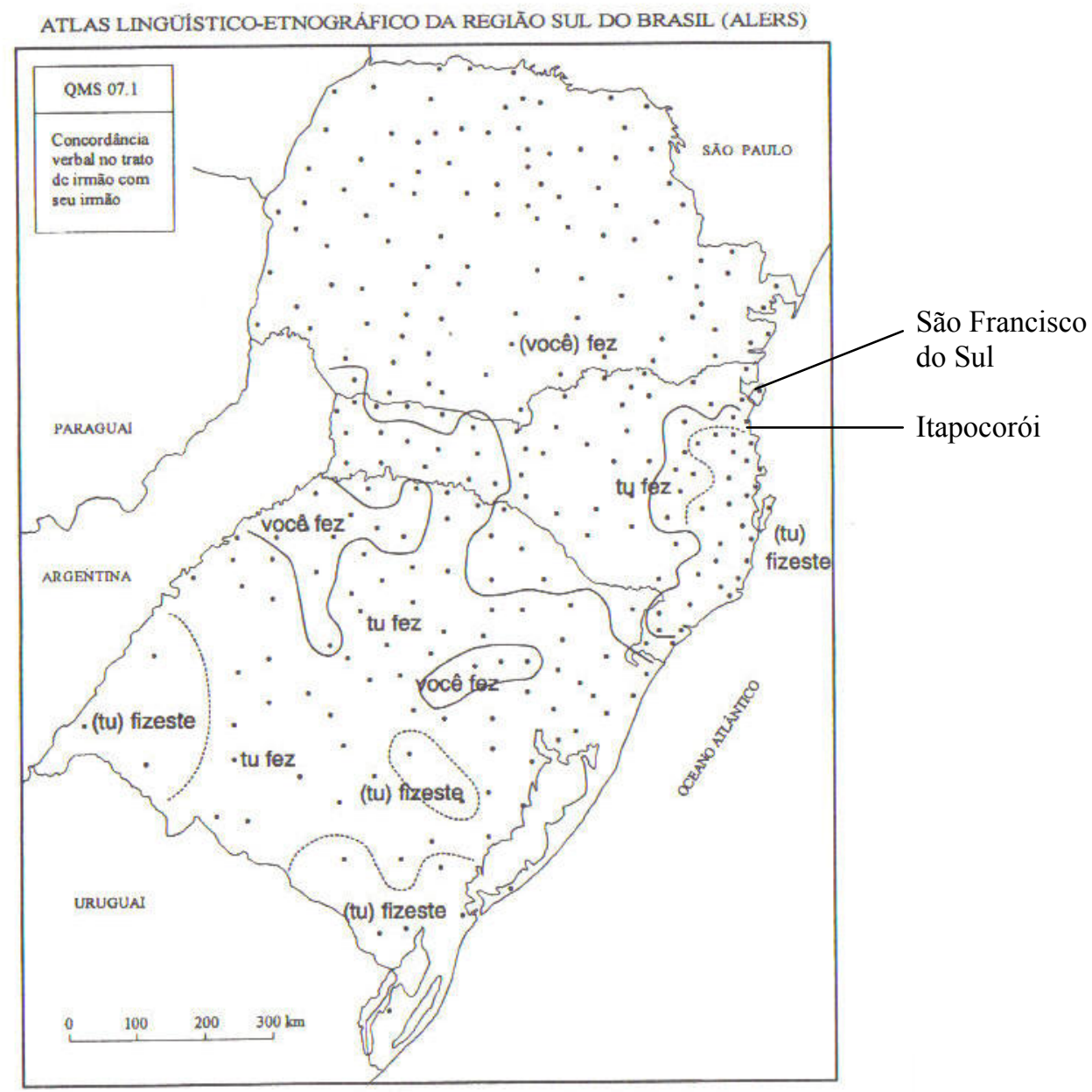

Mesmo os dados não tendo a mesma origem ${ }^{121}$, os dados convergem: o mapa nos mostra que a região de Itapocorói está na área de realização de tu com verbo conjugado na $2^{\mathrm{a}}$ pessoa, o que procede em parte. Já São Francisco do Sul está na área de tu com verbo conjugado na terceira pessoa.

\section{MORFOLOGIA}

Usam o $t i$, pronome oblíquo de $2^{\mathrm{a}}$ pessoa, os informantes: 4AI, 1BI, 3BI, 8BI, 6C e 10C. $\mathrm{O}$ informante $6 \mathrm{C}$, imitando a fala dos antigos, usa $t i$ também. Usam teu e tua, pronomes possessivos de segunda pessoa, os informantes: 3BI, 9CI e 6C. Tais formas são mais comuns no

\footnotetext{
${ }^{121}$ Os dados do ALERS (2002) foram recolhidos por meio da aplicação de questionário. Os dados apresentados neste capítulo são retirados dos corpora de fala espontânea.
} 
português falado no Sul do Brasil. Há a presença de mo (6CI) e mos $(\mathbf{8 C I})$ em vez de meu(s) (também dialetal em Portugal). E também da forma não-padrão com nós (10CI).

Em 3BI, 4BI, 7BI e 2CI encontramos o uso de uma variante da desinência verbal -ste, a saber -sse, para a $2^{\mathrm{a}}$ pessoa do singular do pretérito perfeito do Indicativo:

\begin{tabular}{|l|l|}
\hline 3BI & $\begin{array}{l}\text { tu viesse a pé... } \\
t u \text { fosse } c o m()\end{array}$ \\
\hline 4BI & tu não chegasse a vê?? \\
\hline 7BI & não visse? \\
\hline 2CI & vencesse né? \\
\hline
\end{tabular}

Como nas gravações o entrevistado quase não pergunta, restringindo-se a responder, infelizmente as gravações forneceram poucos dados em relação a esse fato que é bem comum na região, sendo freqüentemente percebido pela pesquisadora em conversas entre os locais de Itapocorói $^{122}$. O mesmo não ocorreu em São Francisco do Sul.

No pasquim do Morto Vivo ${ }^{123}$ a desinência -sse aparece em todos os contextos em que há o uso da $2^{\mathrm{a}}$ pessoa do singular do pretérito perfeito do Indicativo:

\begin{tabular}{|l|l|}
\hline Página 2 & Ficasse lendo na praia \\
\hline Página 2 & Deixasse o Deli morrer \\
\hline Página 14 & Porque fingisse isso tudo \\
\hline Página 14 & Brincasse com tua família \\
\hline Página 14 & Não fizesse confusão \\
\hline Página 15 & Não pensasse nisso não \\
\hline Página 15 & Não matasse não roubasse \\
\hline Página 15 & Apenas fingisse morrer \\
\hline
\end{tabular}

\footnotetext{
${ }^{122}$ Em ALEXANDRE (1994), um dicionário que trata dos termos peculiares de Florianópolis, encontramos a seguinte forma dicionarizada: “VISSE? - Viste?" (v. s. visse). Aqui temos um fenômeno fonético que aos ouvidos da pesquisadora é muito comum em Itapocorói.

${ }^{123}$ Ver: Parte 1, capítulo 2, item 2.3.3. e anexo 3.
} 
MARROQUIM (1945: 121) registra a mesma desinência (-sse) nas falas de Alagoas e Pernambuco: É comum ouvir de senhores de engenho, fazendeiros, comerciantes, o emprego do pretérito do indicativo na $2^{a}$ pessôa, com a flexão dialetal: “João, tu fizesse o serviço?” Faz isso depressa, uvisse?".

Em 7CI predomina o uso do verbo haver como sinônimo de existir, e não o verbo ter, mesmo o informante não tendo recebido educação formal. Em 10BI e 5CI também encontramos tais realizações em, respectivamente, "houve morte" e "a novidade que havia". Esse tipo de construção está, em geral, em desuso no português do Brasil, isso nos explica porque é ausente entre os mais jovens.

Em 10BI e 9B a terminação da $3^{\mathrm{a}}$ pessoa do plural do pretérito perfeito do Indicativo é realizada como: [o] ou [õ]: já morrer[o], comprar[õ] a praia e eles impacar[o]. Esta terminação é considerada arcaica por CUESTA \& LUZ (1971: 120).

Há também o uso da desinência -emo(s) na $1^{\mathrm{a}}$ pessoa do plural do presente do Indicativo de verbos da $1^{\text {a }}$ conjugação (10AI, 1BI, 3BI, 5CI, 4A, 10A, 8B e 9C) ${ }^{124}$ :

\begin{tabular}{|l|l|}
\hline 1BI & $\begin{array}{l}\text { aí voltemo pra Penha } \\
\text { mas nós comecemo a conversar }\end{array}$ \\
\hline 3BI & $\begin{array}{l}\text { também se acabemo } \\
\text { cheguemo na casa dos pai } \\
\text { fiquemo lá } \\
\text { que nós moremo } \\
\text { passemo por ele }\end{array}$ \\
\hline 2CI & $\begin{array}{l}\text { aí já comecemo } \\
\text { aí nós passemo }\end{array}$ \\
\hline 5CI & entremo mato adentro \\
\hline 10CI & matemo muito passarinho \\
\hline 4A & a gente estudemo \\
\hline
\end{tabular}

\footnotetext{
${ }^{124} \mathrm{Na}$ tabela não foram colocados os verbos que se repetiram em um mesmo informante, mesmo que o contexto frasal tenha sido diferente.
} 


\begin{tabular}{|l|l|}
\hline 10A & $\begin{array}{l}\text { já peguemo vento } \\
\text { quase viremo } \text { a embarcação } \\
\text { nós nunca usemo }\end{array}$ \\
\hline 8B & cheguemo a matar \\
\hline 9C & apanhemo aqui na Costinha \\
\hline
\end{tabular}

Diferentemente de outras variantes brasileiras, a desinência de gerúndio costuma pronunciar bem o $-d$. A única exceção é 9CI.

Há algumas conjugações que fogem da regra geral: (5CI) previneu $^{125}$, truxe $^{126} \mathrm{e}$ vinheram $^{127}$ e se intimeda ${ }^{128}(\mathbf{1 C})$. A partir de um *vivir deriva-se uma forma ['vevi ], antiga e espalhada pelo Brasil (10B) (VIARO, 2005: 238).

Quanto ao substantivo, dois casos são notáveis no corpus: a flexão nominal de leão (2AI) e a formação do diminutivo em negócio (2AI). Leão é realizado como leãos e negócio como negocim. No primeiro caso temos uma variação para um plural que tem uma forma fixa em -ões. Já a terminação -im para o diminutivo não é recorrente no sul do Brasil.

Entre as preposições, duas construções que merecem destaque são desde de (1B1) e mais, significando em companhia de (5C1), respectivamente desde dos dez anos e a coitada não vinha... foram ver tava chorando mais os filho na cozinha... A primeira se destaca pela repetição da preposição de, a segunda por ser um uso pouco comum.

Duas conjunções se destacam: pra mor de (6CI) e por causa que (3A). A primeira, por ser um legítimo arcaísmo ${ }^{129}$ e a segunda por suprimir a preposição de - por causa de.

Em relação à sintaxe, como em outras variantes, os adjetivos e substantivos que envolvem concordância de gênero / número são freqüentemente desprovidos de marca de plural. Há, porém, algumas construções curiosas:

\section{AI bastante amigos}

\footnotetext{
125 Forma para $3^{\text {a }}$ pessoa do singular do pretérito perfeito do Indicativo do verbo prevenir: preveniu.

${ }^{126}$ Forma para $1^{\mathrm{a}}$ pessoa do singular do pretérito perfeito do Indicativo do verbo trazer: trouxe.

${ }^{127}$ Forma para $3^{a}$ pessoa do plural do pretérito perfeito do Indicativo do verbo vir: vieram.

${ }^{128}$ Forma para $3^{\mathrm{a}}$ pessoa do singular do presente do Indicativo do verbo intimidar-se: se intimida.

${ }^{129}$ Ver: Parte 3, Análise Lexical, item 1.2.
} 


\begin{tabular}{|r|l|}
\hline 5CI & lagarta macha \\
\hline 9B & mata o camarão tudo \\
\hline 1C & criei eles tudo \\
\hline 4C & dois cirurgia \\
\hline
\end{tabular}

Geralmente, na língua falada, quando se usa bastante acompanhando um substantivo, ele fica no singular, exemplos: bastante carro na rua, bastante coisa pra fazer; porém, 5AI coloca-o no plural. Para lagarta macha, pelo contexto ${ }^{130}$, é possível fazer duas interpretações. Supondo que macha é equivalente semântico de brava, há concordância em gênero. Se for considerado que macha refere-se ao sexo, não há. Em dois cirurgia não há concordância em número e nem em gênero.

Assim como em outras variantes do português do Brasil, ocorre com freqüência de o verbo vir na $3^{\mathrm{a}}$ pessoa do singular quando o sujeito está no plural ou é composto. Outras construções notáveis são as seguintes:

\begin{tabular}{|c|c|}
\hline & vocativo no plural + verbo no singular \\
\hline \multirow[t]{2}{*}{ 2AI } & crianças... sai daí \\
\hline & pronome na $1^{\mathrm{a}}$ pessoa (nós) + pronome reflexivo da $3^{\mathrm{a}}$ pessoa do singular \\
\hline 3BI & $\begin{array}{l}\text { nós se alvoroçamos } \\
\text { se acabemo }\end{array}$ \\
\hline \multirow[t]{2}{*}{ 7C } & nós se alagamo \\
\hline & sujeito no singular (que indica grupo) + verbo no plural \\
\hline 4CI & $\begin{array}{l}\text { a juventude de hoje são } \\
\text { a família casaram }\end{array}$ \\
\hline 4A & a gente estudemo \\
\hline \multirow[t]{2}{*}{ 8B } & a guriada não ligam \\
\hline & sujeito no plural (nós) + verbo no singular \\
\hline 2BI & nós ia \\
\hline
\end{tabular}

\footnotetext{
${ }^{130}$ Antônio Clara ele pegou uma faca... disse "eu vou no sertão... vou lá capar a lagarta”... capou a lagarta fêmea deixou a lagarta macha...
} 
Como a maioria das variantes do português do Brasil, a posição dos pronomes átonos é preponderantemente a próclise. No entanto, alguns fenômenos merecem destaque. Ocorre a ênclise em fui-me embora (8BI) e acabou-se (7C). Dupla pronominalização em se enfiou-se (1BI) e se torna-se (5B). Uso de pra ti + INFINITIVO em 4AI e 1BI, comum nos falares sulinos, respectivamente: pra ti viajar pra outro lugar... e pra ti não se preocupar.

Alguns casos de regência também se destacam. Geralmente, na língua falada o verbo ir é utilizado com a preposição em, como nos exemplos seguintes: ir na padaria, ir no mercado, ir no carro. O informante 1C usa o verbo ir acompanhado pela preposição a, mesmo tendo apenas o primário incompleto: moça não ia a... baile sozinha. Outros casos de regência:

\begin{tabular}{|l|l|}
\hline 5CI & $\begin{array}{l}\text { mete no cacete } \\
\text { acabando o capim }\end{array}$ \\
\hline 7B & deviam que dar \\
\hline 5C & dar de César o que é de César \\
\hline
\end{tabular}

Encontramos em dois informantes construções incomuns na voz passiva: a droga já era existida a quarenta ano passado (8BI) e fui acidentado pelo carro (10CI). Outras duas construções verbais também se destacam: essa de Itaguaçu é perigosa... já tem morrido muita gente... ((praia)) (4C) e uma vez eu tava pescando... lá fora... eu e mais um filho meu... mais um pescador... foi morto... foi falecido... e ai deu um vento forte... (7C). Na primeira construção a locução verbal dispensa o advérbio já, pois o seu uso no contexto acima não é freqüente. Na segunda construção o informante quis passar a informação que pescador que os acompanhou naquele dia morreu, não na pescaria, mas depois. Na verdade ele não tinha certeza se ele tinha sido morto ou se faleceu ${ }^{131}$.

\footnotetext{
${ }^{131}$ É possível saber somente pelo contexto da entrevista.
} 


\section{ANÁLISE COMPARATIVA DO QUESTIONÁRIO VALORATIVO}

São várias as finalidades do Questionário Valorativo: ter um panorama de como um item lexical se comporta ativa e passivamente para os falantes, como cada faixa etária percebe o comportamento lingüístico da outra e se os informantes das localidades estudadas têm consciência das diferenças dialetais que os cercam.

\section{1 - Resposta esperada ${ }^{132}$ : APAIXONADO(a)}

a) Quando se fica muito triste, dizemos que ficamos...

Abatido (7BI, 9B), aborrecido (10AI, 3CI, 3B, 5B, 7C), aflito (1CI), alegre (3C), apaixonado (10CI), chata (2A), chateado (2BI, 9A, 4B), chocado (7CI), coração partido (8A), depende do tamanho da tristeza (6B), desacorçoado (10B), desanimado (2CI, 7B), entristecido (3BI), feliz (1B), jururu (4BI), macambúzio (8C), magoado (2AI, 5AI, 6AI, 9AI, 8BI, 10A, 4B), melancólico (5CI), sem alegria (7AI), sozinho (2C), triste (8AI, 6BI, 8BI, 9BI, 2B, 1A, 3A, 1C, 4C, 6C, 9C, 10C). Não responderam: 1AI, 3AI, 4AI, 1BI, 10BI, 4CI, 10CI, 8B, 4A, 5A, 6A, 7A, 5C.

A finalidade desta pergunta era checar se os informantes conheciam uma das acepções mais antigas do termo apaixonado ${ }^{133}$. Apenas 10CI, o informante mais velho, se expressou como esperado.

b) O que você entende por ficar apaixonado?

Angustiado (4CI), alegria (7B), amor (7C, 1B, 10B, 3C), desgostoso (1CI), ficar bobo (5B), ficar contente (6B), gostar de alguém (3AI, 4AI, 9AI, 10AI, 1BI, 2BI, 3BI, 4BI, 5BI, 6BI, 7BI, 8BI, 9BI, 10BI, 3CI, 6CI, 7CI, 8CI, 9CI, 10CI, 3A, 5A, 7A, 2B, 3B, 4B, 8B, 1C, 2C, 5C, 8C, 9C), não entendo nada (1A, 2A, 4A, 6A, 10C), paixão $(\mathbf{9 A}, 4 \mathrm{C})$, quando você ama alguém e a pessoa não te ama (9B), ressentido (5CI), triste (2CI, 6C). Não responderam: 1AI, 2AI, 5AI, 6AI, 7AI, 8AI, 8A, 10A.

\footnotetext{
${ }^{132}$ Para entender o que seja a resposta esperada, ver o capítulo Trabalho de Campo (1.4 - O Questionário Lingüístico, p.51)

${ }^{133}$ Para mais detalhes, ver o capítulo Análise Lexical.
} 
Os informantes 1CI, 2CI, 4CI, 5CI e 6C não associaram paixão ao seu significado mais corrente no Português do Brasil ${ }^{134}$. Considerando que 10CI, na pergunta anterior, também utiliza o termo apaixonado em sua forma arcaica, totalizamos $10 \%$ dos informantes da faixa $\mathbf{C}$ presentes no corpora. É importante assinalar que das seis ocorrências, cinco apresentam-se no corpus de Itapocorói. Como era previsto, esse arcaísmo ocorre apenas na faixa $\mathbf{C}$.

c) Você conhece outro significado para esta palavra?

Sim: 7BI, 8BI, 5A, 8A, 1B.

Não: 1AI, 2AI, 3AI, 4AI, 5AI, 6AI, 7AI, 8AI, 9AI, 10AI, 1BI, 2BI, 3BI, 4BI, 5BI, 6BI, 9BI, 10BI, 1CI, 2CI, 3CI, 4CI, 5CI, 6CI, 7CI, 8CI, 9CI, 10CI, 1A, 2A, 3A, 4A, 6A, 7A, 9A, 10A, 2B, 3B, 4B, 5B, 6B, 7B, 8B, 9B, 10B, 1C, 2C, 3C, 4C, 5C, 6C, 7C, 8C, 9C, $10 \mathrm{C}$.

Os informantes que disseram conhecer outro significado o especificaram, com suas palavras, dentro da acepção corrente no Português do Brasil, repetindo, com palavras diferentes, a mesma idéia dada no item $\mathbf{b}$. Os informantes da faixa $\mathbf{C}$ que apresentaram o conhecimento da forma mais antiga disseram não conhecer outro significado.

d) Já ouviu alguém falar assim: paixão como tristeza? ${ }^{135}$

Sim, já ouvi os mais antigos falarem assim: 9AI, 4BI, 5BI, 7BI, 9BI, 10BI, 1B, 7B, 8B, 5A, 2C, $5 C$.

Nunca ouvi falar: 1AI, 2AI, 3AI, 4AI, 5AI, 6AI, 7AI, 8AI, 10AI, 1BI, 2BI, 3BI, 6BI, 8BI, 3CI, 6CI, 7CI, 8CI, 9CI, 1A, 2A, 3A, 4A, 6A, 7A, 8A, 9A, 10A, 2B, 4B, 6B, 9B, 10B, 1C, 3C, 4C, 7C, 8C, 10C.

A forma apaixonado(a), com seu significado arcaico, de tristeza ou sofrimento, foi encontrada exclusivamente na faixa C, em $62,5 \%$ dos informantes de Itapocorói (1CI, 2CI, 4CI,

\footnotetext{
134 “1. que ou aquele que está dominado por paixão amorosa, por amor intenso e profundo; enamorado.(...)” HOUAISS (2001)

${ }^{135}$ Essa pergunta não foi feita aos informantes que apresentaram o significado arcaico da palavra apaixonado.
} 
5CI e 10CI) e em 10\% dos informantes de São Francisco do Sul. Alegaram não conhecer nenhum significado para apaixonado(a), no item $b$, os informantes: 1AI, 2AI, 5AI, 6AI, 7AI, 8AI, 1A, 2A, 4A, 6A, 8A, 10A e 10C que ficaram extremamente encabulados com a pergunta, talvez, com exceção de 10C, por questões inerentes à idade. Já a faixa $\mathbf{B}$ tem lembrança dessa forma usada pela geração anterior.

$2^{136}$

a) Você acha que os mais velhos falam de forma diferente? ${ }^{137}$

Os informantes 7A e 1B responderam que alguns dos mais velhos falam de forma diferente, para 4B isso só ocorre com algumas palavras. Os informantes 6A, 5B e 8B disseram que não há diferença. Os demais informantes se restringiram a responder afirmativamente à pergunta.

b) Você acha que os mais novos falam de forma diferente? ${ }^{138}$

\section{Sim: todos os informantes}

Por meio das respostas é possível verificar que os informantes têm consciência das diferenças que a idade implica na fala. Porém, os parâmetros de julgamento de cada faixa etária são distintos e, como veremos pelas respostas dadas nas próximas perguntas, aproximam-se mais dos fatores extralingüísticos ${ }^{139}$.

\section{3}

a) Você lembra de alguma(s) palavra(s) que os mais velhos usavam e hoje não se usam mais? ${ }^{140}$

\section{Basoura e barrer (1BI)}

Bidê (criado-mudo), japona (jaqueta), penteadeira (cômoda) e tagé (balcão da cozinha): 3BI Boceta do joelho (rótula) e está só na pingola (só há um resto): 8BI

\footnotetext{
${ }^{136}$ A pergunta de número dois foi utilizada como encaminhamento para as seguintes, por isso, ela foi tão genérica.

${ }^{137}$ Pergunta para as faixas A e $\mathbf{B}$.

${ }^{138}$ Pergunta para as faixas B e $\mathbf{C}$.

${ }^{139}$ Os fatores extralingüísticos são aqueles que estão ligados à vivência do falante e a todo o contexto social em que ele está imerso.

${ }^{140}$ Pergunta para as faixas A e B.
} 
Caçarola (panela), forro de cama (lençol) e a expressão: fulano, ciclano e bertrano: 4BI

Céu pedrento é sinal que em pouco tempo vamos ter chuva ou vento: 2 B

Dia hoje (um pouco antes): 8AI

Deus me acuda e mexeriqueiro (fofoqueiro): 7BI

Engenho: 9A

Não demore que vou ficar com pensão (preocupado): 9AI

Não usavam gírias: 10A

Rapariga (moça): 5BI e 7BI

Rebojo (vento sul), terral (vento norte): 1B

Usam o "l" no lugar do "r", "aleia" (areia): $\mathbf{3 A}$

Não responderam: 1AI, 2AI, 3AI, 4AI, 5AI, 6AI, 7AI, 8AI, 10AI, 2BI, 6BI, 9BI, 10BI, 1A, 2A, 4A, 5A, 6A, 7A, 8A, 1B, 3B, 4B, 6B, 7B, 8B, 9B, $10 B$.

No item a, dirigido aos informantes das faixas $\mathbf{A}$ e $\mathbf{B}$, as respostas afirmativas, dadas geralmente por falantes da faixa $\mathbf{B}$, foram relativas ao léxico e em menor parte à pronúncia. Não houve qualquer exemplo que desse um caráter valorativo às respostas, como podemos observar nos gráficos.

\section{Faixa A}

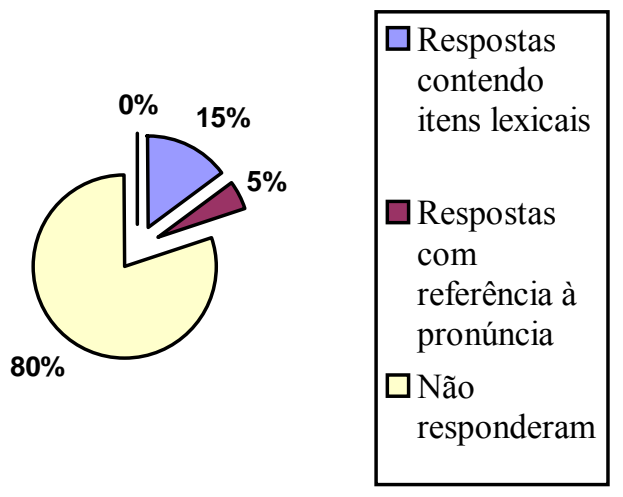

\section{Faixa B}




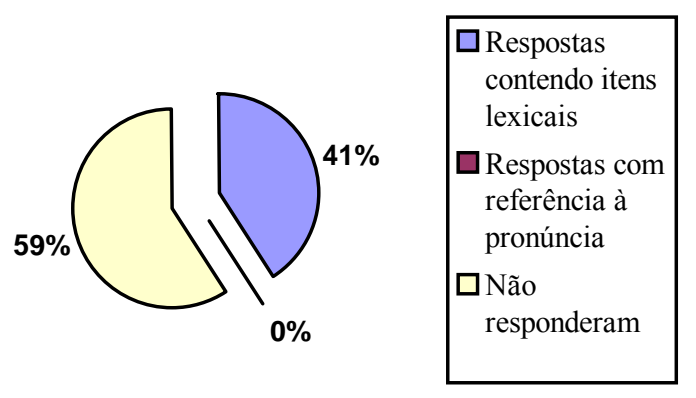

b) Você lembra de alguma(s) palavra(s) que os jovens usam e antigamente não se usavam? ${ }^{141}$

Careta e caduco: $\mathbf{2 C I}$

Gírias: 3BI, 7BI, 8BI, 10BI, 3CI, 4CI, 3B, 4B, 5B, 6B, 9B, 2C, 8C, 9C

Falam mais claro hoje: 10C

Falam tudo trocado: 6C

Na parte de namoros: 5C

Nem é possível dizer: 5CI

Palavras vãs e escandalosas: 10CI

Palavrões: 9CI

Só estou ficando: 7C

Não responderam: 1BI, 2BI, 4BI, 5BI, 6BI, 9BI, 1CI, 7CI, 1B, 2B, 7B, 8B, 10B, 1C, 3C, 4C

No item b, dirigidos aos informantes da faixa $\mathbf{B}$ e $\mathbf{C}$, só dois informantes, 2CI e 7C, fazem uso de itens lexicais para a exemplificação. Neste item predominaram, na verdade, conjuntos de palavras que os informantes da faixa $\mathbf{B}$ e $\mathbf{C}$ consideram negativas: gírias, palavrões e outras que “nem é possível dizer”, de acordo com 5CI.

\section{Faixa B}

${ }^{141}$ Pergunta para as faixas B e C. 


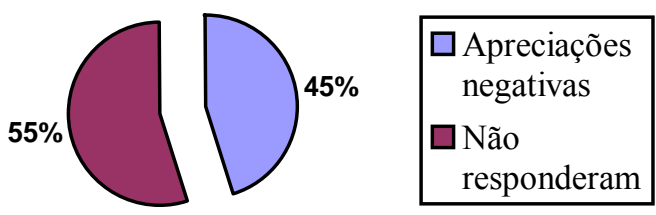

\section{Faixa C}

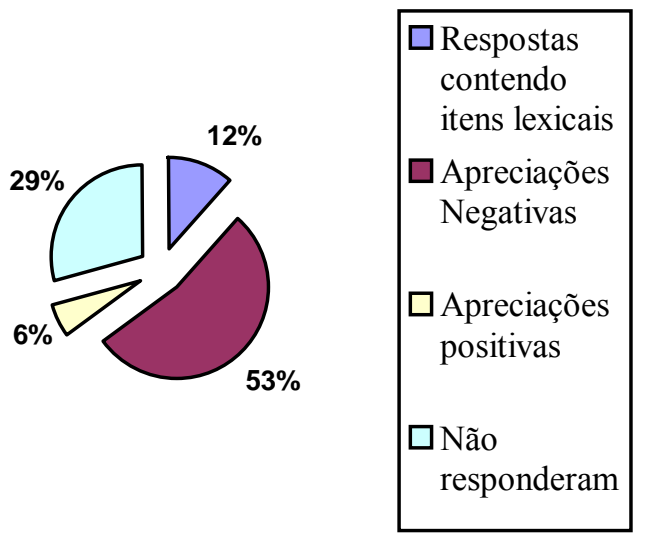

4

a) O que você pensa da forma que os mais velhos falam? ${ }^{142}$

Agora é melhor: 10A

Aprenderam assim: 7BI, 9BI

Atrasada: 2BI

Diferente: 5AI, 7AI, 8AI, 9AI, 1BI, 6BI, 5A

Faz parte da cultura: 10AI, 3BI

Normal: 6AI, 3B, 5B

Mais correta: 4AI, 8BI

Mais educada: 5BI, 1B

Mais feia: 4BI

Não responderam: 1AI, 2AI, 3AI, 10BI, 1A, 2A, 3A, 4A, 6A, 7A, 8A, 9A, 2B, 4B, 6B, 7B, 8B, 9B, 10B

${ }^{142}$ Pergunta para as faixas A e B. 
Os informantes 2BI e 4BI consideram como negativa a fala dos mais velhos, já 4AI, 5BI, 8BI e 1B a consideram como positivas. Os outros que responderam de forma afirmativa mantiveram uma posição neutra ou sem realizar juízos de valores. Nota-se que informantes da faixa A não fazem nenhuma apreciação negativa sobre a fala dos mais velhos.

\section{Faixa A}

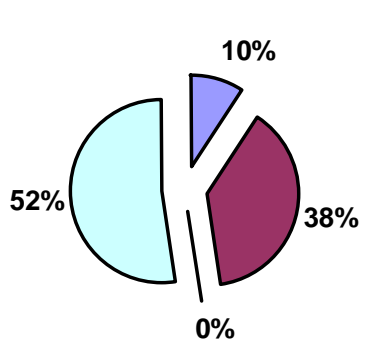

\begin{tabular}{|l|}
$\square$ Apreciações \\
positivas \\
$\square$ Apreciações \\
negativas \\
$\square$ Apreciações \\
Negativas \\
$\square$ Não \\
responderam
\end{tabular}

\section{Faixa B}

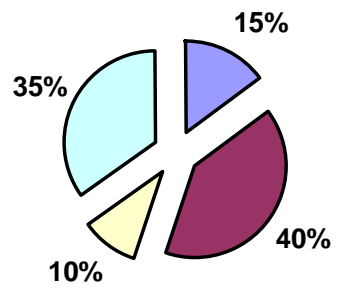

\begin{tabular}{|c|}
\hline Apreciações \\
positivas \\
$\square$ Apreciações \\
neutras \\
$\square$ Apreciações \\
negativas \\
$\square$ Não \\
responderam
\end{tabular}

b) O quê você pensa da forma que os mais jovens falam? ${ }^{143}$

Adolescentes jogam conversa fora: $\mathbf{3 C}$

Artificial e fragmentária: 3BI

É típica da própria geração: $\mathbf{8 B I}$

${ }^{143}$ Pergunta para as faixas B e C. 
Diferente, quase não existe respeito: 6C, 9C

Errada: 2CI

Estranha: 1BI

Falam diferente por causa das drogas: 9B

Falam bem: 4CI

Horrível: 3CI

Indecente: 1CI, 10CI

Inútil: 5CI

Mais moderno: 9BI

Melhor: 6BI

Mudou a educação para pior: 10B, 1C, 5C

Nada que presta: 10BI

Não querem saber de nada: 1B

Pouco diferente: 7C

Pretensiosa (se acham donos do mundo): 2BI

Sabem pronunciar melhor as palavras: 9CI

Sem educação: 5BI, 7BI

Têm mais estudo: 7CI

Usam gírias (depende do jovem): 4BI, 5B

Não responderam: 2B, 3B, 4B, 6B, 7B, 8B, 2C, 4C, 8C, 10C

Uma das questões com o menor número de respostas sem responder, os informantes fizeram considerações sobre o modo como os mais jovens falam. A maioria tem uma visão negativa. Porém, muitos julgamentos não foram lingüísticos, mas comportamentais ${ }^{144}$. Retratam, de certa forma, o descontentamento dos mais velhos em relação aos mais novos.

\section{Faixa B}

\footnotetext{
144 Às vezes, é difícil classificar se a observação do informante foi referente ao modo de falar do outro ou se foi referente ao comportamento. Por exemplo: em 2BI esta "pretensão" está na fala ou no comportamento?
} 


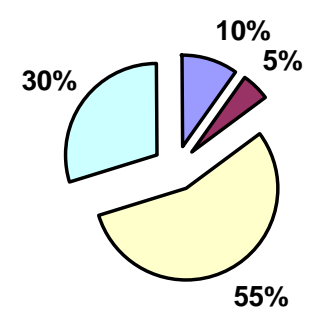

$\square$ Apreciações
positivas
$\square$ Apreciações
neutras
$\square$ Apreciações
negativas
$\square$ Não
responderam

\section{Faixa C}

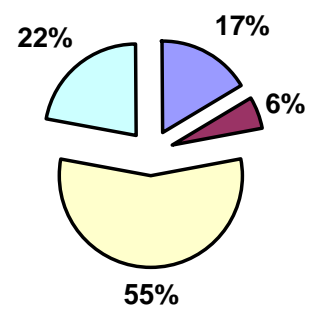

$\square$ Apreciações
positivas
$\square$ Apreciações
neutras
$\square$ Apreciações
negativas
$\square$ Não
responderam

Se compararmos os dados obtidos nos gráficos da faixa $\mathbf{B}$, na questão 4 , é notável como há uma diferença bem nítida em relação à visão que esse grupo tem em relação aos outros grupos. Há praticamente uma inversão na porcentagem entre as apreciações neutras e as negativas. Foram muito mais críticos com a faixa $\mathbf{A}$, sendo que muitas das observações negativas aparentemente estão mais ligadas, como vimos acima, ao aspecto comportamental:

\begin{tabular}{|c|c|c|c|c|}
\hline \multicolumn{5}{|c|}{ Apreciações positivas Apreciações neutras Apreciações negativas Não responderam } \\
\hline Para a faixa $\mathbf{C}$ & $15 \%$ & $40 \%$ & $10 \%$ & $35 \%$ \\
\hline Para a faixa $\mathbf{A}$ & $10 \%$ & $05 \%$ & $55 \%$ & $30 \%$ \\
\hline
\end{tabular}

5

a) As pessoas que moram em outras cidades de Santa Catarina falam de forma igual ou diferente daqui? 
Os informantes 2AI, 5AI e 2A consideram que o modo de falar é igual aos das outras cidades. Para 4A e 5C é pouco diferente, para 3CI e 8B é parecida e para 7CI e 8C é muito diferente. Os demais informantes a consideraram diferente.

Com exceção de 2AI, 5AI e 2A, os informantes tem consciência da variação dialetal dentro de seu próprio Estado.

b) O que você acha disso?

Segundo 6C, isso acontece porque cada lugar tem uma maneira de falar, de pronunciar as palavras. Para 8AI, 2CI, 10CI e 1B o sotaque é diferente. O informante 1CI afirma que os outros falam errado, demonstrando assim uma opinião valorativa, que era o objetivo da pergunta. Já 4BI considera que essa diferença é por causa dos alemães e italianos ${ }^{145}$. Os demais informantes não souberam responder.

c) Lembra de algum exemplo?

Alguns falam mais rápido, outros mais lento: 4B

Aqui se fala cantado porque é de origem portuguesa: 9CI

Falam diferente em São Bento, Mafra, Serra Alta: 1C

Itajaí arrasta mais a fala: 2C

Itajaí fala diferente: $\mathbf{4 C}$

Itajaí fala diferente, o Oeste também: 8C

Itajaí fala mais cantado: 5C

Itajaí fala puxado: 6B

Itajaí e Florianópolis falam diferente: 10C

Muda o estilo da conversa: 8B

No litoral, mais para baixo, na região de Tijucas, entre Florianópolis e Itajaí, Governador Celso Ramos, eles falam muito cantado: 5B

\footnotetext{
${ }^{145}$ Essa consideração mostra que o falante tem consciência das presenças alemã e italiana no Estado de Santa Catarina e suas influências na fala de algumas localidades.
} 
O " $r$ " é diferente, em outros lugares é mais fraco $\left[\ulcorner]\right.$ no começo das palavras ${ }^{146}:$ 3BI

O "s" é diferente, em outros lugares é mais "longo" [ s ], não é como o nosso que é "chiado"

\section{$\left[\int\right]:$ 1BI, 8BI, 2C e 7C}

O uso da palavra pavio no lugar de isqueiro na cidade de Pouso Redondo: 6BI

Não responderam: Nenhum informante da faixa A e 2BI, 4BI, 5BI, 6BI, 7BI, 9BI, 10BI, 1C1, 2C1, 3CI, 4CI, 5CI, 6CI, 7CI, 8CI, 10CI, 1B, 3B, 7B, 9B, 10B, 3C, 6C, 9C

A impressão fonética e prosódica prevalece sobre a diferença lexical da variante. $\mathrm{O}$ município de Itajaí ${ }^{147}$ foi citado por 5B, 6B, 8B, 4C, 5C, 8C e 10C (todos de São Francisco do Sul).

É relevante assinalar que o informante 9CI apresenta a influência portuguesa como causa das diferenças que distinguem a fala de Itapocorói das outras localidades, que é a questão teórica que investiga este trabalho. Os informantes 1BI, 8BI, 2C e 7C citaram como característica da fala de São Francisco do Sul o som [ $\int$ ]. Tal observação é importante porque vai ao encontro da afirmação de FURLAN (1989), que considera esse traço lingüístico como típico da fala açoriana catarinense $^{148}$.

\section{6}

a) Você acha que um catarinense fala de forma igual ou diferente de um paranaense?

Consideram igual os informantes 7CI, 1A e 2C. Para 3A e 10B ela é quase igual. Afirmam que ela é pouco diferente $2 \mathrm{~A}$ e 8B, já para 2BI, 5BI, 7BI, 10CI, 9A, 10A, 4B e 1C a fala é muito diferente. Os outros informantes afirmaram que ela é diferente.

b) Lembra de um exemplo?

O catarinense fala mais atrapalhado: 6BI

\footnotetext{
${ }^{146}$ A pesquisadora notou que tais realizações costumam ocorrer em falantes provenientes das cidades em que há forte colonização alemã. ALTENHOFEN (2000: 80) coloca a realização de /r/ como tepe, em realizações em que são típicas a vibrante múltipla ou a fricativa, no Sul do país, como realizações próprias de cidades com influência alemã e italiana.

${ }^{147}$ Itajaí é uma cidade portuária muito conhecida, talvez, por isso, mesmo estando no litoral considerado de influência açoriana, ela seja vista como uma localidade em que há diferenças.

${ }^{148}$ Para mais detalhes, ver o capítulo Análise Fonética.
} 
O catarinense fala mais rápido: $\mathbf{9 B}, \mathbf{1 C}$

$O$ paranaense fala mais devagar: $6 B I$

$O$ paranaense fala mais rápido: $1 B I$

O paranaense fala menos cantado: $8 A I, 9 B I, 1 C I$

O paranaense fala mais cantado: 6C

Tem outro sotaque: $\mathbf{6 B I}, \mathbf{1 0 B I}, \mathbf{4 B}$

O paranaense tem outro sintoma (sotaque) para falar: 10C

O paranaense tem outro tom para falar: 3C

O catarinense puxa mais o "s" [ $[$ ]: 10BI

O paranaense fala mais chiado nos "s" [ $]$ ]: 8AI, 7C

O paranaense faz "t" chiado [t $\left.\int\right]$ : 2BI, 8BI

O paranaense puxa o "r" [ ] ]: 10AI, 5BI, 9A, 10A

O catarinense usa a forma "tu" para conversar com outras pessoas: 4AI

O paranaense fala mais "tu": $\mathbf{5 A}$

O paranaense fala mais "você": 1B

O uso da expressão “azar lazarento”: $5 B I$

O paranaense fala o "e" final em "leite quente": 10AI, 3BI

O paranaense é mais educado: 9B

O uso da palavra prosear no lugar de conversar 4CI

Não falam o "d" de palavras como assando (gerúndio): 7BI

O catarinense come as letras das palavras: $5 \mathbf{C}$

Pela diferença de criação: 8BI

Não responderam: 1AI, 2AI, 3AI, 5AI, 6AI, 7AI, 9AI, 4BI, 2CI, 3CI, 6CI, 7CI, 8CI, 9CI, 10CI, 1A, 2A, 3A, 4A, 6A, 7A, 8A, 1B, 3B, 5B, 6B, 7B, 8B, 10B, 2C, 4C, 5C, 8C, 9C

Novamente, o aspecto fonético e prosódico foram usados como exemplos. Apenas 6BI fez uma consideração valorativa, respondendo que o catarinense fala mais atrapalhado. A exemplificação foi mais diversificada do que entre cidades do mesmo Estado, o que nos faz pensar que a separação política dos Estados provoca uma maior intensidade no julgamento das diferenças.

Em alguns casos as informações são contraditórias. Para 9B e 1C o catarinense fala mais rápido, para 1BI é justamente o contrário que ocorre: fala mais rápido o paranaense. Para 8AI, 9BI 
e 1CI o paranaense fala menos cantado, para 6C é mais cantado. Outro ponto divergente é o uso dos pronomes tu e você. $O$ informante 1 AI considera que a forma tu é típica da fala catarinense, para 5A o paranaense usa mais o tu. Observa 1B que o paranaense usa mais você. Tais divergências podem indicar que os informantes têm consciência da diferença da fala entre esses Estados, mas, de certa forma, ela não é assim tão marcada.

a) Você acha que um catarinense fala de forma igual ou diferente de um gaúcho?

Disseram 1A e 2A que não conheciam nenhum gaúcho, por isso, não opinariam. Os informantes 5AI e 1C acreditam que a fala nesses Estados seja igual. Para 3AI, 9AI e 8B ela é parecida. Frisam como muito diferente 4BI, 5BI, 6BI, 9BI, 2CI, 4CI, 10CI, 3B e 5B. Os demais informantes a categorizaram como diferente.

b) Lembra de um exemplo?

Os gaúchos falam bruto como os catarinenses: 9B

Os gaúchos falam de forma orgulhosa: 5CI

Os gaúchos falam mais alegre: 1C

Os gaúchos falam mais arrastado: 7B

Os gaúchos falam mais cantado: 2C

Os gaúchos falam mais devagar: 5C

Os gaúchos falam mais esticado: $\mathbf{8 B}$

Por causa da colonização 10AI

Porque são crioulos (do campo): 1CI

Tem a linguagem diferente: 10B

Tem outro sotaque: $\mathbf{5 B I}$ e $\mathbf{5 C I}$

Usam o "ba" quando falam: 5BI, 8BI, 5A, 6C

Usam o "batchê" quando falam: 1BI, 3BI, 4BI, 6B

Usam o "tchê" quando falam: 3AI, 9AI, 6BI, 10BI, 10CI, 5A

Não responderam: 1AI, 2AI, 4AI, 5AI, 6AI, 7AI, 8AI, 2BI, 7BI, 9BI, 2CI, 3CI, 4CI, 6CI, 7CI, 8CI, 9CI, 3A, 4A, 6A, 7A, 8A, 9A, 10A, 1B, 4B, 3C, 4C, 7C, 8C, 10C 
Os exemplos dados para a fala dos gaúchos revelam menor conhecimento dessa variante do que com relação ao paranaense, resvalecendo até mesmo para estereótipos. Em vez de se fazer alusões à fonética ou à prosódia, muitos mencionaram onomatopéias e aspectos extralingüísticos. 


\section{CONSIDERAÇÕES FINAIS}

No decorrer do desenvolvimento deste trabalho, uma questão ficou muito evidente: a influência açoriana no litoral catarinense é algo controverso. Aparentemente, há um enaltecimento das raízes açorianas do litoral catarinense. Para estudiosos como FARIAS (1998, 2000, 2001), PIAZZA (1983) e SOUZA $(1995,2000)$ tal evidência é clara e está manifesta na cultura e nos costumes. Porém, até que ponto isso é procedente é discutível ${ }^{149}$.

“É claro que não existem motivos para colocar em dúvida as tradições genuínas preservadas pelas pessoas mais velhas, aqui ou em outro qualquer lugar do planeta. Os problemas aparecem quando se percebe que algumas destas tradições são também partilhadas, certamente com variações, por outros grupos ou indivíduos (é o caso, entre outros, do tema do boi em divertimentos populares de várias partes do Brasil)." Luís Felipe Falcão ${ }^{150}$

O questionamento feito por Luís Felipe Falcão é pertinente e ainda não foi respondido ${ }^{151}$. Como, por exemplo, inserir histórias de lobisomem e do Boitatá como tradições açorianas se elas ocorrem em outros lugares do Brasil? ${ }^{152}$

Os estudos sobre a influência açoriana no litoral catarinense começaram a despontar na época da Segunda Guerra Mundial ${ }^{153}$. Intensificaram-se a partir da década de 70 e hoje há grupos de

\footnotetext{
${ }^{149}$ Mesmo sendo este um trabalho lingüístico, muitas vezes questões históricas e sociais precisam ser discutidas, pois influenciam diretamente na língua e na visão que se forma dela. Não se questionarão os fatos históricos. Um contingente de açorianos aportou no sul do país, muitos fixaram residência no litoral catarinense, tais fatos são comprovados. Entretanto, mostra-se que há discussões relativas ao grau da suposta influência açoriana.

${ }^{150}$ DIÁRIO CATARINENSE, A cultura açoriana é realmente dominante na Ilha? Especial Açores, Ponto de Vista, 05/03/96, p.11.

${ }^{151}$ Algumas opiniões são ainda mais radicais: “Aliás, os Açores nem são outro país. Os açorianos são portugueses como quaisquer outros de Portugal lá da Europa. Seguem a mesma religião, possuem a mesma cultura e falam a mesma língua. Portanto, não é exagero usar o termo "açoriano" para distinguir algo que apenas diferencia um lugar geográfico e não uma cultura diferente? Ozias Alves Júnior, GAZETA MERCANTIL DE SANTA CATARINA, $\underline{\mathrm{O} \text { mito da }}$ "açorianidade" (2). Caderno D, 05/07/00, p.2.

${ }^{152}$ Ambos estão inseridos no quadro $\mathrm{n}^{\circ} 88$ de elementos que formam a identidade açoriana (FARIAS, 2001: 655).

${ }^{153}$ Parte 1, item 2.4.
} 
pesquisa e de folclore para catalogar e resgatar essas supostas raízes. Ao litoral catarinense foi atribuída uma identidade açoriana. ${ }^{154}$ (LACERDA, 2003)

“(...) proponho a hipótese de investigar o caso açoriano como um fenômeno de etnização da identidade, enfatizando seu caráter organizacional e político no duplo contexto marcadamente multiético da região catarinense e das reações locais aos efeitos homogeneizadores da globalização cultural. O fenômeno da etnização da identidade investe em mecanismos agenciadores com a reconexão com as raízes (os Açores); a marcação de um passado pioneiro, com ênfase numa epopéia fundadora (a saga dos imigrantes açorianos do século XVIII); a seleção de tradições, na forma de novas pautas de eventos evocativos e a difusão de um repertório cultural; a valorização da auto-estima pelo orgulho de ter uma origem, uma identidade e tradições próprias; enfim, de ter uma diferença de identidade a que se possa dar valor próprio em face dos outros." (LACERDA, 2003: 86)

Tal influência também foi estendida para a fala regional, daí o termo variante açoriana catarinense. Aqui há outra polêmica: podemos considerar que a origem do português falado no litoral catarinense é açoriana? Esta é uma questão ainda não resolvida, enquanto Boléo trabalha com a hipótese da influência açoriana, outros, como Rogers e Silva Neto a rechaçam. (FURLAN, 1989)

No sentido da influência açoriana no português brasileiro, argumentou, entre outros, Paiva Boléo que, contudo, não conheceu o Brasil daquele tempo, de própria observação - numa série de artigos a partir de 1943. No seu artigo "Brasileirismos" (1943: 26-30) estabelece mais de uma vez comparações entre a pronúncia da ilha açoriana oriental de São Miguel e o português brasileiro. Dessa forma, especula se a africativização brasileira de /t/ e /d/ diante de [i] não proviria possivelmente de São Miguel (1943: 30). Especifica a influência açoriana na seqüência para o Rio Grande do Sul e Santa Catarina, onde a imigração regional se deixa testemunhar de forma mais direcionada. Já em 1947 Rogers apontava para a fraqueza da tese de Paiva Boléo. Nem por isso, a influência supostamente açoriana no português brasileiro deixou de ser um topos na literatura lingüística. (NOLL, no prelo ${ }^{155}$ )

\footnotetext{
${ }^{154}$ CORRÊA (2000: 42-4) utiliza o termo "marketing" açoriano e também contesta a idéia da soberania açoriana no litoral catarinense. Para exemplificar, o autor cita a cidade de Porto Belo, que já teve o nome de Colônia Nova Ericeira (pois recebeu uma quantidade de portugueses vindos da Ericeira, no continente), onde se cultua a origem açoriana e se apagou esta parte da história.

${ }^{155}$ NOLL, Volker. Das brasilianische Portugiesisch: Herausbildung und Kontraste. Heidelberg: C. Winter, 1997. Trad. Mário Eduardo Viaro (no prelo).
} 
Em KOCH (2000) há uma observação sobre este assunto:

"Dentro do Leque Catarinense caracterizado pelo alto grau de variação das formas no sentido nortesul, distingue-se das regiões vizinhas, como surpreendentemente homogênea em si, uma estreita faixa ao longo do litoral colonizada em meados do século XVII por numerosas famílias açorianas, pelo que se atribui ao falar desta área a designação <<açoriano-catarinense $>>$ (Furlan 1985), sem que estivesse definitivamente comprovado até que ponto o dialeto dos ilhéus efetivamente contribuiu para as seguintes características ${ }^{156}$ (....)" (KOCH, 2000: 57)

Em realidade, há poucos trabalhos que discutem esta questão, ou mesmo que forneçam um panorama da língua falada nos Açores. Geralmente, não há material desenvolvido no Brasil, ou mesmo cópias destes trabalhos aqui, e quando há, às vezes não estão acessíveis.

A falta de estudos sólidos e de consenso teórico faz com que apareçam termos como: variante luso-açoriana-madeirense-vicentista (CORRÊA, 2000), que tentam ser mais abrangentes, mas mesmo assim não são teoricamente mais corretos, pois não fornecem dados científicos que comprovem tais influências, mais uma vez, estamos no campo das suposições.

Os principais traços fonéticos que FURLAN (1989) cita como próprios da fala açoriana catarinense, podem ser encontrados em Portugal Continental ou em lugares do Brasil em que não houve influência açoriana ${ }^{157}$. Quanto ao léxico, muitas das palavras encontradas nos corpora estão também em AMARAL (1920), que estudou o dialeto caipira em São Paulo, ou até mesmo são de origem indígena (tipitim) ou alemã (xilóida) ${ }^{158}$.

Não coube a este trabalho sanar estas dúvidas. O objetivo da pesquisa era fazer um estudo diacrônico descritivo da região da antiga enseada de Itapocorói e de São Francisco do Sul e verificar em que medida os traços arrolados por FURLAN (1989), sem entrar no mérito da questão se eles realmente refletem a influência da fala açoriana, estão presentes nas regiões estudadas. Por isso, sempre que houver referência aos "traços ou características da fala açoriana catarinense", estamos nos referindo aos citados por FURLAN (1989), obra de referência em meio a escassez de material sobre o assunto $^{159}$.

\footnotetext{
${ }^{156}$ Destaque realizado pela pesquisadora.

${ }^{157}$ Parte 3, capítulo 1.

${ }^{158}$ Parte 3, capítulo 2.

${ }^{159}$ Foi cogitada a hipótese de mudarmos o título deste trabalho, suprimindo o termo variante açoriana catarinense, porém, tal medida só iria mascarar um problema, não resolvê-lo, por isso, resolvemos mantê-lo.
} 
Portanto, variante açoriana catarinense, neste trabalho, também engloba a fala de outros que compuseram o quadro populacional da região: portugueses continentais ou vicentistas e índios (primeiros moradores da localidade), além de negros e imigrantes alemães e italianos.

A análise dos corpora por meio do tempo aparente foi uma tentativa de visualizar a língua como um todo, tanto de forma sincrônica como diacrônica. A variação é estável ou os dados podem indicar mudança? Analisando todos os pontos fonéticos, lexicais e morfossintáticos levantados nessa pesquisa, é possível afirmar que as variantes de Itapocorói e São Francisco do Sul estão modificando-se.

Analisando os dados extralingüísticos, verificamos que essas modificações não estão presentes só na região estudada, mas no litoral catarinense como um todo ${ }^{160}$. Fruto de outras mudanças mais profundas, a língua sofre um constante processo de adaptação à realidade que a cerca.

No começo da pesquisa, pensava-se que o parque Beto Carrero World, inaugurado em 1991 na cidade de Penha, era o grande pivô das modificações lingüísticas na região. E esse foi um dos critérios para a divisão dos informantes: faixa $\mathbf{A}$ - aqueles que cresceram com o desenvolvimento turístico da região de Penha. Contudo, isso não descaracteriza a divisão realizada, pois esses informantes estão naturalmente separados das faixas B e C. Posteriormente, por uma questão metodológica, essa mesma divisão foi aplicada em São Francisco do Sul.

Apesar dessa divisão ter sido estipulada antes mesmo da coleta de dados, ela foi muito pertinente e realmente retratou a realidade lingüística dos falantes. Por exemplo, as características do falar regional, assinaladas por FURLAN (1989) como base distintiva da variante açoriana catarinense, sobretudo no componente fonético, se encontram em sua maioria na faixa $\mathbf{C}$.

Essas mudanças são um pouco mais antigas do que havíamos pensado, remontando, aproximadamente, às décadas de sessenta e setenta: a facilidade de acesso gerada pela BR 101 somada com os incentivos fiscais dados pelo governo de Santa Catarina fomentou a vinda de indústrias nacionais e estrangeiras. $\mathrm{O}$ aumento de infra-estrutura dos municípios, para abarcar tais fatos, facilitou, por exemplo, o acesso à escola e a chegada de energia elétrica em locais mais distantes, fatos que tendem a tornar homogênea a fala.

O parque, em Penha, foi o ápice dessas mudanças na localidade, acelerando o processo na região da antiga Itapocorói. Com o radical aumento do número de turistas que a freqüentam, principalmente na época de férias, o contato com outras variantes também aumentou. Apesar de

\footnotetext{
${ }^{160}$ Parte 1, capítulo 2, item 2.4.
} 
muitos turistas serem argentinos, uruguaios, paraguaios ou chilenos, não foram encontrados indícios que a língua espanhola esteja influenciando a variante local. A única referência que podemos fazer está em SOUZA (1995: 71), que traz uma relação de palavras espanholas, cujo entendimento pode melhorar a comunicação entre os moradores e os turistas.

Porém, a preservação dos traços considerados açorianos, por FURLAN (1989), não ocorre da mesma forma nos três municípios que hoje ocupam o território da antiga Armação: Penha, Piçarras e o sul de Barra Velha.

Piçarras e Barra Velha são cidades mais urbanizadas, cujos centros comerciais são bastante desenvolvidos. Penha, cuja área urbana é menor, ainda é a localidade que mais preserva traços culturais, que autores como FARIAS (1998), consideram provenientes dos Açores. Isso é visível, por exemplo, na preservação das tradições religiosas como a Folia de Reis e do Divino, na tradição do pasquim ou na brincadeira do boi na vara; que não ocorrem nos outros dois municípios.

Essas diferenças extralingüísticas são importantes, por exemplo, porque implicaram na hora de conseguir encontrar informantes dispostos a participar. Em Itajuba, parte sul de Barra Velha, não encontramos pessoas com tempo disponível para colaborar com a pesquisa. Em Piçarras, apesar de participar com cinco informantes (1AI, 2AI, 2BI, 6BI e 9CI), a mesma dificuldade foi sentida. O trabalho, as ocupações diárias, e até mesmo a desconfiança em relação a uma estranha, foram maiores nessas duas localidades.

Nas áreas rurais e mais afastadas de Penha foi mais fácil conseguir colaboradores. Afinal, “prosear é sempre bom”, segundo o informante 2CI, morador de Santa Lídia - um dos bairros menos urbanizados da cidade.

Em São Francisco do Sul também houve uma dificuldade maior para encontrar informantes, que mais se encaixassem no perfil, no centro da cidade. Apenas 3B e 8C têm residência no Centro Histórico. A maioria dos moradores da região central, que fica bem próxima ao porto, são provenientes de outras localidades de Santa Catarina, principalmente Joinville e Jaraguá do Sul, duas grandes cidades vizinhas.

Acreditamos que o sucesso de um trabalho de campo está na capacidade do pesquisador de enfrentar dificuldades e novas situações. Além disso, ele precisa dominar um grande leque de conhecimentos. A Sociolingüística, a Dialetologia e a Lingüística Histórica são essenciais para esse tipo de trabalho. Porém, quando se unem outras áreas de conhecimento como a Análise da 
Conversação e a Argumentação, como foi visto brevemente ${ }^{161}$, podemos tornar a visão do pesquisador e sua capacidade crítica e de análise ainda maior.

O Centro Histórico da cidade de São Francisco do Sul guarda uma forte influência açoriana na arquitetura, segundo a Secretaria Municipal de Turismo do município. Diferentemente da antiga região de Itapocorói, onde os traços arquitetônicos considerados açorianos são dificilmente encontrados: as armações não existem mais, as construções da época da chegada dos açorianos, com exceção da Igreja de Itapocorói, também não ${ }^{162}$. A presença de museus e festas típicas açorianas, assim como material bibliográfico é mais abundante em São Francisco do Sul também.

Sendo assim, no primeiro momento da pesquisa, não foi difícil imaginar que os traços típicos da fala açoriana, citados por FURLAN (1989), estivessem mais presentes em São Francisco do Sul. Porém, no estudo dos corpora encontramos uma situação oposta. As características citadas como típicas da variante açoriana catarinense são encontradas em proporção bem menor em São Francisco do Sul do que na antiga região de Itapocorói, como observamos nas análises lingüísticas, principalmente em relação à fonética.

Há algumas hipóteses para tal fato. Primeiramente, se for considerado que São Francisco do Sul é uma cidade portuária e mais industrializada que as que compõem a antiga região de Itapocorói, a circulação de pessoas e o acesso à educação formal é maior, por isso, houve um apagamento mais acelerado dos traços considerados açorianos. A influência açoriana pode não ter sido tão forte como se supõe, então, não haveria razão para que ela deixasse marcas tão evidentes na fala da região. Ou então, seria originalmente um falar vicentista?

“Em Santa Catarina, o mais importante subfalar de origem portuguesa está na região norte catarinense, com epicentro na cidade de São Francisco do Sul. Um subfalar que podemos denominar de falar francisquense. [...] Acreditamos que este falar seja proveniente dos vicentistas que inicialmente colonizaram São Francisco do Sul, daí a acentuada igualdade lingüística entre São Francisco Xavier do Sul e as demais localidades litorâneas de São Paulo, antiga São Vicente. [...] Seria um falar vicentista? Neste caso não seria

\footnotetext{
${ }^{161}$ Parte 2, TRABALHO DE CAMPO.

${ }^{162}$ Há uma discussão se realmente a arquitetura do Centro Histórico de São Francisco do Sul é açoriana. Eliane Veras de Veiga, professora da Unisul, questiona essa influência: “Diariamente, os meios de comunicação multiplicam a idéia - ao nosso ver equivocada - de uma arquitetura colonial herdada dos açorianos, intitulando a nossa arquitetura colonial luso-brasileira como arquitetura açoriana! Nosso objetivo é redirecionar esta idéia, demonstrando que a arquitetura que encontramos em nossos núcleos históricos é uma herança muito mais lusitana do que açoriana." GAZETA MERCANTIL DE SANTA CATARINA, Arquitetura luso-brasileira ou açoriana? Caderno D, 22/08/01, p.2.
} 
este sotaque que sobe até São Paulo e sim desce de São Paulo até a região de São Francisco." (CORREA, 2000: 48)

A religião foi um dos quesitos perguntados aos informantes. Os informantes evangélico alegaram não manter contato com meios de comunicação de massa, não possuindo em casa rádio ou televisão ${ }^{163}$. No começo do desenvolvimento dessa pesquisa, pensava-se que o fator religião, pelo exposto acima, seria fundamental para a manutenção dos traços lingüísticos considerados açorianos.

Se o isolamento em relação aos meios de comunicação de massa existe, o contato entre esses informantes e outras variantes mais padronizadas também: ou por meio de seus próprios filhos e netos, no local de trabalho ou na rua. Com a análise dos dados, foi possível perceber que a religião não é um elemento motivador da permanência dos traços apontados por FURLAN (1989). Eles estão presentes geralmente nos informantes mais velhos, independentemente da religião.

Todos os informantes da faixa $\mathbf{A}$ estão freqüentando a escola, com exceção de $\mathbf{9 A}$, que parou os estudos na $8^{a}$ série. Esse é o fato que separa a faixa $\mathbf{A}$ das faixas $\mathbf{B}$ e $\mathbf{C}$. Na faixas $\mathbf{B}$ e $\mathbf{C}$, temos a seguinte distribuição: sem educação formal 9BI, 1CI, 5CI, 6CI, 7CI, 9CI, 3C, 6C e 9C; com Ensino Fundamental incompleto 1BI, 6BI, 7BI, 10BI, 2CI, 4CI, 8CI, 10CI, 1B, 5B, 6B, 7B, 8B, 9B, 10B, 1C, 2C, 4C, 5C, 7C e 10C; com Ensino Fundamental completo 5BI, 8BI; com Ensino Médio completo 2BI, 4BI, 3CI, 2B, 8C; cursando Nível Superior 3BI e com Nível Superior completo 3B, $\mathbf{4 B}$.

A faixa $\mathbf{A}^{\mathbf{1 6 4}}$ é aquela que apresentou os resultados mais homogêneos em relação aos aspectos fonéticos, lexicais e morfossintáticos, juntamente com os informantes 2BI, 3BI, 4BI, 2B, 3B, 4B e 9C (que possuem mais escolarização que a média dos informantes). Tal fato, que aproxima a fala desses informantes aos usos mais característicos do português do Brasil, parece estar diretamente ligado à escolarização. Com exceção do informante 3CI, que apesar de ter educação formal, aproxima-se das realizações dos outros falantes da faixa $\mathbf{C}$, principalmente nos aspectos fonéticos.

\footnotetext{
${ }^{163}$ Anexo 1.

${ }^{164}$ Com exceção de 3AI. Informante criado pela avó (1C1).
} 
Os traços fonéticos considerados como típicos da fala açoriana estão presentes, em sua maioria, nos informantes da faixa $\mathbf{C}^{165}$. É também na faixa $\mathbf{C}$ em que encontramos o maior número de formas em concorrência.

Um ponto relevante em relação aos dados fonéticos, é que, muitas vezes, as características apresentadas por um falante no questionário lingüístico não conferem com as características apresentadas por esse mesmo informante em sua fala espontânea. Porém, isso não significa que uma dessas formas de obtenção de dados seja superior ou inferior: tanto o questionário lingüístico como a gravação da fala espontânea são, em realidade, métodos que se complementam. Enquanto, por meio do questionário lingüístico é possível avaliar pontos fonéticos específicos, na fala espontânea é possível ver o contexto dessas realizações e se há ou não exceções.

No questionário lingüístico, em sua parte lexical, as palavras que se referiam a objetos como "um tipo de violino feito em casa" (rabeca ou rebeca - pergunta 13) ou "um outro objeto que se usa

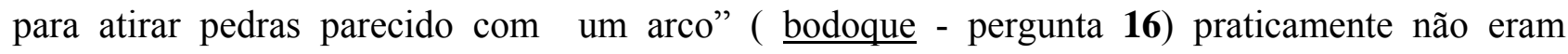
conhecidas pelos informantes da faixa $\mathbf{A}$, assim como a palavra que se referia "àquele tipo de ave que grita tô fraco, tô fraco" (angolista - pergunta 5). Tais objetos e a ave são desconhecidos por esses informantes por não fazerem mais parte da realidade que os cerca.

Entre todo o léxico levantado nas gravações espontâneas e no questionário lingüístico, algumas palavras são reconhecidas como tipicamente catarinenses: bernúncia, fachilete e peca.

Outras aparecem como típicas de outra região ou são arcaísmos. Como palavra típica de outra região, podemos citar a forma, bem conhecida na região de Itapocorói, angolista, que, de acordo com Taunay (1914) é um termo encontrado em certas regiões do Estado de São Paulo para designar a galinha-d'angola.

Como evidentes arcaísmos, por exemplo: apaixonado, baleeira, bareja, pelado e trovoada. Todas essas realizações, com exceção de bareja (a forma mais comum em todas as faixas etárias de Itapocorói, mesmo naqueles que possuem escolarização), só foram encontradas na faixa $\mathbf{C}$, o que demonstra que essas formas tendem a desaparecer com o tempo.

Entretanto, algumas formas usadas não foram encontradas nos dicionários e nas obras pesquisadas com o sentido que foram empregadas pelos informantes: bicha foguinha, bicha rata e bicho pinto (taturana), descascadeira de camarão (pessoa que trabalha na limpeza do camarão), grandeúva (galinha d'angola) imbira (taturana), ㅆniço (diabo), larva peluda (taturana), liquinho

\footnotetext{
${ }^{165}$ Parte 3, Análise Fonética.
} 
(candeia), lucrécia (taturana), pererenga (diabo), postura do boi (pedaço composto de uma parte da garganta, do fígado, do coração e do bofe), queima-queima (taturana).

Outro fato lingüístico que caracteriza a variante açoriana catarinense, segundo FURLAN (1989: 88), é o uso do pronome reto de segunda pessoa do singular tu acompanhado por verbo conjugado na segunda pessoa do singular. $\mathrm{O}$ tu está presente em todas as faixas etárias na região de Itapocorói, porém, geralmente acompanhado por verbo conjugado na terceira pessoa. Em São Francisco do Sul o pronome tu foi muito pouco utilizado ${ }^{166}$. Este é mais um ponto que distancia a fala das regiões pesquisadas da variante açoriana catarinense de FURLAN (1989).

Após a exposição dos resultados obtidos pela análise e pelo contexto histórico e social, não nos parece estranho que os dados levantados não reflitam mais, em muitos aspectos, os estudos feitos por FURLAN (1989) no litoral catarinense. O que nos chamou a atenção foi a velocidade dessa mudança, pois, do ponto de vista lingüístico, os dados apresentados por FURLAN (1989) podem ser considerados recentes, já que possuem menos de vinte anos. O que nos leva a pensar que, em pouco tempo, tais usos serão substituídos por outros mais típicos do português brasileiro geral.

O principal objetivo da aplicação do questionário valorativo foi conhecer como cada informante se posiciona em relação aos informantes de outras faixas etárias. Além disso, verificar se ele reconhece diferenças entre as falas regionais de Santa Catarina e Estados vizinhos.

Quase todos os informantes da faixa B e C fizeram considerações sobre o modo como os mais jovens falam (pergunta 2). A maioria tem uma visão negativa da fala dos mais jovens. Ao contrário, os mais jovens mantiveram uma postura mais neutra em suas respostas.

A maioria dos informantes tem consciência da variação dialetal dentro do próprio Estado de Santa Catarina (pergunta 5). Apesar de reconhecer que há diferenças, eles não souberam explicar o porquê dessa variação dialetal. Quanto aos exemplos dados, a impressão fonética e prosódica prevalece sobre a diferença lexical da variante.

A maioria dos informantes também tem consciência da variação dialetal em relação aos outros Estados que formam a região Sul do Brasil (pergunta 6). Novamente, o aspecto fonético e prosódico foram usados como exemplos. A exemplificação foi mais diversificada do que entre cidades do mesmo Estado, o que nos faz pensar que a separação política de Estados provoca uma maior intensidade no julgamento das diferenças.

\footnotetext{
${ }^{166}$ Parte 3, capítulo 3.
} 
Os exemplos dados para a fala gaúcha revelam menor conhecimento dessa variante do que com relação ao falar paranaense. Em vez de se fazer alusões à fonética ou à prosódia, muitos mencionaram onomatopéias e aspectos extralingüísticos.

Uma hipótese para explicar essa diferença na exemplificação em relação aos dois Estados vizinhos, seria pelo contato maior que há entre os moradores das localidades estudadas (que ficam no Norte de Santa Catarina) e os paranaenses, que freqüentemente passam as férias nas praias da região. 


\section{GLOSSÁRIO}

As definições foram dadas pela própria pesquisadora, baseadas na fala dos informantes. Mesmo que mais de um informante tenha utilizado o item lexical ou expressão, é fornecido apenas um exemplo, retirado do informante que está marcado em negrito. Nos casos em que há significações distintas para um mesmo item lexical, cada uso estará em uma entrada. Para facilitar a leitura, as transcrições fonéticas não aparecem no glossário.

\section{Siglas utilizadas:}

P. = Pasquim;

Q.L. = Questionário Lingüístico;

Q.V. = Questionário Valorativo.

\section{Exemplos:}

abelhuda $=$ criança sapeca (Q.L. -20$)$.

\section{questionário Lingüístico número da pergunta do questionário}

tanso $=$ bobo (P. p.383)

\section{pasquim número da página}

\section{A}

abelhuda $=$ criança sapeca (Q.L. -20$)$.

acavar = cavar (6C): tem que acavar muito ainda "... porque tanto era largo como era fundo... acordeão = instrumento de cordas $(2 \mathrm{C})$ : ai sai com... um violão... um acordeão...

adepois = depois (6C): até um certo... dava pra cavar... aí adepois já... quase não dá pa jogar areia pra cima né?

aeloforte $=$ holofote $(2 \mathrm{BI})$ : pegamo um aeloforte...

agardecer $=$ agradecer $(10 \mathrm{C})$ : o pessoar agardeciam né?

aguaceiro(a) = chuva forte (Q.L. - 1) 
aguaceiro de chuva = chuva muito forte (5CI): aí veio um aguaceiro de chuva que choveu vinte minuto...

AID = AIDS (5CI, 9B): cura da AID ... do câncer e também alimpa o pulmão...

aipim = mandioca (8BI, ICI): nosso café da manhã era aipim cozido com café...

alagar-se = naufragar (7C): nós se alagamo né?... dai passamo mal né?... ficamo o dia todo na água...

alembrar = lembrar (9B): me alembro que ele contava que vinha de carroça...

alevantar = levantar (9C): o relâmpago caiu bem assim perto de nós na água... se alevantou um tantinho de água pra cima...

alimpar = limpar (5CI): cura da AID... do câncer e também alimpa o pulmão...

almanzém = armazém (2CI): começaram a colocar almanzém né?

aluguer $=$ aluguel (6B): também tenho aluguer de... de caiaque no verão...

à moda caralho $=$ de qualquer jeito (5BI): fomos numa barraca daquela... cheia de carne pendurada... tudo assim à moda caralho... não é verdade?

angola $=$ galinha d’angola (Q.L. - 5)

angolista = galinha d’angola (Q.L. - 5) e (3AI): a angolista é a galinha d'angola ...

apá = bodoque (Q.L. - 16)

apaixonado $=$ entristecido, magoado, triste (Q.V. - 1) e (5CI): o Deca da Leonida ficou muito apaixonado... neste enterro da cobra não foi inconvidado...

apovoado $=$ povoado $(10 \mathrm{BI})$ : aqueles comadre... apovoado que... os veranista vieram pra praia... compraram a praia...

arapuca $=$ armadilha para pássaros $(8 \mathrm{BI})$ : nós fazia ... armava arapuca... armava laço...

arco $=$ álcool $(10 \mathrm{CI}):$ lá tinha uma qualidade de..... carrapato porva.... que enchia o braço e a perna da gente ( ) que tinha que raspar com a faca... e botar arco pra matar...

areão = local com muita areia, só areia (2C): aqui era só um areão...

arguém = alguém (10C): derrubava arguém...

argum $=$ algum $(10 \mathrm{~B}, 1 \mathrm{C}, 3 \mathrm{C}, 4 \mathrm{C}, 9 \mathrm{C})$ : argum chefe de casa $\ldots$ que arrecebe bem sabe?... arrecebe bem o pessoal...

arreceber $=$ receber $(3 \mathrm{C})$ : argum chefe de casa... que arrecebe bem sabe?... arrecebe bem o pessoal...

arrepiante de cabelo = assustador (3BI): no verão a gente não aprontou muito... só um pouquinho ((risos)).. O que que a gente fez mais de arrepiante... arrepiante... de cabelo... 
arriar = abaixar (P. p.384) e (9CI): eu arriei o pezinho dela na terra $\ldots$

arriar $=$ desistir $(6 \mathrm{CI}):$ depois mo marido arriou...

artar $=$ altar (7CI): na hora da missa o carro entrou lá no artar...

artesanado $=$ artesanato (9C): é... era bem arte/artesanado... pescaria de tainha...

artura $=$ altura $(5 \mathrm{C}):$ quarenta cinqüenta metro de artura

asfarto $=$ asfalto $(10 \mathrm{C})$ : porque a Petrobrás asfartou daí...

atentada/o = ruim, assombrado (Q.L. - 20) (6C): o lugar assim atentado... ninguém passava lá...

atentado = assombrado (6C): o lugar assim atentado... ninguém passava lá...

atentar $=$ atormentar $(6 \mathrm{C}):$ é porque ele... de certo ficou perdido... atentando né?... e aí vinha atentar os outro...

atracar $=$ lugar em que param os navios no porto (6B): acho que atraca... comporta lá... oitos navios né?... cada... cada atracar né?

automove $=$ automóvel $(7 \mathrm{CI}):$ hoje em dia a gente tem medo de ir até de até de automove...

avoar $=$ voar (1A): eu queria ser o Batman porque eu gosto de avoar...

B

bague $=$ bagre $(2 \mathrm{C})$ : a safa do bague...

baixaria = ação desagradável (4BI): a L. não vai porque ali é uma baixaria...

balea $=$ baleia $(\mathbf{1 B}, 10 \mathrm{~B})$ : Praia Grande sempre aparece balea...

baleeira $=$ barco pequeno (Q.L. - 4)

bambule $=$ bambu (Q.L. -3$)$

banalzinho = bananal (diminutivo) (1C1): lá tinha muita banana ... nós tinha banalzinho...

bancarrota = falência (5C): e aonde existe judeu a coisa vai... só vai a bancarrota...

bandono = abandono (9B): é uma casa que o governo fez pros pescado... mais tá tudo... bandonado aí...

bão $=(8 \mathrm{~B}, 6 \mathrm{C})$ : a hora que voltar tá bão... não liga né?

baraço da batata = ramos do pé de batata (5CI): é pa ela não comer o baraço da batata...

bareja $=$ varejeira (Q.L. -6$)$

barejeira $=$ varejeira (Q.L. -6$)$

barra $=$ entrada do porto (5B): a maré vazante o levou até fora da barra...

barrer $=$ varrer $(\mathrm{Q} . \mathrm{V} .-3)$ 
bassoura $=$ vassoura $(\mathrm{Q} . \mathrm{V} .-3)$

bat = jogo de taco (2AI): jogar bat também... que eu jogo assim né?

bateira (inha) $=$ barco pequeno (Q.L. - 4) e (2CI, 10A, 5C): é... bateira ou canoa... mais é canoa que nós usa né?...

bater $=$ chegar $(2 \mathrm{C})$ : daqui ele foi bater lá em Itajaí...

batiria = bateria (2C): a batiria dele pifou ... então ele não podia vim...

Batuba = Ubatuba (7B, 10B, 1C): uma vez eu era pequena eu lembro que eu fui... ali no Batuba né?

bebante $=$ barbante $(5 \mathrm{CI})$ : pegou dezoito lagarta e amarrou num bebante...

bebo = bêbado (2BI): debulhou ... né?... chapadinho.. chapadinho... bebo bebo bebo bebo...

bebum $=$ bêbado $(P \cdot$ p.382)

bem massa $=$ legal (2AI): brincar de assustar a casa assim... bem massa...

bença = bênção (7AI): tinha que dar a bença...

bernúncia $^{167}$ = uma das personagens do Boi de Mamão (6C, 8C): no Boi de Mamão... tem vários bicho né?... tinha a bernúncia...

bertrano $=$ beltrano (Q.V. - 3)

betara $=$ qualquer peixe pequeno pescado em rede de malha sete (2B, 9B): betara... peixinho pequeno assim...

bicicreta $=$ bicicleta (4A): eu pego a minha bicicreta e vou...

bicha $=$ taturana (Q.L. -7$)$

bicha cabeluda $=$ taturana (Q.L. -7$)$

bicha foguinha $=$ taturana (Q.L. -7$)$

bicha rata $=$ taturana (Q.L. -7$)$

bicharia $=$ bicharada $(10 \mathrm{~B})$ : dançar as coisas... bicharia... cavalo-marinho... onça .. tudo isso tinha...

bicho = demônio (Q.L. - 18)

bicho pinto $=$ taturana (Q.L. -7$)$

bidê $=$ criado mudo (Q.V. - 3)

bidoque $=$ arco de madeira para atirar pedras (Q.L. -16$)$

167 “A bernúncia - animal com o corpo de dragão chinês, de boca grande e móvel, que representa a figura do bichopapão. Assim, procura na brincadeira engolir as criancinhas, que ficam assustadas. No norte do Estado recebe a denominação de barão. (FARIAS, 2002: 209) 
biju $=$ produto retirado da farinha de mandioca (8CI): a gente faz o biju...cuscu... tapioca ...

blindex $=$ tipo de vidro usado em fachada (P. p.381)

bira $=$ taturana (Q.L. -7$)$

biririm bililim = blá blá blá (3BI): cada um com um... e biririm bililim... e daqui a pouco:: a:.... dois relacionamentos se acabam...

bobiça $=$ bobeira (P. p. 385)

boca $[0]=$ pequeno buraco no chão para jogar bolinha de gude: (3AI) peca é um monte de bolinha... tem que acertar na boca...

boceta do joelho $=$ patela $(\mathrm{Q} . \mathrm{V} .-3)$

bodega $=$ bar (5BI): chama o dono da bodega aí ninguém paga merda nenhuma

bodoque $=$ arco de madeira para atirar pedras (Q.L. -18$)$ e $(2 \mathrm{CI})$ : matava passarinho com bodoque...

bofe = estômago (8BI): a postura do boi vinha o pedaço da garganta do boi... um pedaço do figo... um pedaço do coração... um pedaço do bofe...

Boi de Mamão ${ }^{\mathbf{1 6 8}}$ = festa tradicional no litoral catarinense (5AI, 5BI, 3CI, 10CI, 6C): no Boi de Mamão... tem vários bicho né?... tinha a bernúncia...

bombona $=$ frasco bojudo (6B): então carrega bombona... leva penca de marisco sabe?...

bombona $=$ nome da carroceria do caminhão tanque (5BI): o líquido dentro duma bombona você sabe que chacoalha dentro né?

brabo = bravo (P. p.385) e (4A): dai ela ficou braba porque ela não gosta de bagunça...

bodogue $=$ arco de madeira para atirar pedras (Q.L. - 18)

bugio = espécie de macaco (10CI): e na Serra do Cardoso tivemo quatro dia e quatro noite no mato... lá matamo... tatu... bugio...

bujão = botijão (5CI): veio um negócio assim pelo ar... (acima) de uns (doze) metro de altura... tamanho dum bujão...

\footnotetext{
168 “A manifestação do boi-de-mamão é um folguedo popularizado em todo o litoral catarinense, apresentando variações microrregionais, tanto na coreografia, quanto nas peças que fazem parte da brincadeira. [...] A origem deste folguedo é polêmica. Alguns acreditam ser de origem africana. Outros, como o autor, acreditam na origem ibérica, ligado à manifestação popular de aprendizagem da tourada. Inclusive é possível que tenha sido introduzido pelos açorianos no Norte-Nordeste, onde é conhecido por boi-bumbá ou bumba-meu-boi, já que os açorianos, como em Santa Catarina, se fixaram na região no Século XVII e XVIII. A cultura de base açoriana no Brasil é sem dúvida a que mais apresenta esta forte relação entre o boi e o homem." (FARIAS, 2002: 208-9)
} 
bumbu $=$ bambu $($ Q.L. -3$)$
butuca $=$ varejeira (Q.L. -7$)$

C

cabar = acabar (5AI): caba a aula e venho pra cá...

cabreiro = preocupado (8B): a gente fica meio cabreiro por exemplo... eu saí agora na temporada... isso na:: no verão passado agora aí... eu fiquei três dias a deriva aí a fora né?

cacatumba = catacumba $(5 \mathrm{CI})$ : neste enterro da cobra não foi inonvidado... ia dar a cacatumba agora ficou parado...

caçarola $=$ panela $(\mathrm{Q} . \mathrm{V} .-3)$

caíco $=$ pequeno barco (Q.L. - 4)

cambacinha $=$ vasilha, pequeno recipiente (9C): cambacinha de peixe...

cambira $=$ seco e salgado (refere-se ao peixe) (6C): tainha escalada... feito cambira...

cambuca $=$ vasilha (2B): uma cambuquinha ... com assim... um pouquinho de farinha é água...

camininho $=$ diminutivo de caminho (9CI): e aquele camininho... no meio... né?... só com carrinho de boi né?

cance $=$ câncer $(9 \mathrm{~B}):$ a espada por exemplo... dá o cance... né?...

candeeiro = lamparina (8CI): a gente não tinha lui... vivia no escuro... co candeeiro na mão...

candeia = lamparina (Q.L. -10$)$

caniço $=$ bambu (Q.L. - 3)

cara $=$ homem (2AI, 9AI, 2CI, 6CI, 2A): dai o cara chegou... abriu a porta ...

carambota $=$ cambalhota $(7 \mathrm{AI})$ : ai tem um avião lá... o avião vira carambota...

carcular = calcular (10C): isso aqui em época de verão... é carculado assim... certos dias assim... pa quinhentas mil pessoa...

carga d' água = chuva forte (Q.L. - 26)

carma $=$ calma $(\mathbf{1 0 B}, 10 \mathrm{C}):$ carma $\ldots$ carma $\ldots$ que... sempre... às vez quando acontece... sempre tem um:: um pescador daqui que vai lá... socorre...

carrada $=$ muitos $(\mathbf{6 C I}, 10 \mathrm{CI}):$ NETO BISNETO... tenho uma carrada...

carreira $=$ deslocar-se rápido $(P . p .379)$

casário = casario (2C): aonde tá os/esses casário antigo... tem que ser como tá...

cascalhinho = dinheiro (10B): sobra mais um cascalhinho... no verão... 
casqueira $=$ sambaqui $(10 \mathrm{C}):$ a prefeitura começou a... a por um material... uma casca de casqueira... na época podia né?...

casqueira = conjunto de cascas (1C1): na cama só tinha casqueira de banana...

catete $=$ espécie de porco do mato (10CI): matei catete... matei oito tatu...

carreiro = trilha (10BI): por um carreiro lá... eles contrabandeavam uísque...

carrinho de choque $=$ carrinho de batida (7AI): tem carrinho de choque... tem barco Viking...

cascalhinho = dinheiro (10B): vai pescar um pouco de pescada aqui nesse mar pra se vender pra eles... então... sobra mais um cascalhinho... no verão...

cavaquinho $=$ tipo de violão antigo (Q.L. - 13)

cetla $=$ estilingue (Q.L. -15$)$

cetra $=$ bodoque, estilingue (Q.L. - 15 e 16)

chiffon $=$ tipo de tecido (náilon, raiom ou gaze de seda) (8B): essa... tecido de chiffon... então de linha...

coca $=$ cócoras (Q.L. - 23) e (5CI): tu pensa que eu não te vi de coca dento do pasto...

cocho $=$ recipiente $(2 \mathrm{CI})$ : aí pegava no cocho a massa e botava ali...

cócora $=$ cócoras (Q.L. -23$)$

coça $=$ surra (7AI, 10B): o pau comia... era uma coça que levava...

cola $=$ rabo (5BI): o baiano pegou gato pelo pescoço... pela cola... pela cola né?...

CONATRAN = Congresso Nacional de Trânsito (3B): IPHAN ... e o... e o... ETRAN... CONATRAN se não me engano...

conformo = conforme $(2 \mathrm{C})$ : arrumar conforme o estilo dela... conformo tá ali né?...

cordéu $=$ barbante (Q.L. -12$)$

corisco $=$ alguém muito feio (Q.L. -21$)$

coroca $=$ cócoras (Q.L. -23$)$

costamento = acostamento (7AI): meu pai não vinha. tinha que jogar po costamento...

costão = parede íngreme que circunda trechos da orla (4C): foi no costão passear...

crioulo = negro (8AI): negro não... ((risos)) veio assim um crioulo...

croque $=$ cócoras (Q.L. -23$)$

crosena $=$ querosene $(9 \mathrm{CI})$ : não tinha luz naquele tempo... usava crosena né?...

CTG = centro de tradições gaúchas (1B): pa bagunça aí tem... tem o CTG...

cuca $=$ espécie de torta de banana de origem alemã (8BI): cuca é feita com:... é uma... é massa doce... ai é fei / é colocada farofa... é colocada às veze banana... 
curto = culto $(9 \mathrm{CI}):$ lá... no curto... eles oraram...

cuscu $=$ produto retirado da farinha de mandioca (8CI): a gente faz o biju...cuscu... tapioca ...

custoso = difícil (10B): hoje em dia já é custoso o filho da gente pro pai...

\section{D}

Dança do Vilão $^{\mathbf{1 6 9}}$ = dança em se utilizam bastões (2B, 4B, 5B): a Dança do Vilão também né? dar a bença (ão) = pedir a bênção (8BI, 10B): Deus o livre que eu não pegasse a mão dela pra dá a bença...

de a pé = a pé (2CI): era de a pé... antigamente... eu era criança né?

debulhar $=$ exagerar na bebida (2BI): debulhou... né?... chapadinho.. chapadinho... bebo bebo bebo bebo...

deixar em meio = deixar pela metade (6CI): quando ele morreu ele deixou em meio...

demo $=\operatorname{diabo}($ Q.L. -18$)$

dento = dentro (2CI): aí pegava no cocho a massa e botava ali dento...

descascadeira de camarão = pessoa que trabalha no processamento do camarão (8BI): trabalhei nas salga de camarão... de descascar camarão... era descascadeira de camarão...

descansar um pingo = descansar um pouco (7BI): vê se você não descansasse um pingo ainda?...

difíci = difícil (1C): naquele tempo ainda difíci...

dificultoso $=$ difícil $(7 \mathrm{C})$ : era dificultoso... pra gente aqui... hoje em dia tá melhor né?

dito = mencionado (4BI): e o dito boi vinha ( )... vinha em cima dele...

desacorçoado $=$ triste $(\mathrm{Q} . \mathrm{V} .-1)$

descarço = descalço (10B): veste um calção aí e sai descarço...

Deuse $=$ Deus (9CI): Deuse ressuscitou minha filha ... né?

dia hoje $=$ um pouco antes (Q.V. - 3)

169 “A cidade de São Francisco do Sul é a única no Brasil onde se pratica a Dança do Vilão, e isto se deve à delicadeza do senhor Romário Matias que, com integrantes da família e amigos, manteve a chama acesa desta manifestação cultural singular. A cada final de colheita, os escravos, com a intenção de extrair o maravilhoso da coisa imediata e visivel, e que já haviam assimilado fácil os dengos e os movimentos da Dança do Vilão, festejam a produtividade se apresentando no terreiro das Casas Grandes Senhoriais.” A NOTÍCIA (SC), Danças de São Chico: um espetáculo ancestral. ANespecial, 18/04/96, p.8. 
egreja = igreja (6BI): quando eu voltei pra egreja...

eluir = evoluir (7C): modifica muito né?... eluíu né?... muito melhor do que era antigamente...

embarcado = pescador (10BI): meu pai era embarcado...

emborsar $=$ embolsar (9B): só querem saber de... de emborsar o dinheiro...

encharcado de água $=$ molhado (3BI): tava encharcada de água...

entonce $=$ então (1C1): entonce pra nós não era um sacrifício era um prazer...

eroporto $=$ aeroporto $(1 \mathrm{~A})$ : vi o eroporto... vi lá perto...

escalação = ato de escalar, escalada (3BI): tiveram que fazer uma escalação...

escalada $=$ limpo e salgado (referente ao peixe) (6C): tainha escalada... feito cambira ...

espada $($ feminino $)=$ tipo de peixe $(9 \mathrm{~B})$ : a espada por exemplo... dá o cânce... né?

estar só na pingola $=$ estar bem no fim (Q.V. - 3)

estilete $=$ estilingue (Q.L. -15$)$

estivador $=$ trabalhador portuário que trabalha no setor de cargas (7C): tinha um estivador... ali né?

ETRAN = Equipe de Trânsito Aduaneiro (3B): IPHAN... e o... e o... ETRAN... CONATRAN se não me engano...

expelir = exorcizar, mandar embora (5CI): eu dobrei joelho e expeli o Satanás...

expricar = explicar (4A): o professor que dá aula pra gente ele exprica... quantas vezes precisar...

$\mathbf{F}$

faceiro = estar bem (5BI): bem faceiro... tomando meu banho...

facínora = malvado (8C): Francisque Domingues... que era intendente aqui mas era um facínora... $n e ́ ?$

fachelaite $=$ lanterna (Q.L. -11$)$

fachilete $=$ lanterna (Q.L. -11$)$

facho elétrico $=$ lanterna (Q.L. -11$)$

fandango $=\operatorname{dança~}^{170}$ (7CI, 5B): uns fandango pa São Gonçalo... todo cantando...

170 "Dança rápida, cantada e sapateada, fortemente ritmada. Tem origem espanhola. Também aparece no meio rural português, sem canto. É um baile popular apresentado ao som da viola ou sanfona." (AURÉLIO: 1999) 
fato $=$ dobradinha $(8 \mathrm{BI})$ : ele vendia fato... que uns chamam de bucho... outros de dobradinha... mas pra nós era o fato... sabe?...

fechelaite = lanterna (Q.L. -11$)$

ferrobote $=$ ferryboat $(6 \mathrm{C})$ : ali onde tem o ferrobote era tudo do meu avô...

fervo = extremamente movimentado (6B): é muita gente isso aqui... fica um fervo de...

Festa de Nossa Senhora do Rosário = festa em homenagem à santa católica com o mesmo nome (3CI): tínhamos a festa de Nossa Senhora do Rosário... na Penha... ela era feita só pros preto...

Festa de São Gonçalo $=$ festa em homenagem ao santo católico com o mesmo nome (7CI, 7B): é tem São Gonçalo também... festa de São Gonçalo... quando a gente prometia quando dava uma dor na perna... prometia um baile pra São Gonçalo...

Festa de São Sebastião ${ }^{171}=$ festa em homenagem ao santo católico com o mesmo nome (3CI): é $a$ festa de São Sebastião... dia vinte de janeiro...

Festa do Divino = festa em comemoração ao Espírito Santo (10BI, 7CI, 1C, 4C): aí tem na Penha a festa do Divino Espírito Santo...

Festilha $=$ festa anual que celebra as tradições de São Francisco do Sul (5A, 1B, 2B, 4B, 8C): $a$ Festilha é:: é ali no Centro Histórico... na frente do Centro Histórico...

ficar aquela coisarada $=$ várias ações reunidas (3BI): ele olha pra mim eu olho pra ele... ele olha pra mim... e fica aquela coisarada...

ficar com pensão = ficar preocupado (Q.V. - 3)

ficar puta da cara = ficar com raiva, com bronca (3BI): vocês tavam puta da cara comigo...

ficar rolando $=$ ficar um tempo saindo com alguém (3BI): acabou que o G. ficou rolando até quando?

figo = fígado (8BI, 7CI): a postura do boi vinha o pedaço da garganta do boi... um pedaço do figo... um pedaço do coração... um pedaço do bofe...

filé = barbante (Q.L. - 12)

fio $=$ filho (3C): são nove fio... nove vivo e um morto...

Floripa $=$ Florianópolis (2AI, 10AI): eu fui numa viagem com colégio até Floripa...

folheteria $=$ quantidade grande de folhetos (3B): mas é uma cidade carente em muitos aspecto... não só dá folheteria pra pessoa...

fora $=\operatorname{mar}(6 \mathrm{~B}, 9 \mathrm{~B})$ : o pescador sai pra fora... quatro horas da manhã né?

\footnotetext{
171 "Santo milagroso, curandeiro de pestes e doenças no corpo, inclusive de animais. É saudado pelos foliões com a cantoria/refrão, que se sucede a cada verso tirado de improviso." (FARIAS, 2002: 184).
} 
fornear $=$ torrar mandioca $(2 \mathrm{CI}, 5 \mathrm{CI}, \mathbf{1 0 C I})$ : cevava mandioca na mão... né?... fornear do rodo... assim de rodo... né?

forro de cama $=$ lençol (Q.V. - 3)

frecha $=$ flecha $(\mathrm{Q} . \mathrm{L} .-16)$

fumaça $=$ trem $(5 \mathrm{CI})$ : depois botou nas costa e amarrou na fumaça...

funda = estilingue (Q. L. - 15) e (7CI): deixa eu brincar um pouco com a tua funda que tu brinca um pouco com meu carrinho...

futuro de amanhã = futuro (9A): a gente não sabe qual que é o futuro de amanhã...

G

galhambote $=$ cambalhota (2AI): eu fico mais assim na água né? dou galhambote...

gervão $=$ taturana (Q.L. - 7)

gerivau - tipo de barco pequeno (9B): o gerivau mata o camarão tudo...

GPS = aparelho de localização por satélite (2C): dia de serração assim... tem o GPR... o GPS né?

grado = graúdo $(1 \mathrm{C} 1)$ : o Q. só vendia as banana grada...

gradecer $=$ agradecer $(9 \mathrm{C})$ : gradecido a oferta que eles dão...

grandeúva $=$ galinha d`angola (Q.L. -5$)$

granizo $=$ chuva forte (Q.L. -1$)$

greja = igreja (9CI): uma e meia eu passo aqui pra ti levar na greja...

güentar $=$ agüentar (5C): foi que güentamos... só comendo bolachinha mel tal...

guri = menino (7AI, 2BI, 6BI, 8B, 3C): aquele guri deu um pulo...

guria $=$ garota $(6 \mathrm{AI}, 9 \mathrm{AI}, 3 \mathrm{~A}, 10 \mathrm{C})$ : ele e uma guria...

guriada $=$ garotada $(\mathbf{8 A}, 7 \mathrm{~B}, 8 \mathrm{~B})$ : dai a guriada não gosta $\ldots$

$\mathbf{H}$

hipopoto = hipopótamo (4AI): tem.... hipopóto... essas coisas assim... tem vários bichinhos assim... hoe $=$ hoje $(10 \mathrm{C})$ : o povo de ho / hoe já não dá valor nisso... 
imbira $=$ taturana (Q.L. -7$)$

imperativa $=$ criança sapeca (Q.L. -20$)$

inconvidado $=$ convidado $(5 \mathrm{CI}):$ o Deca da Leonida ficou muito apaixonado... neste enterro da cobra não foi inconvidado...

industriar $=$ industrial $(10 \mathrm{C})$ : olha Joinville ... porque é uma cidade industriar...

industriária $=$ industrial $(10 \mathrm{C})$ : e São Francisco ela nunca foi uma cidade portuária... mas não industriária não... né?...

iniço = satanás (5CI): e aquilo que era o iniço eu não entendi que era ele... né?

ingaeiro = ingá (tipo de árvore) (5CI): batia em cima da folha do ingaeiro...

ingrês $=$ inglês $(4 \mathrm{~A})$ : também tem ingrês...

injerção = injeção (5CI): se a cobra morde alguém quero dar injerção...

IPHAN = Instituto do Patrimônio Histórico e Artístico Cultural (3B): IPHAN... e o $\ldots$ e $o \ldots$ ETRAN... CONATRAN se não me engano...

ir com a cara lá no fundo do mar e voltar = ficar com vergonha (3BI): eu vou com minha cara lá no fundo do mar e volto...

$\mathbf{J}$

japona $=$ jaqueta $(\mathrm{Q} . \mathrm{V} .-3)$

jia $=$ dia (9B): o pessoal hoje jia...

judar = ajudar (2A): dai os Power Rangers vão lá e judam eles...

juntar $=$ atropelar $(4 \mathrm{C})$ : porque senão o carro pode te juntar...

$\mathbf{L}$

laço $=$ armadilha para pássaros (8BI): armava arapuca $\ldots$ armava laço...

lagarta $=$ taturana (Q.L. -7$)$

lagartixa $=$ taturana (Q.L. -7$)$

lambada = palmada (7AI): o pai quase me matou de tanta lambada que me deu...

lambicar $=$ processo que transforma a cana-de-açúcar em cachaça (5CI): lambicar cachaça... 
lâmpada geambrada = lâmpada de iluminação noturna e portátil (2BI): uma lâmpada geambrada que nós temos pra fazer iluminação...

lamparina $=$ objeto usado para iluminação (Q.L. - 10) e (5CI): meu irmão correu com a lamparina na mão...

larva $=$ taturana (Q.L. -7$)$

larva peluda $=$ taturana (Q.L. -7$)$

lefante $=$ elefante (6AI): leão... girafa... lefante... todos os bichos assim que se pode imaginar...

leio = baraço (6B): dá um leio na rede...

lestado $=$ vento do leste (6B): vem de fora $\ldots$ Iestado...

lestás = vento do leste (6B): na época de lestás da muito... danifica muito...

levar ferro = dar-se mal (2B): dá uma zebra da temporada meio ruim... temporada chuvosa ... um ano chuvoso... então leva ferro...

liguento $=$ com muita liga, aderente (8B): era barro bem liguento...

liqueide $=$ válvula de controle (2B): chamam de... liqueide... uma válvula que... estourou manguote aquilo se fecha sozinha...

liquinho = lamparina (Q.L. - 10)

long line = cabo utilizado para prender as bombonas na maricultura (6B): é um... um "Iong line" que eles chamaram né?... amarra uma ponta de um lado... uma ponta... uma ponta de outro lado e:... coloca as bombona na corda e ali vai plantando... semente de marisco...

louco pirado = muito doido (7BI): ela tem que ficar em casa cuidando dos doido tudo... dois louco pirado e um sobrinho...

lucrécia $=$ taturana (Q.L. -7$)$

lui $=$ luz (8CI): a gente não tinha lui... vivia no escuro...

M

macambúzio $=$ triste $(\mathrm{Q} . \mathrm{V} .-1)$

machete $=$ tipo de violão antigo (Q.L. -13$)$

magoada $=$ ferimento que produz uma mancha arroxeada (Q.L. -8$)$

maior zona $=$ muito legal, muita bugunça $(10 \mathrm{AI})$ : a maior zona no ônibus...

mambu = bambu (Q.L. - 3) e (2CI): o tipitim é feito de mambu...

mandaruvá $=$ taturana (Q.L. -7$)$ 
mangote $=$ mangueira curta, geralmente de borracha vulcanizada (1B): com tempo ruim estoura um mangote...

marandová = taturana (Q.L. - 7)

mardade $=$ maldade $(10 \mathrm{C}):$ não tinha mardade naquilo...

mariscal $=$ local em que se encontra ou se cultiva mariscos (P. p.380)

maruá = pequeno animal (o informante não deu informações suficientes para caracterizá-lo) (2CI): tinha girafa... tinha:... como é que se diz... um maruá....

massa = legal (2AI, 7AI, 10AI, 10A): só no verão que tem aí um agito massa...

medonho $=$ alguém muito feio (Q.L. - 21)

mese $=$ mês (9B): esses que era os mese de se pa/de se parar do camarão né?

mijar = urinar (5BI): nem dentro pra mijar eu não entro...

mile $=$ mil $(10 \mathrm{C}):$ vira uma cidade de quinhentos mile habitante...

minhoca $=$ taturana (Q.L. -7$)$

mo $=$ meu (6CI): depois mo marido arriou...

mos $=$ meus (8CI): tive mos filho tudo aqui em casa...

molhe $[0]=$ porto de pedra (5C): poderia ter uma marina... aqui entrava no rio... fazia o molhe...

molho de orquídea [o]= buquê de orquídeas (1CI): ia pa Blumenau... com dois molho de orquídea... ia vender em Blumenau pra ajudar a criar meus filho...

molho de pedra $=$ conjunto de pedras (9B): um molho de pedra ali na:... na boca da Barra ali $o h: . .$.

monobóia $=$ base onde ocorre a descarga dos petroleiros

move $=$ móvel $(2 \mathrm{CI}, \mathbf{9 C I})$ : aí eu não tinha nada de move... comprei move usado e mobilhei a casa de novo...

mundícia = imundícia (5CI): "aqui na minha terra essa mundiça não passa"

$\mathbf{N}$

nalfabeto $=$ analfabeto $(9 \mathrm{~B}):$ os pescado... eram mais... nalfabeto...

nhanhá $=$ pronome de tratamento usado pelos escravos (6C): “nhanhá... dá mais um... mais um pedacinho de camarão?"

nhonhô $=$ pronome de tratamento usado pelos escravos (6C): "chama nhonhô pa ver se tá bão o buraco" 
ônibu = ônibus $(\mathbf{1 C I}, 1 \mathrm{C})$ : aí eu ia de manhã... com o primeiro... ônibu... que passava aqui sete hora...

oto = outro (9B): igual os oto né?...

otoridade $=$ autoridade $(3 \mathrm{C}):$ não é porque as otoridade $\ldots$ as otoridade aqui... da nossa cidade... trabalham muito bem sabe?...

оxa = ostra (9B): a ostra é muito bom pra dá... vontade né?... a oxa o marisco...

\section{$\mathbf{P}$}

pa mor de eu = para eu (6CI): pa mor de eu ir pa casa dela ...

paia = palha (2C): casa de madeira... de teia tinha bem pouco... mais era tudo paia...

paiol = lugar em que se guarda aquilo que se colheu (6C): paiol é um... tipo um quarto... cheio... tipo um quartão grande que tem...

Pão por Deus ${ }^{172}$ (Cristo) $=$ tradição de origem portuguesa (4B, 3C, 9C): oferecia aquele Pão por Deus... prum amigo... um namorado... mandava... era muito... assim... uma maneira muito carinhosa de expressar amizade... amor...

parelhar $(\mathrm{com})=$ ficar ao lado $(2 \mathrm{CI})$ : cortei adiante dele... parelhei... parelhei com ela...

pasquim $^{173}=$ versos satíricos e apócrifos $(10 \mathrm{CI})$ : o Q. que tem uns pasquim... muito verso...

Pastorinhas $=$ dança portuguesa em que participam somente mulheres (9C): eu participei das Pastorinhas... isso eu..... trinta ... trinta e nove... as Pastorinhas era... começo de janeiro... patota = grupo de amigos (5CI): senhor Ari da Nina também entrou na patota...

patrimônio história = patrimônio histórico (1C): aquela parte do centro ali... não... não tá muito... mudada não... por causa daqueles patrimônio história né?...

\footnotetext{
172 "Praticado pelos descendentes de açorianos como uma brincadeira popular, o pão-por-Deus era uma nova prova de amizade ou de amor em que se pedia uma prenda, presente, casamento, namoro etc.[...] A pessoa que recebia o coração pedindo um pão-por-Deus tinha o dever de retribuir com um presente. Este presente deveria chegar na mãos da pedinte no mês de dezembro, próximo ao dia de Natal.” (FARIAS, 2002: 227-9)

${ }^{173}$ Ver: Parte 1, Capítulo 2, item 2.3.3.
} 
Pau de fita ${ }^{174}=$ dança em que se trançam fitas (3CI, 4CI, 7CI, 10CI): o pau de fita... era tudo muito bonito..

pavio $=$ isqueiro $(\mathrm{Q} . \mathrm{V} .-3)$

pé de corticeira $=$ pé de cortiça $(8 \mathrm{~B})$ : ia no mato... arrancava um: um..... uma corticeira daquela... um pé de corticeira lá...

pé-de-vento $=$ vento muito forte $(5 \mathrm{CI})$ : parecia um pé de vento...

peca $[\mathrm{e}]=$ bolinha de gude (Q.L. - 14) e (3AI, 7AI, 8B): hoje a guriada sai... fica brincando de реса...

pecisar $=$ precisar $(9 \mathrm{~B})$ : eu até pecisava dá uma entrevista no Fantástico...

pegar = começar $(6 \mathrm{C})$ : ai o preto pegou a cavar...

pelado $=\operatorname{careca}($ Q.L. -9$)$

pelota $=$ estilingue $($ Q.L. -15$)$

penteadeira $=$ cômoda com espelho $(\mathrm{Q} . \mathrm{V} .-3)$

percisar $=$ precisar $(1 \mathrm{C}):$ o tanto que percisava $\ldots$ pra ir... pra fazer/cantar...

parecer $=$ aparecer $(7 \mathrm{C}):$ contava lenda que nesse rio parecia... um barquinho assim... do nada... trazendo um morto...

perarta $=$ peralta (Q.L. -20$)$

pererenga $=$ demônio $($ Q.L. -18$)$

pescada = peixe (10B): vai pescar um pouco de pescada aqui nesse mar pra se vender pra eles...

pescadoro $=$ pescador $(10 \mathrm{C}):$ o pescadoro não... não pega/não está preparado assim pra... pra enfrentar... a... as tempestade né?

pessoar $=$ pessoal $(10 \mathrm{C}):$ o pessoar de fora não... não vem pa a enseada no inverno né?

picardia $=$ esperteza $(5 \mathrm{C})$ : porque os judeus... ele... ele... vive... é da maior picardia...

pilica = bolinha de gude (Q.L. - 14) e (3AI): tem que acertar na outra pilica...

pinguelo = pênis (7BI): se duvidar vai ficar só com o pinguelo...

pipa (masculino) = instrumento de pesca (8B): a linha da rede era tirada do tucum pra fazer o pipa... a tarrafa pra rede...

pobrema $=$ problema $(1 \mathrm{C})$ : já tá cheio de pobrema né?

pocissão = procissão $(5 \mathrm{CI}):$ o enterro tava lindo... era uma pocissão...

${ }^{174}$ É uma dança em homenagem à fertilidade da natureza, formada por uma roda de dançarinos, tendo ao centro um pau-de-fitas coloridas, que representam a árvore e seus frutos. A dança consiste em trançar as fitas e depois desfazer o trançado, ao ritmo da cantoria". (FARIAS, 2002: 199) 
pomboca $=$ lamparina $(\mathrm{Q} . \mathrm{L} .-10)$

poque $=$ porque $(9 \mathrm{~B}):$ a produção tá caindo... poque... as pessoas que fizeram a parada por exemplo...

porcissão $=$ procissão $(10 \mathrm{BI})$ : é o dia de Nossa Senhora dos Navegante... e tem a porcissão também...

portuguese $=$ português $(7 \mathrm{CI}):$ os portuguese que vieram fundava a Armação aqui de Itapocorói... porva $=$ pólvora $(10 \mathrm{CI}):$ lá tinha uma qualidade de:.... carrapato porva.... que enchia o braço e a perna da gente...

posentado $=$ aposentado $(3 \mathrm{C})$ : inclusive sou posentado...

postura do boi = pedaço composto de uma parte da garganta, do fígado, do coração e do estômago (8BI): a postura do boi vinha o pedaço da garganta do boi... um pedaço do figo... um pedaço do coração... um pedaço do bofe...

prantar $=$ plantava $(7 \mathrm{CI})$ : de dia eu tinha que ir pra roça ... prantava...

preguntar $=$ perguntar $(9 \mathrm{CI})$ : preguntou "o que é que tem essa?"

prosa $=$ feliz (P. p.386) e (Q.L. - 19)

\section{Q}

quartele $=$ quartel $(7 \mathrm{C})$ : acho que lá em cima ainda tem uns canhão velho lá... ainda tem... uma unidade que toma conta ali da... da..... o quartele acabaram...

queima-queima $=$ taturana (Q.L. -7$)$

questã = questão (7C): mais a questã é que hoje em dia já...

queca $=$ careca $(5 \mathrm{CI}):$ homem da cabeça lisa tem que usar o boné... e o João Baé era queca...

$\mathbf{R}$

rabeca $=$ tipo de violão antigo (Q.L. -13$)$

ralo/a = pouco $(\mathbf{1 C I}, 2 \mathrm{CI}, 9 \mathrm{CI}):$ antigamente nem tinha ônibu... era $: . .$. ralo... a linha de ônibus...

ranchidade $=$ lugar afastado $(8 \mathrm{BI})$ : ele era de lá... aí ela era também uma ranchidade muito pequena...

ranchinho = construção pequena, lugar (6CI): tinha um ranchinho lá onde dava pa nós cozinhar... ranchinho = pedaço de terra (9CI, 10CI): e aqueles pobre foram comprando um ranchinho... 
rancho $=$ casa, cobertura $(\mathbf{9 B}, 1 \mathrm{CI}):$ eu por exemplo quero um rancho pra botar minhas coisa e não tenho...

rapariga $=\operatorname{garota}(\mathrm{Q} . \mathrm{V} .-3)$

rapaze $=\operatorname{rapaz}(2 \mathrm{CI}):$ ia dez doze rapaze...

rebeca $=$ tipo de violão antigo $($ Q.L. -13$)$

rebojo = chuva ou vento forte (Q.L. -1 e 2$),(\mathrm{Q} . \mathrm{V} .-3)$ e $(2 \mathrm{C})$ : que tá o vento sul aí né? ... esse rebojo que o pescador chama né?...

recardar $=$ arrecardar (9B): a quinta cidade aqui de Santa Catarina que mais recarda dinheiro...

relampo = relâmpago (9C): o relampo caiu bem assim perto de nós na água...

renar = brigar $(2 \mathrm{AI})$ : ela rena daí...

repuxo $=$ força que o mar exerce em direção contrária à praia (10BI): tem uma praia bem mansinha que não tem onda é bem bem pequena... não tem repuxo...

responso $=$ reza em que os presentes respondem em coro ao orador (P. p.378)

ressaca $=$ mar bravo (10AI): tinha a Prainha lá... que era bem... quando dava ressaca atingia toda a rua né?...

retrós = barbante (Q.L. -12$)$

revolve $=$ revólver $(\mathrm{P} . \mathrm{p} .385)$

róia $=$ royalty $(5 \mathrm{C}):$ hoje... é uma potência a Petrobrás... nós temo um róia ((royalty)) é... São Francisco do Sul... média de um milhão e meio mensal...

romper $=$ rasgar $(7 \mathrm{CI}):$ me rompi o vestido e a meia tudo no joelho...

roseta $=$ tipo de planta que nasce na praia, cheia de espinhos $(2 \mathrm{C})$ : aqui era só um... uma roseta... um rosetário... por aqui não tinha nada...

rosetário $=$ lugar cheio de rosetas $(2 \mathrm{C})$ : aqui era só um... uma roseta... um rosetário... por aqui não tinha nada...

S

sabo $=$ sábado $(6 \mathrm{CI})$ tem nessa todo sabo $\ldots$

sacolão $=$ cesta-básica $(P \cdot$ p.379)

safa $=$ safra (2C): aqui nós tinha a safa da:... a safa do cação... a safa do bagre... a safa da corvina... 
salga $=$ local em que se beneficia o camarão ou o peixe (8CI, 5C): trabalhei nas salga de camarão...

salitro $=$ sal proveniente da água do mar (8BI): a mãe enchia balde de água doce... e passava em nós pra tirar o salitro...

sambaqui $=$ depósito antigo de conchas e cascas de animais marinhos $(2 \mathrm{C})$ : aquele carpete de sambaqui...

sarga $=$ salga $(9 \mathrm{CI}):$ quando cheguei o dono da sarga me deu uma casinha...

saúde da pedra = saúde de pedra (6CI): quando eu tinha saúde da pedra eu ia lá na praia...

se haver com = equivalente à expressão: "se ver com" (7B): vocês vão se haver comigo...

seise $=$ seis $(10 \mathrm{CI})$ : nós tava em seise...

simpre $=$ simples $($ Q.L. -22$)$

sinaleira(o) $=$ semáforo (Q.L. - 17)

sistir $=$ assistir (2A): que eu mais gosto de sistir?... é... é... Seus Olhos é:.... a nova novela...

sole $=$ sol (Q.L. -15$)$

sordado $=$ soldado $(2 \mathrm{C}):$ muito sordado... muita gente... vinha gente de Blumenau $\ldots$

sortar $=\operatorname{soltar}(\mathbf{5 C I}, 9 \mathrm{C}):$ “... arrancava o dente a unha depois mandava sortar”...

sote = sótão (1C1): guardava tudo lá naquele sote...

$\mathbf{T}$

tabuleiro = plantação (5CI): ele foi fazer a cova no meio do tabuleiro...

tachilaite = lanterna $($ Q.L. -11$)$

tagé = armário de cozinha $(\mathrm{Q} . \mathrm{V}-3)$

taiá = taioba (1CI, 7CI): trazia chuchu ... trazia taiá... trazia batata ...

Tajuba $=($ Itajuba $)$ nome de um bairro e uma praia de São Francisco do Sul (9CI): Tajuba a mesma coisa também...

tamburete $=$ local em que ficam os tanques de petróleo (10B): segunda-feira tinha duas ali nos tamburete...

tanso $=$ bobo (P. p.383) e (Q.L. -22$)$

tãofraco $=$ galinha de angola (Q.L. -22$)$

tapioca $=$ produto retirado da farinha de mandioca (8CI): a gente faz o biju...cuscu... tapioca... tar = tal (6C): tinha um tar de Benedito... 
tarrafa $=$ rede de pesca $(\mathbf{8 B}, 1 \mathrm{C}, 6 \mathrm{C}, 9 \mathrm{C}):$ a linha da rede era tirada do tucum pra fazer o pipa... a tarrafa pra rede...

tarrafear $=$ pescar com tarrafa (4C): não pude tarrafear mais... ai também não fui mais...

tea = telha (6C): fazia casa de tea né?

teia $=$ telha $(2 \mathrm{C})$ : aqui tinha uma cidadezinha $\ldots$ de... ca/casa de madeira $\ldots$ de teia tinha bem pouco...

Terno de Reis $^{175}=$ festa em comemoração ao dia de Reis, em janeiro (10BI, 2CI, 7CI, 1B, 7B, 10B, 1C, 2C, 3C): você já não tem mais Terno de Reis como antigamente né?...

terral $=$ vento norte $(\mathrm{Q} . \mathrm{V} .-3)$

ti = tio (8B): não conhece o ti J. né?...

tilica = estilingue (Q.L. -15$)$

tipitim = vasilha para torrar farinha de mandioca (2CI): o tipitim é feito de mambu...

tobata $=$ trator de pequeno porte $(\mathrm{P} . \mathrm{p} .386)$

tocar dobrado = música rápida e alegre (9C): passava pela cidade tocando dobrado...

tola = louca (1CI): ai fica meia tola mesmo...

torque $=$ painel com informações turísticas (3B): o torque é é é... é uma idéia que foi lançada pro...

tope $=$ autópsia (5CI): quando ele chegou lá a cobra já tava morta... pa fazer o tope nela chamaram o João Minguota...

trabaiar = trabalhar (5CI, 2C): eu vou pra casa trabaia... fica aí tropa de bobo

trafaco $=$ galinha d’angola (Q.L. -5$)$

tramela $=$ peça de madeira que gira ao redor de um prego utilizada para fechar portas, janelas, portões (P. p.385)

tranquilo $[\mathrm{k}]=$ tranqüilo $(2 \mathrm{CI}):$ é tranquilo...

triatro = teatro (2CI): porque um dia teve... um triatro ali...

triforno = uniforme (1B): ai eles vem... chamam... coloca a gente no triforno...

trovoada $=$ chuva ou vento forte $(\mathrm{Q} . \mathrm{L} .1$ e 2$)$ e $(9 \mathrm{C})$ : é muito ruim e é perigoso... negócio de trovoada...

tucum = tipo de palmeira (8B): a linha da rede era tirada do tucum pra fazer o pipa... a tarrafa pra rede...

175 "As cantorias conhecidas por terno de Reis, tradicionais nas comunidades litorâneas, têm motivações de fundo religioso-profano. O próprio nome terno advém da existência de três vozes: repentista, tripa e coro. Estas vozes é que caracterizam o terno." (FARIAS, 2000: 385). 
ufender $=$ ofender $(10 \mathrm{C})$ : ufende... o... o... parecido com ofensas até né?

V

vançar = avançar $(5 \mathrm{CI})$ : os cachorro vançaram e saíram rolando dentro dum grotão...

vareja $=$ varejeira (Q. L. - 6) e (5BI): tirando o bicho de vareja.... tudo branquinho...

varejeira $=\operatorname{varejeira~}(\mathrm{Q} . \mathrm{L} .-6)$

velhote $=$ pessoa idosa, velhinho $(2 \mathrm{AI}):$ tinham dois caras que tavam correndo dele... e acharam um velhote...

venda = pequeno mercado (2CI, 9CI): meu pai dizia assim... "vai na venda"

veranista $=$ turista $(\mathrm{Q} . \mathrm{L} .-24)$ e $(8 \mathrm{BI})$ : milhares e milhares de turistas... veranistas... isso foi bom pra cidade...

verdureira $=$ lugar em que se vende verdura $(7 \mathrm{CI})$ : não havia essas... verdureira...

veronista $=$ turista $(\mathrm{Q} . \mathrm{L} .-24)$ e $(\mathbf{7 B}, 1 \mathrm{BI}, 6 \mathrm{CI})$ : no verão... tem bem mais movimento... aí as casa tão toda aberta... dos veronista né?...

vineno $=$ veneno $(5 \mathrm{CI})$ : o Raul se preveniu com vineno de primeira $\ldots$

virar $=\operatorname{voltar}(5 \mathrm{C})$ : e virei na minha marinha... que eu toda vida fui marítimo... então... naveguei muito...

vortar $=\operatorname{voltar}(\mathbf{1 0 B}, 9 \mathrm{C}):$ fazia o serviço... e..... vortava $\ldots$

$\mathbf{X}$

xilóida/e = estilingue (Q.L. -15$)$ 


\section{REFERÊNCIAS}

\section{Referências bibliográficas}

AGUILERA, V. A. Estudos dialetológicos no Paraná: caminhos e perspectivas. In: Estudos de Geolingüística do português americano. Frankfurt am Main: TFM, 2000.

ALEXANDRE, A. São Francisco do Sul - ex-ilha, terra de sonhos e tradições. São Francisco do Sul, 1972.

ALEXANDRE, F. Falar e falares da Ilha de Santa Catarina. Florianópolis: Cobra Coralina, 1994.

ALMEIDA, M. M. S. Aspectos fonológicos do português falado na Baixada Cuiabana: traços de língua antiga preservados no Brasil (manuscritos da época das Bandeiras, Século XVIII). São Paulo: USP, 2000 (tese de Doutorado).

ALVES, J. L. A linguagem dos pescadores da Ericeira - Junta distrital de Lisboa. Portugal: Universidade de Lisboa, 1965.

AMARAL, A. O dialeto caipira. São Paulo: O livro, 1920.

AQUINO, Z. G. O. de. A mudança de tópico no discurso oral dialogado. São Paulo: PUC, 1991 (dissertação de Mestrado).

----------- - Conversação e conflito: um estudo das estratégias discursivas em interações polêmicas. São Paulo: USP, 1997 (tese de Doutorado).

ARAGÃO, M. S. S. A despalatização e iotização no Ceará. In: Estudos de Geolingüística do português americano. Frankfurt am Main: TFM, 2000.

BALDINGER, k.; Semantic theory - towards a modern semantics. Oxford: Basil Blackwell, 1980.

BARROSO, V. L. M. (org.) Açorianos no Brasil: história, memória, genealogia e historiografia. Porto Alegre: EST, 2002.

BISOL, L. (org) A variação no português do Brasil. In: Organon, 5, no 8, 1991.

BIVAR, A. Dicionário geral e analógico da língua portuguesa. Porto: Ouro, 1948, v.1.

BOER, P. Barra Velha através dos tempos. Barra Velha: Universal, 1993.

BOLÉO, M. P. Filologia e história (Emigração açoriana para o Brasil). Coimbra: Coimbra Ed., 1945.

BONATTI, M. Aculturação lingüística numa colônia de emigrantes italianos de Santa Catarina, Brasil (1875-1974). Lorena: Faculdade Salesiana, 1974. 
BORGES, N. O. C. Influência anglo-americana no falar da ilha de S. Miguel (Açores). Lisboa: Universidade de Coimbra, 1965.

CABRAL, O. R. História de Santa Catarina. Santa Catarina: Paraná Cultura, 1970.

CARUSO, M. M. L. Mares e longínquos povos dos Açores. Florianópolis: Insular, 1996.

- \& CARUSO, R. C. Índios, baleeiros e imigrantes: a aventura histórica. Tubarão: Unisul, 2000.

CARVALHO, A. B. Pequeno glossário do português medieval. Natal: s/ed., 1983.

COMITÊ NACIONAL DO PROJETO AliB (org.) Atlas lingüístico do Brasil/ Londrina: UEL, 2001.

CORREAA, I. B. Dicionário catarinense: tratado de dialetologia, falares, subfalares e expressões idiomáticas no Estado barriga-verde. Florianópolis: Insular, 2000.

CRUSE, D. A. Lexical semantics. EUA: University of Cambridge, 1986.

CUESTA, P. V. \& LUZ, M. A. M. Gramática da Língua Portuguesa. Lisboa: edições 79, 1971.

CUNHA, A. G. Dicionário histórico das palavras portuguesas de origem tupi. São Paulo: Melhoramentos/EDUSP, 1989.

D’ÁVILA, E. Um açoriano "tardio" na história de Itajaí: Manoel Antônio Fontes, sua contribuição ao progresso social político do município. In: Alcance (História) - Itajaí - ano IV n.0, p. 05-10, junho de 1997.

DOWNES, W. Language and society. London: Fontana, 1984.

DUCROT, O. Dire et ne pas dire - principes de Sémantique Linguistique. Paris: Hermann, 1972.

ELLIS, M. A baleia no Brasil colonial. São Paulo: USP, 1969.

FARIAS, V. F. Dos Accores ao Brasil Meridional: uma viagem no tempo: povoamento, demografia, cultura, Açores e litoral catarinense: um livro para o ensino fundamental. Florianópolis: Editora do autor, 1998.

- Dos Açores ao Brasil meridional: uma viagem no tempo: 500 anos, litoral catarinense: um livro para o ensino fundamental. Florianópolis: Editora do autor, 2000, 2 ed..

- De Portugal ao sul do Brasil - 500 - história, cultura e turismo. Florianópolis: Editora do autor, 2001.

- Penha 243 anos - natureza, história e cultura. Editora do autor, 2002.

FURLAN, O. A. Influência açoriana no português do Brasil de SC. Florianópolis: UFSC, 1989. 
- Vertentes étnico-históricas do atual português dos catarinenses de ascendência lusoaçoriana. PIAZZA, W.F. (org.) In: Anais da $2^{a}$ semana de Estudos Açorianos. Florianópolis: UFSC, 1987.

FERNANDES, F. Dicionário de sinônimos e antônimos da língua portuguesa. Revista e ampliada por Celso Pedro Luft. São Paulo: Globo, 2002.

FERREIRA, (AURÉLIO). B. de H. Aurélio século XXI: o dicionário da língua portuguesa. Rio de Janeiro: Nova Fronteira, 1999.

FERREIRA, C. \& CARDOSO, S. A. A dialetologia no Brasil (repensando a Língua Portuguesa). São Paulo: Contexto, 1994.

FERREIRA NETO, W. \& RODRIGUES, A. C. S. Repensando a questão da transcrição de inquéritos orais. In: Anais de seminários do GEL. Assis, 2001.

FISCHER, L. A. Dicionário de Porto-Alegrês. Poro Alegre: Artes e Ofícios, 1999.

HATCH, E. M. Discourse and language education. New York: Cambridge, 1992.

HIGA, N. M. O. Resgate da cultura açoriana na Armação de Itapocoroy, no município de Penha, SC. Itajaí: Dez, 1997.

HOUAISS, A. Dicionário Houaiss da língua portuguesa. Rio de Janeiro, 2001, (versão eletrônica).

ILARI, R.; GERALDI, J. W. Semântica. São Paulo: Ática, 2001.

IMAGUIRE, L. M. C. Estudo com vista a um atlas lingüístico da Ilha de Santa Catarina: abordagem dos aspectos lexicais. São Paulo: USP, 1999 (dissertação de mestrado).

IRMEN, F.; KOLLERT, A. M. C. Langenscheidts Taschenwörterbuch Portugiesisch. Berlin / München: Langescheidet, 1995.

JAMUNDÁ, T. C. Catarinensismos. Florianópolis: Edem, 1974.

$\mathrm{KOCH}, \mathrm{W}$. O povoamento do território e a formação de áreas lingüisticas. In: Estudos de Geolingüística do português americano. Frankfurt am Main: TFM, 2000.

KOCH, W.; KLASSMANN, M. S. \& ALTENHOFEN, C. V. (org.) Atlas lingüístico-etnográfico da região Sul do Brasil (ALERS). Porto Alegre/ Florianópolis/ Curitiba: UFRGS/UFSC/UFPR, 2002.

LABOV, W. Sociolinguistic patterns. University of Pennsylvania: Press, 1972.

LACERDA, E. P. O atlântico açoriano - uma antropologia dos contextos globais e locais da açorianidade. Santa Catarina: UFSC, 2003 (tese de doutoramento).

LEAL, J. Açorianidade: literatura, política, etnografia (1880-1940). Alcance (História) - Itajaí - ano VIII -n.6, p. 27-41, novembro de 2001. 
LUCCHESI, D. Variação e norma: elementos para uma caracterização sociolingüística do português do Brasil. In: Revista Internacional de Língua Portuguesa, no. 12, dezembro de 1994 (Associação das Universidades de Língua Portuguesa).

LOPES, E. Fundamentos da lingüística contemporânea. São Paulo: Cultrix, 2001.

LYONS, J. Language, meaning and context. Oxford: Blackwell, 1981.

MACHADO, P. Dicionário etimológico da língua portuguesa. Lisboa: Confluência, 1952-59.

MANSUR GUÉRIOS, R. F. Tabus lingüísticos. Paraná: UFPR, 1979.

MARCUSCHI, L. A. Análise da Conversação. São Paulo: Ática, 1986.

MARGOTTI, F. W. Sinonímia e paráfrase: algumas considerações a partir de dados do Atlas lingüístico-etnográficos da região sul - ALERS. In: Linguagem em (dis)curso. Tubarão (SC), v.3, n.2, p.27-46, jan/jun. 2003.

MARROQUIM, M. A língua do Nordeste (Alagoas e Pernambuco). São Paulo: Editora Nacional, 1945.

MATTOS E SILVA, R. V. O português arcaico: fonologia. São Paulo: Contexto, 1996. - (Coleção repensando a Língua Portuguesa).

MEGALE, H. Filologia Bandeirante. In: Itinerários. Araraquara (SP), n.13, 1998.

MELLO, H. R. The genesis and development of Brazilian Vernacular Portuguese. New York: City University of New York. (Tese de doutoramento, mimeo), 1996.

MELO, O. F. Notas sobre a identidade do povoador açoriano do século XVIII. CORRÊA, C. H. P. (org.) In: Anais do simpósio comemorativo ao cinqüentenário do $1^{\circ}$ congresso de história catarinense e 250 anos da presença açoriana em Santa Catarina. Florianópolis: CAPES/MEC, 1998.

MENESES, A. F. A Europa, Portugal e os Açores no limiar de setecentos. Ponta Delgada: Universidade dos Açores, 1993.

MICHAELIS Moderno dicionário da Língua Portuguesa. São Paulo: Melhoramentos, 1998.

MORAES, L. C. Vocabulário sul-rio-grandense. Porto Alegre: Livraria Globo, 1935.

NARO, A. N. \& SCHERRE, M. M. P. Variable concord in Portuguese: the situation in Brazil and Portugal. McWhorter, Jonh (ed.) In: Current issues in pidgin and creole linguistics. Amesterdam, Benjamins (a sair em 1999).

NOLL, V. Das brasilianische Portugiesisch: Herausbildung und Kontraste. Heidelberg: C. Winter, 1997. Trad. Mário Eduardo Viaro (no prelo). 
NUNES, Z. C. \& NUNES, R. C. Dicionário de regionalismos do Rio Grande do Sul. Porto Alegre: Martins Liureiro, 1992.

OLIVEIRA, A. Percorrendo nossa ilha - geografia e história de São Francisco do Sul. Joinville: Letradágua, 2004.

OLIVEIRA, A. J. Dicionário Gaúcho. Porto Alegre: Age, 2002.

OLIVEIRA, G. M. Matrizes da língua portuguesa no Brasil Meridional 1680-1830. MATTOS e SILVA \& VIRGÍNIA R. (org.) In: Para a história do português brasileiro. São Paulo: Humanitas/FFLCH/FAPESP, 2001. v.2 - Tomo II: Primeiros estudos.

OLIVEIRA E SILVA, G. M. Coleta de dados. In: Introdução à Sociolingüística - O tratamento da Variação. MOLLICA \& BRAGA (org.) São Paulo: Contexto, 2003.

PAES, E. F. Alguns aspectos da fonética sul-rio-grandense. Porto Alegre: Globo, 1938.

PEREIRA, C. C. História de São Francisco do Sul. Florianópolis: UFSC, 1984.

PERELMAN, C. \& OLBRECHTS-TYTECA, L. Tratado da Argumentação. São Paulo: Martins Fontes, 1996.

PIAZZA, W. F. Santa Catarina: sua história. Florianópolis: UFSC/Lunardelli, 1983.

PORTO ALEGRE, A. Popularium sulriograndense e o dialeto nacional. Porto Alegre: UFRGS, 1980.

PRETI, D. (org.) Análise de textos orais. São Paulo: FFLCH - USP, 1999.

RODRIGUES, A. C. S. A concordância verbal no português popular em São Paulo. São Paulo: USP. Tese de doutoramento, 1987.

--------- Reflexões sobre fatos de não-concordância verbal no português culto brasileiro. Sem referências, 2002.

SAINT-HILAIRE, A. Viagem a província de Santa Catarina. São Paulo: Nacional, 1936.

SANTOS, S. C. (org.) Santa Catarina no século XX:ensaios e memória fotográfica. Florianópolis: UFSC, 2000.

SILVA-CORVALÁN, C. Sociolingüística. Teoria y análisis. Madrid: Alambra, 1989.

SILVA, M. Grande dicionário da Língua Portuguesa. Lisboa: Confluência, 1949-59.

SILVA NETO, S. Guia para estudos dialetológicos. Belém, Instituto Nacional de Pesquisas da Amazônia, 1957.

SILVA, T. C. Fonética e fonologia do português: roteiro de estudos e guia de exercícios. São Paulo: Contexto, 1999. 
SIMÕES, G. A. Dicionário de expressões populares portuguesas. Lisboa: Perspectivas e Realidades, 1984.

SOUTO MAIOR, M. Dicionário da cachaça. Recife: Massangana, 1985.

SOUZA, C. B. Piçarras de todos os tempos - a história e sua gente. Itajaí: Centenário, 2000.

SOUZA, C. B \& SERPA FILHO, G. A. Penha - a história para todos. Florianópolis: Paralelo 27, Série Municípios Catarinenses, 1995.

TAUNAY, A. de E. Léxico de Lacunas. Tours: E. Arnaut \& Cia., 1914, 5v.

Céos e terras do Brasil. Rio de Janeiro: Livraria Francisco Alves, 1922.

TEYSSIER, P. História da língua portuguesa. tradução Celso Cunha - São Paulo: Martins Fontes, 1997.

TIAGO, A. S. São Francisco - notícia estatístico-descritiva. Instituto Brasileiro de Geografia e Estatística do Estado de Santa Catarina, 1941, publicação 19.

TORRINHA, F. Dicionário português-latino. Porto: Domingos Barreira, 1939.

ULLMANN, S. Semântica: Uma introdução à ciência do significado. Trad. J. A. Osório Mateus. Lisboa: Fundação Calouste, 1964.

WALPOLE, H. R. Semantics: The nature of words and their meanings. EUA: Vail-Ballou, 1941.

VASCONCELOS, J. L. Opúsculos. Coimbra: Imprensa da Universidade, 1928, 2 v.

VIARO, M. E. Semelhanças entre o português brasileiro e as variedades africanas e asiáticas. SILVA, L. A. (org.) In: A língua que falamos - Português: história, variação e discurso. São Paulo: Globo, 2005.

VILLAR, M. Dicionário contrastivo luso-brasileiro. Rio de Janeiro: Guanabara, 1989.

\section{Jornais}

A NOTÍCIA (SC), Açcores. ANespecial, 28/08/00, p.1-12.

A NOTÍCIA (SC), Açorianos em SC. 15/09/94, p.2.

A NOTÍCIA (SC), Anexo Portugal. ANespecial, 16/04/95, p.1.

A NOTÍCIA (SC), Danças de São Chico: um espetáculo ancestral. ANespecial, 18/04/96, p.8.

A NOTÍCIA (SC), Decreto do tombamento da cidade de São Francisco do Sul. ANespecial, 02/87.

A NOTÍCIA (SC), E tudo começou há 500 anos. ANespecial, 05/01/04, p.13-24.

A NOTÍCIA (SC), Encontro discute influência açoriana no Sul. ANespecial, 25/08/96, p.29.

A NOTÍCIA (SC), Falsa história. 10/06/92, p.8. 
A NOTÍCIA (SC), Jóias da coroa. Anexo, 20/07/04, p.4.

A NOTÍCIA (SC), Os colonizadores. 10/06/92, p.8.

A NOTÍCIA (SC), Penha, uma visita à história. ANturismo, 10/01/01, p.1-2.

A NOTÍCIA (SC), Portugal. Anexo, 16/04/95, p.1.

A NOTÍCIA (SC), Quando a farsa toma o lugar da história. ANespecial, 02/07/00, p.4.

A NOTÍCIA (SC), Ribeirão da Ilha. ANespecial, 22/02/96, p.9.

A NOTÍCIA (SC), São Francisco vai sediar festa açoriana. Geral, 17/07/04, p.11.

AÇORIANO ORIENTAL, A emigração para o Brasil. Domingo, 11/08/96. p.8-9.

AÇORIANO ORIENTAL, A “glória” do açoriano no Brasil. Última Página, 15/08/96. p.14.

AÇORIANO ORIENTAL, Açores e Brasil 250 anos de história no rastro da açorianidade. Reportagem, 08/08/96. p.14.

AÇORIANO ORIENTAL, Quando os Açores se chamavam "Ilhas Flamengas" - I. Opinião, 07/08/96. p.14.

AÇORIANO ORIENTAL, Semana comemorativa da chegada dos açorianos ao Brasil, na Casa dos Açores. Opinião, 19/08/96. p.8.

CAMINHOS DE SANTA CATARINA, Açorianos seguem a partir de 1747. 12/03/00, p.10.

DIÁRIO CATARINENSE, A cultura açoriana é realmente dominante na Ilha? Especial Açores, Ponto de Vista, 05/03/96, p.11.

DIÁRIO CATARINENSE, Açoriano tira sustento do mar. 12/04/00, p.28.

DIÁRIO CATARINENSE, Açorianos inauguram a capital. Diário especial, 19/08/92, p.1.

DIÁRIO CATARINENSE, Bruxas povoam noite açoriana. Caderno de cultura, 25/03/96, p.4.

DIÁRIO CATARINENSE, Confronto resgatou memória. Especial Açores, 05/03/96, p. 12.

DIÁRIO CATARINENSE, De uma ilha a outra. Especial Açores - Santa Catarina, 05/03/96, p.3.

DIÁRIO CATARINENSE, Dois séculos marcam isolamento. Caderno de cultura, 03/03/91, p.12.

DIÁRIO CATARINENSE, Origens: povos, costumes e ilha dos Açores. Diário de cultura, 27/01/96, p.5.

DIÁRIO CATARINENSE, Peninha lamenta perda cultural. Variedades, 03/03/91, p.8.

DIÁRIO CATARINENSE, Raízes açorianas. Variedades, 29/03/01, p.1.

DIÁRIO CATARINENSE, Revitalização na espera dos 500 anos. Variedades, 05/01/03, p.4-5.

DIÁRIO CATARINENSE, Só religião mantêm os costumes. Variedades, 03/03/91, p.9.

DIÁRIO CATARINENSE, Sociologia: Estruturas sociais e cultura popular. Diário de cultura, 30/09/95, p.8. 
DIÁRIO CATARINENSE, Tradição: A passio açoriana, momento popular da fé. Diário de cultura, 01/04/95, p.9.

DIÁRIO CATARINENSE, Tradição é ameaçada pela polêmica. 03/04/94, p.31-33.

DIÁRIO CATARINENSE, Uma tradição de dois séculos: festa do divino. 25/05/96, p.29.

GAZETA MERCANTIL DE SANTA CATARINA, Arquitetura luso-brasileira ou açoriana? Caderno D, 22/08/01, p.2.

GAZETA MERCANTIL DE SANTA CATARINA, O mito da "açorianidade" (1). Caderno D, 04/07/00, p.2.

GAZETA MERCANTIL DE SANTA CATARINA, O mito da “açorianidade” (2). Caderno D, 05/07/00, p.2.

JORNAL DE SANTA CATARINA, Açorianos ficaram pelo litoral. Caderno especial, 25/07/92, p.6.

JORNAL DE SANTA CATARINA, Açorianos garantiram o domínios portugueses. Caderno B, 12/11/95, p.5.

JORNAL DE SANTA CATARINA, Colonização açoriana. Suplemento especial, novembro de 1997, p.1-12.

JORNAL DE SANTA CATARINA, Engenho de farinha sobrevive. Caderno B, 02/04/00, p.8.

JORNAL DE SANTA CATARINA, Plano apresenta alternativas para o turismo. Caderno B, 21/11/96, p.10.

O ESTADO, Cultura açoriana luta pela preservação. Cultura, 21/07/96.

O ESTADO, Revitalização da cultura é o objetivo de encontro açoriano. Geral, 26/08/96.

SÃO FRANCISCO DO SUL EM NOTÍCIAS, Programa monumenta - BID - Marco de um novo tempo. Sem data, p.14-15.

ZERO HORA, As raízes que o Rio Grande esqueceu. Caderno especial, 01/09/96, p. 4-5.

\section{Internet}

www.alib.ufba.br

www.ibge.org.br

www.mapainterativo.ciasc.gov.br

www.portaldailha.com.br

$\underline{\text { www.portalsbs.com.br }}$ 
$\underline{\text { www.vertentes.ufba.br }}$

www.wikipedia.org.br

\section{Outras fontes}

MUSEU PORTO AMADO, Museu do Antigo Porto de Armação do Itapocorói; Penha, SC.

SECRETARIA MUNICIPAL DE TURISMO DE SÃO FRANCISCO DO SUL.

SECRETARIA MUNICIPAL DE TURISMO, INDÚSTRIA E COMÉRCIO DE PENHA. 


\title{
ASPECTOS FONÉTICOS, LEXICAIS E MORFOSSINTÁTICOS DA VARIANTE AÇORIANA CATARINENSE
}

\author{
vol.2
}

Dissertação apresentada ao curso de PósGraduação em Língua Portuguesa, Área de Concentração de Filologia e Língua Portuguesa, do Departamento de Letras Clássicas e Vernáculas da Universidade de São Paulo, como requisito parcial para a obtenção do título de Mestre.

Orientador: Prof. Dr. Mário Eduardo Viaro

São Paulo

2007 
ANEXO 1

DADOS PESSOAIS DOS INFORMANTES 


\section{DADOS PESSOAIS DOS INFORMANTES}

O modelo da ficha utilizada para colher os dados dos informantes foi retirado do AliB (Atlas Lingüístico Brasileiro). Divide-se em quatro partes: dados pessoais do informante, contato com meios de comunicação de massa, participação em diversões e um campo para preenchimento após a entrevista.

Por uma questão de espaço e de proteção aos dados pessoais dos informantes, não fornecemos em íntegra as fichas preenchidas. Os dados mais utilizados nesta pesquisa estão apresentados em tabelas nas páginas seguintes. Outros dados, quando necessários, são citados no corpo do trabalho.

Para apresentar o contato com meios de comunicação de massa de cada informante, após a análise das fichas, adotou-se os seguintes parâmetros: grande, médio, pouco e nenhum. Foram considerados informantes que não têm nenhum contato aqueles que não possuem televisão, rádio e não têm acesso aos jornais e revistas.

\section{Siglas utilizadas:}

Inc. $=$ incompleto. 


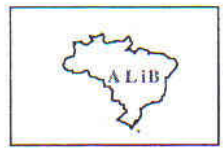

Projeto Atlas Lingüístico do Brasil

Ficha do Informante

No. do ponto: No. do informante:

DADOS PESSOAIS DO INFORMANTE

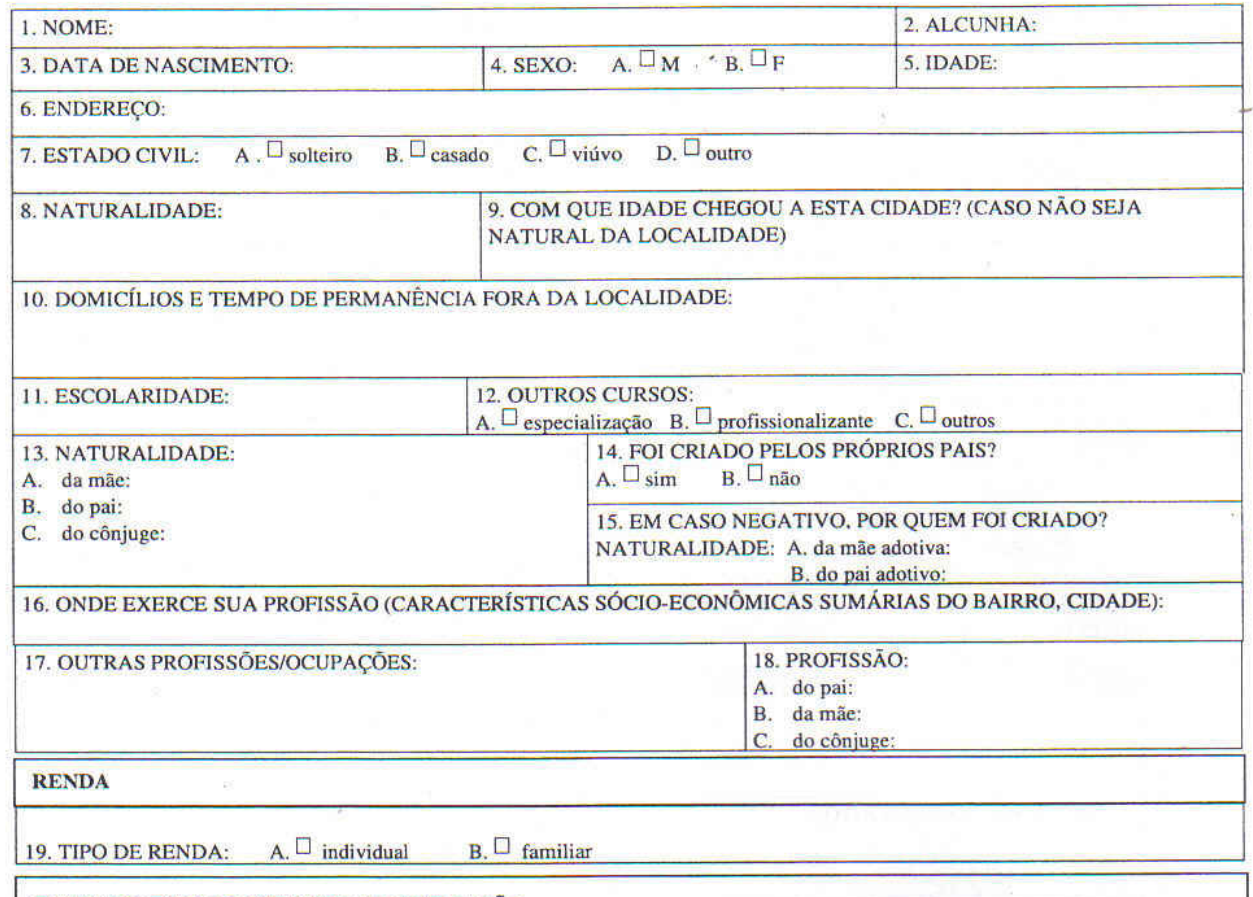

CONTATO COM OS MEIOS DE COMUNICAÇÃO

\begin{tabular}{|c|c|c|c|c|c|}
\hline \multicolumn{2}{|l|}{$\begin{array}{l}\text { 20. ASSISTE TV? } \\
\text { A. } \square \text { todos os dias } \\
\text { B. } \square \text { às vezes } \\
\text { C. } \square \text { nunca }\end{array}$} & AMAS & $\begin{aligned} \text { PREFEI } \\
1 \\
1 \\
1 \\
1\end{aligned}$ & $\begin{array}{l}\text { OS: } \\
\text { noticiários } \\
\text { pr. religioso } \\
\text { filmes }\end{array}$ & G. $\square$ outro \\
\hline $\begin{array}{l}\text { 22. TIPO DE TRANSMISSĀO: } \\
\text { A. } \square \text { rede gratuita } \\
\text { B. } \square_{\text {parabólica }} \\
\text { C. } \square_{\text {tv por assinatura }}\end{array}$ & $\begin{array}{l}\text { 23. OUVE RÁDIO? } \\
\text { A. } \square_{\text {todos os dias }} \\
\text { B. } \square_{\text {às vezes }} \\
\text { C. } \square_{\text {nunca }}\end{array}$ & & $\begin{array}{l}\text { D. } \square_{\mathrm{p}} \\
\text { E. } \square_{\mathrm{o}} \\
\text { F. } \square_{\mathrm{er}}\end{array}$ & $\begin{array}{l}\text { do dia } \\
\text { inteiro } \\
\text { into viaja }\end{array}$ & G. enquanto trabalha \\
\hline \multicolumn{2}{|c|}{ 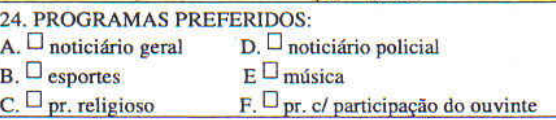 } & G. L & outro & $\begin{array}{l}\text { 25. LÊ JORNAL? } \\
\text { A. } \square \text { todos os dias } \\
\text { B. } \square_{\text {às vezes }} \\
\text { C. } \square_{\text {nunca }} \\
\end{array}$ & $\begin{array}{l}\text { D. } \square \text { semanalmente } \\
\text { E. } \square_{\text {raramente }}\end{array}$ \\
\hline
\end{tabular}




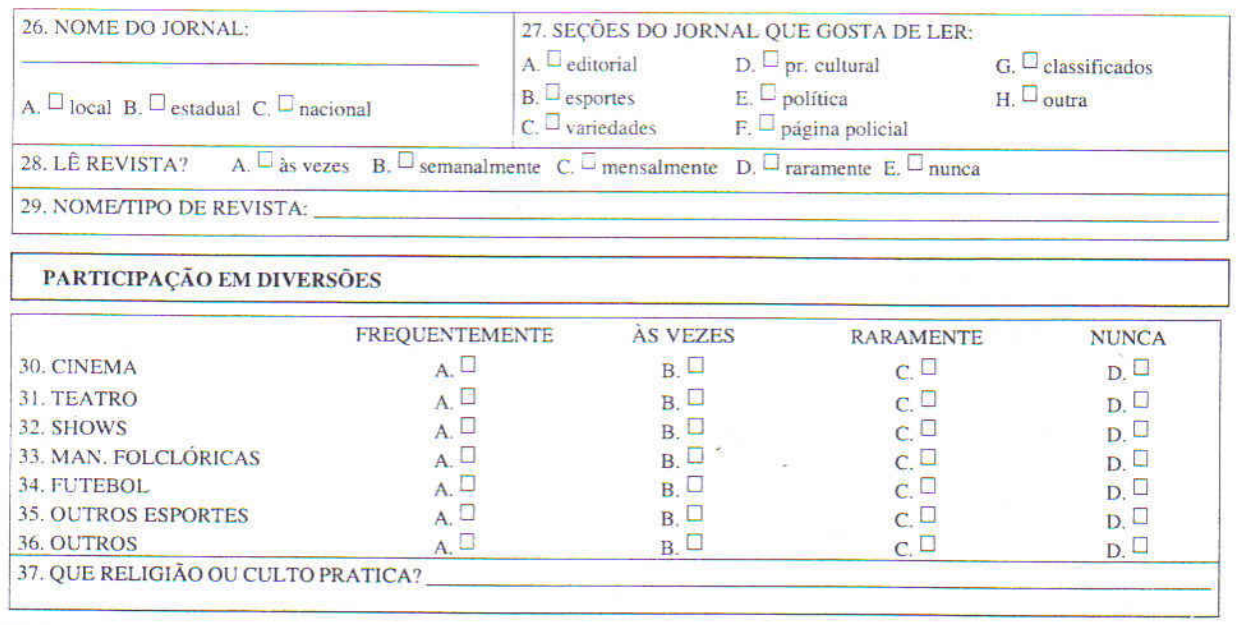

PARA PREENCHIMENTO APÓS A ENTREVISTA

38. CARACTERISTICAS PSICOLÓGICAS DO INFORMANTE:

A. $\square$ tímido B. $\square$ vivo C. $\square$ perspicaz D. $\square$ sarcástico

39. ESPONTANEIDADE DA ELOCUÇÃO:

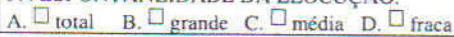

40. POSTURA DO INFORMANTE DURANTE O INQUÉRITO:

A. $\square$ cooperativa B. $\square$ não cooperativa $C . \square$ agressiva $D . \square$ indiferente

41. CATEGORIA SOCIAL DO INFORMANTE:

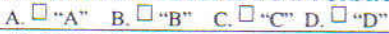

42. GRAU DE CONHECIMENTO ENTRE INFORMANTE E INQUIRIDOR:

$\begin{array}{lll}\text { A. } & \square \text { grande } & \text { B. }\end{array} \square_{\text {médio }}$ C. $\square_{\text {pequeno }}$ D. $\square_{\text {nenhum }}$

43. INTERFERENCIA OCASIONAL DE CIRCUNSTANTES:

A. $\square \operatorname{sim} \quad$ B. $\square$ não

44. CARACTERIZAÇÃO SUMÁRIA DO(S) CIRCUNSTANTE(S):

45. AMBIENTE DO INQUÉRITO:

46. OBSERVAÇÕES:

47. NOME DO ENTREVISTADOR:

\begin{tabular}{l|l} 
48. LOCAL DA ENTREVISTA: & 49. DATA DA
\end{tabular}

CIDADE:

ENTREVISTA:

UF: SO. DURAÇÃO:

$1^{\circ}$ quadro - Informantes da Antiga Região de Itapocorói 


\begin{tabular}{|c|c|c|c|}
\hline INFORMANTES & INICIAIS & IDADE & \begin{tabular}{|l|} 
Data da entrevista \\
\end{tabular} \\
\hline 1AI & L.F.Q. & 08 & 23.07 .2002 \\
\hline 2AI & P.G.P. & 11 & 23.07 .2002 \\
\hline 3AI & G.A.C.S. & 11 & 25.07 .2002 \\
\hline 4AI & J.B. & 12 & 22.07 .2002 \\
\hline 5AI & R.H.C. & 13 & 18. 07. 2002 \\
\hline 6AI & K.S. & 14 & 22.07 .2002 \\
\hline 7AI & B.H.S. & 14 & 18. 07. 2002 \\
\hline 8AI & H.G.R. & 14 & 20.07 .2002 \\
\hline 9AI & C.R.M. & 16 & 22.07 .2002 \\
\hline 10AI & P.N.R. & 16 & 20.07 .2002 \\
\hline 1BI & F.M.A. & 21 & 17.07 .2002 \\
\hline 2BI & A.P. & 23 & 23.07 .2002 \\
\hline 3BI & L.L.S. & 23 & 18. 07. 2002 \\
\hline 4BI & L.A.S. & 40 & 20.07. 2002 \\
\hline 5BI & H.S. & 42 & 19.07. 2002 \\
\hline 6BI & J.P.M. & 42 & 18.07. 2002 \\
\hline 7BI & L.A.R. & 42 & 18. 07. 2002 \\
\hline 8BI & E.S.G. & 43 & 21. 07. 2002 \\
\hline 9BI & M.A.I. & 44 & 21.07 .2002 \\
\hline 10BI & M.G. & 52 & 21.07 .2002 \\
\hline 1CI & C.F.A. & 68 & 21. 07. 2002 \\
\hline $2 \mathrm{CI}$ & J.J.A. & 71 & 25.07 .2002 \\
\hline 3CI & G.A.F. & 72 & 25.07 .2002 \\
\hline 4CI & M.A.C. & 78 & 21.07 .2002 \\
\hline 5CI & J.A.A. (1) & 78 & 21. 07. 2002 \\
\hline 6CI & G.P.A. & 80 & 27.07. 2002 \\
\hline 7CI & E.M.S. & 81 & 21.07. 2002 \\
\hline 8CI & T.M.A. & 81 & 26. 07. 2002 \\
\hline 9CI & A.L.P. & 82 & 19.07. 2002 \\
\hline 10CI & J.A.A. (2) & 83 & 2107.2002 \\
\hline
\end{tabular}


$2^{\circ}$ quadro - Informantes de São Francisco do Sul

\begin{tabular}{|c|c|c|c|}
\hline INFORMANTES & INICIAIS & IDADE & Data da entrevista \\
\hline $\mathbf{1}^{\mathrm{A}}$ & B.L.M.C. & 08 & 19.07. 2004 \\
\hline $2^{A}$ & T.S.M. & 10 & 19.07. 2004 \\
\hline $3^{A}$ & D.A.F. & 11 & 21.07 .2004 \\
\hline 4A & T.A.M. & 11 & 19.07. 2004 \\
\hline $5 \mathrm{~A}$ & B.P. & 13 & 16.07. 2004 \\
\hline 6A & F.S.G & 13 & 16.07. 2004 \\
\hline 7A & B.M.S. & 14 & 16.07. 2004 \\
\hline $\mathbf{8 A}$ & D.P.F. & 16 & 21.07 .2004 \\
\hline 9A & F.C.M. & 17 & 16.07. 2004 \\
\hline 10A & G.S.O. & 20 & 16.07. 2004 \\
\hline 1B & M.S. & 30 & 17.07. 2004 \\
\hline 2B & M.F.C. & 33 & 17.07. 2004 \\
\hline 3B & A.A.P. & 35 & 20.07. 2004 \\
\hline 4B & M.B.C. & 36 & 16.07. 2004 \\
\hline 5B & P.F.J. & 38 & 19.07. 2004 \\
\hline 6B & E.L.G. & 46 & 17.07. 2004 \\
\hline 7B & J.O.M. & 49 & 18.07. 2004 \\
\hline 8B & C.F.P. & 52 & 18.07. 2004 \\
\hline 9B & J.T. & 54 & 18.07. 2004 \\
\hline 10B & J.J.A. & 55 & 18.07. 2004 \\
\hline $1 \mathrm{C}$ & J.F.B. & 60 & 21.07 .2004 \\
\hline $2 \mathrm{C}$ & O.P. & 62 & 16. 07. 2004 \\
\hline $3 \mathrm{C}$ & F.D.O. & 66 & 21.07. 2004 \\
\hline $4 \mathrm{C}$ & A.B. & 68 & 21.07. 2004 \\
\hline $5 C$ & A.F. & 71 & 20.07. 2004 \\
\hline 6C & E.P.O. & 73 & 19.07. 2004 \\
\hline $7 C$ & A.J.J.F. & 79 & 16. 07. 2004 \\
\hline $8 \mathrm{C}$ & C.O.M & 80 & 20.07. 2004 \\
\hline $9 \mathrm{C}$ & E.O. & 82 & 19.07. 2004 \\
\hline $10 \mathrm{C}$ & A.C. & 86 & 20.07. 2004 \\
\hline
\end{tabular}


$3^{0}$ quadro - Informantes da Antiga Região de Itapocorói

\begin{tabular}{|c|c|c|c|}
\hline INFORMANTES & SEXO & ESCOLARIDADE & PROFISSÃO \\
\hline 1AI & Masculino & Primário & Estudante \\
\hline 2AI & Masculino & Fundamental & Estudante \\
\hline 3AI & Masculino & Fundamental & Estudante \\
\hline 4AI & Feminino & Fundamental & Estudante \\
\hline 5AI & Masculino & Fundamental & Estudante \\
\hline 6AI & Masculino & Fundamental & Estudante \\
\hline 7AI & Masculino & Fundamental & Estudante \\
\hline 8AI & Masculino & Médio & Estudante \\
\hline 9AI & Feminino & Médio & Estudante \\
\hline 10AI & Feminino & Médio & Estudante \\
\hline 1BI & Feminino & Primário inc. & Vendedora \\
\hline 2BI & Masculino & Médio & Cabeleireiro \\
\hline 3BI & Feminino & Superior inc. & Professora \\
\hline 4BI & Feminino & Médio & Costureira \\
\hline 5BI & Masculino & Sem educação formal & Caminhoneiro \\
\hline 6BI & Feminino & Fundamental inc. & Do lar \\
\hline 7BI & Feminino & Fundamental inc. & Do lar \\
\hline 8BI & Feminino & Fundamental & Digitadora \\
\hline 9BI & Feminino & \begin{tabular}{|l|} 
Sem educação formal \\
\end{tabular} & Do lar \\
\hline 10BI & Feminino & Primário & Do lar \\
\hline 1CI & Feminino & Sem educação formal & Do lar \\
\hline 2CI & Masculino & Primário inc. & Roça \\
\hline 3CI & Feminino & Magistério & Professora \\
\hline 4CI & Feminino & Primário & Do lar \\
\hline 5CI & Masculino & Sem educação formal & Roça \\
\hline 6CI & Feminino & Sem educação formal & Do lar \\
\hline 7CI & Feminino & Sem educação formal & Do lar \\
\hline 8CI & Feminino & Primário & Roça \\
\hline 9CI & Masculino & Sem educação formal & Roça \\
\hline $10 \mathrm{CI}$ & Masculino & Primário & Roça \\
\hline
\end{tabular}


$4^{0}$ quadro - Informantes de São Francisco do Sul

\begin{tabular}{|c|c|c|c|}
\hline INFORMANTES & SEXO & ESCOLARIDADE & PROFISSÃO \\
\hline 1A & Masculino & Primário & Estudante \\
\hline $2 A$ & Feminino & Primário & Estudante \\
\hline $\mathbf{3 A}$ & Feminino & Fundamental & Estudante \\
\hline 4A & Feminino & Fundamental & Estudante \\
\hline $5 \mathrm{~A}$ & Feminino & Fundamental & Estudante \\
\hline 6A & Feminino & Fundamental & Estudante \\
\hline 7A & Feminino & Fundamental & Estudante \\
\hline $\mathbf{8 A}$ & Masculino & Fundamental & Estudante \\
\hline 9A & Masculino & Fundamental & Pescador \\
\hline 10A & Masculino & Médio & Pescador \\
\hline 1B & Masculino & Fundamental inc. & Pescador \\
\hline 2B & Masculino & Médio & Mergulhador \\
\hline 3B & Masculino & Superior & Engenheiro \\
\hline 4B & Feminino & Superior & Diretora escolar \\
\hline 5B & Masculino & Fundamental inc. & Vendedor \\
\hline 6B & Masculino & Fundamental inc. & Pescador \\
\hline 7B & Feminino & Primário & Merendeira \\
\hline 8B & Masculino & Primário & Pescador \\
\hline 9B & Masculino & Primário & Pescador \\
\hline 10B & Masculino & Primário inc. & Pescador \\
\hline $1 \mathrm{C}$ & Masculino & Primário inc. & Caseiro \\
\hline $2 \mathrm{C}$ & Masculino & Primário & Pescador \\
\hline $3 \mathrm{C}$ & Masculino & Sem educação formal & Motorista \\
\hline $4 \mathrm{C}$ & Masculino & Primário inc. & Motorista \\
\hline $5 \mathrm{C}$ & Masculino & Primário & Comerciante \\
\hline 6C & Feminino & Sem educação formal & Do lar \\
\hline $7 \mathrm{C}$ & Masculino & Primário inc. & Pescador \\
\hline $8 \mathrm{C}$ & Feminino & Magistério & Professora \\
\hline 9C & Masculino & Sem educação formal & Pescador \\
\hline $10 \mathrm{C}$ & Masculino & Primário & Pescador \\
\hline
\end{tabular}


$5^{\circ}$ quadro - Informantes da Antiga Região de Itapocorói

\begin{tabular}{|c|c|c|c|}
\hline INFORMANTES & RELIGIÃO & $\begin{array}{l}\text { Contato com meios de } \\
\text { comunicação }\end{array}$ & NATURALIDADE \\
\hline 1AI & Católico & Grande & Piçarras \\
\hline 2AI & Católico & Grande & Piçarras \\
\hline 3AI & Evangélico & \begin{tabular}{|l|} 
Grande \\
\end{tabular} & Itajaí \\
\hline 4AI & Católico & Grande & Penha \\
\hline 5AI & Católico & Grande & Penha \\
\hline 6AI & Católico & Grande & Itajaí \\
\hline 7AI & Católico & Grande & Penha \\
\hline 8AI & Evangélico & Grande & Penha \\
\hline 9AI & Católico & Grande & Penha \\
\hline 10AI & Católico & Grande & Penha \\
\hline 1BI & Evangélico & Pouco & Penha \\
\hline 2BI & Católico & Médio & Piçarras \\
\hline 3BI & Cético & Grande & Joinville \\
\hline 4BI & Católico & Médio & Penha \\
\hline 5BI & Católico & Médio & Joinville \\
\hline 6BI & Evangélico & Pouco & Piçarras \\
\hline 7BI & Evangélico & Grande & Penha \\
\hline 8BI & Católico & Grande & Penha \\
\hline 9BI & Evangélico & Nenhum & Penha \\
\hline 10BI & Católico & Grande & Penha \\
\hline 1CI & Evangélico & Nenhum & Penha \\
\hline $2 \mathrm{CI}$ & Católico & Grande & Penha \\
\hline 3CI & Católico & Médio & Florianópolis \\
\hline 4CI & Evangélico & Nenhum & Penha \\
\hline $5 C I$ & Evangélico & \begin{tabular}{|l|} 
Nenhum \\
\end{tabular} & Penha \\
\hline 6CI & Católico & \begin{tabular}{|l|} 
Nenhum \\
\end{tabular} & Penha \\
\hline $7 \mathrm{CI}$ & Católico & Pouco & Penha \\
\hline $8 \mathrm{CI}$ & Católico & Nenhum & Penha \\
\hline 9CI & Evangélico & \begin{tabular}{|l|} 
Nenhum \\
\end{tabular} & Penha \\
\hline 10CI & Evangélico & Médio & Penha \\
\hline
\end{tabular}


$6^{\circ}$ quadro - Informantes de São Francisco do Sul

\begin{tabular}{|c|c|c|c|}
\hline INFORMANTES & RELIGIÃO & $\begin{array}{l}\text { Contato com meios de } \\
\text { comunicação de massa }\end{array}$ & NATURALIDADE \\
\hline 1A & Católico & Grande & São Francisco do Sul \\
\hline $2 \mathrm{~A}$ & Católico & Grande & \begin{tabular}{|l|} 
Joinville \\
\end{tabular} \\
\hline $\mathbf{3 A}$ & Evangélico & Grande & São Francisco do Sul \\
\hline $4 A$ & Católico & Grande & São Francisco do sul \\
\hline $5 A$ & Católico & Grande & São Francisco do Sul \\
\hline 6A & Evangélico & Grande & São Francisco do Sul \\
\hline $7 A$ & Católico & Grande & São Francisco do Sul \\
\hline $8 \mathrm{~A}$ & Evangélico & Grande & São Francisco do Sul \\
\hline 9A & Católico & Grande & São Francisco do Sul \\
\hline 10A & Católico & Grande & São Francisco do Sul \\
\hline 1B & Cético & Grande & Joinville \\
\hline 2B & Católico & Grande & São Francisco do Sul \\
\hline 3B & Católico & Grande & São Francisco do Sul \\
\hline 4B & Católico & Grande & São Francisco do Sul \\
\hline $5 B$ & Evangélico & Grande & São Francisco do Sul \\
\hline 6B & Católico & Grande & São Francisco do Sul \\
\hline 7B & Católico & Grande & São Francisco do Sul \\
\hline 8B & Católico & Grande & São Francisco do Sul \\
\hline 9B & Evangélico & Médio & São Francisco do Sul \\
\hline 10B & Católico & Médio & São Francisco do Sul \\
\hline $1 \mathrm{C}$ & Católico & Médio & Itajuba - Barra Velha \\
\hline $2 \mathrm{C}$ & Católico & Grande & São Francisco do Sul \\
\hline $3 C$ & Católico & Grande & São Francisco do Sul \\
\hline $4 \mathrm{C}$ & Católico & \begin{tabular}{|l|} 
Grande \\
\end{tabular} & Tubarão \\
\hline $5 C$ & Católico & Grande & Penha \\
\hline 6C & Católico & Médio & São Francisco do Sul \\
\hline $7 \mathrm{C}$ & Católico & Grande & São Francisco do Sul \\
\hline $8 C$ & Católico & Grande & São Francisco do Sul \\
\hline $9 \mathrm{C}$ & Católico & Médio & São Francisco do Sul \\
\hline $10 \mathrm{C}$ & Católico & Grande & São Francisco do Sul \\
\hline
\end{tabular}


$2^{\circ}$ quadro - Informantes de São Francisco do Sul

\begin{tabular}{|c|c|c|c|}
\hline INFORMANTES & INICIAIS & IDADE & Data da entrevista \\
\hline $\mathbf{1}^{\mathrm{A}}$ & B.L.M.C. & 08 & 19.07. 2004 \\
\hline $2^{A}$ & T.S.M. & 10 & 19.07. 2004 \\
\hline $3^{A}$ & D.A.F. & 11 & 21.07 .2004 \\
\hline 4A & T.A.M. & 11 & 19.07. 2004 \\
\hline $5 \mathrm{~A}$ & B.P. & 13 & 16.07. 2004 \\
\hline 6A & F.S.G & 13 & 16.07. 2004 \\
\hline 7A & B.M.S. & 14 & 16.07. 2004 \\
\hline $\mathbf{8 A}$ & D.P.F. & 16 & 21.07 .2004 \\
\hline 9A & F.C.M. & 17 & 16.07. 2004 \\
\hline 10A & G.S.O. & 20 & 16.07. 2004 \\
\hline 1B & M.S. & 30 & 17.07. 2004 \\
\hline 2B & M.F.C. & 33 & 17.07. 2004 \\
\hline 3B & A.A.P. & 35 & 20.07. 2004 \\
\hline 4B & M.B.C. & 36 & 16.07. 2004 \\
\hline 5B & P.F.J. & 38 & 19.07. 2004 \\
\hline 6B & E.L.G. & 46 & 17.07. 2004 \\
\hline 7B & J.O.M. & 49 & 18.07. 2004 \\
\hline 8B & C.F.P. & 52 & 18.07. 2004 \\
\hline 9B & J.T. & 54 & 18.07. 2004 \\
\hline 10B & J.J.A. & 55 & 18.07. 2004 \\
\hline $1 \mathrm{C}$ & J.F.B. & 60 & 21.07 .2004 \\
\hline $2 \mathrm{C}$ & O.P. & 62 & 16. 07. 2004 \\
\hline $3 \mathrm{C}$ & F.D.O. & 66 & 21.07. 2004 \\
\hline $4 \mathrm{C}$ & A.B. & 68 & 21.07. 2004 \\
\hline $5 C$ & A.F. & 71 & 20.07. 2004 \\
\hline 6C & E.P.O. & 73 & 19.07. 2004 \\
\hline $7 C$ & A.J.J.F. & 79 & 16. 07. 2004 \\
\hline $8 \mathrm{C}$ & C.O.M & 80 & 20.07. 2004 \\
\hline $9 \mathrm{C}$ & E.O. & 82 & 19.07. 2004 \\
\hline $10 \mathrm{C}$ & A.C. & 86 & 20.07. 2004 \\
\hline
\end{tabular}


$3^{0}$ quadro - Informantes da Antiga Região de Itapocorói

\begin{tabular}{|c|c|c|c|}
\hline INFORMANTES & SEXO & ESCOLARIDADE & PROFISSÃO \\
\hline 1AI & Masculino & Primário & Estudante \\
\hline 2AI & Masculino & Fundamental & Estudante \\
\hline 3AI & Masculino & Fundamental & Estudante \\
\hline 4AI & Feminino & Fundamental & Estudante \\
\hline 5AI & Masculino & Fundamental & Estudante \\
\hline 6AI & Masculino & Fundamental & Estudante \\
\hline 7AI & Masculino & Fundamental & Estudante \\
\hline 8AI & Masculino & Médio & Estudante \\
\hline 9AI & Feminino & Médio & Estudante \\
\hline 10AI & Feminino & Médio & Estudante \\
\hline 1BI & Feminino & Primário inc. & Vendedora \\
\hline 2BI & Masculino & Médio & Cabeleireiro \\
\hline 3BI & Feminino & Superior inc. & Professora \\
\hline 4BI & Feminino & Médio & Costureira \\
\hline 5BI & Masculino & Sem educação formal & Caminhoneiro \\
\hline 6BI & Feminino & Fundamental inc. & Do lar \\
\hline 7BI & Feminino & Fundamental inc. & Do lar \\
\hline 8BI & Feminino & Fundamental & Digitadora \\
\hline 9BI & Feminino & Sem educação formal & Do lar \\
\hline 10BI & Feminino & Primário & Do lar \\
\hline 1CI & Feminino & Sem educação formal & Do lar \\
\hline 2CI & Masculino & Primário inc. & Roça \\
\hline 3CI & Feminino & Magistério & Professora \\
\hline 4CI & Feminino & Primário & Do lar \\
\hline 5CI & Masculino & Sem educação formal & Roça \\
\hline 6CI & Feminino & Sem educação formal & Do lar \\
\hline 7CI & Feminino & Sem educação formal & Do lar \\
\hline 8CI & Feminino & Primário & Roça \\
\hline 9CI & Masculino & Sem educação formal & Roça \\
\hline 10CI & Masculino & Primário & Roça \\
\hline
\end{tabular}


$4^{0}$ quadro - Informantes de São Francisco do Sul

\begin{tabular}{|c|c|c|c|}
\hline INFORMANTES & SEXO & ESCOLARIDADE & PROFISSÃO \\
\hline 1A & Masculino & Primário & Estudante \\
\hline $2 A$ & Feminino & Primário & Estudante \\
\hline 3A & Feminino & Fundamental & Estudante \\
\hline 4A & Feminino & Fundamental & Estudante \\
\hline $5 \mathrm{AA}$ & Feminino & Fundamental & Estudante \\
\hline 6A & Feminino & Fundamental & Estudante \\
\hline $7 \mathbf{A}$ & Feminino & Fundamental & Estudante \\
\hline $\mathbf{8 A}$ & Masculino & Fundamental & Estudante \\
\hline 9A & Masculino & Fundamental & Pescador \\
\hline 10A & Masculino & Médio & Pescador \\
\hline 1B & Masculino & Fundamental inc. & Pescador \\
\hline 2B & Masculino & Médio & Mergulhador \\
\hline 3B & Masculino & Superior & Engenheiro \\
\hline 4B & Feminino & Superior & Diretora escolar \\
\hline 5B & Masculino & Fundamental inc. & Vendedor \\
\hline 6B & Masculino & Fundamental inc. & Pescador \\
\hline 7B & Feminino & Primário & Merendeira \\
\hline 8B & Masculino & Primário & Pescador \\
\hline 9B & Masculino & Primário & Pescador \\
\hline 10B & Masculino & Primário inc. & Pescador \\
\hline $1 \mathrm{C}$ & Masculino & Primário inc. & Caseiro \\
\hline $2 \mathrm{C}$ & Masculino & Primário & Pescador \\
\hline $3 \mathrm{C}$ & Masculino & Sem educação formal & Motorista \\
\hline $4 \mathrm{C}$ & Masculino & Primário inc. & Motorista \\
\hline $5 \mathrm{C}$ & Masculino & Primário & Comerciante \\
\hline $6 \mathrm{C}$ & Feminino & Sem educação formal & Do lar \\
\hline 7C & Masculino & Primário inc. & Pescador \\
\hline $8 \mathrm{C}$ & Feminino & Magistério & Professora \\
\hline 9C & Masculino & Sem educação formal & Pescador \\
\hline 10C & Masculino & Primário & Pescador \\
\hline
\end{tabular}


$5^{\circ}$ quadro - Informantes da Antiga Região de Itapocorói

\begin{tabular}{|c|c|c|c|}
\hline INFORMANTES & RELIGIÃO & $\begin{array}{l}\text { Contato com meios de } \\
\text { comunicação }\end{array}$ & NATURALIDADE \\
\hline 1AI & Católico & Grande & Piçarras \\
\hline 2AI & Católico & Grande & Piçarras \\
\hline 3AI & Evangélico & \begin{tabular}{|l|} 
Grande \\
\end{tabular} & Itajaí \\
\hline 4AI & Católico & Grande & Penha \\
\hline 5AI & Católico & Grande & Penha \\
\hline 6AI & Católico & Grande & Itajaí \\
\hline 7AI & Católico & Grande & Penha \\
\hline 8AI & Evangélico & Grande & Penha \\
\hline 9AI & Católico & Grande & Penha \\
\hline 10AI & Católico & Grande & Penha \\
\hline 1BI & Evangélico & Pouco & Penha \\
\hline 2BI & Católico & Médio & Piçarras \\
\hline 3BI & Cético & Grande & \begin{tabular}{|l|} 
Joinville \\
\end{tabular} \\
\hline 4BI & Católico & Médio & Penha \\
\hline 5BI & Católico & Médio & \begin{tabular}{|l|} 
Joinville \\
\end{tabular} \\
\hline 6BI & Evangélico & Pouco & Piçarras \\
\hline 7BI & Evangélico & Grande & Penha \\
\hline 8BI & Católico & Grande & Penha \\
\hline 9BI & Evangélico & Nenhum & Penha \\
\hline 10BI & Católico & Grande & Penha \\
\hline 1CI & Evangélico & Nenhum & Penha \\
\hline $2 \mathrm{CI}$ & Católico & Grande & Penha \\
\hline 3CI & Católico & Médio & Florianópolis \\
\hline 4CI & Evangélico & \begin{tabular}{|l|} 
Nenhum \\
\end{tabular} & Penha \\
\hline $5 C I$ & Evangélico & Nenhum & Penha \\
\hline 6CI & Católico & \begin{tabular}{|l|} 
Nenhum \\
\end{tabular} & Penha \\
\hline $7 \mathrm{CI}$ & Católico & Pouco & Penha \\
\hline $8 \mathrm{CI}$ & Católico & \begin{tabular}{|l|} 
Nenhum \\
\end{tabular} & Penha \\
\hline 9CI & Evangélico & Nenhum & Penha \\
\hline 10CI & Evangélico & Médio & Penha \\
\hline
\end{tabular}


$6^{\circ}$ quadro - Informantes de São Francisco do Sul

\begin{tabular}{|c|c|c|c|}
\hline INFORMANTES & RELIGIÃO & $\begin{array}{l}\text { Contato com meios de } \\
\text { comunicação de massa }\end{array}$ & NATURALIDADE \\
\hline 1A & Católico & Grande & São Francisco do Sul \\
\hline $2 A$ & Católico & Grande & Joinville \\
\hline $\mathbf{3 A}$ & Evangélico & \begin{tabular}{|l|} 
Grande \\
\end{tabular} & São Francisco do Sul \\
\hline $4 A$ & Católico & Grande & São Francisco do sul \\
\hline $5 \mathrm{~A}$ & Católico & Grande & São Francisco do Sul \\
\hline 6A & Evangélico & Grande & São Francisco do Sul \\
\hline 7A & Católico & Grande & São Francisco do Sul \\
\hline $8 \mathrm{~A}$ & Evangélico & Grande & São Francisco do Sul \\
\hline 9A & Católico & Grande & São Francisco do Sul \\
\hline 10A & Católico & Grande & São Francisco do Sul \\
\hline 1B & Cético & Grande & Joinville \\
\hline 2B & Católico & Grande & São Francisco do Sul \\
\hline 3B & Católico & Grande & São Francisco do Sul \\
\hline 4B & Católico & Grande & São Francisco do Sul \\
\hline $5 B$ & Evangélico & Grande & São Francisco do Sul \\
\hline 6B & Católico & Grande & São Francisco do Sul \\
\hline 7B & Católico & Grande & São Francisco do Sul \\
\hline 8B & Católico & Grande & São Francisco do Sul \\
\hline 9B & Evangélico & Médio & São Francisco do Sul \\
\hline 10B & Católico & Médio & São Francisco do Sul \\
\hline $1 \mathrm{C}$ & Católico & Médio & Itajuba - Barra Velha \\
\hline $2 \mathrm{C}$ & Católico & Grande & São Francisco do Sul \\
\hline $3 \mathrm{C}$ & Católico & Grande & São Francisco do Sul \\
\hline $4 \mathrm{C}$ & Católico & Grande & Tubarão \\
\hline $5 C$ & Católico & Grande & Penha \\
\hline 6C & Católico & Médio & São Francisco do Sul \\
\hline $7 \mathrm{C}$ & Católico & Grande & São Francisco do Sul \\
\hline $8 C$ & Católico & Grande & São Francisco do Sul \\
\hline $9 \mathrm{C}$ & Católico & Médio & São Francisco do Sul \\
\hline 10C & Católico & Grande & São Francisco do Sul \\
\hline
\end{tabular}


ANEXO 2

TRANSCRIÇÕES DAS GRAVAÇÕES

CRITÉRIOS ESTRUTURAIS DE TRANSCRIÇÃO DAS ENTREVISTAS 
Para a estrutura das entrevistas, seguir-se-ão as orientações das NORMAS DE TRANSCRIÇÃO DO NURC ${ }^{176}$.

\begin{tabular}{|c|c|c|}
\hline OCORRÊNCIAS & SINAIS & EXEMPLIFICAÇÃO \\
\hline $\begin{array}{l}\text { Incompreensão de palavras } \\
\text { ou segmentos }\end{array}$ & () & $\begin{array}{l}\text { na nossa comunidade não ( ) } \\
\text {.. nada não (3CI) }\end{array}$ \\
\hline Hipótese do que se ouviu & (hipótese) & dezesseis neto... dois (bisneto)... (3C) \\
\hline Entonação fática & maiúscula & tenho uma familia GRANde (3C) \\
\hline Truncamento & / & a Santa Li / história de Santa Lídia (3CI) \\
\hline Silabação & - & in - crí-vel (5C) \\
\hline Interrogação & $?$ & na juventude? (3C) \\
\hline $\begin{array}{l}\text { Comentário descritivo do } \\
\text { transcritor }\end{array}$ & $(($ minúscula $))$ & eu ganhava pra ensinar... ((professora) (3CI) \\
\hline Qualquer pausa & $\ldots$ & trabalhei muito... eu... trabalhei... (3C) \\
\hline $\begin{array}{l}\text { Prolongamento de vogal } \\
\text { (aumenta com a intensidade) }\end{array}$ & $:$ & e:.... a juventude $(3 \mathrm{C})$ \\
\hline Reprodução da fala de outro & “" & aí eles “ai o que é isso?” (6C) \\
\hline $\begin{array}{l}\text { Superposição ou tomada de } \\
\text { vozes }\end{array}$ & $\mathrm{L}$ & $\begin{array}{l}\text { L1 - ela é grande? como } \\
\quad \mathrm{L} 2 \text { - ela é grande }(5 \mathrm{AI})\end{array}$ \\
\hline
\end{tabular}

\section{Observações:}

- Iniciais maiúsculas: só para nomes próprios ou para siglas.

- Fáticos: AH, ahn, uhn etc.

- Palavras estrangeiras estão em itálico.

- Os números estão escritos por extenso.

- Não se anota o cadenciamento da frase.

- Não se indica o ponto de exclamação.

- Não se utilizam os sinais de pausa da língua escrita: vírgula, ponto-e-vírgula, ponto final, dois pontos. Como vimos no quadro, as reticências marcam qualquer tipo de pausa.

- Os sinais podem aparecer combinados: e::... (alongamento e pausa).

\section{CRITÉRIOS DE TRANSCRIÇÃO ORTOGRÁFICA DAS ENTREVISTAS}

\footnotetext{
${ }^{176}$ Seguir-se ão os critérios estruturais do Projeto NURC, projeto de estudo da norma lingüística urbana culta, com algumas mudanças. Adaptamos o quadro fornecido por DINO PRETI (1999 : 11-2), com exemplos retirados dos corpora em estudo, e as observações também.
} 
Com o intuito de divulgar ao máximo o conteúdo das entrevistas, optou-se por uma transcrição ortográfica, com algumas adaptações.

Foram evitadas transcrições intermediárias, do tipo "qui é qui cê vai fazê oji?", que são tão comuns em trabalhos de sociolingüística, dialetologia e geolingüística. As transcrições intermediárias amiúde são preconceituosas (apenas o informante é transcrito assim e não o entrevistador, frisando, assim, o caráter exótico do informante, que não tem instrução acadêmica como o entrevistador). Além disso, os fenômenos apontados nas transcrições intermediárias são normalmente elementos comuns ao português brasileiro de modo geral (como a queda do $r$ do infinitivo, somente presente na fala policiada e formal). Não bastasse isso, as transcrições desse tipo são inconsistentes (ora grafam bunitu, ora bonito, ao sabor da atenção de quem transcreve) e seguem parcialmente as regras de acentuação da norma culta (normalmente acentua-se fazê, mas não bunitu). Sendo assim, optou-se pela transcrição ortográfica, com os seguintes ajustes:

- Todo $-O$ e $-e$ postônico deve ser interpretado como [i] e [u], exceto se for indicado: sapo se lê ['sapu], mas sap[o] se lê ['sapo]. As pretônicas só foram analisadas quando destoavam muito da forma padrão do sudeste: bonito se lê [bu'nitu], mas [u]fende se lê [u'fẽdi].

- A seqüência -ou- é sempre monotongada como [o], exceto quando indicado: falou se lê [fa'lo], mas fal[ow] se lê [fa'low]. A única exceção é tô (forma aferética do verbo estar na primeira pessoa do singular), forma que já é tradicionalmente preferida pela grafia, em detrimento de tou.

- O mesmo ocorre com - ei- antes de $r, x, c h, j$ : monotonga-se, segundo o padrão do português brasileiro, como [e], exceto quando indicado: deixei se lê [de'fej], mas $d[e j] x e i$ se lê [dej'fej].

- $\mathrm{O}-r$ do infinitivo nunca se pronuncia: falar se lê [fa'la], mas fala [r] se lê [fa'lar] (exceção: verbo pôr). $\mathrm{O}-r$ - em posição de coda se lê [r]: mar se lê ['mar], mas $m a[x]$ se lê ['max]. Quando não for pronunciado em outras palavras (substantivos, verbo pôr, futuro do subjuntivo de verbos, adjetivos, pronomes etc.), é indicado como [Ø]: pescador se lê [peska'dor], mas pescado[Ø] se lê [peska'do].

- $\mathrm{O}-l$-, em posição de coda se lê [w]: alto se lê ['awtu], mas $a$ [ł] to se lê ['ałtu].

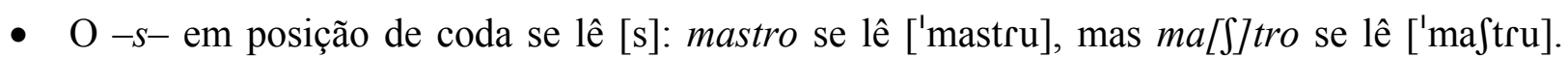
Quando o $-s$ final das primeiras pessoas do plural não são pronunciadas, usa-se [Ø]: vamos se lê ['vemus] e vamo[Ø] se lê ['vemu].

- Palavras oxítonas ou monossílabas tônicas terminadas em $-z,-s$ têm o iode característico de outras falas brasileiras: vez se lê ['vejs] e $d e z$ ['dejs]. Toda vez que outras leituras ocorrerem, o mesmo vale para o pronome nós e para a conjunção mas, que normalmente se lê [majs]. Exemplos: $m a[\mathrm{~s}]$ se lê ['mas], $m a\left[\int\right]$ se lê ['maf], $m a\left[j \int\right]$ se lê ['majS], $m a[\varnothing]$ se lê ['ma] etc.

- As conjunções ou e $e$ se lêem [o] e [i] respectivamente; os artigos $o$, os se lêem [u] e [us] respectivamente.

- O advérbio de negação não se lê [nũ] antes de verbos e [ñ̃w] nas demais situações.

- As seqüências com o, com a, com os, com as se lêem [ku], [kus], [ka], [kas]. No entanto, mantiveram-se as formas pra, pro, pras, pros, prum, pruns e também as formas sincopadas pa, po, pas, pos, que ocorrem esporadicamente tanto no Brasil, quanto em Portugal.

- Foi indicado quando o $b$ da palavra também não era pronunciado: tam[Ø]ém.

- Foram indicadas as diversas formas da desinência de terceira pessoa do plural nos verbos: canta[ru], canta[rũ], canta[rõ], canta[vu], canta[vũ] etc. 
São peculiaridades do catarinense as seguinte produções:

- Os $-t i-,-d i-$ e equivalentes ( $-t e,-d e$ em posição postônica) devem ser lidos como [ti] e [di] e não como [t $\mathrm{fi}$ ] e [dzi], exceto quando indicado: tio se lê ['tiw], mas $\left.t / \int\right] i o$ se lê ['t $\mathrm{t}$ iw].

- A terminação - ndo dos gerúndios se lê com o [d] pronunciado: falando se lê [fa'lẽ du] e não [fa'lenu].

A opção pela transcrição ortográfica não deve ser confundida como uma tentativa de "corrigir" o texto pela norma culta. Todas as características da fala foram mantidas: a colocação pronominal e o uso de ele(s), ela(s) como objeto direto, as concordâncias e a falta de concordância: os outro, o pessoal vieram. Idem para regências, como ir em etc. O infinitivo de vir foi grafado vim quando o $i$ era nasal.

\section{ÍNDICE DAS TRANSCRIÇÕES}

\begin{tabular}{|c|c|c|c|c|c|c|c|c|c|c|c|}
\hline & página & & página & & página & & página & & página & & página \\
\hline $1 \mathrm{AI}$ & 184 & $1 \mathrm{BI}$ & 231 & $1 \mathrm{CI}$ & 255 & $1 \mathrm{~A}$ & 283 & 1B & 320 & $1 \mathrm{C}$ & 356 \\
\hline $2 \mathrm{AI}$ & 198 & 2BI & 234 & $2 \mathrm{CI}$ & 257 & $2 \mathrm{~A}$ & 288 & $2 \mathrm{~B}$ & 324 & $2 \mathrm{C}$ & 359 \\
\hline $3 \mathrm{AI}$ & 201 & $3 \mathrm{BI}$ & 236 & $3 \mathrm{CI}$ & 260 & $3 \mathrm{~A}$ & 291 & $3 \mathrm{~B}$ & 329 & $3 \mathrm{C}$ & 364 \\
\hline $4 \mathrm{AI}$ & 204 & 4BI & 239 & $4 \mathrm{CI}$ & 263 & $4 \mathrm{~A}$ & 295 & 4B & 332 & $4 \mathrm{C}$ & 366 \\
\hline $5 \mathrm{AI}$ & 209 & $5 \mathrm{BI}$ & 241 & $5 \mathrm{CI}$ & 265 & $5 \mathrm{~A}$ & 298 & $5 B$ & 335 & $5 \mathrm{C}$ & 370 \\
\hline $6 \mathrm{AI}$ & 214 & $6 \mathrm{BI}$ & 243 & $6 \mathrm{CI}$ & 268 & $6 \mathrm{~A}$ & 302 & $6 \mathrm{~B}$ & 339 & $6 \mathrm{C}$ & 373 \\
\hline $7 \mathrm{AI}$ & 219 & $7 \mathrm{BI}$ & 246 & $7 \mathrm{CI}$ & 271 & $7 \mathrm{~A}$ & 305 & $7 B$ & 343 & $7 \mathrm{C}$ & 377 \\
\hline $8 \mathrm{AI}$ & 223 & $8 \mathrm{BI}$ & 249 & $8 \mathrm{CI}$ & 275 & $8 \mathrm{~A}$ & 308 & $8 B$ & 345 & $8 \mathrm{C}$ & 380 \\
\hline $9 \mathrm{AI}$ & 224 & 9BI & ---- & 9CI & 278 & $9 \mathrm{~A}$ & 312 & 9B & 347 & $9 \mathrm{C}$ & 373 \\
\hline $10 \mathrm{AI}$ & 229 & 10BI & 252 & $10 \mathrm{CI}$ & 280 & $10 \mathrm{~A}$ & 316 & 10B & 353 & $10 \mathrm{C}$ & 383 \\
\hline
\end{tabular}

L1 - L. F. - ehn::... conta pra mim o que você gosta de fazer pra se divertir...

L2 - jogar videogame e::.... só...

L1 - só jogar videogame?

L2 - uhn... brincar... bola... vôlei... basquete

no videogame?...

L L1 - e o que / que você... que jogo que você mais gosta

L2 - corrida... corrida e futebol...

L1 - futeBOL? E você gosta de assistir televisão?

L2 - GOSto...

L1 - e o que que você gosta de assistir na televisão?

L2 - desenho...

L1 - que desenho? 
L2 - é::... Pernalonga... é::... Pica-pau e só (todo dia) Tom e Jerry...

L L1 - e você gosta de assistir filme?

L2 - gosto...

L1 - que filme legal você assistiu?

L2 - foi o:.... Sexto Sentido...

L1 - como que é esse filme? que eu não vi ainda...

L2 - é:.... BOM...

L1 - conta a história dele pra mim?

L2 - AHN::...

L L1 - AHN?

L2 - tô com vergonha...

L1 - com ver-go-NHA? ahn... eu não AcreDITO... então vamos mudar de assunto então... vamos falar um pouquinho da escola... o que você está aprendendo na escola?

L2 - ( ) matemática... arte... é:.... religião... é:: português... só...

L1 - qual é a matéria que você mais gosta?

L2 - é::... matemática

L L1 - mateMÁtica?... gosta de fazer continha... então... e no Beto Carrero... já

foi?

L2 - não

L1 - NÃO...

L2 - eu ia... mas... o ingresso...

L1 - e você falou que foi pra São Paulo... né?

L2 - Ahn... Ahn

L1 - passou uma semana lá? e com quem que você foi? onde você ficou? o que que você conheceu?

( )

$\mathrm{L}_{\mathrm{L} 2}$ - eu fiquei na casa da minha madrinha... ( ) ((tossiu))

L1 - ficou na casa da sua madrinha?

L2 - uhn... uhn

L1 - e que você viu / onde você foi lá em São Paulo... você passeou... (não passeou)

LL2- passeei... vi o eroport[o]...

vi lá perto... saí... fui no... fui no... $\operatorname{mercad[o]...~aí~(fiquei)~no~shopping~mas~não~deu...~fui~no~}$ metrô...

L1 - AHN... andou de metrô?

L2 - NÃO... ( ) ((barulho de automóvel))

L1 - e:: você falou que gosta de desenho assim do...

L1 - Pernalonga

L L2 - Pernalonga

L L2 - e do Pica-pau...

L1 - e como que é o Pernalonga?

L2 - o Pernalonga é um coelho que... ele gostava/ele era bem (assanhado) ele ficava brincando quando o outro tentava caçar... ( )/ele ia pra baixo/ele/ele o Pernalonga soltava a arma... colocava o cano e entortava... colocava o/assim (perto) pra acertar bem...

L1 - ((risos)) e como que é o desenho do Pica-pau?

L2 - o Pica-pau é... um/é um... passarinho que ele gostava de picar árvore... picar/aí ele pegava aí.. os outro tentava matar ele... quando uma vez ele tava voando com os pato... ( ) com... não sei bem... aí ele pegou e:.... fingiu que tava sentindo/na hora que ele tava caindo... ele fez um monte de 
palhaçada... pegou o balão... encheu encheu encheu... ( ) aí... aí... o:: Pica-pau ((imitou a risada do Pica-pau))...

L1 - (daquele jeito) e do Pokemon... do Digimon...

L2 - Digimon eu gosto... ( )...

L1 - gosTA?

L L2 - Digimon...

L1 - e como que é o Digimon assim?

L2 - é um:: / ( ) Teka... (passou)... Teka Karen... quer dizer... Teka Karen ( ) um livrinho... eles fazem a / um fazem... vira o digimon no mundo do digimon pra lutar com os outro... ( ) e abri o portal... e:.... ( ) tinha um monte de digimon...

L1 - se você pudesse ser um super-herói... quem você seria? e por quê?

L L2 - Batman...

L1 - por que o Batman? o P. queria ser o homem-aranha porque ele gosta de subir nas coisas...

L2 - eu queria ser o Batman porque eu gosto de [a]voar...

L1 - gosta de voar?

$$
\text { L L2 - É }
$$

L L1 - É:... e:.... você gosta de morar aqui?

L2 - gosto...

L1 - e na praia... você gosta de ir na praia?

L L2 - vou

L1 - o que que você gosta de fazer na praia? do que que você brinca?

( ) de ir na praia... de mergulhar... brincar de bola na água...

L L2 - gosto de brincar:....

L1 - É:... e você tem muitos primos?

L2 - tenho

L1 - tem muitos amiguinhos?

L2 - tenho

L1 - quando vocês estão todos juntos... o que vocês fazem... além de bagunça...

L2 - bola...

L1 - bola? ... e você deixa sua mamãe muito maluca?... faz muita baGUNÇA?...

L2 - uhn... não...

L1 - NÃO

L2 - NÃO... eu fazia um pouco... agora não faço mais...

L1 - e::... você fez alguma bagunça que... que mamãe ficou brava? ( $)$

L L2 - JÁ... uma vez que eu tava brincando ela / eu tava brincando no quarto e meu pai tava dormindo... ela disse pra eu sair dalí... eu saí... saí (enfim) ela ficou brava...

L1 - e ela ficou brava com você?

L2 - uhn... uhn...

L1 - e::... quando você falou que gosta de fazer / matemática...

L2 - uhn... uhn...

L1 - e quando você ficar granDÃO assim... o que que você pensa em fazer?.... já pensou... A:.... eu quero ser médico...

L L2 - quero ser médico...

L1 - É:: ( ) eu achei você com cara de médico... e porque que você queria ser médico?

L2 - É:... não sei...

L1 - sabe?... e:... você estuda longe daqui?

L2 - não 
L1 - e você gosta de carro?

L2 - gosto

L1 - que carro você gosta?

L2 - é... o carro que eu gosto é... o Corsa... o... ahn... uma Ferrari... ((risos)) né?

L1 - e você gosta de bicho?

L2 - gosto

L1 - que bichinhos você gosta?

L2 - gato e cachorro...

L1 - você tem gato... cachorro?...

L2 - tenho cachorr[o]... ( )

L1 - como é o nome dele... que raça que ele é... como que é o seu cachorro?

L2 - é Pincher...

L1 - Pincher?... daquele pequeninho... vivem latindo...

L2 - uhn... uhn...

L1 - gosta muito dele?

L2 - gosto...

L1 - e de cavalo... você gosta?

L2 - não...

L1 - nunca andou?

L2 - não...

L1 - gosta de andar de bicicleta?

L2 - gosto

L1 - tem bicicleta?

L2 - tenho...

L1 - como é a sua bicicleta?

L2 - é:.... uma azul... uma azul...

L1 - anda bastante de bicicleta?

L2 - ando

P. G. P. (L2)

L1 - P.... você falou pra mim que está fazendo a quinta série... né? e::: onde você estuda?

L2 - eu estudo no Colégio Alexandre Guilherme ( )

L1 - Alexandre?

L L2 - Guilherme Figueiredo.

L1 - e que matéria você estuda?

L2 - eu estudo português... inglê[ $\left.\int\right]$... estudo história... estudo geografia... estudo ciências... estudo (

) ... educação física... matemática ( )

L1 - e qual é a matéria que você mais gosta?

L2 - a matéria que eu mais gosto é português...

L1 - por quê?

L L2 - Ahn? A::: porque eu me dou muito bem assim com professor... né?... acho o professor legal... e e o... ( )

L1 - ( ) e o que você gosta de ver na televisão?

L2 - eu?

L1 - é... 
L2 - eu gosto de ver filmes (...) desenhos... que passa à tarde... eu gosto de ver filme assim de ação::... de:: (desse tipo)

L1 - e::: fala pra mim de um filme que você tenha assistido

L L2 - Ahn

L L1 - NÉ.. qual filme que você

gostou, que você tenha assistido ultimamente?

L2 - A::: o filme que eu gostei... que eu assisti ultimamente... foi do:.:... foi do... Simão... O Fantasma Trapalhão que eu vi uma vez em casa com Didi...

L1 - você pode contar a história do filme pra mim?

L2 - SIM... era que... uhn... o Didi e o Dedé...né... eles tinham um patrão que... compraram um castelo... assim... bonito né? só que era mal assombrado... daí chegam / daí chegam lá... uhn... eles queriam ver o fantasma... assim né?... que eles gostavam muito dessas coisas... daí... o Didi provocou o fantasma... o fantasma veio... é:: assustou eles... e no fim / é::: daí é:: eles acabaram fazendo amizade... fizeram amizade ficaram amigos ficaram / brincaram um monte... foram ao cinema... jogaram bola... brincaram muito assim de assustar... brincar de assustar a casa assim... bem massa...

L1 - e você gosta de assistir filme de terror?

L2 - alguns... depende (de como é né?)... depende do filme...

L1 - você assistiu algum filme de terror legal?

L2 - JÁ...

L1 - qual filme?

L L2 - Jason... parte oito...

L1 - você assistiu? eu não assisti... conta a história dele pra mim?

L2 - é que:.... o Jason... ele queria se vingar... né? de todo mundo né? daí:... ele foi assim... na parti oito é que ele tava no meio DA tubulação de água né? tava debaixo ( ) né? por baixo dos canos de esgoto... perseguindo algumas pessoas assim né? daí tinham:: / daí tinham dois caras que tavam correndo dele... e acharam um velhote / que falou assim $\mathrm{OH} . .$. a tubulação da água abre às oito horas... falta cinco minutos pra (abrir) / foi guiando eles... até que o Jason encontra eles e mata o velhote né? ... daí... a mulher veio correndo com o cara... daí ela jogou... ácido na cara dele... e ele tirou a máscara assim né?... daí mostrou que ele era um monstro... (ela) saiu correndo pela tubulação da água de esgoto... depois (de escapar assim) ( ) daí aquela água pegou no Jason... né? aí ele começou / tentou se segurar... mas não conseguiu... daí ele morreu... morreu... daí:... ele tava assim... jogado no chão... daí cai um raio na estátua da Liberdade... daí ele vira criança de volta...

criança?

L L1 - quem virou

L2 - o Jason... caiu um raio na estátua da Liberdade aí ele virou criança (de volta)

L1 - e::... conta pra mim... o que você gosta de fazer pra se divertir?

L L2 - EU? Ahn... eu sou mais de

jogar videogame... né?... jogar videogame pra me divertir...

L1 - qual joguinho que você mais gosta?

L2 - AHN... tem um MONte... eu gosto de jogos de corrida... de luta...

L1 - qual jogo de luta você gosta e por quê?

L2 - eu gosto:.... no joguinho de luta... o que eu gosto mais é de (Trip... Trip três...)

L1 - e como que é esse jogo?

L2 - o jogo é assim é::... tem é / tem um lutador de artes marciais... lutador de capoeira... tem:....

lutador de... é / como é?... luta livre... tem lutador de luta pra / pra... ( )

L1 - e::... eu escutei né? que você viajou pra São Paulo

L2 - (foi meu primo)... 
L1 - AHN... tá... e você já fez alguma viagem legal?

L2 - Eu JÁ... quando eu fui eu / e / com cole / eu fui numa viagem com colégio até Floripa... Florianópolis... lá no museu...

L1 - conta pra mim essa viagem... o que que você viu... o que você mais gostou... se você se divertiu...

L2 - Ahn... tinha um monte de coisa assim / era / um / era um museu do mar... assim NÉ?... do mar... (dos) antigo... era assim / o Museu Histórico de Santa Catarina... daí tinha... tinha baleia... eu vi uma baleia lá... baleia de ( ) tinha lancha... lá antiga... bem bonita... tinha... e: como é que eles fazia a pesca... tinha:.... um canhão com arpão... que eles pescavam baleia... tinha um quadro lá... foi pintado... em mil seiscentos / mil novecentos e sessenta...

L1 - e você tem muitos amigos?

L2 - EU... uhn:... no colégio eu tenho mais... mais / fora do colégio eu tenho pouco... bem pouco[S]...

L1 - Quando você está com seus amigos... do que você gosta de brincar?

L2 - AHN... brincar de pega-pega... esconde-esconde... é.... joga / jogar bola assim... é... jogar vôlei... que eu gosto ( )... AHN... jogar bat também... que eu jogo assim né?

L2 - bat... taco... (uns) falam que é taco né?... (mas diz) que é bat...

$$
\text { L L1 - joga o quê? }
$$

L1 - e você gosta da praia? você gosta da praia?...

L2 - gosto... gosto bastante...

L1 - e o que você costuma fazer quando você vai pra praia?

L2 - Ahn... eu do / vou:.... eu fico mais assim na água né? dou galhambote... (faço) um monte de coisa né?...

L1 - fica brincando lá...

L1 - e:: conta pra mim

L L2 - É... fico brincando (no canto...)

L L2 - uhn

$L$ L1 - uhn... eu quero saber se você é muito bagunceiro

L L2 - não não...

não sou bagunceiro... pelo contrário... sou bem assim quieto... parado... não sou ( )

L1 - e você já fez alguma bagunça que a mamãe ficou BRAva com você?

L2 - SIM... Ahn... é que a minha mãe não gosta que... a gente brinca lá na sala né? eu com meu primo né? a gente fica brincando / ela não gosta... ela fala "crianças sai daí... não faz bagunça aí... vem cá pra baixo"... ela rena daí...

L1 - aí ela rena com vocês...

$$
\text { L L2 - ahn ahn }
$$

L1 - TÁ... e:.... você falou que foi pra Florianópolis... mas você já fez outra viagem... com papai... com a mamãe?

L2 - Eu::... fui / eu já fui com Coral Municipal de Piçarras (aqui no) Perpétuo Socorro... fui lá para Catandova... (meio) Paraná... Catandova... é::... eu fui:... nessa semana agora / na:.... antes das férias agora eu fui num museu de artes... fui num museu de artes... lá em Itajaí...

L1 - e você já foi no Beto Carrero?

L2 - JÁ... duas vezes... uma quando eu tinha cinco anos e outra agora com dez anos...

L1 - então você vai ter que me contar... porque eu não conheço o Beto Carrero... o que tem lá no Beto Carrero?

L2 - tem Barco Viking... tem... Max Emotion... tem montanha russa... tem elevador... tem o tapete mágico...

L1 - como que é o elevador e o tapete mágico? 
L2 - o elevador é que a gente sai aqui do chão... vai subindo até lá em cima... lá é bem alto... dá pra ver todo o Beto Carrero... daí a gente vai um pouquinho assim pra frente... espera só um... cinco segundinho... de repente a gente desce com tudo... tá lá embaixo em me / em menos de cinco segundos... bem rápido assim a gente desce... e o tapete mágico... é como se fosse o Barco Viking... só que ele vai assim / ele vai rodando... ele vai assim pra frente e pra trás... vai pegando velocidade até que ele vai rodando... ele vai ficando rodando...

L1 - ( ) e lá tem muitos bichos né?

$$
\text { L L2 - TÊM }
$$

L1 - que bicho tem lá?

L2 - tem... é:... tem macaco... gorila... tem:... canguru... girafa zebra... é:.... como é o nome daquele? ( ) camelo... camelo... tem leão... tigre... ( )

$$
\text { L } \mathrm{L} 1 \text { - e conta pra mim }
$$

$$
{ }_{\mathrm{L} 2}-\left({ }_{\mathrm{L}}\right) \mathrm{L1} \text { - qual é o bicho que }
$$

você mais gostou...

L2 - foi o leão marinho... o leão marinho foi o bicho que eu mais gostei de lá... o mais legal

L1 - o show... você viu algum show?

L2 - VI... vi três shows... vi um do:: Excalibur... vi um do:... show do... como é... dos leãos coisa assim... e vi outro show do faroeste

L1 - como que é o show do faroeste?

L2 - o show do faroeste tem um cara assim né? que / que ele entra dentro assim / (de um salão) de repente ele é jogado pra fora... daí os cara tenta atirar nele... daí ele salta ( ) assim (vai atirando em todo mundo) assim (pra lá e pra cá) daí salva a mocinha... (bem massa) é assim né?... fora assim ao vivo sabe?... não tem assim cortina é... essas coisas assim... ( ) daí cai a mocinha que tem... lá no cavalo... prende os bandido... o xerife

L1 - e o filme Excalibur... como é esse filme?

L2 - Excalibur é do Tarzan... um show com Tarzan Tarzan / que daí / tem (um hom[i] que / Excalibur)... que vai... daí o Tarzan (salva) uma mocinha... que vai se / vai ser aSSAda no fogo assim... no fogo a lenha... daí ele vem... salva todo mundo... vem assim numa corda... vem numa corda assim... bate todo mundo ele... os / os canibal tem escudo... tem lança... e ele vai batendo neles assim né? Daí ele até / tira a arma assim... e:... sai com ela / sai com ela （ )...

L1 - e: que bicho você mais gosta?

L2 - bicho que eu mais gosto? cachorro

L L1 - por quê? tem cachorrinho? ... conta pra mim...

L2 - ahn... por causa do / ( ) eu tenho um cachorro assim... eu gosto de fazer carinho... gosto de brincar... eu dou bastante carinho assim pro cachorro... eu não sei porquê eu gosto mais / eu:: adoro $\operatorname{assim}($ )

L1 - e:: se você pudesse ser um super herói

L1 - quem você seria e por quê?

$$
\text { L L2 - Ahn? }
$$

L2 - se eu quisesse ser um super herói eu seria o Homem Aranha... queria ser o Homem Aranha...

L1 - por quê?

L2 - por / por QUÊ? porque ele (salta) pelas alturas ( ) eu gosto de altura... bem massa

medo de altura?

$\mathrm{L}_{\mathrm{L} 1-}$ não tem

L2 - não... não tenho medo

L L1 - se eu subir numa cadeira eu caio pra trás (risos)

L L2 - (risos) 
L1 - conta pra mim G.... o que você gosta de fazer?

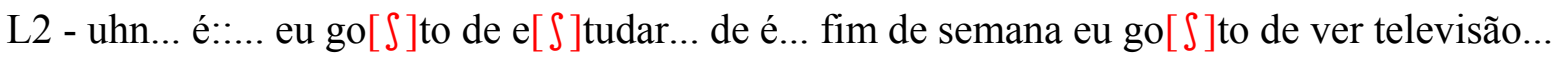

L1 - o que você mais gosta de estudar?

L2 - matemática... inglê[ $\left[\int\right] \ldots$ essas são as dua[ $\left.\int\right]$ matérias que eu mai[ $\left[\int\right]$ go[S]to... ma[jS] a primeira que eu mai[ $\left[\int\right]$ go[S]to é a matemática...

L1 - e::... você falou que gosta de fita né? e qual é o filme que você mais gostou?

L2 - ahn... não sei... assisti um monte... não sei...

L1 - não sabe uma que você gostou da história?

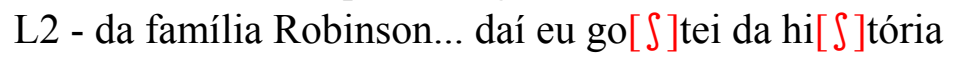

L1 - e como é a história... mais ou menos conta...

L2 - é:: aventura é... ele[S] vão viajar de navio... com / daí... tem um hom[i] que... que / a / que bota ouro nesse navio que o navio era dele... ele empresta pra família... daí ele bota ouro dentro ( ) numa mala... daí ele só / us[ow] a família... pra:: tirar aquele dinheiro fora do paí[S].. daí foram... daí foi o:: / esse::... o que... emprestou o ba[x]co pra ele[S]... foi indo de ba[x]co... e chegou no $\mathrm{ba}[\mathrm{x}] \mathrm{co}$ dele$\left[\int\right] \ldots$ e furou... o ba[x]co afundou e ele[S] foram parar em uma ilha deserta... lá encontraram uma menina... encontraram um monte de coisa... depoi[ $[$ ] volt[ow] esse ba[x]co... esse / ela acendeu o fogo pa cozinhar as comida... né? dá esse... é:: viu a fumaça e foi pra ilha... daí... lutaram... fizeram um monte de coisa lá... um monte de armadilha na ilha... foi assim... e no final ele[ $\left.\int\right]$ pegaram o ba[x]co desse hom[i] / e foram embora...

L1 - e::... e a escola... quem são seus professores... é muito longe da sua casa...

L2 - não:: é ali pe[x]tinho... é professor de matemática... era o professor Julian[o]... só que ele saiu

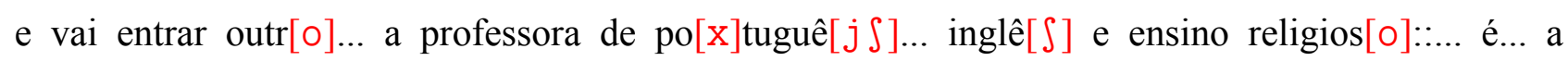
professora Denise... e o ti[o] dela... eu ach[o] que é ti[o]... estu / trabalha com meu pai... lá na Capitania... e o profes / a professora de ciências... professora Patrícia... que de vez em quando vai ali na casa da frente é:: e a professora de Geografia... a professora Ilda... é::.... professor de Educação Física que tam / mora ali pe[x]tenho... é o professor Misael... e... ach[o] que são só / só esse[ [ ] ... eu acho...

L1 - praia... gosta de ir na praia?

L2 - go[S]to... só que... inverno né?... tem que e[ $]$ perar o verão... o último verão que teve... eu só fui dua[S] veze[S] na praia... o pai não go[S]ta muito de ir...

L1 - e seus amigos G... como que / como eles são?

L2 - ehn... o Rodrig[o] que é... um pouc[o] bagunceir[o]... não muito... ehn:... pouc[o] bagunceir[o]... é... muito meu amig[o] me $[\varnothing]$ mo... ele é meu melho[ $\varnothing]$ amig[o] desse an[o]... meu $\operatorname{melho}[\varnothing]$ amig[o] do an[o] passad[o] era o Edison... mora ali pe[x]to da $\left[\int \zeta\right]$ cola... e... também tem a Regina que e[S]tudou comig[0] an[0] passad[o]... quarta série... a Mireli também e[ $]$ tudou comig[o]... amiga da Regina... PAUlo que não e[ $\left.\int\right]$ tudou comig[o] na quarta série... veio de outra e[S]cola an[o] passad[o]... daí é:: também o Robinson... que também e[S]tudou comig[o] na quarta 
série... ele não bagunça um pouquinh[o] mais que o Robinson... não muito ele... o Cleiton... que tava e[ $\left.\int\right]$ tudando comig[o] de tarde só que agora passou pra de manhã... não tá mai[ $\left.\int\right] . .$. o Anderson... que e[ $\left[\int\right]$ tudou comig[o] an[o] passad[o]... ele é muito legal... esse $\left[\int\right]$ daí são meu[S] melhore $\left[\int\right]$ amigo $\left[\int\right] \ldots$

L1 - e o que que você gosta de fazer / brincar... brincar do quê? fazer o que assim quando você tem um tempinho vago?... nas férias... ( )

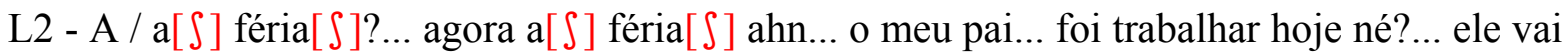
ver se o meu primo... J. ... ele tá de férias já... se ele tiver de féria[S] eu vou passar uma semana lá... que eu tenho duas semanas... e meu primo vai vim passar a $\left[\int\right]$ féria[S] aqui... só que / a [S] féria[S] dele é só semana que vem... daí eu vou passar uma semana lá... e depoi[ $\left.\int\right]$ de uma semana eu volto aqui... e... o E. ... meu / meu outro pri / prim[o] lá de Itajaí... vem aqui pra brincar comig[o]...

L1 - vocês brincam do quê?

L2 - ehn::...

L1 - do que vocês gostam de brincar?... o que vocês fazem?

L2 - com o[ $\left[\int\right] \mathrm{meu}\left[\int\right]$ primo me $[\varnothing] \mathrm{mo} . . . \mathrm{o} /$ adoro brincar no computador... só que quando meu pai tá fazendo um negócio ali... eu... brinco de brincadeira aí... tenho aquele::...

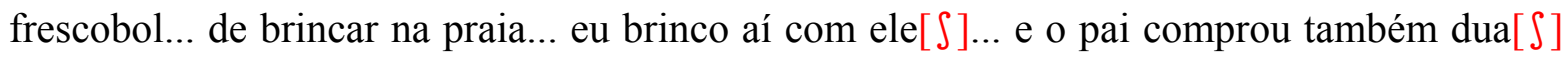
raquete e uma bolinha de têni $\left[\int\right]$... ele vai fazer a mesa... a gente vai brincar...

L1 - ( )

L L2 - falta só fazer a mesa... eu:.... não... sou muito de pipa... mai[ $\left.\int\right]$ o Eric meu primo... ele aDOra soltar pipa... joga $\mathrm{p}[\mathrm{e}] \mathrm{ca}$

L1 - jogar $\mathrm{p}[\mathrm{e}] \mathrm{ca}$ ? como é que você jo / o que é $\mathrm{p}[\mathrm{e}] \mathrm{ca}$ ?

L2 - p[e]ca?

L L1 - É

L L2 - p[e]ca é um monte de bolinha... tem que que acertar na $b[0] c a . .$. depois de acertar na $\mathrm{b}[\mathrm{\jmath}] \mathrm{ca} . .$. um buraquinh[o] na terra... tem que acertar na outra pilica...

( ) $\mathrm{p}[\mathrm{e}] \mathrm{ca}$

$$
\text { L L1 - p[e]ca? }
$$

LL2- $\mathrm{p}[\mathrm{e}] \mathrm{ca}$ é uma bolinha... p[e]ca de vidro... eu acho...

L1 - AHN p[e]ca e pilica

$L_{L} 2$ - ... é me $[\varnothing]$ ma coisa....

L1 - é mesma coisa... bolinha de vidro

L2 - uhn uhn

L L1 - Ahn:: tá

L2 - ( )

L1 - e::... você gosta de bicho?...

L2 - uhn uhn... 
L1 - que bicho que você acha mais bonito?

L2 - cachorro... gato... (isso) daí tud[o] mund[o] gosta... eu acho... passarinho

L L1 - uhn... e você tem

bicho na sua casa?

L2 - UHN... só de ave... tem pato marreco... galinha... passarinho do pai ali não sei qual é o nome... tem / tem o angoli[ $\left[\int\right]$ ta... o faisão...

como que é o nome dele?

L L1 - você falou um passarinho antes do faisão...

L2 - (antes)... AHN não sei o nome...

L1 - mas qual que é? você falou faisão... angolista?

L2 - faisão...

L1 - mas se fala (certinho) assim angolista?

L2 - a angolista é a galinha d`angola...

L1 - ahn...

L L2 - é aquela ali que fica gritando tô fraco... tô fraco...

L1 - ahn ahn

L L2 - essa aí OH ((aponta o animal que está passeando no quintal))

L1 - e o que mais que tem de bicho?

L2 - passarinho eu não sei o nome... só que o pai fala que se soltar... o passarinho pequenininho... que tem ali na gaiola... se soltar ele já é tão acostumado com o pai... com a comida... se soltar ele morre de fome... só come ração... e... tinha: / a gente já teve um monte de cachorro... a Funny... uma poodle preta... teve o Snoppy... o Lupinho... que a Samara botou o nome... é... e... teve o nosso primeiro cachorro... eu não lembro o nome... um daquele que ficava com a bochecha toda... (rivalidade)... cachorro marrom... não lembro qual é o nome... é... ( )

L1 - eu vi duas tartarugas... você tem?

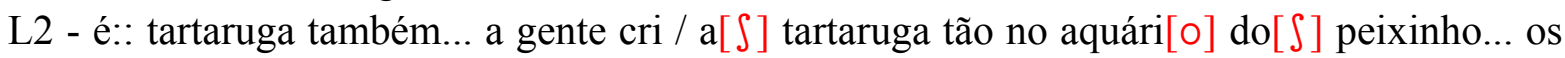
peixinho morreram tudo... daí o pai botou ali...

L1 - você comprou a tartaruga ou acharam por aqui?

L2 - não... o pai que comprou a tartaruga com aquári[o]... e o aquári[o] do[S] peixinho pra mim e pra S. de Natal... só que daí... o[ $\left[\int\right]$ peixinho morreram tudo... o primeiro peixinho que o pai comprou foi o último a morrer... foram morrendo tudo... ficou só ele... por último morreu ele... também se não morresse ia morrer agora de frio... inverno o[S] peixinho morre... no verão a gente vai lá pega mai[S] peixinho... pra botar no aquári[o]...

$$
\mathrm{L}_{\mathrm{L} 1} \text { - ( ) }{ }_{\text {L }} \text { 2 - na cachoeira }
$$

L1 - AHN... na cachoeira que vocês pe...

L L2 - na cachoeira ali... são peixinho pequenininhos...

J. B. (L2)

L1 - J.... é::... você estuda?...

L2 - estudo... 
L1 - onde você estuda... é aqui que vo / que matérias você estuda...

L2 - é... eu estudo no Manoel Henrique de Assis... um colégio que tem aqui pe[x]to... é::

estudo na sexta série... é:: as matérias são... história... matemática... portuguê[j $\left.\int\right] . .$. ciências... geografia... inglês né?... é:: AH... daí tem.... educação física né?... arte... religião... L1 - e você sabe o nome dos professores todos? você lembra o nome deles?... quem dava cada matéria?

L2 - é::... de educação física é o professor Tião... de matemática é o Idenilson... português é a dona Helena inglês dona Helena também... é::... tem Gi / Eliane... geografia é a dona:...

L1 - não lembra?...

L2 - não lembro...

L1 - não lembra não faz mal... TÁ... como que é a sua escola... ela é grande?... ela é pequena... tem muitas salas de aula... descreve a sua escola pra mim...

L2 - ela é grande... é:.... tem biblioteca também... tem... é... acho que tem mais de dez salas... mais de de $\left[j \int\right] \ldots$ e... tem várias escadas assim... pra subir assim...

L1 - é uma escola grande...

L2 - É

L1 - e você costuma ir muito à biblioteca da escola?

L2 - assim... quando tem / tem trabalho... eu vou né?... mais procurar... pegar livro essas coisas eu não vou... só quando a professora pede...

L1 - qual foi o último livro que ela pediu pra você?... a professora de português...

L2 - foi... ahn... uns livros lá de... (país)... chato... pra gente depoi[S] fazer uma redação...

L1 - não lembra de um maior que você leu?... nada... ( )...

L2 - uhn... não lembro...

L1 - não lembra?

L2 - não lembro...

L1 - tá bom... e o que que você faz aqui pra se divertir?... sai com os amigos... você passeia com suas amigas?...

L2 - como?... AH... eu faço... a gente dá voltas... assim... e' $: . .$. jogamo[ $\varnothing]$ bola... ficamo[ $\varnothing]$ conversando assim né?... essas coisas assim...

L1 - e na praia... você vai bastante?

L2 - vou... a gente assim... vai.. dá voltas na praia... só praia...

L1 - e no mar... você gosta de entrar... nadar... você tem medo?

L2 - não eu gosto...

L1 - gosta bastante

L2 - gosto...

L1 - seu pai... e seu pai é pescador né?...

L 2 - É...

L1 - ele já te contou alguma história engraÇAda... alguma coisa que aconteceu com ele no mar... ( ) algum peixe grande que ele pegou... que você pensou "meu pai tá brincando comigo:..."

L2 - OLHA... mas não assim de história engraçada... só de... fatos que aconteceram ( )

pra mim o fato...

L L 1 - conta 
L2 - NÃO... é que... ele:... uma vez ele tava assim no ba[x]co... daí o ba[x]co tava andando... aí tava escovando o dente... daí... de repente o ba[x]co parou... freou... e ele caiu... daí ele ficou debaixo da rede... assim... só que uma coisa que eu não acreditei muito foi que ele disse que ficou mais de quinze minuto debaixo da água... daí eu não acreditei... ((risos))

\section{L1 - ((risos))}

L2 - daí... e /... essas coisas assim... até que.. daí ele::... ele::... não que que aconteceu lá que daí os amigos dele disseram... viram né?... que ele tinha caído daí voltaram e pegaram ele...

L1 - ele contou mais história ou não?...

L2 - não... assim... ele não costuma contar muitas histórias assim... porque... ele não trabalha aqui... ele trabalha em Vitória... daí quando ele vem... a gente não... não conta... ( )

Santo?...

L L1 - Vitória Espírito

L2 - é...

L1 - NOssa... e::... vem cá... ( ) na escola tem bastante festa?

L2 - não... não tem muitas assim...

L1 - não?...

L2 - NÃO...

L1 - quantas têm?

L2 - tem:... ( ) São João... só assim... quando tem ( ) várias festas... então só quando... a gente entra em férias... daí tem uma festa assim... uma festa assim na sala... só...

L1 - e:: R. falou pra mim que... ele já... participou do grupo né?.. que brincava de Boi de Mamão... você conhece?...

L2 - conheço... também já pa[x]ticipei... só que che /... é::... ( ) fiquei também...

L1 - como que é essa brincadeira?...

L2 - ahn... tem várias bichos né? tem... tem o... tem o boi né?... a vovó e o vovô também né?... tem o barão... as onças... o vaqueiro... o médico... ( )

L1 - conta a história... por que tem onça... tem...

L L2 - não sei muito bem né?...só:..... é:..... não

sei te falar... o que que é né?....

L1 - tem alguma música?

L2 - não lembro...

L1 - aqui tem o Beto Carrero né?... um parque grande... você conhece?...

L2 - conheç[0]...

L1 - como que é lá o Beto Carrero?...

L2 - tem:... um castelo né?... têm casas... bem grandão... tem daí / a gente entra em vários brinquedos lógico né?... daí.. tem praça de alimentação... essas coisas assim...

L1 - qual brinquedo que você mais gostou?...

L2 - foi:.... foi o elevador...

L1 - como é esse brinquedo?...

L2 - AH... ele é:: bem grandão assim... aí tem um carrinho deita e sobe assim... ele é bem alto né?... aí... ele (desce) com toda velocidade... dá até medo...

L1 - e:.... tem bastante show lá?...

L2 - tem...

L1 - você assistiu algum?

L2- assisti... é:.... das Águas Dançantes... do... do... palhaço... 
L1 - gostou?

L2 - gostei...

L1 - lá no Beto Carrero... tem bichos lá né?...

L2 - ahn ahn... A... tem o zoológico né?... daí... tem... tem onça macaca... tem:... hipopoto... essas coisas assim... tem vários bichinhos assim...

L1 - você gosta de assistir televisão né?... que você falou pra mim...e:... que filme você gosta de assistir?... lembra de um filme legal que tenha assistido?

L2 - lembro... do... ( ) a... da... ( )... os... os... acho que era os... o... Sexto Homem... é um:... é porque eles são jogadores de basquete... daí eles... é um que é irmão deles e joga desde pequenininho... daí ele morre... é bem triste assim né?...

L1 - pode contar a história do filme...

L2 - daí.. daí ele morre... o irmão dele... via ele... e: ele no jogo ( ) ele ia lá... e ajudava... daí... até qu[e] um dia ele machucou o colega dele... que era amigo do irmão dele... daí disseram que não era mais pra ficar... aí começou a chorar... essas coisas...

L1 - e como termina o filme?...

L2 - ele vai embora... o irmão dele fica lá... só...

L1 - e filme de terror... gosta?...

L2 - gostei...

L1 - que filme de terror legal você assistiu?...

L2 - o Exorcista... esse filme é muito legal...

L1 - então conta a história dele pra mim

L L2 - é uma menina né?... que ela... começa a tipo... a e o

((risos)) o diabo entrou no corpo dela... daí o... a irmã dela chama o:... o padre... o:...o:... o que tira o:... diabo do corpo da... daí ele chama... ela chama ele... lá eles... começam um monte de coisas... daí ela.. aí no final... aí assim... ela... ele vai e não consegue... daí ela mata o padre... aí vai outro lá... daí tira... o... aí ... faz o exorcismo né?... no corpo dela né?... daí ele consegue... (tirar) o espírito que tá no corpo dela dentro... daí... aí... aí tem assim... ela vai embora... daí... aí... (lá naquela) casa... vai outra família mora lá né?... aí não... aí acaba assim o filme...

L1 - o desenho... gosta de desenho?

L2 - gosto...

L1 - qual?...

L2 - os anjinhos ((risos))... adoro...

L1 - eu gosto também... e conta uma coisa pra mim... se você pudesse ser uma... uma super heroína... seria quem?... e por quê?...

L2 - eu:.... não tenho idéia assim...

L1 - se você pudesse ser uma atriz ou uma cantora... quem você seria?...

L2 - eu:... cantora eu queria ser a Cristina Aguilera... ( ) por causa das músicas dela...

L1 - e uma atriz?

L2 - Mel Lisboa

L1 - A Mel... e você assiste novelas né?... qual novela você assiste?

L2 - Malhação... adoro Malhação...

L1 - e o que que tá acontecendo na Malhação agora?...

L2 - aGOra... é uma festa junina né?... os... os... per / personagens assim principais são... aGOra... a Júlia e o Pedro... daí... eles... um não fica com o outro assim... aGOra né?... mas sempre eu acho que... os dois sempre fica junto... 
L1 - e que outra novela você está assistindo?...

L2 - ... eu não assisto muito assim... é ( )... Esperança...

L1 - é história de que Esperança?...

L2 - é do:.... assim... daquele tempo assim que... que eles socavam café assim... que o Brasil ainda... que o Brasil não era... não tinha todas as cidades... só tinha São Paul[o] assim... acho que só tinha São Paul[o]... não sei... e:.... daí eles socavam café... aí teve a guerra ainda... aí tem os personagens que foram pra guerra... daí eles... aí um quase morreu...

L1 - e você falou que adora ler revista...

L2 - ahn ahn...

L1 - por quê?...

L2 - porque... assim... é::... eu gosto de moda... dessas coisas assim né?... e... sempre vem um... um:... um pôster assim do:... do... do grupo que eu gosto assim né?... daí:... sempre vem... aí eu assim... eu gosto da:... do estilo assim da Atrevida né?... tem uma monte de:... de / o ( ) que se pode escolher... coisas assim...

L1 - e você falou... você gosta de música também... que grupo você gosta?

L2 - eu gosto de Backstreetboys... L S Jack...

L1 - foi no show do L S Jack?...

L2 - fui...

L1 - foi?

L2 - fui...

L1 - eu também... e gostei... e Backstreetboys... quem são eles?

L2 - é::... é um grupo de menino que::... eles... são criados na Flórida né?... não são daqui... e:.... tem:... vários... o Nick... que eu mais gosto... o Nick... Kevin... tem mais um... tem mais três... eles são formados de cinco...

L1 - e o do L S Jack... quem são os meninos?... você conhece... sabe o nome deles?

L2 - eu só sei que o guitarrista... o no / o apelido dele é Bicudo... o apelido dele né?... e... o... vocalista... eu sempre esqueço o nome dele... eu não sei...

L1 - quando você foi no show... aqui em Piçarras do LS Jack... você foi com quem?

L2 - fui com a minha irmã...

L1 - você tem uma irmã mais velha que você...

L2 - tenho...

L1 - e como é o seu relacionamento com a sua irmã... você se dá bem com ela ou não dá... quantos anos ela tem... o nome dela...

L2 - ela tem... o nome dela é L. ... ela tem:... dezoito anos né?.. é... às vezes eu brigo com ela né?... ( )

L1 - tem mais irmãos?...

L2 - não...

L1 - só ela?...

L2 - só...

L1 - menino não tem?

L2 - não

L1 - voltando a falar um pouquinho da escola... que matéria você mais gosta?...

L2 - gosto de... português...

L1 - é:: eu também... sou professora de português...

L2 - ((risos))

L1 - e por que você gosta de português? 
L2 - a... porque... as coisas assim... do... tu aprende né?... o... às (vezes) a gente tá falando assim... a gente tá falando o português né?.... aí... aí... mas... aí não sabe se tá falando as coisas certas... e... eu gosto de falar certo né?... tod[o] mundo gosta... aí eu gosto de apren / as palavras certas...

L1 - e o inglês... você gosta também?

L2 - gosto...

L1 - se você pudesse ser professora de português ou inglês... qual você seria?...

L2 - uhn:... português

L1 - por quê?

L2 - porque... aqui... porque assim... a gente gosta... A...a gente... por exemplo... EU... gosto de ensinar o que eu sei... o que eu sei eu ensino né?... daí... e:... como eu te disse né?... português porque é a minha língua né?... já inglês... pode / pode se formar em inglês... pode saber tudo... pra ti viajar pra outro lugar... ( ) nem todo mundo tem essa oportonidade de viajar pra outro lugar...

L1 - e espanhol...

L2 - espanhol eu não gosto de espanhol...

R. H. C. (L2)

5AI

L1 - R.... eu queria que você contasse pra mim... onde você estuda... que matérias você estuda...

L2 - eu estudo... na escola Rubem João de Souza... minha matéria... TOda[ $]$ ?

você estuda?

L L1 - mas quais

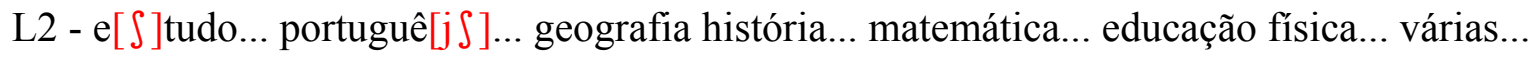

L1 - e::... o que você gosta de fazer... nos finais de semana?

L2 - gosto de con / conversar com os meus amigo[ [ ]... sair... coisas assim...

L1 - sair pra onde?

L2 - eu vou pra... capoeira... eu vou pra... lá pra pracinha...( )

L1 - fala pra mim assim como que é a capoeira... o que você FAZ... se tem música... eu fiz judô... mas sobre capoeira...

L2 - ahn... a capoeira é uma dança... dança típica né? e... todo mundo faz suas coisas né? ...

e:... tem música... que eles toca... berimbau... faz um monte de coisa... coisas assim...

L1 - e:.... você gosta da praia?

L2 - AH... gosto

L1 - vai bastante na praia?

L2 - vou:... só no verão né?

L1 - só no verão?... e o que que você faz lá na praia?

L2 - ahn... tomo um banho... brinco bastante...

L1 - joga bola...

L2 - jogo bola... jogar bola todo mundo gosta...

L1 - tá... e:.... fala uma coisa pra mim... é:.... você tem muitos amigos?

L2 - tenho... tenho bastante amigo[S]

L1 - você é um menino muito comportado ou muito bagunceiro? 
L2 - médio... uhn... sou bastante bagunceiro...

L1 - então conta pra mim uma bagunça que você fez...

L2 - ahn eu faço bagunça... eu / eu começo a incomodar minha mãe... ela fíca brava... deixa eu de castig /... coisas

ficou uma fera... conta pra mim...

L L1 - assim... e você já fez alguma coisa assim... alguma coisa que a sua mãe L2 - quando eu quebrava os cop[o] assim... ela ficava brava comigo... às vezes eu acordo meu pai... aí ela fica brava comigo... bate em mim...

L1 - não lembra de nenhuma?... tinha um menino que eu entrevistei que quebrou o vidro da vidraçaria... com uma funda... o pai e a mãe dele... pegou ele mesmo... não lembra de nenhuma?

L2 - não...

L1 - qual é a matéria na escola que você mais gosta?

L2 - é::... educação física...

L1 - educação física?... e o que você pensa em fazer quando você crescer?

L2 - ahn... eu penso em... sei lá... um ( )... um / médico... que eu vou fazer faculdade... e:.... ter um futuro bom... ter um futuro melho[ $\varnothing] \ldots$

L1 - e você vai fazer faculdade de quê?

L2 - ahn:... eu não sei...

L1 - não tem nenhuma idéia?

L2 - não

L1 - educação física... por exemplo?

L2 - educação física?... não sei...

L1 - ( ) já repetiu de ano?

L2 - JÁ... duas veze[ [S]...

L1 - e:.... fala pra mim... você conhece o Beto Carrero?

L2 - conheço...

L1 - já foi lá?

L2 - fui uma vez...

L1 - como que é lá dentro... eu não conheço...

L2 - legal... tem bastante brinquedo[ $\left[\int\right] \ldots$

L1 - qual que você mais gostou?

L2 - foi a montanha-russa...

L1 - ela é grande? como

L L2 - ela é grande...

L1 - tem outros brinquedos legais?...

L2 - tem... o barco viking... o elevador...

L1 - e como que é esse elevador?

L2 - o elevador é um... um elevador... que sobe...

L1 - em alta velocidade...

L2 - é::...

L1 - tem animais lá... falam pra mim que é parecido com um zoológico

assim.. pras pessoa[ $\left[\int\right]$ verem... né?

LL2-tem... um zoológico

L1 - tem muitos bichos... 
L2 - tem... tem tigre... onça... tem hipopótamo... tem bicho...

L1 - falam pra mim que lá tem shows...

L2 - tem... tem shows... tem... tem o show da Monga... uma mulher que se transforma em... em... macaca

LL1 - já viu?

LL2 - já... já vi... OH:.... saí correndo lá de dentro...

L1 - tem outros shows? que você viu lá ou não?

L1 - ( ) cavalos?...

\section{$\mathrm{L}$ L2 - ( )}

L2 - o único show que eu vi me $[\varnothing]$ mo foi a Monga... o show me $[\varnothing]$ mo... mais nenhum...

L1 - você tem irmãos?

L2 - tenho um irmão...

L1 - irmão... muitos amigos... ou não?...

L2 - tenho... bastante amigo[ $\left[\int\right] \ldots$

L1 - fala o nome deles pra mim...

L2 - do ( )

L1 - não... dos seus amigos...

L2 - dos meus amigo[ $\left[\int\right]$ ?... o nome dele $\left[\int\right]$ ?... Josiane... Neto... deixa eu ver mai $\left[\int\right] \ldots$ Cri[ $[$ ]tian C. ... Daniel... Rosa...

L1 - você falou que gosta de educação física?... que é a matéria que você mais gosta... e você faz capoeira né? em que faixa você tá na capoeira?

L2 - eu tô na verde-cinza...

L1 - verde-cinza... e tem outro esporte que você goste?

L2 - tem... tem vôlei... vôlei...às vezes eu jogo futebol....

L1 - e na televisão... é:... você gosta de assistir filme né?... que filme você gos / fala do filme que você mais gostou?...

L2 - Mar em fúria... Mar em fúria...

L1 - e como que é a história desse filme?...

L2 - (bom)... a história desse filme é que... um... um... pescadores né?... ele $\left[\int\right]$ tavam na terra deles... aí eles foram para o alto mar... procurar peix[e] né? aí... eles arranjaram... assim... bastante cardume de peix[e]... e começaram a pescar os peixe... aí eles tavam voltando pra casa... e era muito peixe... aí... começaram a jogar os peixe fora... aí acho que o tempo / o tempo ficou ruim... começou a dar um furacão... aí vinha onda... quinze... vinte metros... e a última onda foi uma maremot[o]... aí... o maremot[o] engoliu o barco... e morreram... só sobra um...

L1 - AH tá... filme de terror... você gosta?...

L2 - gosto...

L1 - já assistiu algum legal?

L L2 - JÁ... um... já assi[ []ti a Múmia... ( ) a um e a dois...

L1 - então você vai me contar a história da Múmia... por que eu tenho medo de assistir filme de terror...

L2 - a um ou d[o $\left.\int\right]$ ?...

L1 - do um e do dois ((risos))... 
L2 - TÁ... a um:... a um:.... a um:... é que eles vão dentro duma... e:... assim... eles estudam... os antepassados né?

LL1 - são arqueólogos...

L2 - isso...estudam (as coisas) os fósseis né?... de pessoas... de múmia né?... tudo isso aí... eles encontram teorias... e acabam assim... acontecendo... né? e... é:.... acham fósseis que despertam um bicho né?... uma pessoa... começa a decair mal pra todo mundo... aí começa a história do filme... aí acaba assim...

L1 - como que é essa pessoa que eles despertam... ela é boa... ela é má... ( )

L L2 - ela é má... ela é::

assim... eles acham ela só em osso... aí depois ela.. ela... ia ( ) chegava nas pessoas... ele... chupava a pessoa... a carne da pessoa... e... assim ( ) assim... encheram ele de carne... de coisas assim né?... aí... no final do filme ele ficou inteirinho... aí ele foi devolvido às tumbas né?... aí acaba o filme...

L1 - e a dois?

L2 - a dois...ele... ele... ele... é::... ele ressuscita... e começa a:... a jogar as pragas de novo né?... e tinha um outro chefe lá... um deus... que... luta com ele... e ele pede perdão... manda matar outra pessoa... aí a outra pessoa mata os doi[ $[$ ]... aí... a pessoa é jogada pras trevas... aí acaba...

L1 - acaba o filme... e desenho... você falou que gosta... né?... qual que você gosta?

L2 - desenho?... eu gosto de... de... Dragon Ball... de Digimon... Pokemon...

L1 - e você chegou a assistir He-man... Caverna do Dragão...

L2 - He-man... eu acho que já assisti... assisti...

L1 - e qual que você mais gosta?... de todos que você me falou?...

L2 - eu gosto mais me $[\varnothing]$ mo é do Dragon Ball...

L1 - como que é?... história do quê?...

L2 - ahn... Dragon Ball é::... pessoas que... acham as pedras do dragão... aí nasce o / aí nasce o:.... Dragão... que ele faz todos os desejos... aí alguns dese / desejam ser invencíveis... que nunca morrem... e (outros) desejam ser mais forte... ter um futuro melho[ $\varnothing] . .$. algumas coisas assim... aí fazem luta... soltam poderes...

L1 - e se você pudesse ser um super-herói... quem você seria?...

L2 - quem eu seria?... não sei...

L1 - não sabe?... Homem Aranha... Batman... o...

L L2 - eu queria ser o Hom[i] Aranha...

L1 - por que o Homem Aranha?

L2 - porque:... eu sou assim né?... eu gosto de subir em bastante casa né?... e fico com essas fantasias (assim) de brincar...

L1 - se eu subir em uma cadeira eu caio... ( ) a escola é longe daqui?

L2 - é... um pouquinho longe...

L1 - e como você vai pra escola...

L2 - ahn eu vou... me arrumo né?... aí sete horas saio daqui de casa... aí eu vou a pé... demoro uns quinze minuto pra chegar lá... aí chego lá... estudo né?... [ $\varnothing]$ caba a aula e venho pra cá...

L1 - vai sozinho...

L2 - vou sozinho...

L1 - não é perigoso? 
L2 - não...

L1 - não?

L2 - não...

L1 - qual o nome dos seus professores?... lembra?

L2 - lembro... professor Carlos... professor

L L1 - mais de que matérias? ( )

L2 - o professor Carlos é de matemática... o professor... de história... é o... professor Fábio... o professor de:: inglês é o professor Edilson... português é a professora Vilma... matemática é a dona Márcia... que mai[ $\left[\int\right]$... o resto eu não me lembro...

L1 - não lembra?...

L2 - não... não:... de religião o... professor... ( )

L1 - você falou que tem aula de educação física né?... que é o que você mais gosta... o que vocês fazem na aula de educação física?

L2 - AHN... a gente brinca às vez[ $\varnothing]$ de vôlei... às vez[ $\varnothing]$ de futebol... às vez[ $\varnothing]$ joga o joguinho da moeda né?...

L1 - como que é o joguinho da moeda?...

L2 - é um monte de prego numa tábua... aí começa a chutar o... a moeda né? até fazer o gol...

L1 - gol...

L2 - uhn uhn...

L1 - vem cá... é... deixa eu te fazer outra pergunta... tem bastante festa na escola?

L2 - tem... eu acho que até agora... acho que umas duas... duas festas... duas... trê[ [ ] ...

L1 - quais são assim... ( )

L2 - festa Junina... festa... da inauguração da quadra... que mais que aconteceu... festa de bastante coisa... festa de:... esqueci o nome... teve bastante festa já né?...

L1 - tem alguma festa aqui, por exemplo, que você tem que se vestir diferente... uma festa açoriana... ou uma festa de Terno de Reis... uma coisa assim diferente... ou não?

L2 - não:... não... eu acho que até agora não...

L1 - nunca fizeram, por exemplo, uma festa açoriana...

L2 - não...

L1 - uma festa portuguesa?...

L2 - já teve festas açoriana... mas eu nunca fui...

L1 - mas não é na escola?...

L2 - não...

L1 - que festa que tem aqui no município... assim?

L2 - festa me[ $\varnothing]$ mo é... bailão... assim... Boi de Mamão... algumas coisa assim.

L1 - nunca foi no Boi de Mamão?

L2 - já... eu faço... eu fazia / Boi de Mamão...

L1 - como que é? você que fazia o Boi de Mamão... que eu e as pessoas de São Paulo nun / NUNca vi um Boi de Mamão... me desculpe... não sei nem se ele é de mamão mesmo...

L2 - não... o Boi de Mamão... é chamado Boi de Mamão porque antigamente... eles tinham muita pressa... e (fazia) a cabeça do Boi de Mamão... aí fazia o olho né?... aí fazia a cabeça do Boi de Mamão... aí pô[S] que o nome foi Boi de Mamão... e o Boi de Mamão é assim... tem um grupo... canta a música... aí tem o boi... o barão... o vovô e a vovó né?... mais conhecido como a Maricota... tem quem mais... tem o tigre... onça... só...

L1 - e... você... tinha música né?... 
L2 - tinha...

L1 - você lembra alguma música?...

L2 - lembro...

L1 - canta uma pra mim...

L2 - é...

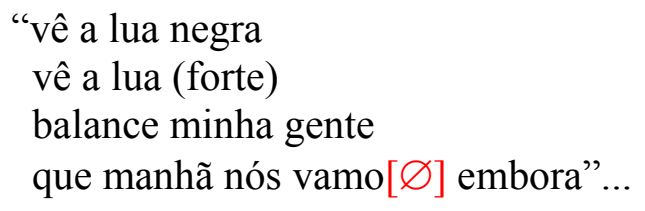

L1 - e vocês iam nas casas? como que era?... era na sua... era na escola?...

L2 - foi num lugar né?... fica embaixo de... no fundo do salão paroquial... foi ali... foi no salão...

L1 - não tem mais isso?...

L2 - até agora não... a professora disse que não queria mai[ $\left[\int\right]$ sair pra fora né?... o Boi de Mamão...

L1 - e acabou então?...

L2 - [Ø]cabou... aí eu saí...

L1 - ia bastante gente na festa?

L2 - ia...

K. S. (L2)

L1 - então K.... eu queria que você me contasse um pouquinho da sua vida aqui na Penha... o que que você faz... conta pra mim...

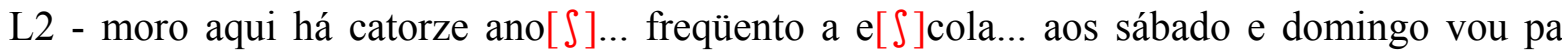
escolinha... bingo... faço tudo que dá pra fazer no fim de semana... por causa que eu e[ $\left.\int\right]$ tudo $\operatorname{assim...}$

L1 - e você faz o que... só o ensino normal?...

L2 - estudante só... é...

L1 - e você tem muitos amigos?

L2 - sim... no colégio... na escolinha... ( )

L1 - essa escolinha que você fala é de quê?

L2 - futebol

L1 - e como que ela é?...

L2 - boa... ela tem bastante amigos... ninguém briga... ninguém apronta com outro... ( ) futebol certinho...

L1 - você pode descrever o lugar...

L2 - é no ginásio de e[S]porte... daqui da Penha... é:.... não é pago... porque é pela prefeitura... e lá tem... forma assim uns trinta e sei[ $\left[\int\right]$... quinze aluno...

L1 - você gosta?...

L2 - muito... 
L1 - do que você mais gosta de brincar?...

L2 - de videogame...

L1 - que jogos?...

L2 - é:: Mário... (deixa) eu ver o que mais... Mortal Combate...

L1 - e como que é o Mário... esse jogo...

L2 - ( )

L2 - é

L L1 - é o super Mário Bros?

L L1 - como que ele é?

L2 - é um bonequinho... é um bonec[o]... tem que salvar uma princesa no moral da história...

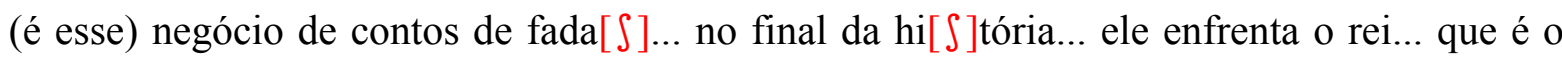
copas... que é o décimo dragão... daí no final... tenta matar ele no caso... e resgata a princesa...

L1 - você gosta de praia?...

L2 - sim... muito...

L1 - e o que... que você costuma fazer na praia?... você vai com quem?...

L2 - geralmente eu vou com a minha mãe... aí meu pai... [ow] às vezes com os meus vizinho... lá eu nado... brinco na areia... jogo futebol...

L1 - você tem muitos vizinhos?...

L2 - tenho

L1 - você gosta deles...

L2 - sim

L1 - e... você viaja... conta pra mim... você já fez alguma viagem legal... pra onde você foi... o que que você conheceu... quanto tempo você ficou...

L2 - uma vez... eu fui com a escolinha de futebol pra Santos... São Paulo... lá a gente ficou cinco dia... não conheci ninguém assim...

L1 - e o que você achou de Santos...

L2 - bom... mais... acho / achei que era muito poluída assim... ( ) daí no caso quando a gent[e] foi... eu senti um pouco a diferença... lá...

L1 - lá...

L2 - é...

L1- e o Beto Carrero... você conhece?...

L2 - sim...

L1 - como que é lá dentro?...

L2 - muito divertido... porque lá... assim... não tem outro lugar pra nós e... então lá é um lugar que a gente tem mais diversão assim... lá é muito bom... dá pra fazer amigos lá dentro...

L1 - como que é lá o Beto Carrero... o que tem lá pra se divertir?...

L2 - uhn:: muitos brinquedos... (deixa) ver mais... brinquedos que se tem... ( ) uma praça de alimentação... um bom atendimento... umas coisas assim...

L1 - tem bichos?...

L2 - tem... é um parque com zoológico assim...

L1 - que bichos tem lá?... lembra de alguns?...

L2 - leão... girafa... [Ø]lefante... todos os bichos assim que se pode imaginar... tem lá dentro... 
L1 - tem::... que brinquedo você mais gosta?...

L2 - montanha-russa...

L1 - como que:... como que é ela?... muito grande...

L2 - é... tamanho... assim: das montanha russa que existe no mundo... é pequena né?.. mas é bom... pelo menos faz alguma $\mathrm{p}[\varnothing]$ ssoa sofrer emoção assim... medo... essas coisa misturado...

L1 - tem um outro brinquedo que você gosta?...

L2 - elevado[x]...

L1 - e como que ele é?...

L2 - é o elevado[x]... que sobe né?... e... supo[ґ]... tipo arrebenta e cabo... daí cai... em alta velocidade... é bom também... só que dá um pouco de medo...

L1 - e:: conta... eu queria que você me contasse alguma coisa que já aconteceu com você... já caiu... se machucou alguma vez?... conta pra mim...

L2 - sim... eu... tava lá nas minha vizinha... tava... tava assim pa pegar goiaba... o galho quebrou... daí eu caí e me ralei todo... machuquei bastante...

L1 - e você tem muitos parentes... muitos primos... irmãos... irmãos...

L2 - irmão eu não tenho... parente eu tenho bastante...

L1 - tem muitos...

L2 - ahn ahn...

L1 - vai na casa deles?...

L2 - sim

L1 - e:: onde eles moram?...

L2 - Itajaí...

L1 - Itajaí...

L2 - principalmente Itajaí assim... que eu nasci lá... daí... os meus parente é tudo de lá...

L1 - e:: como que é a sua casa?...

L2 - (então)... nós se mudamo[ $\varnothing]$ agora né?... e: a gente... desde quando eu vim pra cá... ( ) a gente sempre mora em casa alugada... e agora... meu / meu pai... assim... decidiram fazer uma casa... daí a gente fez aqui... daí o lugar é muito bom... é a melhor casa que eu já morei... lá é bem espaçosa... tem uma... uma área... que eu jogo futebol com os meus amigos... brinco... tudo lá...

L1- e:: como que é o seu quarto?...

L2 - é espaçoso... todas as coisa assim... tão lá no meu quarto... computador... vídeo... antena parabólica... ( ) som também... tudo assim de mais valor... valor... vem do meu quarto assim...

L1 - e o que você gosta de ouvir?...

L2 - música assim?...

L1 - é:....

L2 - banda assim... Legião Urbana... Titãs... assim mais... pop rock...

L1 - e:: televisão... o que você gosta de assistir?...

L2 - filme ...

L1 - que filme?...

L2 - pessoalmente assim de ação...

L1 - qual o filme que você mais gostou?...

L2 - do Gladiador...

L1 - você pode contar um pouco da história do filme pra mim?... 
L2 - uhn uhn

L1 - que esse filme eu ainda não assisti...

L2 - é um... é o tempo medieval... tinha um... um hom[i]... tinha os ( ） daí ele fazia parte... só que daí... os rei mesmo matar[ũ] a sua família... ele também sobreviveu assim... mas ele quis se vingar... daí teve que começar tudo de novo... ele começou indo para as arenas... coliseu... ganhou... assim ganhou todas as lutas assim né?... só chegou no final... chegou no final... quando ele foi enfrentar o rei... os seus capangas... (pra) dizer assim... pegaram ele e o rei mat[ow]... daí como a família tava $\mathrm{mo}[\mathrm{x}] \mathrm{ta} . .$. o filme mostrou ele assim... tipo no céu... um lugar bastante assim... ele se encontrou com a sua família...

L1 - filme de terror... você gosta?...

L2 - gosto...

L1 - e:: você assistiu algum legal?...

L2 - é:... Fantasmas de Ma[x]te...

L1 - e como que é?...

L2 - é um tempo mais avançado... no futuro... que:: um... eles i[ũ] fazer um tipo... a polícia ia fazer um transpo[x]te de prisioneir[o]... de Ma[x]te pa Terra... só que lá... os espíritos de $\mathrm{Ma}[\mathrm{x}] \mathrm{te} . .$. em... em... em corpos de pessoas na Terra... daí lá tinha o líder... eles queriam matar todas as pessoas que tinha em Marte... assim sem saí né?... só que daí... tinha lá... uma da história era uma policia $[\ulcorner] \ldots$ policia $[\ulcorner] \ldots$ que... matou uma ... mais os prisioneiro que vieram resgatar mataram todos... e no final... ela foi presa assim... porque ninguém tinha prova suficiente assim... pa provar que foram esses fantasmas... daí como ele e ela ( ) sobreviveram... foi ela que foi a culpada... só que aí no final... os espíritos veio junto com ele... na nave... no trem... na nave... daí ela matou... ia matar... daí acabou o filme... quando ela veio matar todos... de novo assim... mostra as $\operatorname{imag}[i] \ldots$ não sei se ainda... daí o filme acaba assim...

L1 - e um outro filme de terror?... você se lembra...

L2 - outro filme de terror?... é:.... Pânico...

L1 - gostou?

L2 - gostei tam[ $\varnothing]$ ém...

L1 - você lembra da história do Pânico?...

L2 - o primeiro era... é que um:... o namorado... da principal da história né?... queria vingar a mo[x]te de sua mãe... que foi mo[x]to pelo pai dela... daí a história é namorado... fica pegando a guria... assim... foi matando... sem ninguém... ( ) incomodasse ele... assim... mas ele ia matando... só que chegou no final da história... assim... ela... ela pegou e matou ele... com a... mes / assim... com a mesma arma que ele usava... que era uma faca... ele usava a faca pa matar todo mundo assim... matava em qualquer luga[x]... não tinha medo de ninguém... nem da polícia mesmo... daí no final ela matou ele foi bem divertido esse filme... porque nunca tinha visto... e quando eu vi assim... legal... não achei tão medroso como falav[ũ $]. .$. achei bem divertido...

L1 - e um outro filme de ação... que tenha assistido... que tenha gostado...

L2 - ( ) Sessenta Segundos... 
L1 - aí... conta pra mim... ((risos))... eu já vi... é que eu adorei... então você vai contar pra mim lembrar...

L2 - ahn... era um:... era um cara né?... tinha um irmão... daí eles roubav[u] carro pa vender... pra... po/... re[S] to do mundo assim.. daí... o irmão se meteu numa encrenca assim... que era dar cinqüenta carros em uma semana... só que daí o irmão não cumpriu... daí eles iam matar o irmão... só que o cara... co / como o mocinho da história... aceita essa proposta de e (vender) o máximo de cinqüenta carro em uma semana... daí eles faziam tudo assim

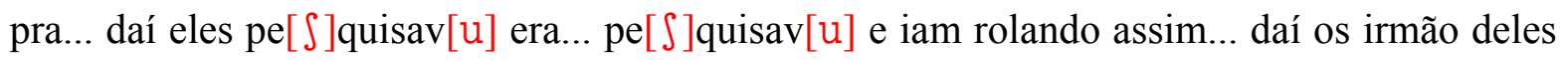
$\operatorname{tam}[\varnothing]$ ém ajudou eles... os amigos do irmão... daí no final... ele... tinha um carro... que ele... se de / o a que ele foi... ele se deu mal... que era um Mustang... daí no final... foi o maior perigo assim... a polícia seguiu ele... ele foi muito rápido e venceu... só que o carro tava cheio... tava... veio po / po pátio... que eles levavam pa outros países... tava cheio... tava todo arrebentado... só que daí... como:... o cara que tinha matado o irmão... tam[ $\varnothing]$ ém quis matar ele... só que daí no final ele fugiu... e o cara foi junto... aí no final ele matou o cara... daí tinha um amigo deles que era policial... como ele tinha salvado a vida do policial... o policial deixou ele sair assim... fugiu...

L1 - ( ) qual o carro que você mais gosta?...

L2 - carro... que não que eu tenha... né?

L1 - é... um carro que você goste... se pudesse... tem catorze anos... quando você tirar a carta... que carro você gostaria de ter?

L2 - Jaguar...

L1 - como que é esse carro?...

L2 - é... assim... não dá pra descrever muito porque a cada ano eles mud[ũ] né?... mas ( ) assim de vista... assim essas coisas... é bem confortável... rápido assim... proporciona aventura tam $[\varnothing]$ ém né?... (porque) é bem rápido... essas coisas... eu gosto de rap / velozes...

L1 - carros velozes...

L2 - é...

L1 - e que cor?...

L2 - verde escur[o]

L1 - escuro... e:: na escola... que matérias você estuda?... qual o nome dos seus professores... o que você mais gosta de estudar...

L2 - mate / matemática é o Edenilson... português é o Júnior... ciências é Eliane... geografia dona Maria do Carmo... religião... dona Ângela... educação física é o Tião... (deixa) eu ver mais... acho... acho que é só... a:... a... dona Raquel... história o Martinho... deixa eu ver mais... acho que só...

L1 - e você gosta de estudar?...

L2 - sim...

L1 - e qual matéria que você mais gosta?...

L2 - matemática...

L1 - matemática?... e você falou que tem aula de religião?

L2 - sim

L1 - em São Paulo a gente não costuma ter... o que ( ) vocês aprendem... 
L2 - a... assim a religião... agora a aula de religião não é como antigamente... só dava religião... hoje em dia é um debat[e] assim... drogas... ( )... essas... essas coisas de guerra... o que é bom... ruim... umas coisas assim não só religião..

L1 - tá... e o que você aprendeu por exemplo... pra mim... sobre drogas...

L2 - drogas assim...droga tam[ $\varnothing]$ ém não é só droga droga... cocaína... essas coisa... é... tudo assim... é... é... tudo assim que faz mal... álcool... cigarros... tam[ $\varnothing]$ ém droga assim pra mim... eu não pretendo nunca usar né?... porque só vai... fazer bem no começo... mais no final o cara pode acabar $\mathrm{mo}[\mathrm{x}]$ to... preso... por causa das droga

B. H. S. (L2)

L1 - B.... e::... que você mais gosta de ver na televisão?...

L2 - é:: é:: Tom e Jerry... Pica-pau... vários desenhos mai[ $\left.\int\right] \ldots$

L1 - e que filme?... você gosta de ver filme?...

L2 - Ahn ahn... aDOro...

L1 - que filme você gosta de ver?

L2 - é... terror... ação e comédia...

L1 - que filme de terror você gostou de ver?...

L2 - até agora?

L1 - é:....

L2 - Lenda Urbana...

L1 - como que é esse filme?

L2 - é uma pessoa com máscara que mata né?... aí no final tu tem que descobrir quem é... tem várias pessoas no grupo... aí vai começando... vai... vão... vão pelos / pe / pe pelos livros eles vão descobrindo que tem uma lenda... essa lenda começa a surgir na... em vida real... e vai matando... vai matando várias pessoas... aí no final o cara chega e tira a máscara para a pessoa pra / pra sua ( ) pra próxima vítima... aí a outra pessoa tem ... tem outra pessoa outros... aí eles combinam tudo pra... matar a vítima... daí ela é presa... ou se não consegue matar a vítima... ela vai presa... porque matou várias pessoas né?...

L1 - e um filme de comédia que você gosta...

L2 - é:... não me lembro

L1 - e de aventura?... qual que você gosta?

L2 - de aventura?... foi... é::... o menino e o amigo panda...

L1 - é bonito?

L2 - é... bonito...

L1 - e sua escola?... você gosta da sua escola?... como que é a sua escola?...

L2 - uhn:: não gosto muito não... é tô querendo falar pa mãe pra eu e pro ( ) porque ali o professor é muito chato... eles fazem pergunta demais... são muito bravo... ( )...

L1 - e como que é a sua escola... é grande... pequena

L L2 - grande... parece uma penitenciária

$(($ risos $)) \ldots$ porque a nossa quadra eles quebrar[u]... ( ) a gente tem que jogar num... lugarzinho bem apertado....

L1 - você tem muitos amigos?...

L2 - tenho... bastante...

L1 - quem são?... qual o nome deles... a idade... eles moram por aqui?... 
L2 - Júlio... a idade não sei... André... André eu acho que tem onze anos... adoro.... o Benício... deixa eu ver mais... o Lucas... o Giovani... o Paulo... o Juliano... o Diógenes.. quase todos da minha sala é meu amigo... (conta) todos eles né?... todos eles porque tem bem pouquinho menino...

L1 - e você gosta de morar aqui?

L2 - gosto... aDOro morar aqui... porque aqui é perto dos meus amigos... dá pra brincar aqui...

L1 - e praia... você gosta?...

L2 - só no verão...

L1 - você gosta?...

L2 - gosto... mas gosto só de vez em quando assim... pa pular das pedra pra água... virar cambalhota ... jogar bola na areia...

L1 - e:: conta uma viagem que você fez assim com seu pai... pra onde você foi... se você viu muita gente...

L2 - Salvador... meu pai: ficou parado num posto lá... até encher carga... daí a gente achou um pessoal né?... um senhor que tinha uma cento e treze... a gent[e] ia na praia... ia brincar...

tinha um gurizinho... um menino... a gente brincava... ele tinha uma bola... a gente jogava bola... ia numa praia MUIto bonita... brincava na ponte... o senhor até deu o endereço onde é a casa dele... só que o pai nunca foi lá...

L1 - uma vez o teu pai falou pra mim que tinha um restaurante... que tinha um couro de cobra grande... você viu?...

L2 - não...

L1 - viu?...

L2 - não tava lá...

L1 - não tava lá?

L2 - uhn uhn...

L1 - que outra cidade você conheceu?...

L2 - Rio de Janeiro... que mais... não sei muito... não... é que a gente esquece o monte que a gente vai... várias... é:: Leopoldo (em Minas) meu pai teve um acidente lá...

L1 - como que foi?...

L2 - ahn... um moço tava indo pra cachoeira tomar banho... aí o pai tava descendo a Serra... caminhão entrou na fren / o:: carro entrou na frente Vectra... aí meu pai bateu no Vectra... aí quase tombou a carreta... aí foi parar do outro lado da pista... ainda bem que não tinha vindo ninguém... se não ia dar de frente...

L1 - perigo né?

L2 - é... ( ) quando eu e meu pai viajava junto... eu e meu pai QUAse levamo[Ø] um acidente... o caminhão vinha ultrapassando em cima do morro... meu pai não vinha.. tinha que jogar po $[\varnothing]$ costamento...

L1 - e tava só vocês dois?...

L2 - nas minhas férias porque minha mãe não gosta de viajar muito... ( ) quando dá acidente ela treme... ela chora... ela chora... ela não gosta muito... (então) vou eu e meu pai...

L1 - e sua irmã quase nunca vai?...

L2 - não... ela não vai... só quando ela era pequena...

L1 - B.... conta pra mim... é:.... você gosta de passear?... ir ao cinema?...

L2 - A:... agora quarta-feira a gente vai no cinema... eu e meu amigo...

L1 - o que vocês vão assistir? 
L2 - a gente não... a gente não sabe (ainda)... a gente vai ver lá ainda o nome do filme... aí de vez em quando também eu vou lá pra casa do meu amigo o nome dele é Gabriel... a gente... ele tem... ele tem ( )... tem vários brinquedo... aí ele:: ele é rico assim né?... aí a gente vai lá brincar... o pai dele leva a gente no cinema... é:... compra... compra presente pra nós de vez em quando... dá vários presente... tênis... roupa...

L1 - você gosta do seu amigo...

L2 - ele é bem legal...

L1 - ele mora aqui... mesmo ou só vem passar as férias?

L2 - ele... não... ele vem sábado... fica domingo... quando é domingo três hora... de tarde assim... ele vai embora... porque ele estuda... agora nas férias ele vai vim...

L1 - de onde ele é?...

L2 - de Jara / de Joinville..

L1 - e:.... você tem primos?... você gosta de brincar com seus primos?...

L2 - claro... ador[o]....

L1 - do que que você mais brinca com eles?...

L2 - futebol...

L1 - que mais?

L2 - p[e]ca...

L1 - p[e]ca?.... o que é p[e]ca?...

L2 - uma bolinha de gude... bolinha de vidro...

L1 - é?... e como é que se joga $\mathrm{p}[\mathrm{e}] \mathrm{ca}$ ?

L2 - segura na mão e joga...

L1 - mas como é que é?... tem que derrubar bolinha...

L2 - tem que acertar na bolinha pra tu ganhar uma outra bolinha... tu joga... aí tem um buraquinho... tem que cair dentro do buraquinho e matar... se tu matar ele... aí se tu errar... aí tu vai jogando até matar... aí quando tu matar... ele joga / joga uma bolinha de gude e fíca com aquela bolinha pra sempre... aí ele tem que pagar uma bolinha pra ti...

L1 - ahn::... e... que matérias você está estudando na escola?... que / qual o nome de seus professores?...

L2 - acho que eu sei todos... é:: Edson... professor de Educação Física... Edinilson de matemática... Fernando de geografia... Shirley de português... religião Shirley também... inglês Helena... é e professor de história é:: Martinho...

L1 - e qual é a matéria que você mais gosta?...

L2 - matemática história e geografia...

L1 - gosta de inglês?...

L2 - e de educação física...

L1 - não? e por que você gosta mais dessas matérias?

L2 - porque:: eles fazem mais aventuras... passeiam com a gente... agora de matemática / é... agora de (livre) a professora só faz trabalho... de... de outras matérias eles só fazem trabalho...

L1 - vocês passeiam aonde?

L2 - a gente... a gente tem que dar... dar o dinheiro pra achar o ônibus... aí a gente vai... ( ) conhece... é:... como que é?... ziô... ziológic[o]... é o:: onde tem vários animais... aí a gente vê... conhece... tira fotos... a dessas fotos... desses trabalho tudo a gente tem que fazer um trabalho em cima disso... 
L1 - e você já foi no zoológico então...

L2 - várias vezes...

L1 - o que você viu lá?...

L2 - tartaruga... cobra... jacaré... arara... macacos... leão... onça.... tigre... é:.... canguro... e vários outros / elefante... e vários outros animais...

L1 - e::... você mora aqui pertinho do Beto Carrero né?... já foi no Beto Carrero?

L2 - já... até outro dia a gente foi lá tentando furar porque...

L1 - pra entrar lá?...

L2 - é:.... pular muro... só que aí tem agora tá cheio de guarda... agora não DÁ...

L1 - antes dava?

L2 - antes dava... tem uma monte de gente que pula... minha prima pula... a C. ... aí a gente foi na casa dela chamar ela... ela não tava...

L1 - e como que é lá dentro do Beto Carrero?...

L2 - tem carrinho de choque... tem barco Viking... tem é... Max Emotion... tem Monga... tem Elevador ... tem montanha-russa... tem trem fantasma... barco Viking... barco pirata... é... carrossel... roda gigante... um monte de brinquedo... do ( ) tu cai na água... o tem teleférico... passa por cima (daqui) todinho... tem várias outras aqui... minha irmã já trabalhou lá... trabalhou lá... quando eu tava na creche eu ia direto com ela... quando chegava da creche era só embarcar... o ônibus e ir embora... chegava lá... entrava de graça...

L1 - qual o brinquedo que você mais gostava?...

L2 - Max Emotion...

L1 - como que é esse brinquedo?...

L2 - é:: ele tinha um telão enorme... ali bota o filme... aí tem que ficar olhando po filme... bota o cinto numa cadeira... segura assim num negoc[̃̃] ... e a cadeira começa a se mexer... é: aí tem um avião lá... o avião vira carambota... e a cadeira faz isso aqui... faz isso aqui ((demonstração)) aí... aí... várias coisa ela... quando ela vai po lado a cadeira cai po lado... cai po outro... quando ela vai pra frente ela cai pra frente... vai pra trás... bem massa... muito legal.. o brinquedo... é o brinquedo que eu mais gosto... montanha-russa também....

L1 - tem quantas montanhas-russas... fala?...

L2 - uma só...

L1 - e::... tem bastante restaurante?...

L2 - tem... tem... tem o pa[x]que que é só pra tu comer assim né?... eles (compra)... tem sorveteria... tem... eles fazem x-salada também... é... fazem comida... é isso mesmo... arroz feijão... carne... pra tu almoçar lá... tu... tu paga o hotel se quiser dorme lá...

L1 - quantos hotéis...

L2 - acho que uns três (até lá atrás) do Beto Carrero...

L1 - são três...

L2 - acho que uns três só...

L1 - B.... você podia contar até dez pra mim?...

L2 - um... dois... três... quatro... cinco... seis... sete... oito... nove... dez...

L1 - B.... eu queria que você contasse pra mim uma arte... uma bagunça que você fez um dia e seu pai e sua mãe ficaram bravos... você lembra de alguma?

L2 - lembro... eu tinha um carrinho uma vez... eu tinha oito anos... tinha um carrinho pequenininho aí... meu amigo tinha acabado de se mudar... aí até eu conhecer ali tudo... ele tinha uma funda... aí o Élcio... era amigo do meu tio... P. ... ele morava aqui no lado no 
vizinho... e ele tinha um carro de vidraçaria ali... aí eu pedi "o menino... deixa eu brincar um pouco com a tua funda que tu brinca um pouco com meu carrinho"...

L1 - o que que é funda?...

L2 - é um:... uma madeira com dois galhinho assim... aí tu amarra um elástico... bota um como atrás... amarra... bota pedra ali no couro... (mira) e joga... aí a pedra [a]voa... aí eu pedi pra ele... aí ele me emprestou... aí ele ficou brincando com o carrinho... aí eu peguei uma pedra enorme... desse tamanhão assim mais o meno $[\varnothing]$... cheguei e falei assim pra ele "vou atirar no vidro do carro"... "não... não atira pro alto"... "não... atirar no vidro do carro"... cheguei mirei e ataquei... PAU... quebrou o vidro... o meu pai tinha que pagar o vidro todinho... apanhei uma coça que só... ((risos))... o pai quase me matou de tanta lambada que me deu... e teve que pagar o vidro...

L1 - H.... eu gostaria que você contasse um pouquinho... de como é morar aqui na Penha?... o que você faz... onde você estuda?...

L2 - eu... ahn... a escola fica bem:... na frente de casa né?... então é só atravessar a rua que já tá dentro do colégio... e morar aqui é legal... porque:... tem praias né?... tem dezenove praias... e... vem muito turista pra cá... inclusive vem um cara que mora em Joinville lá... uns dos amigos nosso... daí ele vem pra cá... e a gente se diverte ali na praia... todo dia no verão...

L1 - e o que você está estudando na escola?... quais as matérias?... quais são seus professores...

L2 - as matérias é:... produção artística... ética e cidadania... matemática... português... história... geografia... fillosofia e só...

L1 - e os professores... você lembra?

L2 - os professores são... é:... a gente costuma chamar muito por apelido né?...

L1 - não lembra agora?...

L2 - não...

L1 - e:... qual é a matéria que você mais gosta?...

L2 - a que eu mas gosto é... é filosofia...

L1 - é mesmo?...

L2 - é filosofia... porque a gente fica refletindo mais...

L1 - nossa... é interessante... conta alguma coisa que você aprendeu legal na filosofia...

L2 - sobre a festa Junina... que foi... muita gente pensa que é por causa do mês de junho... que se chama junina... mas é por causa da deusa Juno... que... a deusa Juno né? que... é... a:: rainha da fogueira ( ) e deu origem em junho Junina... e daí... pular a fogueira tinha / era uma homenagem a deusa Juno...

L1 - eu não sabia... mais alguma coisa interessante pra contar?.. eu adorei...

L2 - uhn...

L1 - me conta como que é um dia da tua vida... da hora que você levanta até a hora que você vai dormir...

L2 - é... acordo às sete... faço lá o que tenho que fazer... vou po colégio... e... (antes) do meio dia eu saiu... almoço... à tarde eu tenho que... ou fico na biblioteca né?... ou fico em casa... (tarde)... uma hora vendo tevê... daí vou po curso de computação...e:... daí vou... vou po 
curso às cinco e meia... volto às sete... e fico vendo umas novela... daí quero ver até as... até o Jornal Nacional... quando começa a novela... eu viro um pouquinho e vou dormir...

L1 - e filme... você gosta de assistir filme?...

L2 - gosto...

L1 - qual é o filme que você mais gostou de assistir?...

L2 - mas gostei?... é:... é... Guerra do Atlântico...

L1 - como que é a história desse filme?...

L2 - é um grupo de... de... marinheiro que se formaram e ganharam vinte e quatro horas de férias... só que... antes de terminar o prazo das férias deles... eles recebem uma missão... que é de pegar uma máquina... de comunicação nazista... eles ficam dentro dum submarino... daí eles têm uma maquininha de... que eles comunica com outro... (e eles) têm que pegar essa maquininha... pra... pra poder matar esses nazista né?... porque senão eles vão se comunicar... aí vão matar os norte-americanos... daí eles têm que se fingir de nazista... invadir o navio... e pegar a maquininha... só que:: eles foram... (por causa) disso avisaram... antes... deles chegarem... avisaram pra chegar um... um submarino pra rebocar o outro submarino que tava estragado... quando esse navio... que ia rebocar o submarino do nazista chegou... (fundiu) o submarino norte-americano... daí eles tiveram que pegar o... os norte americano tiveram que pegar os:... submarino dos nazistas... e chegaram até o destino deles... só que daí eles encontram um navio lá pra destruir e no final ( )...

L1 - e um outro filme bacana?...

L2 - ( )

L1 - terror você não gosta?

L2 - gosto

L1 - lembra de um filme de terror bem bacana que você tenha assistido?

L2 - uhn... Jason X ( )

L1 - você conta a história ( ) porque eu não vi...

L2 - é uma mulher né?... que eles já tinham capturado o Jason... daí quando eles vão chegar pra olhar... o Jason tinha se soltado... e:... eles estavam num laboratório assim... daí veio uma mulher né?... pegou uma escopeta... e atirou três vezes nele... ele caiu numa câmera de gás... de congelamento... ela liga a câmera e ficou olhando ele... daí ele deu uma facada nela... deu no meio da porta... e os dois ficaram dentro da câmera... e começou a vazar e os dois congelaram... daí... quatro séculos e meio... veio um grupo de... um grupo de estudante assim... umas pessoas... que mora já no espaço... que a Terra é um planeta desabitado né?... vem em busca de relíquias... daí encontra os dois... daí levam pro laboratório... descongela a / a moça né?... daí ela lembra do Jason... e o Jason ressuscita... por causa das pessoas que fícavam no quarto lá... daí ele começa a matar todo mundo... daí quando a... uma andróide... explodiu ele... acabou com ele... veio assim aquele... daí... tinha um nego que... negro não... ((risos)) veio assim um crioulo... que tava lá machucado... aí tem uma máquina dele... que parece uma minhoca... que vai no corpo assim e fecha o machucado...e eles deixaram essa máquina ligada... daí vem essa... essas minhoquinha aí e:: (vem) no Jason... começam a reconstruir o corpo dele... só que já / tava sem uma perna... parte do rosto... o braço... daí era muito... muito tecido... muitas células pra máquina daí... a máquina não tinha mais... e... e revestiu o corpo dele com fibra sintética... daí ficou assim... todo cheio de aço... e ficou invencível... daí começaram... a... a fugir da nave... e veio assim o crioulo... pega o nego... e leva assim pra pegar o nego pelos braços... ele tá no espaço já... e começa a botar o nego na atmosfera da terra... daí no final... tem um casal lá vendo o céu... daí vejam a... estrela 
cadente... que é os dois... e... vê elas caindo no lago... que é o lago onde o Jason mora... morava... daí vão lá... e só aparece a máscara do Jason do lado...

L1 - C.... o que você gosta de fazer no fim-de-semana?...

L2 - eu gosto de sair... a noite assim né?... gosto de ir na praia no verão... no inverno também... dar volta na praia... que mais gosto de ficar com meu namorado... que mais...

L1 - você falou que gosta de sair à noite... pra onde que você vai à noite?... e assim... tem algum lugar legal pra dançar?... algum barzinho aqui... como que é a noite aqui?... eu sou de fora e não conheço

L2 - tem... tem... tem assim danceteria eu não gosto dessas coisas... sabe?... eu gosto de... sei lá... de sair... ir num rodízio assim... essas coisa assim... que daí sai todo mundo junto... fica na praia... fica no Júlio Lanches... coisas assim...

L1 - e você tem namorado... conta fala pra mim dele... quando você conheceu ele... como foi que você conheceu ele...

L2 - é que ele anda de skate né?... aí eu conheci ele ali na pista... ali... conheci ele ( )... namoro ele por um ano e meio... e foi na pista que eu conheci ele...

L1 - e onde é a pista de skate?...

L2 - é ali na esquina ali...

L1 - a: tá... e:: você estuda né?... que matérias você estuda... o que que você gosta de estudar?...

L2 - eu estudo... física química... matemática... português... espanhol... inglês... é... qual que eu esqueci... matemática...

L1 - você lembra assim o nome dos professores?... de cada matéria...

L2 - não não não... não ( ) porque eu mudei de escola esse ano né?... eu sempre estudei aqui... daí agora eu mudei pra outro colégio... eu não me lembro assim... o nome dos professores assim...

L1 - e é muito diferente o novo colégio do antigo?

L2 - É:: é porque aqui é público né?... e agora onde eu tô estudando é particular... e é mais... bem mais esforço assim... daí tem que estudar o dobro... não que seja difícil... porque eu sempre estudei assim sabe?... mas... aí tu tem que estudar o dobro... que tu estudava entendeu?... porque se não... porque se não tem que ficar em recuperação... tem que ficar estudando em férias... essas coisas... ( ) tudo pra mim não ficar estudando em férias... estudo durante o ano assim...

L1 - qual a matéria que você mais gosta?...

L2 - eu me dou bem com conta... assim... matemática química física... já matéria... assim... eu... po[x]tuguês assim eu não... não tenho... não pego...

L1 - você já está no segundo colegial né?

L2 - é:...

L1 - então daqui algum tempo... passa bem rápido... você vai prestar vestibular provavelmente vai querer prestar uma faculdade... o que você gostaria de fazer e por quê?...

L2 - eu queria fazer turismo e hotelaria... (talvez) pelo fato de eu nunca ter saído daqui... entendeu?... e conhecer outros lugares assim... porque eu gosto tam[ $\varnothing]$ ém... que é um... é um mercado de trabalho que tá crescendo né?... tam[ $\varnothing]$ ém não quero estudar... esse tempo todo 
da minha vida... e fazer não sei quantos anos de faculdade... pra não trabalhar... pra não ter nada?... L1 - então você vai ter que estudar bastante línguas... justamente o que você não gosta...

L2 - é... mais eu... (preciso mudar)

L1 - português... inglês... espanhol... faz os três né?...

L2 - ahn ahn...

L1 - qual deles você mais gosta?

L2 - gosto de inglês... português é muito difícil... é muita coisa sabe?... inglês já é mais fácil...

L1 - e o espanhol?...

L2 - espanhol é mais fácil ainda... eu acho mais fácil ainda...

L1 - melhor do que português?

L2 - é... não... português é melhor... mas espanhol já é uma coisa mais fácil... ( ) saber falar espanhol é bem mais fácil que aprender a falar inglês... porque já é alguma coisa parecida com a tua língua né?... é bem mais fácil... mas fora isso...

L1 - e:... conta pra mim... na sua escola... ou antes na escola pública... tinha alguma festa típica... alguma coisa assim?...

L2 - tem... todo ano eles fazem... noite cultural... né?... fazem noite cultural... assim... os alunos... pe / tem A:: a:... colonização portuguesa dos Açor[e]s né?... e até hoje eles trabalham muito em cima disso sabe?... em cima dos Açor[e]s... exposição... coisas antigas assim... fotos... e... sabe?... dessas coisas... dança... dessas coisas... eles sempre fazem a noite cultural... lá no meu colégio não... lá eles já não fazem né?...

L1 - e você conhece um pouco da história do município?... ( ) me conta um pouquinho... o que você souber...

L2 - meu pai contou assim né?... daí tinha $0 . .$. o... os portugueses... que pescavam baleia lá na Armação de Itapocoró[ $\varnothing]$... daí ali eles até construíram aquela igreja... que foi usado o óleo da baleia... os osso pra formar aquela...

\section{L1 - carcaça?...}

L2 - aquele muro que os escravo fizeram né?... daí foi... por isso... foi a / Penha tem quarenta e quatro anos de emancipação né?... tem quarenta e quatro anos de emancipação... do ponto que se soltou... entendeu... depois que deixou de escravidão... dessas coisas...

L1 - mais era BEM mais antiga... bem mais de quarenta e quatro anos né?

L2 - É::...

L1 - é::

L2 - é:: tem mais... lógico... só que a emancipação assim... eu tô dizendo assim... a emancipação política... tem quarenta e quatro anos...

L1 - e você tem muitos amigos?...

L2 - aqui não... lá tenho bastante... aqui tenho pouco...

L1 - e onde é a sua nova escola?...

L2 - é lá em Itajaí

L1 - Itajaí?

L2 - uhn uhn

L1 - faz tempo?... foi esse ano que você mudou...

L2 - foi... é que aqui ahn... é muito aqui né?... fico muito aqui nesse lugar aqui... e eu não saio sozinha porque eu namoro né?... eu não saio sozinha... e aqui... nesse lugar assim... as pessoas (antes) andavam junta... mas aí se separam... é muita inveja... coisa eu não gosto de (baile)... eu fico apavorada assim... lógico que eu me sinto sozinha... porque lá eu tô com eles a manhã inteira... a gente sai à tarde... de carro... ( ) aí eu... sinto assim... (posso viver) aqui tenho pouc[o]s... ( ) e olhe lá ainda... aqui não... lá sim... 
L1 - lá você vai no cinema?

L2 - vou... no shopping...

L1 - e qual foi o último filme que você assistiu?...

L2 - o Hom[i] Aranha...

L1 - como que é a história do filme?...

L2 - olha... eu não gostei muito não... é um cara que ele é... é::... ele sofreu uma mutação né?... e daí ele começa a andar pela cidade... assim... jogando aquela teia assim... eu não gostei muito do filme...

L1 - ( ) e agora conta um filme que você gostou muito....

L2 - que eu gosto de ver?... precisa ser no cinema?...

L1 - não... ou até em casa mesmo... vídeo

L L2 - eu gostei do Gladiado[x]... você assistiu o

Gladiado $[\mathrm{x}] ? \ldots$

L1 - não...

L2 - é bem legal o filme assim... o Gladiador... que outro filme... o Jason...

L1 - qual deles?...

L2 - o último que saiu agora... é que na capa ele tá com duas partes diferente e numa faca no meio... L1 - então me conta... eu não vi nenhum dos dois... você pode me contar os dois?...

L2 - o Gladiador é assim... e que o Gladi / o cara ele... ele fazia parte de uma legião de matadores... assim né?... uma legião de gladiadores... daí ele pegou e saiu dali por que o filho / o rei... gostava mais dele do que do próprio filho... e o rei morreu... aí o filho do rei mandou o gladiador embora... aí ele pegou e foi embora... daí depois... tem aquele:: Coliseu... sabe onde tem aquelas lutas?... e o gladiador ele ele ficou (ofendido)... achar[ũ] ele... todo detonado assim... e ele foi vendido prum cara... e disseram o sobrenome dele de Espanhol... e ele usava uma máscara... tudo pra luta... no Coliseu... aí ele pegava e matava tudo sabe?... matava todo mundo assim... daí até que um dia... e o filho do rei era quem mandava na Grécia toda né?... até que o filho do rei viu que era ele... que era o cara que eu não lembro o nome... aí ( ) e no final os dois morreram... ((risos))

L1 - os dois?...

L2 - os dois... o gladiador e o filho do rei...

L1 - e do... do Jason X... qual é a história do filme?

L2 - é um:.... é assim... daí tem o Jason... ele foi congelado... ele e uma guria... foram congelado... aí um outro tempo depois... muitos anos assim... uns dois mil e seiscentos no tempo né?... ele... for[ũ] achado por uma turma... só que não tinha mais o planeta Terra entendeu?... era tudo assim no espaço... assim... feito umas nave assim... aí era tudo no espaço... aí eles foram achado e reanimados assim... entendeu?... aí ( ) veio... aí o Jason pegou... aí o Jason pegou... e foi reanimado e começou a matar todo mundo... matava tudo... até que chegou uma... um rapazinho e um grupo de estudante... aí o rapazinho pegou fez uma:: uma mutante assim... uma mulher... e essa mulher acabou com o Jason... daí só que ele... ele pegou e deitou naquela maquininha onde reanimava... aí de repente essa maquininha ligou... o os bichinho reanimaram ele... aí ele começa a matar tudo de novo... aí eu sei que no final a nave dele estava explodindo aí eles pegaram e passaram pa outra... só que quando eles passar[ũ] o Jason ficou do lado de cá... aí eles pegar[ũ] e saír[ũ]... daí ( ) a nave explodiu assim... e o Jason foi assim na direção deles... com aquela:: aquela faca dele... aí o Jason na hora passou um hom[i] e levou ele... aí caiu em outro lugar assim... e acabou assim...( )...

L1 - e na televisão... o que você gosta de assistir?...

L2 - eu gosto da Malhação...

L1 - e como que tá a Malhação... faz um tempão... eu vim pra cá e não vi mais... 
L2 - ele... ele tão... hoje (tá) uma festa Junina... Julina né?... é em julho... aí tavam numa festa julina... aí eles pegar[ũ] e dividiram um monte de grupo assim... ( )

L1 - tá bacana?... a Júlia ainda tá com o Pedro?...

L2 - NÃO... não... separaram depois que o pai dela... depois que o pai dela deu aquele (defeito) no pai do Pedro... deixou ele com uma perna mais curta... aí eles não ficaram mais junto... agora o Pedro voltou com a Taíssa... tão junto de novo... e a Júlia tá sozinha de novo...

L1 - e você lembra de alguma história que aconteceu aqui no município... alguma coisa que aconteceu com você... com uma amiga... que seja bem engraçada... uma coisa assim divertida... ( ) L2 - comig[o]?... não me lembro assim...

L1 - ( )... uma história triste... todo mundo tem uma história pra contar né?...

L2 - pois é... não sei assim...

L1 - não lembra de uma história ( )... quando você era pequena...

L2 - quando eu era pequena...

L1 - alguma arte... alguma coisa que você aprontou...

L2 - AH:.... quando eu era pequena... eu tava lá na casa da minha tia né?... aí eu peguei o leiteir[o] chegou... aí o leiteir[o] chegou... fui botar o tênis... só que eu botei o pé em cima da língua do tênis... aí derramei o engradado em cima do cara ((risos)) a marca que eu tenho aqui ((aponta uma cicatriz)) (é do engradado) ((risos))

L1 - ((risos))

L2 - sério... e perto do olho é do ar condicionado... ( ) tem uma outra assim... uma outra história engraçada... acho que não... eu tenho... mas não que eu me lembro...

L1 - e você falou pra mim... que você gosta de praticar esporte

$$
\text { L L2 - uhn uhn... }
$$

L1 - qual... e por que você gosta... conta pra mim... onde você pratica...

L2 - eu gosto de vôlei... eu jogo pela fundação da Penha assim... da Penha assim né?... jogo ali no ginásio... a por que que eu gosto é por que eu sempre joguei... desde de pequenininha... daí com o tempo... tu vai... jogando com precisão... ( ) vai jogando cada vez mais... cada vez mais né?... eu gosto... eu não consigo ficar sem jogar assim... fico ruim...

L1 - e você é alta né?

L2 - só... tenho um metro e sessenta e nove...

L1 - pra mulher... ( ) não tem vontade de praticar um outro esporte?...

L2 - não escolho assim... um pouco de tudo... basquete... futebol... só que eu não gosto assim... não sei assim... é ruim jogo quando tu não sabe...

L1 - e você sabe nadar bem?...

L2 - sei nadar sim...

L1 - aí no verão só praia...

L2 - só...

L1 - e você conhece o Beto Carrero...

L2 - o::...

L1 - é legal lá?

L2 - é::

L1 - conta um pouquinho de lá pra mim...

L2 - sei lá... no Beto Carrero a melho[Ø] coisa que tem... Barco Viking... de cabeça pra baixo... e o elevador assim que cai... de uma altura de quarenta prédios... de quarenta andares né?... ele cai em cinco segundos assim... é bem legal assim...

L1 - tem animais lá?...

L2 - tem... tem na... na África Misteriosa tem ( )... 
L1 - quais animais que tem?...

L2 - tem... tem de tudo... tem leão... tem:.... tem aquele... zebra... aquele que tem o pescoço comprido... como que é o nome?...

L1 - girafa...

L2 - girafa... macaco... cobra... tem de tudo lá... ( )

\section{P. N. R. (L2)}

10AI

L1 - P. ... eu queria que você me contasse... um pedacinho da tua vida ( )...

L2 - ( ) ((risos)) AH meu DEus... eu quando saio? estudo?...

L1 - você já fez uma viagem... uma coisa legal?

L2 - JÁ... foi:: o an[o] passad[o]... no final do an[o]... que eu e a L. ... e o pessoal do... que ela dava aula... foi... fomos... numa... numa... num ônibus pra Garopava... de madrugada... cinco horas da manhã a gente pegou o ônibus... e foi cara... muito doido... aí tava / aí a gente chegou no meio... é:... a gente chegou lá... eram quase meio-dia assim... o sol rachando assim... nas praias... só pra ver... maior zona... a maior zona no ônibus... chegamo[ $\varnothing]$ lá... tava aquele / tava tudo feioso entende?... lá o luga $[\mathrm{x}]$... a noite era bem frio... não... não deu nem pra tomar banho lá... praia lá... congelante... oh... em pleno verão... ficamo[ $\varnothing]$ até assustada... (mas) a gente ficou lá / na piscina té[x]mica do hotel... passou na piscina té[x]mica... (ficamo[Ø]) ((risos)) o dia todo lá... a noite inteira ((risos))... aí... ( ) cada um trocava de qua[x]to... o banho... a gente se apoderou do quarto dos meninos que tinha o banheiro... o nosso não tinha... a gente se revoltou... ficava no qua[x]to deles... eles endoidavam...a gente tava... queria tomar banho... e nós três horas lá dentro... fazendo hidromassagem ( )... e:: ficou uns três dias lá... melhor que uma viagem maravilhosa... divertimo $[\varnothing]$ pra caramba... passeamo $[\varnothing] \ldots$ fomo$[\varnothing]$ numa praia... curtir... ficar lá... tiramo[ $\varnothing]$ umas fotos no morro... é:... divertimos pra caramba... bebemo[ $\varnothing]$ um monte... fizemo[ $\varnothing]$ tudo que tinha direito... ficamo $[\varnothing]$ no qua[x]to... bebi um monte... saímo[ $\varnothing]$ à noite... ficamo[ $\varnothing]$ perambulando pela rua...

L1 - é::... eu sei que você morou em São Francisco do Sul... como que é lá... como é viver lá... o que você conhece lá...

L2 - eu era nova... eu acho que tinha: sete anos... quando eu fui morar lá... a cidade é bem... morar... bem parada... mas as praias são magníficas né?... a praia do Forte... que não tem onda assim.... pra criança excelente... e tinha muito pra lá... ( )... tinha a Prainha lá... que era bem... quando dava ressaca atingia toda a rua né?... ( ) é bem ( ) eu morava bem afastada do centro... tudo... tinha que pegar ônibus... ( ) andar de ônibus... era horrível... que a gente se cansava... mais foi bem legal lá... praia tem de monte... (mas) não tem o que fazer né?... falta trabalho... a gente se deu bem... mais o resto não... a praia é / no verão era muito bom... na praia da Enseada... ( ) não tem que falar muito de lá...

L1 - e fala um pouquinho do seu dia-a-dia... o que que você faz... quem são seus amigos...

L2 - ahn... eu:... eu estudo e trabalho num materiais de construção... é bem divertido né?... a gente ficamos bem lá o pessoal... trabalha... legal... é a maior zona assim... o trabalho é super divertido lá... ( ) e chego em casa às cinco... tomo um banho... moro na frente do colégio... como... vou... fico estudando... não faço quase nada... ( ) chego em casa dez e meia... aí vou dormir... quando eu não venho pra casa da L. dormir né?... ( )...

L1 - e qual são seus planos pro futuro?... 
L2 - AH me Deus... tem um monte de planos... nada concreto não... tá tudo ainda em forma de... ainda tá se formando ainda... não sei se vou pra São Paulo... não sei vou pra Floripa... não sei mais o que que eu faço... mas eu pretendo fazer é uma faculdade em área ambiental... alguma coisa relacionada a isso...e.:..... continuar meu inglês... ( )... sei lá...

L1 - e na escola o que você mais

L L2 - um monte...

L1 - e na escola o que você mais gosta de fazer?

L2 - na escola ((risos))... olha... na verdade... na minha escola a gente não fazem nada né?... então... eu fico lá só conversando... e... ( ) não faço nada muito não... presto atenção... ( ) não tem muita coisa assim... porque final do an[o] tal... vou formar esse an[o]... graças a Deus... mas... eu até tô me vendo um pouco melho[ $\varnothing] \ldots$ quero estudar bastante pra fazer vestibular no fim do an[o]... mas acho que eu vou fazer só ano que vem... não sei... mas tudo bem... na escola... é isso que eu tenho pra falar... não tenho muita coisa pra dizer além... é... ( ) e:.... eu aDOro praia... eu am[o] a praia... eu acho que... nunca quero sair daqui do litoral... porque praia é tudo né?... a gente vai lá... ouvi o barulho dos / do mar... mar... das águas... as ondas... e vê o / o sol... assim... bastante areia... tudo... as pedras... as ondas batendo nas pedras... tudo é magnífico assim... eu me sinto CALma... é:... parece que tudo que é de ruim sai... e:... o... vem um monte de vento... é maravilhoso né?... as praias assim... um dos lugares que eu me identifico muito... que eu amo... é a praia... eu acho que eu não:... se eu pudesse eu morava... na frente da praia né?... teria uma casa na frente da praia... é divino ficar ouvindo o barulho do mar de madrugada... é ( ) sair pra festa... ficar curtindo... fico... saiu muito com pessoal do Paraná... Curitiba... tenho uns amigos muito legais... então a gente sai direto... (sai) pra caramba... vai numa sorveteria... ou faz um lanche... e::... eles vêm pra cá de vez em quando né?... nessas férias eles tão aí... a gente (saiu) bastante... foi muito divertido... e:.... ( ) uma vez o outra... a gente assim não... não tem esse compromisso... de ficar né?... aquela coisa todo dia pentelhando a gente... grudado na gente... eu acho muito legal esse tipo de coisa também... e:.... ( ) as aventuras... as aventuras da gente... e:... é... aventura é:.... tomar banho de madrugada... é:: tomar banho na praia eu e o pessoal de Curitiba... você não tava né Amábile?... é... tiramos a roupa... e:... fomos... até a L. conta aqui na outra fita... não sei... mas deve ter contado tudo né?... a gente saiu... ficou até duas horas da manhã... tiramo[ $[\varnothing]$ a roupa... entramo[ $\varnothing]$ na água... isso era verão mas tava frio... e eu dormi... com aquela coisa assim... acho que uma das coisas mais $1[\mathrm{ow}]$ cas que eu já fiz assim... fora outras... ( ) têm muitas... mas... ( ) tem Curitiba... outra vez que a gente saiu... normal... e eu fiquei toda assada daquela água do $\mathrm{ma}[\mathrm{x}]$ que eu fiquei... eu dormi com aquela (água horrível) lá... né?... não podia tomar banho por causa que a tia ia escutar e ia perguntar... ( ) isso foi horrível... e direto... por aqui não dá muito pra sair assim.. porque... as festas aqui é tudo povo daqui assim... enjoa sabe?... enjoa deles... toda aquela mesma pessoa... todas aquelas mesmas caras... que você vê todo dia... ainda mais eu que trabalho ali no materiais de construção... conheço tu / quase todo mundo ne'?... até aprendi alemão de tanto que eu vivo com eles... e:.... todo aquele pessoal é legal assim... (quanto) mas no verão... aí eu faço festa... ainda mas agora que juntou nós três.. antes era só eu e a L. ... esse ano agora que passou... que a Amábile veio... ficamos mais unidas assim né?... ( ) e:: então a gente saiu... ( ) fomos muito pro Bali Hai... eu aDOru Bali Hai... agora tem um lá em Floripa né?... em uma caverna implodida... muito dez... acho que deve conhecer... pequeno assim... pelo poder que tem o Bali Hai né?... acho que... se pudesse conhecer deveria conhecer... é muito legal... e é bem na beira da praia aqui né?... é maravilhoso... a gente sai... vai pra praia... faz um luau... muito massa... fiz um luau ali na Prainha... um luau maravilhoso... tinha um tronc[o] assim... ele era perfurado... assim né?... dava pra ver... o fogo ali no meio do... e era lua cheia... ( ) bem uma lua cheia... foi bem espontâneo assim... é... era um feriadão... fez bem assim 
um dia que tivesse lua cheia... eu acho divino isso... e ficou aquele fogo... assim... ficou (mexendo) assim é... como é que eu vou dizer...entre meio... aquele buraco ali... deixou lindo sabe?... iluminou... a gente viu aquela a:...a:...a:... na água... a:... aquela coisa clara da lua assim... aquela faixa brilhante... maravilhosa... e:... a gente ficou até umas três horas assim né?... tinha um pessoal fumando maconha do outro lado... essas coisas assim... que adolescente... que nós fazemos... EU não... é:... tavam fumando maconha ali do lado... aí... a gente sentou pra cá... viu que tava fícan / ficando frio... ( ) aí a gente entrou pra casa... ficamo[ $\varnothing]$ lá... tava todo mundo até casalzinho... foi animal... quebraram uma cama... de manhã... só acordaram com aquela cama quebrada... ( ) foi animal assim... seis horas da manhã (chego) em casa... e até que eu não curti muito assim... saí tanto... só alguma coisa....

\section{F. M. A. (L2)}

1BI

L1 - eu gostaria que você me contasse um episódio bacana da sua vida... algo que você saiba... pode ficar à vontade...

L2 - bom... primeiro eu queria começar a contar... começar a contar da minha infância... ahn::... quando eu tinha uns dez anos de idade... meu pai começou a juntar papelão... quando ele ficou desempregado... e:... eu e meus dois irmãos ajudávamos ele... e eu saía com ele à meia-noite de casa... e voltava $\mathrm{d}[\mathrm{e}]$ manhã... e daí a minha mãe... eu chegava em casa ia fazer meus deveres... limpar a casa pra minha mãe... fazia comida... daí saía minha mãe e meu outro irmão... saíam pra juntar papelão... ela chegava meio dia... eu deixava tudo pronto... e eu ia pro colégio... e assim foi até os meus treze anos de idade... três anos juntando papelão... passava frio... passei fome... então... em tudo Deus me guardou... ((choro))

L1 - ( ) não é fácil a vida da gente... depois disso que você foi morar na Armação ou não?

L2 - isso... daí eu fui morar na Armação... meu pai... Deus preparou um trabalho pra ele lá... aí a gente foi morar pra lá... ele começou a cuidar de umas terras lá... que as terra tava / tava sendo invadidas... um homem fez um contrato falso... ele queria tomar as terras do patrão do meu pai... daí meu pai ficou lá... eles entravam lá de madrugada e começavam a atirar lá... pra... colocar medo no meu pai... pra ver se o meu pai saía de lá... no... só que o meu pai sempre ficou lá em cima... ele... ele trabalhou anos lá... e:: meu pai ganh[ow] a causa... o patrão do meu pai ganhou a causa na justiça... e... meu pai continuou trabalhando até os cinco anos... nos cinco anos meu pai pediu a conta e saiu de lá... aí volt $[e] m o[\varnothing]$ pra Penha... pra... pro... centro... aí meu pai ficou desempregad[o] de novo... e conseguiu trabalho em outra firma... ahn:.... uma firma que faz ehn:.... ehn::... ehn::... farinha de peixe ( ) daí... ração pra animal... animais... então...

L1 - lá na Armação você lembra de alguma coisa interessante?... você falou pra mim de um episódio da moeda de ouro... conta pra mim?...

L2 - é... uma vez eu tava capinando atrás de casa... daí eu achei uma moeda bem interessante... dum lado dela tinha um... um hom[i] careca... e do outro lado tinha tipo um rabo de peixe... daí eu guardo essa moeda por muito tempo... e meu pai inclusive achou outra... igual... mas eu não sabia... e a dele ele perdeu... a minha eu guardei... guardei por muito tempo... mas pensando que não era... pensando que não era nada né?... guardando assim porqu[e] achava interessante eu mandei ela levar pra ver o que era... e... quando ela voltou daí disse que era uma moeda de ouro... e o relojoeir[o] falou que aonde... aonde eu tinha encontrado tinha muito mais daquela...

L1 - e por que que tinha aquela moeda ali...

L2 - eu eu creio porque lá em cima... lá onde eu morava 
L L1 - lá na Armação...

L2 - na Praia Grande... lá era:.... que o pessoal conta... de lá... lá era cemitério indígena... então lá havia muitos índios... lá... um um hom[i] que morava lá... ele era muito rico... e ele fazia... ele tinha contrabando de uísque... e... os índios embarcavam em uma prainha que tem lá embaixo... por um carreiro lá... eles contrabandeavam uísque... dali vendiam pra muitos lugares... eu... eu creio que ele o os índios o eles mesmos enterraram alguma coisa lá... o talvez um deles perdeu uma... e:: ( ) eu consegui acho ( )...

L1 - e você conheceu muitas pessoas lá?...

L2 - conheço bastante gente lá na Praia Grande... bastante senhora... a maioria do pessoal lá... cerca de noventa por cento eu conheço... todos eles...

L1 - conta a história de alguém que você conheceu... como era essa pessoa... essas pessoas... que você conheceu... você tinha falado de um senhor...

L2 - é... tinha um senhor lá... o nome dele era seu Quentino. ... ele gostava muito... muito de mentir... a vida dele era a mentira... ((risos))... ele... quando chegava os veronistas... o pessoal... porque a maioria é casa de praia... então... quando eles chegar[ũ]... aí ele ia pra frente da casa dele... esperavam passar... parava... e daí falava... inventava alguma mentira... ( ) era muito engraçado... daí uma vez ele... ele chamou um senhor... daí ele disse assim "olha... eu tô com a blusa toda molhada" o senhor perguntou "por que senhor?"... aí ele disse "porque a baleia tava dando mama pro filhotinho daí respingou aqui... pois é... um pouquinho longe da praia”... daí o senhor começou a rir dele... o prazer dele era mentir... e hoje... lá na Praia Grande... é... quando... quando alguém mente alguma coisa... o pessoal... chama de seu Quentino... ele é muito lembrado...

L1 - e é nessa praia que tem a igreja... aquela que tem o sino de D. Pedro... você conhece a história daquela igreja ou não?...

L2 - não...

L1 - não... não conhece... e como que é lá?... lá é um lugar bonito?...

L2 - a igreja fica bem no alto... bem no alto a igreja fica... uma igreja muito bonita... bem grande... muito bonito lá... fica bem no alto... tem uma vista linda...

L1 - e a praia?... como que é a praia...

L2 - a praia... tem dois tipos de praia lá... tem uma praia bem mansinha que não tem onda é bem BEM pequena... não tem repuxo... não tem nada ( )

L1 - o que é repuxo?...

L2 - repuxo é::... é quando tem bastante onda grande... o pessoal vai tomar banho... aí a onda puxa e:... tem caso de pessoas que quando foram com o repuxo até hoje nunca mais voltaram...

L1 - ( )

L2 - teve um na Praia Grande... a Praia Grande já é onda bem enorme... lá quem gosta muito de lá são os surfistas... uma vez eu tava lá... era final de ano... na casa lá de uma colega minha... e os parentes dela... os tios dela tava lá... aí eles foram tomar banho de ma[x]... aí nós começamo[Ø] a procurar eles... eles sumiram e... tava passando um hom[i] ... ele viu... é: que deu um repuxo... é... ele viu que levou tre / dois... duas... mulhe[ $\varnothing]$ e um rapaz... e o hom[i] conseguiu pegar as duas mulhe $[\varnothing]$... ele conseguiu pegar na mão delas... puxou elas... e o rapaz nunca mais apareceu...

L1 - nem o corpo nada...

L2 - nada... nada... aí os... os:.... bombeiro tiveram lá... os mergulhador... porque tem uma pedra lá onde ele sumiu... e ela tem um oco muito grande... bem lá embaixo... aí eles pensar[ũ] que ele tinha... ficado preso lá embaixo né?... aí eles procuraram... mais nunca mais... NUNCA mais $\operatorname{achar}[\tilde{u}]$ o corpo dele...

L1 - isso acontece sempre lá?... 
L2 - sempre sempre não... mas de vez em quando... vem alguém de fora... que não conhecia a praia... sempre acontecia alguma coisa... não assim de sumir... de ser alguma morte... né?... mas sempre alguma coisa acontecia... sempre...

L1 - eu sei que você é casada... e:...... como você conheceu o seu atual marido?...

L2 - eu conheci ele na:: igreja... mas nós comec[e]mo[Ø] a conversar... eu tava um dia num noivado no colégio... eu estudava lá na praia grande... aí ele me deu uma carona até em casa... e meu pai tava me esperando... ele esperava sempre num barzinho... esperava que eu passasse mais esse dia eu fiquei tão empolgada... até esqueci que meu pai tava me esperando... aí:: comecei a conversar com... com quem é meu marido hoje... e esqueci que meu pai tava me esperando... daí fui pra casa... nem perguntei pelo meu pai nada... aí cheguei em casa... meu pai tava dormindo... aí ele pergunt[ow]... onde é que... não... aí foi pra minha mãe "cadê a F.? ela não tá em casa... ela sumiu"... aí a mãe... "não ela tá dormindo"... aí ele disse "como?... ela não passou lá... eu tava até agora esperando ela..." e:.... ele ficou tão bravo comigo...

L1 - e vocês namoraram bastante tempo?...

L2 - nós namoramos um ano... noivamos... e... ficamos noivo... seis meses... depois nós casamos...

L1 - e como que foi sua festa de casamento?...

L2 - olha... eu tava trabalhando... eu aluguei o vestido... e:: consegui pagar né?... e pra mim era um dinheirão... era uma... uma quantia muito alta... mas... mas Deus me deu a graça e eu consegui pagar... e... eu sempre ia na igreja e Deus falava pra mim não me preocupar que ele ia preparar tudo... aí eu fui trabalhar um dia... daí eu encontrei com o meu noivo... daí ele disse "olha... ligou uma pessoa... e disse que é pra ti não se preocupar que ela vai dar o seu arranjo todinho pro seu casamento"... aí eu fiquei muito feliz... eu não tinha condições nenhuma... sempre sonhei casar com pelo menos algumas flores no salão... fiquei muito contente... ela me deu as flores... ela alugou o restaurante... as amigas dela amanheceram passando as toalha do meu casamento... porque... essa senhora que me deu... casou a filha dela... na sexta feira e me deu todo o arranjo pra me casar no sábado... ela pagou mil (era) da filha dela... então as toalhas de mesa sujaram... eram da filha dela... ( ) lavaram tudo... passar[ũ] tudo até no outro dia do meu casamento... pessoas que eu nem conheço..

L1 - ( ) elas são da sua igreja?...

L2 - não... não conheço elas... nenhuma delas... foi Deus que preparou...

L1 - faz muito tempo que você é evangélica...

L2 - desde dos dez anos de idade... a minha mãe era evangélica... quando era pequena... nasceu na Congregação... e:: quando ela conheceu meu pai ela fugiu... com dezessete anos de idade... daí... ela... ela não queria ser mais crente... aí ela... casou com o meu pai e foi morar em Pouso Redondo... aí depois eles voltaram... ela teve uma menina... que é minha irmã né?... F. o nome dela... era o nome dela... e:..... assim que minha mãe ganhou eu... ganhou eu... tinha três meses... deu paralisia infantil na minha irmã... aí ela veio a falecer... eu nem cheguei a conhecer ela... minha mãe fícou muito abalada... esqueceu até que eu existia... fiquei por seis meses na casa de uma parente da minha mãe... uma tia minha... dentro de seis meses minha mãe não sabia que existia... que tinha mais outros filhos... aí quando ela voltou a si ela perguntou por mim... onde é que eu tava... ela levou um choque muito grande... minha mãe sempre guardava dela uma calcinha de babadinho... sempre guardou... aí um dia minha mãe deu pra mim guardar... e eu tenho guardado até hoje... eu nunca conheci ela... ela morreu eu tinha três meses de idade... mais eu guardo a calcinha dela até hoje... 
L2 - bom... tivemos uma saída... saída aí com a turma... fizemos no final de semana... o local... foi feito lá no Morro do Bom Baixo... próximo a Gaspar... e::: tem um lago... tem... tipo a famosa Casnanéia... que tem... tem várias... tem piscinas... áreas de lazer... churrasco tudo... né?.. então:... a turma saiu... a gente saiu pra acampar... pra fazer um acampament[o]... saiu já na sexta-feira... né? então um pouc[o] da turma saiu na sexta-feira... e um pouco saiu no sábad[o]... um pouc[o] trabalhava sexta-feira à noite... aí o que eu posso dizer... que posso (dizer assim pra você)... não posso te dizer do sábado o dia inteiro... posso te dizer o que eu passei no sábado à noite... até domingo... ao anoitecer... mas... eu cheguei lá... eu cheguei... e a gente sempre combina de levar um pouco de cada coisa né?... e:.... eu cheguei lá e olhei... a turma fazendo a bagunça... um povo... bem grande... então foi feito um churrasco... daí o churrasco tava acabando... eu peguei já o churrasco que eu tinha trazido... coloquei na grelha... mas aí quando eu che / aí pensei bom... agora eu vou... na piscina... cheguei na... tomei banho tal... na piscina... brincamo[ $\varnothing]$ um monte né?... aí de repente... quando eu fui ir pra pegar o churrasco e comer... não tinha mais o churrasco... aí eu peguei e falei assim "não... eu vou ficar com esse pedacinho que tem só pedacinho grudado na... na na... no osso"... então eu peguei... fiquei disputando junto com o P. ... o P. chegou assim "não... daqui... daqui"... ficou puxando de um lado pro outro o osso pegou... saiu da minha mão e da dele... e foi pro chão... daí o cachorro que tava embaixo da mesa... pegou e mordeu esse osso... aí eu peguei e chamei ele ( )... peguei e falei pra el[e] "agora tu pega e vai comer o osso"... mas eu falei brincando... e ele pegou e simplesmente... chegou e se enfiou pra baixo da mesa... se enfiou se pra baixo da mesa... e começou a morder junto com o cachorro o osso de um lado pro outro... o cachorro fazia rrrr pra ele e ele também... daqui a pouco... "eu vou te morder"... pro cachorro... o cachorro olhou assim pra ele... pegou o cachorro e mordeu o cachorro... mordeu na orelha do cachorro e... debulhou... né?... chapadinho... chapadinho... bebo bebo bebo bebo... que não se agüentava mais... enquanto isso o gordo tava na ... o gordo que é o... que é o C.... e J. e o R. são dois gordão... só que o R. é mais gordo... aí o gordo deve ter uns... cento e quinze quilo mais ou menos... aí ele pegou e tava sentado na rede... nós inventando de tirar e tirar a rede do engate... e derrubar ele no chão... e nós conseguimo[ $\varnothing] \ldots$ aí conseguimos... pegar ele e derrubamo[ $\varnothing]$ no chão... aí ele ficou bra[bu]... que nós ia se ver com ele... entendeu?... ia pagar caro... aí tá... desse instante ele não deixou ninguém ficar quieto... dormindo... teve uma certa hora... umas duas horas da manhã... mais ou menos... a gente começou a pegar no sono... aí ele... falou assim "agora vocês vão ver só"... pegou a caixa de foguete que tinha e começou a estourar do lado da barraca... enquanto isso os outro... um já tava vomitando do outro lado... bêbado... o outro já tava dentro da piscina boiando... dormindo... o outro boiando só no pescoço e ficou dormindo... boiando na água... enquanto o outro transava na água do outro lado da piscina... o outro ficava no corredor da... da descida do tobogã... ficava deitado escorado que parecia um defunto morto... né?... e a água super fria... gelada mesmo... né?... aí teve o L. ... que ficou deitado num num canto embaixo da mesa... ninguém tinha visto ele... aí eu percebi que ele tava nesse canto... aí peguei e falei pra turma "o L. tá deitadinho ali no canto"... vamo $[\varnothing]$ pegar ele e vamo[$[\varnothing]$ sacanear com ele... ele sacaneou com todo mundo... vamo $[\varnothing]$ sacanear com ele também... pegamo[ $\varnothing]$ ele... tava vomitando ainda já... vomitando... nós pegamo $[\varnothing]$ e jogamo[ $\varnothing]$ ele com tudo... com o corpo quente dele naquela água... gelada... olha... aquele guri deu um pulo... um grito... ( ) que nós não sabia o que tava acontecendo... ( ) aí tiramo $[\varnothing]$ ele da água... ele ficou no fundo... não veio pra cima... ele começou a se afogar eu acho... aí tiramo $[\varnothing]$ ele... depois que deixamo[ $\varnothing]$ ele beber um pouquinho de água... depois nós tiramo[ $\varnothing]$ ele... depois nós tiramo[ $\varnothing]$ ele pra fora... deixamo[ $\varnothing]$ ele lá tal... aí em vez de dar água pra ele demo[ $\varnothing]$ vinho... debulhamo[Ø] mais vinho pra ele... aí ele pegou assim e começou a ficar ruim... 
então... deixamo[ $\varnothing]$ ele quietinho no canto... deixando ele quietinho... aí o:: o E.... que a gente chama de gato pelado... por causa do olho... é o único neguinho que tem o olho azul... né?... é um moreno que tem o olho azul... mas azul mesmo sabe?... aí a gente chama ele de gato pelado... porque o... gato pelado por causa que por ele ser pretinho... peladinho... né?... e de gato porque o olho parecia o olho de um gato... a gente chamava de gato pelado... porque o gato era peludo e ele era pelado... (ou seja) gato pelado... aquele guri também sofreu na nossa mão... nós pegamos ele... ele estava deitado... pegamo[ $\varnothing]$ ele e penduramo[ $\varnothing]$ ele de ponta-cabeça pra baixo... numa árvore lá... né?... e começamo[Ø]... a tacar ovo nele... fazer mira depois de bêbado... usar ele como mira $(($ risos $)) \ldots$ aí começamo[ $\varnothing]$... aí quando chegava nas partes mais pesadas... aí que nós pegava e tacava mais nele... aí saiu e pa... ( ) foi tacando um por um... aí teve uma hora que um... que percebemo $[\varnothing]$ tal que tava faltando mais gente... e o povo se enfiado na barraca... aí fomo[ $\varnothing]$ olhar $\operatorname{assim} . .$. olhamo $[\varnothing]$ olhamo $[\varnothing] \ldots$ um casal dentro da barraca transando... e nós queria realment $[e]$ saber quem é que tava transando... na barraca... aí o gordo chegaram e colocaram "[ $\varnothing]$ pera aí que vamo $[\varnothing]$ ver já quem tá"... pegamo[ $\varnothing]$ um aeloforte... uma lâmpada geambrada que nós temos pra fazer iluminação... e:.... colocamo[ $\varnothing]$ no inverso da barraca... e no outro lado parecia a sombra e ele não tinha percebido... e o pessoal ficou transando ali... e pareceu praticamente tudo da cena... aí ( ) a gente ficou assim e começamo[ $\varnothing]$ a festejar do lado... começar a bater palma e tal né?... aí... oh... estoramo[ $\varnothing]$ foguete do lado da barraca... aí nisso chegou o P. e entrou na barraca no meio dos dois... tirou a calça e entrou pelado dentro da barraca tam[ $\varnothing]$ ém... porque queria $\operatorname{tam}[\varnothing]$ ém... e ficou do lado... e pau e pau... e já passou a mão nela assim... já agarrou ela... levantou e:: dentro da barraca... aí o Alemão já subiu... levantou com tudo na barraca... na barraca... e.:... saiu pra cima... meteu a cabeça no pau da barraca... a barraca queria meio que desmanchar... aí nós assim... "ah não caiu"... então vamo[ $\varnothing] . . .[\varnothing]$ pera aí... aí pegamo[ $\varnothing]$ um cada um no pino da barraca... destruímo[ $\varnothing]$ a barraca inteirinha... enrolou-se todo mundo na barraca... aí daqui a pouco entrou o R. já entrou um monte de gente tudo dentro da barraca... aí achamo[Ø] outro casal... tav[ũ] também... tav[ũ] também transando... dentro do carro... aí nós pegamos o carro e começamos a balançar o carro pra lá e pra cá... quase viramos o carro... o carro do Bocão... o carro... que tava no sentid[o] horári[o] ficou no sentid[o] anti-horári[o]... nós tiramo[Ø] o carro do lugar... aí o... fora os foguete... aí por volta das seis horas da manhã... mais ou menos... já era domingo... e ninguém tinha dormido nada... só na bagunça... aí fomos soltar bastante foguete... bastante... bastante foguete... no mato... não pra cima... do lado da barraca... aí acordamo[ $\varnothing]$ tal... aí umas sete hora da manhã chegou o dono de lá... “é vocês fizeram bastante bagunça né?"... “é... fizemos... fizemos bastante bagunça”... "nós escutamos barulho de foguete ( )"... agora nós vamos tomar um banho e vamos pescar numa lagoa de pesque-e-pague... nós pegávamos os peixe... invés de pegar e depois ir lá levar pra pesar a gente guardava dentro das malas... os peixe... com... o cara pensou que não pegava nenhum... nós guardamo $[\varnothing]$ os peixe dentro das mala... pa... tirava os peixe da lagoa tudo... tiramo[$[\varnothing]$ ali em média de uns vinte a trinta peixe... mais ou menos... ( ) tinha carpa... vários tipos de peixe... aí dali... nós fizemos / saímos dali... e fomos almoçar... aí chegou na hora do almoço... tudo né?... aí não tinha... aí chegou na hora de pagar... aí a turma não tinha dinheiro... aí o outro chegava "eu não comi nada... eu não comi nada"... e não tinha como provar se comeu ou não comeu... porque ela não fez anotação em fichinha nada... então... deu um prejuíz[o] pra mulhe[ $\varnothing]$ de uns cinco lanche mais ou menos... é... uns cinco lanche mais ou menos... teve gente que não pagou... nós távamos ali em cerca de vinte e cinco pessoas mais ou menos... fazendo bagunça direto... eu não lembro de todos eles né?... mas faz tempo isso aí né?... faz uns dois... uns dois não... faz mais uns cinco anos mais ou menos... mas olha... faz muito tempo... a gente era muito moleque... fazia muita bagunça.... demais... 
L2 - bom... eu vou contar uma história... de três prima... no verão de dois mil... e.: dois:... dois mil e um a dois mil e dois... ehn:: as três sem fazer nada... coçando... o saco direto... ehn:: ia na praia todo dia... e:: um dia desses... as duas bem lindas sentada na pedra... A. e L.... pegando sol... a gente avista... a quinhentos quilômetros de distância $((\operatorname{risos})) \ldots$ três moç[o]s... aí... eles vão se aproximando... se aproximando... e:: a gente começa a colocar olho uma em cada um... e:: quando eles chegam perto da pedra onde a gente tá... ahn:: a A. assim BEM:: BEM:: poderosa levanta o pescoço... na maior... e:: olha pros meninos e eles ficam passando... eu... toda recatada e retraída... eu vou com minha cara lá no no fundo do mar e volto... moral da história... o golpe deu certo... os meninos chegaram... ofereceram cerveja pra gente de longe... tiveram que atravessar os pedregulho... tiveram que fazer uma escalação... foram ali onde a gente tava... cada um sentou do lado de uma... tava em duas... ficou um sobrando... ehn:: mas aí a gente conversou com cada um deles... depois marcamos um encontro no final da tarde... cheg[ow] no final da tarde reverteu toda a história... porque a $\mathrm{P}$. chegou... ficou três e três... aí... quem a gente tava conversando... uma tava conversando com o loiro depois tava conversando com o moreno... a história se reverteu toda... lembra?... acabou que no final da noite cada uma ficou com um... bom... aí cada uma ficou com um... eles eram maravilhosos... aparentemente seriam três homens assim... seriam três príncip[e]s encantados... pras três cinderelas... pras três fadas... mais... aí o verão aconteceu... e a gente foi ficando... e a gente foi fazendo festa todo dia... todo dia... as três perigosas iam pra praia... elas não falhavam UM... podia tá chovendo canivete... praia linda... maravilhosa... a praia era nossa... nós ficava lá... nós ficávamos da meia da / da:... das sete... às vezes até meia-noite... aí voltava... se arrumava... festa... Piçarras... festa festa festa festa festa... e bebia até se acabar... e festa todo dia... e todo dia... às vezes eu tava acostumada a dormir da seis da manhã ao meio dia... esse era nosso horário... nosso novo horário... ehn... enfim... aí os meninos... tá... aí:: acabamos... que que fomos ficando com eles... cada um com um... e biririm bililim... e daqui a pouco:: a:.... dois relacionamentos se acabam... e aí um só acaba se consolidando e reinando até hoje... e de quem é?... e de quem é?... tananã... ((risos))... não vou nem falar... vou deixar... bom... mas nesse meio tempo... a gente... uma outra façanha nossa... foi quando a gente foi pra Última Tribo... que:: a gente tava podre:: eu tava chapada... nós tava... não... não tava... não não tinha... a NÃO... a gente tinha combinado com os menino... pra eles irem encontrar a gente lá no Última Tribo... que é um barzinho bem louc[o] lá... em Piçarras... eles não foram... aí nós se alvoroçamos toda... já começamo $[\varnothing]$ a dançar... aí daqui a pouco tava eu e a A. conversando... e a P. já tava conversando com outro... aí eu olho um cara... e digo pra A. "A. olha aquele carinha ali"... e ele sentado na cadeira uns cinco metro longe de mim né?... aí eu já começo a olhar pra ele... ele olha pra mim eu olho pra ele... ele olha pra mim... e fica aquela coisarada... daqui a pouc[o] ele diz "eu vou te dar um beijo" aí eu que digo pra ele "quem vai te dar um beijo sou eu"... não sabia nem o nome dele não sabia... nem quase a cor dele eu via direito... aí:: ((risos))... aí eu levantei... na frente de todo mundo... fui lá... sentei do lado da cadeira dele... numa outra cadeira... eu puxei e sentei... peguei a boca dele dei aquele beijo... não olhei mas pra cara dele... foi a pior das piores esta... mas teve uma também do G. né?... meu DEUS... foram tantas... ((risos))... teve um dia que a gente foi... AH tá... foi eu tu e a P. e a gente encontrou... foi bem no comecinho do verão... aí a gente encontrou o M. aí tu ficou com o M. a P. ficou com um carinha que ela odiou... e eu saí com o G.... que eu voltei às seis horas da manhã... que eu tinha ido pro apartamento dele... lembra?... ( ) a noite inteira... foi a 
maior festa... ele é maravilhoso... aí voltamos... vocês tavam puta da cara comigo... que vocês vieram a pé... né?... e:: tu viesse a pé com o M. a P. junto contigo... a P. tinha que trabalhar no outro dia... não sei... que a $P$. ficou brava... enfim... acabei... acabou que o $G$. ficou rolando até quando?... até junho né?... não... é né?... até agora em junho a gente saiu ainda... mais foi só aqueles meninos que a gente olha só pra beijar na boca... porque... fora isso... só fazer sexo... beijar na boca... porque homem... pra nós... tem uma outra questão... uma outra circunstância... é:: uma outra questão ética política social econômica religiosa ((risos))... tem homens e homens como diz tu... tem homens que a gente olha... sai só pra beijar na boca... outros só pra transar... outros só pra pedir em casamento... né?... como o meu maravilhoso namorado... que é o meu professor de Sociologia Política... que eu amo de paixão... ponto... teve uma outra façanha nossa... uma bem podre... bem podre... que eu não lembr[o].. AH... a minha e da P. no Bali Hai... que eu fiquei caída lá do lado do carro... e os meus alunos passavam... no fim um aluno meu... o M. que me trouxe... o último dia do Bali Hai... Bali Hai é uma danceteria que tem âmbitos internacional... tem na Alemanha... Portugal parece... não lembro agora... e tem agora aqui no Brasil dois lugares aqui do sul... show... foi o último dia.. $\operatorname{tam}[\varnothing]$ ém se $a c a b[e] m o[\varnothing] \ldots$ meu Deus... eu tava podre... no outro dia tinha que fazer um seminário... seminário... um fichamento... ( ) sobre epistemologia da ciência... esse fichamento ficou tão bom que eu tirei dez... nem meu professor acreditou ((risos))... ótimo... ((risos))... ahn:: é:: esqueci da festa... acabou que... uma outra nossa... bem podre... no verão a gente não aprontou muito... só um pouquinho ((risos))... o que que a gente fez mais de arrepiante... arrepiante... de cabelo... depois de ter ido pra praia... encontrado o A... a P. saiu co A. o verão inteiro... pulou a janela... AHN... aquele dia que vocês foram tu... o A. a P. e o R. numa sorveteria... que... depois vocês foram pra praia... e no fim da história vocês acabaram bebendo... tomando sorvete... tava frio... dia de verão mais tava frio... aí a P. tirou a roupa... ficou de calcinha... foi tomar banho era meia-noite?...

L1 - duas da manhã...

L2 - aí o A. ficou correndo atrás da P. na praia... os dois tomando banho... e tu ficando com o R.... não... o R. queria te beijar... e tu não queria... que ele não quer olhar pra tua cara até hoje... deixa eu ver o que mais... vocês chegaram encharcada... acho que tu não... ( ) pularam a janela e dormiram no chão... não entraram pela porta... a $\mathrm{P}$. que chegou a dormir no chão... né?... tava encharcada de água... eu não tinha ido né?... eu tava... acabei estragando meu verão por causa do A. ... né?... teve aquele outro dia do Bali Hai que a gente foi... que tu ficou com o A.... eu fiquei com outro menino e a $\mathrm{P}$. ficou com outro... as três ficaram com três pessoas completamente diferente também... tava uma festa... tava louco... não sei que dia que era... era Natal?... não... era Ano Novo?... não... eu tinha ido de preto... que tu tinha ido de biquíni que a gente tinha bordado seu biquíni todo de lantejoula na praia... lembra?... que tu fosse com ( ) uma coisinha bem ( )... ((risos))... o que mais que a gente aprontou... a gente queria fumar ( )... que mais... a gente aprontou mais cara... isso não foi nada... a mãe e o pai foram viajar... a gente quase botou fogo na casa... os meninos vinham aqui direto... cada dia era um... tinha uma hora que o F. saia pela janela e o A. entrava pela porta... ((risos))... e eu com medo... acabei mantendo o A.... o F... o F. não foi aquilo tudo... o G.... a... e o R.... mas só virtual né?... é... ehn:.... e que mais... ( ) a gente aprontou mais cara.... na praia a gente não ficou com mais ninguém?... eu sei que um dia eu ia pra praia com o A.... outro dia eu ia na mesma praia com o F... passear... os cara da barraca não entendiam nada... não sabiam quem é que era... se mudava eu o se mudava os cara ((risos))... o que mais... A:: o M. depois que chegou... fiquei com ele?... fiquei... tava namorando com o A. já né?... aí que maravilhoso né?... acho que naquela mesma praia eu levei o A.... o M.... o F... quem mais?... o A.... os meninos não chegaram a ir lá né?... eu vou levar o S. agora lá ((risos))... ( ) eu já levei ele... não lembro mais de uma bobeira nossa no verão que a gente se acabou... de festa... a gente aproveitou na praia... e a gente ia 
todo dia à noite né?... lá pra... AH... aquela vez que vocês ficaram... que eu tava no dia do Ano Novo... que tu tava com o C.... e eu vim pra casa... tava chateada que o A. tinha feito aquela briga na praia...

\section{A. S. (L2) 40 anos}

4BI

L2 - a L. "tô com o corpo doendo... tô com o corpo doendo... ai mãe"... amanheceu com febre... febre... aí tomou os remédio ( ) dor no corpo... não resolveu... aí no outro dia a L. "ah mãe tô bem... mas pra escola eu não vou"... pra escola eu não vai... aí ( ) mediu a pressão... aí foi foi foi ainda bem que ela não era registrada segunda terça quarta... e quinta ela não tinha aula que era folga dela... NÃO... quinta ela tinha aula só de manhã e sexta era folga dela... aí ela emendou... segunda terça quarta quinta sexta sábado e domingo... ela só parou mesmo quinta de manhã... que tinha aula de manhã... aí ela pegou ( ) aí melhorou... e o B. também ameaçou de dar mais graças a Deus não... eu quando me dá me bota na casa...

L1 - eu não tenho gripe... me ataca a rinite de vez em quando...

L2 - eu também... é a rinite que me ataca... eu tenho uma rinite mais é uma rinite de inverno... é uma rinite de de temperatura... é aquela aguaceira que solta do nariz... não é aquele catarro... é aquela água água água pelo olho e pelo nariz direto... é um por trás do outro... nariz e olho... um dia fui trabalhar... não deu pra mim trabalhar... eu tava toda hora assim... toda todo o instante chapando o pano... num instantinho eu encharquei um monte de pano de malha... de retalhinho... ( ) meu olho fica vermelho vermelho... aí é ela "L. ... não tem condições de trabalhar"... "eu vim trabalhar" porque eu disse né?... o que adianta falar... aí ela pegou e me mandou embora... aí eu peguei dois dias de atestado... e graças a Deus esse ano... o H. parado... só eu trabalhando?... nós fizemo[ $\varnothing]$ aquela blusinha... nós fizemo[ $[\varnothing]$ calça... nós fizemo[ $\varnothing] \ldots$ ehn... todo tipo de coisa... blusa... shorts... agora tamo[ $\varnothing]$ fazendo shortezinho... de menina assim né?... e camiseta regata... ( ) o verão... e agora não adianta mais... porque eles fizeram inverno... agora eles estocaram um monte de inverno... então quando esfriou... agora nós ficamo[ $\varnothing]$ parado... por causa do inverno... então tamo[ $\varnothing]$ fazendo de verão... fazendo de verão agora... é bom... porque a gente fica em casa o dia todo né Amábile?... aí eu lavo a roupa de manhã... agora o $\mathrm{H}$. tá em casa e me dá uma ajuda né?... alguma coisa aí ( ) e aqui é difícil de arrumar emprego Mábile... terrível... na minha área mesmo não tem... costureira de malharia não tem... só em Brusque... lá tem... ( ) Brusque é a capital da roupa... até que... até aqui... aqui mesmo não tem... eu já trabalhei em duas... todas as duas faliram....agora eu tô na terceira... espero que essa não fali também... trabalhei um ano em uma... faliu... trabalhei um ano certinho em outra... faliu... agora eu tô nessa aí na terceira...não comporta... lugar pequeno né?... o (povo) não tem cultura... não tem ( )... não vou... não vai...

L1 - o Beto Carrero não melhorou?... o que a senhora acha?... ( )...

L2 - não... a prefeitura não apóia o Beto Carrero... o ruim é isso... tanto é que vai saí um asfalto pra ele... ele tá fazendo uma avenida... uma rua pra ele... tu não chegasse a ver?... ( ) Santa Catarina... foi por lá né?...

L1 - eu vi... eu vi um pedaço... mais por quê?... brigado ((oferece um café)) por quê?

L2 - tu viu quando?...

L1 - quando eu fui nas... na... nas Cabras lá com o vô...

L2 - chegasse a ver?

L1 - cheguei

L2 - mais lá na BR...

L1 - sim 
L2 - lá na BR já... lá tem uma pedreira... tão dinamitando porque deram de cara com uma pedreira... dinamitando tudo aquela pedreira... mais lá o... o projeto deles é pra ficar pronto em dois mil e dois... ou no ano que vem... ainda pra esse verão... ele tá fazendo só pra ele por que a prefeitura não apoiou... eles queriam arrumar a rua... queriam fazer uma (pros carro)... aí a prefeitura não apoiou... aí eles brigaram tudo... agora ele tá fazendo uma entrada pra ele aí a Penha vai ficar morta... por que os carro que iam entrar por aqui vão entrar tudo por lá... aí o que vai acontecer... a Penha vai ficar morta... mortinha...

L1 - não dá pra entender... Piçarras é aqui do lado e é tão desenvolvida...

L2 - Piçarras?... e é pequenininha... mais o prefeito de Piçarras é muito bom tanto é que ele ganhou em seguida... ele é ótimo... ( ) ele arrumou a praia de Piçarras... se você chegasse ali... não tinha areia... sabia né?... que a praia tava encostada no Hotel ((Hotel do Beto Carrero))... ela tava encostada no Hotel a praia... o pessoal dos hotéis... das casa ali... tava tudo a venda... ninguém conseguia vender porque ninguém quer comprar... o mar tá comendo tudo... eles gastaram uma fortuna Amábile... a máquina teve aí... as máquinas não eram... eram tudo estrangeira... teve aí trabalhando não sei quanto tempo aí... elas tiraram a areia... lá do fundo do mar... pra botar tudo na praia... e ficou enorme agora... ( ) agora ficou... mas... dizem dizem... mas dizem aí que vai durar dez ano... depois vai voltar tudo novamente... porque o mar vai comendo tudo... ( ) porque o mar... ele tava quebrando quase em cima do Hotel... tava pegando a rua já... o mar tava quebrando... não tinha mais areia pro pessoal ir pra praia se deitar... botar esteira... não tinha mais... ninguém mais ia... não tinha... tava acabando... ( ) apesar que tá todo mundo pagando por mês uma taxa... ele cobrou do povo...

L1 - é cobrado?

L2 - é... é o valor também do apartamento... das casas... uma colega minha... aquilo ali no verão ( ) ... aquilo ferve... aquilo é assim ((gestos com as mãos indicando multidão))... eles faz[i] danceteria a noite toda ali... com banda a noite inteira... vem cantor cantar ali... aquilo é assim... muita gente... muita gente de fora... o povo do Bali Hai que é mais pra frente né?... tem muita gente de fora... muito bonita... ( ) é outra vida... agora chega aqui na Penha... essa mentalidade... essa coisa... essa tristeza...

L1 - e não tem um baile nessa Penha?...

L2 - aqui tem a sexta feira do pagode... ali mas... a L. não vai porque ali é uma baixaria... baixaria... a L. não passa nem ali... ( ) passa ali por cima porque não gosta de passar nem na frente... ( ) só dá maconheiro... uma baixaria... não dá... a L. quando sai no verão... na enseada... vai lá.. tem o pessoal de fora... ( ) ela vai lá... aqui na Penha...

L1 - ( )

L2 - e as praias são bonitas

L1 - não tem o que fazer?

L2 - ahn... tem as praias da Armação... aquelas praias lá... lá é praia... Praia Vermelha... Praia Grande... tem umas praia boa... mais só que o prefeito não... ( ) mas a Penha... é uma coisa assim morta... ( ) tem muita intriga...

L1 - aqui não tem Farra do Boi?

L2 - esse ano foi proibido... foi caçado... foi proibido a festa... todo ano tem... todo ano tem... todo ano tem a farra do boi... todo ano tem... ( ) se alguém coisasse iam prender todo mundo... (farra) do boi... tão matando boi... numa cidade aqui pra cima aqui pra cima eles fizeram... meu Deus do céu... lá na praia...

L1 - como que é essa festa?

L2 - soltam o boi... é:..... aí quem consegue pegar o boi... com ferro ( )... ano passado o boi matou um rapaz aqui... matou mesmo... enfiou o chifre... deixou morto... ( ) MATOU... matou mesmo...

L1 - perigoso 
L2 - ( ) nós fomo $[\varnothing]$ ver... mais ficamo[ $\varnothing]$ do lado de fora... (de bico)... o B. Muito metido né?... ficava ali perto da tela... e o dito boi vinha ( )... vinha em cima dele... ele foi correndo... engatou... ( )... um berreiro...

\section{H. S. (L2) 42 anos}

L1 - eu vinha... eu vinha nove horas da Bolívia... descarregar na Bolívia... eu tava vindo pros lado de Mato Grosso vazio... e:.... cinqüenta quilômetros pra chegar no ( ) em Mato Grosso... o caminhão quebrou... o caminhão quebrou os acoplamento da bomba injetora... como ali não tem... não tem concessionária própria... só em Campo Grande... capital... mais pra cima era Campo Grande... e:: aí liguei pro meu pai... em Piçarras... celular... aí ele providenciou pra mim né?... o sobrinho trabalhava na Wolf em Cuiabá... ( ) mandaram consertar pra mim... mais até que aconteceu... tudo eu passei lá duas noites e um dia... duas noites e dois dias... quebrado lá no acostamento... deserto né?... beirando o Mato Grosso... pantanal do Mato Grosso... aí a noite eu ouvi... berro ( ) dum hom[i]... sei lá se era um hom[i]... uma onça... sei lá o que era aquilo... e quem levava a alimentação pra mim... a marmita... era a própria polícia... quando a polícia vinha pra cá... quando a polícia não ia... eles mandava através dos ônibus que fazia a linha Corumbá... aí uma noite daquela... eu ouvi um monte de grito... e eu já tava lá duas noite... mais... sem tomar banho... sem nada... só a misericórdia né?... e numa noite daquela eu ouvi um bocado de gritos né?... durante a noite... "eu não posso sair lá fora"... quando amanheceu o dia aí chegou a viatura da polícia lá... aí eu perguntei pra ele... a viatura da polícia chegou... foi levar café pra mim... aí eu perguntei pra eles... "tô ouvindo aí uns grito a noite aí rapaz... um berreiro... tipo... um boi... uma coisa assim"... “ahn rapaz... isso aí não é boi não... não sai da cabina que isso tudo aí é leão... isso tudo aí é leão das fazenda... o senhor tá beirando pantanal do Mato Grosso... isso aí é onça... leão... que vivi na beira da estrada pra procurar comida... tá?"... “tá certo... se é leão eu vou servir de comida pra eles"... falei... fiquei por ali... aí no outro dia... sol bonito... já tava ali duas noite e um dia né?... já tava doido pra tomar um banho... aí andei uns trinta metro... uma ponte... olhei pra pra baixo... a água clarinha... bem clara... uma água maravilhosa como cristal... "ahn:.... vou tomar um banho nessa água aí"... uma hora dessas... olhei no relógio... quatro horas da tarde... vai dar de bom tamanho... tirei minha roupa... peguei as coisa... desci pelo barranco a baixo... mas era alto... dava uns dois três metros de altura... desci pelos barranco... pela barranqueira... fui lá embaixo... entrei na água... comecei a me lavar... mas no eu me lavar... olhando pra frente assim... na costa do barranco... eu via assim que... eu escutava um barulho dum negócio caindo na água... eu achava que era o barranco... que a água era forte né?... a água tava batendo no barranco... volta e meia tinha um pedaço aqui... um pedaço lá... eu tava achando que era o barranco que desbarrancava... eu tô dentro da água com água pela cintura... tô bem faceiro... tomando meu banho... mas eu... mas olhe não passou pela minha cabeça... que eu tava correndo risco de vida... quando eu olhei assim bem pertinho de mim eu vi um negócio brilhando por cima da água... ahn... eu olhei... bem pertinho de mim... não tinha mais do que três metro que tava longe de mim... um jacaré... dois olho que parecia... do tamanho de uma laranja... por fora da água... vou acabar comido... ((risos)) ( ) corri de morro abaixo... larguei tudo lá... subi só de cueca... deixei sabonete xampu... creme dental.. deixei tudo lá embaixo... corri e me escondi dentro da cabina... fiquei igual um doido desesperado dentro da cabina... fiquei lá e só fui buscar as coisa no dia seguinte de manhã... quando a polícia chegou ali... eu tava só de cueca... dentro do caminhão... toalha de banho... tudo lá na beira do rio... lá lá naquela lagoa... aí falei com o policial... falei com ele... “o senhor foi tomar banho LÁ?”... "fui tomar banho lá... doido pra tomar banho"... ele "não... não faz isso não... esse rio tá cheio de jacaré aí dentro... cobra e tudo"... "por que que tu acha que eu deixei a minha roupa tudo lá embaixo... um jacaré... um jacarezinho... devia 
ter uns três metros de comprimento... uns dois e pouco"... ele disse "é:.... o senhor nasceu foi de novo... o senhor nasceu de novo"... graças a Deus que no me[ $\varnothing]$ mo dia chegou a peça.. $\operatorname{mostramo}[\varnothing]$ tudo... mecânico montando... fui embora... nunca mais.... quando eu vejo uma lagoa... só... só olho de longe... nem dentro pra mijar eu não entro ((risos))... nem dentro pra mijar eu não entro... tá doido... ( ) e dois foi dois dois aqui dos nossos lá pra Bahia.... ( ) nunca for[ũ] pra lá... inventaram de comer a tal de coalhada... coalhada que eles fazem lá... é a maior nojeira... é do leite... do leite coalhado né?... eles deixaram o leite lá escorrendo... pra mim é uma nojeira... pra mim é comida pra porco... pra comer aquilo... morto da fome... três horas da tarde... tavam comendo... até que apareceu um gato em cima do balcão... aí olhou um pro outro... tiveram uma idéia... "vamos jogar esse gato dentro da coalhada aí...aí chama o dono da bodega aí ninguém paga merda nenhuma e vamo[ $\varnothing]$ embora... nunca vi uma coisa tão ruim"... ( ) "AH joga"... jogaram o bicho dentro da coalhada... chamaram o dono da bodega "OH baiano... OH baiano"... "oche... o que é rapaz" ((imitando o modo de falar))... "olha... olha o gato onde tá aí... no tacho da coalhada aí"... o baiano pegou gato pelo pescoço... pela cola... pela cola né?... suspendeu assim... deu uma espremida assim de cima em baixo... "ochente menino... hoje é a terceira vez que essa porra cai aí dentro... olha"... pensa... pensa dois hom[i] vomitando por aí afora... ((risos)) nunca mais vão ter cara de comer e não pagar ninguém na vida né?... porque... tá louco... é coisa pra doido... outra vez foi L. ... é... foi comigo pra Bahia... quando ela chegou lá... ( ) "compra uma carne seca pra fazer uma carne seca... uma feijoada que... eu não tô agüentando mais comer frango... frango frango"... "tá"... fomos numa barraca daquela... cheia de carne pendurada... tudo assim à moda caralho... não é verdade?... aí sua tia chegou "esse pedaço de carne tá bem bonito... e esses branquinho que tem aqui senhor... essas coisinhas branca aqui pendurada... que que é isso?... que que é?"... e o baiano assim pra ela "não dá nada não"... tirando assim com o dedo... tirando o bicho de vareja.... tudo branquinho... parecendo (cabelinho) de Deus ((risos))... ( ) na cara de pau... ele pegava... "não... não... isso não é problema não... é só uma bichinha... uma mosquinha que pousa... mais não dá nada"... ((risos))

L1 - e o que que o senhor viu esses anos todos que mais espantou o senhor?...

L2 - o que mais me espantou... ( ) eu pa ser sincero pa ser bem sincero me[Ø]mo... com sinceridade... sem brincadeira... eu andei esse Brasil afora de cabo a rabo aí oh... de madrugada... nunca vi nada... nunca vi luz assim... nunca vi disco voador... nunca vi fantasma... coisas do além eu nunca vi nada... até hoje eu nunca vi NA-DA...já ouvi história né?... sabe... o hom[i] que pegou carona com uma moça loira... e na própria parada ela sumiu... o caminhoneiro diz que foi verdade... eu nunca vi NA-DA... a única coisa que mais me espantou me espanta até hoje... na estrada... é a falta de segurança e a roubalheira por parte dos próprios policiais rodoviários federal... isso é a coisa que mais me deixa indignado... a insegurança e a cara de pau dos policiais na cara dura... isso é o que mais me deixa injuriado... lá pro Nordeste mesmo é:... é coisa de doido... é absurdo o que eles fazem... é absurdo o que eles fazem... fora disso... se eu vi um disco voador... eu vi uma luz branca... se eu disse que eu vi alguma luz eu taria te mentindo... aconteceu um caso comigo e com P.... um amigo meu aqui... de nós dois tá dormindo no caminhão... e o caminhão... mexeram assim no caminhão... deu uma chacoalhada assim que a impressão que tavam tirando carga de cima... e nós saltamos do caminhão... ele por uma porta eu pela outra... ele com revólver na mão... e não tinha um ventinho... a árvore tava paradinha que não tinha um ventinho de nada... ( ) até hoje nunca sabemos o porquê daquilo né?... o que aconteceu... nós estávamos carregado de bombona... produto químico né?... o produto químico é:... o líquido dentro duma bombona você sabe que chacoalha dentro né?... o caminhão quando pára... ( )... o próprio chacoalhar do líquido faz com que o caminhão né?... (vai chacoalhar né?)... então nós paramos... nós dormimos... lógico que o caminhão ficou um pouco chacoalhando né?... depois de tudo normalizou-se... ficou paradinho e nós fomo[Ø] deitar... uma meia hora depois... nós tava deitado... deu barulhão assim... deu a 
impressão que tivesse alguém batido na carroceria do caminhão sabe?... com outro caminhão?... ele deu aquela chacoalhada toda... ( ) e nem puxaram a cortina nada... e o segurança do posto... um velho amigo meu... seu L. ... ( ) ele tava na nossa frente... sentado na cadeira assim... coisa assim de uns cinco metro... nós saltamos do caminhão... de revólver na mão... seu L. já chegou também com uma doze... "o que que foi o que que foi?"... "alguém mexeu no nosso caminhão... o senhor não escutou o barulho?"... "não... não... vocês tão vendo coisa... vocês tão muito cansado... vocês deve ter sonhado"... "NÃO seu L. ... jogaram alguma coisa de cima do caminhão pro chão"... foi a única coisa que aconteceu até hoje em quinze anos que eu vivo assim... de coisa estranha né?... mais fora disso... ( ) no Ceará... no sertão da Bahia... de Pernambuco... da Bahia... de madrugada... dormia de porta aberta... nunca me roubaram nada... nunca ninguém... nunca vi nada... pra ser since / NUNca vi NA-DA... NA-DA... fantasma... disco voador... nunca...

L1 - e qual foi o lugar mais bonito que tu conheceu assim em todos esses anos de estrada?... lugar onde o senhor pudesse voltar hoje... amanhã vou pra aquele lugar de novo... ( )

L2 - olha... se eu pudesse voltar... lugar bonito... tem vários lugares bonitos... vários lugares bonitos... nessa região do Paraná... eu... pra mim... foi o Nordeste... Fortaleza pra mim é fantástico... lugar que eu tenho paixão de voltar lá e::... tenho vontade de morar em Fortaleza... depois pra mim vem Mossoró... vem Natal... João Pessoa... Recife... lugar que eu achei muito bonito... Salvador não gostei... Salvador não gostei... porque... é uma cidade muito suja... dentro da cidade me[ $\varnothing]$ mo é uma imundice... é::... eu... eu considero Salvador igual o Rio de Janeiro... Salvador só é bonito na orla marítima... só na orla marítima...

\section{J. P. M. (L2)}

6BI

L1 - eu queria que a senhora contasse um pouquinho da / como que era Piçarras antigamente... aqui onde a senhora morava... como que é hoje... mudou?...

L2 - antigamente não tinha nada quase... poucos prédio

$\mathrm{L}$ L1 - a senhora fala um pouquinho mais alto

L2 - eu dizia que tem mais prédio né?... construíram... na minha época... quando eu era criança... tinha pouco... ( ) eu nasci e cresci em Piçarras... pai trabalhava numa casa... trabalhava numa casa de diari[S]ta... trabalhava como faxineira... aí ele ganhava o salário dele $(\quad$ ) ... daí ele sustentava naquela época dez filho...

L1 - como foi a infância da senhora aqui... do que a senhora brincava... o que a senhora fazia...

L2 - ( ) a nossa infância foi descascando camarão... quando nós assim ( ) quando tinha cinco ano... seis anos... nós alcançava na mesa... nós descascava camarão já... trabalhava pa ajudar o pai... depois que eu cresci mais um pouco eu ficava cuidando dos meus irmão... pro pai e pra mãe trabalhar... ( ) depois viemo[Ø] morar mai[S] pra cá... aí comecei a trabalhar numa firma de peixe... com dez anos... acho... pa ajudar meu pai... depois que eu tava trabalhando uns dois ano nessa firma aí... tinha uns dois ano.. comecei cuidar de criança dos outro... de babá... ( ) cuidava deles... depoi[S] com... quando eu ia completar dezessete ano eu fugi daí... aí eu fui com meu marido pa... ( )

\section{L1 - como a senhora conheceu ele?...}

L2 - o pai e a mãe não deixava namorar... eu conheci aqui ( ) morava no barzinho do irmão dele ali... trabalhar... aí nós se conhecemo[ $\varnothing]$... meu pai e minha mãe não queria né?... porque ele não era da nossa igreja... não era crente... aí nó[j $\left.\int\right]$ namorava assim escondido... depoi[ $\left.\int\right]$ fugimo[Ø]... a mãe ficou até doente... ficou de cama... ficou muito sentida... ( ) aí fiquemo[Ø] lá pa Passo 
Redondo uma semana... ou mais um pouco... depois volt $[e] \operatorname{mo}[\varnothing] \ldots$ chegu[e]mo[ $[\varnothing]$ na casa dos pai... aí fomo[ $\varnothing]$ morar de aluguel... moramo[ $\varnothing]$ um pouco com o pai primeiro... depois não deu certo... minha mãe tinha criança pequena... eu e a minha mãe junto... aí não deu certo... aí fomo[ $\varnothing]$ morar em casa alugada... numa casa alugada... noutra... noutra... até encontrar um chão pra fazer uma casinha... ( )

L1 - e a senhora tem quantos filhos?...

L2 - eu tenho quatro... tenho uma morta e três vivi... tenho uma menina que morreu com ano e quatro meses... aí depois nasceu a F. ... quando a F. tinha dois meses e quinze dias ela morreu... a F. nasceu prematura né?... aí quando fez quinze dias que a $\mathrm{F}$. saiu do ho[S]pital... que ela ficou dois meses internada... na e[ $\left[\int\right]$ tufa né?... aí a outra morreu... tinha um ano e quatro meses... já andava tudo... aí ela morreu e:.... depois eu tive mais dois rapaz... o F. e o F.... ( )

L1 - e a senhora tem um menino pequeno também...

L2 - eu tenho um adotivo... esse aí eu adotei com três mezinho... de um irmão meu... meu irmão ajuntou-se com uma mulher... depois ele ( )... aí a mulher ganhou a criança e deu pra ele... ela não tem como criar... aí ele deu pra mim... eu criei... ele tá com cinco aninho agora... ( )

L1 - a senhora tem a F. né?... a senhora lembra de alguma coisa que ela fez na infância... alguma bagunça... quando... uma coisa que vale a pena contar... uma história... não precisa nem ser ela... qualquer uma das crianças...

L2 - a F... a F... a F. mesmo aprontou... uma vez tava brincando ela e uns coleguinhas lá... e o F.... e[S]te meu outro guri... tava... fizeram fogo... tavam fazendo comidinha né?... (quatro meninos) tava brincando mais fizeram fogo lá... ninguém viu... eles fazendo fogo... aí daqui a pouco diz que o F... meu guri... pegou... tira a calça e foi fazer xixi no fogo... aí ela empurrou ele em cima do braseiro... mas tinha cinza assim... ela pensou que tava apagado... e empurrou ele ali em cima... aí ele caiu... todo queimado... e ela... saiu gritando... foi se esconder... ficou com... que não queria nem sentar depois... a bunda dele ficou toda queimada... meu Deus... ela era terrível...

L1 - e faz tempo que a senhora é evangélica?

L2 - eu faz... desde que eu nasci... só que daí quando eu fugi eu fiquei afastada da igreja daí... fiquei un[S] treze ano... afastada da igreja... aí faz dez... dez... É... faz dez ano que eu voltei... aí F. tinha dez ano... doze ano... a F. fez onze ano... a F. tinha dez ano quando eu voltei pra [e]greja...

L1 - e:: aqui nessa casa faz quanto tempo que a senhora mora?...

L2 - aqui nessa casa vai fazer dois ano... que nós moremo[Ø]... eu já tinha essa casa...

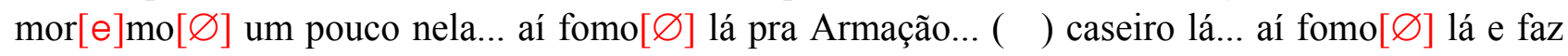
dois ano que viemo[ $\varnothing]$ que volt $[e] \mathrm{mo}[\varnothing]$ pra cá de volta... ( )

L1 - como que é a Armação?... bonita...

L2 - Praia Grande... nós morava lá em cima no morro... era bem bonito lá... bem legal... cheio de praia por volta... ( )

L1 - e a senhora sente falta de morar mais perto da praia?...

L2 - ahn:.... sim senhora... era gostoso... só que era muito isolado... era lá em cima do morro... pra gente saí é de pé... assim era ruim... era ruim... era muito lá em cima... mas eu gostava de lá...

L1 - e:: voltando assim a falar um pouco da igreja... que dias a senhora vai... conhece muitas pessoas...

L2 - conheço pouca... eu vou bem pouco na igreja... só aqui em Piçarras me[ $\varnothing]$ mo... às vezes eu vou umas vezes em Itajaí com P. e com a F.... a F. congrega aqui me[ $\varnothing]$ mo em Piçarras... no sábado... às vezes as quarta... mais no sábado... 
L1 - ahn ahn... e:: quando a senhora era mocinha... a senhora não podia sair nem fazer nada... conta um pouquinho disso pra mim...

L2 - a é... a gente não sai mesmo... nem no aniversário de alguém que era católico o pai e a mãe não deixava ir né?... que naquele tempo eles eram... bem enérgico... hoje em dia a gente é crente... mais se os filho não quer... a gente né?... vai naquele que quer... a gente era obrigado mesmo né?.. a gente ir pra igreja... aí quando tinha um aniversário assim... na casa de uma coleguinha... que a gente pedia po pai e pa mãe... se eles não não... a gente não podia e... a gente não conhecia... porque o pai e a mãe... não deixava... pra brincar com outras criança só quando eles saíam... a gente fugia... ia lá brincava e voltava rapidinho né?... antes que eles chegasse...

L1 - e a senhora acha que a juventude de hoje... né?... é muito diferente

L L2 - é muito diferente... bem diferente né?... bem diferente... meu[ $\left.\int\right]$ filho já foram criado diferente... já não foram criado assim como nós fomo[ $\varnothing]$ né?... tão preso... a gente só ia da igreja pra casa... da casa pra igreja... ou pro serviço né?... eles não... já saem... vão clube dos jov[i] ... numa reunião de mocidade né?... naquele tempo nós não ia... porque existia... mas só que a gente não tinha dinheiro... o pai e a mãe não tinha dinheiro pra dá pra gente e e... a gente trabalhava... ajudava... mas era pra casa... pa comer... porque é muito difícil... nós era em dez irmão...

\section{A. R. (L2) (diálogo entre duas catarinenses: L2 e L3 ${ }^{177}$ )}

L2 - a L. falou que ela tá meio assim lelé...

L3 - eu achei ((com interesse)) já conheço ela a tempo...

L2 - ela é ruim... só que ela é assim... ela quer que o marido veste a roupa que ela quer... camisa que ela quer... a calça que ela quer... é assim pra mim ela é boa pessoa né?...

L3 - ( )...

L2 - ela perdeu um... ( ) ela perdeu três... teve três... todos três já morreu...

L3 - mas já faz tempo...

L2 - faz vinte ano... que ela perdeu

$$
\begin{aligned}
& \text { L L3 - (...) } \\
& \text { L L2 - ahn?... }
\end{aligned}
$$

L3 - não foi por causa disso não...

L2 - AHN?... AH mãe OH... ela lutou pela vida dele dez ano... câncer

$$
\begin{aligned}
& \text { L L3 - não... não (...) } \\
& \text { L L2 - ( ) não não }
\end{aligned}
$$

mãe não mãe... ela sofreu...

L3 - não se esquece minha filha... eu nem vou falar...

L2 - ela sofreu muito... por causa daquele pivete ... ( ) o médico falou que ele ia morrer... morreu com dezoito ano... porque ela teve dois menino gêmeo... morreu aí veio mais esse... morreu também... ela tem sete mulhe $[\varnothing] \ldots$ aí ela ficou muito triste... (não queria ter perdido esse filho)... ela sofreu ( )... aí ela é uma pessoa mais ruim né?... entrou em depressão... ficou meia...

L3 - depois que aquela... que aquele tudo da B. ali... né?... que ela tava

${ }^{177}$ (L3) é o informante (1CI). As realizações desta informante também serão analisadas. 
L $\quad$ L2 - AHN... que ela foi assaltada... ela o marido... fizer[ũ]... fizer[ũ] tudo... tudo lá no chão... levaram muito dinheiro... bater[ũ] nela... arranharam ela todinha...

L3 - aí fica meia tola mesmo...

L2 - aí ela ficou mas

L L3 - é obrigado a ficar tola...

L2 - depois a filha dela casou... tarde... tava na hora... casou já com trinta ano... mas tava bem... tinha uma casa... era bem empregada... aí o (cara) se enrolou... deixou ela na miséria... ainda ganhou um nenezinho Down que nem o meu... e ainda abandonou... trocada por uma velha...

L3 - tá vendo quanto sofrimento...

L2 - é muito pra uma mãe... a filha mais bonita que ela tinha... roubou hom[i] casado e fugiu com ele... a MAS bonita que ela tinha... a filha dela... solteira... roubou hom[i] casado e fugiu embora com ele... não é ( )

L3 - de onde é de onde é...

L2 - Itajaí...

L3 - tá vivendo?...

L2 - tá vivendo com ele mas... pra uma mãe não é fácil né?... ver uma filha nova... solteira linda...

L3 - e eu sou falada...

L2 - fugir com hom[i] casado?...

L3 - toda minha vida é uma MIL maravilha...

L2 - e a filhinha dele morreu:.... de depressão... a filhinha pequenininha... ( ) morreu de depressão...

L3 - ( ) de depressão?...

L2 - não?... se pensa que uma mãe não grava tudo de cabeça... que

ela ficar velha...

L L3 - CLAro que grava... quando

L L2 - a filha mais velha ela casou com malandro... ele só bebe... ele não trabalha... ela que sustenta a casa... ele é bonzinho... mais ele não trabalha... ( ) todo isso aí... só tem aquela filha ali... que é a prima R. F. não tem?... só aquela ali que tá bem de vida... só aquela... só a L....

L3 - só de sete filho ehn?...

L2 - porque a L. casou velha com um cara meio tansinho... meu:... esse dias ele botou ele capotou a moto

L L3 - quem?

L2 - o filho do velho X....

L3 - a foi?...

L2 - não sei se ele se ele passou bem... se morreu... se escapou... não sei de nada... não telefono pra lá...

L3 - ( )

L2 - olha... ela não pode ficar doente porque ela cuida de DOIS filho... uma louca e um ( )... ela não pode ficar ruim... a dona N. ... ela tem que ficar em casa cuidando dos doido tudo... dois louco pirado e um sobrinho...

L3 - e o nosso irmão agora... o nosso irmão... fofocaram pro pastor que ele tá meio pirado...

L2 - quem?...

L3 - seu G.... ( )

L2 - era bem rico?...

L3 - era bem rico... casou bem bem 
L L2 - por que ficou pobre?

L3 - aí o C. ... pastor... quando viu que ele era rico... e:.... ficou em cima dele... em cima da casa... em cima da casa... é em cima dele... em cima da casa... deixou ele pobre pobre pobre....

L2 - a pessoa se cria assim muito

L L3 - ele ele cego... filho cego... já falei né?... ( ) ele cego... filho cego... tu visse ele lá?... tinha casa

\section{L2 - ( )}

L L3 - tinha casa... tinha casa pra morar... não tem nada... sem móvel nem nada... a C. deu fogão...

L2 - falei do seu vizinho que foi ( saltando o portão... ela veio encontrar ele né?... ela não pesa vinte quilo... não pesa vinte quilo... meu DEUS... aí ( ) tem gente que não pode ficar sem fazer nada... olha aí... quem dizia... a senhora... ela é mais magra que a mãe da F.... ahn... foi criada pela mãe da F... eu acho... eu acho que é a única... falta só enterrar... ((risos))... capinando e varrendo dentro da casa... se ela morrer não tem

L L3 - é só um pinguinho...

L2 - se ela morrer não precisa nem enterrar... não vai feder... não tem carne...

L3 - só um pinguinho... ( )

L2 - ( ) eles não são daqui...

L3 - mas tem casa lá pior do que isso aí ainda

L2 - tem...

L3 - como disse a C. eles pra mim é fichinha... ela dizia que a Z. é fichinha pra ela...

L2 - quem?

L3 - C.... amiga do G.... deixou o G. só com as ( )... se duvidar vai ficar só com o pinguelo de fora...

L2 - já pensou... pra menina passar a mão... né A.?.. aí ( ) vão ter que passar a mão no pinguelo do G....

L3 - só com o pinguelinho de fora...

L2 - ( ) aí quando chega lá ((risos))

L3 - ((risos))

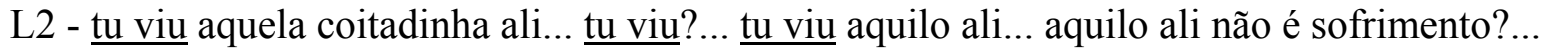

L3 - quê?

L1 - a tia falou pra mim que ela tem quarenta anos?

L2 - quarenta e três anos...

$$
\text { L L3 - quem é?... }
$$

L2 - ela é da idade da tua mãe... ela é um pouquinho mais novinha... ela fazia agora em agosto... a S.... a cunhada da mãe... que é mulhe $[\varnothing]$ do ti J.... não conhece o ti J. né?...

L1 - não...

L2 - a mulhe $[\varnothing]$ do ti J. é irmã da mãe dela...

L3 - quem é que tá?

L3 - agora ela tá... ( )

L L2 - a S.... né mãe?

L2 - ( ) ela teve um nenê solteira... com quinze ano... a L. ali... so[x]te que a L. é neta da tia L.... eles não são pobre...

L3 - não são muito pobre... não são rico

L L2 - a casa é dela e o vô D. paga aluguel... ( )

L3 - AH meu Jesus... com tanta coisa...

L2 - ( ) saíram de Santa Lídia pra morar ali... ( )

L3 - ( ) 
L L2 - ela só teve um filho e não pode ter mais... só tem um e só tem essa neta... mas não casado...

L3 - só uma neta né? ( )

$\mathrm{L}$ L2 - muito sofrimento pra aquela mulhe $[\varnothing] \ldots$ essa mulhe $[\varnothing]$ aqui... nunca vi... outro dia a F.... viu que bonita a filha dela?... não viu se não visse?

L1 - não reparei...

L2 - ela tava ali a mais velha... né?... ela é tão bonita... precisa ir ver um dia lá com a gente... a casa... até me admirei...

L3 - Oh L.... como é que faz o pão?... tu amassa tanto por quê?...

L2 - pa passar um pouquinho mais de tempo...

L3 - não... porque... a Z.

$\mathrm{L}$ L2 - ( )

L L3 - a Z.... não adianta nem eu ir na casa da Z....

L1 - ahn... porque ela não mora aqui...

L2 - aquela menina é ( )... ela que não arranje mais filho... que o dia que ela ganhar filho eu não vou lá ver... tá orientada já... porque eu sei que dão trabalho...

L3 - a mulhe $[\varnothing]$ que arruma filho tem que sofrer me $[\varnothing]$ mo... filho é pra tempo dos bobo... que não tinha juízo na cabeça....

L2 - hoje em dia tá muito difícil de criar... por causa das droga... por causa das doença... muita doença... muita droga... muito difícil... muito caro...

L3 - vê se você não descansasse um pingo ainda?... por causa dos teus filhos... ( )

L2 - ( ) vou dá um dinherinho pra ele pagar...

L3 - tem que pagar ainda?...

L2 - ( ) põe cinco real pra cada um... fica todo bobo... mas eles não compra besteira... eles compra coisa pra ele mesmo... roupa... meia... se fosse pra eles comprar besteira eu não dava... ele pagava um iogurte...

L1 - ( )

L3 - e será que a N. tá sozinha?... não sabe?

L2 - tá... tá sozinha... ( ) conhece os filho da N.... não conhece a Z.?

L1 - não...

L2 - nem a tia D. nada?

L1 - não...

L2 - a tia D. não é legal... não é... ( ) não é legal não... mais a tia N. é...

L1 - não conheço ninguém...

\section{E. S. G. (L2) 43 anos}

8BI

L1 - conta uma história pra mim... fica à vontade...

L2 - olha... eu venho de uma família de dez irmão... ( )pobre né?... não tivemo[ $\varnothing]$ quase estudo... não tivemo[ $\varnothing]$ mesmo... porque:: a gente já ia ficando grande já tinha que ajudar os pai né?... trabalhava aí de empregada doméstica pra... tentar ( ) pra Curitiba.... faz é:..... fiz o ginásio aqui... com muita dificuldade né?... e:.... a gente era pobre mas era feliz né?... chegava a época de Natal... a mãe comprava nossos presente de Natal... ela comprava... era tudo escondido ( )... ela guardava tudo em cima do guarda-roupa... aí chegava na véspera de Natal.. nós pegava... catava aí... era... era panela... era forma de cuca... era forma de pão... nós enchia de caquinho... botava aquelas florzinha de Natal... aí nós ia lá na casa do padrinho... dava a bênção e deixava um ninho... no último dia de $\mathrm{Na} /$... de Natal de manhã... nós ia lá pegar o ninho de volta... aí a mãe comprava alguma lembrança 
pra nós levar pros padrinho né?... ia na ( ) dos padrinho... dava a benç[a]... entregava uma lembrancinha... e pegava nosso ninho de volta com presente que o padrinho deixava...

L1 - deixa eu fazer uma pergunta... o que que é uma forma de cuca?...

L2 - forma de cuca é:... uma forma quadrada...

L1 - pra fazer cuca...

L2 - pra fazer cuca... cuca é feita com:... é uma... é massa doce... aí é fei / é colocada farofa... é colocada às vez[i] banana...

L1 - AH:: tá...

L2 - essa é a cuca... e:.... as festinha da escola a gente pa[x]ticipava... com muita... dificuldade... dia das mãe... às vez[i] a professora pedia bolo... né?.. a gente chegava em casa... cobrava da mãe... a mãe disse que tem que levar o bolo né?... era presente... a professora queria presente pra pra... pra dar pra mãe... a gente não tinha é::... coitada... ela não tinha como comprar... às vez[i] ela dava o que ela já tinha em casa... pra nós dar pra ela novamente... entende?... e nós toda vida na luta trabalhando... trabalho muito pra ajudar eles né?... e:: a gente cresceu... tivemo[ $\varnothing]$ uma educação bem rígida... hoje né?... hoje que já passou a idade da gente... a gente sabe que o que eles fizer[u] foi pro bem da gente né?... que o pai foi um hom[i] que ele não deixava nós ir dançar porque a mãe não levava... entende?... pai... só se a mãe levasse nós pra ir dançar... quando chegava meianoite...uma hora da manhã... nós tinha que tá em casa... ele não deixava nós sozinho... então nós dançava sábado... nós ia na festa só daqui a quinze dia... entende?... ele não deixava... nós se criamo $[\varnothing]$ na beira da praia mas nunca usamo[ $\varnothing]$ biquíni... nós nunca... nunca sabemo[ $\varnothing]$ o que era botar biquíni pra tomar banho de mar ou se queimar na beira da praia... nós tomava banho de mar... porque nós ia ajudar na roça... e nos aterro da roça ficava aqueles pedaço de lenha com carvão... e nós se sujava... e como nós não tinha banheiro pra tomar banho... então nós tomava banho na água salgada... pra tirar aquele carvão... aí nós chegava em casa... a mãe enchia balde de água doce... e passava em nós pra tirar o salitro... né?... então... foi isso... mas foi bom né?... a gente cresceu bem com a educação deles... graças a Deus né?... não temo[ $\varnothing]$ o que se queixar... foi muito difícil mas... graças a Deus cada um cresceu e seguiu a sua vida né?... e:.... a infância era boa... nós brincava de pipa... nós fazia... armava arapuca... armava laço... no mar... no outro dia de manhã nós ia lá vê... roubava passarinho que tinha na arapuca do amigo né?... mas era muito bom...

L1 - e o que a senhora acha que mudou?... aqui... em relação a sua juventude... uns vinte anos atrás... o que a senhora acha...

L2 - mudou des da... mudou des da alimentação... porque... nós se criamo[ $\varnothing]$ comendo peixe... nós não sabia o que era carne... nós não comia carne... nós comia carne em Natal... nós comia carne em Páscoa entende?... ninguém comia carne durante a semana... às vez[i]... tinha um hom[i] que passava de bicicleta... e ele tinha uma caixinha atrás da bicicleta... ele vendia fato... que uns chamam de bucho... outros de dobradinha... mas pra nós era o fato... sabe?... e era a postura do boi... a postura do boi vinha o pedaço da garganta do boi... um pedaço do figo... um pedaço do coração... um pedaço do bofe

L1 - como que é o nome?

L2 - postura... postura do boi... então minha mãe comprava a postura do boi... aí:.... pra render... ela fazia ensopadinho pra nós comer com mamão verde... entende?... então a carne nós comia só... dia de Natal... aí ela comprava um pedaço de carne no açougue... nós nunca fomo[ $\varnothing]$ de comer pão... nosso café da manhã era aipim cozido com café... era batata doce com café... era abacate café com farinha... e hoje em dia não... hoje em dia... a juventude de hoje eles não querem comer mais peixe... 
eles procuram mais comer... é::... carne... é::... hambúrguer... é:: mudou desde a alimentação já mudou... ( )...

L1 - e em relação a:: a violência... se mudou... se tá igual...

L2 - é que no nosso tempo nós fomo[ $\varnothing]$ criado... mas preso nos pai... sabe?... nós fomo[ $\varnothing]$ criado mas preso no:: no pai... nós não tinha... nós não:... a gente não era liberado... não... nem nós mulhe $[\varnothing] . .$. e nem os outro... entende?... porque... não se via falar em droga... não se via... falar em revó $[\ulcorner] \mathrm{v}[\mathrm{i}] \ldots$ em assalto... naquele tempo não existia isso... talvez existia só que a gente nem... talvez a droga já (era) existida a quarenta ano passado né?... só que... na nossa época não... só que hoje a criançada tá muito liberada né?... tem... tem filho que nem falam pros pai onde é que vão... não dão satisfação... às vez[i] a mãe acha que tá ali em uma danceteria... já tá em outra cidade dançando... né?...

L1 - a senhora tem filhos?...

L2 - eu tenho... de vinte e quatro anos... no sábado ele saiu pra trabalhar... (que era serão)... ele trabalhou até às dez da noite... e depois sabe onde é que ele foi?... foi lá no Café Pinhão... em Perequê ver um show de rock... então:... pra ver a criação dele e a minha...

L1 - a senhora tem um menino e uma menina?

L2 - não... eu só tenho um rapaz...

L1 - só um rapaz

L2 - só um rapaz...

L1 - casado né?... que a senhora me falou...

L2 - é:... agora ele tá sozinho...

L1 - tem filhos?...

L2 - tem... tem uma menina...

L1 - e::... como a senhora conheceu o seu marido?

L2 - o meu marido eu conheci em Joinville... aí eu trabalhei muito na Armação... trabalhei em supermercado... trabalhei muito de doméstica... e eu fui-me embora pa Joinville... daí eu trabalhava lá... aí eu conheci meu marido lá em Joinville... aí casamo[ $\varnothing]$... casamo[ $\varnothing]$... vai fazer em janeiro agora vinte e cinco ano que nós somo[ $\varnothing]$ casado... aí nós fomo[ $\varnothing]$ morar pra Mafra... que ele era de lá... aí ela era também uma ranchidade muito pequena... quase não tinha serviço... era mais ferrovia... sabe?... aí tivemo[ $\varnothing]$ em Itajaí... eu tenho uma irmã que mora ali... aí moramo[ $\varnothing]$ um tempo com ela... tam[ $[\varnothing]$ ém não deu... aí voltamo[ $\varnothing] \ldots$

L1 - por exemplo assim né?... é.. a senhora acha que o Beto Carrero ele... traz assim... por exemplo... milhares e milhares de turistas... veranistas... isso foi bom pra cidade... isso não é bom... é... aumentou... aqui a senhora sentiu?...

L2 - foi muito bom... talvez... ahn:.... o que o o que... o descobrimento da Armação foi o Parque do Beto Carrero... o descobrimento da Armação foi o parque do Beto Carrero porque... o nosso lugar aqui... ele não tinha turista... né?... antigamente nós não morava aqui... nós morava lá na Praia Grande... a nossa casa era aqui... como no outro lado da rua era o mar... então... janeiro... e mês de junho pra nós era indiferente... porque tu não via ninguém na praia... tu não via o veranista... tinha... claro... final de ano ( )... de Blumenau... tinha alguns de Curitiba... esses alemão que nós trabalhava... tinha do Rio de Janeiro... que eu também trabalhei na casa dele... mas era pouquíssimo... e serviço aqui também não tinha... aqui hoje... como eu trabalhei... eu trabalhei muito em fábrica de peixe lá na Penha... trabalhei nas salga de camarão... de descascar camarão... era descascadeira de camarão... ou então... tu tinha que sair daqui por que não tinha outra escolha de serviço pra ti... e o parque do Beto Carrero ali trouxe... ele trouxe bastante emprego... ele empregou muita gente... apesar que tem muita gente de fora... de... que vieram atrás de serviço no parque... 
mas a:: mas eu acredito que quem descobriu a Armação foi o Beto Carrero... né?... tanto ganha o pessoal que mora aqui... quanto o próprio município em si... daí também arrecada os imposto e::...

L1 - e:: a senhora estudou... como que era estudar aqui vinte... quase trinta anos atrás... quando a senhora era menininha... tinha dez anos... tinha escola?...

L2 - tinha... tinha a nossa escola aqui na... no morro... escola... professor João Batista Paiva né mãe?... é o nome né?... é antiga... é a mesma... é a mesma ainda... tô com quarenta e três ano...

L1 - então a escola tem mais de quarenta anos...

L2 - tem mais de quarenta ano... eu fiz... eu fiz o meu primário... e depois eu fiz uma parte do ginásio... e eu não tenho estudo minha nega... trabalho como digitadora... tenho muito conhecimento mas...

M. G. S. (L2)

10BI

L2 - bom... posso falar da fe[S]ta ali da Penha... fe[S]ta do Divino... que é muit $\left[\int\right]$ o bonita... uma tradição de muitos anos... e:.... ele[ $\left.\int\right]$ vinham né?... fazer a visita aqui na casa da gente... dos empregados... como meu marid[o] foi empregado... esse ano... nem todo o ano vem o[S] foliõe[S] tocar... festa assim... nas casa... e é muit[ $\left.\int\right]$ o bonit [ $\left.\int\right]$ o uma tradição linda... é... e [a]depois tem a fe $\left[\int\right]$ ta... que é na Penha... então é muit $\left[\int\right]$ o bonit $\left[\int\right]$ o... sempre vem todo ano... nunca acabou essa tradição...

L1 - a festa do Divino?...

L2 - festa do Divino

L1 - em que mês?...

L2 - mês de:: é:: mês de maio... mês de maio... dia do Divino... dia do E[ $\left.\int\right]$ pírito Santo... ( ) dia do

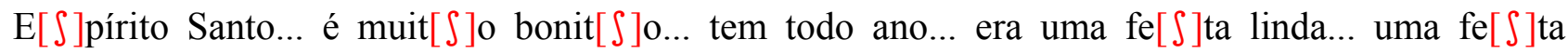
bonita... nós temos aqui... fe[S]ta aqui na Armação... fe[S]ta de São João e São Pedro... fe[S]ta $\operatorname{pro}\left[\int\right] \operatorname{pe}\left[\int\right] \operatorname{cad}[0] . .$. tem a:.... pr[u]cissão no mar... também... saída do Trapiche... vai até a Penha e volta com o::... com a imag[i] ... é uma fe[ $\left.\int\right]$ ta bonita... aqui também... sempre... sempre... cento e quarenta... acho que foi cento e quarenta e oito ano que... que tem essa festa aqui na Armação... desde que foi fundada a igrejinha ((da Armação)) que é... que tem essa tradição de festa...

L1 - a senhora conhece a história da igrejinha aqui?... que é bem antiga né?...

L2 - essa nossa aqui é bem antiga... antiga... ela foi feita de pedra... ela foi bem antiga... ela foi fundada acho é... duzentos e quarenta e oito ano... ( ) ela é muito bonita pra festa né?...

L1 - e tem outras festas aqui... histó

L L2 - tem outra fe[ $\left.\int\right]$ ta aqui também aqui em Santa Catarina... que

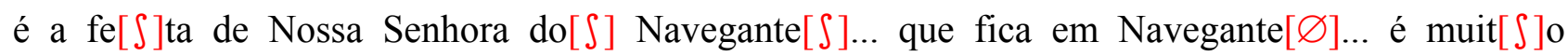
bonita... todo ano tem essa festa... né?... é o dia do[ $\left.\int\right]$ de fevereiro... é o dia de Nossa Senhora dos Navegante $[\varnothing]$... e tem a $\mathrm{p}[\mathrm{ux}]$ cissão também... pelo mar... que vai até lá em cima e volta... vai até a boca da Barra... na Barra do Mar... é muito bonita é... lindo lindo lindo mesmo... a gente... eu vou todo ano vê essa festa... porque é linda... e bonito... é tudo religiosa assim né?... é... e também tem

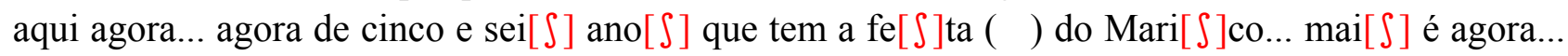
faz pouco tempo né?... também... é muit[ $\left.\int\right]$ o bonita a fe $\left[\int\right]$ ta do Mari[ $\left[\int\right]$ co...

L1 - e a respeito das festas antigas... por exemplo... do Terno de Reis... do Boi de Mamão 
L L2 - tem o

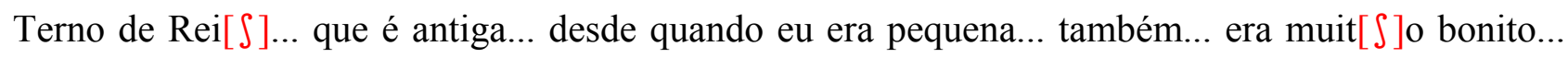
era até em época de Natal... o Terno de Reis ia até dia seis de janeiro... que é dia de Reis então eu tinha... o Terno de Reis vinha de Navegantes... cantar pra cá... daqui ia pra lá... cantar... os hom[is] antigo até... que cantava já morrer[o ]... então acabou... não tem mais... mais.. essa tradição... essa que saiu pra cantar... né?...

L1 - e a senhora sabe de onde veio isso... de que país... que lugar...

L2 - não sei daonde é que veio não... não sei se foi só daqui do::

L2 - da região da ( )... não sei...

L L1 - da região

L1 - e a festa da fita... a senhora conhece?... chegou a vê?... Pau de Fita...

L2 - a festa do Pau de Fita?

L1 - que dançavam e trançavam... dançando com a fita...

L2 - eu conheci aqui no[ $\left.\int\right]$ colégio... que fazia as festas junina... e aí tinha o Pau de Fita.... e' :... na festa açoriana... e:..... tem também esse pau de festa aí... a dança do Pau de Fita...

L1 - e quando que é essa festa açoriana?...

L2 - essa festa açoriana sempre se dá em julho.... a prefeitura fazia essa festa né?... ia daqui pra outro lugar... do outro lugar vinham pra cá... fazer essa festa açoriana... era muit[ $\left.\int\right]$ o bonito... mais agora não tão vindo mais... não vai nem daqui pra lá... nem eles vem pra cá... o pessoal me[S]mo aqui faz[i]... agora eles fizeram ali num restaurant[e] italiano... sábado... eles fizer[ũ] a festa:: açoriana... só que assim não teve essa dança de fita não... mas teve assim uma festa que é tradição aqui da Armação...

L1 - a senhora sabe porque esse lugar se chama Armação?...

L2 - por quê?

L1 - e a senhora falou que viajou pra Nova Trento?...

L2 - eu fui em Nova Trento na festa né?... agora... a madre Paulina é agora Santa Paulina né?... o Papa... é:: ela beatificou ela dia dezenove de de maio... e a fe $\left[\int\right]$ ta foi agora em julho... e foi data do aniversário dela... e fizeram dia catorze... domingo passado.... fez uma semana ont[i]... ma[ $\left.\int\right]$ tava muito linda... muit[ $\left.\int\right]$ o bonito...

L1 - e:.... é bonita a cidade?... como que é a cidade...

L2 - é bonita é... é bem bonita... tem Nova Trento... aí depoi[S] de Nova Trento tem vai para ( )...

L1 - e a senhora sabe o nome dela?.. o verdadeiro nome dela? lembra?...

L2 - da madre Paulina?...

L1 - é...

L2 - ... era um:: Amábile

L1 - Amábile... Amábile é o meu nome...

L2 - acho que é Amábile Paulina... madre Paulina...

L1 - é o mesmo nome do meu...

L2 - Amábile...

L1 - e a senhora foi nascida e criada aqui... o que que mudou aqui nos últimos trinta anos...

L2 - mudou bastante... mudou bastante porque:.... quando eu era pequena... que nós morávamos lá na Praia Grande lá na outra Praia lá... então era:.... tinha roça que o[S] o[S]... daqui plantavam... milho mandioca feijão... daí era todo cheio de roça... meu pai plantava... minha mãe plantava... meu pai era embarcado... mas a minha mãe plantava com os meu irmão quando era pequeno... e:.... e não 
tinha rua... era um campinh[o]... era mai[ $\left.\int\right]$ mato... assim né?... assim foi crescendo muit[ $\left.\int\right]$ o... cresceu bastante aqui... pra nós aqui... não era como era assim... trinta anos... quarenta anos... pra... pra... eu casei faz trinta e dois ano né?... que eu sou casada né?... mudou ba[S]tante... mudou

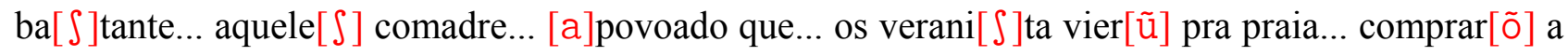
praia... quem morava na praia como a minha mãe... como nós morávamos... foi vendida a praia pros veroni[S]ta ( ) de Curitiba... de outros estado... vieram aqui pra praia... compraram a praia... e a

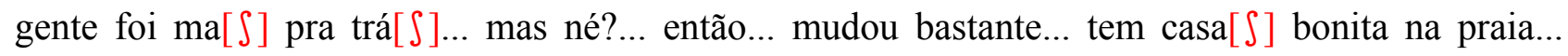
calçadão na praia.... e não tinha.... era como um caminho... bem pequeno... era um caminho... L1 - e em relação à violência... o que a senhora acha que mudou?...

L2 - violência?... mudou... agora já tem... aqui não tinha violência... agora já tem violência... muita violência... bem violento... já não falo fora... o que a gente vê pela televisão... fora... mas aqui... aqui já tem violência...

L1 - assalto...

L2 - JÁ... roubo... roubo aqui... aqui pertinho... roubo de roubar tudo que tinha dentro de casa.... e ainda assim ( )... roubar[ũ] tudo que era de roubar... né?... isso aqui já tem... a gente... a gente escutava incrédulo... lá em São Paulo... e agora já tem aqui... já houve morte aqui... assim... estupidamente... ano passado esfaquearam um colega da gente aí... foi morto... e:..... ( ) e aqui já tem violência...

L1 - e o Parque Beto Carrero... a senhora acha que trouxe melhoria?... o que ele trouxe...

L2 - o Parque do Beto Carrero trouxe melhoria né?... porquê... ele deu muit[S]o emprego pras pessoa[S] daqui... deu ba[S]tante emprego... só que trouxe muita gente de fora... de São Paulo pra cá... e talvez a gente diga assim... "é gente lá do Beto Carrero que rouba”... é gente de fora... veio muita gente de lá pra cá... veio bastante... veio... ma[S] trouxe bastante emprego... muita gente daqui trabalha no Beto Carrero...

L1 - é importante o turismo...

L2 - vem muit $\left[\int\right]$ o turi[ $\left[\int\right]$ ta... vem ba[ $\left[\int\right]$ tante turista... ba[ $\left[\int\right]$ tante ba[ $\left[\int\right]$ tante turi[ $\left[\int\right]$ ta... até... até... até o Cafu que teve aí... Cafu... já teve aí... o que eles pass[ũ] lá na... no SBT... no:....

L1 - Gugu... Ratinho...

L2 - é o Ratinho... o Ratinho já teve... vem... vem muit[ $\left.\int\right]$ o artista lá no Beto Carrero... É... tem bastante... tem bastante... e tem o dia do município... da Penha... que foi dia dezenove... ele:.... o:.... o prefeito dá... envia ingresso pra... pros veread[o]... ou então nos colégio... pra dá... pra gente ir no Beto Carrero... a gente vai no Beto Carrero.. mas a gente não pode pagar... ma[S] quando a gente ganha ingresso pra duas pessoa... pra três pessoa... ou pra uma só... e a gente ganhando... a... gente vai no Beto Carrero também visita... vê tudo... né?...

L1 - é bonito lá dentro?...

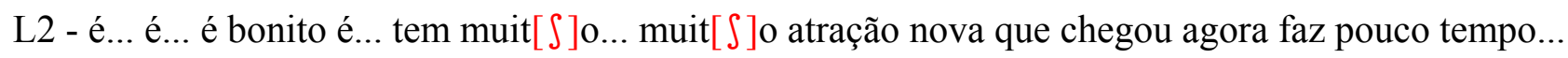

$\mathrm{L} 1-()$

L2 - tem... tem coisa bonita no Beto Carrero... é coisa bonita o Beto Carrero... é um parque bonito... tem barraca lá...

L1 - e:: a gente sabe que é uma diversão recente... por exemplo:... uns dez anos pra cá...

L2 - é... é...

L1 - na sua época de moça... assim... que a senhora tinha a minha idade... a idade da F.... o que que a senhora fazia... o que que tinha aqui pra se divertir?... 
L2 - no meu tempo não tinha quase nada... não tinha nada... nos domingo saía... umas dua[ $\left[\int\right]$ trê[S] colegas... a gente ia até o seu Alívio... na casa do seu Alívio... ia e voltava... só... porque não tinha nada... não tinha atração nenhuma... só fe $\left[\int\right]$ ta... que era a fe $\left[\int\right]$ ta de São João... fe $\left[\int\right]$ ta do Divino que é ali da Penha... Espírito Santo que era ali da Penha... só... a gente ia ainda muito pouco... a mãe não... os pai não deixava quase a gente sair... a gente não saía de noite... só um carnaval... tinha aqui... é uma festa que tem todo ano... e... a gente ia... ainda quando tivesse salão... era fe $\left[\int\right] \mathrm{ta} . .$. e a gente não tinha outra tradição... outra festa... outro divertimento... a gente não tinha nada... aí a quarenta trinta... trinta e cinco ano atrás não tinha... não tinha nada... e a gente praticamente... a gente não saía de casa...

\section{F. A. (L2)}

1CI

L2 - ia pa Blumenau... ia pa Blumenau... com dois $\mathrm{m}[$ ○]lho de orquídea... ia vender em Blumenau

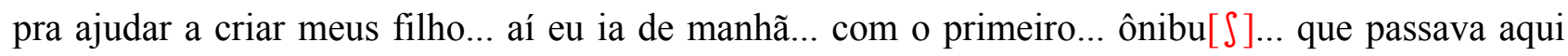
sete hora... e voltava às sete da noite... trazia cesta... trazia arroz batata assim go[ $\left.\int\right]$ tava de criar meu[S] filho... o o meu marido... o meu marido trabalhando na roça... lá no mo[r]o... uma enxada na mão... uma foice... de lá trazia o pão... trazia chuchu... trazia taiá... trazia batata... e eu ia granjear pra fazer dinheiro pra comprar sabão... pra comprar roupinha das criança... (dinheiro que fazia vendendo orquídea)... ia pra vender... catei de levar dois $\mathrm{m}[$ [o]lho de orquídea ali na praia... peguei $\mathrm{ma}[\mathrm{i}] \mathrm{um} \mathrm{m}$ [○]lho da orquídea primeiro... depois eu pensei... tratar depois de levar... quando eu fui levar o $\mathrm{m}[$ [o]lho da orquídea... a mulhe[ $\varnothing]$ tava na frente da casa... ela mandou o empregado dela soltar o[S] cachorro... os cachorro chegou... dava bocada em mim... dava bocada pra pegar... aí eu pedi a $\mathrm{Deu}\left[\int\right]$ pra me guardar... que desse misericórdia... eu tava vendendo aquela orquídea era pra ajudar a criar meus filhos... [a]depo[S] fui na praia de Piçarras vender $\mathrm{m}[$ [o]lho de orquídea cheio de $\mathrm{fl}[\mathrm{o}] . .$. bastante $\mathrm{fl}[\mathrm{O}] \ldots$ todo florido... bem bonito... cheguei lá... ofereci pra mulhe[ $\varnothing] . .$. mulhe $[\varnothing]$ comprou mais ela primeiro... antes de me pagar... ela cortou as $\mathrm{fl}[\mathrm{O}]$ tudo tudo... ela cortou ... jogou a $\mathrm{fl}[\mathrm{O}]$ que tinha no $\mathrm{m}[\mathrm{o}] \mathrm{lho}$ da orquídea... ela cortou tudo aquelas $\mathrm{fl}[\mathrm{o}]$ linda... flor bem novinha... ela cortou todo... aí ela cortou a fl[o] e foi levar em casa... e eu fiquei cá esperando o dinheiro... daqui um pouquinho ela apareceu e disse "dona... pode ir embora"... fui embora chorando... vim pra casa chorando... com fome... eu tava cansada... aí vim chorando com o $\mathrm{m}[0] \mathrm{lho}$ da orquídea sem flor... né?... ali não tinha... não tinha quem comprasse ma[ $\left[\int\right]$ não tinha não tinha mais graça... porque já tava feito... e a flor que ela tirou ela não me pagou... (vindo cá) no caminho vinha pedindo a Deus que Deu[S] me ajudasse... me abençoasse... e pudesse vender aquela orquídea... que Deus tivesse pena de mim... fiquei bem longe... depois de passar Piçarra... chegar na Penha... aí uma mulhe[ $\varnothing]$ velha tava assim... a mulhe[ $\varnothing]$ do $\mathrm{C} . .$. dona duma firma... ela tava sentada assim.. "a senhora não quer comprar essas orquídea minha... pra vender... pra ajudar a criar meus filho"... aí ela pegou o (m[o]lho) da orquídea sem $\mathrm{fl}[\mathrm{o}]$... ela comprou... pagou e foi embora... ( ) graças a Deus... chegava em casa as criança tava todo me e[ $\left.\int\right]$ perando né?... pra... dinheiro pra mim comprar o pão... dali eu não parava mais... dali eu já ia... já ia... socar o café... o café era todo 
em grão... café seco... daí ia socar no pilão... nós tinha o pilão que nós socava o café... tinha uma mão assim a gente socava... pra socar... duas torrada de café... a gente levava umas duas hora[ $\left.\int\right]$... e daí depois de socar... no outro dia... aí ia torrar o café... na [r]ua... não tinha um rancho... não tinha nada... começasse a chover eu tinha que ficar ali naquela chuva... só se chovesse muito grosso... daí torrava... to[r]ava aquele café tudo... socava tudo com aquela mão de pilão... depois ia passar na peneirinha... máquina eu não tinha pra moer o café... depois eu ia socar todo naquele pilão... depo[S] acabava quase de noite... naquela hora em diante o meu marido ainda tá lá no morro... na roça... aí ia cortar lenha... ia botar em casa... depois... ia uma das criança na venda comprar querosene... pra encher a $\mathrm{lu}\left[\int\right] \ldots$ chegar a noite a gente já tem a:: querosene na $\mathrm{lu}\left[\int\right] \ldots$ depois chamava as criança tudo pra dentro de casa... porque não tinha $\operatorname{lu}\left[\int\right]$ onde nós morava... naquele tempo não tinha luz... mandava tudo pra dentro de casa que ficava uma e[ $]$ curidão na rua... aí ia $\mathrm{ca}[\mathrm{r}]$ egar água... ca[r]egar água... ca[r] $[$ gava água de longe... carregava no balde... carregava num pote em cima do ombro... vinha pra casa cas criança tudo pequeninho... com uma luzinha na mão... bem pequenininha... dava comida pra aquelas criança tudo com a aquela luzinha... não alumiava nada... ficava na escuridão... mas a gente tava acostumado... aí dava comidinha pras criança... primeiro lavava... dou banho na banheira... e depo[S] que dava banho as criança ia tudo deitar... tudo dormir... porque daí não tinha mais pra onde ir... dormir... descansava... durmia no sótão que tinha aqui em casa... lá tinha muita banana... nós tinha banalzinho... e daí o Q. só vendia as banana grada... as banana miúda ele deixava em casa... guardava tudo lá naquele $\mathrm{s}[\mathrm{o}] \mathrm{t}[\mathrm{i}]$... chegava de manhã... ia lá arrumar a cama... na cama só tinha casqueira de banana... que ele[S] comia do[S] trê[S] cacho de banana crua... tudo antes dele ir dormir... eles er[ũ] tudo go[x]dinho...tudo saudável... nunca levei no médico... nunca levei na farmácia... eles não era amarelo... eles não era ba[r]igudo... eles eram normal... tudo com saúde... graças a Deu[S]... comiam banana de manhã... em jejum... e comiam banana à noite antes de dormir... de manhã se levantava... vestia a roupinha neles... só que eles tinham que lavar bem o nariz... porque o nariz ficava todo esfumaçado... ficava todo preto da fumaça... daí eles iam pa escola ... meio-dia vinham comiam... iam lá pro mo[r]o... lá onde meu marido trabalhava... pra lá ajudar meu marido na roça... a noite elas chegav[ũ]... só deixava uma mais velha em casa pra cuidar dos mais moço... os outro podia trabalhar... aí eles vinham com saco na[S] costa[S]... um trazia taiá... outro trazia batata... trazia aipim.. sei que elas vinham de saco cheio nas costa... chegavam em casa... tinha tudo ali... já tinha fogo... fogão de lenha... tinha fogão BEM grande... ali eu botava dois (pratos) (dois potinho) bem grande... esquentava a chapa toda ali... eu enchia aquela chapa de amendoim... to[r]ava... enchia de banana... assava... tudo ( )... daí eles chegava do morro já tava tudo prontinho pra nós comer... minha vida alegre... ali não tinha tanto:.... não tinha tanta ambição... não tinha assalto... graças a Deu[ $]$... ali não tinha ambição... não tinha luxo... a gente $a[r]$ emendava $[r]$ oupa... andava com [r]oupa [r] emendada... dia de chuva eu tirava pra remendar roupa... todo dia que chovia... quando chovia eu já sentava no chão e ia $[\mathrm{r}]$ emendar roupa do[S] filho... roupa do marido... [Ĩ]tonc[i] pra nós era um sacrifício era um prazer... porque a gente não tinha aquele pensamento de comprar aquilo lá... comprar aquilo lá... aquele terreno lá... aquele móv[i]... fazer aquela casa imensa... a gente costumava com tudo... o que a gente não tinha ( )... e graças a $\operatorname{Deu}\left[\int\right] \ldots$ até hoje tô vivendo... 
tenho sessenta e sete ano... tô com vida... graças a $\operatorname{Deu}\left[\int\right] \ldots$ não tenho muita saúde... ma[ $\left[\int\right] \ldots$ ainda ando bem... ainda faço meus serviço... ainda faço meus ( )... não tem quem me manda... então eu faço tudo... graças a Deu[ $\left[\int\right]$... tem um pouquinho de doença mas isso nunca fui no médico... graças a Deu[ $\left[\int\right] \ldots$ também peguei um medo de ir no médico... porque uma vez eu fui no médico... o último filho... o meu último filho... nove filho... que eu fui pra maternidade eu não tive sorte... o médico tentou tirar minha criança fora... do meu ventre... a minha criança veio a falecer... eu... eu vim pra casa com a bexiga furada... o médico foi irresponsável... fez uma cirurgia mal feita... e eu vim pra casa... com a bexiga furada e sem o meu filho... mas daí... eu sofri três ano... mas a cabo de três anos... o senhor ainda me deu a vitória... graças a Deu[ $\left[\int\right]$... vitoriosa... (peguei) a minha saúde... minha ( ) bexiga de volta... tenho minha bexiguinha nova... graças a $\mathrm{Deu}\left[\int\right] \ldots$ urino normal... aqui contente... graças a Deu[ $\left[\int\right] \ldots$

\section{J. J. A. (L2)}

2CI

L2 - Terno de Reis antigamente... tinha Boi de Mamão que eles brincava né?... antigamente... e... o pessoal aqui não tinha tanta casa como tem hoje... só tinha muit[o] pouca casa... engenho de farinha... que fazi[ $]$ farinha...

L1 - e:.... eu queria saber que o senhor me contasse... eu por exemplo não conheço... como que é um engenho?... como que é uma festa de Boi de Mamão?

L L2 - ahn... como é que era?

Reis?... o que que tem?...

L L1 - uma festa de Terno de

L L2 - o que que tem?... ali tem... o que eles faz[i] assim de:: eles faz[i] de madeira assim um Boi de Mamão e botam roupa em cima assim né?... quase e[ $\left.\int\right]$ tatura dum boi... fazem e[ $\left.\int\right]$ tatura de um boi... e aí eles brincam por as casas de noite... cantam o Terno de Reis e:.... brincam com o Boi de Mamão... que... o vovô... tinha uma porção de bicho assim... tinha:.... como é que se diz... tinha o tubarão... né?... tinha girafa... tinha:... como é que se diz... um maruá....

L1 - maruá?

L2 - um bicho pequeno que tinha... o cara ia pra baixo dele ali né?... e brincava né?... parecia que tinha uma boca bem grande... e:: ( ) e a vida do pessoal era isso aí... não tinha venda... era muito ralo... duas três venda aqui... o pessoal fazia... botava o boi no engenho... pa rodar o engenho pa rodar o engenho pa cevar mandioca... cevava... depois botava no tipitim... tipitim... botava na prensa e prensav[ũ]... iam puxando... quando secava a massa botava no forno assim de barro e começava a mexer com o rodo né?...

L1 - e o que é um tipitim que eu não sei?...

L2 - o tipitim é feito de [m] ambu... eles faz[i] ali o o... naquele... antigamente os hom[i] fazia o tipitim... vinte... trinta... quarenta tipitim... eles teci[ũ] tudo...

$\mathrm{L}$ L1 - mas era uma vasilha?...

L L2 - aí pegava no cocho

a massa e botava ali dent $[\varnothing]$ o... aí levava numa prensa que tinha... uma parte aqui embaixo e uma parte em cima... tinha um furo... eles iam rodando... ia secando a massa... né?... depois de secar levava no cocho... peneirav[u]... peneirav[u]... e colocav[ũ] pra secar no forno... botava lenha de 
baixo da fornalha... e começav[u] duas pessoa... uma do lado e outra no outro né?... rodava... era do[S] forno que tinha... ali secava a farinha... depois de seca... colocava né?... tirar o ( ) do:: do:: do forno...

L1 - e o senhor conhece um pouco da história aqui da Penha... quem que... que foi o primero morador daqui?...

L L2 - o primeiro morad[o] daqui... AH o primeiro daqui que eu sei foi o sogro dela... o falecido Atanásio Raimundo ((bisavô da entrevistadora))... foi o falecido Chico Cordeiro... o:.... Cipriano Custódio... o Legário Quentino... Onorato Severino... o... o Lúcio Policarpo... que era os primeiro morador daqui né?...

L1 - e::

L L2 - mas tudo longe um do outro...

L1 - e tinha assim... muito estrangeiro?... tipo alemães... portugueses

L L2 - não... só tinha um casal de alemão aqui.... ( ) lá no sertão... dona Vi / Videloa... né V.?... ((esposa do informante))... era dona Videloa e o nome dela eu não sabia como era... de estrangeiro que tinha aqui era ele[ $\left.\int\right]$... não conhecia mais nenhum...

L1 - e:.... quando o senhor era jovem... o senhora gosta de caçar.... de fazer isso... meu avô fala que adorava fazer uma caçada...

L2 - o seu avô gostava... eu caçava assim... pouco... mas caçava né?...

L1 - o senhor tem uma história interessante de uma caçada do senhor... ou que o senhor caçava...

L2 - matava passarinho assim às vez $[i]$... né?... caçava de gaiola... pegava os passarinho na gaiola...

é o que a gente fazia naquela época era isso né?... ia dez doze rapaz[i]... nós era tudo novinho né?... ia po mo[r] o caçar... seu vô ia... seu tio essas turmas tudo aqui que ia pro morro... né?... e caçav[ũ] com bodoque... matava passarinho com bodoque... o bodoque era feito assim com uma madeira... botava corda... e aí atirava no passarinho...

L1 - e como o senhor conheceu a sua esposa?...

L2 - como é que eu conheci?...

L1 - isso...

L2 - nós morava aqui mesmo... ela morava lá em cima e eu morava aqui... aí já comec [e ]mo[Ø] a conhecer... porque um dia teve... um $\mathrm{t}[\ulcorner\mathrm{i}]$ atro ali... um... aí eu um outro rapaz... ia pra lá... "vamo[Ø] vê quem é que le / namora com a V.?... quem é que leva ela?... quem for mais ligeiro pega ela... TÁ?...

L1 - o senhor falou que teve o quê?... um triatlo?... o que que é isso?...

L2 - é... um t $[\ulcorner i]$ atro... ali na casa do t[ $\ulcorner$ i] $]$ atro é um negócio de:: filme... filme... que passava... e era foi... ela era nova né?... eu era novo... e eu conheci outro colega... o N.... "vamo[Ø] ver quem leva ela... vamo[ $\varnothing]$ ver"... aí fomo[ $\varnothing] \ldots$ quando chegou ali adiante... cortei adiante dele... parelhei... parelhei com ela... né?... cheguei do lado dela e ele ficou parado... depo[S] ele falou pra mim... “vencesse né?"... mas é assim né?... bobeou... ((risos))... bobeou... venci... aí fui conversando com ela... o pai dela veio com o chicote $(($ risos $)) .$. queria dá uma surra nela... porque ela nunca tinha namorado né?... aí nós pass [ e ] mo[ $\varnothing]$ por ele... aí ele ficou do lado da estrada e não fez nada não... L1 - e o senhor teve muitos filhos... eles moram aqui ainda?...

L2 - filho tem... tem cinco filho... tenho sete filho... do[S] primeiro morreu... tem cincos vivo... quatro mulhe $[\varnothing]$ e um hom $[i] \ldots$ 
L1 - e eles continuam morando em Santa Lídia ou eles mudaram?...

L2 - olha... em Santa Lídia... olha não mora nem em Santa Lídia... tá morando no Gravatá... mora em Armação... e outra mora em... mora em... a (D.) morava na Penha né V.?... e uma mora no Rio de Janeiro... em Macaé...

L1 - e o senhor gosta de morar aqui?...

L2 - gosto... gosto de morar aqui... às vez[i] eu quero vender isso aqui... não dá coragem de vender porque (eu gosto) demais daqui...

L1 - é tranqüilo?

L2 - é tran[k]ilo...

L1 - por exemplo... e em relação à violência né?...

L2 - pois é... é sobre isso que eu ia te falar agora... não dá violência né?... em outros lugar aí é demais... não dá briga... vê briga é briguinha de cachaça à toa... mas no outro dia tão ( ) todos ele $\left[\int\right] \ldots$ aqui não dá assa[ $[\ulcorner]$ to aqui... graças a Deus... né?... um lugar bom de morar... melho[ $\varnothing]$ não tem... né?... pode ter igual... melho[ $\varnothing]$ não tem...

L1 - e o que que o senhor acha que mais mudou aqui na região... desde quando o senhor era novinho...

L2 - AH... mudou muito... aumentou a população demais... né?... naquele tempo não tinha casa... era casa de... de trezento quatrocento metro de distância tinha uma casa... e hoje o pessoal for[ũ] vendendo lote... e tá bem aumentado... casa encostada uma na outra... né?...

L1 - e veio pra cá... faz mais ou menos dez anos o parque né?... o Beto Carrero...

L2 - é... agora esse Beto Carrero ajudou muito... deu muito serviço po povo também né?... quer dizer que tá aumentando isso aí... cada vez mais aumentou... quer dizer que a Santa Lídia... do jeito que era... aumentou cem por cento...

L1 - e:: por exemplo... a gente vê em Piçarras... né?... é:.... e outras cidades aqui de Santa Catarina... não vamos nem pegar Piçarras... pegar por exemplo Blumenau... Itajaí é bem mais nova... $\mathrm{L}$ L2 - bem mais nova

L L1 - Penha é uma cidade MUIto mais antiga...

L 2 - é... Penha é mais antiga...

L1 - e por que será que Itajaí desenvolveu... se transformou em uma grande cidade...

L L2 - Itajaí se desenvolveu mais por causa do porto... né?... o rio ali... começou ali a encostar navio... depo[ $\left[\int\right]$ fizer[u] aquele forte da viação na Barra do rio né?... aquilo ali foi aumentando... tinha aquelas madereira né?... hoje não tem mais... ma[ $\left[\int\right]$ tinha antigamente muita madereira... e tudo ali o... tinha aquele porto que eles pegav[ũ] madeira... pegav[ũ] tudo ali né?... aí foi aumentando... foi crescendo né?... começar[ũ] a colocar [aw]m[ã]zém né? e foi indo... e foi indo... o comércio foi aumentando... o pessoal do sítio foi tudo trabalhar na cidade... trabalhar na madereira... trabalhar no porto...

L1 - e antigamente... pensando quando o senhor era novinho... como o senhor fazia pra ir daqui pra Itajaí...

L2 - AH... era de a pé... antigamente... eu era criança né?... não existia carroça... só [Ĩ]xistia carro de boi naquela época né?... só tinha carro de boi só... meu... pra ir daqui pra Itajaí tinha que ir a pé... $[\varnothing]$ travessar uma bateirinha que tinha... uma lancha pequena né?... passava seis oito pessoa cada vez... não passava mais porque era pequena... e a única condução que tinha era aquela ali né?... depo[S] foi melhorando... um comprou uma carroça... o outro comprou outra... e foram 
comprando... aí começaram a viajar de carroça pra Navegante[ $\varnothing]$... pra Itajaí... não passava né?... depos fundar[u]... primeira barca ali foi do Antônio Ramos né V.?...

L2 - ia pra ensinar... hoje ele[S] vão.... não vou dizer toda[ $\left.\int\right] \ldots$ que existe boas professora[S] também sabe?... a maioria é só por causa do dinheiro... por causa das féria[ $\left.\int\right] .$. no meu tempo teve uma que disse... "eu quero trabalhar de professora"... filha de um médico... "por causa dos do[ $\left[\int\right]$ meses de féria[S] no fim do [a]no..." deve ensinar alguma coisa?... eu pelo menos já não era assim... eu ganhava pra ensinar... ((professora))

L1 - e a Penha... a Santa Lídia... mudou muito nesses últimos anos?... a senhora que mora aqui há muito tempo...

L2 - Santa Lídia mudou bastante... era um lugar... bem pequeno né?... hoje a população aumentou ba[ $\left[\int\right] \operatorname{tante} . .$.

L1 - a senhora tem idéia de quantos moram aqui em Santa Lídia?...

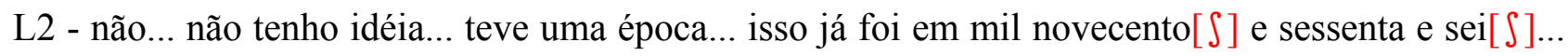

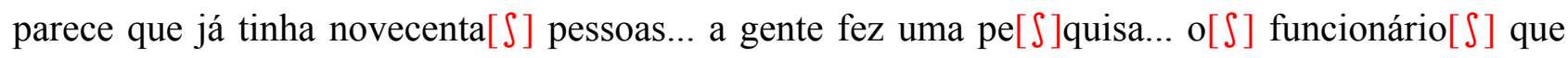
mandaram... porque novecentas famílias não tinha... agora hoje tu vai ver... é difícil... aumentou bastante... tem ruas pa tudo quanto é canto... Santa Lídia cresceu muito... ( )

L1 - e a senhora acha que o fato... de vir o Beto Carrero pra cá... a senhora acha que isso melhorou ou trouxe problemas com... porque traz turistas... pessoas de fora... o que a senhora pensa?...

L2 - pode ser... que o Beto Carrero tenha trazido problema[ $[$ ]... pras outras comunidades... eu acho que na nossa comunidade não ( ) ... nada não...

L1 - bom e:: tem muito turista pra cá?... nas férias?...

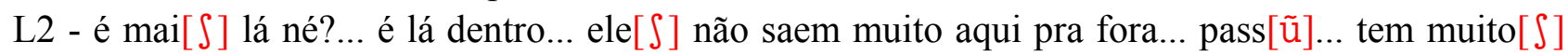
carros né?... ma[S] tá indo pra praia né?... pro Beto Carrero... melhorou né?... melhorou pro município...

L1 - e em relação aos costumes locais... costumes aqui... há festas que acontecem só em Santa Lídia?... por exemplo... religiosas... ou não... tem muitas festas aqui?...

L2 - é... aqui tem a[S] festa religiosa[ $\left[\int\right] \ldots$ temo[ $\left[\int\right] \mathrm{a}\left[\int\right] \mathrm{fe}\left[\int\right]$ ta junina... ainda teve né?... teve aqui na igreja... ma[ $\left.\int\right]$ foi lá na creche... né?... festa também eu acho que melhorar[u] bastante...

L1 - aqui se chama Santa Lídia né?... eu já até já perguntei e ninguém sabe me explicar bem... por que que tem esse nome... é uma santa... por que que colocaram aqui?...

L2 - eu tenho uma hi[ $\left[\int\right]$ tória... que até eu queria e[ $\left.\int\right]$ crever um livro... sobre a Santa Li / hi $\left[\int\right]$ tória de Santa Lídia... ma[S] comecei a pesquisar alguma coisa... guardei... e não fiz tudo... uma pessoa me falou que Santa Lídia recebeu e[ $\left.\int\right]$ te nome porque tinha uma senhora de idade com esse nome... aí colocaram esse nome... outra pessoa falou que um dia chegou uma máquina com umas letra vermelhas pra trabalhar aqui... e tinha nessa máquina o nome Lídia... então eles colocar[ũ] o nome da comunidade de Santa Lídia...

L3 - mais antes de Penha o nome daqui era Vale Verde... Verde Vale ou Vale Verde... ou Monte Verde... uma coisa assim 
L2 - não sei...

L3 - já teve outro nome... já teve outro Santa Lídia... foi uma pessoa de idade que me falou isso...

L2 - tinha outro nome?...

L3 - já teve outro nome...

L2 - o nome dessa rua... dessa rua... Santa Lídia?

L3 - não... o nome do bairro... por causa desse morro aqui em baixo... só não lembro agora do nome do lugar...

L2 - chamava sertão do Burço lá pra dentro...

L3 - não não... em âmbito geral... Santa Lídia no geral... antes era outro nome... todo ( ) antes era outro nome... Verde Vale... alguma coisa assim... achei interessante... tipo Cabras... que hoje chamam Nicolau... mudou...

L2 - interessante ( )

L3 - não lembro o nome exatamente... mas é alguma coisa em relação ao monte aqui de cima...

L1 - pode ser uma dessas duas origens... o nome de Santa Lídia... mas eles fazem uma festa pra uma santa mesmo... né?.. Santa Lídia... tem uma igreja...

L2 - pra Santa Lídia?...

L1 - é

L2 - é a padroeira da nossa cidade... faz a festa dia treze de ago[ $\left.\int\right]$ to... é o dia de Santa Lídia... todos

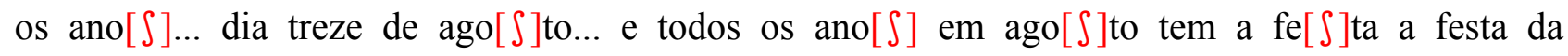
padroeira...

L1 - a senhora gosta de morar aqui?...

L2 - outra[S] fe $\left[\int\right]$ tas religiosas... é a festa de São Sebastião... dia vinte de janeiro... a de Santo Antônio em treze de junho...

L1 - e eu conversei com uma senhora... da... da Prainha de São Miguel e tinha a festa do Boi do Campo... né?... aqui tem?... a festa do Boi do Campo?

L2 - não... isso deve ser lá... já teve lá no Juca né?

L1 - e como que é essa festa?

L2 - eles faz[i] uma mangueira... colocam o boi lá dentro...

L1 - um boi de verdade?...

L2 - um boi...

L3 - um animal bravo...

L2 - aí as pessoa[ $\left[\int\right]$ vão lá... tem un[ $\left.\int\right]$ que conseguem entrar lá dentro...

L3 - pegar o boi a unha

L2 - igual assim o toureiro.. aí eles corre... e outros ficam do lado de fora observando... vendo...

L1 - e de onde será que esse costume aqui pro Sul não?... isso é típico da Espanha

L3 - ( )

L2 - bem que não é uma fe[S]ta... é uma brincadeira

L3 - é uma tradição né?... em Florianópolis

L L2 - o Boi de Mamão... também tinha...

L1 - ela falou pra mim... mas não me explicou como que era a festa... não tem ( )

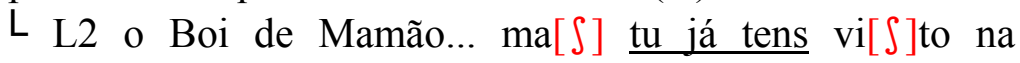
televisão nada?... tem diversos personag[i] né?... tem o boi... tem o cavalinho... a pessoa se veste... tem uma boneca... como eles chamam?...

L3 - Maricota 
L2 - e eles faz[i] aquela brincadera... ele[ $\left.\int\right]$ vão brincar de luta... ela faz assim né?... ela abre... aí ela entra aí...

L1 - mais é uma pessoa?

L2 - é uma pessoa... ela abre e fecha... entra pela boca sai...

L1 - mais tem formato de quê?... de um bicho?

L3 - é

L2 - tem tem

L1 - dragão?

L3 - ( )

L1 - ainda tem ou não?...

L2 - é raro

L3 - ( )

L2 - apresentar[ũ] ali no rio acima... foi apresentado lá na frente...

L3 - ( )

L2 - é bonito

L3 - for[ũ] pra Brasília se apresenta...

L2 - é... assim... brincav[ũ] aqui... depois não tem mais... tá mais raro...

L3 - Terno de Reis

L1 - as coisas vão perdendo...

L2 - nó[ $\left.\int\right]$ tínhamos a festa de Nossa Senhora do Rosário... na Penha... ela era feita só pros preto... ( ) aí se acabou com a fe $\left[\int\right]$ ta...

L3 - era só preto?

$\mathrm{L}$ L2 - era dia vinte

L L3 - era só preto?

L2 - $[\varnothing]$ cabou

L3 - mais era só pessoas pretas que participavam?...

L2 - era... no início sim... mais depois começaram a passar para os brancos...

M. A. C. (L2)

4CI

L2 - eu continuo pra frente... eu tô lutando ainda com a família... a família casar[u] tudo... fiquei sozinha... não posso nem contar minha vida... vida muito doída... muito sacrificada... uma vida $\mathrm{m}[\mathrm{u}] \mathrm{t}\left[\int\right] \mathrm{o}$ pesada... ((chora))

L L1 - não fica assim...

L2 - ma[S] ( ) vou vivendo graças a Deus... tô no evangelho... Deus tem me dado muita força pra mim suportar até o dia da chamada... por isso que eu tô aqui...

L1 - e a senhora acha que Penha mudou muito... a senhora é daqui daqui né?...

$$
\text { L L2 - é }
$$

aqui?

L2 - a Penha não tinha ninguém... era só quatro quatro casa bem dizer... nunca mudou... nunca aumentou muito... mas aumentou ba[ $\left[\int\right]$ tante... no Gravatá onde eu tô tá quase uma cidade... Santa Lídia também não tinha ninguém... as [ $r$ ]ua não tinha nada assim de calçamento... agora já tão 
começando a calçar... a Armação também aumentou muito... a Penha aumentou pouco... Piçarras tá uma cidade... Piçarras né?... então é assim... e a vida continua...

L1 - e:: e o Beto Carrero? ( )

L L2 - o Beto Carrero também... ali tinha nada... ma[I] depo[S] que o Beto Carrero veio aumentou muito o emprego... e... muita gente de fora... muita coisa então tá bonito agora lá né?...

L1 - e a senhora acha que::... o Beto Carrero ajudou a melhorar ou a piorar?...

L2 - não... eu acredito que o Beto Carrero ajudou um pouco porque der[ũ] emprego pra muita[S] pessoa né?... minha gente tão trabalhando... muita criança... muita moça nova... muita coisa... quer dizer que aumentou né?... (no vale) de Armação...

L1 - e aqui... a senhora conhece alguma festa típica... uma alguma coisa que acontece sempre aqui....

L2 - na igreja que tu diz né?... isso acontece né?... tem bingo... sempre acha bingo aí pra ajudar aquele[S] que necessit[u]... também como no Gravatá também... como na Armação... às vez[i] tinha pessoa inválida que... que não tem soco[r] e e eles soco[r]e com bingo... alguma coisa... e aí ajuda né?...

L1 - e as festas típicas tipo o Boi de Mamão... né?...

L2 - é:: antigamente tinha muito essa[ $\left.\int\right]$ coisa... Pau de Fita e tudo... ma[S] tão terminando já... tão terminando já... porque... tá se acabando as fe[ $\left[\int\right]$ ta tudo... tá se acabando...

L1 - mas por que que a senhora acha?...

L2 - é porque sei lá... e[ $\left.\int\right]$ ta mocidade agora ( ) não é como a antiga... que tinha o respeito... que podia fazer uma coisa... que podia outra... mas aquele tempo também quase não existiu evangélico aqui... quase ninguém era evangélico... e depois começou a entrar o evangelho... aí a pessoa mudou mais um pouco...

L1 - a senhora acha que a juventude... é muito diferente?... por exemplo... a senhora quando era menina a senhora

$\mathrm{L} L 2$ - muito diferen[t $\left.\int \mathrm{I}\right] \ldots$ muito diferent $\left[\mathrm{t} \int \mathrm{I}\right] \ldots$

L1 - o que a senhora acha que mudou?...

L2 - a juventude de hoje são... a juventude violenta... são muit[S]o violento e::... e depo[S] que entrou essa droga no paí[ $\left[\int\right] .$. que tá $[\varnothing]$ cabando com o país... Brasil... tá indo assim uma coisa... cada dia pior... cada dia pior... cada dia pior... por causa da violência... por causa da droga... por causa desse estupro... dessas coisa... parece que não tem mais quem governa... parece que não tem mais governo... parece que não tem mais presidente... parece que não tem mai[S] nada... e o mundo tá na mão do maligno... essa gente... criminosa... muita morte... muita coisa né?... é uma tri[ $\left.\int\right]$ teza... a gente tem medo até de sair... de passear... de medo de [a]receber... porque... eles roub[ũ]... eles mat[ũ]... eles faz[i] tudo que não pre[ $\left.\int\right]$ ta né?... e aquele tempo passado não era assim.... as pessoa era melho $[\varnothing]$ de viver...

L1 - era melhor...

L2 - era melho[Ø]

L1 - acha que passou o tempo e

L L2 - é:: agora... então tá bom e tá ruim né?.. porque... tá bom pra viver... mais tá ruim porque não dá por causa da droga... tristeza... 
L2 - eu fui caçar com o meu irmão... de noite... caçar tatu com o cacho[ $[$ ]o... e a lua tava bem clara... era lua cheia... $\mathrm{n}\left[\mathrm{\rho}_{\mathrm{j}}\right]$ entremo[ $\left.\varnothing\right]$ pelo mato adentro... ( ) o cacho[ $[\ulcorner]$ o pegou o rastro do bicho aí $\mathrm{n}\left[{ }_{0}\right]$ travessamo[ $\left.\varnothing\right]$ travessamo[ $\left.\varnothing\right]$ travessamo[ $\left.\varnothing\right]$... fez uma vo[ $[\ulcorner]$ ta... aí meu irmão diss[e] “( ) é um tatu e ele vem chegar aqui"... aí o cacho[ $\varsigma$ ]o vei[o] latindo "quém quém quém quém quém quém" (voou) em nossos pé... entrou... embaixo das perna dele... ( ) a lua tava igual ao dia... (e nós perto do de ingaeiro)... aí vei[o] um aguaceiro de chuva que choveu vinte minuto... mas a água de chuva BEM grossa... batia em cima da folha do ingaeiro (que acaba) mas embaixo não

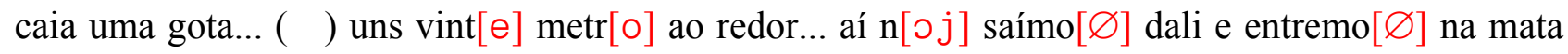
$\operatorname{virg}[\mathrm{i}] \ldots$ quando $\mathrm{n}\left[\mathrm{\rho}_{\mathrm{j}}\right]$ entremo[Ø] ( ) uns cinqüenta metr[o] de mato adentro... cai um pau acima de $\mathrm{n}\left[\mathrm{\rho j}^{\mathrm{j}}\right.$ n no mato que sacudiu co / a terra... foi um feNÔmeno... uma coisa TREmenda...

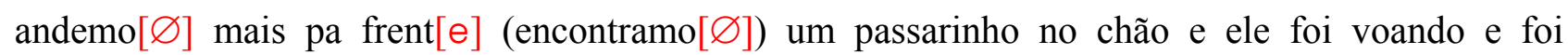

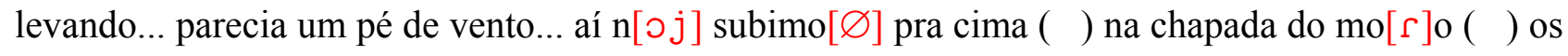
(trê) cacho[ $[$ ] o ficaram assim de lad[o]... ( ) veio um negóci[o] assim pel[o] ar... (acima) de uns (doze) metr[o] de altura... tamanh[o] dum bujão... branc[o]... um pouc[o] mais comprid[o]... passou bem encostado no meu ombro... passou assim [e] bateu... bateu [e] os cachorro [Ø]vançaram e saíram rolando dentr[o] dum grotão... [o] meu irmão correu com a lamparina na mão... a lamparina caiu da mão aí eu desci... os cachorro tava tudo arrepiado ( ) mordendo traVAdo no negócio... mas não era nada... ele mordia mas não vi nada... eu dobrei joelho e expeli o Satanás... "diAbo Satanás... em NOme de Jesus eu te repreendo"... aí meu irmão ficou atemorizado [ $\varnothing]$ garrou-se ne mim eu disse "não... agora vamo[Ø] caçar aqui que não vão incomodar mais"... ( ) desde [o] início [o] cachorr[o] já (grita) já era el[e]... aquel[e] pau já era el[e]... aquel[e] passarinh[o] era el[e]... tava se manifestando assim... (ele) manifesto-se dessa forma... ( ) "agora

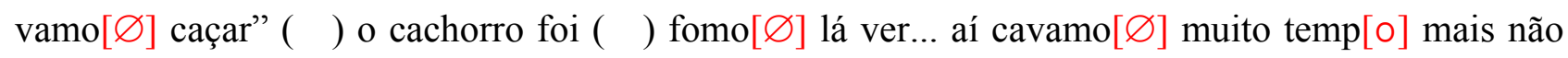

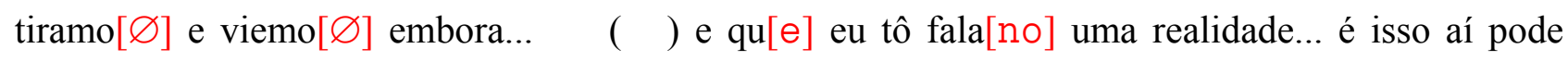
fechar... então eu vou cont[aৎ] d[e] nov[o]... isso aí aconteceu ( ) (tá limpo?)... isso aí aconteceu ( ) el[e] manifesto-se num bich[o] (cachorro) depois num aguaceir[o] $\mathrm{d}[\mathrm{e}]$ chuva... aquel[e] pau foi $\operatorname{art}[\mathrm{e}] \operatorname{del}[\mathrm{e}] \ldots$ aquel[e] passarinh[o] foi EL[e]... aquilo lá em cima qu[e] parecia um bu / ali... eu / ali eu entendi... ver... eu era crent[e] e tinha orado... e aquil[o] que era o iniço eu não entendi qu[e] era el[e]... né?... tu veja... qu[e] LÁ naquela hora... é qu[e] o Senhor me fez entender qu[e] era um demônio que tava ali se manifestando... ( )

L1 - vô... você sempre caçava LÁ... no morro?

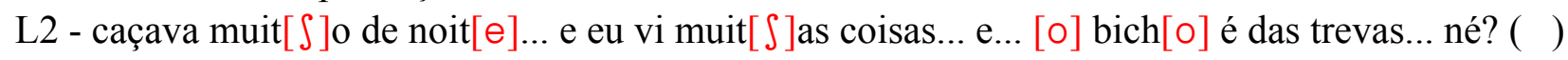

L1 - como que era vô trabalhar lá no / no morro... como é que era o seu dia... acordava cedo...

L2 - quando eu acordava... tá gravado?...

L L1 - tá... tá gravando 
L2 - quando eu acordava... (ainda) tava noit[e]... duas hora... três hora da madrugada... pra trabalhar... pra (fornear) farinha... [Ø]lambicar cachaça... moer cana no engenho com o boi... fazer açúcar... ( )... às sete hora... seis hora tomava o café... ia pro serviç[o]... roça... cafeeir[o] apanhar café ou capim ou mandioca... apanhar milho ou colher feijão... roça pasto... depende d[o] serviç[o]... vinha pra casa às onze e meia... almoçava... descansava... uma hora da tard[e] começava $\mathrm{n}[\mathrm{o}]$ serviç[o]... apanhava feixe...

\section{Observação: trechos de pasquins recitados pelo informante.}

\section{“A Jaracuçu” (L2)}

iss[o] foi em um mês $\mathrm{d}[\mathrm{e}]$ abril... às oito hora do dia... estava na minha casa vi uma gritaria... eu corri para sabe[ [] a novidade que havia... quando cheguei na estrada já vi um sururu... era só gent[e] com pau [e] pedaç[o] de bambu... na casa da Mariquinha pra matar [o] Jaracuçu... primeir[o] qu[e] chegou foi [o] senhor Leopoldo... depois diss[e] assim "o bicho tá muito morto... eu vou pra casa traba[j]a fica aí tropa de bobo"... [o] senhor João da (Desa) tem fama d[e] atirado $[\ulcorner] \ldots$ deu oito tir[o] na cobra... nenhuma bala acertou... a cobra não mordeu el[e] porqu[e] o outro matou... [o] seu José Atanásio... com uma faca na mão... "vou tirar [o] couro dela... isto é um remedão... cura da $\operatorname{AID}[\varnothing]$... do câncer e também [a]limpa o pulmão”... senhor Manoel Alexandre diss[e]... "se eu tivesse lá... eu pegava a cobra viva e não deixava matar... arrancava o dent[e] a unha de[S]pois mandava so[ৎ]tar"... senhor Ari da Nina também entrou na patota... quando ele chegou lá a cobra já tava morta... pa fazer [o] tope nela chamaram [o] João Minguota... João Minguota chegou... não deixou ninguém falar... assentou a (pá) dele a trabalhar... a bala é trinta e oit[S]o pode mandar ente[ᄃ]ar... eu achei interessante foi [o] Luís da Belenha... el[e] foi lá ver a cobra e não levou a lixinha... el[e] saiu d[e] manhã e só voltou à noitinha... [o] senhor Manoel Macena pegou a sua pistola... quando chegou $\mathrm{n}[\mathrm{O}]$ caminh[o] a arma caiu a mola... tinha cinqüenta an[o]... pegou ela e jogou fora... fez meia-lua na estrada arrancou-se e foi se embora... [o] senhor Antônio Cordeiro é um homem respeitado... neste ente[ $\varsigma$ ]o da cobra ele foi [o] encarregado... às duas horas da tarde o pov[o] foi convidado... o José do João da Oncila ficou de dar [o] caixão... mandou para a Mariquinha uma caixa de papelão... só não mandou as velas pa não fazer confusão... o povo gostaram muit[o] d[o] Amauri da Zenaide... é um homem muito bom qu[e] sempr[e] faz caridad $[e] \ldots$ foi convidado pro ente $[\ulcorner]$ o à duas horas da tarde... o ente $[\varsigma]$ o vai sair... vão chamar a Mariquinha... chamavam chamavam chamavam mais a coitada não vinha... foram ver tava chorando mais os filho na cozinha... senhor Castilho de Freita vai ser [o] coveir[o]... ele foi fazer a cova no meio do tabuleir[o]... "eu faço tud[o] de graça e não vou cobrar dinheir[o]”... o Pedro de João Zia com uma (agulha) na mão... "eu sou [o] doutor daqui e hoje tô d[e] plantão... se a cobra morde

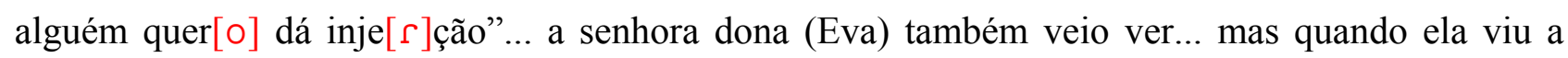
cobra já começou a tremer... "minha gente me acode que a cobra quer $\mathrm{m}[\mathrm{e}]$ morder"... vou chamar 
o doutor Pedro que ele vem socorrer... o ente[ $[$ ] o vai sair... quem vai levar o caixão... com[o] já tá intimado vai ser os quatro irmão... (Zinho) co Aristo... o Gildo e o João... [o] enterro vai sair... quem vai bater [o] $\sin [0]$ ?... como já tá intimado é o (Bando) Venturindo... qu[e] bateu com tanta força que ainda tá zunindo... o Deca da Leonida ficou muito apaixonado... neste enterro da cobra não foi [Ĩ]convidado... ia dar a cacatumba agora ficou parado... às duas hora da tard[e]... quando chegou a Curela... "eu vim pra vim no enterro e $\operatorname{tr}[u] x[e]$ uma caixa $d[e]$ vela... $\operatorname{tr}[u] x e$ um buquê de flor pa botar na cova dela... o enterro tava lindo... era uma $\mathrm{p}[\mathrm{u}]$ cissão... o retrat[o] de São Bento em cima $\mathrm{d}[\mathrm{o}]$ caixão... o povo todo rezando de vela acesa na mão... aí chamaram o (Zilho)... era pra ele rezar... ele abriu a sua boca e começou a excomungar... deram um tapa na cabeça e mandaram el[e] levantar...

\section{“A lagarta” (L2)}

a lagarta começou na terra dos fazendeir[o]... na casa do Antoinho ela invadiu o terreiro... e el[e] até pensou $\mathrm{d}[\mathrm{e}]$ ir chamar [o] corp[o] bombeir[o]... cá na terra $\mathrm{d}[\mathrm{O}]$ Domingo a lagarta atravessou... a Maneca d[o] Sabino muit[o] trabalh[o] passou... passou muit[o] com o chapéu... o rest[o] ele enxotou... depois [o] bich[o] saíram e vinheram para ( ) e não mexeram na grama e nem roeram a floresta... só não roeu a Carminha porqu[e] ela foi esperta... seu Antônio Satir[o] é o (tutu) d[o] sertão... venha ver como ficou a cana $\mathrm{d}[\mathrm{O}]$ alemão... a lagarta comeu tud[o] só deixou [o] espigão... senhor Beto Vinturino "vocês chamam Ricardão... pa fazer um benziment[o] na linguagem alemão... para tirar essa PRAga d[o] capim lá do sertão"... o Beto Vinturino disse "quanto é [o] pagament[o]?"...[o] Ricardão disse assim... “o preç[o] d[o] benziment[o] a pequena eu vend[o] a um... a mais grand[e] a duzent[o]"... o Antoninho da (Noda) ele foi lá $\mathrm{n}[\mathrm{o}] \mathrm{Chiquinh[o]...} \mathrm{a} \mathrm{lagarta}$ lá em casa já tapou [o] caminh[o]... tu vai lá matar comigo que eu não dou conta sozinh[o]... e na casa do Duda a lagarta invadiu... subiu pelas parede el[e] coitado não viu... roeu a orelha del[e]... tava dormindo não viu... o Chico (Antonico) homem qu[e] morr[e] na raça... pegou um saquinh[o] plástic[o] e encheu el[e] $\mathrm{d}[\mathrm{e}]$ lagarta... depois botou nas costa e amarrou na fumaça... diss[e] "aqui na minha terra essa $[\varnothing]$ mundiça não passa"... senhora Júlia do Traça ela pegou a lata... começou a bater pa enxotar a lagarta... é pa ela não comer o baraço da batata... senhor Bernardo da França ficou muito assustado... e pegou no telefone e telefonou pro Bernardo... perguntando se a lagarta roía a unha do gad[o]... o Bernardo diss[e] assim "Júlio tu não tenha med[o]... ela só come a grama [e] a folha do arvored[o]... não vai no past[o] descalço que ela vai roer seu ded[o]"...[o] amig[o] Moacir (cujo) homem ignorant[e]... pegou dezoit[o] lagarta e amarrou num $b[e]$ bante... levou pra $\mathrm{mo}\left[\int\right] \operatorname{trar}$ po pov[o] do Navegant[e]... o Raul se previneu com $\mathrm{v}[\mathrm{i}]$ neno $\mathrm{d}[\mathrm{e}]$ primeira... na casa do Bernardo ele fez uma trincheira... foi lá cercar a lagarta pra não ir pra (arrozeira)... (João) Antônio Clara ele pegou uma faca... disse "eu vou no sertão... vou lá capar a lagarta"... capou a lagarta fêmea deixou a lagarta macha... [o] seu Dudu Zacarias... pois ele disse assim... "a lagarta no sertão tá acabando [o] capim... eu vou lá em Florianópolis fazer queixa pro Amim”... eu vou falar pro 
hom[i] / vou arrumar um bombeir[o]... aqui bem perto tem um... o Zacarias Cordeiro... ele vai botar $\mathrm{d}[\mathrm{e}]$ graça e não vai cobrar dinheir[o]... seu Aníbal (Teodoro) hom[i] qu[e] anda n[o] past[o]... "lagartinha lagartuxa lagartixa lagartaxa... tu vai lá e larga fog[o] larga a lagarta no mat[o]"...[o] seu Duarte quero dizer pra ti... [o] seu (Duardo Zanguete) "se vai no mat[o] virg[i]... e corta um mont[e] de porrete... quando a lagarta chegar você mete no cacete"... seu Bento Venturin[o] "tu fala pro seu Maneca... botar el[e] d[e] vigia na frent[e] da sua cerca... quando a lagarta entrar mete um pau na cabeça"... senhor Antônio Rodrigue... sua cueca d[e] sac[o]... $\underline{\text { tu}}$ pensa que eu não te vi $\mathrm{d}[\mathrm{e}]$ coca dent[u] do pasto... matando lagarta a soc[o]... jogando de água abaixo... senhor Antônio Rodrigue dessa coisa tu sabia... pra que não pagass[e] [o] Neca e [o] João Clara de vigia... e ele matava ela e [o] capim não comia... quem tirou ess[e] versinho eu quero dizer quem é... foi [o] Neca Marimbondo mandado d[e] João (Baé)... hom[i] da cabeça lisa tem que usar [o] boné... e [o] João Baé era queca... e é só iss[o]...

\section{G. P. A. (L2)}

6CI

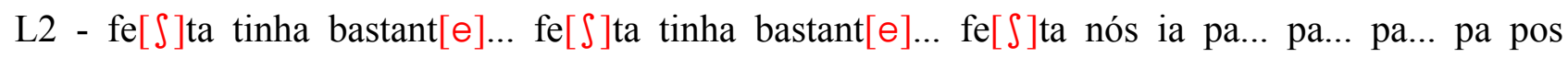
Machado... nós ia pos Machado a pé... a pé ( ) vinha a pé... até qu[e] tinha um hom[i] que tava doente na cama passou um rapaz co $\mathrm{n}\left[\odot_{j}\right]$... foi o $\mathrm{n}\left[\supset^{j}\right] \ldots$ ( ) e ele passou cantando assim... e ele... e ele tava / tava capinando... esse cara tava capinando... aí ele deu com n[॰j] e (deu) co a enxada em baixo do braç[o]... aí esse rapaz ( ) quando eu passei aqui tinha um hom[i] capinando... co / a enxada ( ) aí minha filha quando ele passou ( ) tava com a faca na mão pa matar ele ((risos)) $\mathrm{n}[\mathrm{O}]$ ia po Navegant[e]... ia pa São João... pa festa / agora que eu não vou missa / fui ali mais fui agora mais não deu mais de eu e... eu eu... ia à missa do Machado... ia à missa do Navegantes... ia à missa da Armação... ia pa Aparecida... tinha um mont[e]... tenho onze viag[i] na Aparecida d[o] Nort[e]... co / marid[o] sem marid[o] ( ) porqu[e] nós tinha uma vaquinha qu[e] tava dando leit[e]... ( ) por causa da vaquinha... mais... tinha festa por aí tud[o]... era (padre) por aí tudo agora tá bem (baixo) não tem nada... isso aí não tem nada / mas de primeir[o] era padre que andava (pintando) por as porta... também a gente ia / chegava pela noit[e] as mãe ( ) olha é hora d[e] ir embora e sai[ũ] pela porta afora e aí vinha tud[o] embora...

L1 - ( ) a senhora foi muitas vezes em São Paulo... em Aparecida do Norte ou não?

L1- a senhora foi MUITAS VEZES em Aparecida

L L2 - Ahn?

L L2 - em ApareCIDA?... nove vezes

LL1- nove

vezes... e a senhora ficava muito tempo lá ou não?

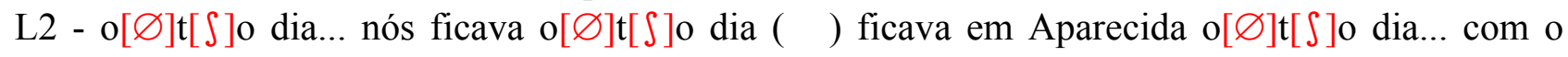
marid[o] foi bastant[e]... (esse) foi bastant[e]... eu mais eu... ia el[e] ficava... el[e] ficava... eu... eu ficava... (mandava em mim)... 
L1 - e a senhora gosTAVA... de lá?... o que a senhora fazia quando ia lá?... gostava?

L L2 - ( ) lá?...

lá?... tinha um ranchinho lá ond[e] dava pa nós cozinhar... nós (punha assim) a água $\mathrm{n}[\mathrm{o}]$ fog[o]... e fazia um cafezinh[o]... mais era água da (caixa) e era ruim... aí ia lá na font[e]... na... ( (Iguape) buscar água pa... pa fazer a comidinha... nós ia lá...

L1 - mas a senhora nunca morou fora daqui?

L2 - não... nunca vivi fora daqui... tem minha / minha neta... mora / pa convidar pa mor de eu e... pa mor de eu ir pa casa dela... mas eu não vou porqu[e] tem rapaz pequeno tem muit[o] barulh[o] ninguém pode tomar um banho ninguém pode ( ) porqu[e] tem rapaz pequeno... porqu[e]... deixa eu aqui sozinha... ainda ontem me doeu ess[e] nerv[o] por aqui tud[o] ((aponta para a coluna))... por aqui tud[o]... passei a noit[e] sozinha... aí... ( ) um cafezinh[o]... ((choro))

L1 - mas a senhora está melhor né?

L2 - ... é... eu passo trabalho... ((choro))

L1 - não fica assim... imagina... vamos falar de coisas mais / mais alegres... para a senhora se animar... pra não ficar triste... senão eu vou ficar triste também...

L2 - ( ) ((choro))

L1 - e:... a senhora conversa com bastante pessoas... tem contato... fica muito sozinha... fica muito sozinha aqui?

L2 - s[u]zinha?

$$
\text { L L1 - é? }
$$

L L2 - é::...

L1 - a senhora tem muitos filhos... muitos netos...

L L2 - ( ) tenh[O] uma ca[r]ada... NETO BISNETO... tenh[o] uma ca[r]ada... tenho uma carrada... mais só minha afilhada que tem um filh[o]... tenh[o] um ali... [e] tenh[o] uma filha que mora lá na praia... aqui mo[r]eu / que agora faz quatro ano com os quarenta e seis ano... com quarenta e seis ano... ele morreu...

L1 - na praia aqui em ( )?

L2 - el[e] morreu aqui (uma válvula) que arrebentou por dentr[o]... exempl[o] d[e] um trabalhad[0]...

L1 - e:.... a senhora tem é:... bastante... bastante NETOS né?

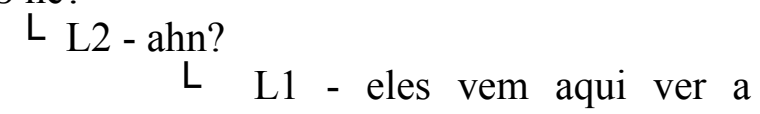

senhora?... os seus netos... eles vem aqui?

\section{L2 - NETO?}

L1 - é

L2 - não ( )... eles vem...

L L1 - ahn

L1 - AH::... mais é tudo NEto já?

L2 - ( ) falar mais d[e] net[o] e net[o] tenho uma ca[r]ada... ca[r]ada...

L1 - AH:... e:.... aqui... aqui nesse... nesse lugar

L1 - tem algo... tem alguma festa assim...

\section{L2 - AHN?}




\section{L2 - FE[S]ta? \\ L L1 - é::}

L2 - tem a d[e]... ali n[o] mo[r]o... agora já vão fazer fe[ $\left.\int\right]$ ta... tem a d[o] ( ) tem nessa tod[o] $\mathrm{sab}[\mathrm{o}] \ldots$ já tem até uma igreja bonita no morro... sabe ( ) tem uma igreja bonita... igreja bonita que $\mathrm{m}[\mathrm{o}]$ / foi $\mathrm{m}[\mathrm{o}]$ marido começou... depois $\mathrm{m}[\mathrm{o}]$ marido arriou... o filh[o] pegou... quando el[e] mo[r]eu ele deixou em mei[o]... hoj[e] o / um cara lá de ( ) (trouxe) acabada... agora el[e] entregou foi-se embora... el[e] entregou pa... pa... $\mathrm{m}[\mathrm{o}] \mathrm{gen}[\mathrm{r}] \mathrm{o} . .$. entregou po pos outro... $\operatorname{ma}[\mathrm{I}]$ agora vai ter festa $\mathrm{d}[\mathrm{o}]$... vai ter festa $\mathrm{d}[\mathrm{o}]$ São Pedro... vão fazer agora / tão fazendo agora um quart[o] pront[o] tão fazendo tud[o]... (igreja bonita)

L1 - e tem muita gente na FESta?

L2 - tem tem tem tem

L L1 - tem?... e como é o verão aqui?... tem mais GENte no veRÃO?

L2 - ahn?

L L1 - no veRÃO... no verão no calor

L L2 - OH::::::: tem uh::: barbariDAde... n[o] verão aí não dá pa passar aí na estrada minha velha... não dá pa passar na estrada... sem falar que são tudo veroni[ $\left[\int\right]$ ta... tudo tudo pra lá... (sem falar) da casa que fizer[u] lá po mo[r]o... agora... a casa que fizer[u] lá pro mo[r]o... tem gent [e] com fartura aí... tem veroni[ $\left[\int\right]$ ta com fartura...

L1 - e eles são as / eles são educados ou fazem muita bagunça?...

L2 - é:...

L1 - eles fazem muita / eles são educados?

L2 - são educado

L1 - e:: a senhora gosta de de ir na praia?... do mar ver o mar..

L L2 - é... eu não vou... não chego na praia...

L1 - não gosta?

L2 - não... não não não chego mais na praia...

L1 - não pode né?... já foi antes ( )?

L L2 - é... eu não chego mais na praia...

L3 - mas a senhora já foi antes quando era mais nova?...

L2 - quando eu tinha saúde da pedra eu ia lá na praia... ma[i] agora na velhice...

L L1 - e::

L2 - agora tô tomando um bocad[o] de comprimid[o]... ( ） um b[u]cad[o] de comprimid[o] aí... (preto)... po:.... um bocad[o] de comprimid[o] do nerv[o]... esse nerv[o]... dout[o] ( ) dali da Penha... deu comprimid[o] pro nerv[o]... mais ele salva a perna deixa / me $[\varnothing]$ rebenta o corp[o]... me $[\varnothing]$ rebenta o corp[o]... eu já fui... eu já fui já... ( ) em Itajaí... da cabeça... né?... eu gritava... (me doía) a cabeça... me doía a cabeça... ( ) a veia que não circula... ( ) ((choro))

E. M. S. (L2)

7CI

L1 - eu queria que a senhora contasse pra mim um pouquinho da vida aqui da senhora... quando a senhora era moça... tinha a idade nossa... 
L2 - É... a gente trabalhava na roça... quase não saía de casa... muita pobreza né?.... miséria de roupa... e a comida $\operatorname{tam}[\varnothing]$ ém era $\mathrm{m}[\mathrm{u}] \mathrm{t}\left[\int\right] \mathrm{o} . . . \mathrm{m}[\mathrm{u}] \mathrm{t}\left[\int\right] \mathrm{o}$ ma[ł] passada... fomo[ $\left.\varnothing\right]$ criado sabe no quê?... folha de taiá... fazia ensopado... minha mãe fazia ensopado pa nó[S] comer... né?... e esse luga $[\varnothing]$ era um luga $[\varnothing]$ pobre... não tinha morad $[0] \ldots$ aqui na ponta da Cruz ali era o cemitério... o cemitério era ali... o[ $\left.\int\right]$ portugues[i] que vier[u] fundava a Armação aqui de Itapocorói... foi fundada pelos portuguê[S]... e tiver[u] aquela igreja de São João... isso ali... aquela ma[S] pequena... ela fez agora duzentos e quarenta ano... aqui vier[u] pa pe[ $\left.\int\right]$ ca da baleia.... aquela igreja foi feita com pedra e óleo de baleia... e nós o São João que era padroeiro... só um Santo que tinha... e a gente ia vivendo assim... aqueles baile daquela gente pobre... não tinha $1 \mathrm{u}\left[\int\right] \ldots$ não tinha nada... L1 - e::... e hoje o que a senhora vê que mudou... da juventude... a senhora saía muito... hoje o jovem

L2 - a NÃO... mudou $\mathrm{m}[\mathrm{u}] \mathrm{t}\left[\int\right]$ o minha filha... ninguém saía de casa... o[S] pai não deixava... era só saída com o[S] pai... hoje em dia não... né?... mocinha nova o[ $]$ pai não lig[u]... sai tudo pa rua... tudo novinha de quinze ano já tão tudo grávida... me admiro muito dessa mocidade de agora... me admiro muito...

L1 - e:.... a senhora é casada há muito tempo...

L2 - sessenta ano... fiz em maio... a[S] minha filha fizer[u] uma torta... botar[u] um casal de noivo... o noivo caiu... ((risos))

L1 - e como a senhora conheceu o marido da senhora

ficava lá enchendo o saco ((risos))...

L L2 - ele morava pertinho... era um primo meu...

L1 - e a senhora teve muitos filhos?...

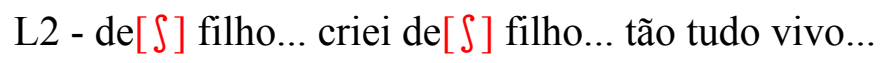

L1 - e como que era criar dez filhos antigamente?

L2 - era um trabalho minha filha... não havia uma ro / se a gente quisesse comprar uma roupinha prum bebê feita não tinha... era todo comprado em metro... aí eu tinha uma máquina... dessa máquina de mão... eu botava uma e[ $\left.\int\right]$ teira e a máquina em cima dum caixão... pra fazer a roupinha de noite... de dia eu tinha que ir pra roça... p[ᄃ]antava e... meu marido embarca se... e aí eu $\mathrm{p}\left[\ulcorner]\right.$ antava e dava pum hom[i] fazer farinha de meia... e eu comia o feijão... eu $\mathrm{p}\left[\ulcorner]\right.$ antava $\mathrm{a}\left[\int\right]$ outra coisa...

L1 - e assim... a senhora é católica né?

$\operatorname{assim...}$

$$
\text { L L2 - É }
$$

L $\quad$ L1 - tinha... tinha muita festa?... o que se fazia

L2 - não... o mais que nós tinha era a festa de São João... que é nosso padroeiro aqui de toda vida... aqui na Armação... é só festinha boba que se faz aqui... São João... aí tem na Penha a festa do Divino Espírito Santo... ( )

L L1 - e Terno de Reis... a senhora chegou a conhecer?

L L2 - É:... cantava um monte... amanheci[ũ] na nossa porta... é tem São Gonçalo também... festa de São Gonçalo... quando a gente prometia quando dava uma dor na perna... prometia um baile pra São Gonçalo... aí fazi[u] uns fandango pa São Gonçalo... todo cantando...

L1 - e::... a senhora chegou a conhecer a dança da fita... aquela que os portugueses faziam?... 
L2 - É:.... o Pau de Fita... é...

L1 - e como que era assim... porque me falaram mas não explicaram...

L2 - é... é um pau carregado de fita e tudo dançava... e trançava por dentro e por fora... até (entrançar) aquela fita... depois eles cantando ( ) depois começava a vo[ \ulcorner] tar pra desandar aquela fita todo... outra ve[ $\left[\int\right] \ldots$

L1 - e hoje ainda costuma ter?...

L2 - não... não... não fazem mais nada dessas coisa...

L1 - não tem mais?...

L2 - não...

L1 - e hoje a senhora acha assim... olhando... né?... pensando na juventude pra cá... como que tá a violência... o que a senhora acha que mudou?

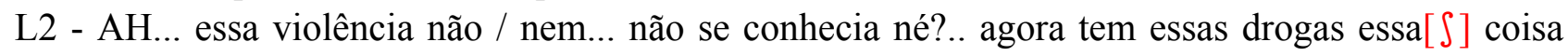

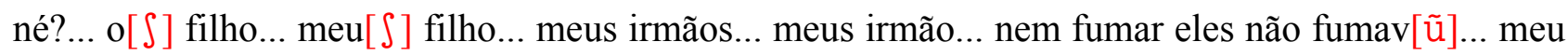
pai não fumava e não deixava os filho fumar... quando meu pai saía de casa... o cigarro era feito de fumo picado com palha... eles jogav[ũ] ... o fogo era fogo de grelha... não havia fogo a gá[j $\left.\int\right] \ldots$ eles jogav[ũ] um pau de fogo na rua... pra quando meu pai saía de casa eles lá... acender um cigarro e fumar... e meu pai não deixava eles fumar...

L1 - e:... assim... o comportamento do jovem hoje... pensando assim mais no jovem... nos meninos... eles começavam a trabalhar mais cedo... hoje é mais tarde... o que que a senhora acha... eles não tinham escola... iam trabalhar mais cedo

L L2 - é não tinha e[ $\left.\int\right]$ cola não... tinha e $\left[\int\right]$ cola pouquinho... ma[ $\left.\varnothing\right]$ quando chegava no quarto ano... pronto... se acabava... agora o[S] pai que era pe[S]cad[o] levava o[S] filho para pescar... e o que não era pescad[o] ficava por aí... e o lavrad[o] ficava na lavoura com o[S] pai... o pe[S]cad[o] levava... meu marido levou quatro filho que eu tenho... dois agora é mestre de barco... e um é motori[ $\left[\int\right]$ ta... tudo trabalhando...

L1 - na pesca...

L2 - na pesca...

L1 - e a senhora falou que foi lá em Nova Trento... não?...

L2 - fui... coisa mais linda...

L1 - conta essa história pra mim... como que a senhora foi lá... com quem... a senhora gostou da cidade...

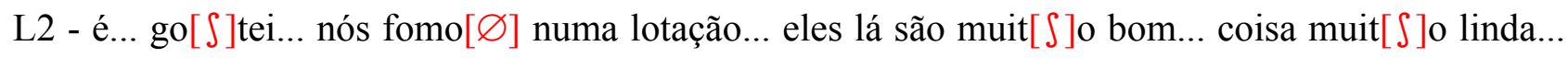
né?... aquela santa... a madre Paulina né?... daí fizer[u] uma limpada ali do lado da igreja... e aí a missa... foi lá campal... aí veio uma procissão... tudo de bandeira [e] umas criancinha tudo de vestidinho... tinha um ca[ $[\ulcorner]$ o... um ca[ $[\ulcorner]$ inho de boi... um duas mulhe[ $\varnothing]$ dentro... fazendo que era a madre Paulina... por que ela foi criada na lavoura... no ca[ $\varsigma]$ o... na hora da missa o ca[ $\varsigma]$ o entrou lá no a $\left[\ulcorner] \operatorname{tar} .\right.$. carrinho de boi (vai) lá dentro... achei muit[ $\left.\int\right]$ o bonito... muito interessante... uma coisa linda ( )...

L1 - e a senhora lembra de alguma história aqui divertida... alguma coisa que tenha acontecido... aqui... que a senhora queira contar...

L2 - não... não... essas coisa assim...

L1 - aqui da sua mocidade... alguma coisa que a senhora tenha feito... alguma coisa diferente... 
L2 - meu casamento foi de carroça... lá na prefeitura de Penha... fomo[ $\varnothing]$ casar lá... embarquei na carroça... quando fui descer da carroça ((risos)) me rompi o vestido e a meia tudo no joelho ((risos))

( )

L1 - e e igrejinha... tinha quantas aqui?...

L2 - tinha só a de São João... essa pequena... a grande foi feita agora a pouco tempo... tinha só aquela...

L1 - e a senhora tem muitos amigos aqui?...

L2 - tenho... a gente se dá ( )... tem os filho da gente... aquela...

L1 - e a senhora já fez alguma viagem... já saiu daqui?...

L2 - já fui na Aparecida do Norte... já fui até o Rio... passei a ponte do Rio Niterói... tive no campo do Maracanã... já andei por lá tudo...

L1 - e como que a senhora foi... quando... conta um pouco dessa história pra mim...

L2 - eu fui com as minha minha filha... com dua[S] filha minha... com quem que eu fui?... com quem?... fui com duas nora minha e com sobrinho meu lá de Joinville que pagou minha passag[i] [e] mais uma sobrinha daqui... mas é muito lindo... agora só que eu não vou ma[S] ... porqu[e] eu passo ( ) de noite... aqui na Madre Paulina a gente vai e vem no mesmo dia... e lá não... a minha filha foi agora em junho de novo... eu não fui...

L1 - lá pro Rio...

L2 - lá tam[ $\varnothing]$ ém é muit[ $\left[\int\right]$ lindo...

L1 - e a senhora acha assim muito diferente o Rio daqui?...

L2 - é:: barbaridade... hoje em dia a gente tem medo de ir até de até de automóv[i]... eles se mat[ũ] tanto né?... quem vê na televisão... muit[ [ ]o matam né?... naquele tempo nosso não havia isso... não se falava de matar o outro... não havia nada... gostei tanto de ficar lá no Maracanã... campo lindo né?... ((risos))

L1 - e o que a senhora foi ver lá?...

L2 - ahn?

L1 - jogo?... foi jogo?...

L2 - jogo... ma $[\varnothing]$ ninguém demorou porque nós queria ir lá pra Niterói... tão bonito...

L1 - e em Aparecida... como foi sua viagem para Aparecida?...

L2 - Aparecida é muit[S] lindo... fiquei lá no hotel... tem uma passarela que vai pra igreja nova lá em cima... você nunca foi lá é?

L1 - não...

L2 - a igreja velha tem uma passarela grande que vai pra igreja grande lá...eu com medo... minha sobrinha que me levou de braço ( ) ((risos))

L1 - e é muito grande?

L2 - é muit [ $\left.\int\right]$ grande... uma coisa muit $\left[\int\right]$ o linda...

L1 - muito bonito então... e alguma vez a senhora já foi pro mar?... de barco...

L2 - não... eu tenho muit[ $\left.\int\right]$ o medo de andar em barco... só quando chove... eles faz[i] a fe $\left[\int\right] \mathrm{ta}$ de São João... faz[i] a fe[ $\left.\int\right]$ ta de São Pedro eu já tenho ido...

L1 - nunca foi então... e o que a senhora gosta de assistir na tv... gosta de novela?.. qual novela?...

L2 - essa novela das seis eu tô vendo... agora tem aquela outra... E[S]perança... novela também é bonita... essas coisa... quando tô bem... quando não tô vou dormir cedo e não vejo...

L1 - faz tempo que eu não vejo a novela das seis... como é que tá?... o menino ficou com a mãe?... 
L2 - ((risos))... é o Lipi... tá com a mãe... mais tá uma encrenca ainda... tá uma briga... OH meu Deu[ $\left[\int\right]$ do céu... $(($ risos $)) \ldots$

L1 - e a senhora conheceu muita gente de fora... assim... muito estrangeiro... sabe se veio muito português?...

L2 - é::... ali daquela e[ $\left.\int\right]$ quina da Armação até aquela pedra que se chama Pedra da Fortaleza... era tudo gente de fora... tudo alemão... eu quando me criava ia vender...ia vender peixe... ia vender

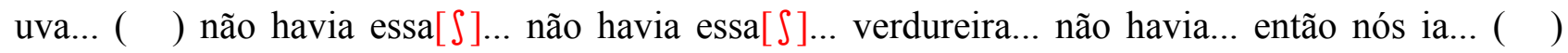
vender tudo as coisa pra lá...

L1 - tinha bastante estrangeiro então...

L2 - tinha tinha

L1 - e a senhora conversava com eles... era...

L2 - é... muit[ $\left.\int\right]$ o bom... é...

L1 - eram mais o quê?... a senhora lembra?... eram mais alemães... italianos...

L2 - eram mais alemã / ale /

L L1 - portugueses também?

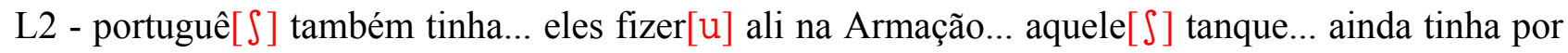
ali naquelas casa... de botar o azeite da baleia... o figo da baleia... e aquele[ $\left[\int\right]$ tanque de óleo... tudo guardado ali...

L1 - era aqui né?...

L2 - era aqui na Armação... aqui... em frente à igreja... por ali... pra lá...

L1 - eles pegavam as baleia...

L2 - hoje em dia se quiser ver uma baleia não tem... né? ( )

L1 - a senhora chegou a ver alguma... chegou a ver?...

L2 - vi... ( )

L1 - aqui mesmo?... a senhora viu

L L2 - é... foi ali... ficava boiada... foi ali...

L1 - faz tempo que a senhora não vê então...

L2 - AH é... depoi[S] que eu fiquei grande eu não vi mais...

T. M. A. (L2)

8CI

L2 - AH::... no princípio eu passei mal na vida... porqu[e] a gente era pobre... eu me casei com... com vinte e cinco ano... porque... eu andava assi / meu pai morreu... minha mãe meus irmão tudo... eu fiquei sozinha... morava com um... morava com outro ((choro))... aí me casei com um... fugi com... de dezessete ano... aí quando ele tava com quarenta ano ele morreu... criei oito filhinho e tudo... ( ) lá foi... fiquei sozinha outra vez...

L1 - a senhora tem filhos?...

L2 - tenho... tenho cinco filha mulhe[ $\varnothing]$ e dois hom[i] vivo... tenho dois filho morto...

L1 - e a senhora gosta de morar aqui? aqui era um engenho / o que era aqui... um engenho?

L2 - tive mo[S] filho tudo aqui em casa... não fui pro ho[ $\left[\int\right]$ pital... eu ganhei... ( )

batido...

L L3 - aqui é de chão

L2 - aí eu ganhava... deixava no berço e ia pa roça... ia pa roça trabalhar..

L1 - a senhora trabalhou muito... 
L2 - ( ) ia pa roça... tirava o tamanquinho... botava na sombra e ia capinar né?... porque precisava né?... precisava... a gente ganhava pouco... não tinha dinheiro a gente não tinha nada pra comer... né?... a gente comia peixinho assado com farinha... café... na roça... banana... isso a gente passou... mais agora... graças a Deus... agora já a vida tá melho[ $\varnothing] \ldots$ mais só que a gente tá velha... ( ) agora tá bom... pessoal todo aposentado... tem bastante emprego... na / não tinha... mercado... não tinha açogue... não tinha ( )... não tinha padaria...

L1 - como era sua vida de solteira... como era viver aqui... como era a vida aqui?... como era a vida aqui?... viver aqui em Santa Lídia... tinha muita coisa aqui ou não tinha nada pra fazer... tinha pouquinha casa... como era?...

L2 - tinha pouquinha casa... a gente não tinha água dentro de casa... a gente não tinha $1 u[j]$... vivia no e[ $\left.\int\right]$ curo... com o candeeiro na mão... velinha... ficava lá... ligada naquele morro... nos poste... ( ) vida né?... lavava $[\mathrm{r}]$ oupa no poço... lá no mo[r]o... em cima dum lavad[o] de pedra... de croca ali L1 - de pedra?... lavava lá?...

L2 - ( )... a barriga desse tamanho... encostado no lavad[o]... É::... tô vivendo NÉ minha filha...

L1 - e a senhora estudou... foi na escola... nunca estudou...

L2 - não

L1 - não tinha escola aqui...

L2 - não:... muito[ $\left.\int\right]$ filho[ $\left.\int\right]$ não estudar[ũ]

L1 - e o marido da senhora também é daqui?...

L2 - aí quando elas crescer[ũ] for[ũ] trabalhar de (empregada)... for[ũ] se empregando... pra se

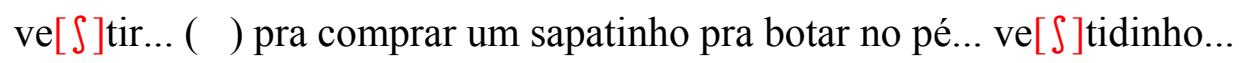

L1 - o que que a senhora gosta de fazer aqui?... o que que a senhora gosta?... o que que a senhora faz?... tem bastante amizade...? a senhora tem muitos amigos que vem na sua casa?... a senhora costuma sair?... ir na igreja... conta um pouquinho...

L2 - na igreja eu vou... go[S]to de ir na igreja... só que na igreja ( )... longe... lá em Santa Lídia... aí eu tenho um filho ali... quando eu quero e ele me leva de carro...

L1 - aí a senhora vai com ele...

L2 - com ele... a mulhe $[\varnothing]$ dele...

L1 - e a senhora é católica?...

L2 - agora não porque tá muito frio né gente?((risos)) a gente sente muito frio...

L1 - e a senhora é católica?

L2 - vou no cemitério fazer visita... minhas irmã tão tudo lá... meu[ $\left[\int\right]$ cunhado... meu marido...

L1 - netos... tem netos...

L2 - OH:: tenho uma ca[r]ada...

L1 - uma carrada de netos

L2 - tenho vinte e poucos neto vinte bisneto...

L1 - bisneto a senhora já tem?... e eles vêm muito aqui... eles vêm na sua casa?

L2 - vêm... vêm

L1 - vêm brincar aqui... e faz quantos anos que a senhora mora aqui?...

L2 - aqui faz... mais de sessenta ano...

L1 - nessa mesma casa?

L2 - é

L1 - me conta como que era essa casa... o que que mudou?... a senhora mora aqui há sessenta anos né?.. como que ela era antes... como essa casa era antes...

L2 - era um engenho... 
L1 - era um engenho...

L2 - é... nós tinha uma casinha... né? e nós morava lá na praia... quando eu me casei eu morei lá na praia com a minha sogra... aí ele trabalhou e comprou madeirinha e fez uma casinha... depoi[S] ele disse... "vamo[ $\varnothing]$ vender minha casa... vamo[ $\varnothing]$ vender a casa e comprar um engenho"... é tão bom a gente fazer farinha... a gente faz o biju...cu[S]cu... tapioca... farinha... saía tudo dali né?... tinha farinha pra vender... pa passar a vida... aí ele pegou e fez um engenho aqui... aí nós fomo[ $\varnothing]$ trabalhando... os filho for[u] crescendo... ajudando na roça...

L1 - o... o meu vô... Ataná / ... aqui é Quinca né?... conhecem como Quinca aqui né?... o Quinca... trabalhou aqui... meu avô...

L2 - (meu) marido?

L1 - não meu vô... o Quinca... o Quinca... marido da Santinha... ele trabalhou aqui?

L2 - não... foi na Santa Lídia...

L1 - Santa Lídia...

L2 - é... tu é filha de quem?...

L1 - eu sou filha da / minha mãe mora em São Paulo... da Lídia...

L2 - tu é de São Paulo...

L1 - sou... ele é meu tio ((referindo-me a L3)) ... ele é meu tio... eu sou neta do seu Quinca do Atanásio...

L2 - ele é filho do Quinca?...

L1 - é... ele é filho... e eu sou neta

LL2 - o senhor Atanásio... meu Deus... o engenho dele...

L1 - conta pra gente... conta um

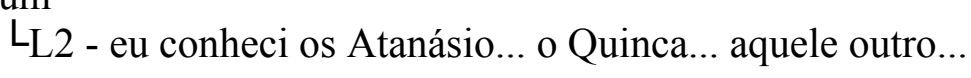

L3 - o Joca...

L2 - é

L1 - conta pra mim um pouco... a senhora conheceu... conversava muito com eles...

L2 - a gente conversava... mais agora depois... ele também... a gente morava longe... né?... eles for[u] também se acabando... for[u] se casando... for[u] saindo né?... a gente também foi ficando mais estranho né?... quando a gente é solteira a gente conversa com todo mundo... né?... conhece muito...

L1 - tinha muita festa aqui?...

L2 - tinha... tinha

L1 - como era o nome das festas tio? ((dirigindo-me para L3))

L2 - antes era na Penha... essas festa...

L1 - tem festa de São João aqui?... festa de São João?...

L2 - é na Armação

L1 - festa de São Pedro... tem aqui?... festa de São Pedro?...

L2 - de São Pedro também na Armação...

L1 - na Armação?

L2 - é

L1 - que festa tem aqui na Penha... na Penha aqui...

L2 - na Penha tem...

L1 - na Santa Lídia... tem o quê?...

L2 - tem pa Santa Lídia... pa uma Santa que tem que se chama Santa Lídia...

L1 - é uma santa mesmo?

L2 - é

L1 - tem igrejinha aqui?... igrejinha de Santa Lídia?... tem igreja aqui em Santa Lídia... 
L2 - tem... vão por aqui que vocês vej[ũ]...

L1 - a senhora conhece a história dessa santa... dessa Santa Lídia... conhece a história dela?

L2 - não...

L3 - acho que ela não tá entendendo... quer que eu falo?

L1 - fala...

L3 - a senhora conhece a história de Santa Lídia... qual festa que tem aqui... mais tradicional... assim... que a senhora já foi... porque... porque o nome Santa Lídia... ela quer saber...

L2 - é porque... é porque o lugar é Santa Lídia né?...( ) chama Santa Lídia... esse é nome da Santa

A. L. M. (L2)

9CI

L2 - eu quando cheguei aqui... cheguei com... com trê[ $\left.\int\right]$ filho... e a mulhe $[\varnothing] \ldots$ meu primo veio trazer com a ca[r]oça... tinha nada... depois eu fui trabalha[nv]... numa... firma de camarão... trabalha[nu]... trabalha[nu]... adquiri... em primeiro luga[ $\varnothing]$ eu adquiri onz[e] filho... ((risos))... e depois toda vida trabalha[nu]... não trou[S]e nada de lá da praia do Navegant[e]... é... aqui foi que eu [a]levantei a minha vida... né?... comprei casa... comprei lote de te[r]a... né?... e:.... depois e:.... e depois quando eu tinha feito isso tudo... tinha casa... tinha te[r]a... tinha tudo né?... que criei os filho tudo... a minha mulhe $[\varnothing]$ saiu de casa e carregou os nove tudo e foi morar com um tio... aí eu fiquei dentro da minha casa... aí eu não tinha nada de mov[i]... comprei mov[i] usado e mobiliei a casa de novo... é... e:: ma[S] eu tenho a graça de Deu[S]... oro a Deus... todo que eu peço a Deus... Deus me dá... dá uma enfermidade... eu dobro meu joelho... oro a Deus e Deus liberta né?... e assim eu vou levando a minha vida...

L1 - faz tempo que o senhor freqüenta a igreja?... onde que o senhor vai na igreja?...

L2 - fa[S] quarenta e quatro ano que eu fui levar minha filha... minha filhinha no médico... fa[S] quarenta e quatro ano que eu fui levar uma filha no médico... que ela tava morrendo nos meus braço... aí tratei quinze dia no médico... aí o médico não deu conta e desenganou... aí eu vinha embora com a minha filha pa morrer em casa que o médico mandou... e aí eu... ali no posto da passag[i]... eu chamei a Deu[zi]... preparou um servo dele... que era um crente... botou a mão aqui no meu ombro... p[re]guntou “o que é que tem essa?”... aí eu falei “essa criança tá enferma há quinze dia e o médico desenganou... ela tá morta mesmo"... ali ele olhou e disse "é:.... ainda... o médico desenganou a tua filha mais Deus não desenganou ainda"... tratou comigo pra levar eu na[S] $[\varnothing]$ greja... na Congregação... ele veio pro outro lado... pra cá comigo... até a porta da casa que eu tava parando... ali... ele deixou (ele)... "quinta-feira... uma e meia eu passo aqui pra te levar na[S] [Ø]greja...” aí quinta-feira uma e meia ele passou com a e[ $\left.\int\right]$ posa dele... casa[ł] de filho dele... e levou eu com a minha e[ $\left.\int\right]$ posa na igreja com a criança morta no colo... lá... no cu[ \ulcorner] to... eles $\operatorname{orar}[\mathrm{u}] . .$. e eu vim embora... quando eu cheguei na casa daquela mulher que eu tava parando... eu disse pra ela... "hoje eu vou embora pra minha casa... porque tudo que eu tinha pra fazer pra minha filha eu já fiz... agora eu vou embora pra minha casa"... peguei a criança... e vim pra casa... quando eu cheguei na praia... que eu desci do Navegant[e] pra praia... que naquele tempo só andava pela praia... não tinha e[S]trada... a criança pediu com a boca que queria urinar... eu arriei o pezinho dela 
na terra... e ela urinou... e veio pedindo até eu chegar em casa... sempre urinando... sempre sempre... andava... pedia de novo... botava urina... e ali quando eu cheguei em casa que botei a chave na porta... a a menina pediu comida... que queria comer... então pra mim... Deu[zi] ressuscitou minha filha... né?... e isso ficou guardado no coração até a data de hoje... hoje tô servindo a Deus... tô com

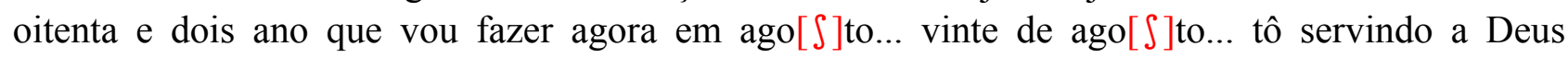
me $[\varnothing]$ mo... ( ) é uma alegria né?...

L1 - como era vida aqui do senhor... quando o senhor chegou... como que era a cidade...( )

LL2-quando

cheguei aqui... quando cheguei aqui... não tinha ninguém... não tinha nada... era só lá na praia... uma[S] casa bem rala... ( ) tinha um salão de baile... do[S] Figueiredo né?... tinha só a família Figueiredo... né?... família:... Figueiredo e o[S] Pinto... família Pinto e a família Figueiredo que e[ $\left.\int\right]$ istia aqui em Piçarra... né?... isso aí era tudo deles... aí veio gente de fora... gente de fora... e ele $\left[\int\right]$ for[ũ] vendendo terreno... hoje tá uma cidade... Piça[r]a já passou pra município né?... que naquele tempo a Penha só que era a cidade... agora Piça $[r]$ a cresceu e a Penha diminuiu... entende?... agora... a Penha vai crescer tam[ $\varnothing]$ ém... sabe por quê?... porque aquele[S] velho da

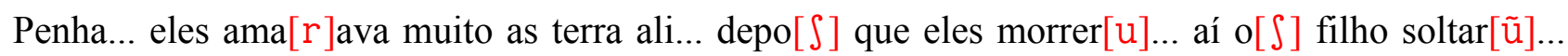
foram vendendo né?... o[S] filho for[ũ] vendendo... a Penha hoje tá estendendo... tá uma cidade né?... já emendando com a Armação né?... Armação também já tá uma cidade... Armação já emendou com a Penha... (torno) cidade né?... e quando eu cheguei aqui né?... eu cheguei bem pobrezinho... $\mathrm{ma}[\mathrm{i}]$ bem pobrezinho... entrei na $\mathrm{sa}[\ulcorner]$ ga de camarão pra trabalhar... quando cheguei o dono da sa[ৎ]ga me deu uma casinha... e ainda comprou louça... roupa de cama... era um senhor de São Paulo... chamava-se Ernesto... ele faz uns seis... seis me[zi]... mais ou menos que ele faleceu... era uma pessoa muito boa...

L1 - São Paulo...

L2 - São Paulo... ele que foi que me deu uma mão pa me ajudar...

L1 - o senhor conhece outras cidade de Santa Catarina?...

L2 - daqui conheço Barra Velha né?.. que tam[Ø]ém era um lugarzinho bem pobre... as casinha né?... as casinha era tudo de palha... de ba[r]o de... só tinha um... duas ou trê[S] casa... de gente rica... ( ) que auxiliava aquele[S] pobre né?... e aquele[S] pobre for[ũ] comprando um ranchinho... for[ũ] bateirinha... for[ũ] pe[S]cando... né?... for[ũ] levando a vida pra frente... hoje Barra Velha tá numa cidade tam[ $\varnothing]$ ém né?... AH:: a $[\varnothing]$ Tajuba... mesma coisa tam[ $\varnothing]$ ]ém né?... era um lugar assim... só umas casinha né?... hoje tam[Ø]ém tá numa cidade emendando com $\mathrm{Ba}[\mathrm{r}] \mathrm{a}$ Velha... né?... ( ) e daqui pra lá tá tudo em cidade... né?... lá tinha um luga[ $\varnothing]$ que se chamava as Area né?... as Area... porque quem ia / uma[S] casinha bem rala... era no meio do mato... tinha até medo de passar... eu fui com o meu cunhado... da praia do Navegante até a praia da Barra Velha lá... dava medo da gente passar... era mato fechado do lado e do o[ $\varnothing] \mathrm{t}[\varnothing]$ o né?... e aquele camininho... no meio... né?... só com carrinho de boi né?... naquele tempo... não tinha carro... não tinha nada... só carro de boi... depois então fui usar a ca[r]oça né?...

L1 - e o senhor é uma pessoa que já viveu bastante... e:.... olhando hoje pra juventude... o que o senhor acha dos jovem de hoje?... comparando assim com a juventude do senhor... qual é a diferença?... tem muita diferença ou não? 
L2 - sim... porque quando eu me criei... meu pai dizia assim... "vai na venda"... botava o dinheiro na minha mão e eu já saía... né?... às vez[i] perto da noite saía correndo... porque criança né?... então eu saía correndo... vinha da praia... da praia do Navegante no Gravatá... compra um litro de crosena... que não tinha $\mathrm{lu}\left[\int\right]$ naquele tempo... usava crosena né?... compra um litro de crosena... vinha correndo... chegava cá... comprava o litro da crosena e saía correndo... saía correndo... chegava em casa... entregava pra minha madra[S]ta... que a minha mãe... quando minha faleceu eu tava com aninho de idade...

L1 - era bebê...

L2 - era pequeninho... e:: e é assim né?...

L1 - e os de hoje?..

L2 - hoje tá tudo diferente... $\mathrm{m}[\mathrm{u}]$ to $\mathrm{m}[\mathrm{u}]$ to $\mathrm{m}[\mathrm{u}]$ to diferente... o pai manda o filho... o filho manda o pai... né?... tá tudo diferente...

L1 - o senhor sente isso...

L2 - ( ) eu cheguei lá na casa da I. ... sabe o que acontece?... da minha filha... o pai mandava o filho... e o filho mandava na irmã... eu achei muito diferente... né?... e ali quem foi na venda... foi o pai... ((risos))... acabou indo na venda o pai...

\section{J. A. A. (L2)}

10CI

L2 - mi[ł] novecentos e vinte e quatro... meu pai... e mais algum agricultor aqui de Santa Lídia... contratar[u] um professor pra dar aula pras criança aqui do / desse lugar... a professora era Lavínia... Lavínia... nós sentava no chão... sem banco e sem carteira... no chão... só a professora que tinha mesa e uma cadeira de sentar... estive ali um ano... saía ali da escola... ia cortar uma carrada de cana que era o serviço por dia... cortava uma carrada de cana... ama[r]ava e tal... depois tive um ano fora... não fui... outra aula... sim... era cinqüenta... era... quinhento réi[S]... quinhentos réi[S] por mês era pago para professor por aluno... depois fomo[Ø] parar nas Cabra... outra escola particular lá também... o professor era o Pinto... ( ) ademais um ano e meio... mais esse ano e meio eu tive só um ano por causa da lavoura... depois vim para a Santa Lídia... até mil novecentos e trinta e quatro... nesse tempo foi dez ano de aula... em dez ano eu tive dois ano e meio só de aula... saí no livro terceiro da época... o livro do soldadinho de chumbo... trabalhei na lavoura... sempre com o meu pai... depois saí e fui pra São Francisco do Sul no tempo da guerra... trinta e nove... trabalhei um ano e meio lá na estrada do forte... do exército... depois vim... casei... vivi treze ano cá primeira mulhe $[\varnothing] . .$. mulhe $[\varnothing]$ tinha dez filho... ela me enganou... fiquei sozinho... acabo de um ano e dois mê[S] casei de novo... com outra... ela teve... quinze filhos... sou pai de vinte e cinco filhos criado moço... e depois... agora em noventa e quat[ [S]o ela morreu... e eu casei com essa outra... faz sete ano que eu casei com essa outra... tô vivendo com ela... sempre trabalhei na lavoura... trabalhei no comércio... muito no comércio... dez ano de comércio... viajei muito com o caminhão... com essas coisa assim né?... e depois trabalhei na lavoura mesmo sempre né?... tinha uma fábrica de farinha... e:: depois fui acidentado por um carro... me arrastou dez metro freado em cima de mim... me quebrou o nari[ $\left[\int\right]$... trê[S] costela... tirou ( ) do pulmão... aí tive que vender a fábrica que não pude trabalhar mais... mas a cabo de um ano... melhorei... saí... ( ) agora estou aposentado... faz dez ano... estou vivendo por aqui ainda... viajo... sempre viajo pro Rio Grande... pro Rio de Janeiro... no Paraná muito... em Santa Catarina quase tudo... 
L1 - e me contaram uma história que o senhor matou uma cobra grande pra fazer banha...

L2 - AH... eu matei uma cobra que deu três metro e vinte que / de comprimento... Jaracuçu... tinha sessenta e quatro ovo grande do tamanho de ovo grande... do tamanho de ovo de galinha... tinha duzento e quarenta e três pequeno... e mais de dois disco assim comprido com ovinho miúdo... não sei quanto era... deu um litro e meio de banha... o couro deu quatro met[ $\left.\int\right]$ o... abriu trinta e sete centímetro o coro de largura... deu quat[ $\varnothing]$ o metro de comprimento o couro... roubar[ũ]... deixei do lado de fora... uma mulhe[ $\varnothing]$ de Piçarra veio comprar... e: dava vinte mil... vinte cruzeiro... ( $)$ pelo couro... não quis... deixei na rua... me roubar[ũ]... tinha outros dois metro e meio três metro... matei muita cobra aí direto... cacei muito cacei muit[S]o... matei muito quati... muito tato... catet[S] e... agora não mato.... agora não cacei mais...

L1 - conta uma história de uma caçada pra mim...

L2 - fui caçar com o seu Paulo... fomo[ $\varnothing]$ de barco... embarcamo[ $\varnothing]$ aqui em Itajaí e fomo[ $\varnothing] . .$. lá no Bom Abrigo saímo[ $\varnothing]$ pra Serra do Cardoso... e na Serra do Cardoso tivemo[ $\varnothing]$ quatro dia e quatro noite no mato... lá matamo[ $\left[\int\right] \ldots$ tatu... bugio... mais... lá tinha uma qualidade de:.... carrapato porva.... que enchia o braço e a perna da gente ( ) que tinha que raspar com a faca... e botar arco pra matar... e... lá tinha um [i]dio... lá que andava com nós no mato e nas gruta né?... e depois tinha um $[\mathrm{r}]$ io pra travessar... o [i]dio foi atravessar com nós com a uma canoa rachada pequeninha... nós tava em seis[i]... daí eu fiquei com medo... não quis travessar na canoinha né?... era muito comprido... aí atravessou os cacho[r]o o pessoal... fiquei atrás depois atravessou eu sozinho... por fim... quando eu cheguei na casa do índio... ele tinha seis filho... tava tudo no... e a própria mulhe $[\varnothing]$ do índio... ( ) $\ldots$ fez um cafezinho pra nós... ( )... quando volta uma pessoa lá... vai lá... é quase um dia de barco pa enterrar... morreu lá por causa de uma tempestade não deu... enterrar[u] na areia... contar[ũ] pra $\mathrm{n}[\mathrm{oj}]$... dois ranchinho assim... muito pobre lá... aí deu uma gorjeta lá pro menino... né?... o menino queria vim comigo... queria vim com o Coca... ( )... essa foi uma das caçada que fizemo[ $\varnothing]$ lá... mat $[e] \mathrm{mo}[\varnothing]$ muit $\left[\int\right] \mathrm{o}$ passarinho... muita caça... muita coisa naquele mato... e no Paraná eu também cacei... uma caçada muito boa... dormi no mato também dois dia... matei catete... matei oito tatu... matei quatro cutia... matei jacu...

L1 - o que é um catete?...

L2 - catete é um porco do mato... mas não é um porco... é tipo porco ma[i] não é... é porco ma[i] é de outro tipo né?... chama se catete... tem o catete... o queixo branco... o porco do mat $\left[\int\right]$ o... o javali...

L1 - e tem alguma história que tenha acontecido aqui na região... divertida... que o senhor queira contar...

L2 - aqui tem uma:: uma história muito maravilhosa... esse lugar aqui... de quando começou esse lugar aqui... o município... aqui em Santa Lídia... tinha um alemão do tempo da guerra... José Ichiarrendoi... fugiu da guerra de catorze... da Alemanha... e veio morar aqui... comprou um terreno...na época... no sertão do Burço... por sete mi[ł] naquela época... alemão... ( ) chamava-se estrada Nova... que foi feita em mil novecentos e doze... o alemão veio pra aqui... ( ) trouxe uma imag[i] lá da Alemanha chamada Santa Lídia... ( ) aquela ali o Basílio... esse lugar... puser[ũ] o nome aqui desse lugar de Santa Lídia por causa dessa imag[i] dessa santa que veio lá... da Alemanha... que o apóstolo Paulo chamava Santa Lídia... que ele foi orar na beira-mar... ( ) e tal... aí ficou o lugar chamado Santa Lídia... aí na época de mi[ł] novecentos e vinte nove o Talandar 
(Bernardino)... Laurinda... ele... foi trabalhar no Rio de Janeiro e foi acometido da tuberculose... ficou ( ) no hospital... estava pra morrer... desenganado... e chegou uma pessoa crente lá e orou por ele e ele recebeu a cura... em mi[ł] novecentos e vinte e nove ele veio em casa dos pais dele aqui em Santa Lídia... trazer o evangelho pra cá... o primeiro culto que foi feito aqui foi em mi[ł] novecentos e vinte e nove / nove... cantar[ũ] três hino... o duzentos e quarenta e quat $[\varnothing]$ o... o quinze e o cento e quat $[\varnothing]$ o... depois ele foi embora... o primeiro hom[i] que aqui nesse luga[ $\varnothing]$ aceitou Jesus foi um ta[ৎ] de João Quintino da Sirva... mais não permaneceu que foi embora... depois aí na casa do (Bebé) do Arlindo começar[u] a fazer missa... o padre veio fazer missa... até que desmachar[ũ] a casa e fizemo[ $\varnothing]$ uma igreja lá... ( ) cada um deu um caibro pra fazer a primeira igreja aqui de Santa Lídia... eu tinha uma menina... o nome de (Afonsa)... e o Antônio João Amaro tinha uma menina também... vier[u] cá... e puxar[u] o a $[\ulcorner] \operatorname{ta}[\varnothing]$... puxar[u] a toalha que tava e a Santa caiu... quebrou... puser[u] uma toca de ( ) bambu... a Santa lá... e o ta[ৎ] de José Raimundo foi em Camboriú onde tinha um pouco de Santo lá... imag[i]... de baixo do cafezal... e pegar[u] uma Santa daquela... uma imag[i] daquela... limpar[u]... e[S]covar[u]... depoi[S] de e[ $\left.\int\right]$ covar pintar[u]... ((risos)) é essa que está na igreja hoje... Santa Lídia... essa é uma história passada... tem muito mais outras história... isso aqui foi um luga[ $\varnothing]$ que quase não morava ninguém... um luga $[\varnothing]$ pobre... tinha pouco morad[o] na época... eu conheço muita coisa... disso aqui... como é que se trabalhava... fazia farinha... cevava mandioca na mão... né?... fornear do rodo... assim de rodo... né?... tostava bem... ra[Ø]pando mandioca... eu o Quinca e minhas irmã... e:: já meia noite quase dormindo... na época... meu pai comprava azeite de baleia... azeite de cação... a gente fazia candeeiro... candeeiro era feito de lata... ou botava um pavio de fio que acendia ( ) lembra? ((dirigindo-se ao irmão que estava presente))... no monte da mandioca... que nós [r]aspava... e nós tava cochilando pra dormir meu pai jogava uma raiz de mandioca de lá de onde ele tava cevando... batia no meio lá... e nós acordava pra começar... muitas vezes eu dormi eu dormi em cima do bagaço... eu ele ( )... acordava e começava a trabalhar... (trabalhava) muito na época né?... e:: assim foi a nossa vida na época né?... trabalhava muito... farinha forneada a [r]odo assim... e foi nossa luta e nossa época... hoje é uma maravilha... hoje... uma bênção... ( ) com máquina... naquele tempo era BRAço... foi ( ) meu pai... eu semana... inteirinha no mato derrubando madeira... não tinha motosserra... não tinha nada... na foice... na enxada... trabalhava muito... eu na idade de cinco ano comecei a trabalhar na roça... cinco ano... cinco ano... Quinca também ((irmão))...

L1 - e uma outra história... o senhor não tem uma divertida...

L2 - história aí... várias... do Boi de Mamão...

L1 - CONta

LL2 - Pau de Fita...

L1 - eu queria porque a gente não conhece... eu não conheço

$$
\text { LL2 - Cavalinho }
$$

$\mathrm{L}_{\mathrm{L} 1}$ - eu não conheço

L2 - o Quinca que tem uns pasquim... muito verso... quem sabe muit[ $\left.\int\right]$ o verso canta um verso pra ela aí

L3 - da outra vez ela fez pesquisa lá em casa... 
L2 - ela já fez a pesquisa... aqui no nosso tempo... era novo... tinha acho que doze ano... dezoito anos tinha a dança do Pau de Fita... o Pau de Fita era doze hom[i] vestido de mulher[i]... hom[i ]... algum tinha mulhe[ $\varnothing]$ com trança... então o pau tinha uma roda em cima... tinha uma pessoa... e aí tinha aquelas fita... um trançava por lá... outro trançava por cá... e trançando e dançando com as viola nas porta... né?... a gente cantava... pedia licença pra entrar...

\section{B. L. M. C. (L2)}

\section{$1 \mathrm{~A}$}

L1 - fala pra mim B.... você gosta de morar aqui na Enseada?...

L2 - gosto

L1 - o que que você gosta de fazer pra se divertir?

L2 - jogar bola

L1 - e você tem bastante amigos que jogam bola?

L2 - tenho

L1 - como é o nome... dos seus amigos?

L2 - Joelso...acho que não lembro mais...

L1 - você gosta de ver tv?

L2 - gosto

L1 - o que você mais gosta de assistir?

L2 - é:.... novela

L1 - e que novela tu tá assistindo agora?... tá passando?

L2 - Pícara Sonhadora

L1 - como que é a Pícara sonhadora?... conta pra mim...

L2 - ela... ela é uma menina... que que eles... eles ficam... ele ele eles quer... é namorar com ela... aí ela só escolheu um... daí daí ela... ela ela resolveu ficar com um só e:..... e::... (eu vi)

L1 - tá certo... e filme... você gosta de filme?

L2 - gosto

L1 - que filme que você assistiu que você lembra?

L2 - da Mu/da Múmia

L1 - como que é a história?... contra pra mim...

L2 - é que eles querem um tesouro... daí daí... ele tinha o livro dos mortos... daí eles... é é::... abriram o li/o livro dos mortos e... e eles soltaram uma... múmia... daí a... eles tá... a múmia quer pegar quem soltou ela...

L1 - e aí o que que ela faz?... ela corre atrás das pessoas?... ela é má?...

L2 - ela... ela... ela pe/ela ela ente/ela enterra... ela pega aqui pelo pescoço e os e os hom[is] ficam tudo podre...

L1 - e como que termina o filme?

L2 - termina que... que... eles eles eles acaba... eles acabaram com a múmia e eles viveram felizes pra sempre só...

L1 - e fala pra mim um outra coisa... você... tem um outro filme que você lembra?... que você assistiu e é legal?... NÃO?

L2 - não lembro nenhum

L1 - e::... desenho você gosta?

L2 - gosto

L1 - qual desenho você gosta?

L2 - do (Pernalonga) 
L1 - como que é o Per/o Pernalonga?... como que é?

L2 - é é um... é um coelho que tem cachorro que vai atrás dele... mas ele engana todo mundo...

L1 - e como que ele é?

L2 - ele é um... ele é um coelho...

L1 - mais que cor que ele é?... o tamanho dele?

L2 - ele é cinza e branco... tamanho dele é::... um metro

L1 - uhn

L2 - é grande

L1 - e o que ele gosta de comer?

L2 - cenouras

L1 - AH... e que outro desenho você gosta?

L2 - Power Rangers

L1 - como que é o Power Rangers?

L2 - ele eles tem que enfrentar o mal e quem está... e quem está fazendo um mont[ $\left.\int\right]$ e de mal pros outro...

L1 - como... você assistiu Power Rangers hoje?... sobre o que que foi?... conta a história pra mim...

L2 - eles foi... tem um um bicho... que mais... a dá pra tirar a cabeça dele... daí eles eles... o bicho

é... é a dona do bicho te/teve que mandar ele acabar com todas as crianças daí... daí os Power Rangers é... é... mataram ele...

L1 - É:.... ele é malvado assim?... e você assistiu Sítio do Pica Pau Amarelo?...

L2 - assisto... às vezes...

L1 - assistiu hoje?

L2 - hoje não...

L1 - não... e Hantaro... você gosta?...

L2 - Hantaro eu gosto

L1 - assistiu?... que que foi o Hantaro hoje?

L2 - Hantaro foi que... que... a... a mãe... a mãe da da dona do Hantaro... ela ela estava de aniversário... daí... ela o... eles fizer[ũ] todo serviço pra ela o... daí eles... o... o marido de/da dona do... o marido da da mãe da da da dona da da (Candy) esqueceu de comprar flor pra... pra... mulher dele... daí Hantaro foi lá e pegou é::... um monte de flores vermelha lá numa montanha...

L1 - pra dá pra ela de presente...

L2 - é::...

L1 - e você assistiu Os Vingadores hoje?

L2 - assist [ $\left.\int\right] \mathrm{i}$

L1 - que que foi que passou?

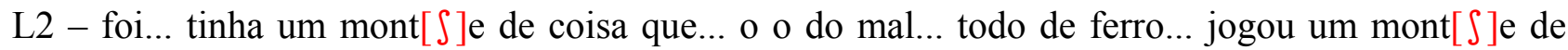
coisa feita de árvore... um mont[ $\left[\int\right]$ e de bicho feito de árvore... daí Os Vingadores acaba com tudo... da... daí... Os Vingadores estava tentando acabar com o... chefe deles... daí eles... eles não conseguiram...

L1 - e se você pudesse ser um super herói... quem você seria?... e por quê?

L2 - o Power Ranger vermelho

L1 - por quê?

L2 - porque ele é mais forte...

L1 - uhn... e se você pudesse ser um cantor quem você queria?

L2 - Leonardo

L1 - é?... por quê? 
L2 - porque a gente... eu... eu gosto... dele

L1 - gosta de ouvir a música dele?

L2 - é

L1 - e:.... se fosse pudesse ser um bicho... qual que voce seria e por quê?

L2 - vixi...

L1 - qual o bicho que você mais gosta?

L2 - tartaruga

L1 - tu queria ser uma TAR-ta-RU-ga?

L2 - NẪO ((risos))... ( ) o bicho que mais que eu gosto é tartaruga... mas... eu quero ser um... um...

L1 - seria um bichinho do mar?... um golfinho ou um cachorro... cavalo

$\mathrm{L}_{\mathrm{L} 2}$ - cachorro... cachorro

L1 - cachorro?

L2 - não lobo lobo lobo

L1 - lobo?... por que um lobo?

L2 - porque eu eu adoro assist[ $\left.\int\right]$ ir filme dos lobo

L1 - você já assistiu algum?

L2 - já

L1 - é legal?... como que é um filme de lobo?... o que tem?

L2 - é que tem uma cachorra que... tem aqui... que enfrentar o lobo... daí ela... ela perde

L1 - AH tá... e fala pra mim... voce tem medo de monstro?

$\mathrm{L} 2$ - tem

L1 - você conhece alguma história de monstro?

L2 - não

L1 - NÃO?... você tem medo da Cuca?

L2 - não

L1 - hum... e do lobisomen

L2 - não

L1 - e do vampiro?

L2 - tenho

L1 - você já assistiu filme de vampiro?...

L2 - já

L1 - o que os vampiros... que que eles fazem?... como eles são?... como é que se mata um vampiro?... conta pra mim...

L2 - é... tem é... pra gente matar ele tem que ter uma... uma... uma coisa bem pontuda... daí a gente pega... aí dá no coração dele... daí daí ele morre...

L1 - uhn... e na escola?... você gosta de escola?

L2 - gosto

L1 - que que você está aprendendo?

L2 - eu estou aprendendo... a fazer um monte de texto

L1 - você gosta de escrever?

L2 - gosto

L1 - gosta de ler?... já sabe ler?... você lê livrinho na escola?

L2 - leio

L1 - você tem quantos professores?

L2 - um

L1 - a tia?... você chama ela de tia?

L2 - não

L1 - como que é o nome da sua professora?... 


\section{L2 - Leonete}

L1 - e o que que você mais gosta de aprender?

L2 - o que eu gosto mais de fazer é fazer texto

L1 - fazer texto?... AH que legal... que texto que você já fez?...

L2 - eu já fiz... o texto de... de uma... de uma bruxa

L1 - como que foi a história?... conta...

L2 - a bru/que a bruxa queria matar todo mundo... daí tinha tinha um monte de gente que era... que era... que era um monte de... de... de... ( ) daí eles eles queriam matar ela... daí eles perder[ũ] porque porque a... matou eles...

L1 - hum... e fala pra mim... você tem quantos irmãos?

L2 - comigo eu tenho...

$\mathrm{L} 1$ - deve ter um monte... ((risos))

L2 - cinco... comigo cinco

L1 - é... e vocês já fizeram alguma viagem?... já viajou alguma vez?

L2 - nós tudo não

L1 - mas você já foi com a sua mamãe pra algum lugar?

L2 - fui

L1 - pra onde?

L2 - pra Joinville

L1 - voce gosta de Joinville?

L2 - gosto

L1 - é igual ou diferente daqui?

L2 - diferent[ $\left.\int\right] \mathrm{e}$

L1 - por que diferente?

L2 - porque lá lá tem... um mont[ $\left.\int\right]$ e de... tem mais mais mercado que aqui

L1 - é uma cidade maior?

L2 - tem... é

L1 - tem mais casa?... tem mais rua?... como que é Joinville?

L2 - tem mais casa... mais eles eles... só ficam saindo... daí daí... eles ficam saindo... tem mais carro que casa...

L1 - hum

L2 - verdade

L1 - e você e seus irmãos... brigam muito?

L2 - briga

$\mathrm{L} 1$ - e por que que vocês brigam?

L2 - porque... porque ela fica me riscando ((apontando para a irmã presente))

L1 - e você já fez... e você é muito bagunceiro?... B.?

L2 - não

L1 - todo B. é bagunceiro

L2 - não

L1 - não é bagunceiro?... tá querendo me enganar... porque todo B. é bagunceiro

L2 - e não sou

L1 - mas você gos/você faz arte?

L2 - faço alguma ((risos))

L1 - conta alguma

L2 - eu fiz... na hora que a minha mãe saiu... e o meu pai estava ali dormindo... daí eu a... eu e a minha irmã foi... fomo[ $\varnothing]$ lá ir jogar... lá no coisa... pegar... a gente jogamo[ $\varnothing]$ um areia no outro... 
L1 - e a mamãe?

L2 - na hora da chuva ainda...

L1 - e aí?... quando a mamãe descobriu?

L2 - AH... não... o pai já viu a gente... e puxou a minha orelha... puxão de orelha na gente e mandou a gente tomar banho... daí a mãe chegou... percebeu nada...

$\mathrm{L} 1$ - e a roupa suja de areia?

L2 - o pai guardou... o pai escondeu...

T. S. M. (L2)

L1 - T.... como que é morar aqui na... na Enseada?... perto da praia?.. é bom?... você gosta?... não gosta...

L2 - AH... eu gosto... é legal aqui...

L1 - gosta?... vai bastante na praia...

L2 - não muito

L1 - mais gosta?

L2 - gosto

L1 - sabe nadar?

L2 - sei

L1 - bastante?... e na escola... como que é a sua escola?... ( )

L2 - AH... ela é grande... tem... sei que ela é grande mais ( )...

L1 - ela tem cantina?... biblioteca?...

L2 - tem... tem

L1 - e que matérias você tá estudando?

L2 - português... matemática... ciências... geografia... espanhol... artes... inglês...

L1 - inglês?... espanhol?... você tá estudando?... qual que você gosta mais?

L2 - de artes... é mais legal

L1 - o que se faz na aula de arte?

L2 - eu pinto e desenho

L1 - só isso?

L2 - só

L1 - e::... história... você tem?

L2 - história eu tenho...

L1 - que que se tá aprendendo?

L2 - AH::... é é... aprendo mais de texto... coisas assim ( )

L1 - você conhece a história aqui de São Francisco do Sul?... não?... já aprendeu alguma coisa sobre... e o Boi de Mamão?... o Terno de Reis?... que é folclore aqui da região... você já aprendeu alguma coisa?

L2 - não não aprendi

L1 - é pra deixar ela a vontade ((arrumando a disposição da poltrona))

L2 - não aprendi...

L1 - não?... vem cá então... é:.... em português?... tem que ler bastante?... você lê muito livro de história na biblioteca?...

L2 - não

L1 - NÃO?

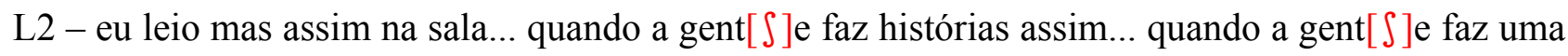
coisa de história...

L1 - e qual o nome dos seus professores?... você lembra?... 
L2 - tem Rosele... é... eu não chamo muito minha professora de inglês assim... de inglês... espanhol e de artes... eu não chamo... chamo só de... de... teacher... de:....

L1 - inglês?

L2 - inglês?... e::... maestra de espanhol

L1 - AH tá... e você gosta de ciências... gosta de ciências?

L2 - tenho

L1 - gosta de ciências?

L2 - não ((risos))

$\mathrm{L} 1-\mathrm{NA} O$ ?...

L2 - não

L1 - e o que você faz pra se divertir?

L2 - eu brinco

L1 - você não gosta de televisão?

L2 - gosto

L1 - assiste?

L2 - ahn ahn

L1 - gosta de assistir desenho?... que desenho você gosta de assistir?

L2 - Pica pau... Luluzinha... Hantaro... Power Ranger... Os vingadores... tem um monte de coisa...

L1 - conta a história pra mim do... do Power Ranger... quantos são?... o que que eles fazem?... eles são bonzinhos?... são maus?

L2 - ele $\left[\int\right] \ldots$ ele $\left[\int\right]$ são... ele $\left[\int\right]$ ajudam esse pessoal que pass[ũ] perigo... ele... eles ajudam assim

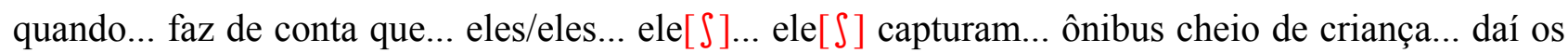
Power Rangers vão lá e $[\varnothing]$ judam eles... a capturar as crianças...

L1 - eles são... eles tem superpoderes?... não tem?...

L2 - não... eles tem só armas assim...

L1 - e o Hantaro?... o que que é?

L2 - Hantaro eu vejo (de vez quando) só... ele é... a gente assim... ele ele... ele fica:.... fazendo assim... faz de conta assim... ele ver alguma coisa... hoje quando eu assist [ $\left.\int\right]$ i... ele ele... foi tá... tá em perigo assim... ele foi arrancar flor vermelha... e quase caiu do morro... foi bem legal...

L1 - e Os Vingadores?... é novo não é?...

L2 - é

L1 - que que é?... eu não assisti nenhum ainda

L2 - eles assim... é... é um pouco Rangers também junto... só que eles tem poderes... eles não tem armas... tem poderes

L1 - tem poderes

L2 - deixa eu ver... poderes de ficar invisível... um monte de coisas...

L1 - e filme... você gosta de assistir filme?

L2 - o que são legal sim... não gosto de filme de terror...

L1 - que filme legal que você já assistiu?

L2 - o Pinóquio

L1 - AH... Pinóquio... AH... eu adoro... sabia que eu assistia desenho do Pinóquio?

L2 - é?

L1 - é... agora não tem mais... mas quando eu tinha a sua idade eu assistia... como que é o filme?... do filme eu não lembro muito assim...

L2 - assim... ele... ele foi pro circo... da daí... os outro... o quem... quem construiu ele de madeira... o... que era o pai dele... que chama de pai dele

L1 - o Gepeto 
L2 - é... ele ia po colégio... e... o pai dele mandou ele pro colégio... daí ele foi pro circo... que tava visitando pra cá... daí ele... ele virou um desses bonequinho que mexe ( )...

L1 - marionete

L2 - é... daí ele... quando ele... ele foi fazer... ele... ele ajudou os pessoal sair né?... os bonequinho?... eles... os bonequinho falava tudo... daí ele foi preso:.... baú... daí ele... como que é?... ele saiu... daí o per/o pai dele perguntou "onde você esteve Pinóquio?"... "eu estive no colégio vou/pai"... "mentira... você esteve lá no circo né?... teu amigo veio aqui falar comigo"... daí ele falou assim... daí o nariz dele cresceu...

L1 - porque ele mentiu né?

L2 - é

L1 - e como que... que o filme vai... vai terminando?

L2 - aí eu não me lembro...

L1 - o que ele aprontou?

L2 - eu não me lembro...

L1 - ele foi engolido pela baleia não era?... quem que é... engolido?... é o Gepeto não é?

L2 - não sei... eu não me lembro do final...

L1 - e um outro filme legal que voce tenha assistido?... de aventura?...

L2 - eu assisti da... da como que é ( )?... o filme da múmia lá?...

L1 - AH... o Retorno da Múmia?...

L2 - não sei... acho que é... não sei

L1 - como que é a história?

L2 - ele... disse que... ele tava procurando... tesouros daí... daí ele... tinha ( )... parece que tem besouro... que ficava dentro da pele assim... e fazia... caveira assim...

L1 - isso é terror ((risos)) não é?

L2 - mas é que... sabe... esse aí eu gos/eu não gosto de assistir filme de terror de noit[S]e... que aí eu não consigo dormi[^] entendeu?... esse filme foi de dia... daí ele... ele... o bichinho entrava

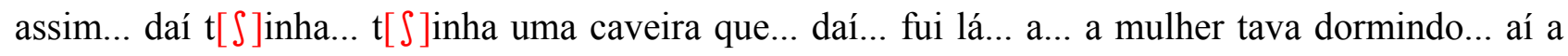
caveira a caveira assim foi lá e... e deu um... um beijo nela assim... daí o cara chegou... abriu a porta... e pum pum... deu quatro tiros... daí ele ficou quando ele sumiu... chegou no castelo dele... dos mortos... e comeu um besouro por aqui... e tinha duas bocas... tinha uma boca por aqui... e uma coisa assim aberta... comeu um besouro... só... que eu falei... que eu me lembre...

L1 - AH... e novela... você assiste?...

L2 - assisto

L1 - qual que se tá assistindo?

L2 - ahn?

L1 - qual novela?

L2 - que eu mais gosto de $[\varnothing]$ ssistir?... é... é... Seus Olhos é:.... a nova novela... Senhora do Destino...

L1 - e:.... como eu tô viajando né?... eu não tô em São Paulo... eu não tenho tv onde eu tô... como que é a novela?... como que é a história?... você lembra alguma coisa?

L2 - lembro... é assim... quando a mulher tá/morava no:.... esqueci o nome do estado lá... só tinha areia... sem praia... sem chão... daí ela queria ir embora com os filho dela... com os marido dela... ( ) po Rio de Janeiro... ela queria ir pa... pa Rio de Janeiro tam[ $\varnothing]$ ém... daí ela tinha um irmão no Rio de Janeiro... daí ela ia lá... daí ela foi... daí ela... ela tinha um cachorro chamado baleia... cachorro... ali ela ela... ela prendeu... ela não levou o cachorro junto... ela... ( ) ela prendeu o cachorro tudo... daí né?... quando tava bem longe... que... que ela no ca/caminhão pra ir lá pra pegar ônibus... a mulhe $[\varnothing]$ soltou o cachorro... o cachorro nadou o rio inteirinho pa encontrar né?...no meio do 
caminho ela foi... o cachorro foi atropelado... daí... quando ela... che/em em:.... daí ela pegou o ônibus tá... daí quando ela chegou em Rio de Janeiro... estava em... guerra... daí ela perdeu a filha dela... Lindalva... que era neném... ela tinha... cinco filho... ( ) e uma menininha... nenenzinha... daí ela... na guerra ela foi presa... daí ela deixou... a o a neném dela que é a Lindalva... deixou co... com filho mais velho ( ) tinha nove anos por aí... daí né?... chegou uma mulher de... de... de enfermeira que... ela... ela não queria perder o marido... e ela é... ela era ma/ela era amant[ $\left.\int\right]$ e do marido... que... e o marido t[ $\left.\int\right]$ inha outra mulher... daí como ela não queria perder o marido... ela já tava grávida assim... mas ela... ele falou... "que/quero a separação... se você não tiver um filho vou me separar de você... daí ela... ela roubou a... a Lin/a o neném... fingiu de enfermeira... e:.... roubou o neném... daí... até agora... eles tão procurando a Lindalva que é a neném... mas daí... eles tão... ma $[\varnothing] . .$. passou o tempo tudo... daí a mulher cresceu... a mãe da Lindalva... daí começou a procurar de novo a Lindalva... daí ela... daí tem o namorado dela né?... que trabalha em pesquisa assim... daí ela... ele... foi que acha que a... a mulhe $[\varnothing]$ que roubou a filha dela... ( ) o marido... o namorado dela foi acha como ela tava antes assim... daí... tem até... aí tem um lá que gosta da mulher ali né?... que fez de tudo pa achar a Lindalva né?... e ela... o... tem um gordão lá que chama Madruga... que trabalha pra ele né?... que ele falou que ajuda... achou a menininha daí... ela... ele ele foi lá... viu a menina... ( ) aí acabou...

\section{A. F. (L2)}

L1 - D. fala pra mim... você gosta de morar aqui?...

L2 - gosto...

L1 - o que você faz aqui pra se divertir?...

L2 - brinco... brinco...

L1 - brinca de quê?

L2 - vôlei... futebol...

L1 - gosta de esporte então?..

L2 - gosto...

L1 - e quando crescer... que você vai querer fazer?...

L2 - veterinária... ser veterinária

L1 - por quê?

L2 - porque eu acho legal assim às vez[i] ... salvar assim... os animal...

L1 - e você tá na escola?

L2 - tô

L1 - que série?

L2 - que série?

L1 - o que que você tá aprendendo... que matérias você tem?...

L2 - matemática... português... geografia... arte... história... religião... física... só...

L1 - e qual é a matéria que você mais gosta?...

L2 - português...

L1 - o que que você mais gosta de fazer?... ( ) o que que você mais gosta de português?

L2 - de:.... assim... fazer frase... botar ponto...

L1 - e você gosta de filme?

L2 - gosto...

L1 - qual foi o filme que você assistiu que você mais gostou?

L2 - Titanic 
L1 - como que é a história do Titanic?

L2 - é sobre um navio que afundou... com duas pessoas que se amam dentro... que nem se conheciam antes de entrar ali... aí se apaixonam... é bem romântico...

L1 - mas como que é?... ela é rica ou ele é rico?...

L2 - ela é rica... ele não...

L1 - como que termina o filme?

L2 - o navio afunda e um... e ele morre

L1 - e tem um outro filme que você gostou... assistiu...

L2 - Harry Potter

L1 - como que é o filme?

L2 - é os mágico... daí... ele voa numa vassoura... eu não assisti o final...

L1 - não?... e você gosta de desenho animado?

L2 - gosto...

L1 - qual você gosta?

L2 - Tom e Jerry...

L1 - tem mais algum que você goste?

L2 - Scooby Doo

L1 - o que que você mais gosta do Scooby Doo?

L2 - o monte de aventuras... pra ele descobrir os segredos... aí eles sempre descobrem...

L1 - e::... você gosta de novela?

L2 - gosto...

L1 - e qual... você tá assistindo alguma?

L2 - três

L1 - qual?

L2 - Da Anie... dá... Seus Olhos e:.... a Outra

L1 - conta pra mim... como que é a Anie...

L2 - a Anie é uma menina que:: faz.. ela é... gosta assim de fazer aventura de menino... daí eles tiram ela do pai dela porque ela não tem família... só tem o pai dela... o pai dela não é de verdade... ele é... ele só achou ela né?... e daí tem o pai dela verdadeiro... ele não morreu... só a mãe dela... o pai dela verdadeiro é um rico... ele é dono duma fábrica... uma casona... daí ela não sabe... ela tem uma tatuagem que ele não viu ainda... o pai dela verdadeiro...

L1 - uma marca?...

L2 - é... daí um menino se fingiu... botou uma tatuagem falsa e enganou o (Afonso)...

L1 - AH... e a outra novela... A Outra.. sobre que que é?

L2 - sobre duas pessoas que se amavam... daí ela/ele pensa que a mulher morreu... mas a mulher não morreu... daí es/essa... sabe por que eles se separaram?... por causa que a mãe dessa mulher não não queria... porque ela era muito malvada... daí não queria que eles se casassem... daí ela pegou e... não gostou mais dele... daí ele pensa que ela tá morta... daí... a mulher dele verdadeira que é brava morreu... daí ela foi lá e vez o papel da outra... aí expulsaram a outra... a:....

L1 - é bacana então... você falou mais uma outra novela...

L2 - Seu Zóio...

L L1 - como que é?

L2 - também era de duas pessoas assim que se amav[ũ]... só que essa já era casada... daí ele destruiu um casamento... daí um filho ficou pra ela... porque ela pensava que ele não era casado né?... daí depois ela ficou com outra pesssoa... daí esse hom[i] foi lá... matou... raptou ela... pra ela não ficar... daí o:.... o sogro dela pegou o neném e deixou no parque né?... pra acudir outra pessoa... daí ele sai correndo aí foi a mulhe $[\varnothing]$ lá e pegou... o neném... 
L1 - hum

L2 - daí ficou separado...

L1 - tá todo mundo separado... você assistiu ontem a novela?... como que foi o capítulo... que que aconteceu?

L2 - ontem o::... o Tiago chegou na festa da Guida e deu uma porrada no Vítor... daí o... o ele falou assim... você me deve vinte anos de cadeia... daí o:.... o Vítor pegou e falou... "meu amigo né?"... aí deu um soco no Vítor e falou que ele deve vinte anos de cadeia... daí a mulhe[ $\varnothing]$ dele foi lá e acabou a festa... depois foi lá no quarto do Vítor... "levanta daí seu ( )"... "vem dormir aqui minha mulher"... daí ela pegou e disse "a partir de hoje em diante eu não sou sua mulher"... daí ele pegou e saiu do quarto...

L1 - e como que foi a Anie ontem?

L2 - AH:.... ela voltou daí... eles querem tirar... o pai... tem/tentar... tão tentando tirar o... o pai/o pai do Raul... que ela gosta... pra... levar ele no mar... pra ele se salvar...

L1 - e a outra novela lá... a Outra... o que que aconteceu de legal?

L2 - a Outra... o Álvaro quer se separar dela pra casar com outra mulhe[ $\varnothing]$... só que a outra mulhe $[\varnothing]$ vai morrer em poucos dias... só... que ele não sabe... daí... os pais for[ũ] tentar falar pro Álvaro mas não conseguem...

L1 - por quê?... ela tá doente?

L2 - tá... não a outra... a outra a outra

L1 - e::... vamos voltar a falar da escola... você gosta dos seus professores?

L2 - menos do de inglês...

L1 - por quê?

L2 - muito brava... só que tiraram ela... ela ficou nervosa com duas/duas gurias por causa do marido dela...

L1 - como assim?

L2 - por causa que tinha um homem que sempre ia lá né?... o marido dela... ela é muito velha... tem (trinta) anos... daí umas gurias passava por lá e começava a rir deles... aí ela ficou com ciúmes... foi brigar com a guria dentro da escola... foi pensar que a guria tava se engraçando... daí expulsar[ũ] ela... e botar[ũ] outra pessoa...

L1 - e você gosta do inglês?

L2 - não

L1 - não?... se você pudesse ser uma cantora... quem você seria e por quê?...

L2 - não gosto de cantar...

L1 - não... ( )

$\mathrm{L} 2-()$

L1 - e o que que você gosta de fazer de final de semana pra se divertir?...

L2 - sábado eu ajudo minha mãe e domingo vou brincar... com as minhas amiga...

L1 - você tem muitas amigas?

L2 - assim não né?... eu falo assim

L1 - qual o nome das suas amigas?

L2 - Maiara... Camila... Juliana... Luda... a Fê... Amanda... Patrícia e a Daniela...

L1 - e o que que vocês fazem quando tão juntas?... são bagunceiras?

L2 - somo[Ø]

L1 - que bagun /que tipo de bagunça que vocês fazem?

L2 - a gente fica mexendo com os menino assim...

L1 - ((risos) $) \ldots$ mas assim... paquerando ou só bagunçando com eles...

L2 - só bagunçando... 
L1 - e:: o que que você tá aprendendo em ciências agora?...

L2 - sobre planeta

L1 - planeta?... e você que tá na escola agora... é... o que que você aprendeu que você mais gostou?...

L2 - sobre como que os homens vieram... daí um menino falou pro professor... deu uma briga...

L1 - por que briga?

L2 - porque o profe/ele falou assim... o professor... falou que o homem veio do macaco... daí o menino falou... por causa da igreja... "não veio não... vem de Deus"... daí eles começaram a discutir... "ah não ele veio do macaco"... daí o professor bem assim... "se retirem... eu tô dando aula... é por isso que tem história... porque é história... daí ele bem assim... "não... vem de Deus"...

L1 - AH... entendi... briga de religião então... e.: e você... além do Harry Potter... do Titanic... você gosta de filme de terror?

L2 -não...

L1 - não?... nunca assistiu nenhum?...

L2 - assisti...

L1 - qual você assistiu?

L2 - do Fundo do Mar...

L1 - como que é a história?

L2 - é sobre uma baleia grandona que ataca eles... eles ficam no fundo do mar... numa casa né?... daí a baleia vai lá e ataca eles... daí eles começam a fazer planos... matam a baleia...

L1 - baleia ou tubarão?

L2 - tem duas... baleia e tubarão...

L1 - é::?... e você gosta de nadar aqui... vai muito na praia...

L2 - às vezes... só no verão...

L1 - sabe nadar... ou não?

L2 - se eu sei nadar?... sei

L1 - nada bastante... e você já fez alguma bagunça que a mamãe já ficou brava com você?... você tem cara de bagunceira...

L2 - eu tava jogando bola ali no canto ( )...

L1 - quebrou o vidro...

L2 - não... o meu irmão já quebrou o vidro... ele tava jogando ali daí ele pegou... bufe... aí quebrou...

L1 - mas você é boazinha então?...

L2 - ( ) daí meu irmão quis pegar um cachorrão... daí minha mãe mandou ele cuidar e ele não cuida... daí eu tenho que cuidar... tenho três cachorro lá em casa...

L1 - gosta de bicho?

L2 - gosto... uma vez eu vi um bicho lá no centro que tava com a cabeça toda cortada... pedi pra mãe trazer ele... mãe não deixa... ( )

L1 - você quer ser veterinária né?...

L2 - hum hum

L1 - e qual bicho você gostaria de cuidar?

L2 - cachorro...

L1 - cachorro...

T.A. M. (L2)

4A

L1 - como que é morar aqui? 
L2 - é legal... tem praia... bem legal

L1 - e o que que você gosta de fazer pra se divertir?

L2 - a::... pegar conversar com as minhas amiga... é brincar de bola...

L1 - e quando você vai na praia... você sabe nadar?...

L2 - não

L1 - você tem alguma história legal pa contar de quando você foi na praia?... alguma coisa bacana que aconteceu...

L2 - eu não tenho

L1 - não?... o que você gosta de assistir na televisão?

L2 - novela filme... desenho

L1 - e um filme que você gostou?

L2 - AH... tem um monte... eu gosto assim de filme... filme assim que:.... que passa em desenho...

L1 - filme que passa em/você lembra de algum?

L2 - Rapunzel

L1 - como que é a história da Rapunzel

L2 - AH... ela é muito bonita... daí é... dum bruxo assim... daí ele tem/ela ele transformou ela em uma::... em um... aqueles coisa que voa?... [ĩ]gual ganso mais voa... é::...

L1 - CISne?

L2 - isso... daí no final... daí a... ela ficou com o::... o príncipe... bem legal...

L1 - bacana... e novela... que novela você assiste?...

L2 - Da Cor do Pecado... Maria Assunção... também aquela... Senhora do Destino...

L1 - como que tá... a::... a Cor do Pecado?... que eu não as/eu não assisto essa novela... como ela é?... me explica mais ou menos...

L2 - AH... é bem legal assim... tem o Paco né?... ele gosta da Preta... mas ele tá... tentando pegar uma chave lá da:.... da casa da Bárbara... a Bárbara é... fica fazendo coisa pra aquela... quer ser rica...

L1 - mais como que é o Paco?... como que era no começo da novela?... o que aconteceu com ele?... você lembra ou não?

L2 - não... eu lembro um pouco... assim daí ele foi lá pra:.... uma cidade lá... conheceu a Preta... depois aí ele voltou... pa casa dele... ele é muito rico... daí depois foi lá pa Preta... daqui a po/a Bárbara foi lá... e daí eles entrar[ũ] no avião... e o Paco... caiu... o avião caiu no mar... daí o Paco ficou lá dentro... mais aí a Bárbara ela nadou e foi lá pra uma ilha daí ela... achar[ũ] ela... mais o Paco... um... um menino... um:.... assim... o irmão dele... ele não sabia que era irmão... daí o irmão dele... achou ele... pensando que era o outro irmão gêmeo... daí ele explicou certinho que ele era o Paco... não era o Apolo... que o Apolo tinha morrido no mar... daí eles foi lá pa casa... do... irmão dele... e pensando que era o Apolo... daí ele... ele teve uma namorada que se chamava (Amor)... depois se separou e foi lá pra... uma cabana que era dele mesmo... agora ele tá morando com a Preta...

L1 - com a Preta... a tá... e a:.... a outra novela agora... Senhora do Destino?

L2 - isso... eu não assisto todo dia... assim mais...

L1 - você sabe mais ou menos como é a história?

L2 - AH não... eu sei mais ou menos da Malhação

L1 - então conta pra mim... faz muito tempo que eu não assisto...

L2 - AH... é muito legal... tem de... tem um monte de pessoas... também... é assim... tem um menino... uma menina que eles só ficam brigando né?... que é::... e daí hoje... eu assisti um capítulo que eles iam acampar... daí a rua... ela ficou... tava chovendo daí não dava pra passar... daí eles ficaram lá numa e[ $\left.\int\right]$ cola... lá não tinha comida... eles arranjaram comida... cuidaram das crianças... 
daí eles agora... ele... um... um pouco foi pa... po hotel... um pouco ficou acampado ata/no quintal da e[ $\left[\int\right]$ cola...

L1 - é legal?

L2 - é...

L1 - e de domingo... o que você gosta de assistir na tv?

L2 - Domingo Legal... também Todos Contra Um... também Go... não Didi...

L1 - e como que é a sua escola?

L2 - ela é bem legal... a minha escola... eu gosto dela...

L1 - e como que ela é?... descreve a sua escola fisicamente?... se ela é grande... pequena... quantas salas de aula...

L L2 - ela é grande... tem um:... um assim aonde que a gente joga vôlei... onde que a gente joga futebol... assim... é tudo coberto... eles cuidam bem da gente lá... bem legal...

L1 - que matérias você tá estudando?

L2 - eu tô estudando... matemát[S]ica... português ... ciências... geografia... artes...também... religião... também eu faço física

L1 - o que que você aprende em religião... por exemplo?

L2 - AH... eu tenho um livro agora que a gente faz um monte sobre... coisa de... Jesus... de desde Jesus pequeno... até agora quando ele... ele cresceu... bem legal... tem a historinha... daí a gente preenche umas coisas lá...

L1 - e qual é a matéria que você mais gosta?...

L2 - AH... eu mais... eu mais gosto de matemát[ $\left.\int\right]$ ica

L1 - você acha importante?

L2 - é muito legal... o professor que dá aula pra gente ele exp[^]ica... quantas vezes precisar... a gente entende... eu tiro nota mais alta em matemát $\left[\int\right]$ ica...

L1 - e como são seus outros professores?

L2 - AH... eles são bem legais... o mais legal que eu gosto é de matemát[ $\left.\int\right]$ ica... porque ele dá mais atenção pros outro... daí tem o de geografia... que ele... ele é muito briguento... tem a... a de... a professora Teresinha de português que ela é um pouco louca... ela só dá poema... poema... poema... e nunca dá prova.. sempre dá assim... concurso no cade[I]no... e também tem a de religião... que ela também é um pouco chatinha também tem ing[ᄃ]ês... bem legal...

L1 - e você acha importante aprender inglês?

L2 - AH... acho... tem umas palavra bem legal... que a turma aprender[ũ] sobre os móveis... sobre a casa... aprendemos também as cores... as fruta... os alimento já aprendemo[ $\varnothing] \ldots$

L1 - e você você pudesse... é:.... tirar uma matéria da escola... qual seria?... e por quê?

L2 - AH... seria geografia... é porque a geografia a gente não entende quase nada... e também eu tiro só nota baixa um pouco assim... eu tiro sete... cinco...

L1 - não vai tão bem né?...

L2 - não

L1 - e você... é uma menina arteira?

L2 - não

L1 - mas tem alguma bagunça assim que você já fez?... alguma coisa que você aprontou que a sua mãe ficou muito brava?... ( )

L2 - hum... minha mãe fica brava quando eu quebro alguma coisa né?... porque... e também eu... quando eu faço bastante bagunça... porque minha mãe saiu um dia né?... daí eu tava aqui com a 
minha prima e minha irmã Lena... daí quando ela chegou... a gente tava fazendo bastante bagunça daí ela ficou bra[b]a porque ela não gosta de bagunça...

L1 - AH... ela não gosta de bagunça então...

L2 - não

L1 - e como que... como que a... quantas irmãs você tem?

L2 - tenho... tem... tenho uma que mora com a gent $\left[\int\right]$ e... e uma com o meu pai verdadeiro... ele arranjou uma mulhe $[\varnothing] \ldots$ daí agora eu tenho duas...

L1 - AH tá... você gosta das suas irmãs...

L2 - aí... aquelas que tá com o meu pai... eu nunca... quase nunca vi ela... só essa daqui é bem legal ela... mas tem dia que eu brigo com a minha irmã... ela briga comigo...

L1 - é normal né?... e conta pra mim uma coisa... como você faz pra ir pra escola?... é longe daqui?

L2 - não... é bem pertinho ali na escola Rogério (Isaac)... eu pego a minha bicic[ $\ulcorner$ ]eta e vou...

L1 - vai de bicicleta... e violência?... tem violência aqui onde você mora?...

L2 - não... nunca vi roubo nada...

L1 - tranqüilo?

L2 - tranqüilo... não tem perigo nenhum...

L1 - não tem mesmo?... e na praia não tem perigo?

L2 - nunca vi nenhum... ninguém

L1 - e na escola... você alguma vez já aprendeu alguma coisa sobre o Boi de Mamão?... o Terno de

Reis... essas tradições antigas?

L2 - não... nunca aprendi isso aí

L1 - e... vo/você já aprendeu a história de São Francisco do Sul?

L2 - AH... eu tenho um livrinho que ele conta um monte de coisa... até conta sobre esse negócio de Boi de Mamão... essas coisa aí...

L1 - mas... você não teve que estudar o livrinho ainda?

L2 - não... a gente estud[e]mo[ $\varnothing]$ um pouco mais agora nós tamo[ $\varnothing]$ estudando outras coisa em português... outras coisas assim estudando agora...

L1 - se você pudesse um/mudar daqui você mudaria?

L2 - a não... aqui é muito legal... meu pai minha mãe já falava de mudar mais eu não quero...

L1 - gosta daqui...

L2 - é... já tenho meus amigos... são bem legais...

L1 - quem é sua melhor amiga?

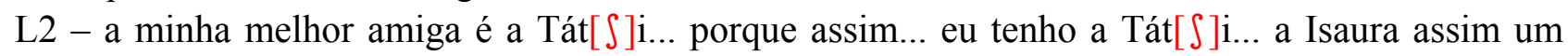
monte de amigos... mas a Isaura tem vezes que ela briga... e a Tát[ $\left.\int\right]$ i não a Tát $\left[\int\right] i$ é legal...

L1 - sua amiga

LL2 - a Tatiana e a Marina

L1 - e elas estudam com você?... na mesma sala?

L2 - na mesma sala... só que eu estudo na segunda carteira e... e elas estudam na última já...

L1 - mas por quê?... tem diferença?... quem que coloca pra sentar

L2 - não... é... nosso regente... o professor de física...

$\mathrm{L} 1-\mathrm{AH} . .$.

L2 - ele troca de lugar... e elas são muito bagunceira sabe?... daí os mais quieto coloca na frente e os mais bagunceiros atrás...

L1 - é mesmo?... uhn... interessante... e se você pudesse ser uma heroína... quem você seria?...

L2 - ah... eu não sei

L1 - uma atriz? 
L2 - AH... assim... queria assim... dançar... [ĩ]gual a Sheila Carvalho... legal... queria dançar... queria... fazer novela...

\section{B. P. (L2)}

L1 - fala pra mim se você gosta de morar aqui...

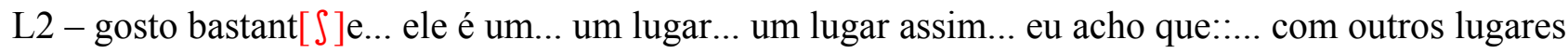
como assim...Para/Curitiba São Paulo... não é por nada... mas... é um lugar bem silencios[o]... tem paz aqui...

L1 - o que que você gosta de fazer aqui?

L2 - vou na praia...

L1 - vai na praia

L2 - às vez[i] a gent[ $\left.\int\right]$ e faz um luau... ( ) às vez[i] a gente ( )... entra na sala... (bate papo)... a gente faz isso...

L1 - sabe mexer em computador? na escola tem?...

L2 - não

L1 - não?.. como que é a sua escola...

L2 - aí:.... é chata... não... os professores são um pouco legais... a diretora é MUIto chata... mais eu nem conheço ela...

L1 - e como que ela é fisicamente... o que ela oferece... tem biblioteca... sala de vídeo...

L2 - tem biblioteca... sala de vídeo... mais:: a gente não usa muito nem a biblioteca nem a sala de vídeo... nem a sala de (game)... por qu[e] eles não deixam entrar lá... só os professores que pode entrar...

L1 - na biblioteca também?... qual foi o último livro que você teve que ler pra escola?...

L2 - pra esCOla... O Café da Manhã

L1 - O Café da Manhã?... já leu outros...

L2 - já já li Harry Potter... já::... aí... tem mais um que eu não lembro... sei... qual que é o nome...

L1 - você gosta de ler na escola?... e qual é a matéria que você mais gosta?...

L2 - matemática

L1 - e o que que você pretende fazer quando você crescer... estudar nessa área ou não?...

L2 - eu quero ser advogada...

L1 - advogada?... conhece algum advogado já... algum...

L2 - meu t[S]io é advogado

L1 - e porque que você quer ser advogada?... o que que você acha que um advogado precisa... ter de qualidade...

L2 - saber luta[x]... saber lutar por... por que ele tá defendendo... é:: isso é (essencial) pra... um::

pra ser pra ser advogado... estudar bastante também... ((risos))

L1 - e gosta do que mais?... gosta de ler bastante né?

L2 - com certeza

L1 - tem que sab/estudar bastante português... gosta de português?

L2 - um pouco

L1 - tá estudando inglês também na escola?... e se você pudesse aprender uma outra língua na escola... qual que seria?...

L2 - espanhol

L1 - espanhol?... você já ouviu alguém?... tem contato com alguém... 
L2 - já... eu conheci uma amiga... uma amiga minha que ela morava na Espanha... ela veio aqui para passar temporada...

L1 - foi passar temporada aqui... e aí você... dava pra entender direitinho com ela?

L2 - era meio difícil

L1 - mas conseguia...

L2 - um pouco

L1 - e quais são assim... todas as matérias que você estuda... você lembra... o nome dos professores?

L2 - matemática... história... é inglês... português...é:.....geografia... o nome dos professores tem a Adriana... tem a a professora Darlim... qu[e] é de inglês... tem o professor Clóvis que é de português e o (Péricles) de educação física... tem... tem... a professora de inglês e história... e tem mais alguns... Jorge...

L1 - e:: o que que você tá aprendendo em... ciências?

L2 - ciências?

L1 - não lembra?... tá em férias então né?... tá em férias né?... então vamos parar de falar de escola... vamos falar de passeio... aqui na Enseada... tem... o que que dá pra fazer aqui pra se divertir?

L2 - bom (agora) nas duas semanas de junho e julho... aqui agora tá tudo vazio... até de noite aqui... dá... em abril chega a Festilha

$\mathrm{L}$ L1 - eu quero que você me conte mais sobre a Festilha... porque pra que você me conte mais sobre a Festilha... porque pra mim é bem interessante saber... e aonde que é... o que é que tem na Festilha... isso ninguém me falou ainda...

L2 - a Festilha é:: é ali no Centro Histórico... na frente do Centro Históric[o]... ela... ela tem essas histórias de... tem sala de computador... tem sala de videogame... então é grátis... na Festilha... tem::... o:: a sala de dança... dança tem... tem essa... o palco ( )... tem banda que toca...

L1 - e tem manifestações assim... folclóricas... como o Boi de Mamão... Terno de Reis

baixo... que nem a $\mathrm{F}$. falou né?... só pra lá... só lá pra baixo...

L L2 - tem... lá pra L1 - mas tem assim/como que tem... tem na com/porque as pessoas que moram fazem ou são grupos só... coisas isoladas...

L2 - só o que mora

L1 - mora aqui que organiza

L2 - é...

L1 - lá pra baixo que você fala é onde?

L2 - lá na Praia Grande

L1 - na Praia Grande... é muito longe daqui?

L2 - AH... tem também a Baúfesta... vai ter:: no final desse mês... que é lá pro dia vinte e nove que vai ter ali... é assado... é assado três bois inteiro... no rolet $\left[\int\right] \mathrm{e}$

L1 - e qual é o nome da festa?

L2 - Baúfesta

L1 - Baúfesta... e aqui tem a festa da:.... da:: sar/da

L1 - da tainha né?... já foi?... é boa?...

L L2 - da tainha...

L2 - é legal...

L1- você já assistiu algum Boi de Mamão... algum Terno de Reis... alguma coisa neste estilo?

L2 - não

L1 -não?... não conhece? 
L2 - não conheço não ( )... eu não conheço

L1 - na escola vocês estudam... fazem grupo... o professor de história

L2 - não

L1 - já aprendeu um pouco da história de São Francisco do Sul?

L2 - não

L1 - aquela história do Centro Velho... sabe porque que... por que aquelas... é:: aquelas construções ainda tão ali... aqueles casarões?... nada... tá ((a informante nega com gestos da cabeça))... e aqui na praia... como que é a praia no verão... pensando agora no inverno... tem muita diferença na cidade?...

L2 - tem... tem mais movimento... como assim... em Joinville... o pessoal de Joinville vem todo pra cá... só pra se ter uma idéia... da pra... tem vezes que nós não tem lugar pra andar... tem que andar no meio da rua... pra poder andar... porque a calçada são cheia... cheias de gente... aí:: é diferente...

L1 - você conhece Joinville né?

L2 - conheço

L1 - é muito diferente daqui?

L2 - bastante

L1 - no quê?

L2 - a violência... é bem diferente daqui... lá é muito perigoso... de dia de noite tanto faz...é bem mais perigoso... aqui não... é calmo... só mais tarde... entre dez... até mais tarde...

L1 - aí já é mais perigoso... a tá... você já ficou sabendo... tem... costuma ter muito assalto... muito crime por aqui?

L2 - sinceramente não ((risos))

L1 - que bom né?... e:: Joinville... você ficou sabendo de alguma coisa lá... mais assustadora?

L2 - não

L1 - não?... e aqui na cidade... conhece alguma lenda?... alguma história?

L2 - não

L1 - não?... daqui nada?... sobre... nem história de pescador... nunca ouviu falar?... não tem nenhuma lenda?... e se você pudesse... quando você crescer quer ser advogada né?... você pretende trabalhar aqui?

L2 - não

L1 - não?... pra onde você gostaria de ir?

L2 - Rio de Janeiro

L1 - Rio? por quê?

L2 - por que:: lá:: o... o meu tio fez faculdade lá... e a faculdade que ele fez ele falou que era boa... aí eu quero ir pra lá...

L1 - fazer faculdade lá... trabalhar lá... você acha que você não vai sentir falta?

L2 - vou... muita falta daqui

L1 - muita falta daqui né?... também acho... é bem diferente o Rio de Janeiro... cidade de praia né?... diferente... e:: se você pudesse hoje fazer as malas e viajar pra um lugar... pra onde você iria?

L2 - pra Bahia

L1 - por quê?

L2 - por que é muito bonito pra lá... eu já fui uma vez... tava de férias... com a minha mãe né?... (

)... a gente foi... ficou uma semana depois voltou... é muito bonito...

L1 - o que que você mais gostou lá da Bahia?

$\mathrm{L} 2$ - as praia

L1 - as praias... são bonitas mesmo?... qual que era a mais bonita...

L2 - a praia (dos Campo)

L1 - qual a diferença das praias daqui? 
L2 - aí... não sei...

L1 - eles tem coqueiro... porque nós não temos coqueiro né?... lá tem um monte né?... acho que essa é a grande diferença... visual né? e:.... se você pudesse ter uma casa... a sua casa... como você a faria?

L2 - como assim?

L1 - se você pudesse construir uma casa pra você... morar... como você seria... como ela seria?

L2 - ela seria bem grand[3]e...

L1 - eu quero que você conte pra mim como é viver aqui em São Francisco...

L2 - legal... assim... é bom...

L1 - pode falar alto... mais alto... pode deixar a vergonha pra lá...

L2 - eu gosto daqui... sempre morei aqui... acho que aqui é um lugar bom assim né?... pra morar assim... sossegado... não... não... não incomoda muito assim... sabe?... eu gosto de morar aqui... mais calmo tudo sabe...

L1 - e você:: tá em que série mesmo?

L2 - quinta

L1 - e qual é o nome da sua escola?

L2 - escola de Educação Básica professor Nicola da Silva...

L1 - e o que que você mais gosta de estudar?

L2 - ciências e educação religiosa...

L1 - ( ) você gosta de ciências?

L2 - AH... eu acho... eu acho... que vou estudar pra ser professora... alguma coisa assim...

L1 - e seu pai e sua mãe... também são daqui:.... com que que eles trabalham?

L2 - meu pai trabalha assim... com a roça... sabe?... e minha mãe limpa casa assim...

L1 - e você foi criada aqui tudo... você curte muito a praia?

L2 - bastante... mais no verão né?... que no inverno faz... só só só chuva... no verão é bom... vem bastante gente aqui...

L1 - e você gosta de sair?... sai bastante?... com suas amiguinhas... ( )

L2 - a gente... de noite eu não saiu muito sabe?... só de tarde... mas de TARde assim... sabe?... de fim de semana eu saio bastante...

L1 - pra onde você vai?

L2 - AH... a gente dá umas voltas na praça... lá na frente... na quadra esportiva... vários lugares...

L1 - você gosta de caminhar aqui?

L2 - ahn ahn

L1 - e o que tem aqui pro... pro jovem... da idade de vocês... pra fazer?... tem cursos... tem danças... tem... o que tem aqui na cidade... ( )

L2 - a::... tem um grupo aí que é... que eles ensinam a dançar... assim...

L1 - que tipo de dança?...

L2 - todo tipo...

L1 - estilo tecno... e:.... que mais... tem assim... curso de música... tipo... tem piano...

L2 - não...

L1 - não tem nada disso?

L2 - nada... 
L1- e que diversão... tipo cinema... teatro... você já foi... aqui tem... não tem... quero que você conte um pouquinho pra mim...

L2 - aqui não tem... eu já fui mas não aqui... foi lá em Camboriú... lá eu já fui...

L1 - AH tá... e você tem acesso a computador?

L2 - não

L1 - e no rádio... que tipo de música que você gosta de ouvir?

L2 - pagode...

L1 - mais alguma outra coisa...

$\mathrm{L} 2-\operatorname{rock}($ )

L1 - e na escola né?... o que que você tá aprendendo agora em português?

$\mathrm{L} 2-($ )

L1 - tá... e quais outras matérias que você tem?

L2 - ciências... matemática... religião... português... inglês... história...

L1 - e o nome dos professores... essas coisas...

L2 - é:... Caroline... Keila... Ronilda... Márcia agora... agora é a Darlim... que aí dá de inglês e história... e o Leonel... e tem o professor Roberto...

L1 - e:.... você é uma menina muito levada?... ( )

L2 - não

L1 - nunca aprontou alguma coisa...

L2 - às vezes né? ((risos))

L1 - então conta... conta alguma coisa divertida pra mim que você já fez

L2 - agora não me lembro assim... ((risos))

L1 - não lembra nada?... uma história que teu pai e tua mãe quiseram te pegar... lembra?...

L2 - não

L1 - você tem irmãos?

L2 - tenho... dois

L1 - são mais novos?... mais velhos?...

L2 - tenho uma irmã de dezesseis anos... e um irmão de doze...

L1 - você se dá bem com eles?

L2 - ahn ahn

L1 - e na televisão... o que que você gosta de assistir?... Malhação né?... falou pra mim né?...

L2 - é

L1 - como é que tá... conta pra mim um pouco da Malhação... quero ver se você é boa de memória...

L2 - não... eu gosto de assistir no SBT... a Outra

L1 - QUAL?

L2 - a Outra...

L1 - como que é... conta pra mim

L2 - legal assim né? ((risos))

L1 - mas você tem que contar pra mim como é a novela... porque eu não conheço...

L2 - ahn... eu não quero contar isso...

L1 - não... o que que você quer me contar... filme... gosta de filme?...

L2 - gosto

L1 - qual filme bacana que você assistiu...

L2 - é... Titanic

L1 - Titanic... aquele com o Leonardo de Caprio...

L2 - é... 
L1 - você contaria pra mim a história do Titanic... ((a informante acena um não com a cabeça)) ( ) você não quer ser professora?... não gosta de contar histórias?... NÃO... e:.... ((nesse momento o informante mostrava-se pouco disposto a responder as perguntas))... então você vai me contar o que você gostaria de me contar... sobre um filme

L3 - conta alguma coisa ((interferência da colega que assistia a entrevista))

L1 - fala de alguma coisa que te aconteceu... tem namorado... tá paquerando... olha... eu sou de fora... eu não vou publicar seu nome... é só pra te conhecer... não vai sair no jornal... ( )

L2 - ((risos))

L1 - nem paquerinha... nada?

L2 - ((risos)) mais ou menos

L1 - e você gosta de praticar esportes?...

$\mathrm{L} 2-\operatorname{sim}$

L1 - você faz algum?...

L2 - futebol

L1 - futebol... gosta de jogar?... aí você joga no time de meninos ou de meninas?...

L2 - às vezes a gente faz um time só de menina né?... ou às vezes vou... tudo misturado... mesmo... menino com menina... mas a gente gosta mais mesmo de fazer um só de menina... tá ligado? ( )...

L1 - na escola né?

L2 - é

L1 - tá... e como que é a sua sala de aula... o pessoal é bagunceiro... depende da matéria...

L2 - é... depende... depende da matéria e do professor né?... quando o professor é mais bravo assim... eles ficam mais quieto né?... daí agora quando o professor é bonzinho assim... daí eles fazem mais bagunça ( )

L1 - AH tá... e você e seus irmãos... quando tão juntos... vocês bagunçam bastante... brigam muito...

L2 - às vez $[\varnothing]$ um pouquinho a gente briga né?... quando... por conta de uma coisa assim... quando um quer fazer uma coisa o outro não quer... o outro quer outra... às vez[i] tá assistindo uma novela o outro quer outra... daí a gente começa a discutir... assim... ( )

L1 - e:: você vai muito lá pro Centro Histórico... lá pra São Francisco?... não...

L2 - não... às vezes eu vou sim quando é pra ir pagar alguma coisa assim... sabe? entendeu?...

L1 - e:: lá... você conhece um pouquinho da história lá... de São Francisco... da colonização... já aprendeu alguma coisa na escola...

L2 - não

L1 - que foi colonizado por portugueses... já ouviu falar alguma coisa?... então... uma outra coisa que seria interessante me contar... seria sobre as manifestações folclóricas daqui... se tem Boi de Mamão... Terno de Reis... alguma dessas coisas... mesmo que seja só na escola...

L2 - às vezes... ali perto da minha casa... tem tipo um bar... algo assim sabe?... às vez[i] eles fazem... tudo ano eles fazem né?... eles fazem uma fogueira grande assim... ( ) botam uma fantasia assim de animal...

L1 - é o Boi de Mamão

L2 - é

L1 - e tem Terno de Reis?

L2 - não...

L1 - Pau de Fita...

L2 - tem

L1 - TEM? E onde que tem... Pau de Fita?... 
L2 - lá quando chega no tempo de fazerem essas festas aí daí eles fazem... ali no colégio também eles fazem... a de pau...

L1 - aí você participa...

L2 - ahn ahn

B. M. S (L2)

7A

L1 - B. eu quero que você fale pra mim como é morar aqui na Enseada...

L2 - é::... sossegado aqui... legal né?... sabe... é legal ser sossegado também assim... muito assalto não tem...

L1 - tranqüilo...

L2 - é tranqüilo assim

L1 - e como que é a tua escola?

L2 - legal assim... tem alguns alunos lá... bagun/alunos bagunceiros assim... mas é normal... assim

L1 - e como que você é como aluna?...

L2 - eu converso um pouquinho mas... eu presto atenção assim nas aula... eu me comporto assim...

L1 - e:: quais os nomes dos professores e as matérias que eles ensinam... se lembra?...

L2 - português ( )... geografia... matemática... geografia... daí tem o Leonel... Darlim... Caroline...

Keila e Leonel...

L1 - e:: você tem uma família grande?... como que é sua família?...

L2 - na minha casa é em:: em oito né?... é... eu e meus cinco irmão e o pai e a mãe...

L1 - e você é a mais nova... a mais velha?...

L2 - não... a:: tem outra ainda... além de mim tem outra de oito ano... que é ma/mais nova...

L1 - seus irmãos já são casados?...

L2 - só dois só... um de vinte ano que é casado e a outra de vinte e dois...

L1 - e:: e:: você é uma menina mais sossegada ou você é muito levada...

L2 - não

L1 - já aprontou alguma coisa assim de grande memória?...

L L2 - não não não

L1 - não?... e voltando pra escola... você gosta de praticar algum esporte na escola?...

L2 - é vôlei... futebol

L1 - futebol... e como que vocês jogam?...

L2 - é:: tem assim tipo é... menino... e garotas e garotos... ou às vezes só ( )

L1 - AH tá... e na escola qual é a matéria que você mais gosta?

L2 - é:.... ciências assim...

L1 - que que você tá estudando agora?

L2 - agora é... seres vivo

L1 - o quê?

L2 - seres vivos... eu acho...

L1 - VIvos?... tá... e o que que você tá aprendendo... fala um pouquinho dos seres vivos pra mim...

L2 - como que os seres sobrevivem assim...

L1 - é sobre... seu pai trabalha com o quê?

L2 - ele é pintor...

L1 - pintor?... e aqui é uma cidade de muita pesca né?... você tem algum parente que trabalha na pesca?

L2 - não

L1 - não... o que que você faz aqui... fora a escola...pra se divertir... por exemplo...

L2 - eu saio com minhas amigas assim no final de semana... é isso aí... 
L1 - pra andar aqui né?

L2 - é na praia assim...

L1 - tá... você gosta de mexer no computador... sabe mexer?

L2 - sei...

L1 - sabe:.... e dos... das suas amigas assim... o que que vocês gostam de fazer... para se divertir?

L2 - sair assim... dá uma volta na praia... assim... jogar vôlei no fim de semana...

L1 - e filme... gosta de assistir?

L2 - gosto

L1 - que filme bom que você assistiu?

L2 - Titanic assim o melho[ $\varnothing]$

L1 - não quer contar pra mim resumidamente a história?

L2 - não não

$\mathrm{L} 1-\mathrm{NA \tilde {O }}$

L2 - não não lembro

L1 - não lembra... e tem algum que você lembre e queira contar?

L2 - não

L1 - não?... gosta de música?

L2 - gosto...

L1 - o que que você gosta... pra ouvir...

L2 - rock assim é legal...

L1 - rock?... que bandas que são legais?...

L2 - é... agora não lembro de cabeça... CPM22 né?

L1 - já foi em algum show?

L2 - não... é::... aqui já teve já algum... da Siangue... Das Aranha vieram aqui...

L1 - já foi ao cinema?...

L2 - não... não tem...

L1 - não tem... teatro... e as manifestações folclóricas... o que que você conta pra mim...

L2 - só quando tem ali no colégio né?... ( )

L1 - tá... e o que que você... vamos voltar pro/pro colégio... tem muitas amigas lá?... qual que é o nome... das suas principais amigas...

L2 - é... muitas assim... é... tem a... Bruna Francislene... Aline... Vanderléia... tem várias assim...

L1 - tá... e... como... descreve a sua escola... como que é... é uma escola grande... pequena...

L2 - é grande assim... é grande... é a melhor...

L1 - mas que que tem na escola?... o que ela oferece... tem laboratório... o que é que ela tem?... tem só salas... tem quadra?...

L L2 - tem as salas... aí tem os banheiro... ( )... biblioteca... sala dos professores...

L1 - tem quadra na escola?

L2 - tem quadra

L1 - sala de vídeo...

L2 - não

L1 - laboratório... NÃO?... e tem muitas salas...

L2 - tem... eu acho que:.... seis... SEte salas...

L1 - sete salas... e.: agora pensando na na sua família... foi nascida e foi criada aqui né?... você acha que a cidade anda... tá mudando com o tempo?... você percebe alguma mudança?... ou pra você ela é sempre a mesma...

L2 - não... não... não tá mudando... é sempre igual

L1 - sempre igual? 
L2 - não tem diferença

L1 - muda muito aqui do inverno pro verão?...

L2 - muda... muda...

L1 - o que que muda?...

L2 - no verão se tem... mais gente de fora... assim sabe... já no inverno muito...

$\mathrm{L} 1$ - e esses turistas... o que eles gostam de fazer aqui na cidade?

L2 - OI?

L1 - o que que os turistas gostam daqui?... de fazer aqui?

L2 - da praia né?... eles gostam mais ( ) de se divertir nas praia...

L1 - e... você... o que que você gosta pra se divertir aqui... já que não tem teatro... não tem cinema... tem shopping né?...

L2 - não... sair com as amigas assim...

L1 - e o que que você gosta de comer?...

L2 - lasanha com queijo... sei lá

L1 - sabe cozinhar já?...

L2 - já

L1 - o que que você cozinha?

L2 - AH... AH... ( ) fazer comida assim... os almoço sempre eu que faço né?... quando... quando meus pais tão tão trabalhando...

L1 - você que faz almoço?

L2 - é... de vez em quando né?...

L1 - não quer me dar nenhuma receita?

L2 - não

$\mathrm{L} 1-\mathrm{N} \tilde{\mathrm{A} O}$ ?

L2 - não

L1 - tem uma comida assim que tu saiba fazer bem e queira me dar uma receita?

L2 - não

L1 - NÃO?... e animais... você gosta?

L2 - gosto

L1 - e que bi/animais você gosta?

L2 - cachorro assim gosto... cachorro... cachorro assim... passarinho ( )

L1 - e:: português... o que que você tá estudando agora?

L2 - português... é sobre... agora eu não lembro da matéria... não lembro...

L1 - não lembra?

L2 - não lembro...

L1 - inglês lembra?

L2 - não lembro também... acho que tô sem memória...

L1 - imagina... ( ) e o que você tem vontade de... de estudar... fora ciências assim...

L2 - educação religiosa

L1 - o que vocês aprendem em educação religiosa?... que essa matéria não tem no ensino em São Paulo...

L2 - é::... sobre assim... ser católico assim... todas as religião assim sabe...

L1 - bons costumes

L2 - é

L1 - tá... o que que você aprendeu numa dessas aulas que você não esqueceu... que você guardou... achou interessante...

L2 - AH... tudo né?... mas não... 
L1 - e se você estivesse que estudar além do português e do inglês... tem vontade de aprender uma outra língua?

L2 - não

L1 - NÃO?... o que você acha... acha que é bacana ter quer aprender inglês na escola?

L2 - é... acho que é...

L1 - você acha que usa

L2 - é usa...

L1 - e matemática... gosta?

L2 - gosto

L1 - história?

L2 - também... um pouquinho de cada a gente gosta...

L1 - e história... conhece a história aqui da sua cidade?

L2 - não... um pouco só...

L1 - que pouquinho você conhece... conta...

L2 - um pouco assim sabe?... de São Francisco...

L1 - pode falar pra mim... sem medo de errar

L2 - não não não

L1 - um pouco de história que você conhece

L2 - não gosto dessa não...

$\mathrm{L} 1$ - OI?

L2 - é:: assim sobre... tudo assim né?... que eu gosto ((risos))

L1 - não quer me contar um pouco da história?

L2 - não não

L1 - não precisa ficar tímida por causa do... do... gravador... pode falar... agora fala pra mim sobre... casa... se você pudesse ter uma casa sua... como ela seria... uma casa dos seus sonhos... no dia que eu puder ter uma casa... casar... ou puder fazer minha casa ela vai ser assim... quantos quartos... ( ) L2 - não sei quantos quartos

D. P. F. (L2)

8A

L1 - D. o que que você tá aprendendo na escola... que matérias você tem...

L2 - matemática... inglês... ciências... educação artística... tem um monte... várias...

L1 - e qual é a matéria que você mais gosta?...

L2 - (física)

L1 - física?... eu moro com três estudantes de física... superior né?... fazem faculdade em física... porque que você gosta de física?... o que que você tá aprendendo de legal?

$\mathrm{L} 2$ - AH::... assim várias coisas...

L1 - não lembra de um exemplo?... não?... o que que você faz final de semana pra se divertir?...

L2 - AH... daí... eu faço qualquer bobagem... dar uma volta... jogar bola...

L1 - gosta de praia?... vai bastante?... sabe nadar?...

L2 - AH... surfo...

L1 - surfa?... como que é surfar?... explica pra mim como se fosse professor de surfe... e eu nunca peguei uma prancha de surfe na mão... o que que eu tenho que fazer... que roupa eu tenho que vestir... que dia que é bom... dia de chuva... dia de sol... como que é pra fazer?

L2 - depende... dia de assim... dia de sol tu não precisa usar o neopreme... a roupa de borracha...

L1 - qual é o nome? 
L2 - neopreme... a roupa de borracha... aí pode vim... só de bermuda... aí chega na praia... primeiro coloca a prancha do lado... faz um... uma (flexão)... depois só entrar na água... e... tu entra na água... na hora que vier a onda... tu senta na prancha... na hora que tiver a onda... assim... rema e fica em pé...

L1 - AH tá... e:: você tem muitos amigos aqui?

L2 - quase todo mundo eu conheço... todo mundo aqui... eu moro aqui...

L1 - você nasceu aqui... foi criado aqui... e voltando a falar da sua escola né?... você falou que gosta muito de física... e dos professores... gosta de todos os professores?...

L2 - gosto...

L1 - são bonzinhos?...

L2 - são...

L1 - como que é a sua escola... fisicamente... ela é grande é pequena?...

L2 - ela é meio grandinha...

L1 - tem biblioteca?...

L2 - biblioteca tem... acho que (três) salas... seis sete salas...

L1 - quadra...

L2 - tem quadra grande...

L1 - AH tá... e você gosta de assistir televisão?...

L2 - gosto...

L1 - e você falou que assisti Turma do::

L2 - Turma do Gueto

L1 - como que é... Turma do Gueto... que história que é?... o que conta?...

L2 - é::... o povo que mora na periferia... daí tem dois chefão de gângster... eles... eles disputam ponto de drogas...

L1 - e você assistiu ontem?... que passou ontem?...

L2 - toda a quarta... porque eles tinham matado um... matado um... o chefão... daí eles tava atrás de quem tinha matado... aí pegar[ũ] um cara lá... um cara lá ( )

L1 - e você... é:.... aqui é um lugar violento?... onde você mora?...

L2 - mais ou menos...

L1 - já aconteceu alguma coisa aqui que você ficou sabendo?... conta pra mim...

L2 - aqui o carro virou... o carro virou lá na frente com a casa... (bem de frente)... não sei se roubaram... chegaram a roubar...

L1 - mas se acha que é como no filme?... como na série lá da Turma do Gueto?... ou é mais tranqüilo?

L2 - é diferente... lá eles andam com a arma na cinta... na cintura... pra ficar mais seguro... policial tem medo... (aqui não)

L1 - aqui é mais tranqüilo então... tá... e::... e filme... você gosta de assistir filme?

L2 - hum hum

L1 - que filme que você mais gostou?

L2 - Jack and Sham

L1 - o que que ele conta?... esse filme?...

L2 - um... ele luta...

L1 - AH ele luta... mas ele defende o bem?... ele é malvado?

L2 - ele... ele é policial... ele luta com os bandido... ele é artes marciais...

L1 - tem outro filme que você tenha gostado?... você gosta de filme de terror?..

L2 - gosto...

L1 - você já assistiu algum legal?...

L2 - a Filha do Diabo... 
L1 - hum

L2 - era uma mulhe $[\varnothing]$... ela namorava todo mundo... daí ela teve um filho com o diabo... daí ele veio em forma de homem daí ela teve... ( ) tava...

L1 - e você já assistiu outros filmes de terror assim?...

L2 - não... de noite eu não fico em casa... vou dar uma volta...

L1 - aonde?

L2 - aqui em baixo...

L1 - AH:.... e paquera... tem bastante?... tem muita menina bonita por aqui?... tem?

$\mathrm{L} 2$ - tem

L1 - as pessoas são bonitas aqui... e você é um menino bagunceiro?...

L2 - só na rua... quando tô com os meu colega...

L1 - e o que que vocês fazem quando você sai?...

L2 - quebrar vidro... avacalhamo[ $\varnothing]$

L1 - vocês avacalham tudo né?... tem cara de bagunceiro mesmo... e na escola... é bagunceiro?...

L2 - na escola... eu não gosto assim de bagunça na escola...

L1 - que arte que você já ( )?

L2 - brigar só...

L1 - por que você brigou?... conta pra mim uma briga... e por quê?

L2 - nós ficava ali... no colégio... daí o meu colega... aí começar[ũ] a falar pra ele... xingar[ũ] ele...

daí ele puxou uma faca... ( ) meu outro colega veio daí ele ( )...

L1 - cruzes... briga de faca na escola... não pode... e:.... aqui na rua... você já brigou?

L2 - direto... todo dia...

L1 - NOSSA... porque que você briga tanto?...

L2 - é... que vem o pessoal de fora aí... daí a guriada não gosta...

L1 - aí tem briga...

L2 - a guriada não gosta...

L1 - você parece ser tão calmo...

L2 - assim que eles passa aqui... um olha... começa a olhar... pass[ũ] de boné virado... meio playboy... daí a guriada não gosta e vai xingar ele...

L1 - tem briga aí...

L2 - tem direto...

L1 - e em casa... você é muto bagunceiro?...

L2 - hum... não fico bagunçando...

L1 - você já fez uma bagunça e a sua mãe ficou muito brava com você?...

L2 - ( ) com uma festa...

L1 - AH você tem?... como que é uma festa?... é um tipo de... música toca?

L2 - é... assim... é de chão batido assim... é mais bailão dos velho...

L1 - e você vai fazer o que no bailão dos velho?... ((risos))

L2 - ( ) tem demais hip-hop

L1 - aonde?...

L2 - aqui...

L1 - você já vai?

L2 - só que não pode entrar... daí como meu primo é segurança... daí... ele deixa...

L1 - e lá na Enseada... você costuma ir lá pra se divertir?

L2 - não... lá é... de vez em quando pra ir jogar bola... contra o time deles...

L1 - você conhece aqui São Francisco do Sul?... lá o Centro Ve/Centro Histórico?... você gosta?... você conhece a história daquele Centro Velho? 
L2 - não... não conheço tudo não...

L1 - não conhece?

L2 - não não ( )

L1 - e:: você já entrou num barco?... foi pro mar?...

L2 - já

L1 - legal... como que é... você já foi longe... viu algum animal?

L2 - fiquei oito dias fora...

L1 - oito dias o quê?... dentro dum barco?... pescando?...

$\mathrm{L} 2-()$

L1 - e aí como é?... é bacana?... você viu baleia.. tem tubarão?... como é que é?

L2 - é assim... passa um... daí a gente pára pa tomar banho...

L1 - tomar banho aonde?

L2 - tomar banho lá fora...

L1 - mas vocês pula no mar assim... não tem medo?...

L2 - não não...

L1 - não é fundo?...

L2 - não... tipo num lago...

L1 - não tem tubarão gente?...

L2 - só cação... o cação virou um barco...

L1 - como assim?

L2 - é um peixe

L1 - o cação não é o tubarão?

L2 - é... é tipo um tubarão... filhote de tubarão...

L1 - ele virou um barco?.. como?

L2 - pegou na rede... pegou rede e embarcou o convés...

L1 - era grande então...

L2 - era

L1 - já aconteceu aqui algum ataque aqui nessa praia?

L2 - só na Enseada

L1 - na Enseada?... se lembra o que que foi?...

L2 - foi um peixe grande... daí... der[ũ] um lance... daí um colega meu pulou no meio da rede... daí o cação veio e ( )

L1 - machucou bastante?

L2 - tirou a batata da perna...

L1 - quantos pontos?

L2 - não... ele arrancou tudinho a batata da perna... ( )

L1 - aqui na Enseada?... tava pescando isso né?...

L2 - é... tava pescando...

L1 - não foi no raso não né?

L2 - não... é no fundo...

L1 - AH tá... e fora a Turma do Gueto... mais algum outro filme que você gosta... algum outra novela que você acompanha...

L2 - não vejo novela...

L1 - nunca fica em casa pra assistir... e você tem muitos irmãos?...

L2 - tenho quatro

L1 - e vocês brigam muito?

L2 - não

L1 - você é o mais velho?... 
$\mathrm{L} 2-()$

L1 - você é o mais velho?

L2 - tenho o meu irmão de dezoito...

L1 - dezoito... e o que que você quer fazer quando você crescer?... já sabe com o que vai trabalhar... nunca pensou... "AH eu quero ser médico"... "AH eu quero ser pescador"...

L2 - ( ) eu fui fazer um teste pra jogar futebol...

L1 - você gosta então de jogar bola... esporte... seria um professor de educação física...

L2 - hum hum

L1 - então F.... conta pra mim... como que é morar aqui na Enseada...

L2 - AH... é legal... eu gosto bastante de ir na praia... mas eu gosto mais em época assim de verão né?... porque tem bastante gent[ $\left.\int\right]$ e de fora... que aqui é muito pequeno muita gent[ $\left.\int\right]$ e conhecida...

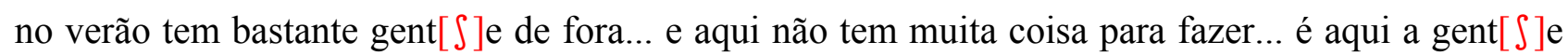

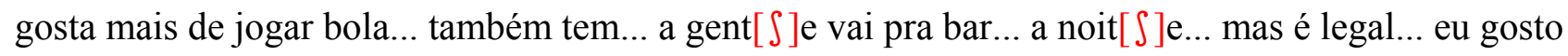
de morar aqui...

L1 - e conta uma coisa pra mim... você falou que gosta muito de ir na praia né?... você já passou alguma vez susto?... te aconteceu alguma coisa perigosa?... com um amigo teu?...

L2 - não... só uma vez que eu levei uma bronca dum salva-vida porque::... a gent[S]e foi...

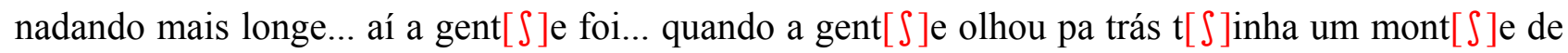

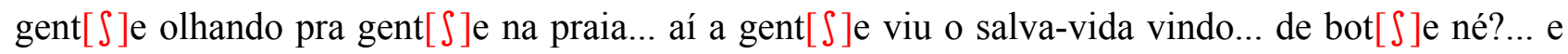
ele... brigaram aí a gent[ $\left.\int\right]$ e mais... acho que não teve nada demais... já teve muito afogamento... já teve amigo meu que morreu né?... afogado... mas comigo mesmo nunca aconteceu muita coisa não...

L1 - e:: fala uma coisa pra mim... como que é a sua escola?

L2 - AH... a minha escola... eu... ( ) normal... tem acho que aqui em (Santo)... assim tem poucas... e essa... é... todo mundo diz aqui é legal de estudo...

L1 - e::... o que você pretende fazer... você já trabalha na pesca né?... trabalha na pesca... é... provavelmente já faz um pouquinho que você trabalha... se você não trabalhasse na pesca você queria trabalhar com o quê?...

L2 - a eu... que/meu sonho mesmo é montar uma loja de videogame... de... do pessoal vim jogar né?... da molecada vim jogar que eu gosto muito... é... eu queria montar... comprar uma televisão... uns videogame e alugar por hora...

L1 - legal... fala uma coisa pra mim... é::... o que que você mais gosta de jogar no computador... no videogame?

L2 - AH... eu gosto de jogar... jogo de corrida... que eu mais gosto né?... mais eu gosto também de jogar muito futebol...

L1 - tá... fillme... gosta de filmes?

L2 - gosto... gosto sim

L1 - você assis/que tipo de filme você gosta?... terror... aventura... romance?...

L2 - gosto de ação... de ação e de::... terror também... que é o que eu gosto...

L1 - conta/ que filme de terror legal que você assistiu?

L2 - AH... o que eu mais gosto é o Exorcista

L1 - conta pra mim a história do Exorcista 
L2 - AH... é uma menina que... é possuída pelo demônio... e:.... que a família dela... não... leva ela no médico... mas na verdade não é... e... tinha o padre... aí o padre faz o exorcismo... muito bom...

L1 - e um outro filme de terror?... tem um legal?

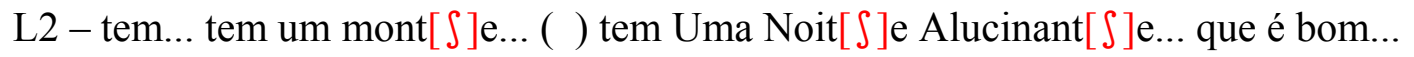

L1 - então conta... ( )

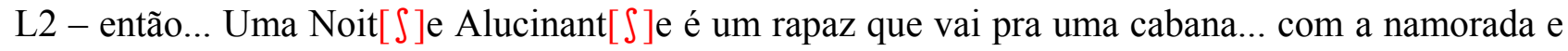
com os amigos... aí chegando lá... ( ) ele encontra um livr[o]... e esse livr[o] tinha uma maldição e acaba... todo mundo... morto né?... uma... uma coisa da floresta ( )...

L1 - e você gosta de filme assim de... ficção científica?... sabe o que é fícção científica?

L2 - ficção científica eu sei é um... uma fantasia né?... uma coisa que não exist[ $\left.\int\right]$ e de verdade... pode ser que exista né?... um dia...

L1 - e você já assistiu algum legal?

L2 - eu gosto do... De Volta Para o Futuro... que é o.:... o do cara voador... que viaja no tempo... já viu NÉ?

L1 - vi vi sim... ( ) é legal... você lembra da história do... do primeiro filme?... que ele vai pro passado né?...

L2 - faz muito tempo que eu vi... só lembro que tinha o carro... e que o:.... é ele/é esse mesmo... ele ia pro passado... aí encontrava os pais... aí encontrava os pais e acabava atrapalhando toda a vida dele...

$\mathrm{L} 1$ - e por que ele teve que ir pro passado?...

L2 - AH... foi sem querer... foi um acident $\left[\int\right]$ e... que o... o cientista tava mostrando pra ele como é que funcionava a máquina... ele... o cientista leva um tiro e pra fugir do:.... mafiosos... e os cara pega o cientista... ele acaba indo viajar no tempo... sem querer...

L1 - e::... você falou uma vez pra mim que você::... é::... caiu uma vez de uma árvore... conta essa história pra mim... como é que foi?

L2 - AH... foi uma vez que o... eu fui colocar a lanterna de Natal... aí eu subi no galho né?... da árvore... eu e o meu t $\left[\int\right]$ iu... a gent $\left[\int\right]$ e colocou uma forquilha né?... uma tipo a (forca) de uma madeira... só que não agüentou o peso... e acabou quebrando... caí... de uma altura muito... muito grand[3]e... e quebrei a perna...

L1 - você ficou muito tempo engessado?

L2 - fiquei seis meses de cama

L1 - e::... fora isso... tem mais alguma hospitalar?... que eu tenho um monte...

L2 - não... não... já quebrei o braço caindo de bicicleta... e:.... e só... já fiz uma operação também

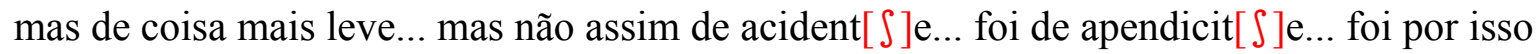

L1 - tá... você gosta de sair com os seus amigos aqui na cidade?... nos barzinhos?

L2 - eu gosto... gosto de jogar sinuca... ultimament[ $\left.\int\right]$ e assim é o que eu mais tenho feito é jogar sinuca... mais... é... eu tô... meio difícil né?... agora tá... não tenho tempo pra sair né?... porque eu tô estudando... e ainda tô... (aprendendo) sobre pesca né?.. que eu ( )... então... ultimamente faz tempo já... que eu não... não saio com meus amigos...

L1 - e você e se/você tem alguma história legal pra contar?... o que vocês faziam ou se aprontavam alguma coisa errada?

L2 - AH... a gent[S]e não é de aprontar muito porque aqui é muito conhecido né?... quando era

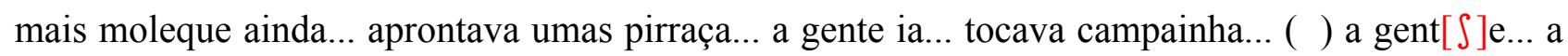
gent $\left[\int\right]$ e pichava... fazia uma baderna né?... faz muito tempo (já)... parei com... quinze anos... 
L1 - se parou faz pouco tempo hein?

L2 - não... já faz tempo... dois anos... nun/nunca mais fiz nada...

L1 - ahn ahn... tá bom... e:.... você gosta de assistir televisão?

L2 - não muito... novela só... de vez em quando... mas... não... assisto mais filme... que eu gosto...

L1 - e se tá acompanhando alguma novela?

L2 - não... não... ultimament[ $\left.\int\right]$ e estou sem tempo né?

L1 - e no domingo?... o que que se... vê na televisão ( )?

L2 - AH... eu não... sou de assistir televisão... eu quero jogar videogame né?... com uma turma ( )... eu gosto de jogar videogame...

L1 - e:: você que não tem videogame em casa né?... ( ) onde você joga?

L2 - jogo na locadora que tem aqui perto né?...

L1 - em São Francisco né?

L2 - isso... fica na... ali perto da padaria ali não é longe daqui... é:.... acho que aqui em São Francisco só tem essa me $[\varnothing]$ mo... conheço só essa... mas ela é legal... porque todos meus amigos vão jogar lá... aí a gent [ $\left.\int\right]$ e faz um futebol... corrida também...

L1 - então... é é... e por que que você não assiste tanta televisão?... não gosta?...

L2 - não é que... tem coisa mais interessant[S]e pra fazer eu acho... eu gosto mais de... prefiro jogar bola... prefiro jogar videogame né?... então... tenho... eu tenho final de semana quando dá tempo eu vou pa locadora jogar... então... ( ) jogar uma pelada com os amigo aí...

L1 - e você tem namorada?...

L2 - não... eu tava... eu tava namorando mas agora não tô mais não...

L1 - não?... casar algum dia?... ter filhos?...

L2 - olha... até pretendo... mas... espero que demore bastant $\left[\int\right] \mathrm{e} . .$.

L1 - ahn ahn

L2 - primeiro eu quero me divertir... bastant[ $\left[\int\right]$ e... ter minha casa... meu carro... quem sabe até ter meu barco também...

L1 - aí é interessante... dá pra ganhar muito dinheiro né?... e aqui tem ataque de tubarão... o mar é perigoso

L2 - não... tem afogamento mais é difícil também... é mais em época de verão né?... que vem mais turista... tem o pessoal que bebe muito e vai pra praia... morre afogado né?... ( )

L1 - e... eu sei que a situação é difícil... que aqui não tem faculdade... você tem vontade de fazer algum curso em universidade?... ( )

L2 - tenho... quem sabe né?... eu tenho vontade sim... esse ano eu não vou poder né?... quando eu terminar a escola mais... assim que eu tiver um dinheiro né?... porque eu também preciso ajudar em casa né?... depois... depois que ajudar em casa eu vou... quero fazer faculdade sim...

L1 - interessante... ( ) você sabe surfar

L2 - sei... mas não muito bem né?... porque eu só... eu não tenho prancha... então eu pego emprestado com... tem amigo meu que tem né?... então quando eles querem emprestar... eu pego... brinco um pouco né?... eu brinco um pouco...

L1 - e... você falou que gosta de... de jogar sinuca... é no bar... e nos bailões... tu vai?

L2 - não... eu ia também bastant[ $\left[\int\right]$ e em danceteria... tem... tem... uma pra falar a verdade era mais um bar... bar é o que eu gosto mais...

$\mathrm{L} 1-(\mathrm{)}$

L2 - não não... eu gosto mais de sossego assim... tem um barzinho... uma sinuca... tomar um refrigerant $\left[\int\right] \mathrm{e} . .$. uma cerveja... 
L1 - e você conhece a história de São Francisco do Sul?... alguma lenda... alguma coisa... aprendeu na escola?...

L2 - não... já teve assim trabalho de escola... mas quando era muito moleque nem me lembro muito bem assim da história agora... eu era menino quando aprendi... conheço assim... história boba assim... de assombração que tem né?... e muito poucas... (era menino)

L1 - e:.... seu pai né?... ele é pescador... ele conta alguma coisa assim... que você... sabe que é história de pescador...

L2 - conta... conta... e a gent[ $\left.\int\right]$ e dá muita risada... inclusive ele contou até uma história que... ele tinha achado um tubarão... no... no mar... ele tinha caído porque tava o mar revolto e o tubarão quase abocanhou ele... até hoje eu duvido...

L1 - ah é... é a história de pescador né?... e a sua mãe... o que ela faz?

L2 - minha mãe é dona de casa

L1 - dona de casa... tem irmãos?

L2 - não... sou só eu

L1 - só você... e é bom ser filho único?

L2 - AH eu gosto... porque... não tem ninguém mexendo nas minhas coisas né?... só seu...

L1 - você tem dezessete anos né?... desde que idade que você pesca?

L2 - desde pequeno meu pai me leva pra pescar... acho que eu tinha uns sete ano ( )

L1 - É:: NOSSA... quanto tempo hein?

L2 - então né?... mais aqui todo mundo começa cedo...

L1 - mas... mas por quê?... conta... conta pra mim... é:.... pra ajudar o pai né?

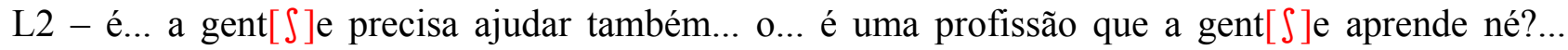

porque... bem ou mal... ela... é uma profissão... a gent[ $\left.\int\right]$ e não sabe qual que é o futuro de amanhã... e a pesca é uma coisa que eu gosto... queria... ( ) ser um doutor talvez mas não... pesca não é tão ruim...

G. S. O. (L2)

10A

L1 - o que você... mais gosta de fazer aqui em São Francisco do Sul... de final pra se divertir?

L2 - jogar uma bola... uma peladinha... sair com os amigos...

L1 - como que é surfar?... me explica assim... a técnica de surfista... rapidinho... que que eu tenho que fazer pra me equilibrar?... eu não conheço nada...

L2 - só remar e ficar em pé na onda... na prancha

L1 - que simples né?... ((risos))... mas é difícil não é?

L2 - é fácil... só não pode ter medo... só no começo que é difícil... depois...

L1 - vai acostumando... e na escola... você ainda tá estudando né?... fazendo o segundo colegial como você falou pra mim... quais são as matérias que você mais gosta?...

L2 - matemática...

L1 - por que que se gosta de matemática?...

L2 - porque... uma conta ali... torna mais um... metade de uma coisa ali...

L1 - interessante... e quais outras matérias você tá estudando?

L2 - AH... geografia... química... biologia...

L1 - você tem vontade de terminar o... o colegial e depois fazer uma faculdade?...

L2 - não

L1 - não tem?

L2 - terminando isso aí... já era... 
L1 - e o que que você pretende fazer então?... como profissão?...

L2 - vamo[ $\varnothing]$ ver... ninguém sabe até... o dia de amanhã...

L1 - mas você já trabalha na pesca né?... como que é trabalhar na pesca?...

L2 - AH... pescar... tem dia que dá... tem dia que não dá...

L1 - como que vocês... é um barco menor né?... como que é esse barco?... que que vocês levam... de acessório?... pra ajudar na pesca...

L2 - nós leva... a rede né?...

L1 - e o barco?... é um barco desses comuns?

L2 - é... bateira ou canoa... mais é canoa que nós usa né?...

L1 - e você já passou algum susto?

L2 - já uma vez só...

L1 - conta pra mim...

L2 - foi em Ubatuba ali... peguei um mar ruim... bastante onda... era pequeno ainda... quase vire $[e] m o[\varnothing]$ a... embarcação... quase $\operatorname{vir}[e] \operatorname{mo}[\varnothing] \ldots$ conseguimo $[\varnothing]$ chegar em terra ainda... só isso aí... porque depois... já pegu[e]mo[ $\varnothing]$ vento... chuva... mais isso aí faz parte né?...

L1 - e você não ficou com medo?

L2 - não

L1 - e você pretende realmente continuar na... na pesca

L2 - até o dia em que vim alguma coisa... legal pra fazer... ( )

L1 - e:.... a pesca... é::... você acha que ela... cê/quanto tempo você tá na pesca?

L2 - uns dez ano

L1 - dez anos JÁ?... e:.... mudou muita coisa em dez anos?

L2 - agota tá mais... não dá/não dá peixe igual antes... antigamente... a gente ia ali... pegar... matava uma bateira dessa aí cheia e vinha embora... hoje tem que ir lá pa... ficar quase o dia todinho... não pega nem a metade da... bateira...

L1 - por quê?

L2 - peixe de sol né?... depois que fechar[ũ] o linguado já... ( )

$\mathrm{L} 1-$ o... o peixe ele tem... época?...

$\mathrm{L} 2$ - tem

L1 - qual é assim?... dos peixes principais... você lembra?...

L2 - só tainha... tainha dá agora no... no inverno... já no verão não dá...

L1 - tem festa da tainha aqui?

$\mathrm{L} 2$ - tem

L1 - como que é a festa da tainha?

L2 - eles vende tainha... recheada assim... assada...

L1 - e tem música?... tem dança?

L2 - tem música... bailão...

L1 - e lá na... no centro histórico de São Francisco... você já foi assistir alguma peça... alguma coisa folclórica?...

L2 - não

L1 - e na sua escola... tem alguma coisa nesse sentido?... Boi de Mamão... Terno de Reis... tem?

L2 - não

L1 - e o que que você tem... você tem educação artística... teve?

L2 - já tive já um tempo... quando estudava aí... no ginásio né?...

L1 - o que que você aprendeu em educação artística por exemplo?

L2 - fazer desenho lá... Boi de Mamão... saci pererê...

L1 - mas nunca fez... nunca organizaram esse tipo de festa na escola? 
L2 - não

L1 - e:.... fora a.... e quais as outras matérias da escola você gosta?... fora a matemática... português... por exemplo?

L2 - não português não

L1 - não vai bem?

L2 - não

L1 - história... geografia...

L2 - história ainda é legal...

L1 - estuda bastante?

L2 - muito muito não

L1 - você aprendeu um pouco sobre a história aqui do município?

L2 - aprendi... só uma base só

L1 - e conta pra mim... eu não conheço... sou de fora...

L2 - os portugues[i] vier[ũ]... e ficaram um monte de gente daí né?... os índios... ganharam a terra... não sei... esqueci... estudei um pouco só

L1 - você conhece muitos portugueses... coisas assim ou não?

L2 - daqui daqui?... aqui não tem muito...

$\mathrm{L} 1$ - tem muito estrangeiro morando aqui?

L2 - tem... eu acho

L1 - ( ) alemão... francês... não?

L2 - não

L1 - e de final de semana aqui... por exemplo... se você quiser... sair pra se divertir... tem o quê?...

L2 - AH... tem o bar pra jogar uma sinuca... só isso...

L1 - bailão?

L2 - a tem... bailão tem... acho que só... coisa boa só... só no verão que tem aí um agito massa...

L1 - e aonde que é melhor pra se divertir... lá no centro o na Enseada?

L2 - na Enseada

L1 - tem muita diferença aqui do número de pessoas do inver/do inverno e do verão?

L2 - tem... no inverno é só::... gente que mora aqui mesmo... no verão já é... turista... que tem casa na praia...

L1 - enche?

L2 - enche

L1 - e aí?... e como fica pra vocês na cidade... aqui é melhor ou pior?

L2 - melhor... tem bastante... gente diferente

L1 - e pra quem trabalha com pesca... é melhor ou é pior?

L2 - é bem melhor né?... melhor não... acho eu verão é só sol...

L1 - peixe vende mais... e seu pai?... seu pai que trabalha na pesca... ele já passou algum susto que ele conta pra vocês... alguma coisa assim?...

L2 - ele falou que já...

L1 - você lembra de algum?

L2 - foi num dia de:.... dia santo... foi pescar... e:.... foi e caiu dentro da canoa... só isso que ele fala...

L1 - não pode pescar em dia... santo né?... AH tá... e você conhece alguém que... já sofreu algum problema na água?... já perdeu algum amigo aí na pesca?...

L2 - não

L1 - e quando você era mais menino... o bairro aqui era diferente?... ou ele

diferente...

LL2 - era bem... bem 
L1 - o que que mudou?

L2 - mudou tudo né?... invadir[ũ] tudo daí...

L1 - só tinha a avenida aqui então?...

L2 - só tinha:: o asfalto que era barro assim... o outro lado era mato... aqui era tudo mato... só tinha... casa... o pedacinho de colégio ali e pronto... bem diferente...

L1 - não tinha... casas pra praia?

L2 - NÃO... era só mato

L1 - e na época do seu pai... como é que teu pai fazia para ir pro centro de São Francisco?

L2 - aí não sei

L1 - por que ônibus... não faz muito tempo que tem... faz?

L2 - acho que ia de bike eu acho... pegava a bike aí...

L1 - às vezes nem isso tinha... e você conhece a história do centro lá?... da cultura açoriana?... ou não?...

L2 - não

L1 - não?... e:.... na sua escola... tem bastante paquera?... como... como que é na sua escola... ela é grande... ela é pequena?... o que que ela oferece... ela tem muitas salas?... como é a sua escola... assim... fisicamente?

L2 - ela é... ela é grande legal né?... tem bastante sala...

L1 - tem biblioteca?

$\mathrm{L} 2$ - tem

L1 - sala de vídeo?

L2 - tem tudo...

L1 - vocês usam bastante?

L2 - não... nós nunca us[e]mo[Ø]... eu estudo a noite né?... eles... os moleque que... usam de tarde... de manhã...

L1 - então você nunca usou sala de vídeo?... nunca viu um vídeo na escola...

L2 - a vi... a vi... só... uma duas vez[i]...

L1 - o que... por exemplo?

L2 - assistimo[ $\varnothing]$ lá uma fita

L1 - e... e a biblioteca?... você usa não?...

L2 - não

L1 - já teve que ler algum livro pra escola?

L2 - já usei já... duas três vez[i] já... peguei uns gibizinho pa ler...

L1 - a professora não pede leitura na escola?

L2 - não

L1 - nunca pediu?

L2 - já pediu mais... hoje em dia é bem difícil...

L1 - por que você acha que não pede?

L2 - não sei...

L1 - se acha que... e inglês... tem inglês?

$\mathrm{L} 2$ - tem

L1 - aprendeu alguma coisa?

L2 - nada

L1 - morre de fome nos Estados Unidos?

L2 - nada...

L1 - e se você pudesse aprender uma outra língua?... aprenderia... uma outra?

L2 - não sei... 
L1 - tem vontade de estudar espanhol... alemão?

L2 - não

L1 - se acha que é útil pra você... por exemplo... estudar inglês na escola?

L2 - não

L1 - por que não aplica?

L2 - muito difícil... falar...

L1 - já viu algum estrangeiro aqui... alguém que fala... só inglês?

L2 - já vi... argentino... no verão... aí eles falam com a gente... nós... ninguém entende nada...

L1 - os argentinos?... e os americanos... já viu algum?

L2 - argentino... americano... os que chega aí a gente nem sabe que tem ((risos)) ( )

L1 - e::... sua família é grande?... quantos irmãos?

L2 - são... três irmão e duas mulhe[ $\varnothing] \ldots$

L1 - sua mãe também é daqui né?

L2 - é

L1 - você sempre trabalhou na pes/na pesca?

L2 - não... eu trabalho na pesca faz quinze anos... eu trabalho com meu pai na lanchonete...

L1 - e como que é trabalhar na pesca?... é bom?... gosta?

L2 - pra mim não tem... serviço melhor... saiu por aí... às vezes vou passear pa... pa Joinville... vou vou... tomar meu (chopp) sabe?... não vejo a hora de vim embora pa ir trabalhar... pa pesca... pra mim não tem... serviço melhor...

L1 - e como que é... um dia de um pescador?... qual que é a sua rotina?... você tem hora pra vim pra cá?...

L2 - não... a gente não tem hora porqu[e]... não tem patrão né?... se a gente tivesse mando aí... na hora que quiser vim vem... na hora que não quiser vim não vem... fica em casa... a pesca é... o melhor da pesca é isso né?...

L1 - não tem hora... e:: como que... nesses quinze anos que você tá na pesca... você tá sentindo diferença na... na produção de peixe?... nesse tipo de coisa ou não?

L2 - AH... isso tem bastante diferença... tem muito barco... barco de firma né?... que trabalha aqui um... mais... aí tá acabando com tudo... cada ano que passa é menos... é muito barco... muito barco indústria... cada ano que passa vai diminuindo a pesca... pra nós que somo[ $\varnothing]$ pescador artesanal fica pior né?... cada ano fica mais fraco...

L1 - por exemplo... vocês são pescadores artesanais... então vocês não têm sonar... esse tipo de coisa... como você sabe que o dia tá bom pra ir pra pesca?... se vai render?... é pelo tempo?... como você sabe?

L2 - o tempo a gente vê pelo... pelo céu né?... quando tá... quando tá ruim da de ver... tá escuro... tá feio né?... e como vai render ninguém sabe... ninguém tem (previsão)... tem que ir né?... depende de tem que ir...

L1 - não tem então uma previsão né?...

L2 - não...

L1 - AH tá... e:: você gosta de morar aqui na Enseada?

L2 - eu gosto

L1 - foi criado aqui praticamente né?... você tá sentindo diferença... de quando você veio pra cá pequenininho pra agora?... a cidade tá crescendo bastante?... ou a cidade sempre foi a mesma?

L2 - não... tá crescendo bastante... mas tá bom ainda... não tá ruim de morar não... 
L1 - tem violência?

L2 - não... não a pouca violência que chega é no verão... é temporada... bastante gente de fora né?... aí vem um pouco de violência... mas agora no inverno não...

L1 - e:: eu vi... que... a... eu não com o/eu não... calmo... conhecia aqui... eu vim pra cá no inverno... e achei a cidade bem vazia né?... muita casa fechada tudo... como que é aqui no verão?... tem muito mais gente?

L2 - no verão é cheio de gente né?... no verão... pa gente andar de carro na estrada é um sufoco danado... tem muito movimento demais...

L1 - aí tem que... botar... e como que ficam assim os serviços... tem restaurante... falta água... falta luz ou não... é normal... só o trânsito...

L2 - não... a luz falta... tem vezes que falta né?... com... com toda a cidade quase toda sempre às vezes né?... mas restaurante tem bastante... bom almoço comida... bom restaurante... é bom...

L1 - e:.... pensando agora ali no centro histórico... ali de São Francisco... você conhece ali?... bem?

L2 - conheço

L1 - sabe a história dali... por que que tem aquelas casas antigas... o que elas representam?...

L2 - daí eu... daí eu não sei...

L1 - não conhece né?... e aqui... é... vo/tem festas folclóricas aqui?... você já foi?... por exemplo tipo... Boi de Mamão... Terno de Reis...

L2 - tem... tem... todo ano tem... tem Boi de Mamão... tem a festa... de São Francisco né?...

Festilha... aí tem... apresentação do Boi de Mamão... Terno de Reis é... é Natal né?

L1 - é

L2 - Natal é... ( ) o pessoal sai... nas casa com...

L1 - mas isso... isso tem lá... em festa assim de dia marcado... ou faz parte da vida de vocês... por exemplo... tem aqui na... na comunidade... no bairro... ou isso é gente de fora que vem apresentar?

L2 - o... o Boi de Mamão... é ( ) tem o pessoal que faz aqui... tem... tem... a festa... como tem a

Festilha eles vão se apresentam... como agora tem a festa aqui no... no (Manguinho)... aqui vem a Julifesta... se ele pedir po pessoal vim se apresentar o pessoal vem se apresenta... entende?

L1 - tá... mas é... então é daqui... e aquele Pão por Deus... ainda tem ou não?... já ouviu falar?...

L2 - não... esse não ouvi falar

L1 - Pau de Fita tem?

L2 - Pau de Fita tem

L1 - e a coloni/a colonização aqui foi principalmente... portuguesa né?... ( ) foi o que eu li em livros... é:.... tem muito português aqui?... tem muito alemão?... qual?... tem muito estrangeiro... ( )

L2 - não tem... poucos... tudo aqui né?... um pouco de cada raça...

L1 - tem um pouco de cada né?... tem alemão... tem francês né?

$\mathrm{L} 2-$ tem

L1 - tem... você conhece a história da... do... do Forte aqui é... que fica aqui perto?

L2 - não

L1 - não?

L2 - falando nisso eu moro aqui faz vinte poucos anos... nunca fui lá... nunca subi lá em cima do Forte...

L1 - NÃO

L2 - não

L1 - NOssa... pensei que você já tinha... subido lá... e você conhece alguma lenda... alguma coisa típica daqui?

L2 - não

L1 - não?... nenhuma história?...

L2 - hum hum... 
L1 - e você que já trabalhou tanto tempo na... tá na pesca já uns bons anos... já passou algum susto aí no mar?...

L2 - já... a gente passa bastante susto né?... passa bastante susto... vai lá... às vez[ $\varnothing] \ldots$ o tempo vira duma hora pra outra... quando é de dia nós da... não tão perigosa... mais ruim é a noite né?... quando chega a parte da noite e a gente tá lá pescando pega um tempo ruim na virada... a virada tempo ruim a noite é

L1 - você já pescou algum assim que te assustou?... aconteceu algum problema no barco?...

L2 - já já... já peguei muita coisa ruim na noite

L1 - já... aí se assustou bastante né?... porque... imagina né?... e tem baleia pra cá... tubarão... esse tipo de coisa?

L2 - P[ea] tem... bal[ea] agora no no no... passou agora... nesse mês que passou é tempo da tainha né?... a gente tá pescando tainha... na na Praia Grande sempre aparece bal[ea]... sempre vê... uma duas três... e tubarão já tá mais escasso né?... tubarão deu muito... o pessoal matava tubarão aqui na beira da praia... mas agora acabou-se...

L1 - não tem mais

L2 - não... tá difícil... acabou-se... tá acabando... cada ano que passa tem menos...

L1 - e pra... e pra estudar aqui... tem escola aqui?... é boa?

L2 - tem... colégio tem... eu estudei aqui até a sexta série... aí depois... caí na pesca não quis mais saber...

L1 - se precisar fazer uma faculdade tem por aqui?

L2 - tem... tem em Joinville faculdade né?...

L1 - AH tá

L2 - aqui não tem... tem em Joinville

$\mathrm{L} 1$ - e o porto... conhece?

L2 - o porto conheço de vista né?...

L1 - grande né?... ( ) fora a pesca aqui... tem muito emprego... tem outras coisas pra trabalhar aqui?

L2 - fora a pesca... o único emprego que tem é... ou é de construção... ou a Petrobrás né?... agora tá saindo... saiu Usinalar... em São Francisco... tá saindo um monte de firma... agora que tá me/tá desenvolvendo mais né?... tá parecendo mais emprego... mas se não fosse isso é só pesca e Petrobrás... ou... serviço de pedreiro né?... construção...

L1 - não tem indústria... esse tipo de coisa...

L2 - agora tá saindo...

L1 - ahn ahn

L2 - saindo em São Francisco por sinal né?... mas antes não tinha não...

L1 - não tinha né?.. e:.... antes né?... São Francissco era a cidade principal aqui... servia tudo pra Joinville... e agora é Joinville que fornece as coisas pra cá... ela que se desenvolveu... por que será que Joinville... ficou tão grande... e... e... a:.... e São Francisco ficou mais tranqüila... não veio tanta indústria pra cá... o que será que é?

L2 - aí eu não sei... aí pode ser... coisa de governo né?...

L1 - gosta de Joinville?

L2 - pa passear é bom... pa passear eu gosto

L1 - e que que Joinville oferece que aqui não oferece?

L2 - hoje em dia... parece que lá tem shoppings... tem... pa você tem lugar bom... pa e muito passear... tem um monte de coisa pa gente fazer... aqui é... a praia é só isso aqui... a única coisa que tem de bom na praia aqui é o verão... que aí tem barzinho com música né?... agora no inverno não... no inverno assim... esse marasmo... essa calmaria... 
L1 - pra se divertir aqui então... que tem pra se fazer aqui... durante o final de semana?... pra você descansar

L2 - no final de semana... pra descansar...

L1 - é

L2 - pra descansar é só ficar em casa

L1 - ((risos))... aí não... então só pra bagunça?...

L2 - pa bagunça aí tem... tem o CTG... tem a festa... do pessoal aí né?...

L1 - tem CTG aí aqui na Enseada?

L2 - tem tem... na Enseada não... quem vai pra São Francisco... na reta... ali tem CTG...

L1 - a tá... e tem barzinho... esse tipo de coisa aqui né?...

L2 - tem barzinho tem

L1 - tá... barzinho... porque cinema e teatro não vem pra... e tem cursos aqui... é... de de inglês?... computação?... pra quem quiser fazer

LL2 - tem tem... aqui na aqui na Enseada me[Ø]mo tem... ali né?...

a informática... tem curso de... de computação... em São Francisco tem o colégio que dá cursos né?... profissionalizantes...

L1 - e quando você... trabalhava com o seu pai né?... seu pai ele... ele sempre... sempre foi comerciante?... ele nunca quis trabalhar na pesca...

L2 - não... nunca quis trabalhar na pesca... toda a vida com lanchonete...

L1 - e você tem irmãos que trabalham na pesca?... ou não?

L2 - eu tenho um irmão que trabalha não... trabalhava na pesca comigo... mas agora tá também na Petrobrás...

L1 - mas pra... pra trabalhar lá eles chamam muita gente da pesca aqui?... ou tem que... tem uma diferença?

L2 - não... e pa chamar lá... pessoal que trabalha lá só... a não ser quando dá um vazamento... uma coisa aí... que esque/p[i]cisa o pessoal da pesca... ainda vamo[ $\varnothing]$ dá um auxílio pra ele...

L1 - e aconteceu algum vazamento?... alguma coisa por aqui?

L2 - já já... sempre acontece... quase sempre acontece...

L1 - e aí o povo tem que correr pra...

L2 - aí eles vem... chamam... coloca a gente no triforno... no/chamam... aí a gente vai dá um auxílio pra eles...

L1 - mas já chegou assim a manchar praia?... coisa aqui...

L2 - não... mancha lá fora só... só na monobóia mancha né?...

L1 - é muito... é muito longe aí?... da....

L2 - daqui na monobóia de barco... dá quarenta minutos...

L1 - é onde é a estação então de...

L2 - não... aonde o navio descarrega petróleo né?... tem a monobóia... é uma... uma bóia grandona redonda... ela descarrega petróleo ali... aí às vez[i] com tempo ruim estoura um mangote... uma coisa... só que aí estourou já tem um... já tem um... chamam de... liqueide... uma válvula que... estourou mangote aquilo se fecha sozinha... aí pára de vazar...

L1 - AH tá... e é... é grande?... eu não conheço... onde que fica a... a...

L2 - a monobóia fica ao pé desse morro aqui...

L1 - ahn ahn... e a Pe/Petrobrás fica aonde?

L2 - a Petrobrás é no fi/final da... aqui é o terminal deles né?

L1 - ahn ahn

L2 - e a Petrobrás mesmo aqui atrás... onde tem os tanques... lá pa trás

Ł L1 - não vi não vi... 
L1 - o senhor foi nascido e criado aqui?

L2 - isso... nasci e me criei aqui...

L1 - e qual é o seu nome... conta um pouquinho pra mim da sua família...

L2 - minha família e meu nome?... meu nome é M.F.C.... sou casado... tenho uma filha... G.... minha esposa L. ... meus pais são daqui né?... quer dizer... minha mãe não é daqui... minha mãe é de Itajaí... de Armação... praticamente... meu pai é daqui... fui criado aqui... a vida toda aqui né?... sou mergulhador profissional... trabalho na área da Petrobrás... criado direto na água... praticamente dentro da água... pescando... com meus pais... meu pai praticamente... pescava antigamente... ( ) moro aqui... não:.... saí pra fora pra trabalhar... mas acabei voltando pra cá... pra área da Petrobrás mergulho... voltei... tá aqui hoje e amanhã já não tá...né?... trabalhei... em Itajaí e tal... faço um serviço por fora e::....

L1 - e:: como é essa vida de trabalhar de mergulhador... como o senhor entrou nessa área?

L2 - (foi é::) isso já é uma paixão né? isso aí já vem de... quando eu era pequeno eu via o pessoal mergulhar aí... sair... eu ficava vi/vidrado... ficava impressionado... como é que pode os cara ir pro fundo do mar e... e ficava... aí comecei gostar e fui fazer o curso de modelo... aí passei... tô trabalhando até hoje né?

L1 - e como que era a cidade aqui? o senhor sempre morou nessa parte aqui nessa parte da Enseada?

L2 - sempre morei aqui nesse mesmo local... aqui na... frente a peixaria ali... e como que era bem diferente... pra você chegar na praia ali... na Avenida Atlântica... tinha que andar... ( ) andar uns cinco minutos pra chegar no mar... hoje você desce na praia ali tá na água já...

L1 - tinha mais areia então?

L2 - tinha bem mais areia... vem mais assoriado... e pra cá... era tudo... não tinha mais nada... aqui era tudo mangue... aqui era só... aqui era... isso aqui era areia aqui $\mathrm{OH}:$ :... ((aponta para os locais)) não tinha... não tinha asfalto né?... aqui na frente era só cabaninha de pescador só... pescadores... só vinte anos atrás pra cá era tudo mangue e:: não tinha nada... não tinha mais nada...

L1 - e o senhor tem idéia de quantos habitantes tinha aqui?... vinte anos atrás?

L2 - daí eu não tenho idéia... de vinte anos atrás não...

L1 - mas cresceu muito então?

$\mathrm{L}$ L2 - cresceu muito mais

L L1 - dá pra dizer que cresceu umas dez vezes...

L2 - de quinze vinte anos pra cá... meu Deus... cresceu... e:.... cresceu e cada vez cresce mais né?

L1 - e escola... tinha escola aqui?...

L2 - tinha... sempre teve escola... ahn... quinze pra trinta anos atrás meu pai fala/meu pai sempre falou que aqui ele... ele estudou até a quarta série até... até a quarta série primária... depois tinha que ir pra São Francisco... e na minha época já teve... só o ginásio... segundo grau também só em São Francisco... hoje tem segundo grau aqui... tem tudo já né?... posto médico tudo... hoje tá bom pra viver aqui pra morar né?... antigamente era:: não era:.... não tinha um posto de saúde... não tinha nada... era um banco né?... hoje você já tem banco... tá tá tá precário ainda mais tem que... tem que melhorar bem mais agora... mas pronto socorro tem... o atendimento é bom... bombeiro... tá crescendo é:... tá acompanhando né?... o lugar tá crescendo e o pessoal tá né?... investindo aqui... tão... a prefeitura também tem que investir mais aqui também eu acho... tá faltando... ahn:.... tão deixando a desejar é o:: o prefeito aqui... entra um sai outro e a Enseada eles vão... vão deixando... L1 - e::... e as tradições assim? porque lá no centro né? eu fiquei sabendo da Festilha... de festas 
L2 - é por exemplo como o Boi de Mamão... é comum aqui... tinha antes... morreu...

L1 - o senhor conhece uma dessas festas?

L2 - é isso aí desde que eu me/me conheço por gente já... já existe isso aí... ( ) até hoje... Boi de Mamão... é... ( ) a Dança do Vilão... é:.... o:.... o pessoal sai na rua pra cantar reis né?... dança dos Reis... tinha bastante coisa aí... agora... não recordo bem aí...

L1 - mas ainda tem... é::....

L L2 - não... ainda tem... mas não é que nem antigamente né?... antigamente o pessoal levava mais a sério...hoje já tá mais... agora tá mais relaxado já... mas sempre tem... na época da Festilha... aqui... aqui na Enseada que eu tô falando... aqui eles vão deixando mais de lado... que aqui tinha a Fenapesca né?... a festa da:.... tipo... a festa da tainha... tinha no bar do Mário... acabou... as coisa... o pessoal vão... sei lá...

L1 - vai deixando

L2 - vai deixando... o negócio não era pra perder né?... continua aqui a tradição depois aí... chama mais o povo aqui... agora é férias de julho né?... não tem nada aí... não tem...

L1 - tá bem vazia a cidade né?

L $\mathrm{L} 2$ - pois é...

$\mathrm{L} 1$ - bem vazia... e:.....

L L2 - só no verão que enche... no verão isso aqui é uma loucura né?

L1 - não deve dar para andar né?...

L2 - verão...

L1 - e como que fica a cidade no verão?... tem infra-estrutura pra tanto turista... ou não?...

L2 - Olha... fica complicado no verão também... chega até/s vez chega a faltar água né?... o esgoto... aqui também nós estamos... no esgoto... uma uma uma rede de esgoto aí... tem que melhorar essa... tem que fazer né? não sei né? uma rede de esgoto boa né?... como é que eu vou te dizer ehn... saneamento básico né?

L1 - básico...

L2 - falta muita coisa... no verão mesmo... se der uma temporada boa de sol mesmo... aí o bicho pega... falta água... aí a praia aí até ( ) contamina a água do mar aí...

L1 - aí não dá né?... e a pesca... ainda se vive da pesca como se vivia antigamente... o mar ainda é o mesmo...

L2 - não... isso aí vai se acabando né?... pesca artesanal mesmo... tá... tá se acabando... hoje em dia quem sobrevive da pesca são os barco pesqueiro... que pesca aí fora... porque aqui... a pesca artesanal aqui já já era... o pescador... ( ) o tipo da tainha... che/tamo[ $\varnothing]$ na época da tainha... esse ano deu uma::... foi uma época boa né?...

L1 - qual é a época da tainha?

L2 - mês de maio junho e julho né?... final de maio até... meado de julho... até essa época agora... esse ano deu bem... ano passado já deu menos... então... mas tá complicado... a pesca mesmo... só pra poder viver né?... não... (quem queria um barco)... melhorar o seu barco né?... melhorar sua casa... fica lá estacionado... aí fica... mete em dívida com com... fornecedores né?... pega dinheiro... depois vai ter que pagar com peixe e não consegue... fica preso né?... fica preso aquele negócio ali... antigamente não... antigamente os pescadores enterrava o peixe na praia... de tanto peixe que tinha... não tinha pra quem dar... quem vender... enterrava... fica ali a fora...

L1 - só ficando aqui

$$
\begin{aligned}
& \mathrm{L} L 2 \text { - só aqui é:: } \\
& \qquad \mathrm{L} \text { L1 - aqui no rasinho... }
\end{aligned}
$$

L2 - é:: é... só aqui... hoje é... arrastão de praia aqui... quando eu era pequeno... eu acompanhava isso aí... até ia junto... voltava... hoje em dia não tem 
mais... o peixe não vem mais na beira da praia... o pescad[o] tem que ir lá fora... cada vez mais fora pra... pra buscar o peixe... com isso aí com o tempo vai se acabando né?... vai acabando...

L1 - que outros peixes se pescam... aqui... ou a pesca é uma coisa que pára um tempo... como que é?...

L2 - é... aqui tem a festa da tainha que é... todo ano né?... só de junho/maio junho julho... é dois meses de pesca... depois tem a corvina... tem o linguado... que é tudo peixe de época também né?... tá naquela época de setembro... agora é época do linguado tal... depois vem a corvina... o cação... só que... isso aí reduziu pra caramba né?... antigamente os pescad[o] ia pra fora... vinha... com a canoa cheia... com barco cheio... hoje um... com duas três caixa de peixe... peixe de malha sete caiu bastante... camarão...

L1 - o que é peixe de malha sete?... porque eu nem sei o que é... ((risos))

L2 - ((risos))... peixe miúdo né?... pescadinha... betara... peixinho pequeno assim

L L1 - ahn... tá

L2 - peixe menores né?... peixe maiores não... agora peixe pequeno e o grande tá... tão... tá difícil... o que... o que salva o pescad[o] aqui mesmo... é tipo a época da tainha... a caça do camarão também... eles consegue arrumar um dinheirinho... fora disso aí...

L1 - e:.... pensando aqui na colonização... do do... da região... da Enseada... ela foi muito depois de São Francisco ou não?... São Francisco ali no centro...

L2 - sei...

L1 - ou sempre teve gente morando pra cá... ou isso aqui é uma coisa nova?

L2 - NÃO... sempre teve né?... sempre teve... era bem pouco né?... São Francisco era mais... mais sempre pescador aqui... sempre... era mais (colônia) de pescadores né?... depois começou a vim gente de fora aí... os turista... começaram... um lugar muito bonito...

L1 - realmente

L2 - começaram a invadir terra... aí... ( ) o negócio tá crescendo cada vez mais ligeiro... parece que só vai crescer pra cima agora... porque por baixo não tem mais onde crescer... já tão começando fazer prédio... isso aqui futuramente vai ser um balneário de Camboriú da vida...

L1 - nossa... o senhor acha / vai ficar grande então

L2 - vai... tem... temos qualidade de vida aqui... tipo a nossa praia aqui... as praias aqui são boas... as águas né?... calmas... tem a praia pra... como é que é... surfar... tem a praia dos surfistas... se quer pescar tem a Praia Grande... quer levar seu filho tem a praia de Enseada... Ubatuba... mais agitada... Itaguaçu... tem praia pra tudo quanto é gosto... pra esporte... pra surfar... pra andar de caiaque... pra correr onda... pra mergulhar... pra nadar... e a água aqui sempre foi clara né?... não foi poluída... no verão que dá uma... uma sujeirinha aqui... muita gente... depois... mas isso aí... nunca deixou de... nunca atrapalhou né? o turismo aqui...

L1 - eles fazem muita propaganda aqui da região... ou os turistas chegaram aqui por indicação...

L2 - foi mais por indicação porque propaganda... tá... tá bem precária também... tá bem... deixa a desejar também... lugar bonito como esse aqui... o pessoal... acho que devia ter mais propaganda... ser mais divulgado... o nome daqui da praia né?... falam mais de São Francisco tal... mais... esqueci da da praia de Enseada... ou então... tem

já chega...

L L1 - lá não tem praia né? ( ) lá não... o mar

L2 - pois é...

$\mathrm{L} 1$ - direto

L1 - é baía

L L2 - lá é baía né?

L2 - é o porto... o que movimenta São Francisco é porto né? 
L1 - o porto... o senhor conhece... já trabalhou ( )

L2- -já trabalhei no porto já... porto... então... ali é uma fábrica de dinheiro né?... só que... sei lá... tá aumentando o porto também... agora veio a Usinove pra cá também... o negócio tá... a Usinove veio pra cá... essa Weg do Sul... ( ) aqui na Enseada... principalmente... tá morando bastante gente que trabalha lá... fica lá...

L1 - de onde que é essa empresa?

L2 - essa empresa é da França

L1 - da França?

L2 - ahn

L1 - tem muito francês então pra cá... ou não...

L2 - veio... veio francês... pessoal de fora né?... daqui também... tá dando emprego pro pessoal daqui... mais... mais é pessoal de fora né? traziam pessoal pra ficar já né?... de repente tão qualificando alguém pra trabalhar... mas... vem muita gente de fora aí... tão morando aí... tem pessoal do Rio de Janeiro... que... mora... são vizinho meu... aqui... muita gente de fora aí...

L1 - são poucas as... eu::eu:.... tava conversando com ele... com o T. ... são poucas as pessoas nas/foram nascidas e criadas aqui assim em São Francisco...

L2 - é::... são poucas hoje...

L1 - muita de fora...

L2 - muita gente de fora... pra você ver... o... praticamente... eu... saiu por aí por... antigamente... não... dez quinze anos atrás aqui... eu conhecia todo mundo aqui... hoje já não conheço quase ninguém aqui... a maioria de fora... sério... conhece uns amigo assim... os que for[u] criado... mais muito já saíram daqui... for[u] morar em outra cidades né?... e daqui... por... você... pra você morar aqui... você tem que ter o que... tem que ter um serviço... tem que trabalhar aqui... pra trabalhar você vai trabalhar aonde... (tem a) Petrobrás... aí em São Francisco tem o porto... tem as agências né?... prefeitura... viver da pesca tá... tá...tá difícil... tão... não sei... a pessoa tem/que quer tem um... quer se alguém na vida... tem que sair daqui senão...

L1 - tem universidade... por aqui...

L2 - Joinville só né?... São Francisco... agora até... acho no Iperoba... tão trazendo... aqui pra cá... acho... que esse ano aqui só...

L1 - ainda não começou então...

L2 - ainda não começou então...

L1 - então pra fazer nível superior tem que sair daqui...

L2 - tem que sair daqui é... no caso da minha esposa... tá... tá fazendo faculdade de informática... Joinville... ela tem que sair cinco hora da manhã daqui...

L1 - nossa

L2 - chega uma hora da tarde...

L1 - e:: faz uma viagem hein?...

L2 - é:: complicado...

L1 - é uma viagem...

L2 - isso aí é gasto... despesa e força de vontade também né?

L1 - e é muito longe daqui em Joinville... assim... vai de ônibus... vai de ônibus... vai de carro...

L2 - é vai de ônibus é... tem o ônibus... que a prefeitura ajuda parece aí... vai com... uma porcentagem aí... com... daqui a Joinville dá o que... sessenta quilômetros... mais ou menos...

L1 - sessenta né?... e e a história... ali da colonização... muitos falam... uns falam... que foi colonizado por português... outros por francês... aí tem aquela briga toda ali... é:.... como que é... o senhor sabe alguma coisa sobre isso... ali de São Francisco... um pouco da história... ou não?

L2 - eu não acompanho muito não... que falam... português né? 
L1 - açorianos...

L2 - açorianos é... agora... quem vai saber?

L1 - quem vai saber...

L2 - eu não acompanho muito essa história...

$\mathrm{L} 1$ - e aqui tem jornal... tem canal de tv... daqui próprio... como que é?

L2 - não... jornal nem tv nada... jornalzinho tem aí o pessoal aí que... tem um senhor aí que fez um jornalzinho aí... mais é só pra criticar São Chico e mostrar o que é errado... tem a Notícia que é de Joinville... vem tudo de Joinville pra cá... televisão também... só de Joinville... Joinville... Santa Catarina... cidade de maior população de Santa Catarina em número de habitantes é Joinville né?

L1 - maior que Florianópolis?

L2 - é... maior do que a capital... em habitantes... por número de habitantes... por número de habitantes por pessoa

$\mathrm{L}$ L1 - porque será que Joinville... porque lá é mais nova... não é?

L2 - é... Joinville é bem mais nova...

L1 - por que será que que lá foi... desenvolvido né?

L2 - desenvolveu tudo... fábricas... indústrias... essas coisas... malharia... pra cá... Joinville... São Chico... pra cá... agora ver... São Chico tem quinhentos anos... agora que tá começando a... depois de quinhentos anos... que isso aí contam o pessoal contam uma história aí que... foi um padre que rogou uma praga né?... que... São Chico só ia andar depois de quinhentos anos... soltar[ũ] / amarrar[ũ] o padre né?.. botar[ũ] numa canoa com/com um pratinho... uma cambuquinha... com assim... um pouquinho de farinha e água... sei lá... e pão... e soltar[ũ] ele... ele foi lá pra Vila da Glória... atravessou lá... não sei direito essa história aí... ele parece que... parece que olhou pra São Francisco e rogou uma praga... São Chico só ia pra frente depois de quinhentos anos... ((risos)) L1 - quinhentos anos tá fazendo agora... ainda bem né?... ainda bem...

L L2 - pois é... não sei direito essa história aí... mais é... mais ou menos isso aí L1 - é bom... é bom saber...

\section{A. A. P. (L2)}

3B

L2 - então... como eu tava falando... desenvolvi e tal... com a participação da Unesco.. tivemos há um mês atrás na região (na região)... em final de maio... dois arquitetos ou seja... unidade Central de Gerenciamento... fica dentro do do... do Ministério da Cultura que é o Programa Monumento... que hoje... ( ) é da Unesco ( )... aqui no terceiro parágrafo ali já é como aquilo que eu comentei com relação assim... ao fundo né?... recuperação sustentável né?

L1 - eu como... como visitante... eu ( ) não me esqueço... apesar de não ser nascida aqui... morar em São Paulo... minha mãe é catarinense ali da Penha... e lá tenho muita família... toda família né?... venho sempre... e:: vim semana passada... então o primeiro dia foi só pra... conhecer esta cidade... fui ao Museu Histórico... ao Museu do Mar... à biblioteca... ao Mercado... andei aqui na Baía da Babitonga... andei de escuna... fui até o outro lado... voltei ( ) né?... fui ali à Secretaria de Turismo... e uma coisa que te falo... como turista... é a necessidade de um posto de informações... um lugar em que pudesse pegar um folheto... um mapinha da cidade... porque fica meio perdido ( ) aí

L2 - um guia...

L1 - um guia... como me localizar muito bem né?... então... ( ) 
L2 - a Secretaria de Turismo tem algumas informações né?... a Associação Comercial... ( )... a gente porque recebe muito... tem alguma coisa aqui... é:... é... mas é uma cidade carente em muitos aspecto... não só dá folheteria pra pessoa...

L1 - não não é:: é pedir informações... por exemplo

L2 - é... é... orientação

L1 - é orientação... realmente

L L2 - quem tá desenvolvendo... criando ali um... um... torque... sabe né?... o torque é é é... é uma idéia que foi lançada pro... IPHAN... o IPHAN... aprovou a idéia... mesmo havendo... um um... uma normalização associada entre a Associação Turística... pela Embratur... IPHAN... e o... e o... ETRAN... CONATRAN se não me engano... existe um manual que:.... uma cartilha com modelos de procedimento de cor... de tipo de letra... tudo isso... só que a gente procurou desenvolver alguma coisa aqui... é:: mais focada na nos/na nossa diversidade... além de ter a... a... atividade orientativa... teria aqui que procurar divulgar o que é o monumento ali local... e pro turista principalmente... então a idéia seria colocar... alguns torques em lugar estratégico... sem agredir algum aspecto... uma foto... alguma coisa... pra que as pessoas pudessem chegar ali e encontrar... informações orientativas... pra onde seguir né?... e ali ter uma foto... mais ou menos daquele local como era antes... eu vou the mostrar umas imagens ((mostra slides com fotos antigas da cidade enquanto nós conversamos)) e você vai dizer... "pô... como é que a pessoa vai saber?"... só tendo essas imagens ali... pra... ( ) as obras ali embaixo... eu já relacionaei pra você né?... alguns dados... valores... o total... nós fizemos agora em... em junho... o novo aditivo... uma solicitação... em Brasília... política econômica do governo federal... um aditivo de prazo... ano passado nós fizemos em junho de dois mil e três... um ano atrás... fizemos um aditivo de valor... nosso convênio aqui era de seis milhões e alguma coisa... e foi pra oito... houve um acréscimo de dois milhões a nível de convênio... a nível de valor... e agora houve um aditivo... de... prazo... que se estendeu até dois mil e seis... então todas essas noções que estavam em princípio né?... voltadas até final de dois mil e quatro elas foram redistribuídas né?... a localização né?... imagem do satélite né?... pra você ter uma idéia... Paranaguá... Curitiba... a nível de Estado... a esquerda... o mapa de Santa Catarina... todo o litoral... e a Ilha de São Francisco... aí a localização do município... o grande diferencial a nível de de de:: de programa... o programa veio somar uma série de outros que tão acontecendo... coincidência delas... essas da Weg do Sul... incremento ENORme na movimentação do porto... e isso... tem um reflexo direto na economia da cidade... e a idéia de que São Francisco... principalmente o Centro Histórico... se torne um centro regional de lazer... então por isso mais do que nunca assim... a... a vontade de que aconteça um Monumento aqui ((Projeto de Preservação Arquitetônica do Governo Federal)) né?... São Francisco... se você for ver... ele... aqui... ele ele... é um... a parte dele é um... um... num raio de quinhentos quilômetros né?... você::... é... tem assim um um:.... uma potencialidade turística enorme né?... você pega São Paulo... num raio menor... você... você pega num raio menor... duzentos quilômetros... duzentos quilômetros... você pega Curitiba... que é... você sai de lá numa sexta-feira... uma hora e meia... pista dupla... você tá aqui...

L1 - sem pedágio...

L2 - é verdade né?... mas Curitiba... por exemplo... outra cidade próximas... do Paraná... é:: aqui de Santa Catarina... Florianópolis... Blumenau... Jaraguá... Joinville... São Bento... ver... todo o litoral... tem a possibilidade das pessoas... num fim de semana ( ) porque ela não é só histórica... ela tem essa parte histórica e também oferece praias belíssimas... então... é uma questão de juntar o útil ao agradável... você pode vir... sábado de manhã... você tem... faz um passeio aqui... ser tiver um teatro... museus... teatro que foi inaugurado agora

L1 - pode fazer um passeio cultural

L L2 - justamente... agora... as praias... por isso... em dezembro... de dezembro a março... as praias por si só já... elas já são um apelo turístico né?... elas conseguem 
aqui... você vê... em... no pico ali de dezembro... na virada do ano... a cidade que tem oficialmente trinta e dois mil habitantes... que censo de dois mil... oficialmente tem trinta e dois mil... mas na época do verão chega a cento e cinqüenta... no pico do verão... carnaval... e virada do ano... são os dois picos maiores... principalmente a virada do ano ali né?... a região toda aqui é uma ci/uma região muito industrializada... desde São Bento... Jaraguá... Joinville... eles promovem férias coletivas né?... as pessoas vêm... depois do Natal... e ficam aí dez... quinze vinte dias na praia... alugam muitos têm residência... então... as praias se transformam... ( ) agora... o que se tem sentido... de outubro... nas pesquisas... eu por exemplo que moro aqui no Centro... a gente sentiu que deu um aumento... do fim do ano... no meio também... fora da temporada... mês de junho... festival de dança de Joinville tem reflexos aqui... ( ) as pessoas... o barco Príncipe... diariamente vem de Joinville... pára aqui no Centro... as pessoas saem... visitam... inclusive vêm em casais... voltam depois com suas famílias... o que é aquela propaganda apesar:.... que a gente ainda sente... tem consciência dessa car/dessa sinalização... ( ) não...

L1 - é porque uo:.... fui destinada pra cá... pra trabalhar... apesar de ter família em Santa Catarina... vir pra cá desde criança... conhecer Florianópolis... Jaraguá... São Bento... Blumenau... eu nunca tinha ouvido... detalhes sobre São Francisco... passava... via a placa... mas

L2 - não tinha te chamado atenção...

L1 - de praia né?... é uma cidade que tem o litoral bonito... como todo o litoral catarinense é bonito... e eu fiquei surpresíssima quando comecei a trabalhar na faculdade com isso... com mapa... história... nossa né?... quando eu cheguei aqui no primeiro dia "tô em Ouro Preto"... não acredito... minha mãe ficou estupefata... Amábile... que é tão assim... por exemplo... Penha tem uma tradição açoriana... carrega muitas tradições... mas do ponto de vista arquitetônico não há... não há um conjunto... não ficou algo físico mesmo... e aqui a gente pára ali na esquina... olha pra cá... volta duzentos anos no tempo... voltei na história

L L2 - é é...

L1 - como que eu não sabia disso antes?... liguei pro meu orientador... já que sou aluna de Mestrado também... a cidade é um espetáculo... belíssima... vale a pena a visita... tô planejando passar o carnaval... que parece ser um carnaval gostoso... porque...

L2 - que ver... carnaval aqui é muito bom ( )

\section{L1 - eu já tô apaixonada já...}

L2 - tem... tem nas praias... que é durante o dia... mas a noite é aqui... salão... Cruzeiro... que é aqui no aterro... a prefeitura promove um baile público... só que o baile... só de noite né?... madrugada... existe o carnaval desfile... do bloco Sujo... e as escolas de samba e tal... é bem movimentado... mas o o... o que você tá falando e algo que tá me lembrando muito assim no início... do programa... cada consulta... aí eu tava envolvido diretamente no programa... depois eu continuei no planejamento... mas em dois mil e um nós tivemos aqui um... um grupo de consultores que foram enviados pela... Monumento do Ministério da Cultura... então era mais pessoa de São Paulo... era era:.... dois colunistas e um arquiteto... duas pessoas... um dos colunistas e esse arquiteto tinha trabalhado naquele... memorial da América Latina... bom... pessoas mais do que qualquer uma envolvidas...

L1 - na cultura...

L2 - justamente... e aí... é::... esse arquiteto... tinha combinado de sair com ele à noite.. aí nós fomos no centro de táxi... é longe... mas de carro é muita gente... então fomos lá... olharmos... enfim... todo o limite do Centro Histórico... principalmente na região da orla... fomos nos baile... ele não falava... ele olhava... sacudia a cabeça... pensava... esse cara tá...

L1 - com problema ((risos))

L2 - "mas o que que tá acontecendo?"... "não não não acredito"...

L1 - o mesmo que eu 
L2 - assim "eu não acredito... não acredito"... nós sentamo[ $\varnothing]$ no bar ali... ele sacudia a cabeça... sabe... eu achei que no início era uma brincadeira... mas foi insistindo... e ficou... aquele troço tão... aí ele foi embora na sexta... pegou o avião em São Paulo... eles for[ũ] né?... aí no sábado à tarde... tava lá no meu escritório... moro aqui perto... tenho um escritório ( )... e aí.. ele me liga... sábado à tarde no meu celular... ( ) C.... tá tal tal... achei curioso de ele me ligar né?... nós só tínhamos convivido três dias... eu nunca... eu nunca tive amizade... legal... C. me ligou... "olha A. você sabe"... ( ) e ele é muito gozador né?... "mas o quê?"... "eu já liguei pra umas dez pessoas amigas... das do meio... todas arquiteto... metidos aqui com tudo aqui é coisa... e aí algumas que sabiam que eu tinha ido pra lá me perguntaram como é que tinha sido a viagem... mas a maioria nem sabia que eu tinha viajado... aí eu pergunto pra elas se elas já tinham ouvido falar em São Francisco do Sul... daí todas sem exceção disse que não... aí eu digo de boca cheia... como vocês são ignorantes"... ((risos))

L1 - ((risos))

L2 - ele me ligando pra falar isso... "como vocês são ignorantes"... daí ele começa a contar coisas... pinceladas... falar até do Saí... Vila da Glória...

L1 - eu fui... eu fui

L L2 - mas fala da história... ( ) que aí foi um médico francês que foi... fundador do... do primeiro hospital pré-pago do Brasil... existe até hoje no Rio de Janeiro.. são coisas assim que ele... essas pinceladas... ele saiu daqui maravilhado né?... aí ele me liga pra me falar isso... quer de/uma pessoa que mais do que qualquer outra né?... que não deveria ter obrigação de saber... mas ele... uma pessoa que trabalha dez anos no Memorial da América Latina... não é um arquiteto... vamo $[\varnothing]$ dizer de projeto... é um arquiteto que trabalha a história...

L1 - estuda né?

L2 - aí o cara disse que nunca tinha ouvido falar em São Francisco... que no caso esteve em dois mil e um... e que em dois mil e quatro ia comemorar quinhentos anos... ( ) a terceira mais antiga do Brasil... ( ) quando ele me liga pra me falar isso... aí eu até eu acredito que... realmente durante esses dias que ele andava sacudindo a cabeça... ele... aí eu eu vi que ele não tava de sacanagem... já que teve o trabalho de me ligar pra falar isso né?

L1 - como que é morar aqui em São Francisco do Sul?... é bom?... é tranqüilo?

L2 - tranqüilo... muito tranqüilo

L1 - o que a cidade assim... oferece... que a senhora acha que é mais bacana aqui na cidade... em matéria de diversão ( )...

L2 - uma parte de:.... de... as... as festas né?... festas em abril... tem a Festilha... né?... que é uma festa grande... que envolvi a cidade toda né?... e.:... só... também as festas religiosas... que aqui é uma coisa... muito... tem essas raízes... muito FORtes ainda né?... e... outra... e agora o ci/o cine teatro $\operatorname{tam}[\varnothing]$ ém que tá funcionando... já tá funcionando... teve algumas apresentações né?... a cidade também gira em / em torno disso... e no... na época de... do verão né?... o movimento na praia... o show...

L1 - a senhora podia detalhar pra mim um pouquinho mais sobre a Festilha?... o que é?... qual o objetivo?... ( )

L2 - Festilha é festa das tradições da Ilha né?... então essa Festilha é a... a gastronomia é toda da região... a daí é onde é onde... há as apresentações folclóricas né?... Pau de Fita... Boi de Mamão... é as Pastorinhas... é... tem outras apresentações também... ( ) né?... no caso são vários... vários dias... e::... o pessoal... há bastante participação... aí da comunidade nessa festa né?... das tradições né?... 
L1 - e essas tradições como o Boi de Mamão... o Pau de Fita... elas ainda tão... elas tão vivas na comunidade?... a senhora sente isso?... ou é mais uma coisa mesmo já de grupo folclórico?

L2 - mais... relacionado com os grupos folclóricos... tá se tentando... fazer um trabalho com as escolas pra resgatar... né?... mas... ainda mas assim é... um determinado período em que elas pede pra... organizar os grupos pra fazer apresentação... a comunidade mais a faculdade ( ) deixa o grupo já definido né?... todo ano tem aqueles mesmos grupos que... se apresentam...

L1 - a senhora conhece algum aqui em São Francisco?...

L2 - é::

L1 - ou numa praia... algum local que eu podia encontrá-los?

L2 - é:: Morro Grande... a comunidade de Morro Grande... onde tem o Boi de Mamão... tem o... a dança do Pau de Fita... e o:.... a Dança do Vilão também né?... a Dança do Vilão... acho que são essas três que tem... lá... isso já é formado pra trabalhar na apresentação...

L1 - e o Pão por Deus?... tem ainda aqui?

L2 - AH... tem alguma... tem também uma comunidade... sei de uma escola que tá... programando pra fazer na... na festas... aqui no final do mês... de agosto né?... quer trabalhar com o Pão por Deus daí... mas não é uma coisa que a gente tam[ $\varnothing]$ ém esteja sempre puxando nas escola tá?... fica mais restrita... a... a uma determinada época né?...

L1 - e aqui... em relação a história?... aqui é é um município muito rico de história... é muito antigo né?

L2 - uhn uhn

L1 - é... as crianças vêem isso na escola?... o:... tá presente ou não tá presente?

L2 - não... não muito como deveria né?... mesmo eu acho... porque assim $\mathrm{OH} . .$. tem professor... que muitos professores que não são da... da... da região também... são de fora né?... e daí... ele às vezes não tá preparado pra contar... não conhece a história né?... é::... nesse ano... é no início do ano a gente recebeu um livro... mais... de uma professora inclusive... daí todos os alunos receberam... os professores... contando a história de uma forma assim mais didática... pedagógica né?... um livro assim dá pra trabalhar na escola... bem interessante o livro da... daí tá tá se policiando (pra usar)...

L1 - e::... resumidamente... a senhora poderia me contra alguma coisa sobre a história de São Francisco?... quais os principais pontos (pra conhecer...)... por que aquele centro dela é todo tombado né?...

L2 - sim... é:.... tem... tem muita lenda né?... em torno também da... da própria história né?... então tem coisas assim que ficam meio... obscuras.. e (não sei) entendi se faz parte realmente da história... ou se são lendas né?... é... e eu... e eu assim oh... eu conheci mais na história... um/muito mais agora quando eu me tornei adulta... com conhecimento... com educação... do que... no tempo que eu era criança... adolescente... a gente não ouvia falar... ouvia muito falar das lendas... que as pessoas contavam... mas não da da da história propriamente dita né?... e:.... eu acho bastante intrigante aquela história do... do padre né?... que se amarra... que o bispo colocaram ele na... na canoa e ele::... jogou uma praga ( ) aqui em São Francisco... que São Francisco não iria progredir enquanto... esse padre... não não... há uma controvérsia nessa história né?... então que a gente não sabe... assim... nem eu sei bem ao certo o que que aconteceu né?... dizem que era um piRAta... outros dizem que era... que era um padre... então não ficou muito clara né?... essa parte da história... L1 - e::... em relação a... as lendas assim... tem mais alguma que marque assim a história de São Francisco... ( ) em relação aos portugueses... por exemplo... aos açorianos né?... todo aquele centro a fachada... do século dezoito... açoriano... tem alguma coisa que envolva os portugueses?

L L2 - que envolva os portugueses?... que eu lembre não...

L1 - tem muito aqui?... falando como/como moradora... como uma pessoa da comunidade... que eu sei que a senhora é diretora

L L2 - sim o quê? 
L1 - tem muitos portugueses?

L1 - que a cultura deles tá...

\section{L2 - portugueses?}

L2 - eu acredito que não... pelo menos eu não sinto isso... eu acredito que não... não tem essa convivência assim... não tem... não tem convivência e não vejo que tenha tanta influência assim... L1 - alemão... em maior número ou não?... franceses... por que aquele outro lado né?... da baía da Babitonga... ( ) é tida como comunidade dos franceses...

L2 - dos franceses...

L1 - isso pra senhora é procedente?...

L2 - é::... acredito que não... pelo menos a gente que mora aqui sempre sempre... morou sempre aqui... não vê dessa forma... que tem tanta influência assim... uma coisa que ficou bem... de repente não foi resgatado realmente né?... esquecido né?... agora que tá sendo né?... resgatado... de repente daqui pra frente a gente percebe que há... mas por enquanto... eu não sinto isso...

L1 - e aquele... e o Forte?... a senhora conhece a história do Forte... que ali também tem uma... história toda né?...

L2 - a história realmente ali eu não conheço... não conheço muita coisa não... bem pouco falado também... agora já tem um restaurante lá... de aparência ( )... tá muito mais bonito né?... ( ) da história mesmo... porque assim... não tenho... (não sei) muito não

L1 - e daquele?... eu não sei se é um hospital ou se é um leprosário... fica no morro... isso é... isso é verdadeiro?... existiu mesmo?... ou é só lenda que as pessoas contam?

L2 - eu também eu também fico na dúvida... que é uma lenda realment[S]e... ( ) nunca vi quando criança que era um leprosário... a gente escuta

L1 - ali da... da Igreja Matriz... que ela tem... é de mil e seiscentos... feita com óleo de baleia... é verdade ou não... por exemplo... quando a senhora era muito mocinha não tinha igreja ali...

L2 - tinha igreja... a:.... eu acredito mais na palavra lá que como igreja... que deva ter... é tudo real... as paredes elas são... muito grossas ali... eles contam realmente... essa é uma história que... teve... isso a gente ouvi bastante... talvez porque eu seja ligada assim à Igreja... e... e... realmente tem é... túmulo do padre lá dentro... tem passagem por trás né?... que as pessoas se escondiam daí... quando vinha... chegando algum... embarcação né?... eles iam lá em cima... eles se escondiam também... que tem uma porta... que dá por trás né?... essas histórias aí realmente eu sei que tem bastante coisa em relação à Igreja seja verdade...

L1 - e a senhora é... é... acha que é frutífero... como educadora... essa retomada... dessas histórias?

L2 - eu acredito... muito... e deveria ter muito mais né?... com mais rapidez né?... tenho a impressão que é bem lento... a educação é um pouco lenta... né?... o resgate aí é acho que é bem importante... não só quando tem aquela festa né?... ( ) tem que ser mais né?

L1 - quais são as opções dos jovens aqui... em matéria... por exemplo... de... de diversão... que el / além da escola... sabe que eles passam uma boa parte do tempo... ou na na televisão... ou fazendo alguma outra coisa... o que seria essa outra coisa... ou se eles são só da TV também... como São Paulo...

L2 - olha... não temos (biblioteca)... é desde que eu moro nessa região aqui né?... quem é:.... tá mais é::... perto do centro... aí... talvez que mude a diversão... que nossa região aqui da praia... na época de verão... daí... é é... se centraliza tudo nas praias aqui... e numa época assim de inverno... não tem muita opção... eles vão muito assim pra... é:.... quadras né?... jogar futebol... vôlei... se reúnem muito aqui na escola né?... o ginásio fica ( ) da comunidade... direto... todas as noites... grupos de... de... de adolescentes... de adultos né?... vêm jogar vôlei futebol voleibol... aqui não tem muita opção... nessa época... de lazer

L1 - e em matéria de cursos aqui pros jovens... tem... alguma coisa em São Francisco... porque... eu acho que não tem universidade aqui 
L2 - não tem muita opção também... são mais cursinhos de computação... são cursinhos básicos assim né?... curso mesmo...

L1 - seu J.... como é morar aqui na... em São Francisco do Sul?...

L2 - morar aqui é bom né?...

L1 - como... mudou muito com o tempo?... o senhor que foi criado aqui?

L2 - não... foi desen / desenvolveu apenas... desenvolviment[o] normal de de... ((pára para atender ao telefone, depois busca um jornal que fala da história da cidade))... tem de tud[o] aí... toda a história entend[e]?... do do... inclusiv[e] tem tudo aqui $\mathrm{OH} . .$. a polêmica em torn[o] da data...

$\mathrm{L} 1$ - AH... como o senhor faz... deixa eu tirar xerox?

L2 - não tem mais nenhum lá filha?... ((pergunta para a filha))

L3 - deve ter ( )...

$\mathrm{L} 1$ - esse aqui é igual $\mathrm{OH}$

L2 - tem mais alguma coisa pra lá ((pergunta para a filha))... aqui tem ( )... o mito do fundador... a polêmica... cultura po / popular permanec $[e]$ viva... ((começa a mostrar o jornal))

L1 - mas eu quero saber a opinião do senhor...

L2 - então vamo[ $\varnothing]$ lá...

L1 - o senhor falou que o desenvolvimento é normal na cidade?... naquele dia o senhor tava falando também um pouquinho do porto...

L2 - não... o porto agora tá com o / com com... com esse negócio de... da exportação... nosso port[o]... $\mathrm{n}[\mathrm{o}] \mathrm{s}$ últim[o]s... cinc[o] ano cresceu cem por cent[o]... nos últim[o]s cinc[o] ano dobrou a:.... a capacidade... dobrou a carga... [o] volum[e] de carga exportada... inclusiv[e] o container aumentou muit[o]... a soja também aumentou muit[o]... e agora aumentou mais vint[e] por cent[o] da $b[u]$ bina de aço que vem de Vitória Espírit[o] Sant[o]... que vem pra... pra Wega né?... descarrega ali na Wega então... aí automaticament[e] aumentando a carga também... aumenta o caminhão... tudo...

L1 - e::... fora a festa... o porto... tem muito emprego aqui na cidade?

L2 - não... tem o turism[o] que vem desenvolvendo como em tod[o] [o] litoral né?... inclusiv[e] lá... agora no litoral de São Paul[o] lá... inclusiv[e] aquelas cidad[e]s mais ali pra... que antigament[e] o turism[o] em São Paul[o] era Sant[o]s... Sant[o]s São Vicent[e]... tanto São Vicent[e] [e] Bertioga... hoj[e] não... hoj[e] aquelas praia for[ũ]... devagarzinho... for[ũ]... foi invasão imobiliária na praia né?... foi o que houve aqui né?... (aí) tem o turismo... tem a pesca... agora a a indústria me $[\varnothing]$ mo agora que tá chegando... chegando a Wega... chegou mais a Pecuagr[o]... a Ceval... ( ) é o que tem chegado agora... ( )

L1 - e aqui/aquele que o senhor até me mostrou ali do jornalzinho... das tradições aqui em São Francisco... por exemplo... as pessoas mais velhas tinham me falado do Boi de Mamão... do Terno de Reis... é:: o senhor chegou a conhecer?... tem ainda?...

LL2 - eles tão resgatando agora né?... tão... tão... tem o o... o Boi de Mamão... mais ele ficoo:.... alguns anos... ficou parado... porqu[e] quando começou havia esse negócio do salão... no tempo da discoteca aí:.... essa coisa então 
club[e]s... aí então acabou... acabando com... mas agora tem al / alguns grupo que tem resgatado essa... essa cultura... inclusive ( ) tem o Pau de Fita né?... até deve ter aqui no nos:.... alguns livros desse aqui... então tem grupo tentando resgatar esse... oh... aqui tem o Pau de Fita... o fandango... ((começa a mostrar um livro)) a Dança do Vilão... então... inclusive no Mercado Público agora abriu um... todos os sábado à tard[e]... inclusiv[e] a apresentação para esses... esses grup[o]... mas ficou.. alguns anos parado...

L1 - mas por exemplo... o senhor quando era criança... tinha?... tinha?... ou já não tinha?

L2 - não não... no meu tempo... não:.... (a turma daí)... é tud[o] bobagem...

L1 - isso aí é bobagem?

L2 - é::... temo[ $[\varnothing] \ldots$ discoteca e::... salão de dança... já não tinha mais essa...

L1 - esse tipo de tradição né?

L2 - tinha acabado um pouco... agora os mais... os mais antigo... inclusiv[e] tão... há... há um consens[o] né?... em São Francisco de reviver a... as tradições... tendo em São Francisco...

L1 - mas... por/por que que o senhor acha que isso agora?... por que que foi isso?...

L2 - AH:.... porqu[e] provavelment[e] o povo sentiu falta da sua história né?... das suas tradições... daí (juntar[ũ]) algumas pessoas... inclusive com o apoio da pré / da prefeitura... pessoas com melhor de condições... começaram a voltar... e:.... até pra ter... algumas pessoa até inclusiv[e] deixaram de ter o que fazer porqu[e] se... o... os aposentado que não fizer isso não faz nada... então... tão procurando... porque hoje em dia a terceira idad[e] tem crescido muito... as pessoas com cinqüenta e poucos anos aposentada e tá com saúd[e]... vive até setenta... setenta e pouco... então são vinte ano que ele tem que arrumar alguma coisa pra... pra fazer...

L1 - e o senhor acha que aqui em São São Francisco do Sul... aquele centro:.... Centro Histórico lá... o que que o senhor acha?... acha bonito?... acha que deve conservar?... o senhor sabe a história dali?... o senhor aprendeu alguma vez?... é:: sobre isso...

L2 - não... ali ali inclusiv[e] foi a fundação da cidade... inclusive hoje existe a cidade antiga... que tá lá... não pode inclusiv[e] mexer né?... e existe a cidade nova que::... que aí pode a construção... que ali não pode:.... não é bonito... porqu[e]:.... se acabar aquilo acaba até o turismo né?... se acabar aquela tradição... o pessoal vem aqui pra ver o quê?... vem pra ver... as rua... as igreja... de duzentos ano... cento e cinqüenta ano... (aquelas casa)... se mexer... se torna-se uma cidade moderna... como Joinville e outras cidade que não tem...

L1 - e tem muita diferença de Joinville pra São Francisco?

L2 - TEM... lá não tem mais traços histórico né?... inclusive nem casa... isso acabou-se tudo... o próprio centro foi... todas as casas antigas foram sendo demolidas... dando lugar pros prédio...

L1 - e lá é assim... é maior ( )...

L2 - sim... é a maior cidade de Santa Catarina...

L1 - mas... ( )... mas que nem... escola tem normal lá em São Francisco tudo... agora... universidade já não tem...

L2 - tem... tá abrindo...

$$
\text { L L1 - tá abrindo? }
$$

$\mathrm{L}_{\mathrm{L} 2}$ - aqui... aqui na... naquele posto policial... a Univill[e]...

L1 - uhn:.... que bom pra::... 
L2 - é... vai ter:.... agora parece que tão funcionando como:.... agora... oceanografia... tão trazendo inclusive... só que as aula de Joinville que vem aqui... que agora em... vai ter... vai abrir agora em agosto três curso...

L1 - é bom pro pessoal daqui

L2 - é::... [o] daqui... [o] de:.... quem passar...

L1 - quem passar... tá certo... e aqui em época de verão... muda muito?... a::... o número de pessoas... a cidade fica inCHAda?...

L L2 - é::... tempo de / é::... época de verão... o pessoal de Joinville... inclusiv[e] quinhentos mil habitante de Joinville... cem mil vêm pa cá é?... no mínimo

L1 - ((risos)).. pra São Francisco

L2 - de São Francisco... Barra do Sul... Itaquá... AH... ( ) e a população... cresce umas cinco vez[i] né?...

L1 - fica bom né?... acho que vem dinheiro...

L2 - daí a::... a gente chama a época da temporada... é época de ganhar dinheiro...

L1 - tem que ganhar dinheiro...

L2 - não tem o que chegue...

L1 - ( ) e aqui na região... tem violência?... é tranqüilo morar em São Francisco do Sul?...

L2 - é tranqüilo... agora... a violência ( ) tá começando a ficar meio... como em todo luga[ $\varnothing]$ né?... não é um $\mathrm{p}[\mathrm{o}] \mathrm{b}[\ulcorner]$ ema que enfrentamos aqui como em São Paulo... conforme vai crescendo... vai vindo... os marginal... e:.... o traficante...

L1 - é muito recente isso?... é recente isso ou já... ( )

L L2 - não... foi de uns dez ano pra cá... que de uns dez pra trás era bem mais... a criminalidade... o nível que cresce é um nível em São Francisco é o nível do Brasil... não tem muita diferença... do Brasil tem...

L1 - ( ) infelizmente né?... e em ma/matéria do... do jovens assim... o desenvolvimento da cidade também acarreta um desenvolvimento na educação das crianças... e como que o senhor sente isso?... até como pai... ( )... o comportamento...

L L2 - é que antigamente se obedecia mais né?... e hoje... quase... hoje não querem obedecer... então... ess[e]... mas isso não é influenciado tanto... até por causa da mídia... da televisão... dos pobre/que aqui têm os me $[\varnothing] \mathrm{mo} \mathrm{p}[\mathrm{o}] \mathrm{b}[\ulcorner] \mathrm{ema}$ que você sente em qualquer lugar... do Brasil... o Estatuto da Criança... que... alguns dados tão pra criança... mas também

L L1 - superprotege...

L2 - então... acabou... tirando um pouco da da... o próprio Estatuto da Criança é muito bom dum lado... mas outro lado acabou tirando um pouc[o] da autoridade do pai e da mãe... então... então a criança... e::... eles ach[ũ] que não pode... agora o pai não pode mais falar... não pode obrigar realmente bem... só que aí o Estatuto proteg[e] dum lado mas na realidade há exploração sexual... a::... o abandono das pe / tudo isso continua na na na... cada vez pior...

L1 - e só voltando a falar um pouquinho da lenda... da mitologia assim... o senhor conhece alguma lenda aqui da cidade?... é::... que seja bem típica dessa região?

L2 - é::... aí::... é a coisa que a gente conhece inclusiv[e] tá todas aqui nesse... nesse livro que tem $\mathrm{d}[\mathrm{o}] .$. é o:.... ( ) a:.... o padre que que não queria que o::... diz aqui né?... que:.... ele tinha (problema) com o capitão mor... que... isso aqui é:.... todo morad[o] conhece né?... chamado Domingos Francisco Francisques... e era mais conhecido pelo apelido de Cabecinha... era cruel... 
autoritário... conta a lenda qu[e] certa vez que ele quis sepultar um padre debaixo do altar da Igreja Matriz... mas o vi / mas o vigário da época... foi o Fernando... se recusou a aceitar o pedido... Cabecinha ficou furios[o] e mandou colocar o frei em um canoa com uma cuia de farinha e outra de água... a maré vazante [o] levou até fora da barra... mas disse que antes de ser posto na canoa lançou uma maldição sobr[e] Cabecinha e sobre São Francisco... até a quarta geração de descendente do Cabecinha... a cidade não iria desenvolver...

L1 - essa é bem típica daqui...

L2 - esse todo mund[o] com o / (das coisas) aqui de São Francisco que é almadiço / ERA... que agora com o o desenvolvimento acabou... mas isso aqui antigamente.. . principalmente... não ia pa frente dizi[ũ] que o culpado era::... a praga do padre...

L1 - e tem um Forte aqui pra trás né?...

$\mathrm{L} 2-$ tem...

L1 - ali é::... ( ) ele funciona?

L2 - ( ) desativado e funciona como colônia de férias do próprio o:.... Forte... só para os militar[e]s... não é::... inclusiv[e] lá tem um museu de arma lá em cima...

L1 - a gente pode subir?

L2 - pode... paga parece dois reais... três reais para professor... no horário normal... pode subir lá em cima... pode fotografar... é um museu de arma... tem os canhões antigo né?... de quando do desenvolvimento... ah ali tem... tem muita história ali...

\section{E. L. G. (L2)}

6B

L1 - como que é... a comunidade dos pescadores aqui?... como que o senhor... trabalha com eles?... o que que o senhor faz?

L2 - então... a gente tá fazendo... é... a gente sempre trabalhou... unidos né?... mas aí... agora a gente tá... tá... eu sou... dá dá... da Colônia de São Francisco... da Colônia de pescadores... a gente tá montando soc / tamos juntos aqui né?... pescadores... e:.... a comunidade trabalha juntos... um ajudando o outro... puxar barco... e:.... arrumar rede né?... sempre um ajudando o outro...

L1 - e... como que é o dia de um pescador aqui?

L2 - o pescador sai pra fora... quatro horas da manhã né?... é... não tem hora pra voltar... que dá um leio na rede... problema no barco... Deus o livre... não tem hora pra ele voltar né?... é só seu lanche e... sai... quatro horas... ou às vez[i] sai até na boca da noite... e volta no outro dia...

L1 - o senhor já trabalhou na na pesca assim... em barco?...

L2 - sim... eu tenho meu próprio barco né?... e sempre tive... sempre trabalhei com ele... com tainha... camarão...

L1 - já passou algum susto no mar assim?...

L2 - de vez em quando... às vez[ $\varnothing]$ a gente passa um susto né?... o mar tá calmo... calmo... a gente confia muito... de repente vem uma tempestade né?... eu saí fora... mas demora até chegar em terra...

L1 - e o senhor aqui... como::... como o responsável aqui... é bacana.... é tranqüilo?... como é morar aqui?... não em relação às pessoas que o senhor trabalha.... mas em relação a Enseada aqui... toda essa parte... aqui... 
L2 - nunca tentei sair daqui né?... que... o lugar da gente é aqui... mesmo... mas muito... muito bacana... pessoal muito bacana... muito calmo... muito... um ajuda sempre o outro né?... nunca falta com respeito... um com outro... não dá briga... não dá... sempre muito bacana...

L1 - e aqui na Enseada né?... é:: é... um lugar tranqüilo pra viver?... ou... ou já tem violência?... a violência já chegou?... a gente sabe que tem lugar que a violência não chegou ainda... ou tá chegando né?... como o senhor sente como morador?

L2 - não não... aqui a gente deixa até... carro aberto... sai de casa deixa a porta aberta... não tem violência... não tem... roubo quase... muito tranqüilo...

L1 - o senhor conhece um pouco da história ali da colonização ali de São Francisco? ali?...

L2 - da da colônia?...

L1 - é... ali da cidade... do Centro Histórico.. ali...

L2 - conheço um pouco né?... tem... museu né?... tem... tem os barco lá... as coisa do mar... a gente conhece lá... tem o porto de São Francisco do Sul né?... tem... uma prefeitura muito boa... que ajuda a gente $\operatorname{tam}[\varnothing]$ ém aqui... fez a casa do pescador né?... o prefeito que é... então é... muito bacana viver aqui dentro...

L1 - e como que é o:: o porto lá?... ele é um porto grande?... ele é pequeno?...

L2 - grande grande... acho que atraca... comporta lá... oitos navios né?... cada... cada atracar né?... quatro de um lado... quatro de outro só...

L1 - é grande então?

L2 - é...

L1 - é grande... e a produção aqui... de peixe... né?... como você sente que ela... ela se mantém... ela cai com o passar do tempo... como que é organizada a coisa aqui?... ou não?... é igual...

L2 - tem a safra né?... tem a safra do camarão... a safra da tainha... caiu um pouco sabe?... pelos meus conhecimentos... e... quando eu era mais novo né?... meus avós... meu pai... é... sempre pegava mais... aqui... aqui na beira da praia... hoje tá mais distante... a... a coisa né?... a gente tem que sair pra me $[\varnothing]$ mo fora pra pegar... não consegue nada...

L1 - e o senhor acha que é por quê?... poluição?... ou... ou ou... porque as pessoas... não não não... não respeitam a natureza?...

L2 - AH::... eu acho que o ser humano tá comendo... tá... comendo muito peixe e camarão né? ((risos))

L1 - ((risos) $) \ldots$ é bom...

L2 - eu acho que é isso... que... tão comendo muito e:.... aprender[ũ] a gostar né?... do peixe né?...

que antigamente acho que ninguém queria... mas é... isso aí sabe... é muito... é muito cobiçado o peixe... o camarão né?

L1 - e antigamente como que... como que era vendido aqui?... sempre foi vendido aqui mesmo?

L2 - sempre foi vendido aqui mesmo né?... até... é... eu acho que em... me lembro o ano... faz quarenta e seis... quarenta e cinco anos... eu tinha um ano de idade que a minha mãe me conta... deram um lance de tainha aqui na... na beira da praia... quarenta e seis mil e setecentos... tá marcado lá naquelas... naquelas pedra lá ainda ((apontando para o lugar)) sabe?... é:: muito tainha né?... aí é vendido sempre vende aqui me $[\varnothing]$ mo... é o peixero daqui que pega... pode pegar... sete mil quilo... cinco mil quilo... ele pega... leva tu/tudo né?

L1 - aí vai... vai pra fora né?

L2 - eles mandam acho que... pra Itajaí daí

L1 - AH tá...e o senhor falou da... da mari / maricultura que chama?

L2 - isso... ainda só:: eu sou presidente ali... faz... quatro anos né?... da:: da Associação de Maricultores... de vez em quando só... aqui... o ma[I]... na época de lestás da muito... danifica muito... danifica muito né? 
L1 - na época de quê?

L2 - leste... o mar é...

L1 - le / lestás? ( )

$\mathrm{L} \mathrm{L} 2$ - o mar ( ) vem de fora... lestado...

$\mathrm{L} \mathrm{L} 1-\mathrm{é}$

L2 - então carrega bombona... leva penca de marisco sabe?...

$$
\begin{aligned}
& \mathrm{L} \text { L1 - como?... } \\
& \text { L } \mathrm{L} 2 \text { - arrebenta cabo... }
\end{aligned}
$$

L1 - como que é... por exemplo... eu não tenho a mínima idéia do que se /s abia... eu sei... que é mari / sei que marisco... mais... só sei que é as boínhas ali... como que eles ficam?... eles pra baixo?... eles ficam em corda?... o que que é aquilo?

L2 - é um... um long line que eles chamar[ũ] né?... amarra uma ponta de um lado... uma ponta... uma ponta de outro lado e:.... coloca as bombona na corda e ali vai plantando... semente de marisco... planta dois quilos de marisco pra... em seis sete meses... tá... quarenta... trinta quarenta... quilo né?

L1 - e:.... as pessoas assim... que... por exemplo... eu sei que ali na cidade de:.... perto ali de Piç / Piçarras ali... Penha também tem um... um grande assim né?... as pessoas reclamam do visual? ou não?... nunca reclaMAram?... falam de impacto ambiental alguma coisa assim ou não?

L2 - não... aqui não né?... acho que tamo[ $\varnothing]$ tudo certinho... eu acho que não tem ninguém... não tem o que reclamar né?... que é... faz parte do... do emprego da gente também né?... sustenta família... dá emprego pros outro... acho que... não estraga nada a praia não...

L1 - em relação... fora a pesca... em relação a emprego... trabalho... o que que tem pra trabalhar aqui?... ou a pesca é a principal atividade da cidade?

L2 - a pesca é a principal atividade... pescador sempre faz uma casinha né?... a mais... pra alugar na temporada né?... tem gente que tem um barzinho... um... ( )... no verão se vende mais peixe né?... porque... o turista come muito peixe né?

L1 - eu por exemplo tô aproveitando... vim de São Paulo e lá... tá caríssimo... acho que o quilo da tainha lá tá dezoito vinte reais...

\section{L2 - é mesmo?}

$\mathrm{L}$ L1 - eu tô comendo tainha aqui a dois reais... eu tô comendo tainha aqui a dois reais... eu tô achando... eu tô até desconfianda... porque... será que a tainha?...

L L2 - sabe que é?... o:.... o peixero aqui paga... três e cinqüenta né?... é... aquela peixaria dele é seis reais o quilo né?... já ganha um monte né?... o atravessador...

L1 - é ganha...

L2 - é... mas o peixe é... muito bom né?... a tainha mesmo é especial eu acho...

L1 - a tainha é boa... e como que... sempre tem tainha?... tem época?

L L2 - não... tem a época né?... é:.... é maio... junho e julho né? a época da tainha... depois já acaba já... já tá acabando né?... é... vai... sai do Rio Grande do Sul ... vai até... acho que pra Argentina né?... vai embora o peixe... depois volta para desovar... algumas voltam... algumas não voltam... entra no rio né?... desova ali mesmo...

L1 - e... eu... eu caminho aqui na... na praia aí... tem um monte de casa fechada ... tem... tem muito turista aqui né?

L2 - isso... tem... tem bastante turista é... o pessoal fazem casa né?... aí vem só no verão né?... pega uns dois três meses... um mês... tem gente que nem vem... [Ø]caba alugando...

L1 - e é... agora... época de inverno a cidade tá bem vazia né?... como que fica no verão?

L2 - no verão... é... no ano retrasado... tinha seiscentas mil pessoas dentro dessa praia... entre Ubatuba... foi feito uma reportagem... é muita gente isso aqui... fica um fervo de... também tenho 
alugue $[\ulcorner]$ de... de caiaque no verão... boto aí né?... tenho barco de turismo também... pro pessoal passear... pescar...

L1 - deve ser divertido né?

L2 - bom... muito bom

L1 - mais e e:: a cidade ela dá conta de tanta gente?... falta alguma coisa?... água... não sei...

L2 - água não... água... falta mais é:: eu acho que::... banheiros público né?... que o pessoal usa... que é muita gente né?... mais sempre... acho que... tá até comportando ainda o pessoal que chega... L1 - e... antigamente ali né?... no Mercado Municipal... aquela região histórica ali... como... como que se fazia pra sair daqui e ir pra lá?... sempre teve ônibus ou não?... era difícil acesso?... porque eu achei longe:....

L2 - sempre teve né?... daqui a São Chico dá dezoito quilômetros... tem ônibus por / é... de uma em uma hora... de meia meia hora... não sei... mas sempre teve ônibus né?...

L1 - e... antigamente... São Francisco de Sul era a cidade mais importante de toda a região... ela até abastecia Joinville... Jaraguá... e hoje a gente vê o contrário né?... Joinville cresceu demais... e hoje... ela... até assim... eu sei eu sei que aqui por exemplo não tem universidade né?... se quiser estudar tem que ir pra... pra Joinville que é a mais perto... mais perto... por que será que Joinville deu essa crescida e ficou São Francisco mais pacata?... será que foi uma opção das pessoas? ou?

L2 - é... eu não sei né?... deve ser porque... São Chico tem... tem... o que tem de grande ali é o porto né?... e a Petrobrás aqui... mas é... dá pouco emprego... pouca pouca coisa... eu acho que é... é e:.... quanto a:: faculdade é... tem sempre só em Joinville que eu conheço né também né?... que é... que São Francisco ainda não tem né?... pessoal... segundo grau né?... inclusive eu tô com uma filha de catorze anos muito estudiosa até... é... tá no... primeiro do segundo já... é... exemplo da escola...

$\mathrm{L} 1$ - ai que bom

L2 - já foi convidada até pra... representar a escola na... na... em Brasília lá... na no presidente lá... no ano passado lá... não foi porque não quis...

L1 - é:... pra sua menina aqui... pro jovem... de forma geral... o que que tem pra se divertirem aqui... aqui na... na... nessa região?

L2 - futebol... que eles jog[ũ] ... assim... teve joguinho aí... nas férias... começou ontem... e:.... e::... televisão que eles assiste... é isso aí... não tem muita... muita diversão aqui não...

L1 - e cursos pra... pra juventude tem?... inglês... por aqui

$\mathrm{L} 2$ - tem tem

L1 - informática...

L2 - minha filha tá fazendo informática já né?... mas... tem sim... aqui na cidade tem... tem em São Francisco... tem na Enseada...

L1 - e o senhor mudaria daqui?... continuaria aqui?

L2 - mas nunca nunca... não sairia daqui pra nada...

L1 - é... acostumou né?... é... eu também gostei... achei muito... uma cidade muito bonita... e a sua menina?... ela pensa sair daqui... já que ela é mais nova? como que o jovem sente a cidade?... eles gostam?

L2 - acho que gostam né?... tão junto com os pais... os pais... fazem... ( )... filho de pescador ainda também vão em frente... minha filha diz que quer ser advogada...vamo[Ø] ver né?... a gente vai ver até onde $[\varnothing]$ güenta...

L1 - AH... no estudo sim... se ela é estudiosa né?... gosta de ler... eu acredito que... ela possa ser uma boa advogada....

L2 - o pessoal aqui é... estudioso também né?... que a gente conhece aí... é isso aí...

J. O. M. (L2) 
L1 - senhora J.... como que é morar aqui em São Francisco?

L2 - olha... pra mim num é muito bom

L1 - o que a senhora mais gosta daqui?

L2 - eu Acho que antes... no nosso tempo de nascida... aqui era bem sossegado... não tinha né?... morador de fora... era só... ( ) era natural daqui mesmo né?... agora que tem... morador de fora... mais antes era bem sossegado aqui... agora tá cada vez mai[ $\left.\int\right] \ldots$ né?... aqui... mais... muito movimento... mudou né?... ( ) de morar... eu GOSto de morar aqui... é sossego...

L1 - como era cidade aqui quando a senhora era pequena?

L2 - não lembro assim como era

L1 - era grande?... tinha água?... tinha luz?... tinha

LL2 - não... antigamente em São Francisco tinha a luz... aqui no nosso bairro não tinha... era a ru / a rua... a estrada era de chão... aí que depois foi feito o asfalto né?... era de chão... areia mesmo que a gente olha pa passar era ((risos)) né?... antigamente era assim... aí depois de um tempo... foram fazendo o asfalto... ( ) era tudo mato né?... não tinha essas casas... era só... era um caminho assim... ( ) era contado tinha as casa sabe?... era duas três casa assim oh... era bem raro as casa aqui... agora não... agora tá uma vila mesmo que... São Francisco mesmo já tá emendando... com o... aqui com o bairro né?...

L1 - e violência?... tinha violência

L L2 - não... naquele tempo violência incl / violência naquele tempo era bom porque não tinha negócio de violência... e agora tá... pessoal que tá vindo de fora... Paraná... aí tá

L1 - e tem muita diferença assim?... tá vindo muita gente de fora é::... eu tava passeando ali nas praias... na Enseada... Ubatuba ali... as casas tão tudo fechadas... tem diferenças do número de pessoas que moram aqui?... que são daqui?... do inverno pro verão?... que eu acho ( )

L2 - no verão... tem bem mais movimento... aí as casa tão toda aberta... dos veronista né?... que sai nas praia mais sábados e domingos... mas no inverno fica tudo fechado... aí na temporada... mês de dezembro final de novembro... aí já tem ( ) né?... pa temporada nas praia aí... aí fica mais movimentado né?...

L1 - e... a senhora conhece a história de São Francisco?

L2 - ainda no tempo de... de quando de...

L1 - ( ) a senhora lembra alguma coisa?

L2 - aí... não lembro

L1 - que os pais da senhora contava?

L2 - a minha mãe que sempre contava aqui... só que eu não lembro mais a... ela sempre falava né?... que naquele tempo tinha Boi de Mamão... ( )

L1 - é... eu queria que a senhora me detalhasse mais isso... a senhora chegou a ir num Boi de Mamão?

L2 - fui... uma vez eu era pequena eu lembro que eu fui... ali no [ $\varnothing]$ Batuba né?... com a minha mãe...

L1 - como que era?... a senhora tem alguma lembrança... ( )

L L2 - AH:.... era só (de disfarce) sabe?... eles dançava... o boi... ia atrás o pessoal ( ) pra entrar na roda... depois se atirava no forró que naquele tempo não era baile... era forró que se fazia... aí fazia o:.... assim a::... aqueles baile... de São Gonçalo que se falavam também antigamente sabe?... aquele também eu já fui... ( )

L1 - e Pau de Fita... tinha?

L2 - Pau de Fita... tinha uhn uhn

L1 - Terno de Reis? 
L2 - e' ... ( ) também... ano passado eles tiver[ũ] lá em casa... Terno de Reis...

L1 - É:?... como que é o Terno de Reis?

L2 - é assim né?... tem que / são três canto[Ø]... que tiver[ũ] lá em casa... o gaiteiro... tem o:.... pandeirista e tem... o violão... aí eles cantam na entrada do... do reis né?... da... do Natal... e.:... puxa no dia de reis né?... que tem o dia de reis mesmo né?... aí eles cantam... é bonito... é muito bonito... L1 - e::... foram na sua casa mesmo?

L2 - ano passado que tiveram aí... nós atendemos eles a um real pra eles (entrar) nas casa sabe?... ( )

L1 - e hoje... acabou? ( )

L L2 - não... esse ano assim até... né?... não teve... não tiver[ũ] lá em casa... não sei se eles andaram até ali... ( ) de noite né?... é:.... antigamente era melhor do que agora... era mais animado...

L1 - e... por exemplo... a senhora que... a senhora que tá todo dia com os jovens... muitos jovens né?... pensando na educação que a senhora teve?... tem alguma diferença?

L L2 - CLAro... muito mudado... muito diferente... no tempo nosso pa agora é muito diferente...

L1 - que diferenças a senhora sente?

L2 - eu acho assim... porque agora eles não respeitam... os mais idoso... sabe?... naquele tempo não... a gente criou como eu... criei cinco filho... né?... cinco e um é morto... tem quatro... ( ) a gente falava com eles... ouvir né?... eles tão novo ainda mais... eles tinha que dá essa educação que eu tive antes... que meus pais me deram né?... e hoje aí que vê aqui na escola... porque... essa guriada eles não têm... eu acho que... eles não obedece às vez[i] eles debocham da gente... ( ) né?... eu acho assim que é uma educação que vem de casa... o pai com a mãe tem que dar em casa... como eu dei pros meu... eu acho que né?... que... os pais deviam que dar ( ) pos filho também educação... eu acho assim... "vou te mandar pra escola"... "(olha) que vocês não faz[i] assim... que o dia que vier uma reclamação... da escola pra casa... vocês vão se haver comigo"... "que você tem que ir na escola... e quem manda em vocês são é os professores"... em casa sou eu... agora você tem que obedecer... e hoje em dia não... eles não obedecem os professores... eu trabalho na cozinha... eles não obedecem a gente... que às vezes eu falo pra eles que eles tão fazendo bagunça ali sabe?... e eles debocham de mim... ( ) eu falo pra eles... "que educação que vocês têm... isso aí é a educação que vocês trazem de casa?"... eu falo sabe?... isso aí há muito tempo eu (não vejo)... que né?... a nossa criação eu não vejo... acho que mudou... tá muito mudado...

L1 - e em matéria por exemplo... de... de namoro... quando a senhora era nova... como é?... e hoje a senhora que tá aqui ver... como que as crianças...

L2 - AH meu Deus... muito diferente... ( ) naquele tempo... naquele tempo não dava nem pra encostar a perna ((risos)) né?

L1 - é

L2 - e aí a mãe ficava do lado... que naquele tempo... meu pai morreu cedo né?... então nós era tudo pequeno... aí a mãe... a minha mãe que acabou de criar né?... eu e meus irmão né?... aí... mas era assim né?... onde nós ia ela ia junto... então hoje em dia não... as moça... essas moça hoje em dia sai de noite sozinha... vão no baile sozinha... nosso tempo não tinha isso aí...

L1 - e agora... a senhora... pra senhora falou que antigamente era mais animado... o que tá se fazendo pra se divertir em São Francisco?... ( )

L2 - olha aqui... só tem esse negócio de baile... é só tem... que ir na igreja... de final de semana assim... diversão aqui é esse negócio de baile... só... de salão... é bem bom... ( ) eu gosto... mas a gente já trabalha a semana toda... tá cansada... então não sei mais a animação que tem... 
L1 - e a senhora gosta realmente de morar aqui?... moraria em outro lugar?...

L2 - nada... eu gosto daqui... eu já morei em ( ) quando me casei... morei em Paranaguá... morei em Guaruna... mudei e voltei... muito bom... acho que tá vindo muita gente pra cá porque eles gostam... daqui de São Francisco...

L1 - a senhora acha aqui em São Francisco... esses turistas... essas pessoas que vêm... tá melhorando ou tá piorando a cidade?

L2 - olha os turistas não... eu não acho... o que eu acho que tá piorando... tem muita violência são os morad[o] que São Francisco tem... tem muita gente desconhecida... é a violência né?... ( ) agora não dá... eu mesma de noite tenho medo de sair na rua de noite... antigamente ver... antigamente não tinha luz... mas de dia... anoitecia... com a porta aberta... a casa tava aberta... não tinha perigo né?... agora não... trinco na porta... trinco na janela...

L1 - senhor C... eu queria que o senhor contasse pra mim... como que era a cidade aqui quando o senhor era criança...

L2 - bom... aqui::... no nosso bairro aqui no balneário... isso aqui era:: na época... que eu nasci... aqui não tinha nada né?... era só uma ruazinha de chão aqui na frente... e:.... não tinha mais nada... era::... era bem pouca população... população aqui era... devia ter mais ou menos uns... mais ou menos assim umas duzenta e cinqüenta pessoas... não tinha mais do qu[e] isso na época... e:.... o serviço... ( ) das pessoas que tinha aqui era... era a pesca né?... não tinha outra... ( ) não tinha mais nada pra fazer... então... era pesca ou roça né?... hoje por exemplo... já... começou... bastante a chover né?... já não:.... não conhecem... já o:: o pessoal... que existia aqui porque... vem muita gente de fora né?... então ficou assim... a:: a casa tá bem aumentada aqui...

L1 - e como que era assim... a infra-estrutura como luz... asfalto... posto de saúde... escola...

L2 - isso aí nada existia na época né?... isso aí não:.... isso aí... o asfalto... isso aí... foi... foi vim aqui a:... quando a Petrobrás chegou... a luz... a luz... por exemplo eu já tinha:.... quinz[e]... dezesseis anos... de idad[e] quando o... o primeiro poste de... de... colocaram aqui que veio a luz né?... inclusive a gente tava pescando e::... quando a gente chegou de::... da pesca... é que surpreende que tava tudo iluminado né?... aí já nem sabia onde que era o local... porque era só escuridão antes né?... tudo lu / luz de lampião né?... então a gente chegou a gente já não sabia aonde:: que era mais o lugar... o porto da gente... que tava tudo iluminado... a gente foi pescar... à tarde... e quando voltou à noit[e] já tava tudo iluminado né?... então... isso aí... já faz uns... na faixa de uns... quarenta anos por aí... a gente já pescava já... a gente ia pescar com idade de:: de oito ano nove ano já tava no mar já...

L1 - e como que é assim... o dia de um pescador... como/que horas que você tem que ir pro mar?... como que é o dia... como que você pesca... é artesanal?... mudou a pesca... esse tipo de coisa pra mim é muito importante...

L2 - é:: é:: a pesca é::... há uns anos atrás aí era tudo artesanal né?... a gen / a gente que construía... fazia... é:.... tecia as rede... o cabo também né?... o chumbo era chumbo de barro... também tudo artesanal... tudo feito...

L L1 - chumbo?

L2 - é...

$\mathrm{L} 1-\mathrm{AH}$ 
L2 - peso da red[e] né?... peso da red[e] por exemplo assim... que::... hoje a gente chama de... chamava de chumbo mas era de barro né?... é:: chumbo... mas era... porque el[e] é pesado... entend $[e]$ ? mas... na verdade era barro... era feito de barro né?...

L1 - e não:: como é que fala... não desmanchava na água?

L2 - não... não... era bem... era bem... era bem... era feito... de barro... era feito... era pego no morro... era barro bem liguento... depois esse barro era... era feito um monte da da da... da beira da rede e queimado né?... ficava forte que... até hoje existe algumas ainda... ( ) de material... e as bóia eram tudo de cortiça né?... ia no mato... arrancava um:: um:.... uma corticeira daquela... um pé de corticeira lá e::... fazia uma bóia pra gente que ela flutuava né?... pescava era no cipó... é:: essa... tecido de chiffon... então de linha... a linha da rede era tirada do tucum pra fazer o pipa... a tarrafa pra rede... era tudo artesanal... depois que modificou né?... aí veio a linha do nayl[o]... aí é... e hoj[e] já tá assim né?... naylon já existe... a uns quarenta anos mais ou menos... nayl[o] plástico né?... não sei...

L1 - e:.... em matéria assim de peixes... por exemplo... tinha mais... hoje tem menos... é mais fácil hoje do que antigamente...

L2 - não... hoj[e] pra viver na pesca... hoj[e] é melhor... na época era uma... uma... tinha peixe mas não tinha dinheiro né?... era... pescador sofria muito... inclusive a gente comenta isso aí com o pessoal né?... por exemplo... na época não ter... aqui... chegu[e]mo[ $\varnothing]$ a matar... quarenta e seis mil e setecentas tainha num ano... né?... de tanto que tinha... por exemplo... tinha tanto que tinha... por exemplo... tinha tanto peixe... mas só que você não podia comer... o pescador não podia comer um peixe bom... o pescad[o] não levava um linguado pra casa... não levava um camarão pistola... por que tinha que vender aqueles peixe melho[ $\varnothing]$ pra fazer dinheiro né?... que era muito barato...

L1 - uma curiosidade... pra quem vendia e aonde vendia...

L2 - não... esse peixe aqui era vendido aqui mesmo... aqui... já... existe aí... por exemplo... ainda existe... tava conversando com ele essa semana ainda... que hoje é um empresário... o maior empresário de pesca da América Latina... ele é daqui da praia... e:.... esse hom[i] comprava o peixe nosso... do meus pai... nosso... meu... essa semana ainda tava conversando com ele... aí depois da que... de... aí... a:: o mercado foi ficando pequeno pra ele... foi onde ele foi pra Itajaí né?... lá formou-se... um dos maiores empresários de Santa Catarina... de... da América Latina... de pesca né?... é:.... por exemplo... barco de ( ) barco de sardinha... barco de... tudo quanto é tipo de peixe ele tem embarcação aqui ( ) ele que pegava o peixe da gente tudo aqui... na época né?... ele tinha mercearia... e nós trazia o... daí começou a vim o naylon e tudo... e... a modificação da da da da região aqui... quem... ele que trouxe... ele saía pra fora pra vender o peixe... e lá ele tinha uma coisa boa lá... um motor... tinha... tinha... uma rede boa lá... trazia pro pescador... daí o pescador comprava... ele vendia... o pescador financiava... o pescador pagava pra ele...

L1 - e tantos anos na pesca... o senhor já passou algum susto?

L2 - já já... já passou... de vez em quando a gente aí um... hoje em dia tá carimbado com essas coisas assim... a gente hoje não... não não não tem... mas... a gente fica meio cabreiro por exemplo... eu saí agora na temporada... isso na:: no verão passado agora aí... eu fiquei três dias à deriva aí afora né?... no mar... fiquei três dias à deriva porque faltou a bateria lá e tava confiando que tinha outra bateria... e:.... acabou... ficou à deriva... aí passamo[ $\varnothing]$ medo porque... o barco... fica à deriva... você... à noite... fica... é::... sem sinalização nenhuma porque não tinha luz né?... então a gente tem medo de outra embarcação bater na gent[e]... um navio por exemplo né?... é... chegou... chegou a ficar lá perto da Barra... da boca da Barra do Itajaí... então lá é:.... perigoso... é uma saída de lá... 
uma passagem de barco de pesca... fica no escuro... não tem iluminação nenhuma... então... fica meio cabreiro... leva um susto né?

L1 - tá

L2 - é isso aí então...

L1 - e em relação assim ao comportamento dos jovens... o que o senhor acha... mudou... como que era antigamente...

L2 - não... mudou mudou... mudou um pouco... né?... antigamente o jovem... a gent[e] por exemplo... eu quando era... eu quando era jovem... tinha mais respeito assim pelos antig[o]... tinha o que mandava ( )... tinha uma cobrança... por exemplo assim... o:.... mesmo na pesca né?... então por exemplo... se tinha um... se tinha um... se um antigo... ele ia jogar uma tarrafa lá... é:.... tinha dez antig[o]s... se tinha dez pessoas mais antiga... aí eu que era guri... aí eu não ia lá jogar tarrafa lá na frente deles... porque eles pensava... tinha medo... podia até me bater né?... na época era assim... era rigoroso a coisa né?... é:: não modificou tão... pouco assim... hoje por exemplo... a guriada não ligam... ( ) soltam uma bomba ali no pé de... de um senhor... uma senhora... né?... faz uma... não tem aquel[e] respeito mais... qu[e] tinha antigament[e] não tem... até:: até em casa né?... por exemplo... teve uma filha né? de primeiro... é:: o pai da gente... eu ia lá levar um café de manhã... meu pai tava lá em cima daquela pedra lá... tinha que chegar a hora certinha lá levando o café pra ele... senão... já ( ) "por que que tu atrasou?... por que que tu fez isso"... se mandava comprar uma coisa na venda... tinha que ir correndo voltar correndo... por que ele... era marcado aquilo ali né? hoje a guriada sai... fica brincando de $\mathrm{p}[\mathrm{e}] \mathrm{com}$ a... fica andando de bicicleta... né?... a hora que voltar tá bão... não liga né?... já modificou um pouco assim...

L1 - senhor J.... faz muito tempo porque o senhor trabalha na pesca?

L2 - trabalho uns vinte ano

L1 - e como que:: é ser um pescador?... o dia de pescador aqui... na Enseada...

L2 - igual os o[ $\varnothing] \mathrm{t}[\varnothing]$ o né?... a pessoa sai pra fora pescar... depois vem... assistir televisão... é:.... vai pra fora... vai na... vai remendar red[e]... volta... o.: dia a dia...

L1 - e como o senhor sabe que hoje... por exemplo... é um dia bom ou não pra ir pro mar pescar?

L2 - é que a gente vê pelo tempo né?... a gente conhece pelo tempo... pelas nuv[i] a gente já sabe se o dia vai tá bão ou não... a gente já tem uma base...

L1 - é bom morar aqui na Enseada?

L2 - é... Enseada é bom

L1 - o que que tem pra se fazer... por exemplo... pra descansar?... quando o senhor quer descansar... trabalhou a semana inteira...

L2 - aqui pra descansar não tem nada né?... aqui a gente... fica parado mesmo... assistindo televisão... descanso aqui não tem né?... então o dia que a gente não vai pra fora vai descansar...

L1 - vai descansar... e em matéria de violência aqui... como que é?... tem violência?... não tem?...

L2 - sobre os pescad[o] aqui são tudo gente boa... a violência mesmo que vem às vez[i] é de fora... mas aqui não...

$\mathrm{L} 1$ - é... é isso que eu quero saber... por exemplo... tem roubo... tem assalto aqui na cidade? 
L2 - não não... aqui não tem... se acontece às vez[ $\varnothing]$ é gente de fora... Joinville Curitiba... mas o pessoal aqui... os pescad[o]... não mexe um com outro... pode ver que as rede tão tudo jogada aí... ninguém mexe nada...

L1 - e::... aqui né?... no mar... o senhor... não sente / tá sentindo que nesses vinte anos tá caindo a produção do peixe... por que o senhor acha?

L2 - a:: a produção tá caindo... po[Ø]que... as pessoas que fizeram a parada por exemplo... do camarão... fizer[u] errado... a parada em vez de ser agora... por exemplo... em julho agosto... setembro... esses que era os mes[i] de se pa / de se parar do camarão né?... fizer[u] errado... fizer[u] ... mês de março abril e maio... aí justamente a hora que dá o camamrão é que tá parado... e agora que abre não tem mais camarão... $\mathrm{OH}$ o nosso caso agora... agora não tem camarão...

L1 - tá aberto pra pesca?

L2 - tá aberto pra pesca... então é::... essas pessoas que faz[i] isso aí não tem noção... é que nem... por exemplo... eu tenho noção o peixe que faz bem para pessoa... o peixe que faz mal... eu conheço tudo inclusive eu até $\mathrm{p}[\varnothing]$ ecisava dá uma entrevista no Fantástico... mas é que eu não quero ir lá... por exemplo... a betara... é::... dá corrimento na mulhe[ $\varnothing] .$.

L2 - betara é um peixe né?

LL1 - o que é betara?

L1 - ahn ahn...

L2 - a espada por exemplo... dá o cânce[ $\varnothing] . .$. né?... o câncer na pessoa... muita gente não sabe... por exemplo... o camarão é::... é muito bom pra fazer sexo... dá vontade né?... então muita gente não sabe... o marisco mesma coisa né?... a ostra... principalment[e] pra mulhe[ $\varnothing]$ né?... que não... às $\operatorname{vez}[i]$ a mulhe[ $\varnothing]$ não tem vontade... a ostra é muito bom pra dá... vontade né?... a o[S]a o marisco... então essas coisas são tudo coisa do mar que é bom pa pessoa aí... e muita gente não sabe né?... só que ele $\left[\int\right]$ quando come por exemplo o camarão... eles come com peixe... com... come com arroz... come com feijão... e não pode... o camarão tem que comer puro... aí dá a sensação... então... principalmente essas pessoas de idade... sessenta setenta ano... que às vez[ $\varnothing]$ já não... já não tem vontade de fazer sexo nem... isso aí é muito bom... levanta rápido... e::... é uma coisa muito boa... o:: para pessoa né?... pas pessoa de idade né?... e:: $\mathrm{p}[\varnothing] \mathrm{e}\left[\int\right]$ isa... o que $\mathrm{p}[\varnothing] \mathrm{e}\left[\int\right]$ isava aí é um apoio né?... do governo... para... mudar esse negócio do camarão... porque aí melhorava tudo... porque não tendo camarão não tem peixe... não tendo camarão não tem peixe...

$\mathrm{L} 1-\mathrm{AH}:: . .$.

L2 - então isso aí...

L1 - e aqui na::... na cidade... é::... conversando com pessoas mais antigas... falaram que antigamente tinha festas... antigamente... que hoje não tem mais... eu não sei se o senhor chegou a presenciar... festas como o Boi de Mamão... o Terno de Reis... Pau de Fita...

L2 - AH:.... isso aí tinha... antigamente isso aí tinha... mas hoje já não... o pessoal hoje [3i]a tá mais tudo... já ninguém mais assiste essas coisa por causa da novela... a pessoa fica tudo na novela... $\mathrm{o}[\varnothing] \mathrm{t}[\varnothing]$ o fica no jogo né?... então chega domingo... o pessoal vai $[\varnothing]$ ssistir jogo... outro já vai pra novela... o outro já vai... dançar... e:: (aquela festa)... e pescad[o] também be / gosta de beber muito... ba[I] ... a maior parte dos pescad[o] tá tudo no bar né?...

L1 - e como... por exemplo... o senhor chegou a ir... num Terno de Reis... num boi

$\mathrm{L}$ L2 - fui fui... é bom o

Terno... é bom... para gente... a gen/a gente ia naquele tempo era novo né?... ia se divertia... era bonito... 
L1 - como... como que é um Terno... de Reis?

L2 - Terno é:.... eles faz[i] aquela fita né?... bota uma fita pra cima e o cara fica fazendo volta... fica enrolando aquela fita... depois desenrola a fita... ficam cantando... fica... tocando gaita... é um divertimento para turma né?... hoje... não...

L1 - o Boi de Mamão também era...

L2 - o Boi de Mamão era.... era... antigamente era assim... hoje já eles usam diferente né?... já pegam o boi... já querem matar o boi... quer surrar... antigamente $\mathrm{p}[\varnothing]$ ssoa corria atrás do boi... hoje não... hoje já... já querem atacar o boi... então já ficou diferente... mudou né?

L1 - e::... ali em São Francisco ali... no:.... no centro ali... o senhor aqui ele... esqueceram também dessas coisas...

L2 - AH:: ali não tem não... não tem mais esse negócio de antigamente né?... hoje em dia tá tudo esquecido isso aí...

L1 - é por que ali eles preservam assim... a arquitetura... né?... as casas... antigas né?...

L1 - o senhor conhece a história dali?... por que preservam aquilo?

$$
\text { L L2 - é é }
$$

L2 - é... eles preservam por causa da cidade muito antiga né?... então querem ser a cidade histórica né?... mas isso aí não... não tem muita importância... né?... acho que o que tinha mais importância... era... na Bahia né?... ver esse negócio do camarão que tá tudo errado... esses... esses engenheiro que $\operatorname{par}[\tilde{u}]$ o camarão... isso aí... eles não entende nada... isso aí eles tinha que conversar com alguém que entende...

$$
\mathrm{L} \text { L1 - que trabalha }
$$

L L2 - pa parar... pa parar... diferente né?... por exemplo... a Bahia não podia pescar de jeito nenhum... eles tinham... que totalmente... trancar a Bahia... porque é da Bahia que cria o camarão que sai pra fora... então eles deix[ũ] o gerivau... o gerivau mata o camarão tudo... quando chega na safra do camarão... cam / camarão não sai mais pra fora... porque já mataram tudo... eles trancaram lá dentro...

L1 - ahn ahn

L2 - é que nem a safra da tainha... por exemplo... se começa a pescar tainha lá dentro do Rio... lá dentro do Rio Grande... quando chegar na safra não sai... peixe pra fora... eles acabam com tudo lá dentro...

L1 - e a tainha vem de onde?

L2 - a tainha vem do Rio Grande...

L1 - do Rio Grande do Sul né?

L2 - é::... ela sai dia primeiro de abril... do Rio Grande... ela viaja até o dia trinta de julho... pro norte... aí depoi[ $\varnothing]$ do dia trinta de julho ela volta... para... pro rio Grande de volta...

L1 - e tem festa da tainha... da ( )

L L2 - tem... a / aqui não tem... mais na Barra do Sul tem né?... mais... não faz festa da tainha...

$\mathrm{L} 1-($ )

$\mathrm{L}_{\mathrm{L} 2}$ - quase tu / quase tudo igual

L1 - e o senhor... tantos anos na pesca né?... já passou algum susto aí nesse mar?

L2 - já já... já fiquei... já fiquei quarenta e oito hora afundado com... com barco... mais [a]depois com/consegui...

$\mathrm{L} 1$ - teve socorro?... da...

L2 - É... eu tive socorro do próprio pescad[o] me[Ø]mo né?... passou rádio e outro foi lá socorrer...

L1 - e assim... tem:: e:: por exemplo... baleia... tubarão... tem essas coisas por aqui?... ou... 
L2 - não... a baleia tem... mais a baleia não incomoda... a baleia não... não faz mal pa ninguém... o tubarão também tem... mas já é lá fora... aqui em terra... não tem perigo...

L1 - não tem perigo né?

L2 - não...

L1 - de banhista nada

L2 - não não... na praia não

L1 - bem tranqüilo né?

L2 - bem tranqüilo

L1 - e antigamente... como se fazia pra ir até São Francisco

L2 - AH:.... muitas vezes a gente ia de bicicleta naquele tempo... falecido meu pai:.... comprava as coisa e vinha de carroça... me [a]lembro que ele contava que vinha de carroça... as coisa... não tinha estrada naquele tempo né?... mas naquele tempo era muito sacrificado... me [a]lembro que eu ia de bicicleta para cidade...

L1 - e pra vender o peixe? quem que

L L2 - o peixe aqui a gente já vende aqui... o próprio peixeiro já compra né?... e ele mesmo vende em casa... o peixe... então... normal

L1 - tudo normal né?

L2 - é

L1 - e assim... Joinville é uma cidade... nova...

L2 - é

L1 - né?... e antigamente São Francisco que fornecia tudo pra Joinville... por que será que inverteu... que hoje Joinville tá tão desenvolvida... e São Francisco ficou mais uma cidade histórica... mais pacata...

L2 - é por que os prefeito daqui... não deixa... as firma fazer a:: a:.... fazer as firma né?... não dão... a:: condiç[õs] para pessoa chegar aqui e fazer... e montar uma firma... eles impac[u] né?... os próprio prefeito por exemplo... como... antigamente era o Flávio né?... o:: Flávio Camargo né?... e depois foi o filho... e antes do Flávio né?... os prefeito antigo... eles impacar[o] a cidade... não deixaram crescer... por que vinham... por exemplo... um empresário... queria o terreno pra fazer uma::... uma firma... aí... ele só... ele só aceitav[ũ] se os filho dele fosse o gerente da firma... e aí aonde que empacou muitas coisas... inclusive... a Saveiros tá... essa firma de rebocad[o]... é:.... veio pra cá por que o próprio Z . ... pediu que o filho dele fosse o gerente... aí eles concederam... aí veio... senão também não vinha... então... nada se cria em São Chico porque eles querem que os filho dele seja os gerente das coisa... e aí é onde que não se cria né?... e São Chico / Joinville... por exemplo... eles abre a mão... dão terreno... a prefeitura libera um pouco o imposto... e aqui não... aqui eles... eles impac[u] tudo... é que nem a Petrobrás... a Petrobrás não correu daqui já... porque ela é obrigada a ficar aqui porque aqui o nosso mar é mais fundo... senão já tinha corrido... porque o imposto aqui é demais... inclusive... São Francisco... é uma das quinta... cidade... que mais $[\varnothing]$ rrecarda dinheiro... e não faz nada...

L1 - eu não sabia disso...

L2 - é::... a quinta cidade aqui de Santa Catarina que mais [ $\varnothing]$ rrecarda dinheiro... que só a Petrobrás paga... parece... (dois bi) e pouco por mês... pra prefeitura... e:.... a prefeitura ganha um dinheiro fantástico daqui... e mas não faz nada por aqui... se vê que até... até... a casa do pescad[o] aí tá tudo jogada aí oh...

L1 - e isso aqui é... como que é?... é uma 
L L2 - é uma casa que o governo fez pros pescad[o]... mais tá tudo... [ $\varnothing]$ bandonado aí... se ver... eu por exemplo quero um rancho pra botar minhas coisa e não tenho... eu tenho que dá pro outro colega ali... botar o remo... essas coisa... não tem... então... ninguém faz nada né?... por exemplo... aqui... o que tinha que fazer para aumentar a Enseada... era fazer... por exemplo... um $\mathrm{m}[0]$ lho de pedra ali na:.... na boca da Barra ali oh:.... e o rebocad[o]... inclusive a Petrobrás... queria fazer isso... eles não deixar[ũ] ... antigamente... os pescad[o]... er[ũ] mais... [Ø]nalfabeto... pensav[ũ] que ia estragar a praia... aí é... é burrice dos cara... então hoje... se fizesse aquela pont $\left[\int\right]$ e... é um $\mathrm{m}[0] 1$ ho... e fizesse aquela ponte funda... entrava os barco tudo lá pra dentro... entrava os iate tudo pra dentro... e formava uma grande marina aí atrás... o os pescad[o] saiu tudo da frente da... da praia... e a praia ficava muito ma[ $\varnothing]$ bonita... saía essa... esses barco tudo daqui e entrava tudo pra lá... e a Enseada gerava um turismo muito grande...

$\mathrm{L} 1$ - AH::... entendi

L2 - mais só que... os prefeit[o] não deixa né?... a Petrobrás quer fazer... mas eles não deix[ũ]... eles impac[ũ] tudo as coisa... então não tem um prefeito que olhe pra... pro progresso da cidade... eles não... não visam as coisa... entendeu?... se fizesse o $\mathrm{m}[$ [o]lho ali... essas / esses barco entrava tudo...e os iate grande... esse ricaço vinha tudo pra cá... mais eles não deix[ũ]... faz[i] nada...

L1 - que não tem onde ancorar realmente

L L2 - não... não tem... porque aqui é mar aberto né?... aqui é um perigo... aí se entrasse ali pra dentro do rio... se tu quiser eu posso te levar ali depois... aí tu vai ver que coisa maravilhosa...

L1 - então é grande... o rio é grande pra lá...

L2 - lá é grande... muito grande...

L1 - nossa

L2 - então tem um rio muito grande... então ali podia botar uma fábrica de gelo... podia fazer umas duas marina para entrar os iate... como tem lá em Guaratuba... e tudo... e dá... gerar... um monte de emprego... mais... os prefeit[o] não faz[i] nada... só querem saber de... de embo[^]sar o dinheiro... aí...

L1 - aí não dá né?

L2 - aí não dá... onde que... fica parado... e não vai... aí não cresce a cidade... não cresce... Joinville... Joinville cresce... e São Francisco não cresce...

L1 - puxa... e aqui na... em relação à... agora é uma época que a gente vê que a cidade tá praticamente vazia... eu tô até assustada... porque... eu andei ali na... na beira da... ali da... da praia ali... tá tudo... as casas... são todas fechadas né?

L1 - mas é o quê?... muito turista né?

L L2 - é... justamente... agora tá tudo fechado...

L2 - é tudo turista de Joinville... de Curitiba... essas casa... são... tudo... na maior parte são de Joinville... então eles são vem pra cá no verão... que agora... não:.... não vem pra cá... porque não tem nada aí... é... não tem um divertimento... não tem um baile... não tem... não tem tem nada... então... o pessoal não ficou aqui... não tem um shopping... não tem nada...

L1 - e no... e no verão... imagino que de / uns dias de muita gente pra cá...

L2 - é... no verão enche tudo aí... não tem lugar pra estacionar... que nem onde nós tamo[Ø] aqui ( )

L L1 - tem infra-estrutura pra cá é... suporta a cidade?... 
L2 - aí não... su / suporta né?... um pouco... mais... é:: é é:: é tudo assim na base do sufoco né?... que não tem nada né?... aí o $\mathrm{p}[\varnothing]$ ssoal domingo que vai lá pra cidade... que aqui não tem nada... L1 - chega a faltar água... luz...

L2 - não... não não... água não falta... água tem mantido... água luz não tem problema... mas o problema é que não tem nada né? a $\mathrm{p}[\varnothing]$ ssoa quer se divertir vai pra Joinville... vai pra Curitiba... vai pra... pra São Francisco... São Francisco também tem pouca coisa... só o carnaval que é mais ou menos... o resto não tem nada...

\section{J. J. A.}

10B

L1 - seu J.... eu queria que o senhor contasse pra mim da... da hisTÓria aqui da... da região... como é ser um pescador aqui?... é bom?... é bom morar aqui?

L2 - bom é né?... a gente $\mathrm{v}[\varepsilon]$ ve da pesca... e:: (todo dia pesca)... só que... o problema nosso aqui é:: os barco de pesca né?...

L1 - o senhor pesca há muitos anos eu acredito que sim... a pesca vem mudando?... como que era antigamente?... como é hoje?... em matéria de equipamento... esse tipo de coisa...

L2 - equipamento pra embarcação nossa pequena:.... não tem... tendo tanta diferença... a única diferença que eu pes / a pescada tá diminuindo né?... embarcação maior... avança mais... e aí nós vamo $[\varnothing] \ldots$ ficamo $[\varnothing] \ldots$ só com pouquinho que fica aqui mais por perto...

L1 - e aqui na na cidade... como que era isso aqui antigamente?... na sua infância?... mudou muito pra... pra hoje?

L2 - AH... mudou... dia pa noit[S]e né?... mudou muito...

L1 - e o que que mudou... assim... que que se lembra mais ou menos quando que veio asfalto... luz... ou essas coisas já tinham na sua infância?

L2 - NÃO... não tinha ainda... eu... quando comecei... quando era pequeno... saía pra fora... já saía sem luz... não tinha estrada... era só uma picadinha... uma picada... po cara passar... só... aí:.... ( ) foi mudando né?... hoj[e] em dia tá aí uma cidade...

L1 - e como o senhor fazia antigamente pra ir pro centro de São Francisco?

L2 - a gent[e] ia a pé... daqui até lá...

L1 - a pé mesmo... quantas horas de viagem?...

L2 - AH:: isso aí a gent[e] não marcava... ia lá... fazia o serviço... e:.... vo[ [ᄃ]tava... se precisava de um remédio tinha que ir lá no $[\varnothing]$ Batuba... ou lá em São Francisco a pé buscar... cansei de ir com o meu pai né?... quando era pequenininho... ( )

L1 - e:.... aqui na... na região... é... como que tá a questão da violência... é um lugar tranqüilo pra se viver ou

$\mathrm{L}$ L2 - por enquanto... a maior tranqüilidad[e]... por enquanto né?... mais um roubo mas é mixaria... mas o resto aí... pra se ver... vai levando né? porque o pobre é... é acostumado já... vai levando a vida...

L1 - e uma outra... uma outra pergunta... em relação à cultura aqui né?... porque eu conversando com outras pessoas... elas me contaram que antigamente tinha festas que hoje não tem mais...

L L2 - é que... na festa do interio[I] se era um baile... levava a:: a patroa... brincava à vontade... né?... tinha aquelas música... hoj[e] [e]m dia não tem mais nada disso... hoje em dia já pa::... pa levar a patroa já num bail[e] aí já... já... a juventud[e] $\mathrm{d}[e]$ hoj[e] [e]m dia é mais do 
fumo... então... começa a beber... já apronta... já então... em dia não dá... não tem mais aquele conforto como a gente tinha... lá no interior... que podia brincar à vontade... ( ) não tem mais...

L1 - e festas como o Boi de Mamão... tinha?...

$$
\text { L L2 - tinha }
$$

L1 - como que era uma festa do Boi de Mamão... porque pra gente é desconhecido...

L2 - eles saí[ũ]... em po[I]ta em po[I]ta né?... dançar as coisas... bicharia... caval[o]-marinh[o]...

onça... tudo isso tinha... então... batia lá... e... mandava eles dançar... chegava... cumprim[e]nava... dava uma gorjeta pra eles... saía dali e ia pa outra casa... e assim ia... aTÉ a gente me[ $\varnothing]$ mo quando saía dali ia acompanhar a brincadeira que tava... que era gostosa...

L1 - e o Terno de Reis... tinha também?

L2 - tinha... a me $[\varnothing]$ ma coisa... Terno de Reis tam[ $\varnothing]$ ém

L1 - era feito no dia seis né?

L2 - é

L1 - seis de janeiro... Pau de Fita?

L2 - Pau de Fita...

L1 - e o Pão por Cristo?... tinha aqui?

L2 - não... aqui não... aqui não tinha... mas hoj[e] em/aGOra é que as mulherada aí... tão inventando aí... aí vai numa casa... vai na outra... tão fazendo agora... mais antes... não tinha... a brincadeira era o Boi de Mamão... Terno de Reis... isso aí

L1 - e em relação ao comportamento das pessoas... por exemplo... é... a forma como o senhor foi educado e a forma como o senhor vê os jovens serem educados hoje... o que que o senhor sente... muita diferença?

L2 - olha... diferent $[e] \ldots$ diferença grand $[e] \ldots$ e:: do meu tempo... se passasse uma velha ali... Deus o livre que eu não pegasse a mão dela pra dar a benç[a]... hoje em dia... não se vê mais isso... não se vê mais isso... tinha que dar a benç[a]... se não desse a benç[a]... chegava em casa contasse pro meu pai... pra minha mãe... o pau comia... era uma coça que levava... até hoj[e] em dia não tem mais isso... hoje em dia já é custoso o filho da gente pro pai... então... então... não tem mais aquela... não existe...

L1 - e::... ali no centro de São Francisco do Sul né?... o senhor conhece ali a história do lugar?... por que que tem aquele Centro Velho ali... por que que eles preservam aquelas casas...

L2 - aquilo de lá é dos:.... dos antigos né?... aquilo lá for[ũ]... for[ũ] guardando... alguma coisa tinha... hoj[e] [e]m dia tá lá né?

L1 - ali no Centro Velho né?... e:.... como que o senhor conheceu é:: a sua esposa... foi aqui mesmo?

L2 - aqui me $[\varnothing] \mathrm{mo..}$.

L1 - aqui mesmo na Enseada

L2 - me casei... com quinze ano... eu com quinze... ela com catorze...

L1 - casava cedo assim... ou o senhor que quis casar cedo?...

L2 - não... é que naquel[e] tempo... os velho pegav[ũ] né?... pegav[ũ] e vai casar e pronto... aí me casei... tô até hoje

L1 - tem filhos?

L2 - seis

L1 - tem escola aqui pra eles estudarem direitinho?

L2 - escola

L1 - estudaram bastante aqui... 
L2 - o que eu não tive de estudo eu tô dando pra eles...

L1 - mas.... tem universidade... coisa assim... ou não?

L2 - tem pra São Francisco né?

L1 - cursos... o senhor sabe se tem alguma coisa pra juventude fazer?

L2 - tem... eles sempre tem alguma coisa aí...

L1 - agora... voltando pro assunto da pesca né?... o senhor... tantos anos na pesca... já passou algum susto no mar?... alguma coisa

L2 - AH já... isso aí... tempo ruim no (armador)...

L1 - como?

L2 - tempo ruim assim... vento né?... às vez[i] o motor quebra lá fora e você fica enguiçado lá né?... então é... é sofrido né?

L1 - teve alguma assim que marcou o senhor... que o senhor gostaria de contar... pra gente ter uma idéia

L2 - ( )

L1 - porque pra gente é tão... é tão fora da nossa realidade...

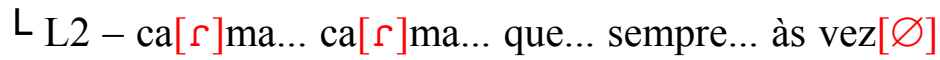

quando acontece... sempre tem um:: um pescador daqui que vai lá... socorre... [ĩ]vita mais... acident $[\mathrm{e}]$ lá fora... ( ) perigo... perigo... ( )

L1 - os sustos... imagino né?... e em relação assim... acham que tem tubarão baleia... tem essas coisas tem por aqui... tinha...

L2 - bal[ea] ainda tem... bal[ea] tem... porções... chega nesse tempo agora aí... é... agora... segunda-feira tinha duas ali... nos tamb[u]rete... tinha umas ali... tinha duas... duas...

L1 - aqui essa água é perigosa pra banho?... tem tubarão?

L2 - não...

$\mathrm{L} 1-(\mathrm{)})$

L2 - não... claro que... o pessoal fica à vontade aí... não tem...

L1 - tranqüilo né?

L2 - aqui é... pra banho aí é... tranqüilidade...

L1 - e fora a pesca... tem assim a:: muita indústria... muito emprego aqui... ou tem que trabalhar fora...

L2 - não... aqui não tem nada... emprego não... saí pra fora né?... aqui não tem nada de emprego... pra Joinville... pra São Francisco... mas aqui... pra emprego... pa fillho... aqui... não temos...

L1 - por que será né?... porque... que Joinville é bem mais nova que aqui né?... que São Francisco do Sul... bem mais nova que... e ela desenvolveu né?... e hoje ela é... pelo que eu li nos livros né?... antes era São Francisco que fornecia é... tudo pra região aqui né?... por que será que inverteu?

L2 - por que lá tão... é que tá os hom[i] do dinheiro né?... lá os empresário são tudo... de lá né?... e aqui nós não temo[ $\varnothing] \ldots$ aqui... é uma pa[J]te ( ) $\ldots$ não temos... é... temo[ $\varnothing]$ alguma cidadezinha aí... alguma coisa aí mais... isso aí é... o pessoal da... turista... né?... que vem aí sobre... outras coisa aí... dá... pra emprego aqui... nadinha... não chegou ainda... eu acho que nem vai chegar... ( ) emprego...

L1 - e aqui tem muita diferença da cidade numa... numa época dessa de inverno pra uma de verão?...

L2 - tem... tem... no verão tinha por causa que... o verão traz o pessoal de fora né?... vai então... vai pescar um pouco de pescada aqui nesse mar pra se vender pra eles... então... sobra mais um cascalhinho... no verão... 
L1 - ali nas praias ali... eu dei uma.... uma andada boa ali... é... a maioria das casa tão todas fechadas... são pessoas de fora né?...

L1 - ali em Ubatuba ali...

$$
\text { L L2 - são... }
$$

L2 - são de Joinville... a maior parte nossa daqui são de Joinville... da maior parte aí... pessoal de Joinville...

L1 - são poucas as pessoas daqui... MESmo... né?... nascidas e criadas aqui...

L2 - é... temos bem pouco... aqui acho... na (base) acho que tem mais... cinqüenta pessoa mais ou menos

L1 - que sejam naturais do local né?

L2 - que seja daqui... filho daqui...

L1 - filho da terra né?

L2 - filho da terra...

L1 - é... eu tô tendo essa dificuldade pra... pra encontrar pessoas que realmente tenha sido criadas aqui... até JOvens... eu tô falando... não só pessoas... tem uma garotada aí... mas tá vindo muita gente de fora morar aqui... por que será?... tanta gente tá procurando aqui?...

L2 - por que aí... aí pra fora... tem muito desempreg[o] né?... e o custo de vida é... é maior qu[e] aqui né? aqui você... veste uma... veste um calção aí e sai desca[^]ço... na cidade já não dá... eles corre mais pra beira de praia... aí a $[\ulcorner]$ gum vai pescar... outro vai... inventar uma coisa... e fíca aí...

\section{J. F. B. (L2)}

1C

L1 - seu J. como que é morar aqui... na beira da praia?... um lugar tão tranqüilo...

L2 - é::... a gente mora aqui... porque:.... aqui é $\mathrm{m}[\mathrm{i}]$ lhor... já tá cheio de $\mathrm{p}[\varnothing] \mathrm{ob}[\ulcorner]$ ema né?... então... dá pra gente ganhar... ( ) cuidar daqui...

L1 - e o senhor gosta de morar aqui?

L2 - gosto...

L1 - e o que que / o senhor gosta de São Francisco do Sul?...

L2 - gosto...

L1 - lugar bom pra viver?...

L2 - é:.... não é ruim não...

L1 - e aqui tem violência?...

L2 - era mais calmo... já tá... ficando meio agitado...

L1 - como era aqui quando o senhor veio morar pra cá?...

L2 - AH... aqui era:.... só tinha essa propriedade aqui mesmo... daí não tinha rua... o acesso era pela praia ou... por uma trilha aqui... e o pessoal do batalhão vinham fazer instrução... vinham fazer instrução na praia...

L1 - é muito longe daqui o Forte?

L2 - na... é pertinho... final do morro...

L1 - tá... e:.... o senhor... seus pais assim... eles gostavam... gostam daqui do Sul?... gostam de Santa Catarina?... gostam de morar aqui também?... gostavam?...

L2 - gostavam...

L1 - e:: o senhor... o senhor quando era novo assim... o senhor chegava a ir naquelas brincadeiras de Boi de Mamão... Terno de Reis...

L2 - ((consente com a cabeça))

L1 - como que é um Terno de Reis? 
L2 - é::... as roupa... eu não sei quanto é que precisa pro:.... Terno de Reis... mas é... ( ) traz um pau ali... o tanto que $\mathrm{p}[\mathrm{e} \varsigma]$ cisava... pra ir... pra fazer / cantar... pra ir nas casa... aí...

L1 - e o:: Boi de Mamão... o senhor chegou a ir?... chegou a assistir?...

L2 - cheguei... até um tempo eu participei também de... brincadeira de Boi de Mamão...

L1 - como que é uma brincadeira de Boi de Mamão?...

L2 - olha... o boi... ele canta e:.... grita... ele brinca com o boi... ele brinca com o boi e outro brinca com o outro bicho que tiverem também... daí... sai sai... sai daí o outro proprietário que era que... ele cheg[ũ] ... daí ele cheg[ũ] ali... daí começa a brincar com o boi... e o que... tem um que canta ali... não sei bem como que é... esse canta ali... como se chama?... sempre tem um que canta né?... então... sai um brincar com o boi... o outro... o outro como touro... e assim faz[i] a brincadeira...

L1 - e a festa do Divino... tinha?

L2 - eu acho que::... eu não me lembro que tem festa do Divino aqui... não me lembro... disso aí não me lembro...

L1 - Pão por Deus... tinha?

L2 - não tinha...

L1 - e hoje... tem ainda o Terno de Reis?... o Boi de Mamão?...

$\mathrm{L} 2-$ tem...

L1 - mais é freqüente?... ou quase não:.... não tem como era antigamente...

L2 - não... muito... muito pouco né?... que... são mais... são faz mais onde a população é maior... é::... aqui como a população é pequena já... já quase não sai... o pessoal já não tão preferindo tanto... mais que tem tem...

L1 - e como que o senhor fazia pra ir daqui pra:.... pro centro de São Francisco?

L2 - AH... pegava ônibus lá no $[\varnothing]$ Batuba... o:.... ali na estrada do Forte... até hoje... eu pego ali na estrada do Forte ainda... é aonde que tem mais perto... ( ) antigamente nem tinha ônibu[ $\varnothing] \ldots$ era:.... ralo... a linha de ônibus... acho que eu tinha as perna boa... andava bem... a gente ia lá no [Ø]Batuba... e vinha embora pra casa... fazia as compra lá em São Francisco... pegava um saco de compra e trazia nas costa... pela praia afora...

L1 - São Francisco mudou muito com o tempo?... o ela continua a mesma cidade?... aquela parte ali do centro?...

L2 - aquela parte do centro ali... não... não tá muito... mudada não... por causa daqueles patrimônio história né?... que não pode mais mexer... não pode mais... não pode:.... modificar né?... então fica assim... umas coisa meio... meio isolada...

L1 - o senhor acha bonito?... acha que deve preservar?... sabe por que eles preservam aquilo?...

L2 - eu acho que não... acho que não... aquilo ali devia dem[○]lir... deixar os proprietário fazer do jeito que eles querem né?... fica uma visão ma / mais muito mais bonita... fica... depois desenvolve um pouco também... aí::... o pessoal... fica mais... fica mais atraente por coisa nova né?... então... eu acho que por isso que devia ser liberado... pra... pro pessoal fazer do jeito que querem fazer né?... os proprietário...

L1 - e aqui na na:.... na praia de Ubatuba... Enseada aqui... Itaguaçu... tem diferença de número de pessoas de inverno e de verão?

L2 - tem... a cidade... agora é muito pouco só... os trabalhador que trabalha aqui... e os proprietário... pessoal que mora... e:.... turista... pessoal de fora a::... só mais na::... no feriadão e:.... no verão...

L1 - e como que fica a cidade?... fica muito cheia?... fica mais perigosa?... é bom pro geral?... pros turistas?... 
L2 - eles... eles gost[ũ]... porque às vez[i] não tem outro lugar... mais apropriado pra ir... então já vem pra praia... principalmente as parte... mulher... que:: que são mais atraente pelas praia né?... L1 - e a praia aqui?... ela é boa pra banho?... é perigosa?...

L2 - ela não é uma praia... uma praia de confiança mesmo que::... que pode:.... tem muito buraco em... embaixo... a areia... dentro da água né?... então acontece às vez[i] afogamento porque:.... as pessoa tá ali no baixo... dá uma passada pra frente... o po lado já::... entra pelo buraco... já e::...

L L1 - se apavora...

L2 - e é aí que acontece afogamento...

L1 - já aconteceu muita coisa aqui?... sempre acontece... ou não?...

L2 - já... já teve... vários afogamento aqui... que não é tanto como é nas outras né?... mais que já tem acontecido a[ \ulcorner] gum já...

L1 - e o senhor... o senhor gosta de pescar?... aproveita o mar?... ou não?...

L2 - não não... eu gosto de pescar... só que agora não posso mais...

L1 - e na época que o senhor pescava... o senhor chegou a:.... a a ir... pescava só aqui ou ia de barco?... passou algum susto alguma vez?...

L2 - não... só pescava aqui... tarrafa na praia... gostava muito... e gosto... mas é que não posso mais entrar...

L1 - nunca tomou nenhum susto né?...

L2 - não...

L1 - mas sempre é:.... é perigoso...

L2 - é... que a:.... pescaria de tarrafa é sempre aqui no baixinho... não sei como... ter perigo de... ( )$\ldots$

L1 - e o senhor... é::... como que era a sua infância?... o que que o senhor fazia?... o senhor ia pra escola?... o senhor estudou pouco né?

L2 - estudei pouco...

L1 - trabalhou desde menino?... conta pra mim um pouquinho da sua infância...

L2 - AH é... fui criança numa vida muito difícil... ( ) à custa de braço... meu avô era tudo... custa de braço... daí... a... que:.... que naquele (dia era pouco)... que hoje em dia... hoje em dia::... naquele tempo ainda difíci $[\varnothing] / \ldots$ ainda dava... por causa ( ) com muita dificuldade... mais hoje em dia... na época que nós temo[ $\varnothing]$ agora... se se... se viver de roça... à custa de braço não faz nem... não adianta nem... nem se meter... porque... se não tiver maquinário... pra produzir bastante... pra aparecer um renda boa... a custa de braço não... não faz nada...

L1 - e o jovem no dia de hoje?... por exemplo... pensando na educação né?... o senhor foi educado de uma maneira... como que o senhor vê hoje a juventude sendo educada?... o que o senhor acha do jovem hoje?...

L2 - eu acho... bem... bem diferente da... da nossa época... a gente obedecia os pai... não cometia certas coisa que ... que não devia admitir... tem que... tem (criar) com um carinho mais honesto... mais... hoje em dia tá muito diferente a juventude de agora... moça não ia... moça não ia a... baile sozinha... fora do pai e da mãe... não ia a festa... tem uma parte que era rapaz que sempre ia né?... mais é... mais só na base de... de se divertir... e não se via esse negócio de droga... essas coisa de... de (doideira).. bebida tinha mais ninguém se metia como hoje em dia... e:.... ficou totalmente... que a vida era mais difícil também... não dava pra fazer muita... graça que... ( ) das pessoas... era assim...

L1 - e hoje o senhor acha que tá... a juventude... 
L2 - AH... tão liberado para tudo né?... que os pai ( ) às vez[i] que:.... que bate num filho... aí ( ) toma providência... que não pode bater... porque isso... porque aquilo... aí não se intim[ع]da porque o pai não bate... daí eles.. cada vez ficam mais confiante...

L1 - e a televisão... o senhor acha que a televisão ajuda nisso?...

L2 - eu acho... televisão ajuda muito... naquele tempo a gente não tinha nada dessas coisa... nem pensava que ia ver... uma pessoa lá de São Paulo... até lá do estrangeiro... dentro de casa... na na tela...

L1 - e o senhor acha que a tv é muito violenta?...

L2 - eu acho que um pouco ela ajuda também né?... sabe onde tem... ( ) os posto de droga... tudo... já sabe tudo que passa pelo mundo já... já... já tá sabendo pela televisão... onde tem os posto de droga... traficante... essas coisa...

L1 - aqui o senhor acha que tem dessas coisas... aqui no Sul?...

L2 - ( ) não assim de ter essa (negociada)... essas coisa... mais em rodovia...

L1 - e não é fácil né?... criar os filho hoje né?... o senhor tem uma família grande?...

L2 - AH... minha família eu tive só quatro... é um hom[i] e três mulhe[ $\varnothing] \ldots$

L1 - o senhor tem netos?...

L2 - tenho... criei eles tudo desde pequeno... quando a... a mãe morreu a mais moça tinha só um ano de idade... criei eles sozinho... e era mais fácil aqui onde eu moro... daqui... porque... porque se fosse trabalhar numa firma fora... fora daqui aí não tinha como criar eles...

L1 - como deixar... com quem deixar...

L2 - é... como eu tava morando aqui foi mais fácil pra criar... a situação financeira era difícil... mais... mais a gente sempre tava perto deles...

\section{O. P. (L2)}

2C

L1 - eu queria que o senhor me contasse... o senhor sempre trabalhou na pesca?

L2 - sim... sempre trabalhei...

L1 - como que é o... o dia de um pescador aqui?...

L2 - é::... o dia do pescador é... ele ele tem que traba[j] ar todos os dia né?... aqui... aqui... só não... só não trabalha... não pesca num pesca num dia que nem hoj[e]... que é... que tá o vent[o] sul aí né?... esse reboj[o] que o pescador chama né?... que é o vento que é mais... que é mais respeitado... na... na costa brasileira... na pesca principalmente né?... então... num dia que nem hoje eles tão tudo dia... é sábad[o] doming[o]... é feriado... é todos os dias...

L1 - e::... o senhor já passou algum susto aí na na no mar?... aí

L2 - não não... eu não passei... já peguei... já peguei... ventos trovoadas... assim reboj[o] assim... ma[Ø] não foi de de de de... de perigar não foi... mas teve... já teve uns amigo aí... que já fícavam aí à deriva no mar... agora faz uns... faz uns três meses aí... teve um amig[o] nosso... o C. aí pescador aí... ficou $\operatorname{tr}[e$ es] dia à deriva no mar aí... sem sem água... sem comida... o grave é quando chegou um... barc[o] lá pert[o] dele que... aí passar[ũ] o rádio acident[e]... passar[ũ] o rádi[o] pos barc[o]... pas capitania... aí um barc[o] lá fora escutou e... foi a procura dele e achou... que mar... daqui ele foi bater lá em Itajaí ( ... no mar de Itajaí... aí era só a bat[i]ria né?... a bat[i]ria dele pifou... então ele não podia vim... então o cara arrumou a bateria do barco deles... o indivíduo bateu na partida do... do motor... pegou... e ele veio bonzinho embora... 


\section{L1 - poxa vida}

L2 - só por causa de uma bat[i]ria quase que o cara... se dana aí fora aí... sem comida... sem sem... sem água... três dia... dois / três dia e duas noit[e] aí fora aí...

L1 - e como que é a... a... produção aqui?... ela é a mesma em todos anos de pesca? ou as coisas tão mudando?...

L2 - ah não... muda muito... muda muito né?... muda muito... toda... toda qualidade de pesca... e pesca muda muit[o]... agora a... a...do[s] anos pra cá... tá cada vez mais difíci[Ø]... que aqui nós tinha a saf $[\varnothing]$ a da::... a saf $[\varnothing]$ a do cação... a saf $[\varnothing]$ a do ba[gi] ... a saf $[\varnothing]$ a da corvina... o cação não deu mais... o ba[gI] não deu mais... a corvina vai... vai chegar ir... é o tempo dela agora né?... mas ano passado já não deu nada... e ano... e anos aí... de corvina aí de nem querer matar mais de tanto que dava né?... toda canoa era mil quil[o]... oitocent[o]s quil[o] né?... é... tava a preço de banana aí... agora... ( ) ano passado não deu nada... o rapaz que pega peixe aí tá se batendo aí... L1 - porque que o senhor acha que isso tá acontecendo?

L2 - AH::... deve ser os grandes barc[o] né?... deve ser os barc[o]... os barc[o] aqui... no norte da ilha que nós chamamo[ $\varnothing]$ aqui... ou da ilha lá... a / aqueles barco de pesca lá... de... Ita / de chegar... de carregar três barco... na faixa de... sessenta tonelada cada barc[o] daquel[e]... dá cen / cento e oitenta mil quilo de corvina né?... é mole?... então o barco vão pegando... vão matando... (todo) isso aí... quer dizer... cento e oitenta tonela / aqui... isso aqui... é corvina pra matar... quat $[\varnothing]$ o... cinco... ano... três ano... conforme eles vão... vão... essa quantidade de corvina aqui... do do barc[o] depois de um lanc $[e]$ só... eles tem aparelho... tem sonda... tem sonar... tem tudo né?... ( ) é o peixe certo na certa né?

L1 - e::... aqui é uma coisa mais artesanal... por exemplo... o senhor não tem um sonar... uma coisa dessa...

\section{L2 - não não}

L1 - como o senhor sabe que... ali que tem peixe... o... o mar que tá bom...

L2 - a não... ali que tem peixe não sabe... não sabe nada... vai botar a red[e] ali na... na sort[e] mesmo... deu deu... se não deu... às vez[i] na sort[e] que passa um cardum[e] ali... se pega bastante... e às vez[i] você vai lá e não pega nem pra comer... nem que for pra pagar o óleo dá... e tem vez[i] que pega bastante... bota a rede ali... bota... bota em cima do cardum[e]... o cardum[e] (bate de fora)... se enche no início da noite que chega aí... então... não tira nem pra comer... bem dizer... três quatro quil[o]s... cinco quil[o]... é assim...

L1 - pouco né?...

L2 - pouco... e eles não tem... aqui eles só tem... algum tem a bússola para navegar só... para viajar né?... para navegar de noite... dia de serração assim... tem o GPR... o GPS né?... que... que... que lá na bóia... eles quer ir lá na bóia... eles tão... um dia de nublado assim... e quiser voltar... ali tem ou GP/ o GPS... daí... da para... para... e só para navegar né?... agora para acusar peixe...

L1 - e::... o senhor mora aqui há muito tempo... né?... foi praticamente nascido... nascido aqui...

L2 - foi foi... foi sessenta e dois an[o] vivido aqui...

L1 - como era a cidade na sua infância?

L2 - AH... aqui era mat[o]... tudo mat[o]... mat[o] aqui... mat[o] aqui não tinha nada aqui... aqui era

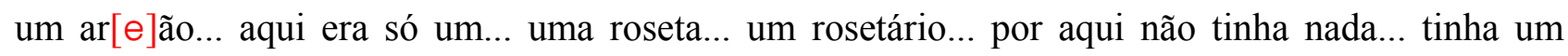


caminho de areia aqui na frente... daqui até o asfalto ali... era uma rua de areia né?... ar[e]ão e nós andava só com ( )... era um escuridão aí que não tinha nada... naquele tempo... peixe tinha com fartura... só que tinha peixe já não tinha... não tinha pra quem vender... não tinha gelo... se matava... dava um lance de peixe aí... aqui ( ) foi enterrado de de... de mil... de doze mil quilo de peixe ali... que apodrecia né?... matava o peixe e não tinha para quem vender... não tinha gel[o].. não tinha gel[o] naquele temp[o]... agora dá... dá... se mata um pouquinho de peixe no gel[o] já resolve... se ligar... já vem um caminhão com gelo já... já vem prontinho... e era só um montão... escur[o]... escuridão aí para atrás me $[\varnothing]$ mo... ali... para atrás aqui não tinha nada... aqui tinha uma cidadezinha... de... com a / casa de madeira... de te[j]a tinha bem pouco... mas era tudo pa[j]a... então lá pos ano... cinqüenta... cinqüenta e do[s] mais ou menos que veio a luz pra cá... depois... fizer[ũ]... passou um caminhão na pontezinha lá... fizer[ũ] uma estradinha de... casca... daquela casca do... do coq / do sambaqui né?... fizer[ũ] aqui/aquel[e] carpet[e] de sambaqui fizer[ũ]... depo[s]... depo[s] foi vendido... isso aqui era de herdeiro da... da Enseada aqui né?... sabia... meus avós fazi[ũ] parte de uma herança aí... aí for[ũ] vendendo... pos... aí... aí... foi vendido aqui pro Milton Mavele aqui de São Francisco né?... aí el[e]s vender[ũ] pra... depo[s] eles fizer[ũ] um negócio na imobiliária catarinense de Itajaí... essa que tem até hoj[e]... então essa aí veio pra cá com o trator... desmatou tudo... foi aqui que deu um igual daí... veio a Petrobrás pra cá... aí a Petrobrás que deu... um avanço bom... aí asfaltar[ũ]... já veio a Petrobrás... já asfaltar[ũ]... aí já tinha luz... aí foi embora... aí para atrás já tava tudo loteado... tudo tudo... com rua... com tudo... aí depois que a Petrobrás veio pra cá... foi...

L1 - aí desenvolveu né?

L2 - desenvolveu

L1 - e aqui na:.... fora a pesca... tem uma outra atividade tem indústria por aqui?

L2 - não... a única atividad[e] que tem é a construção civil né?... construção civil que o pessoal trabalha aí... e outros traba[jũ] no... traba[i]a nessa lojinha aí da... na Ense / tam[Ø]ém é mais na temporada né?... no inverno dá pouco... comércio aqui na Enseada é frac[o] aqui... pra pra loja... pos troç[o] aí né?... farMÁcia... tem muita gente que trabalha em lojinha... em farmácia... em supermercado né?... mais é frac[o]... no invern[o] é... é só por... tem alguma que não faz[i] nem pa pagar o aluguel aí... aluguel é caro né?... aluguel de mil real por mês... quinhent[o]s... oitocent[o]s... seiscent[o]s né?... então é... tem gente aí que vem pra cá... aluga um ponto aí... fica no verão... quando termina a temporada sai mais pobr[e] do que veio... não sei... não tira o dinheiro né?... às vez[i]... dá uma zebra da temporada meio ruim... temporada chuvosa... um ano chuvoso... então leva ferro... aí le/vai embora... deixa... entrega... hipoteca o carro... vende o carro... dá um arrendatário pro aluguel... é assim...

L1 - e tem muita diferença duma estação... que nem... agora aqui tá muito inverno... tá frio né?... a cidade tá bem... tá bem vazia... eu andei... tem muita casa fechada né?... e:.... no verão?

L2 - AH... no verão é uma loucura... no verão é uma loucura... nós que moramo[Ø] aqui pra nós já não tá prestando mais aqui... caso que moramo[Ø] mais aqui po centro né?... moro aqui uns cinqüenta metr[o]... atrás de ti... é... já no verão não dá mais pa... gente mora mais... pra nós que gostamo $[\varnothing]$ de... descansar... aqui não dá mais... muita loucura... muita lo / gent[e] a noite inteira... 
carro... essas moto com escap[e] direto... é bagunça direto né? esses bar também que faz... faz... botar som ao vivo... é...é uma loucura... só... pa pa pa comércio é bom... comércio é bom... os comércio aí... é um bom a gente faz um pé de meia... no verão...

L1 - no verão né?

L2 - é...

L1 - e aqui... conversando com outras pessoas né?... me falaram que antigamente... tinha... festas como o Boi de Mamão... Terno de Reis...

L L2 - a tinha (existia) muito

$\mathrm{L}$ L1 - e hoje não tem mais

L1 - o senhor chegou a acompanhar?

L L2 - não

L2 - AH... acompanhei... minha minha... minha meus avô... eles gostav[ũ] muito... isso aí era de Portugal né?... eles gostav[ũ] de Terno de Reis... inclusive sai[ũ] junto... cantava né?... a minha vó... mas eu conheço muito aqui... Terno de Rei... Boi de Mamão... Pau de Fita... esse troço todo... ( )... agora acabou né?... os hom[i] certo... esse pessoal mais novo já não... já não não... gosta mais de sair né?... então às vez[i] / a gente quando faz uma festa assim... agora é época de São João... fogueira assim eles faz[i]... festa junina é... ali eles faz[i]... Boi de Mamão... essas coisa aí... às vez[i] ... agora no verão... na temporada... aí vem... ainda vem Terno de Reis de São Francisco... de Joinville...

L1 - como que é um Terno de Reis?

L2 - é assim... por exemplo... três quatro pessoas se juntam assim né?... aí sai com... um violão... um acordeão... coisa é... e tem doze... tem do[s] canta né?... um um... um canta primeiro... para tirar é... para tirar $0 . .$. o verso... o $[\varnothing] \mathrm{t}[\varnothing] \mathrm{o}$ chega numa casa... assim pa acordar a pessoa né?... aí... depo[s] canta os dois junto... é legal é bonito... é bonito... esse ano passado aqui nós tivemo[Ø] aqui... na tenda aqui da... da igreja aqui... teve missa ( )... aí... aí... a prefeitura aí... foi os quinhentos anos de São Francisco né?... aí trouxe... trouxe ( ) um Terno de Rei de Joinville... AH... foi muito bonito... muito aplaudido... encheu de gente aí... a tenda aí... botar[ũ] uma tenda em frente à Igreja Católica aqui... encheu... tava muito bonito...

L1 - e como que é... aquele centro ali... antigo ali... tem aquelas casas antigas... o senhor conhece um pouco da história ali?... do centro de São Francisco do Sul?...

LL2 - São Francisco... AH sim... aquilo ali... aquelas casa antiga ali... aquil[o] ali... aquil[o] ali não pode mexer... aquilo ali né?... primeir[o] se tem que... consertar ela... arrumar conforme o estilo dela... conform[o] tá ali né?... cidade histórica né?... ali tem... o museu... o Museu do Mar... aquilo dali... tudo tu/tudo aqueles prédio... casarão... tudo antigo ali... ali vocês têm que reformar ele... mas deixar como... no estilo como ela tá né?... não pode... reformar ela des / de de outro jeito... de outro tipo... tem que ser assim como tá ali... tem eu tenho vinte / tenho quarenta lá em São Francisco... já for[ũ] tudo ( )... tem que ser como é... quer reformar... reforma... ma[ $\varnothing]$ faz estilo como era antes... e pa mudar não...

L1 - não pode

L2 - não pode... só aqui... se você comprou o terreno aí va / vazio... aí você pode fazer... mas aonde tá os / esses casári[o] antig[o]... tem que ser como tá...

L1 - e o senhor conhece a história ali do... do... do... tem um forte ali né?... você conhece a história dele?... 
L2 - é::... o Forte eu conhe / eu conheço mas pouco né?... porque é... mas o Forte aqui é... é uma área de segurança né?... aqui na entrada de barra de São Francisco aqui era muito... era muito falado esse porto aqui... aqui servia... um / muito so[ $[\ulcorner] \operatorname{dad}[0] \ldots$ muita gente... vinha gente de Blumenau... de Itajaí... tudo se via aqui né?... depois foi fracassando... foi indo aí... aí... tirar[ũ] daqui levar[ũ] ... parece... pra lá pra uma cidadezinha do Paraná... agora só tem os... os casarões... tem tudo os canhões em cima do morro... é cuidado... é vigiado né?... é:: é... quem comanda aí é o treze de Joinville... lá tem um batalhão lá em Joinville... então de lá se desloca aí os so[^]dad[o] que vem aí fazer a manutenção... a limpeza... limpar... lavar... pintar... cuidadinho... mora... inclusive mora... so[ৎ] dad[o] direto ali né?... direto ali... fizer[u] em cima daquele morro lá... lá é... aquilo lá é muito bonito lá em cima... lá tem os canhões... mas tem um... um... uma casa grande assim que nem essa assim... com tudo... com todos os troços ali embaixo ali... fotografia... tem tudo dali... aqueles caras antigos que servir[ũ] ali... os coronéis... é... tem tudo aquelas fot[o]... de de... dos presidente que já falecer[ũ]... ali é muito bonito... mas mas tá desativado né?... ali virou tipo uma colônia de férias né?... dos militar ali ( )... em temporada eles vêm passar as férias deles ali né?...

L1 - seu F. como que é morar aqui onde o senhor mora?... perto do Forte... é bom?...

L2 - é... concordo que já foi melhor... hoje não ah mora toda a a população do Forte... é mais pessoal de fora... não é como antigamente não... o Forte já foi... bem melhor... mais não é um bairro ruim também não... é um bairro bom também né?... problema de serviço aqui é::... não é muito bom... eu inclusive sou $[\varnothing]$ posentado...

L1 - o senhor trabalhava com o quê?

L2 - eu... eu eu eu... eu era motorista do... toda a vida eu trabalhei como motorista... sabe?... e hoje... trabalho também muito em minha firma... né?... trabalhei em firma de fora... trabalhei em firma de São Paulo... em firma de Curitiba... é nessa firma toda né?... e... trabalho muito tempo... na... na prefeitura de Joinville... trabalhei na prefeitura de São Francisco... que... quando completou a minha idade de sessenta e cinco anos eu me aposentei... tenho uma boa aposentadoria graças a Deus... nunca... não... ( ) minha aposentadoria... tenho uma família GRANde... tenho uma família grande... praticamente quase todos depende de mim né?... ajudando um filho... o que mais eu posso fazer pela minha família é ajudar eles... tenho muitos amigo... vixe barbaridade... muitos amigo que me querem bem... sabe?... e é assim... tenho... dezesseis neto... dois (bisneto)... tenho... genro... tenho dois... tenho três gen $[r]$ o né?... filho... são nove fi[ $\varnothing]$ ]o... nove vivo e um morto... todos mor[ũ] praticamente junto comigo... aquela ali é uma filha que mora ali... essa aqui é outra filha... aquela é outra filha ((apontando para as mulheres que conversavam no quintal))... mor[ũ] tudo junto comigo... e tem os meus amigo que me adora... que me apreci[ũ]... são uns amigo bom... eu sou... graças a Deus... eu sou um bom elemento dentro do meu lugar... praticamente... trabalhei muito... eu... trabalhei... que cheguei a minha aposentadoria com quatro ano e dez meses e quinze dias... que... me aposentei qua/ praticamente mais por idade... não chegou... não chegou o meu tempo certo... ( ) o tempo certo de me aposentar daria trinta e cinco ano... me aposentei com trinta e quatro e dois meses de serviço... e:.... tô contente com o... com a minha aposentadoria... assim eu vivo... tenho meu carro... e... e a minha família toda em redor de mim...

L1 - e como que era morar aqui na sua juventude?... tinha muita diferença do que é hoje?... L2 - na juventude? 
$\mathrm{L} 1-$ é

L2 - era bom...

L1 - mas como que era?... tinha muita casa... tinha pouca casa....

L2 - não... aqui no Forte antigamente não tinha casa nenhuma... que tinha... umas seis... umas oito casa era muito... né?... se tinha oito casa era muito... no tempo aqui... do quartel... hoje ainda existe um batalhão aqui sabe?... né?... eu... batalhão fui servente aí... a gente o pessoal aqui sentiu muito quando o batalhão saiu... e::... e hoje em dia a população cresceu mais (porque) gente de fora... e antigamente não tinha... tantas casa sabe?... mas... te / tenho meus amigos que são pescador... vive da pesca... da pesca da tainha... da pesca do camarão... e é assim sabe...

L1 - e a juventude?... o senhor foi criado... é:: o senhor acha que mudou muito hoje... por exemplo... a educação das crianças?...

L2 - não... eu quando era guri eu fui criado... tinha um... pais maravilhosos... souberam me criar... me criaram com carinho... com muito amor... e:.... inclusive hoje eu não tenho eles mais... eu perdi meu pai e perdi minha mãe... hoje eu vivo com a minha família... minha mulhe $[\varnothing]$... ela chama-se H.... e:.... a juventude... eu tenho... na juventude (guri) de escola... eu tinha muitos amigos... muito amiguinho na escola né?... que hoje... quando me encontra... já tão na minha idade... os que tão vivo... encontram... falam comigo... é... a[ $\varsigma]$ gum que tiveram no batalhão comigo também serviram... hoje tudo tudo meus amigo... e a.... e a juventude... a juventude pra mim foi boa... eu me criei... como guri... respeitando o ser humano... uhn?... respeitando todo mundo... nunca dei trabalho pros meus professores... e... tenho... não cheguei terminar o estudo... tenho o quarto ano primário... tenho o quarto ano primário eu tenho... e assim levei minha vida... hoje eu tô com sessenta e seis anos... muito sofrido... a minha família sabe?... tenho... minha filha que mora... tenho uma filha que trabalha na Petrobrá[ $\left.\int\right] . .$. ( ) tenho outra filha na polícia militar... talvez até vocês passar[ũ] ali ela tava no posto trabalhando...

L1 - ( ) e fala uma coisa pra mim... aqui é um lugar violento?... tem violência pra cá?...

L2 - aqui no Forte... aqui no Forte... não é um lugar violento... não é... não é porque as [o]toridade... as [o]toridade aqui... da nossa cidade... trabalham muito bem sabe?... discutem muito bem... sabe?...mostram severidade... mostram severidade... nós temos... a nossa Oto / otoridades aqui den / dentro da nossa cidade é bom... então ele $\left[\int\right]$ cuida muito aqui do bairro sabe?... eles cuida do bairro... coisa de louco... sobre a autoridade não temo[ $\varnothing]$ nada contra... do nosso delegado... dos hom[i] dali né?...

L1 - e o senhor conhece ali o::... a história do Centro:.... do Centro Histórico ali?... o senhor sabe que... porque aquelas casa são antigas?...

L2 - AH... o Centro Histórico de São Francisco?... o Centro Histórico de São Francisco eu trabalhei na prefeitura... aquilo ali... antigamente... é um museu você quer dizer né?

L1 - é... mas assim

L L2 - um museu velho né?

$\mathrm{L}_{\mathrm{L} 1}$ - as casas são antigas né?... ali tem o... perto do Mercado... aquele Mercado antigo... aquelas casas...

L2 - AH sim... o Mercado antigo... quem chamou aí agora?... aquele Mercado antigo ali... já foi reformado parece que umas duas ou três vezes... entendeu?... é... foi reformado pelo... prefeito... agora nós temos o nosso prefeito... o O . ... muito bom... fez muita coisa... trabalhou... um ótimo prefeito certo?... O. ... e eu... e é isso aí que eu posso falar...

L1 - e o senhor quando era novinho... o senhor chegou a ver festas de Terno de Reis?... Divino Espírito Santo?... Boi de Mamão?

$$
\text { L L2 - HÁ... tinha... }
$$




\section{$\mathrm{L} \mathrm{L} 1$ - tinha essas coisas por aí?}

L2 - tinha... tinha tudo... tinha tudo... tinha aqueles ve / aqueles pessoal antigo... que hoje não são mais vivo... mortos... nós tinha aqui Terno de Reis...muitos baile... muita diversão... ( ) violência nenhuma não tinha sabe?... o pessoal naquele tempo era civilizado... então nosso bairro aqui... não é ruim também sabe?... com a cidade de São Francisco... a cidade de São Francisco... não aumenta e não... fica nisso... mais... nós temos... um povo bom... não é uma cidade violenta não...

L1 - e:.... essas festas como o Terno de Reis... o Boi de Mamão... tem ainda hoje?... ou acabou?...

L2 - NÃO... agora... hoje hoje em dia você já não tem mais Terno de Reis como antigamente né?... o mais acabou... o pessoal já não fazem mais a festa... o pessoal não... aqui no meu... no meu / no nosso bairro sempre há uma... uma festinha como agora mês passado... acho que... semana passada teve uma festinha aqui... nosso amigo... tenho um amigo aí que gosta muito de fazer uma festinha... ( ) com baile... trezentas pessoas...

L1 - como que era um Terno de Reis?... que eu nunca vi...

L2 - AH... chegav[ũ]... o Terno de Reis é o seguinte... chamavam nas casa... mais ou menos dez onze horas... ( ) a[ \ulcorner] gum chefe de casa... que [a]rrecebe bem sabe?... [a]rrecebe bem o pessoal... vixe... era sempre com educação né?... mas muitos não gost[u]... não go[ $\left.\int\right] \mathrm{t}[\mathrm{u}] \ldots$ então quando o Terno de Reis sai... um agradeci com uma coisa... se tem dinheiro... dá um... um pouco de dinheiro... outro agradece com alimento... é assim Terno de Reis...

L1 - e o Pão por Deus... tinha aqui?..

L2 - Pão por Deus?

L1 - é

L2 - tinha... acabou... tinha Pão por Deus... tinha:.... bandeira do divino Espírito Santo... a bandeira ( )... (então) acabou... mais isso é antigamente... o pessoal antigo sabe?... enfim...

$\mathrm{L} 1$ - e o que que os jovens fazem hoje pra se divertir...

L2 - AH... hoje os jovens fazem é campo de futebol... é bola... é:.... nessa quadra aí... todos domingo é futebol... ( ) jog[ũ] a rapaziada... mas sem violência também... sem briga né?... inclusive a gente até... a gente junto também até diverte né?... porque... sabe que jogo de futebol... a boca de muito jogado[Ø] que não são civilizado... vem a... não se controlam... então... tem a[^]gum que é que é civilizado... e sabe como:.... como que vai proceder... mais... e:.... e isso que eu tenho pra declarar...

\section{A. B. (L2)}

4C

L1 - o senhor gosta de morar aqui?

L2 - gosto

L1 - como que é viver aqui em São Francisco do Sul?... é bom?... é confortável?... tem violência?...

L2 - não... aqui é muito bom... (vai chover forte)...

L1 - já foi... a cidade aqui ela é calma?... é tranqüila?...

L2 - aqui é...

L1 - não tem violência?

L2 - não... de vez em quando né?... ( )

L1 - dá pra... dá pra criar as as crianças ainda de forma tranqüila?...

L2 - tranqüilo

L1 - e o que o senhor acha do jovem do dia de hoje?

L2 - olha... 
L1 - e como que o senhor foi educado?... como foi a educação do senhor?... como hoje o jovem é educado?... o que que o senhor... como uma pessoa vivida...

L2 - da maneira que eu fui educado hoje tá muito errado... eu acho... eu não... se eu tiver filho pequeno eu vou educar ele direito... (não como que) tá hoje... hoje tá muito diferente... e a gente não pode estranhar porque... a coisa assim muda... diferente... tem que acostumar do jeito que tá hoje...

L1 - mas o senhor não não... concorda...

L2 - não

L1 - mas o que que o senhor acha que tá diferente?... as crianças tão...

L2 - a maneira de trabalho... que os pais não dão mais serviço pra eles... vai... estuda até meio-dia... de tarde... zanzando pela estrada... vai às vez[i] dá uma ocupação pra eles... o rapaz ( )... eu sou contra isso aí... o governo diz é:.... porque... tem que estudar... tem que estudar... concordo com estudar... mas... uma ocupação... tem que ter uma ocupação... po resto do dia... então não é demais o... o pai dá um serviço pro filho fazer durante à tarde... ele estuda até meio-dia... faz um servicinho à tarde... é melho $[\varnothing]$ ficar trabalhando... fazer uma coisinha do que ficar andando na rua fazendo arte... eu acho né?...

L1 - o senhor quer atender o telefone? ((pausa))

L2 - era a máquina (vinha trabalhar)

L1 - a máquina vinha trabalhar?... com essa chuva né?... que::... agora... pensando um pouquinho ali em São Francisco do Sul... do centro ali... o senhor conhece a história do cen / do Centro Histórico?

L2 - NÃO... aí eu ouvi pouco... eu ouvi muito pouco aí... ( ) eu não saiu... de vez em quando dá... eu vou lá quando é preciso...

L1 - como como que era aqui quando o senhor veio morar?... como que era o seu bairro?... como que era aqui?...

L2 - AH:.... era só mato... aqui nessa parte... não sei se vocês andaram aqui pra trás... se vocês conhecem a praia aqui...

L1 - pouquinho...

L2 - aqui... não te / só tinha duas casas aonde eu morava... tinha nada... daí uns trinta ano... isso aí pra trás tá uma cidade... mas quando eu vim pra cá tinha duas casas aí pra trás...

L1 - e como que é::... é aqui por exemplo... agora é inverno né?... então a cidade tá mais vazia... como que é no verão?... tem diferença?...

L2 - AH:.... no verão enche... no verão isso aí entope... não dá pra passar... se precisar atravessar a rua tem se que parar e olhar... porque senão o carro pode te juntar... chegou o verão aqui é triste... ( )

L1 - e o que que o senhor acha?... muito... muito turista o senhor acha que ajuda?... atrapalha... né?...

L2 - ajuda... certa parte ajuda... deixa muita renda pro município... bastante

L1 - e quando o senhor era jovem... o senhor chegou a a a::... a freqüentar festas assim como o Boi de Mamão?... Terno de Reis?

L2 - bastante...

L1 - é::... festa do Divino Espírito Santo?...

L2 - eu era cantor de Reis né?...

L1 - Nossa... Era?... como que é um Terno de Reis?... que eu nun /eu nunca assisti um...

L2 - AH é gostoso... brincadeira legal... ( ) a brincadeira é legal né?

L1 - mas como... como que é?... eu não tenho idéia... nunca assisti um... que que acontece?... que dia que é?... 
L2 - época de fim de ano né?... Natal né?... até... até meados de janeiro... de fim de ano... vinte e cinco de dezembro até dia oito de janeiro... é brincadeira na fase de Rei né?... aí é todo sábado... todo domingo...

L1 - mas o senhor era?... era...

L L2 - daí ia nas casa... cantava nas... na porta... entrava pra dentro... tomava café... tomava doce... daí ia de uma casa pra outra... passava a noite toda assim...

L1 - e::... o senhor lembra de alguma des / dessas canções?... ( )

L2 - mas não é... mas pouco... faz muito tempo... eu cantava rei desde a idade de nove ano... dez ano eu cantava Reis... cantor de Reis... cantor de coral de Reis... tinha muito coral também... agora hoje eu não posso cantar mais...

$\mathrm{L} 1-\mathrm{e}: . . .$.

$\mathrm{L}$ L2 - que eu tenho problema até pra falar... que eu fiz uma cirurgia aqui ((aponta para a garganta))...

L1 - ahn ahn...

L2 - dois... dois cirurgia... tenho um tumor na garganta... até hoje nem a dentadura não posso usar porque... me entortou o carrinho... a dentadura não encaixa...

L1 - e::... como que é o:.... Boi de Mamão?... chegou a participar?

L2 - não... dele mesmo não... assim... assisti alguma brincadeira... porque nós fazíamos uma parte... eles faziam outra... cada parte (joga numa parte)... ( ) então... do Boi de Mamão eu quase não participei... conheço tudo assim esses tipo de brincadeira... mas participar não participei...

L1 - e:.... e hoje... tem ainda?... não tem mais?

L2 $-\mathrm{a}[\ulcorner]$ gum lugar tem... aqui pra cá não tem aqui... mas tem muito lugar que ainda tem... não tem televisão... é legal... é legal...

L1 - e o senhor... é::... sente falta dessas coisas?...

L2 - sinto falta

L1 - e aqui o... por exemplo... antigamente tinha esse tipo de brincadeira... pra as pessoas se divertirem... e hoje o jovem... como que ele se diverte?...

L2 - essa pergunta eu vou te deixar no ar... porque eu não sei...

$\mathrm{L} 1-(($ risos $))$

L2 - eu não sei como é que esses jovens se diverte... porque não se vê... ( ) meu Deus... é brigar... é fumar é:... essa é a brincadeira deles... eles não têm uma brincadeira sadia como nós tinha antigamente... nós tinha sábado e domingo pra se divertir... mas era pra se divertir... agora hoje... (eles nem) pode se ver que eles fazem... e isso eu acho errado...

L1 - e:.... o senhor conheceu a sua esposa aqui?...

L2 - lá em Tubarão...

L1 - lá em Tubarão... o senhor tem uma família grande?...

L2 - não:.... só nove... ((risos))

L1 - o quê?... NOve filhos?

L2 - é...

L1 - nossa... o senhor deve ter bastante neto já...

L2 - vinte e dois... vinte e dois neto e um bisneto...

L1 - tem uma família bem grande...

L2 - ai... no dia que eles vêm tudo aqui dá vontade de correr pro mato...

$\mathrm{L} 1-(($ risos $))$

L2 - ((risos))... é um Deus nos acuda... essa mesa aqui oh... duas dessa não chega...

L1 - nossa... parabéns...

L2 - dia das mãe... dia dos... um dia ( ) mais grande assim ( )

L1 - e o senhor gosta de::... de:.... das crianças assim... de ter toda essa... 
L2 - gosto...

L1 - é bom ter família assim né?...

L2 - bom... ( ) acho que eles gostam de mim também... porque... se não gostassem

L L1 - não vinha né?

L2 - não vinha...

$\mathrm{L} 1-\mathrm{e}:$ :

L L2 - eu tenho dois que mora em Itajaí... tenho... dois formado em Itajaí... formado de... negócio de:: de:: produto natural... e tem outra... uma filha... que tá em Itajaí... tá desempregada... mora de empregada do meu filho... trabalha na farmácia pra ele... tem um que mora em Itajaí... trabalha no cais... ( ) trabalhinho... e o resto mora aqui... ( )

L1 - e o senhor costuma freqüentar a praia?...

L2 - não não...

L1 - pescar?... não gosta?...

L2 - gostava muito de pesca... mas depois que eu:.... perdi a dentadura (não presto)... não pude tarrafear mais... aí também não fui mais...

L1 - e como que é::... por exemplo... é::... pescar assim... como que o senhor sabe que dia tá bom pra ir pescar:.... o senhor tem muitos amigos pescadores?... que é uma... muita gente trabalha na pesca... né?

L2 - AH sim... a maioria do pessoal aí trabalha na pesca... depende da maré né?... se a maré tá cheia não presta... se tá vazia... ( )

L1 - o senhor já tomou algum susto pescando?...

L2 - já... ((risos))

L1 - que susto foi esse...

L2 - AH... eu andei me afogando... outro dia... caí na água... só isso né?... a gente só na praia... só de tarrafa... eu nunca saí pra fora... aí pra fora não saí... embarcar em canoa não embarquei...

L1 - tem medo

L2 - AH::... não embarco... canoa...

L1 - e é perigoso aqui?... tem tubarão?... nessa praia aqui

L L2 - não não... tubarão... perigoso aí é cair

na água né?... quem não sabe nadar... quem cai morre...

L1 - a praia é funda aqui?

L2 - aqui é... esse lado aqui é... tem muito buraco... essa praia aqui não... é uma beleza... mas aqui... essa de Itaguaçu é perigosa... já tem morrido muita gente...

L1 - AH é?...

L2 - aí é... em outubro passado... retrasado... morreu uma moça lá na Prainha... nem é daqui... é de fora...

L1 - veio de fora?...

L2 - veio passear aí... foi... lá nas pedra... lá... caiu lá e ficou lá...

L1 - nem foi na água então?... caiu na... na na

L L2 - caiu na... do do costão... tá frio né?... foi no costão passear... não tem prática... escorregou... caiu lá no buraco lá... ( ) não tem medo...

L1 - ela tava sozinha será?...

L2 - AH... parece que tava só ela e o namorado... parece...

L1 - é perigoso né?...

L2 - AH... tem morrido muita gente... praticamente.. gente de fora né?... porque o pessoal daqui já sabe né?... já não vão... vai o pessoal de fora não conhece... quer tirar... ( )

L1 - ( ) é verdade... 
L2 - nó[jS] morávamos em Paranaguá... era... fornecedor de navio... aí nós fomos... é... levei a família pra São Paulo... e:: residência na Avenida Santo Amaro... do[S] quatro do[j $\left.\int\right] . .$. São Paulo... perto do Mappim... Itaim Bibi... e lá nó[j $\left.\int\right]$ tocávamos... temos uma salga aqui na Barra do Sul... e::... uma média de oito nove dez... quatorze quinz[e] toneladas de camarão pra São Paulo... e eu tenho uma pequena indú[S]tria de beneficiamento... empacotamento e vendia no atacad[o] da Santa Rosa... São Paulo... grande quantidad[e]... grand[e] escala... é:: uma média de::... preparação de vinte tonelada... dezoito toneladas de camarão ao mês... todos os meses... depoi[ $\left.\int\right]$ teve a falta do camarão... teve uma época em que no Sul acabou o camarão... então aí... eu toquei representações de madeira... na Lapa... fiz um depósito muito grande... aluguei um terreno... então fornecia madeira pros prédio... só que... vinha uma média de cada caminhão uns vinte metro... vinte e um cúbico... né?... e:.... você vendia pros judeu[S]... que são... porqu[e] geralmente... quem faz aquel[e]s prédio... tem... quem tem a GRANA mesmo em São Paulo é os judeu[S]... e foi aí que... eu capital que eu tinha foi tudo à falência porque os judeus... ele... ele... vive... é da maior picardia... na maior inteligência em cima do... dos pequenos... então ele dá um cheque pra você... primeiro ele vai comprar e promete uma coisa... na hora que você vendeu... entregou... aí ele já... dá chequ[e]... não é aquilo à vi[ $\left[\int\right]$ ta... já é trinta dia... aí você acha ruim... "não o contrato foi outro e tal"... ele então manda você levar de volta... aí então você tira da onde tá... aquela encomenda... então você aceita... aí passa $\mathrm{o}\left[\int\right]$ trinta dias não tem... vai pra quarenta e cinco não tem... vai pra sessenta não tem... e aí

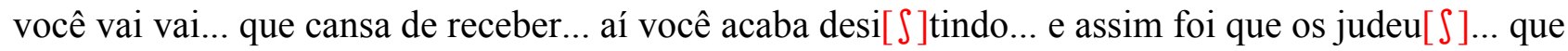
eu vendia uma média de vinte e doi[ $\left.\int\right] \ldots$ cúbico... vinte... quarenta cúbico... trinta cúbico... diário... e fui à falência... fui à falência com os judeus... então... ele[ $\left.\int\right]$... cada vez arranj[ũ] MAis dinheiro...

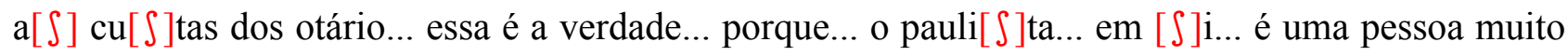
decente... muito bom... muito hone[ $\left[\int\right] \mathrm{t}[\mathrm{O}] . .$. agora... i[ $\left[\int\right]$ to lá... dentro de São Paulo que a maioria é

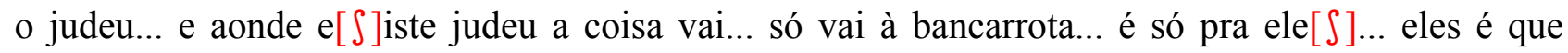
manobr[u]... eles é que dominam o comércio total... e foi aí... que eu então me vi que... não não me servia isso pra mim... que a minha criação foi outra... hone[S]tidade... dar de César o que é de César... e... foi o caso que eu desi[ $[$ ]ti de São Paulo totalment[e]... e virei na minha marinha... que eu toda vida fui marítimo... então... naveguei muito... e[S]terior tal... fiz o meu pé de meia na marinha... depois desembarquei... vim pra Enseada... a Enseada... nós chegamos aqui em mi[ł] novecentos e quarenta e três... antes da guerra... tinha oit[o] morador[e]s aqui... aqui tinha muita malária... nós enfretamo[ $[\varnothing]$... muita malária... uma fartura incomparável de pescados... peixes... então... dinheiro você não via... via assim os peixe... muito peixe... ia lá levava vender... é:.... por que aqui ninguém comia carne... era só peixe... só peixe... então por isso que hoj[e] eu me sinto... que eu tenho setenta e um ano... tenho uma vitalidade fabulosa... com a... armadura perfeita de saúde... danço... corro... pinto... bordo... me sinto muito bem com setenta e um... vou fazer setenta e dois... e... então... peixe é saúd[3]e... e... saúde é que nos interessa... certo?... 
L1 - e o senhor falou que trabalhou muito tempo como marítimo... teve alguma viagem que marcou o senhor?...

L2 - AH teve... teve teve... eu tive... eu tive tempe[ $\left[\int\right]$ tades... de... eu pensei que nunca mais ia ver a família... eu vi com meus olho[S]... vi coisa que... é in / inacreditável... ondas de cinqüenta metro de $\mathrm{a}[\ulcorner]$ tura... quarenta cinqüenta metro de $\mathrm{a}[\ulcorner]$ tura... coisa in - crí $-\mathrm{v}[\mathrm{I}] \ldots$ o navio... nesta época... for[ũ] sei[S] navios... for[u] a pique... e o nosso navio não foi porque ele tava em meia carga e era novo... da ( ) dinarmaquês... bandeira dinarmaquesa... peguei esse navio em Buenos Aires... eu morava em Buenos Aires... peguei ele lá... passaporte né?... mais eu tive no ( ) brasileiro... então nós éramos em trinta e... quatro tripulantes... trinta e quatro tripulantes... e:: todos eles ficar[ũ] bêbad[o]... ficar[ũ] torto... todos ele $\left[\int\right] \ldots$ menos quem segurou a peteca mesmo... foi eu... o comandante e um pilot[o]... que seguramos a peteca três dias e ter / duas noite... três dias e duas noite ali no pau... o navio era enorm[e]... cent[o] e seten / cent[o] e sessenta e oito metros de comprimento... nós tava... completamente $\mathrm{m}[\mathrm{u}] \mathrm{lhado} .$. da cabeça aos pés lá no sétimo andar... lá no forte / lá em cima... porqu[e] a onda... ela vinha muito grande e o navi[o] não conseguia arcar... subir no mar... então a onda... engolia ele... então tinha que diminuir a... a máquina enquanto a onda vinha... quando a onda pegava... então tinha que dar toda força... que é pra ele sair da onda... senão a onda dominava ele... então aquel[e] control[e] ali... era eu como marinheir[o]... primeir[o] marinheir[o]... o comandante e um pilot[o]... foi que $[\varnothing]$ güentamos... só comendo bolachinha mel tal... porque não tinha condição... nem de fazer comida... que os tripulante estav[ũ] tudo caído... morto... completamente... drogado... e nó[jS] tava lá cima... não podíamos sair de lá... então...

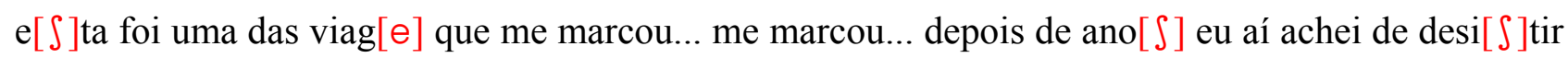
da marinha... depois de quatorze anos navegando... então... porqu[e] tudo tem o seu temp[o]... certo?... você... eu acho que Deus designa... você vai morrer em tal data... outro tal data... então... às vez[i] também a pessoa procura... é... vamo[ $\varnothing]$ supor... é... subir num morro e se jogar no abismo... então ele procurou fazer isso... mas se ele não subir naquele morro ele também não vai morrer... então tem que evitar o máximo...

L1 - perigo né?

L2 - hoje... trabalhei na Petrobrás... quando eu desembarquei... tenho o conheciment[o]... a

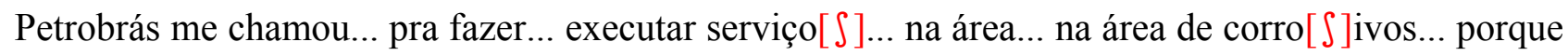
eu preparei lanchas e:.... trabalhei com noventa hom[i $\left.\int\right] .$. na área da Petrobrás... pintando tanques... chapeando e pintando é:.... desde o começo... da era da Petrobrá[ $\left.\int\right] .$. mi[ł] novecentos e setenta e um... que eu fiquei de setenta e um a setenta e três... fazendo tudo os serviço necessário pro término do terminal... terminal da Petrobrás... e... hoje... é uma potência a Petrobrás... nó[S] temo[Ø] um róia ((royalty)) é... São Francisco do Sul... média de um milhão e meio mensal... ( ) que eu eu... a... o impo[S]to da Petrobrás... do óleo né?... cinc[o] por cent[o]... e... não temos $\mathrm{m}[\mathrm{i}]$ lhora porque nós não temos um prefeit[o]... adequado... só entra vigari[〕]ta... eu batalhei

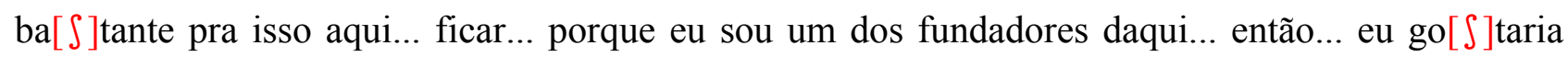
que isso aqui não acabasse mudasse... por que [o] própri[o] pescador... tem essas bateirinha aí que você tá vendo... e essas bateira eles tem que pular na água molhar o pé e tal pra ir pra embarcação... 
quando que poderia ter uma marina... aqui entrava no rio... fazia o $\mathrm{m}[$ ○]lhe... saía tudo isso aqui... ficava a praia limpa... bonita...

L2 - pro turista ia ser bom...

L1 - é... é todo... os pescad[o] não molharia o pé pra... pra ir pro mar... que as embarcação deles são boas... são grandes... então... mas não... a prefeitura só quer saber... é... dá um jeitinho... fazer projet[o] e tal pra querer angariar o troco pra botar areia no poço... e o necessário até hoje não foi feito... sai um prefeito era outra... e não... nada...

L1 - e morar aqui... o senhor que acompanhou todo o desenvolvimento da cidade... a cidade mudou muito né? aqui?

L2 - olha:: aqui moradia... eu conheço o Brasil de Iapoque ao Chuí... o Chuí é Rio Grande do Sul... Iapoque é o Rio Grande do Norte... finalzinho do Rio Grande do Norte... e mais pra frente aí... as Guianas... é:.... Trindade e Tobago... até... os... a possessão espanhola nos Estados Unidos... toda essa costa... mas eu ainda não vi... até hoje que eu conheço mais de duzentas praia... uma praia igual a Enseada... nó[S] temo[S] três mar... o mar bravo... médio e manso... não [ĩ]xiste... em parte nenhuma do Brasil uma praia igual a essa daqui... vai com uma criança... quer um mar manso tem... quer mar médio tem... quer brav[o] tem... então aqui... nosso povo é... feio... ( ) porque você chegando num lugar... se você não for[u]... bem atendido... se também não vai go[ $\left.\int\right]$ tar e não fica naquele lugar... muda-se... então o pessoal aqui quando ele chega... eles são bem atendido... são acolhido... então eles se dão muito bem aqui... e todos que ficam aqui são gente boa... gente bacana....

\section{E. O. (L2) Informante 9C e E. P. O. (L3) Informante 6C (análise conjunta)}

L1 - quanto tempo o senhor trabalha na pesca?...

L2 - olha... trabalho desde... maio de de $\left[\int\right]$ inqüenta ano...

L1 - na pesca?

L2 - desde de idade de quatorze ano eu trabalhava na pesca

L1 - e como que era... trabalhar na pesca quando o senhor começou a trabalhar?... tinha barco grande?... era uma coisa mais artesanal?...

L2 - pescaria de tainha...

L1 - era uma coisa bem artesanal?

L2 - é... era bem arte / artesanado... pe[ $\left.\int\right]$ caria de tainha... quer dizer... eu ia pa... pra baixada com o com o meu pai... meu pai me ensinava na na vigia... então eu fiquei desde quase idade de quatorze

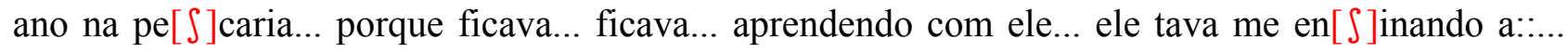
espiar... ver... conhecer o peixe...

L1 - e por exemplo... como o senhor sabe que hoje é um dia bom de pescar ou não?... é pelo tempo... como que é?

L2 - o tempo é... é ficar um tempo ruim assim é ma / muito ruim de pescar... é muito ruim e é perigoso... negócio de trovoAda... essas coisa assim... mais... tempo de sol assim não tem perigo...

L1 - e o senhor ta / já tomou susto em todos esses anos na pesca?

L2 - passei

L1 - tem algum que o senhor queira contar assim?... que o senhor lembra... 
L2 - passei susto dum... duma trovoada que nós apanhemo[ $\varnothing]$ aqui na Costinha... que o relamp[o] caiu bem assim perto de nós na água... se [a]levantou um tantinho de água pra cima... e a ( ) bateu em nós... uma distância de um... quinz[e] metro mais ou menos... que não pegou nas coisa...

L1 - e o senhor senti diferença na pesca...

L L2 - hoje os outro caça mas mas peixe... naquele tempo também havia muito peixe... mas é que hoje... a vantagem de hoje é o peixe... é o pessoal hoje já não tem (ridículo) com história na pescaria... eles vão lá de manhã... vo[ $[\ulcorner] \mathrm{t}[\mathrm{u}]$... oito hora tão em casa de vo[ৎ]ta... ou vão pa outro lado... e:.... nós naquele tempo... não na na pescaria da tainha... era tudo... saía de casa madrugada... chegava de noite em casa... é muito diferente... hoje...

L1 - e como que era aqui quando o senhor... veio morar / o senhor nasceu e foi criado aqui... como que era aqui... setenta anos atrás... quando o senhor era moço?...

L2 - era tudo mato... mato... a estrada um trilho...não passava $\mathrm{ca}[\mathrm{r}] \mathrm{o} . .$. era... não tinha ca[ $\mathrm{r}] \mathrm{o}$ não tinha nada... era só o ca[r]o que tinha era um antigo ca[r]o do Forte... e o Pedro Júlio e o Foca era dois cara que tinha aqui... três ca[r]o...

L1 - e o senhor conhece a história daquele Forte?

L2 - a estrada eu conheço

L1 - conhece a estrada do Forte... conhece o Forte ali?...

L2 - ahn ahn

L1 - o senhor conhece a história dele... o que que era ali era um

L2 - agora daquele eu não posso informar

L1 - e daqui da região?... o senhor conhece uma história bacana?... sobre o lugar... alguma coisa sobre o centro histórico de São Francisco?

L3 - ele não entende... ((aponta para o ouvido indicando que L2 tem dificuldades auditivas))

L1 - AH tá... mas sim... mais ali da... da da por que foi colonização portuguesa... esse tipo de coisa

L3 - ele é daqui... dos portugueses

L1 - É:.... é isso que eu queria saber... e o senhor... é de família portuguesa

L2 - tenho uma geração junta portuguê[j $j]$

$\mathrm{L} 1-\mathrm{E}$

L3 - português e francês

L1 - que bacana... e a senhora conhece alguma... história daqui?... alguma lenda?... por exe / tem a lenda do... do padre que amaldiçoou a cidade né?... por que colocaram ele no meio do barco... na Baía da Babitonga... a senhora conhece outra?...

L3 - aquela ali... é da... daquele lá da Laranjeira... tinha um... a família Pereira.. hoje tão tudo bem estudado tudo né?... até tem padre... tem doutor... tem tudo... mas primeir[o]... tinha um... que tinha apelido de Cabecinha... aquele era muito ruim... muito ruim aquele hom[i]... então... a história não é tão bonita mais né?

L1 - NÃO... mais eu quero escutar...

L3 - aí ele... ele... ele era assim... tem / tinha duas casa... duas praiazinha assim... e o... e tinha as duas casa... no lado da casa... então... quem passava... tinha que tirar o chapéu... cumprimentar el[e]... se não cumprimentasse el[e]... mandava... os como é?... os... os preto né?... que eram os escravos né?... aí mandava bater... judiar e tudo... aí diz que... passou um hom[i] não... um padre que ia levar o Santíssimo Sacramento pra um enferm[o]... aí ele... ia assim né?... de cabeça baixa... 
aí ele pegou e disse assim chamando o escravo "OH... pega aquele sujeito e solta a $\mathrm{Ba}[\mathrm{r}] \mathrm{a}$ fora.. ele tá me desobedecendo... não me cumprimentou...” aí os preto não queri[ũ] fazer né?... era obrigada

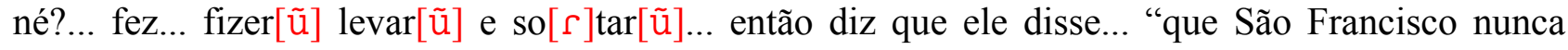
haverá de aumentar"... ele disse né?... aí não sei... então... diziam que São Francisco não aumentava... porque quando desmanchavam três casa fazia uma só... mas era uma mas era melhor do que as outras né?... aí... passou assim... foi foi... aí então agora dizem que já completou o tempo daquela praga... porque... agora... tá tudo melhor... tá melhorando... graças a Deus

L2 - agora cresceu muito... São Francisco

L3 - mas é... lá era... aquele aquele era triste... diz / que ele pegou... aí ele ele orde / ordenava pa pa filha dá... a filha com a mulhe[ $\varnothing]$ era boa de coração né?... mas ele era mau... então diz que ele dizia assim "olha... camarão e meio pa cada preto"...ca[r] egando pedra na cabeça... judiação né?...aí diz que quando foi num dia... ele não tava... aí a filha pegou... deu camarão e meio... aí o preto... $\mathrm{ca}[\mathrm{r}]$ egando aquele camarãozinho ali... aí foi e disse assim "nhanhá... dá mais um... mais um pedacinho de camarão?... sob[ow] ainda pi[1]ão"... é... pirão né?... pirão... aí... ela pegou olhou pôs ali... não viu o pai... trouxe um punhado... deu... botou no prato do preto... pra ele comer... aí nisso ele chega... "olha negr[o]... come bem... enche a ba[r]iga..." olha que a comida não era tanta pra encher a ba[r]iga ((risos))... "enche a ba[r]iga porque você tem um seviço pra fazer hoj[e] a $\operatorname{tard}[e] " . .$. aí (o ot $[\varnothing]$ o)... "sim senhor nhonhô"... comeu ali ligeiro... aí depois ele disse... "OH vem cá agora... vou te dizer o serviço"... aí chegou lá num lugar... ele (falou) que era pro preto fazer um buraco... bem fundo... aí o preto pegou a cavar... até um certo... dava pra cavar... aí [a]depois já... quase não dá pa jogar areia pra cima né?... aí... ele ( ) "chama nhonhô pa ver se tá bão o buraco"... aí... a nha / ela ali com pena do preto... mais... ( ) e o preto cava cava... aí chamaram o pai dela... o pai dele... "NÃO... EH... tem que [a]cavar muito ainda"... porque tanto era largo como era fundo... e cava... e corta e cava... aí... umas hora ele disse assim... aí ela se afastou né?... aí ele veio cá... "tá bom negr[o]... espera aí um pouco"... aí ele parou de cavar... aí ele chamou a filha... "vem cá (Guari)"... aí ela veio ele empu[r]ou a filha... e mandou os outro escravo tampar... naquele buraco mo[r]eu a filha dele com o negr[o] lá... crueldade né?... aí... a... mo[r]eu os dois lá... mandou tampar o burac[o]... tampar... mas ele através dos escravo... fazia muita farinha... tinha muita farinha... então ele tinha vários paióis... assim... de farinha né?... aquilo tudo cheio... paiol é um... tipo um quarto... cheio... tipo um quartão grande que tem (aqui)... aí... diz que quando foi no outro dia... a mulher foi pegar a farinha... ela viu aquela farinha... tremendo assim... aí olhou assim... (cavou)... tudo cheio de sangu[e]... foi no outro paiol... do me[ $\varnothing]$ mo jeito... tudo... castigo né?... Deus castigou né?... aí diz que não deu pra aproveitar nada daquela farinha daquele paiol... aí não deu pra aproveitar aquela farinha... e ele era assim... judiava muito muito muito... muito... mandava os escravo assim o dia inteiro ca[r] egar pedra na cabeça sem... uma proteção... então diz que aquilo $\operatorname{esco[}[r]$ ia sangue assim... e foi assim foi assim... até que depois ele mo[r]eu... ele mo[r]eu... então diz que o povo... lá dava muito camarão... lá na Laranjeira dá muito camarão... ( ) aí diz que eles iam tarrafear naquela praia... diz aquele... aquela coisa... aparecia aquele GRANde homem... muito grande assim né?... aí eles “aí o que é isso?”... daqui a pouco se jogava uma ta[r]afa ( ) aí eles se afastavam dali... já tinha um ta[r]afeando... se afastavam... chegava lá... outro lá... é tanto que eles chegava a co[r]er... porque não dá... não dá pra ta[r]afear... então aquela praia ficou ma[ł] 
assombrada... ma $[¥]$ assombrada... depois o pessoal... quando assim caçavam né?... de noite... diz que não dava... aquela... aquelas assombrações... ia assombração... coisa que... amdrontava eles... tinham que co[r]er... ali naquel[e] te[r]en[o] daquele Pereira... sabe?... não dava pa pescar... nem caçar... nem nada... porque já tinha assombração... mas não é... é porque ele... de certo ficou perdido... atentando né?... e aí vinha atentar os outro... e a minha... tia... nós morava bem pré / perto desse te[r]eno né?... então a minha tia contava... tinham duas famílias... uma Pereira e outra Cardoso... o Cardoso era muito bom... Cardoso era até meio assim alemão... então esses eram muito bom... diz que os preto... roubavam ta / tainha... tainha escalada... feito cambira... ele / ele... os $\operatorname{pret}[\mathrm{o}][\mathrm{r}] \operatorname{oubav}[\tilde{u}] \ldots[\mathrm{r}] \operatorname{oubav}[\tilde{u}]$ ova... ova da tainha seca... ia na venda... pedir pra trocar por cachaça... o negro gostava de uma pinga ((risos))... pra trocar por cachaça... aí ele dizia assim... "olha... mas cuidado... tu não vai me comprometer... senão o teu... o teu amo"... "não o nhonhô é bonzinho o nhonhô é bonzinho... ele nhonhô é bonzinho"... e como era bom... porque os pret[o] podia comer com ele na mesa... ele mandava dar uma batatinha... uma pinguinha pros preto... tudo assim... mas o tal de Pereira... era... foi mesmo ruim... o lugar assim atentado... ninguém passava lá... um dia... souberam que tinha... dinheiro ente[r]ado lá... diz que... uma prima minha com o primo disse... "vamo[ $\varnothing]$ ver esse dinheiro... vamo[ $\varnothing]$ tirar?”... ora... que idéia né? ((risos))

L1 - eu não ia ((risos))

L3 - aí for[ũ] ... for[ũ] tirar o dinheiro... aí chegou lá... diz que... a minha prima pegou... assim... a desmaiar... aí o meu primo olhou... chamava-se Orlando... e ela Verônica... aí... "crê em Deus Pai todo poderoso... tu fica aí... eu vou-me embora..." deixou a irmã lá e saiu co[r]endo... saiu co[r]endo e deixou ela... [a]depois acabou de tempo que ela voltou e... se... aí ela vo[r]tou pra casa... foi embora... mas tudo por com a / da daquela:.... era uma tentação... uma coisa que ficou ali... aquilo ficou por muitos ano... muito muito... até nunca eu mais fui... aí [a]depois disso teve gente minha que morou lá... pa tomar conta... das duas praias largadas... mas eu não fui lá... não fui...

L1 - por quê?

L3 - É:.... não me convinha me $[\varnothing]$ mo não ficar no meu te $[r]$ eno e:.... nosso te $[r]$ eno ficava perto... meu avô... era da família dos Silva... então ele tinha muito... ali onde tem o fe[r]obote era tudo do meu avô... lá na Laranjeira... ali pra trás da Igreja... era tudo do meu avô... e lá no... lá na:.... no final da Laranjeira ele tinha outro te[r]eno... muito grande na praia de Jacutinga... tam[ $\varnothing]$ ém muito te[r] $[$ eno em tudo... mas ele não... fazia casa de te[Ø]a né?... tudo chegava lá colhia laranja... fazia uma coisa cortava outra... ( ) aí pra que tanta ganância?... a gent[e] não é daqui né?... pra que tanta ganância... um dia a gente vai e fica tudo né?... AH... mas esse Pereira era ruim... e o Cardoso era bom... Cardoso era bem ( ) como o nosso te[r]eno assim... gente muito boa... só que depois $\operatorname{mo}[\mathrm{r}]$ eu... for[u] $\operatorname{mo}[\mathrm{r}]$ endo... foi indo... ficou só o Anistides que era o último que fícou ali... também faleceu... aí... a família já tinha estudado bem tudo... saír[ũ] for[ũ] pra fora... e não... vender[ũ] tudo e não quiseram ficar... porque ali era só pra quem gostava de trabalhar... porque eles tinha vários bananal... colhiam muita banana... tinha cafezeiro... cafezeiro grande... te[r]a... muita te[r]a pra trabalhar... mas só pra quem era daquele ramo... porque né?... sabia trabalhar... sabia... olaria... de fazer tijolo... engenho de fazer farinha... engenho de fazer açúcar... tudo... mas... depois 
que o ver / o pai morreu... acabou tudo... aí vender[ũ] tudo... bacharel... tudo assim bem colocado né?...

L1 - e a senhora... é... quando a senhora era mais nova... o senhor também seu E. ... tinha a::... é festa de Terno de Reis?... Boi de Mamão?... essas coisas?... então o senhor vai me contar do Terno de Reis... e a senhora me conta do Boi de Mamão... como que era... um Terno de Reis?

L2 - era um... eram duas pessoa três pessoa... até quatro... então... saiam cantando na porta... as pessoas cantavam... depois o pessoal... aquele da da casa... abria a porta... eles entravam... falavam e:.... cantavam... sentavam-se... conversava um pouco ali com o dono da casa... conversav[ũ]... aí o dono da casa dava... oferta pra eles né?... dava oferta pra eles... aí eles cantav[ũ] ... outra vez de vo[ $[$ ta ali também ali... agradecido a oferta que eles dão... depois sai[ũ] e i[ũ] já cantar em outra casa...

L1 - e o Boi de Mamão?...

L3 - no Boi de Mamão... tem vários bicho né?... tinha a bernúncia... tinha o sapo... tinha o corv[o]... tinha de tudo

$$
\text { L L2 - cavalo }
$$

L3 - tinha o cavalo marinho né?... então né... cada:.... cada de cada pra cada bicho tinha um verso... eles cantava aquele verso... mas era muito divertido... muito... lá na Laranjeira faziam muito... tinha um $\mathrm{ta}[\ulcorner]$ de Benedito que ele que... ele formava aquilo né?... tinha de cor... não sei como é aquel[e]s vers[o] tudo... mas era muit[o] bonit[o]... a gente que é criança gostava de ver... quando chegav[ũ]... “AH vem ver filho vem"... "vem mãe vem"... a mãe chamava os filho... "vem ver... olhe"... olha o cavalo... oh o boi... o Boi de Mamão... a bernúncia... oh o ganso... a tinha um ganso desse tamanho assim ((risos))... aí vinha assim... e a gente ia montar nele assim... e montav[u]... a não... quer dizer que não era ganso né?... era era um... uma coisa

$$
\text { L L2 - imitação }
$$

L3 - uma imitação né?... mas era muito mais... uma diversão muito... muito alegre... muito diferente de agora... porque agora dá muita...

\section{L2 -tá doida mulhe[ $\varnothing]$ ?}

L3 - ( ) aqui onde nós moramo[ $\varnothing] \ldots$ ainda ont $[i]$ a minha vizinha teve aqui...

L2 - era uma praia... mas... morava mais gent[e] lá pra cima... ( ) aqui era poucas casa... pouca gent $[\mathrm{e}]$ sabe...?

L1 - tinha asfalto... tinha luz...

L2 - não... não... asfalto veio... pra cá em setenta e seis mais ou meno[ $\left.\int\right] \ldots$ o asfalto... luz não também...

L1 - não tinha luz...

L2 - não tinha luz...

L1 - e::... o senhor tinha escola aqui...

L2 - ahn:.... antes... quando eu era... era garoto... tinha escola mais era assim né?... da Colônia... de pesca... só estudava o primário... depois tinha... depois é que que foi crescendo... daí... eles fizer[ũ] grupo ali... ( ) no meu tempo era escolinha... só pra... 
L1 - como que é trabalhar na pesca?

L2 - trabalhar na pesca a gente saía cedo né?... acordava... naquele tempo não era motor sabe?... ( ) não era barco... era canoa... a remo... a vela... a remo... na maioria saía madrugada... três da manhã... quatro hora... saía por esse mar afora aí pra... pegar alguma coisa... era ruim... pra vender o peixe era difícil né?... não tinha comprador aqui... o rio ali não tinha pont[e] nada né?... tinha que passar de canoa... ( ) então era dificultoso... pra gente aqui... hoje em dia tá melhor né?... já é motorizada... a embar / embarcação... maiores né?... ( ) maiores... então é mais fácil... ainda assim era difícil porque tinha que lá à noite... só que dava muito peixe aqui... mas perto né?... aqui na praia... dava... hoje em dia é mais de dia que tem que é bem lá fora né?... bem fora ( ) sempre difícil... pesca artesanal... não é muit[ $\left.\int\right]$ o fácil...

L1 - ahn... tá... e:.... fala uma coisa pra mim... aqui da... da cidade... o senhor vê muita diferença do que ela é hoje... pra como era antigamente?...

L2 - AH... bem diferente... hoje em dia... é bem movimentada... já já... no verão já... muit[S]os turi $\left[\int\right] \operatorname{tas}$ né?... acumula muito... muita gente... porque... é... no verão... no verão passado enchia... na época do verão... ali... ahn... a região... a festa ali ( ) já encheu... não tinha nem lugar né?... então era muito diferent $[\mathrm{e}]$ do que era antigament $[\mathrm{e}] \ldots$ antigament $[\mathrm{e}]$ era cheio de mato... praia... hoje em dia não... hoje dia... ( ) lá pra Praia Grande... ( ) no verão é muit[S]o movimento...

L1 - e o senhor... tantos anos na... na pesca... o senhor já passou por alguma situação que te deixou com medo... ou não...

L2 - claro... passei...

L1 - conta... conta um pra mim

L2 - uma vez eu tava pescando... lá fora... eu e mais um filho meu... mais um pescador... foi morto... foi falecido... e aí deu um vento forte... aí fomo $[\varnothing]$ correr e:: nós se alagamo $[\varnothing]$ né?... daí passamo $[\varnothing]$ mal né?... ficamo[ $\varnothing]$ o dia todo na água... quando fomo[ $\varnothing]$ escapar já era três horas... quatro horas da tarde... ( ) um vento forte... chegava hora que a gente ia chegava em terra... e nem dava vontade de saí... mas tinha que ir né?... que era profissão...

L1 - AH tá... e o senhor já viu algum assim... tubarão... baleia

L2 - baleia... antigamente tinha muito... dava muito por aqui... às vezes aparece alguma... tem cação bem grande... a gente matava... a gente via lá fora...

L1 - e aqui na:.... na Enseada... tem alguma tradição... alguma lenda... alguma história que o senhor conta pra assustar... o senhor lembra alguma?...

L2 - não... é::... uma lenda assim né?... nesse rio aí [ $\varnothing]$ parecia... ((interrupção por um terceiro que chegou no recinto)) então contava né?... contava lenda que nesse rio [ $\varnothing]$ parecia... um barquinho assim... do nada... trazendo um morto... aí oh...

L1 - e::... aqui tem muita influência dos açorianos né?...

L2 - é

L1 - dos portugueses

L2 - dos portugueses

L1 - o senhor sabe de alguma história... conhece famílias portuguesas aqui...

L2 - não... eu não faço nem idéia... eu não sei se tem aqui... aqui eu sei qu[e] tinha a pesca de baleia né?... pescavam baleia lá na Ilha... tinha tanque de derreter... eles vinham destripar... eles vinham cortar baleia aqui na praia... isso aí a gente sabe... tem que saber também... descendent[e] $\mathrm{d}[\mathrm{e}]$ portugu[e]s... meu avô era portugu[e]s...

L1 - AHN... português... AHN que bacana... interessante... e:.... sua avó também? 
L2 - ahn... ahn... minha vó... minha vó... por parte da minha mãe já era assim mais cabelo curto... mais claro... ( )

L1 - ahn ahn... tem muita mistura aqui...

L2 - mistura

L1 - o senhor sabe a história da colonização aqui de São Francisco do Sul ou não?

L2 - é::... aí é::... a gente sabe às vezes alguma coisa né?... porque tem né?... eu sei que a hi[ $\left.\int\right]$ tória como ainda era a matriz... quando ainda era a Santa da Graça aí na Igreja... que for[ũ] trazida pelos portugueses né?... morar[ũ] aí... ( ) quando ( ) não tinha a Nossa Senhora da Graça... a Santa né?... e tinha:.... tinha aquele negócio de antigament $[e] \ldots$ que eles falam... tem essa Igreja aí de... a madrinha de São Francisco... a Igreja Velha né?... tem mais de duzentos anos... então... ( ) sem contar quando... sempre tem... quase da idade do descobrimento...

L1 - ahn ahn

L2 - o centro de São Francisco já já já... os espanhóis... já já já incendiaram isso daí...

L1 - e uma outra coisa que eu queria saber ali... da... de São Francisco ali... tinha um hospital psiquiátrico... o que que era ali?... um leprosário... o senhor já ouviu falar nisso ou não?

L2 - é é:.... disse que tinha uma casa aqui... não é bem em São Francisco... é pra cá um pouco sabe? Ali na:: já... no mont[e] que entra ali que vai pro Paulas... ali tinha uma casa... casa de leproso...

L1 - ahn... tá... mas já fechou

L1 - e ali na::

L L2 - não... já... há muitos anos acabou-se...

L L2 - depois fizer[ũ]... instalar[ũ] um... sindicato né?... na parte de cima... e tem um hospital de caridad[e] que é velho... aquela cadeia toda acabou-se modificando...

L1 - e ali na:.... no Morro do Forte... o senhor conhece?...

L2 - ali tinha é::... tinha o Forte né?... o Forte Marechal Luz ali né?... tinha uma cidade de hom[i] ali... ( ) acho que lá em cima ainda tem uns canhão velho lá... ainda tem... uma unidade que toma conta ali da... da:.... o quarte[le] acabaram... por escrito... agora eles tomam conta lá... mais ali o Forte foi... teve muitos muit[ $\left.\int\right]$ os anos ali...

L1 - muitos anos né?... tá... o senhor acha que tem muita diferença hoje do jovem de antigamente e do jovem de hoje?

L2 - eu acho que tem né?... sempre tem né?

L1 - quais diferenças o senhor acha... por exemplo... comportamento...

L2 - isso aí né?... antigamente também tinha né?... mas a quest[ã] é que hoje em dia já... já vai ter mais dessas coisas... o jovem que é mais liberto... mais liberal... é:.... a gente... naquel[e] tempo era mais a gente que se criou-se como pescador... tinha que ajudar... tinha que trabalhar né?... então... eu acho que hoje em dia a turma... hoje em dia em parte tá melhor né?...

L1 - que parte tá melhor?

L2 - tá melhor pra gente...

L1 - e:: uma outra pergunta

L L2 - dificuldad[e] que tinha antigament[e] era que tinha... não tinha ônibus... tem ônibus aí toda hora né?... tem tudo... ( ) posto de saúde... modifica muit[ $\left.\int\right]$ o né?... e[Ø]luíu né?... muito melhor do qu[e] era antigament $[e] \ldots$ 
L1 - e uma outra pergunta pro senhor... como que o senhor conheceu a sua esposa... conta a sua história...

L2 - nós era vizinho aí... é:.... é... ela nós éramos vizinho aqui... aí... a gente foi indo... foi crescendo junto... foi indo indo... aí casamo $[\varnothing]$... cinqüenta e cinco ano de casado... tenho um... sabe... tenho um filho... tenho três neto... tenho um neto que é engenheiro mecânico... tenho duas neta... uma tá ( ) a outra menor também e[ $\left[\int\right]$ tuda ( ) estudiosos

L1 - parabéns...

$\mathrm{L} 2-($ )

L1 - o senhor conhece o porto de São Francisco... já trabalhou lá?...

L2 - não... no porto nunca trabalhei... o porto ali agora eu não conheço muit[ $\left.\int\right]$ o bem... não filha...

agora modificou né?... primeiro mexiam em navio lá... trabalhavam... tinha um estivador... ali né?... trabalha... antigamente era carregado ali... tinha guincho à mão... hoje em dia já... o porto já tem uma estrutura melhor...

L1 - e no Museu do Mar... o senhor já foi?

L2 - ahn?

L1 - no Museu do Mar?

L2 - ( ) eu passei batido... mas tem... mas tem muita coisa boa lá...

L1 - encontrei bastante coisa lá... e como que é assim... o dia de um pescador?... conta pra mim... que horas que o senhor acorda... como é que o senhor...

L2 - é::...

C. O. M. (L2)

8C

L2 - estudava alemão né?... minha mãe me botou na aula particular de alemão... era assim... alfabeto gótico...

L1 - nossa... eu não sabia que ensinavam o alfabeto gótico...

L2 - comecei... depois não... no ginásio já era alemão... o nosso ginásio estadual... não era federal então... estadual nós tínhamos alemão em vez de inglês... porque o federal era... o currículo era o mesmo... a única coisa que mudava era que o nosso era alemão... e o:: federal era inglês... então continua com o inglês / com o alemão... só que... no nosso alfabeto assim... a nossa letra comum... não era mais alfabeto gótico... meu DEUS... o [s] tem três qualidade de [s] né?... tem um que tem um negócio atrás... tem um que tem assim... do outro não me lembro... o [a] era assim... eu não me lembro mais... eu era pequena...

L1 - e agora vamos falar um pouquinho de São Francisco do Sul

$$
\stackrel{L}{L} 2-\operatorname{sim} L \text { - a senhora que é }
$$

daqui... fala um pouquinho do avô da senhora... ( )...

L2 - meu avô não... meu bisavô não conheci... eu não conheci... eu soube que ele era de Açores... porque eu tenho... um inventário... um inventário assim... que ele deixou... pra... pra esposa né?... ali diz que ele é da Ilha de Açores... de Faial... do inventário... mas não sei...

L1 - como é viver aqui em São Francisco?... a senhora gosta?...

L2 - já gostei mais... era muito tranqüilo... a gente... eu agora moro num estacionamento ((risos))... eu moro num estacionamento... a minha rua aqui é estreita... os carros par[ũ]... tem mão e contramão... estacionam dos dois lados... então ficou meio... e os carros ali pra lá e pra cá né?... passa carro bicicleta caminhão... carroça... e a gente quer passar... é uma dificuldade né?

L1 - como que era aqui quando a senhora era moça? 
L2 - oh... era bom...

L1 - era muito diferente?... as casas?...

L2 - não... a cidade aqui no Centro não... praticamente não mudou nada né?... não é porque foi tombada... foi tombada... eu já era casada... mas era a mesma coisa né?... eu morava numa casa... antiga... colonial... onde hoje... fica localizado o hotel Zibamba... ali era a casa... que foi construída... pelo... tio da minha avó paterna... ele era o padre Benjamim Carvalho de Oliveira... era um casarão grande... ali morou... a minha avó... meus tios... depois for[ũ] embora... uns morreram... ficou só meu pai... foi quando meu pai casou... a mamãe passou a morar lá... e nós todos nos criamos lá... tem quintal grande... a casa era grande... era uma beleza... parecia que a gente não tava nem em São Francisco... que a gente se isolava né?... cozinha era grande... as salas eram grandes... L1 - e::... a senhora... quando a senhora era mocinha assim... a senhora chegou a a conviver com tradições... como o Terno de Reis... o Boi de Mamão...

L2 - o Boi de Mamão... sempre... em dezembro... acho que começava né?...

L1 - como que é um Boi de Mamão?...

L2 - era assim... não tem idéia?... puxa... tem o (militar) e o boi né?... embaixo fica... uma ou duas pessoas... e esse Boi de Mamão... tem o quem controla o Boi de Mamão vai vai... vai puxando o Boi de Mamão pelo chifre... numa corda... e quando pára na... nas casas... começa a cantar... perguntando se quer que cante ali... aí vêm outros... e aí eles... AH... tem uma cantiga muito boa... muito bonita... aí vem uma porção de bichos... vem sapo que pula... vem bernúncia... bernúncia é um bicho comprido comprido comprido... com uma boca muito grande... corri atrás da criançada... a criançada faz uma farra porque tem medo... tem cabrito... tem a vovó... que é uma mulher... uma boneca bem grande... ( ) era isso aí... e recebem dinheiro né?... aí... depois que recebe o dinheiro eles fazem... um agradecimento... e vão pra outra casa... mas o:.... vem o / um que mata o boi... depois o boi ressuscita... ((risos))... quando vem o doutor... que trata do boi... aí o boi ressuscita... e::... dá aquele pulo... aí todo mundo corre... porque o boi sai correndo também... é muito interessante... e também quando eu era pequena tinha o Pão por Deus...

L1 - eu ia perguntar pra senhora..

L2 - o Pão por Deus... eu até tenho aí uma lembrancinha de um Pão por Deus que veio uma vez... numa propaganda... ele era assim... um papel que se... recortava todo né?... e dentro... faz... e ficava um coraçãozinho... e aí... oferecia aquele Pão por Deus... prum amigo... um namorado... mandava... era muito... assim... uma maneira muito carinhosa de expressar amizade... amor... que mais... que mais tinha... eu participei das Pastorinhas... isso eu:.... trinta... trinta e nove... as Pastorinhas era... começo de janeiro... a gente saía... era a... a igreja católica que... era da igreja católica né?... a gente ia pra recolher também dinheiro né?... ajudar a igreja... a gente se vestia a caráter né?... botava um chapéu... lenço... aquela saia... tinha... no meu tempo tinha um que tocava violino... um cantor também... tinha o violão... mas um... e as moças que cantavam né?... e a gente andava até meianoite... uma hora da manhã... mas antes a gente mandava um... um aviso... dizendo que naquela noite as Pastorinhas iam passar ali... e havia casas que eles... mandavam a gente entrar... e dav[ũ] ... um refrigerante... uma bolachinha... era assim... era bom...

L1 - e::... e tinha ou não... a festa do Espírito Santo?

L2 - AH... (claro) que tem... a festa do Espírito Santo era uma festa muito bonita... muito grande... porque a música sempre acompanhava... nós tínhamos a banda de música né?... passava pela cidade tocando dobrado... a gente já sabia... ia pra nossa igreja... muito bonito... e no dia da festa também a... a banda acompanhava o... o imperador... eu sei disso porque meu pai foi uma vez o imperador... e a banda acompanhou até... até a residência né?... ( ) o imperador... não tem imperatriz... que no meu tempo... era assim... o imperador era de uma família e a imperatriz era de outra família... hoje não... hoje é o casal... o imperador e a imperatriz... mas naquele tempo acho assim que era pra... pra 
facilitar a doação né?... que aí o imperador dava... a imperatriz dava... combinav[ũ] e davam uma esmola ( )... mas era muito bonito... e na véspera... na última novena... na porta da igreja depois... que terminava a novena... tinha... o leilão... de massas... massas do Espírito Santo chamavam... então... faziam promessas né?... tinha boneca... tinha perna... de massa... era massa assim... de pão com melado... de pão... cabeça... menino... mas era tão bom né?... o papai sempre... ele sempre ia depois ele levava pra casa... boneca... eu gostava muito das bonecas né?... então a massa de boneca era assim muito bonita... toda enfeitadinha...

L1 - e hoje... tem alguma dessas coisas?... ainda...

L2 - NÃO... hoje nós temos a festa... temos as novenas do Espírito Santo... também são muito bonitas... esse ano também... foi muito bonita... imperador... foi o G.... G. ( ) ele fez um trabalho muito bonito... até no dia ele trouxe um coral... de Joinville... né?... tava muito assim... muito bom mesmo... ele conseguiu dá um impulso muito grande pra essa terra... que já teve quase desaparecida... há uns anos atrás... ( ) quase não nem se falava... aí tivemos um ( )... mas era uma festa muito forte...

L1 - o Boi de Mamão tem ainda?

L2 - o Boi de Mamão... continua... mas como assim... eu eu... eu não sei... porque eu não vejo aqui na cidade né?... assim... quando tem uma festa... uma Festilha... o Boi de Mamão vem né?... tem o Boi de Mamão... Pau de Fita... tem as Pastorinhas... aí eles se apresentam... diversos horários durante os dias da festa... mas assim... sair na cidade como saía... eu não vejo... pode ser que pelos bairros né?... e tem a festa do Espírito Santo... também tem os que vão... levando a bandeira do Espírito Santo e cantam nas casas... daí eles avis[ũ]... o a pessoa pede que vá na sua casa cantar... também recebem a bandeira... também oferecem né?... salgadinho... docinho... e começou de uns tempos pra cá também... porque tinha quase que desaparecido...

L1 - e a senhora conhece alguma... alguma lenda... alguma história que seja MUIto a cara de São Francisco... que todo mundo aqui conhece... que seja bem daqui... me contaram já do Forte Marechal Luz... né?... contaram

$$
\text { L L2 - AH tá... }
$$

L1 - da praia do Capri... mas... duas do leprosário né?...

L2 - AH sim...

L1 - falaram pra mim dos franceses lá

L L2 - AH tá... isso não é lenda... existiu mesmo né?...

L1 - mas assim...

L2 - uhn uhn...

L1 - histórias do local... me falaram também do:: Cabecinha...

L2 - a o Cabecinha foi o... Francisco... Francisque Domingues... que era intendente aqui mas era um facínora... né?... e ele mandou botar o pobre... padre Fernando que chama... numa canoa... ( ) final de mil e setecentos né?... numa canoa... com uma cambacinha de peixe... senão me engano... uma coisa com farinha de trigo... com farinha de:: mandioca... e soltou na baía porque:.... o filho dele morreu e ele queria que o padre enterrasse na igreja... mas ele... o padre não permitiu porque não eram pessoas dignas de ter essa sepultura dentro da igreja né?... mas ele mandava né?... ele... mandava e não... não (podia)... e o padre não fez a vontade dele... ele soltou o padre... ( ) não se tem notícias desse padre... ele foi embora... desapareceu... parou em alguns lugares... se morreu ninguém sabe... mas o Cabecinha depois... o governo soube das atrocidades que ele praticava aqui né?... e mandou prendê-lo... mas ele fugiu... e:.... desapareceu no mato... nunca souberam dele... ele morava lá na Laranjeira... ele obrigava as pessoas que passav[ũ] por ali a botar pedra... pra fazer um muro de pedra né?... aquelas pedras que vai pondo uma em cima da outra... e todo mundo que 
passava por ali tinha que ajudar a colocar as pedra pra fazer o muro né?... ainda hoje você tem res/assim os restos ainda dessas... desse muro... não sei se você nunca viu né?...

L1 - e a igreja... ela sempre foi assim ou ela já foi diferente?...

L2 - olha... eu me criei sem a outra torre... ( ) ela só tinha uma torre... porque eu acho que o estilo dela era só de uma torre né?... mas em mil novecentos e vinte e três... o padre... não sei se era... Gregório... começou a construir a outra torre ((apontando para a igreja))... mais foi só a primeira parte... sabe... só a primeira... ali né?...

L1 - o senhor disse que nasceu e foi criado aqui e aqui não tinha nada... continua a contar pra $\operatorname{mim} . .$.

L2 - isso aí é uma região que não tinha nada... nós não tínhamos nem estrada pra chegar aqui... é... a e[ $\left.\int\right]$ trada que nós tínhamos aqui era uma estrada de chão batido... que vinha de São Francisco até a Enseada... mas isso era muito difícil né?... transporte passar aqui era difícil... ficou muitos anos assim ... aí depois de mil (novecento) e cinqüenta e quatro... depois que foi aberto de Ubatuba até a Enseada... fica na ponta né?... vai... foi aberta só a:: a mata e ficou... assim... chão de... chão ficou muito tempo... aí depois mais tarde é que a prefeitura começou a... a pôr um material... uma casca de casqueira... na época podia né?... então começou a tirar umas casca de casqueira... na época podia se mexer em casqueira né?... então começou a tirar uma casca de casqueira... a gente ia (desbastando) ... e:.... aí começou... estamos aí... está melhor... ficou até... es / essa estrada assim péssima até mil novecentos e:.... setenta e $\left[\int\right]$ inco... quando a Petrobrás entrou aqui... setenta e

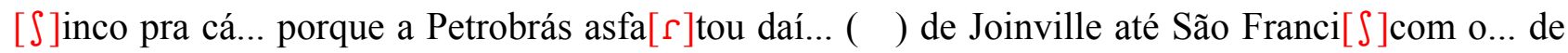
São Francisco até a Enseada... que hoje nós temos uma estrada muito boa... um transporte muito bom aqui né?...

L1 - e água... luz... o senhor sempre tem?

L2 - agora sim... mas a lu/luz também chegou aqui em $\left[\int\right]$ inqüenta e quatro também... mas e $\left[\int\right] \mathrm{a}$

luz ficou den / nas casas... não te / não tinha poste... não tinha nada né?... hoje não... hoje nós

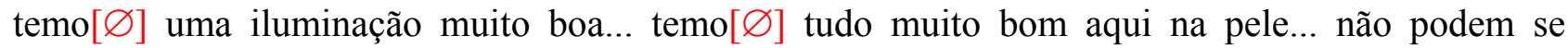
queixar...

L1 - e::... como que é o... dia-a-dia de um pescador?...

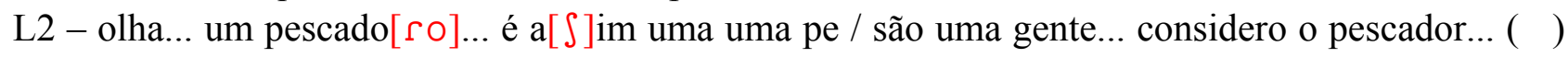
na lama... muito ingrato sabe?... porque o pescador ele pega ele... ele só pode ganhar a[ $[\ulcorner] g u m$ dinheiro quando o tempo e[ $\left[\int\right]$ tá bem... tá bom... o tempo quando fica... meio né / ( ) o tempo o pescador já não tem produção... o pescado[ৎo] não... não pega / não e[ $\left.\int\right]$ tá preparado assim pra... pra enfrentar... a... as tempe[ $\left[\int\right]$ tade né?... é tudo barquinhos pequeno... não tem recurso... então... quando você precisar... pode ganhar dinheiro... pode não ter ele... ficar... pensando assim... arrumando uma rede... qualquer coisa tem que melhorar novamente...

L1 - e:.... o senhor que já... tanto tempo na pesca... o senhor já passou algum susto aí no mar?

L2 - [ $\left.\int\right] \operatorname{im} . .$. a gente se assusta... assusta porque quem vai pro mar... ele tá sujeito a tudo né?... dá tempe[S]tade.. não tem pra onde correr... ele tem que ficar lá agüentando até aqui... ( ） i[S]o aconteceu muitas vez[i] comigo e com os out $[\varnothing] \mathrm{o}\left[\int\right]$ também...

L1 - e baleia... tubarão... essas coisas tem por aqui?... o senhor já viu?... 
L2 - tem... baleia $\left[\int\right]$ im... baleia nós temo[ $\left.\varnothing\right] \ldots$ vai come $\left[\int\right]$ ar agora do mês de ago[ $\left[\int\right]$ to em diante... ela fica aqui na beira das praia aqui... temos na Praia Grande... vinte e oito quilômetros de praia... então ela vai bem pertinho da pedra assim... agora... tubarão não... tubarão nós pescava... nos tempo que nós pescava de rede grossa aqui... nós matava algum tubarão... uns pequeno... mais nunca atacou ninguém não... coisa diferente é ataque de tubarão guria...

L1 - e como que é agora em relação à violência?... tem violência aqui na cidade... não tem? ( )

L2 - olha... já e[ $\left[\int\right]$ tá apare $\left[\int\right]$ endo... tá apare[ $\left[\int\right]$ endo... em compensação do que vi a Enseada... $\mathrm{a}\left[\int\right] \operatorname{im} . .$. quando cheguei aqui... é... era um lugar muito ca[ \ulcorner] mo assim... muito... quieto... hoje não... hoje já tem violência... ainda... já... que / apareceu até a morte aqui já... e a gente... não pode... $\left[\int\right]$ aber porque... mais já já já apareceu...

L1 - e ali a... o senhor conhece ali o centro de São Francisco... a história... porque que tem aquelas casa ali antigas...

L2 - é... São Francisco é uma cidade muito antiga... ela completou quinhentos ano agora em dois mi[ł] e quatro ela completou quinhentos ano né?.. então ela:: as as construção antiga é... é... o

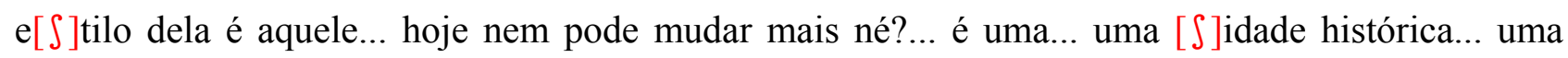
$\left[\int\right]$ idade de ... vai ser conservada sempre a[ $\left[\int\right] \mathrm{im} . .$.

L1 - e::... ali na na... em São Francisco mesmo fiquei sabendo da história... que São Francisco era a cidade mais importante de toda a região...

$$
\mathrm{L} \text { L2 - isso isso }
$$

L1 - agora é Joinville...

L2 - é

L1 - porque será que mudou?

L2 - olha Joinville... porque é uma $\left[\int\right]$ idade indu[ $\left[\int\right] \operatorname{tria}[\varsigma] \ldots(\quad)\left[\int\right]$ idade que tem muita indústria cresce a cidade... e São Francisco ela nunca foi uma cidade portuária... mas não industriária não... né?... e porto não chamou tanta atenção... tanta gente até que ela crescesse né?... Joinville não... Joinville tem indústrias né?... sai muito loteamento... cada loteamento ficou uma cidade né?

L1 - lá cresceu...

L2 - cresceu muito... vira uma [S]idade de quinhentos mil[e] habitante... ela tem tudo lá... dentro da... da... Joinville... que se procura lá tem... e São Francisco não... São Francisco já não acom / ( ) Joinville né?

L1 - e aqui em São Francisco... aqui na Enseada... tem muita diferença? dessa época do ano... pra época de verão... do número de pessoas?...

L2 - tem tem... tem... isso aqui tá muito grande... isso aqui em época de verão... é ca[ \ulcorner] culado $\mathrm{a}\left[\int\right] \operatorname{im} . .$. certos dias a[S]im... pa quinhentas mil pessoa... de gente aqui... na En[S]eada... e quando chega nessa época de inverno... nós temos aqui só a nossa população que mora aqui né?... o pessoa $[\ulcorner]$ de fora não... não vem pa a enseada no inverno né?... ela vem só no verão...

L1 - e o senhor acha que eles não vem por quê?... por que não tem o que fazer?... o...

L2 - não... eles não têm o que fazer... e depois o povo também nessa época... tem $/ \mathrm{ma} /$ o povo traba $[j]$ a no inverno... entende?... a férias do povo no inverno é muito pequena... entende... não dá pra... pra gastar tempo... no vê / no verão não... verão todo mundo gasta... na temporada todo mundo tem tempo né?... é férias de (quinze) dia... (vinte) dia... então si compensa até... e... é o motivo que dá muita gente aqui na praia... muita gente... e você vê... a... a... a temporada o povo que tem aqui... ( ) poxa... tem gente que não merece... muita gente... 
L1 - e::... antigamente né?... conversando também com pessoas mais velhas né?... que falavam que tinham festas que hoje não tem mais... como o Boi de Mamão... o Terno de Reis... o Pau de Fita... com/como eram essas festas?... o senhor chegou a conhecer aí?

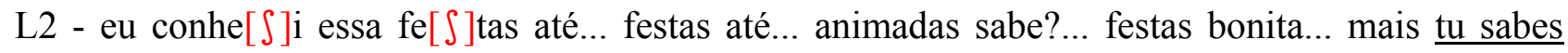
que... que eu nosso mundo moderno... as coisa mudou... entende?... aquela geração... que que fazia aquela fe[S]ta... aquele povo acabou... veio uma outra mentalidade... a mentalidade de hoje é.... ( ) já é diferente né?... então foi acabando... acabou... o povo de ho / ho[i] já não dá valor disso...

L1 - e como que era o Terno de Reis... por exemplo...

L2 - olha... era muito bonito... esse pessoa[ $[\ulcorner]$ saía cantando a noite... na época de... na época de Ano

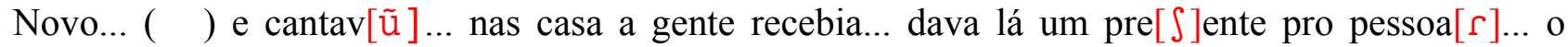
pessoa $[\ulcorner]$ ag[a $\varsigma]$ deciam né?... acompanhavam muito a gente... era muito bonito assim... e hoje não existe... a gente vê essa criançada aí... eles já não quer ( )

L1 - e o Boi de Mamão... o que era o Boi de Mamão?...

L2 - também era... ficava um hom[e] dentro... o par daquele Boi de Mamão... dançando... fazia...

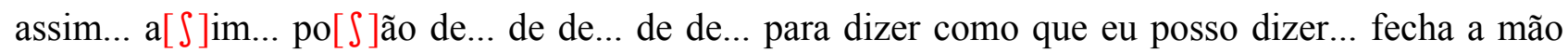
com que as/que assim... [u]fende... o... o... parecido com ofensas até né?... ele dava a cabeçada em um povo... é... é... derrubava a[ৎ]guém... é... ( ) era bonito.. era uma brincadeira assim que... brincar de assoalho... que se pode dizer né?... não tinha ma[ \ulcorner] dade naquilo...

L1 - acho que o Pau de Fita também tinha...

L2 - também... também cantav[ũ ] ... também dançav[ũ ] o Pau de Fita... era tudo muito bonito.. eu vi aquilo... e hoje eu fico... pensando assim... acabou... o pessoa[ $[$ ] não vê... a própria minha família não conhece isso...

L1 - e o pão por por por Cristo? ... tem ainda?... o que que é isso?

L2 - o quê?

L1 - pão por Cristo... o pão por Deus... eles também chamam...

L2 - HEI... tinha o pão por Deus... era / era mês de outubro novembro... fazia assim ( ) botav [ ũ ] dentro de um envelope... uns versos assim... 
ANEXO 3

PASQUIM DO MORTO VIVO 
Todas as palavras e trechos que estão em negrito são analisados na terceira parte desta dissertação.

\section{PASQUIM DO MORTO VIVO}

Eu vou fazer umas rimas

Sobre um fato que ocorreu

Foi ali na Santa Lídia

Um morto que não morreu

24/11/2002 foi um dia de tumulto

O Deli sumiu na praia 
Ele desapareceu

E para o povo do lugar

Muito trabalho ele deu

O Deli deu a chave

Pra Laurinha segurar

Disse vou dar um mergulho

E logo já vou voltar

Pra ir lá pra Santa Lídia

Aquele bingo cantar

O tempo anda depressa

A hora começou a passar

A Laura com a chave na mão

Começou se desesperar

Que demora do Deli

Onde será que ele está

E por toda aquela praia

A coitada foi procurar

Muito rápido a noticia

Na Santa Lídia se espalhou

O tão querido Deli

Na praia se afogou

Ele foi dar um mergulho

Até hoje não voltou

E a coitada da Laura

Todo a culpa levou

Laura, como que pôde

Tudo isso acontecer

Ficasse lendo na praia

Deixasse o Deli morrer

Coitada da dona Vida

É ela quem vai sofrer

O povo da Santa Lídia

De muito bom coração

Foram numa busca em conjunto

Lá na praia de Armação

Ficaram lá toda à tarde

E a noite fizeram um serão

Quando a maré subia

Paravam pra descansar

Mas logo ela baixava

Todos iam para o mar

Com rede pra todo lado 
Para seu corpo encontrar

O Batista que é seu tio

Tanto se esforçou

Ficou tanto tempo na água

Que seu corpo até murchou

Muito triste se sentia

Pois nada ele encontrou

Foi quando o filho dele

Agindo como criança

Sem ordem superior

Pegou emprestada a lancha

Procurando mar adentro

Ele tinha tanta esperança

Coitada da Maria Luiza

O joelho chegou a inchar

Fez promessa a todos os santos

Pro seu sobrinho achar

Não ia ficar conformada

Se o corpo ficasse no mar

Seu marido Zé Olavo

Vendo ela chorar

Pagou uma escuna

Pra fazer busca no mar

Coitada da minha Luiza

Não se cansa de rezar

Todo o corpo de bombeiro

Estava tão empenhado

Na busca do corpo dele

3 corpos foram encontrado

foi tudo pro IML

para ser identificado

O tempo ficou muito feio

\section{Começou a trovejar}

\section{O corpo dele agora \\ Pra fora o mar vai levar}

Coitada da sua família

Como é que vai ficar

Só depois de 5 anos

É que o seguro vai pagar

acharam um corpo na praia

não deu pra reconhecer

uma coisa se garante 
puxa a sunga pra saber

se duro era $4 \mathrm{~cm}$

mole não dá nem pra ver

até a sua intimidade

o povo veio a saber

só media $4 \mathrm{~cm}$

não veio a desenvolver

isso já é de nascença

nada se pode fazer

o seu Antonho Anjo

foi o primeiro a chegar

lá na casa do Zequinha

mas nada queria falar

Pois o cara é seu amigo

E não podia se assustar

Mas chegou o Pedro da Elza

E começou a falar

\section{$\mathrm{O}$ quirido, $\mathrm{O}$ quirido}

Como o teu filho foi se afogar

$\mathrm{O}$ bingo já foi suspenso

Para o povo procurar

Quando o corpo der na praia

Eu venho aqui te avisar

A dona Benta muito chocada

Logo lá apareceu

Fez um chá de laranjeira

E pro seu Zequinha ela deu

Fica calmo meu compadre

$\mathrm{O}$ teu filho não morreu

Agora que já estou calmo

Me leva pra praia ligeiro

Não posso ver o meu filho

Mas conheço pelo cheiro

Esse meu filho querido

Me deixou em desespero

A dona Vidinha chegou

Começou a chorar

O Zequinha passou mal

Levaram lá pro (P A)

Deram nele uma injeção

Para ele se acalmar

Todo povo lá na Penha

Muito também se abalou 
Quando soube da notícia

Da morte do professor

Um moço ainda tão jovem

Foi na praia e se afogou

Já falaram até que ele

Foi engolido por uma baleia

Outra hora já se diz

Ele nadou lá pra Ilha Feia

Só falta o povo dizer

Que ele virou sereia

A pobre dona Chiquinha

No muro foi se apoiar

Pra quem passava na estrada

Começava então a falar

È só rezando um responso

Para o Deli encontrar

A Santinha do Quinca

Que sofre do coração

Quando soube da notícia

Subiu a sua pressão

Ela não ia agüentar

Ver o pobre no caixão

A dona Bela Machado

Já avançada de idade

Falou pra Dona Vidinha

Te conforma comadre

$\mathrm{O}$ teu filho foi pro céu

Partiu pra eternidade

O Deto do Amadiu

Amoleceu o seu coração

Para passar a noite

Deu mais de 50 pão

Ele muito se comoveu

Com toda a situação

Até o pobre do Fonso

Não quis abrir o seu bar

Mas chegou o Tonho da Barba

Para uma pinga tomar

Preciso de uma cachaça

Pra poder me consolar

A Barba quando soube 
Que o Deli morreu no mar Ficou tão desesperada

E começou a chorar

Disse e agora o sacolão

De quem é que vou ganhar

A Andreza com a Sueli

Não conseguiram se deitar

Passaram a noite na estrada

Andando pra lá e pra cá

Não queriam estar lá na casa

$\mathrm{Na}$ hora do corpo chegar

Foi quando a Sueli

Numa hora até falou

Já fiz um chá pro Calinho

$\mathrm{O}$ danado não tomou

Está três noites sem dormir

Por que muito se chocou

Até a Bela do Zé

Nessa rima vai entrar

Falou pra dona Vidinha

Não adianta chorar

Esse é o fim de todos

Nós temos que se conformar

O Má do Chiquinho Balbino

Não queria se conformar

Pegava na mão do povo

Começou a lamentar

Nos perdemos um grande amigo

$\mathrm{O}$ mais ilustre do lugar

O Bronildo muito doido

Correu lá para saber

Ficou lá a noite inteira

Esperou amanhecer

Disse só saio daqui

Quando o corpo aparecer

A Mariquinha do Bronildo

Falou eu também vou lá

Queria andar bem ligeiro

Começou a manquejar

Eu quero estar lá na casa

Quando o corpo chegar 
A Bel não quis ir sozinha

Esperou o Mauro chegar

Então a dona Vidinha

Eles foram visitar

Foram com a Zete na praia

Mas ele não estava lá

Até o Gilson do Júlio

Não pode se controlar

Abraçou a dona Vidinha

E começou a chorar

Ele era meu companheiro

Na missa lá no altar

A Lica pra lá correu

Começou a gaguejar

$\mathrm{O}$ povo nada entendia

$\mathrm{O}$ que ela queria falar

Pra mim ele era bom

Até me deu um sacolão

A dona Mariquinha

Pra D.vidinha falava

O teu filho era tão bom

O povo dele gostava

Pois fazia sacolão

E para os pobres entregava

A Marli do Isaias

Também foi lá de carrera

Preciso saber a verdade

Tá me dando uma tremedeira

Foi pra casa e fez um chá

E rezou a noite inteira

O Tantão chegou de fora

Muito se lamentou

Do meu irmão Campeão

O povo não se lembrou

Só porque ele bebia

Nele não se falou

Até o Bim da Beta

Que havia desaparecido

Demorou tanto tempo pra achar

Que o povo já tinha esquecido

Só porque ele bebia

Ninguém ficou comovido 
O seu Dudu muito exibido

Quer falar certo demais

Disse o corpo a essas horas

Está lá nos mariscais

E se isso for verdade

De lá ele não sai mais

Outra hora ele disse

\section{Que um responso foi rezado}

Que o corpo do Deli

Estava na pedra trancado

O seu Osmar e a dona Lora

Movidos de compaixão

Passaram na casa três noites

Levaram uma sacola de pão

Junto com a Luciana Bento

Que é boa de coração

O Prefeito de Piçarras

Muito triste ficou

Pra casa do falecido

Coroas de flor mandou

Ele era bom funcionário

Muita saudade deixou

O Coelho também veio

Fazer uma visitinha

Tudo pra consolar

D. Vida e o seu Zequinha

Disse estou a disposição

Pra tudo o que precisar

Se o corpo for encontrado

Uma coroa vou mandar

Aqui o Baco da Tinha

É um homem bem respeitado

Quando soube da notícia

Ficou muito abalado

Depois tudo veio à tona

Ele ficou revoltado

\section{Qui qui qui se eu encontro ele}

Eu bato ne ne nesse safado

Passou 4 dia de busca

Nada se pode encontrar

Foi quando toda essa história

Então começou a mudar 
Parece que ele está vivo

Ninguém sabe onde ele está

O jornal Diarinho logo noticiou

Que um professor na Penha

Sua morte simulou

E foi com essa notícia

Que o povo se revoltou

O moço que era tão santo

Tão denegrido ficou

O povo de Santa Lídia

Que não gosta de fofocar

Em torno dessa história

Começou a revelar

Coisas que ninguém sabia

Agora em publico está

Coitada da Ana Maria

Está em má situação

O povo está até falando

Que ela seqüestrou o irmão

Pra saudar a sua dívida

Armou toda a confusão

Quase que matou os pais

Por causa da eleição

Se fosse arte da Hildes

Aquela que diz que bebia

Talvez o povo daqui

Essa história entendia

Mas a coisa sempre sai

De onde ninguém desconfia

A Laura foi à missa

E subiu lá no altar

E para todos fiéis

Começou a falar

Sei que o povo da Santa Lídia

Já quer até me linchar

Não tenho nada com isso

Só vi ele entrando no mar

O Paulinho da Olga

Ele estava nessa missa

Quando a Laura falou

O povo abaixou a crista

Se ela não disse a verdade

Então é uma grande artista 
A polícia quer saber

Foi tirar informação

Na Penha ele não está

Nem tampouco na Armação

Talvez então ele esteja

Se confessando ao padre João

Sendo santo como era

Pecado ele não tem não

Pediram ao padre Inácio

Para rezar uma missa

Não posso fazer isso

Sem saber de mais notícia

Pois não posso me envolver

Neste caso de polícia

A Sueli do Dorico

Na hora correu pra lá

Chegava perto do povo

Queria compartilhar

Precisava tomar um banho

Pro seu cheiro melhorar

Pois perto dessa mulher

Não dá nem pra respirar

Será que ela está usando

Um perfume de gambá?

Pra calar a boca do povo

E acabar a confusão

Eu agora vou contar

Essa ultima versão

Bem vivo ele está

Morto ele não esta não

Ele foi atropelado

Por uma lancha na contra mão

Levaram pra Curitiba

Está em recuperação

Num hospital de louco

Pra convencer o povão

O Ponga falou pra Laurinha

Nem sei como te falar

Sinto muito mas a sala

Tu tens que desocupar

Eu já soube que o povo

Ta querendo apedrejar

Se quebrar o meu blindex

Tu não vai querer pagar 
E com esse prejuízo

Eu não quero ficar

A Laura não pensava

Que o povo desse lugar

Nas coisas do passado

Também fosse cutucar

Já não sabe o que faz

Para então se explicar

Ela diz sou uma vítima

Mas ninguém quer aceitar

A Laurinha alugou

Uma sala na Armação

Saiu daqui rapidinho

Não fez nem liquidação

No meio desse povo

Eu não posso ficar não

Vou acabar ficando louca

Com toda essa confusão

O Liso muito valente

Ficou nervoso no bar

Disse na minha frente

Ninguém vai do Deli falar

Ele achava que nessa rima

O seu nome não ia entrar

Se o Deli é inocente

Ele vai ter que provar

O Zico ficou de fora

Disse não vou me envolver

Andaram roubando boi

E queriam me prender

Do Deli eu não sei nada

E não quero nem saber

Isso é tudo que sei

Por aqui eu vou parar

Quando souber de mais coisa

Então vou continuar

Não quero ofender ninguém

Isso é só pra brincar

O povo de Santa Lídia

Já está desconfiado

Que isso é arte do Quinca

Mas estão muito enganado

Ele não faz mas pasquim 
Já está aposentado

E também se fosse ele

$\mathrm{Na}$ rima não tinha entrado

A coitada da Irani

Não pode ir até lá

O Antonho tá doente

Dele ela foi cuidar

A hora que achar o corpo

Vocês mandam me avisar

Foi quando seu Atonho

Começou se lamentar

Se eu não tivesse doente

Eu também ia pra lá

Mas estou tão mal da perna

Que não posso nem andar

A dona Santinha do Buca

Não quis ir pra lá sozinha

Pegou no braço da Bela

E foi consolar a Vidinha

Passou a mão no rosário

Rezou a noite inteirinha

A Tudinha do João

Seu comércio não fechou

Com todo esse movimento

Muito então ela lucrou

$\mathrm{O}$ estoque de biscoito

Em dois dias se acabou

A dona Celina disse

A minha loja eu vou fechar

Hoje é um dia de luto

Ninguém vem aqui comprar

E na casa da vizinha

Ela também foi chorar

A Varda e a Cimira

Também foram visitar

Já estavam combinando

De um terço rezar

Foi quando o P.Joãozinho

Nessa hora foi chegar

Trancou-se dentro do quarto

Pra falar particular

Até hoje não se sabe

$\mathrm{O}$ que ele foi fazer 
Saiu da casa calado

Ninguém pôde entender

Pois o que ele não queria

Era o seu nome envolver

O seu Domingo Bento

Homem de bom coração

Quando soube da notícia

Pegou sua embarcação

Levou lá pra praia na hora

Pra fazer um arrastão

Estava ele pensando

Que na rima não ia entrar

Ms foi ele que levou

O Pepe bebum o pra lá

Quando a rede trancou

Começou ele a puxar

Achando que era o sobrinho

Chegou até desmaiar

O Batista dentro da água

Gritava com o Pepe

Se fosse pra tu ajudar

Não era pra tu beber

A Terezinha e o Di

Ficaram pra lá e pra cá

Chega de comer arraia

O meu cardápio vou mudar

Queremos um saco bem grande

Pra um pouco de peixe levar

O Nelso sabendo disso

Uma caixa foi buscar

Vou levar essa espada

Para a Dete fritar

Com um pirão escaldado

Como até me babar

O Junior marido da Conca

Que é de pouco falar

Um pouco curioso ele veio a ficar

Pegou a sua moto

E notícia foi buscar

Só pra acalmar a Zoéte

Que não para de falar

O Domingo da Maria

Sendo esperto como é

Aproveitou o movimento 
Pra vender seu picolé

Vendeu tanto a tarde toda

Nem parou para o café

Morre um pra bem do outro

Veja só como é que é

O Ouride já estava

9 anos separado

Quando soube da notícia

Ficou muito apavorado

Tenho que falar pra Celça

Não posso ficar calado

O pobre do Amauri

Não conseguiu mas jogar

Pegou sua bicicleta

E foi pedalando pra lá

Ficou na areia pensando

Eu também vou mergulhar

Veio o Pepe e disse

Amauri vem me ajudar

Sai daí que tu tá bebo

Até pode se afogar

Não posso ir aí contigo

Porque eu não sei nadar

Quando puxaram a rede

Muito peixe saiu do mar

Tinha muito veranista

Que queria até comprar

O Domingo Bento falava

Quem quiser pode levar

Na salguinha do Nei

Esse boato ocorreu

O Deli está bem vivo

Ele nunca que morreu

O povo ainda não sabe

Onde ele se escondeu

O seu Mario Paiacam

Lá também a noite passou

Ficou por ali quietinho

Muita coisa investigou

Coisa que só ele sabe

Pra ninguém ele contou 
A marreca chorava muito

E falava pro Marinho

Coitado do Deli

Ele era tão bonzinho

O povo aqui dessa rua

Tá na beira do caminho

A espera de notícia

Do seu querido vizinho

A Tude assim falava

Eu não quero acreditar

Se ele nadava tanto

Como foi se afogar

Começou lembrar do Neim

Que estava lá no mar

Entrou pra dentro de casa

E começou a rezar

Esta tão triste notícia

Em Cabras também chegou

$\mathrm{O}$ povo naquele lugar

Muito triste ficou

Ele é muito conhecido

Por que é um professor

Foi aí que o Dengo disse

Amanhã eu vou pra lá

Vou passar no bar do Fonso

Para ele me contar

Quando soube da mentira

Não queria acreditar

Ele voltou pra casa

Não sabia o que falar

Disse o cara que tinha morrido

Acabou de ressuscitar

Isso é o que o povo de lá tá falando

Vocês podem acreditar

O João Clara muito tanso

Correu pra lá também

Em vez de dar os pêsames

Ele deu os parabéns

Muita gente analfabeta

Nesse lugar ainda tem

A Cida falou pra Isaura

Vamos comigo pra lá 
Ela disse eu jamais

Vou sair do meu lugar

Com o povo jeca daqui

Não posso me misturar

Ela se acha granfina

$\mathrm{Na}$ hora que vai falar

Toda rebolada na estrada

O povo vê-a passar

Sempre de salto alto

Ela sai pra trabalhar

Faz todo tipo de curso

Pra de profissão mudar

Ela já está cansada

De suas unhas quebrar

O serviço de faxineira

Não dá mais pra agüentar

Como vou manter a fama

De Rainha de Sabá

A Cida foi na Sueli

A Silvana convidar

Para que fosse com ela

Dar uma voltinha pra lá

Vestiu uma saia curtinha

E começou a falar

Se eu ficar trancada em casa

Eu vou me entediar

O Isaias teve um sonho

Lá fora em alto mar

Ficou todo arrepiado

Começou interpretar

Sempre que sonho com porco

Morre gente do lugar

A Graça do Bileu

Não queria acreditar

Ele é tão inteligente

E sabia até nadar

Acho que ele não ia

$\mathrm{Na}$ praia pra se matar

A Odenes quando soube

Falou para o Orione

Essa história ainda vai

Para a boca no trombone 
Não precisa fazer isso

E gastar com telefone

Eu vou chamar minha irmã

E dar pra ela um mega-fone

O seu Santo do mercado

Pegou o seu caminhão

E também foi lá na praia

Ajudar no arrastão

O Pepe quando viu ele

Já pediu o garrafão

Tenho que tomar uma pinga

Pra acalmar meu coração

O Beto da padaria

Também fez muito esforço

Trabalhou a noite inteira

Fez um saco de biscoito

Eu agora trago esse

Amanhã eu trago outro

Ninguém ficou sem café

Ali na casa do morto

O Cantidio e Maria

Também foram lá pra ver

Ficaram até meia noite

Não quiseram amanhecer

$\mathrm{Na}$ hora que achar o corpo

Vocês mandam me dizer

O Isaias e a Marli

Foram de moto na Armação

A moto furou o pneu

E deixou eles na mão

Ele veio encima do tanque

Arrumou e tomou um café

Voltou pra buscar a Marli

Que já estava vindo a pé

O Ninico também foi

Andando de passo a passo

Quando chegou na Vidinha

Tava morto de cansaço

Chegou perto do Zequinha

E chorando deu um abraço

O Domingo da Varda

Estava no bar tocando

Arriou o seu violão

E foi pra casa chorando 
Vou lá buscar o Deli

Que nas águas tá nadando

A Leia da Cimira

Muito se compadeceu

Está esperando gêmeos

E quase que ela perdeu

Teve um ataque de choro

Quando soube que ele morreu

O seu Moacir Legal

Homem que nunca chorou

Com esta triste notícia

Muito chocado ficou

Chegou até passar mal

E quase que desmaiou

O Bernado muito triste

Bem ligeiro eu já vou

Bater o sino da igreja

Que o Zequinha mandou

Ai a Georgina disse

O Bernado não faz isso

O morto ainda não chegou

O Zico do Mané Silva

Também entrou na função

Com um chapéu na cabeça

Parecia o Lampião

O Zequinha botou ele

De guarda no seu portão

Com uma mão na tramela

E outra no garrafão

O Samuel marceneiro

Queria fazer boa ação

Separou umas taubinhas

Para fazer o caixão

O Zequinha disse assim

Samuel muito obrigado

Quando achar o Deli

O corpo vai ser cremado

Até a D. Lelena

No meio de muita gente

Ela ficou muito braba

Chegou a ranger os dentes

Disse eu sou da raça Ferreira 
E também sou valente

Comigo a coisa é no braço

Com isso não tô contente

Vou chamar o delegado

Pra prender toda essa gente

É melhor parar com isso

Não levar isso pra frente

Eu já vou sair daqui

Que tô de cabeça quente

Se eu pegar o revólve

Posso atirar pra frente

Vou acabar até matando

Muita gente inocente

O Zequinha disse Zico

Leva essa coroa pra lá

Ele pegou a coroa

E foi no pasto jogar

Botou no pescoço da vaca

Para o pasto enfeitar

A vaca saiu assustada

E começou a pular

Caiu lá no ribeirão

Quase veio a se afogar

A Célia da Olga disse

Não é que eu tenho preguiça

Só quando abaixar a poeira

É que eu vou na missa

Esse caso do Deli

Já virou uma bobiça

Sábado vai ter missa

Para o padre esclarecer

O Deli é seu amigo

Mas não pode aparecer

O povo vai ficar atento

No que ele vai dizer

O seu Jóca Atanásio

Homem que "nunca mentiu"

Disse que viu o Deli

Lá perto do Amadiu

Depois saiu perguntando

Para onde ele fugiu

Disse ele foi embora

Para fora do Brasil

Ele já está em Roma 
Foi embora e ninguém viu

A Salvelina também queria

Até lá na praia chegar

Saiu de bicicleta

E com a graça foi falar

Convidou também a Lica

E foram as três pra lá

Chegaram lá muito suada

De tanto pedalar

Foram molhar o pé

Para se refrescar

Encostaram a bicicleta

Para o corpo descansar

Pedalaram até lá

Porque queriam saber

Com detalhes como foi

Que ele veio a morrer

Nós vamos ficar aqui

Até ele aparecer

E ficaram lá rezando

Até escurecer

E o Didi da Sônia

Que também é capelão

Estava no hospital

Tratando do coração

Se pudesse ia voando

Para a praia de Armação

A Maria também queria

Ir até lá com o Dé

Mandou chamar um táxi

Que ele não anda de pé

Quem vai pagar a corrida

É o compadre João Baé

O Felício da Sandra

Falou eu não posso ir lá

Pulando num pé só

Ele não ia agüentar

A Sandra quis levar no colo

Mas não pôde segurar

Espere um pouquinho

Que um táxi vou chamar

O Seu Raul quando soube 
Pegou o seu caminhão

Encheu ele de criança

E levou pra Armação

E lá viu o Seu Dudu

Parecia um capitão

Vai buscar o seu trator

Pra ajudar no arrastão

O Julho da Zenilda

Parou de trabalhar

Tá fazendo a casa do filho

Que logo vai se casar

Vou pegar minha tobáta

E também vou ajudar

Passou na frente da igreja

Já começou a chorar

Vou ficar emocionado

Quando o corpo aqui entrar

O Seu Genésio Ranguett

Chegou e abraçou o Zequinha

Deu um abraço tão forte

Quase quebrou a espinha

Foi quando ele gritou

Me acode Vidinha

O Seu João do Vitor

Ele também foi lá

Disse eu sou viúvo

Vim aqui pra namorar

Olhou para a Sueli

E começou a piscar

Isso aí vai dar noivado

E depois vão se casar

Ele tem que acostumar

Com o cheiro de gambá

O Seu Jóquinha aranha

Ele foi vê o Deli

Queria levar a Tidi

Ela não queria ir

Falou tanto a noite inteira

Não deixou ninguém dormir

O Seu Dudu muito prosa

Que mal consegue andar

Com sua perna dura

Começou entrar no mar 
Se não fosse o reumatismo

Eu conseguia nadar

É melhor eu sair d'água

Antes de me afogar

O Bastião da Maria

Quando soube da notícia

Saiu de casa na hora

Quase morto de preguiça

Só vim aqui pra saber

que hora vai se a missa

E também quero bater

um papinho com o Batista

a Landa e o Chiquinho

vieram de Paranaguá

com a sua filha Lê

foram pra praia chorar

eu só vou pra casa agora

quando a busca terminar

tenho muita esperança

que hoje ainda vão achar

D.Edga e seu Venâcio

Saíram pra caminhar

Passaram lá no Zequinha

Mas não quiseram entrar

Só vamos à hora da missa

Pois gostamos de rezar

O Gervásio do Dórico

Ele fez muito bem

Ficou dentro de casa

Não saiu pra ver ninguém

ficava na janela olhando

A hora que o corpo vem

E o Geazi do Gildo

Estava desanimado

Estou esperando o Nei

Mas ele esta atrasado

Vou acabar ficando louca

Se ficar sem namorado

Saiu e foi sozinho

Como sempre rebolado

O Gildo do João Luzia

Dirigindo o seu fuscão

Para saber de notícia 
Parava na contra mão

Ele dirige assim mesmo

Não estava bêbado não

Tudo o que ele queria

Era mais informação

Saiu pela estrada a fora

E foi lá para o Sertão

D. Márcia da escola Também veio se abalar

Eu vou chamar os alunos

E com eles ensaiar

Um linda homenagem

Quando o professor chegar

Na missa de corpo presente

Eles vão apresentar

O coral da igreja

Também queriam cantar

Na missa de 7 dias

Para ele homenagear

Será a missa mais linda

Que terá nesse lugar

$O$ que não se esperava

É que ele fosse ressuscitar

Me desculpe minha gente

Não precisa se zangar

Eu só fiz essa rimas

Para o povo consolar

Foi para secar as lagrimas

Que caiu nesse lugar

Tem até gente falando

Que vai me processar

Tem que botar na cadeia

Quem fez o povo chorar

A mulher mais querida daqui

É a dona Maurina do Zéca

Ela logo fez um chá

E esfriou na caneca

Deu para Jane e disse

Não precisa chorar

Toma todo esse chazinho

Que tu vai se acalmar

Á Jane da Terezinha

Também foi pra lá ligeiro 
Passou no salão da Cida

Para pintar o cabelo

Tava toda enfeitada

Parecia um pinheiro

Toda sua maquiagem

Sempre foi um exagero

A Edileuza então disse

Eu não posso andar na estrada

Tenho que me comportar

Sou uma mulher casada

Se eu passar a noite lá

Sei que vou ficar falada

Meu marido é muito bom

Não vou dar essa mancada

Não posso esquecer a Lorinho

Ex-mulher do Ademar

Ela muito nervosa

Também veio a ficar

Fazia tanta careta

Chegava até a fungar

Parece que vai morder um

$\mathrm{Na}$ hora que vai falar

E a Cleuza do João

Que gosta muito de ajudar

Quando falava no morto

Começava a piscar

Serve até de pisca-pisca

Para o natal enfeitar

A Cida cabeleireira

Não podia fechar o salão

Ligou e seu celular

Esperando informação

Se Ciço estivesse aí

Eu ia com ele na armação

A Ló agora é viúva

Ela também foi pra lá

Precisa de um namorado

Está louca pra casar

Tem que ser o cara bom

Pro seu fogo apagar

A Bia do Maneca Sabino

Em todo velório que vai

Ela começa a tremer

Dá um ataque e cai 
Disse aqui eu não faço isso

Porque o velório não sai

O Zé Nazario vereador

Para isso é muito bom

Foi ele quem ajudou

Enterrar o campeão

Se Zequinha precisar

Ele também dá uma mão

Pode ajudar a pagar

A metade do caixão

A D. Jaci não queria

Deixar o Valdeci ir pra lá

Fica aí dentro de casa

Pode alguém te atropelar

Tem muito movimento

De carro pra lá e pra cá

Já me incomodei com o Banga

Então vim te avisar

O Valdeci então disse

A vó não pode nem falar

Se eu quiser eu vou e pronto

Ninguém pode me amarrar

Eu agora aprendi

Pelo beirado andar

Pode ficar tranqüila

Ninguém vai me atropelar

A Carmem ficou com medo

De ir com o marido pra lá

Pode alguém gostar dele

E dela querer roubar

Se foi difícil arranjar esse

É melhor não arriscar

A Eliane irmã da Bel

Convidou a seu Ari

Para ir com ela na praia

Vê se encontrava o Deli

Ele um pouco enciumado

Disse que não queria ir

Já está muito tarde

Vamos para cama dormir

A Conca veio correndo

Dizendo pra D. Santinha

Mãe, quem morreu afogado 
Foi o Deli da Vidinha

Ela muito assustada começou a tremer

Corre e faz um chá ligeiro

E traz aqui pra eu beber

Os seus vizinhos de Armação

Ficaram tão tristes com a morte

E fizeram corrente de oração

Pois vai fazer muita falta

Era um motorista tão bom

Já o tinham como fillho

Dentro do seu coração

Ele todo metidinho

Dirigia uma bela $\mathrm{f} 1000$

Com um óculos escuro

Pensa que ninguém viu

Achava que tava abafando

Que era o rei do Brasil

O Daniel do seu Joca

Não estava por aqui

Senão a notícia ia

Do Iapoque ao Chuí

Pois é o maior fofoqueiro

Igual ele nunca vi

A Preta do Mané Silva

Mulher de devoção

Ela acendeu muitas velas

Para São Sebastião

Rezava pra achar o corpo

E colocar no caixão

Ele está bem vivinho

Sua prece foi em vão

O Beto da Lela saiu pra anunciar

Foi pra Penha e pra Armação

Também passou no Gravatá

Enfim ele se empenhou

E foi por todo lugar

Será que ainda tem bobo

Pra esse bingo jogar

Por muita gente do lugar

O Deli é idolatrado

Tem gente daqui no asilo

Que vive lá desprezado 
Gente honesta que precisa

Pelo povo ser visitado

Tem até quem está falando

Coitadinho do Deli

Ele já se arrependeu

Talvez tenha se arrependido

Pois seu plano certo não deu

Ele pode enganar quem quiser

Mais jamais engana eu

A Luciléa da Lica

Agora está desempregada

A Laurinha tá falindo

Pois está endividada

Já não pode mais pagar

O salário da coitada

Será que a Ana Maria

Pôde tudo isso planejar

Se o Bim Ladem encontrar ela

Ele vai querer contratar

Essa foi a maior bomba

Que caiu nesse lugar

A Matilde do Bagum

Começou a chorar

Sem o seu décimo terceiro

Ela não queria ficar

Se ele tivesse morrido

Seu natal ia estragar

Como sempre a mulher do padre

É a ultima achegar

Dirigindo seu carro velho

$\mathrm{Na}$ praia ela foi chorar

Tirou o rosário do porta-luvas

E rezou com muita emoção

Com bolinhas do rosário

Fez até calo na mão

O Deli jamais pensou

No sofrimento que fez

Pro povo de Santa Lídia

Que a ele queria bem

Eu só quis deixar escrito

$\mathrm{O}$ que ele aprontou

Fingindo que estava morto 
Muita gente ele enganou

Se um dia eu encontrar o Deli

Vou assim lhe perguntar

Porque fingisse isso tudo

Nessa altura da tua vida

Brincasse com tua família

E com o povo de Santa Lídia

Se estavas com problemas

Ou em má situação

Arranjasse outro jeito

Não fizesse confusão

Não precisava acabar

Com a tua reputação

Há tanto lugar pra morar

Não pensasse nisso não?

Era só comprar passagem

E fugir de avião

O povo assim ia guardar

De ti boa recordação

Se um dia tu vier a público

Se desculpar diante do povo

Dizer que se arrependeu

E não vai fazer de novo

Pode ser que o povo perdoe

Porque errar é humano

Espere pra fazer isso

Daqui a 2 ou 3 anos

Por hora fique escondido

Para nisso refletir

Porque o pior disso tudo

Sobrará pra ti na verdade

Pois os teus muitos segredos

O povo todo já sabe

Más pra tudo tem um jeito

Pois ninguém é perfeito

Não matasse não roubasse

Apenas fingisse morrer

É só da um tempo pro povo

Que um dia vai esquecer

O que é bom dessa estória

De tudo que foi ocorrido

É que tu está bem vivo

Pior se tivesse morrido 
Mas pra não morrer de verdade

Tens que ficar escondido

Tem quem gastou muito dinheiro

Está zangado contigo

Tem quem arriscou a vida

Porque era teu amigo

Autoria desconhecida

(totalmente oculta)

Fins lucrativos: Papelarias

"que faz xerox" 